DEUSANILDE DE JESUS SILVA

\title{
QUÍMICA DA PARTE ÚMIDA EM PROCESSO DE FABRICAÇÃO DE PAPEL - Interações em interfaces sólido- líquido
}

SÃO PAULO

2010 
DEUSANILDE DE JESUS SILVA

\title{
QUÍMICA DA PARTE ÚMIDA EM PROCESSO DE FABRICAÇÃO DE PAPEL - Interações em interfaces sólido- líquido
}

\author{
Tese apresentada à Escola Politécnica da \\ Universidade de São Paulo para obtenção \\ do título de Doutor em Engenharia
}

São Paulo

2010 


\section{QUÍMICA DA PARTE ÚMIDA EM PROCESSO DE FABRICAÇÃO DE PAPEL - Interações em interfaces sólido- líquido}

Tese apresentada à Escola Politécnica da Universidade de São Paulo para obtenção do título de Doutor em Engenharia

Área de Concentração:

Engenharia Química

Orientador:

Prof. Dr. Song Won Park

São Paulo 


\section{FICHA CATALOGRÁFICA}

Silva, Deusanilde de Jesus

Química da parte úmida em processo de fabricação de papel: interações em interfaces sólido-líquido / D.J. Silva. -- ed.rev. -São Paulo, 2010.

243 p. + apêndices

Tese (Doutorado) - Escola Politécnica da Universidade de São Paulo. Departamento de Engenharia Química.

1. Fabricação do papel 2. Polímeros sintéticos 3. Química Coloidal 4. Nanotecnologia I. Universidade de São Paulo. Escola Politécnica. Departamento de Engenharia Química II. t. 


\section{DEDICATÓRIA}

Dedico este trabalho aos meus pais,

Terezinha Cardoso da Silva e

Deijaniro Jonas da Silva, in memoriam. 


\section{AGRADECIMENTOS}

Ao Professor Dr. Song Won Park da Escola Politécnica da Universidade de São Paulo, Poli-USP, pelo convite para realização deste trabalho.

Ao Professor Dr. Orlando Jose Rojas da Universidade do Estado da Carolina do Norte, NCSU, pela acolhida, pelas trocas de idéias, pela sua incessante disposição em ajudar aos seus orientados, pela motivação, pelo aprendizado e pela amizade.

Ao Professor Dr. Martin Allen Hubbe, NCSU, pela acolhida, pelas trocas de idéias, pela convivência, pelas sugestões e pela amizade.

Ao meu marido, José Mauro de Almeida, e ao meu filho, Victor Augustus Silva de Almeida, pela paciência e pela compreensão nos momentos difícies da elaboração do presente trabalho.

Aos colegas da Escola Politécnica da USP, pela amizade e convivência durante o tempo de Pós Graduação.

Aos colegas Wilson Hirota e Michele Rocha da Poli-USP, pela ajuda no uso dos equipamentos Coulter N4 Plus e Malvern Mastersizer, respectivamente.

Aos profissionais do Departamento de Engenharia Química da Escola Politécnica da USP, Alexandre Rodrigues de Oliveira, Fabrícia Rodrigues Lima de Souza, Fátima Suely Roldan, Maria das Graças Alves de Sousa, Maria do Carmo Neves, Maria Elisete Alves Monteiro, Maria Lúcia Adamo Attar, Sílvia Martins Baeder e Terezinha Miranda Costa, pela suas respectivas contribuições e amizade.

Aos colegas da Universidade do Estado da Carolina do Norte, NCSU, especialmente aos colegas do Grupo de Colóides e Interfaces, pela convivência, pelas trocas de idéias e pela amizade que fizemos, apesar do pouco tempo em que estivemos juntos.

Ao colega Junlong Song, NCSU, pelo treinamento da técnica da balança microgravimétrica (QCM-D) e da técnica para confecção de filmes finos de celulose. 
Ao colega Takashi Yamaguchi, Nippon Paper Co., pela sua contribuição nos testes desenvolvidos no Laboratório de Wet End Chemistry da Universidade do Estado da Carolina do Norte e por algumas comunicações pessoais sobre o processo de fabricação de papel.

À colega Sofia Contreras, NCSU, pelo treinamento na técnica de espalhamento estático de luz.

À colega Ingrid Hoeger, NCSU, pela ajuda na confecção das imagens no microscópio de força atômica, AFM.

À colega Kelley Spence, NCSU, pela ajuda nos ensaios de ângulo de contato.

Ao colega Youssef Habibi, NCSU, pelos ensinamentos e troca de idéias que contribuiram de forma significativa no andamento dos testes de laboratório.

Ao colega Xavier Turon, NCSU, pelas trocas de idéias e interpretação dos resultados de adsorção de polímero com a técnica QCM-D.

Ao Dr José Mauro de Almeida, pela sua grande ajuda na montagem de equipamentos para testes de laboratório na Universidade do Estado da Carolina do Norte.

Aos colegas do Instituto de Pesquisas Tecnológicas do Estado de São Paulo, IPT, Antônio Santos Filho, Luiz Fernando dos Reis, Maria Luiza Otero D’Almeida e Patrícia Kaji Yasumura, pela contribuição em todas as etapas dos testes físicos em papéis.

Aos colegas da Votorantim Celulose e Papel (VCP), Piracicaba, Reginaldo de Oliveira e Shinji Sato, pela disponibilização do laboratório para testes de retenção e drenagem.

À colega Gabriela Morishita, VCP Piracicaba, pelo acompanhamento na realização dos testes no laboratório de retenção e drenagem.

Aos fornecedores de especialidades químicas para o setor de celulose e papel, Jorge Freire e Alexandre Frangioni da Blanver Farmoquímica Ltda, Roberto Cahen da Corn Products Brasil, Pérsio Alessandro Rodrigues e Nobuyuki Fujiwara da Eka 
Chemicals do Brasil S. A.; Sílvio Takayama da Kemira Chemicals Brasil, e Júlio Costa da Specialty Minerals, pelo fornecimento de amostras de aditivos para a etapa da química da parte úmida da fabricação de papel.

A todos aqueles que colaboraram, direta ou indiretamente, na elaboração deste trabalho. 


\section{RESUMO}

Um polieletrólito catiônico (poliamina), com baixo peso molecular e elevada densidade de carga, normalmente aplicado como agente coagulante do lixo aniônico, foi usado para estudos de retenção e drenagem na fabricação de papel. $O$ uso do carboximentil celulose de sódio para simulação do teor de lixo aniônico e seu efeito na retenção de cargas minerais foi uma característica importante para este trabalho. Pode ser observado que o aumento da dosagem do polímero catiônico tanto melhora a retenção de cargas minerais, avaliada pela turbidez do filtrado, quanto melhora a drenagem do sistema, avaliada pela velocidade de escoamento. Entretanto, elevadas dosagens deste polímero comprometeram os resultados destes parâmetros devido à inversão de carga do sistema. Pode também ser confirmado que forças de cisalhamento excessivas prejudicam a retenção de cargas minerais. Ademais, um polianfótero, com peso molecular e densidade de carga elevados, contendo grupos positivo ( $N$-[3-( $N^{\prime}, N^{\prime}$-dimetilamino)propil]acrilamida), negativo (ácido metileno butanodióico) e nulo (acrilamida) na mesma cadeia, foi testado como agente de resistência a seco do papel. Todos os estudos em nível molecular sobre o comportamento do polianfótero em solução e o seu comportamento de adsorção sobre superfícies modelos carragadas, em diferentes condições de $\mathrm{pH}$ e de força iônica, foram importantes para explicar tanto dos fenômenos de adsorção, envolvendo fibras celulósicas e polianfótero, quanto o seu efeito na resistência mecânica do papel. Foi observado que a solubilidade do polímero aumenta à medida que o $\mathrm{pH}$ se distancia do seu ponto isoelétrico, $\mathrm{pH}_{\mathrm{PIE}} 7,3$, e reduz para valores de $\mathrm{pH}$ próximos ao $\mathrm{pH}_{\mathrm{PIE}}$. $\mathrm{O}$ tamanho das estruturas do polianfótero depende do $\mathrm{pH}$ do meio de dispersão. As características de tamanho do polianfótero tanto sob a forma de cadeias individuais ou quanto sob a forma de agregados, foram medidas através da técnica de espalhamento dinâmico de luz. As propriedades viscoelásticas das camadas adsorvidas e a quantidade de polímero adsorvida foram medidas através da técnica da balança microgravimétrica com dissipação de energia. Estas duas determinações, associadas às imagens no microscópio de força atômica, foram importantes para o entendimento dos resultados práticos do uso do polianfótero como agente de resistência a seco do papel. Maiores resultados de resistência do papel, avaliada através da resistência à tração, foram alcançados para valores de $\mathrm{pH}$ próximos ao ponto isoelétrico onde foram encontrados o seguinte: (1) maiores tamanhos para as estruturas do polímero em solução, (2) maior quantidade de massa nas camadas adsorvidas e (3) a formação de camadas mais viscoelásticas. O fenômeno de separação de fases, associado à mudança da solubilidade do polímero em solução devido ao balanço dos grupos positivos e negativos ionizados ao longo da faixa de $\mathrm{pH}$ estudada, foi considerado o principal aspecto para a variação em tamanho dos agregados. Embora este polímero tenha apresentado comportamento antipolieletrólito devido à expansão da sua cadeia e ao aumento da densidade de carga com o aumento da força iônica, considerando o efeito da força iônica para pH 4,3, o comportamento de adsorção do polianfótero foi avaliado como o comportamento de um polieletrólito monocarregado de alta densidade de carga. Maiores e menores quantidades de massas adsorvidas foram encontradas para valores intermediários e extremos de força iônica, respectivamente. As interações eletrostáticas foram consideradas as principais responsáveis pela adsorção do polímero sobre superfícies carregadas. Entretanto, a blindagem de cargas foi considerada a explicação para os baixos valores de massa adsorvida para valores mais elevados de força iônica. 
Palavras-chave: Polímeros sintéticos. Polieletrólito. Polianfótero. Interações eletrostáticas. Retenção e drenagem. Agente de resistência a seco do papel. Nanotecnologia. Química coloidal. Balança microgravimétrica com dissipação de energia. Microscopia de força atômica. Espalhamento dinâmico de luz. 


\section{ABSTRACT}

A cationic polyelectrolyte (polyamine), with low molecular weight and high charge density, usually applied as anionic trash coagulant, was used for the retention and drainage studies in the papermaking. The use of sodium carboxymethyl cellulose to simulate the anionic trash content and its effect on the filler retention was an important feature of the work. It could be noted that the increasing of the cationic polymer dosage improves both the filler retention, evaluated by the turbidity of the filtrate, and the system drainage, evaluated by the flow speed. However, high dosages of this polymer compromised the results of these parameters due to the reversal of the system charge. It can also be confirmed that excessive shear forces affect the filler retention. Furthermore, a polyampholyte, with high molecular weight and charge density, containing positive $\left(N-\left[3-\left(N^{\prime}, N-\right.\right.\right.$ dimethylamino)propyl]acrylamide), negative (methylene butanedioic acid), and neutral (acrylamide) groups in the same chain, was tested as a dry strength agent. All of the studies at molecular level concerning to the polyampholyte behavior in the solution and its adsorption behavior on charged model surfaces at different conditions of $\mathrm{pH}$ and ionic strength, were important to explain both the adsorption phenomena, involving cellulosic fibers and polyampholyte, and its impact on the paper strength. It was observed that the polymer solubility increases as the $\mathrm{pH}$ moves away from its isoelectric point, $\mathrm{pH}_{\mathrm{IEP}}$ 7.3, and decreases when the $\mathrm{pH}$ approaches close to $\mathrm{pH}_{\text {IEP }}$. The sizes of the structures of the polyampholytes depend on the $\mathrm{pH}$ of the dispersion medium. Also the size characteristics of polyampholyte, both in individual and aggregated forms, were measured by dynamic light scattering technique. The viscoelastic properties of adsorbed layers, as well as the amount of the adsorbed polymer, were measured by quartz crystal microbalance technique with energy dissipation. These two measurements, associated with the atomic force microscopy images, were important to understand the practical results of polyampholyte usage as a dry strength agent. Best results of paper strength, evaluated by paper strength index, were achieved at $\mathrm{pH}$ close to the isoelectric point on which one were found the following features: (1) larger sizes of the polymer structures in solution, (2) higher amount of mass in the adsorbed layers, and (3) the formation of more viscoelastic layers. The phase separation phenomenon, associated with the change in the solubility of the polymer due to the balance of the positive and negative groups throughout the studied $\mathrm{pH}$ range, was considered the main aspect for the variation in size of the aggregates. Although this polymer shows antipolyelectrolyte behavior due to the expansion of the its chain and the increasing in charge density with the ionic strength, considering the effect of ionic strength at $\mathrm{pH}$ 4.3, the adsorption behavior of polyampholyte was evaluated as a monocharged polyelectrolyte behavior with high charge density. Major and minor amounts of adsorbed masses were found for intermediates and extremes values of ionic strength, respectively. The electrostatic interactions were considered the main cause of the adsorption on charged surfaces. However, the electrostatic screening was considered the explanation for the low values of adsorbed mass at higher values of ionic strength. 
Keywords: Synthetic polymers. Polyelectrolyte. Polyampholyte. Electrostatic interactions. Retention and drainage. Paper dry strength agent. Nanotechnology. Colloidal chemistry. Quartz crystal microbalance with energy dissipation. Atomic force microscopy. Dynamic light scattering. 


\section{ÍNDICE DE FIGURAS}

Figura 2.1 - (A) Fotomicrografia de uma folha de papel mostrando as direções do comprimento da máquina (MD) e da largura da máquina $(C D)$ e $(B)$ fotomicrografia de uma folha de papel na direção perpendicular (ZD) às direções MD e CD.

Figura 2.2 - Fotografia digital mostrando duas folhas de papel com tamanho de flocos diferentes: A- Folha formada com flocos maiores e B- Folha formada com flocos menores.

Figura 2.3 - Fluxograma das etapas de formação de folha de uma fábrica genérica.

Figura 2.4 - Etapas da fabricação de papel - máquina com mesa plana.

Figura 2.5 - llustração da molécula de água....................................................14

Figura 2.6 - llustração da estrutura da fibra de madeira. 16

Figura 2.7 - (A) Ilustração de partícula de sílica coloidal com $5 \mathrm{~nm}$ e área superficial de 500 a $800 \mathrm{~m}^{2} / \mathrm{g}$; (B) Partícula de sílica coloidal com elevada carga aniônica, e (C) llustração de partícula de sílica na forma de gel com área superficial de $1200-1400 \mathrm{~m}^{2} / \mathrm{g}$.

Figura 2.8 - (A) llustração de partícula de bentonita com área superficial acima de $800 \mathrm{~m}^{2} / \mathrm{g}$, e (B) Ilustração de um micropolímero.

Figura 2.9 - Ângulo de contato entre uma gota de líquido e uma superfície plana horizontal. .29

Figura 2.10 - Ângulo de contato entre uma gota de líquido e uma superfície plana horizontal.

Figura 2.11- Mecanismo de reação da cola AKD com a celulose.

Figura 2.12 - Mecanismo de reação da cola ASA com a celulose. .32

Figura 2.13 - Diagrama esquemático da estrutura da amilose.

Figura 2.14 - Diagrama esquemático da estrutura da amilopectina.

Figura 2.15 - Complexação das substâncias orgânicas dissolvidas e coloidais sobre a superfície do material fibroso. 36

Figura 2.16 - Constituintes da suspensão de fibras. 
Figura 2.17 - Classificação, em tamanho, dos constituintes da suspensão de fibras.

Figura 2.18 - lonização de grupos carboxílicos. .46

Figura 2.19 - llustração da estrutura polimérica da cadeia de celulose. Detalhe: presença de grupos carboxílicos e hidroxílicos.

Figura 2.20 - Distribuição dos potenciais elétricos ao redor de uma partícula eletricamente carregada.

Figura 2.21- llustração da dupla camada elétrica da superfície do material fibroso.

Figura 2.22 - Energia potencial entre duas partículas.

Figura 2.23 - Comparação entre os tamanhos dos substratos presentes na suspensão de fibras e as dimensões de uma abertura da tela formadora (uc corresponde à unidade de comprimento).

Figura 2.24 - Compressão da dupla camada elétrica.

Figura 2.25 - Efeito da carga do contra-íon no potencial de superfície da partícula.

Figura 2.26 - Esquema ilustrando o modelo de floculação tipo patch.

Figura 2.27 - Etapas do modelo de floculação por pontes: (a) adsorção; (b) formação de loops e caudas; (c) agregação entre duas partículas; e (d) crescimento do floco.

Figura 2.28 - Esquema ilustrando a redução da eficiência de um polímero floculante submetido à forças hidrodinâmicas e de cisalhamento.

Figura 2.29 - llustração de sistema de floculação com a adição de dois polímeros de cargas opostas.

Figura 2.30 - Ilustração do modelo de floculação com nano ou micropartículas....77

Figura 2.31 - Mecanismo de floculação com nanopartículas de sílica catiônica e polímero aniônico na presença de polpa.

Figura 2.32 - Ilustração de floculação por rede.

Figura 3.1 - llustração do mecanismo de floculação com nano ou micropartículas

utilizando amido como polímero catiônico, polímero aniônico e sílica coloidal...95

Figura 3.2 - Caracterização da suspensão de fibras..........................................104

Figura 3.3 - Medidor do potencial zeta Mütek SZP-06 ........................................105

Figura 3.4 - Jarro de Britt para determinação da retenção e do teor de finos da

polpa. 
Figura 3.5 - (A) Medidor da demanda catiônica Mütek PCD-03 Particle Charge Detector da BTG e (B) Acessório para o medidor da demanda catiônica Mütek PCD-T3 Titrator Three da BTG.

Figura 3.6 - Curva para ajuste da demanda catiônica (DC) inicial do sistema com solução de carboximetilcelulose de sódio (CMC-Na).

Figura 3.7 - Efeito da dosagem de coagulante na demanda catiônica e na turbidez da água branca. Dosagens base papel seco: amido, $9 \mathrm{~kg} / \mathrm{t}$; cola AKD, 0,95 kg/t; carga PCC, $20 \%$ base papel seco; polímero aniônico, 0,1 $\mathrm{kg} / \mathrm{t}$; sílica aniônica, $3 \mathrm{~kg} / \mathrm{t}$.

Figura 3.8 - Efeito da dosagem de coagulante na drenagem do sistema.

Figura 3.9 - Efeito de forças de cisalhamento na demanda catiônica e na turbidez da água branca. Dosagens base papel seco: ATC, 0,5 kg/t; amido, 9 $\mathrm{kg} / \mathrm{t}$; cola AKD, 0,95 kg/t; carga PCC, $20 \%$ base papel seco; polímero aniônico, 0,1 kg/t; sílica aniônica, $3 \mathrm{~kg} / \mathrm{t}$.

Figura 4.1- Tratamento enzimático utilizado para limpeza dos sensores usados nos testes de adsorção, antecedendo a limpeza química.

Figura 4.2 - Procedimento de preparação de filmes finos de celulose.

Figura 4.3 - Fotomicrografia dos filmes de celulose gerada pela técnica de AFM. 127

Figura 4.4 - Procedimento para limpeza de sensores de sílica para QCM. 128

Figura 4.5 - Princípio de funcionamento da balança microgravimétrica com cristal de quartzo e dissipação de energia.

Figura 4.6 - Dissipação de energia: (A) Filme rígido e (B) Filme macio.

Figura 4.7 - Geometria da superfície modelo revestida com uma mono camada

(A) e o esquema do modelo viscoelástico de Voigt (B). Em que " " é a camada e " $f$ " é fluido.

Figura 4.8 - (A) Esquema do funcionamento do microscópio de força atômica.

(B) Forças interatômicas em função da distância para os três modos de operação do microscópio de força atômica: contato, contato intermitente e não contato.

Figura 4.9 - Princípio de funcionamento do AFM. 136

Figura 4.10 - Diagrama de bloco do funcionamento do COULTER N4 PLUS. ......138

Figura 4.11 - Princípio de funcionamento do Mütek PCD-03.

Figura 5.1 - Diferentes conformações para as cadeias dos polianfóteros assimétricos. Em azul são os monômeros carregados negativamente; em 
rosa são os monômeros carregados positivamente e em cinza são os monômeros neutros.

Figura 5.2 - Esquema das configurações da cadeia de polianfótero próximo à superfície carregada: (a) Regime de pólo; (b) Regime de cerca e (c) Regime de panqueca.

Figura 5.3 - Esquema da configurações das cadeias de polianfóteros adsorvidos em camadas. (a) Multicamadas de cadeias estendidas: lado esquerdo. (b) Multicamadas de cadeias estendidas com falso pincel: lado direito.

Figura 5.4 - Composição molecular do polianfótero preparado randomicamente via polimerização por radical livre.

Figura 5.5 - (A) Volume de PVSK consumido em função do tempo de retenção na adsorção do polianfótero, e (B) curva de calibração massa do polianfótero em função do volume de PVSK gasto na titulação.

Figura 5.6 - Efeito da dosagem do polianfótero no comprimento de autorruptura do papel. Condições dos testes de adsorção: $168 \mathrm{mg} / \mathrm{L}, 1 \mathrm{mM}[\mathrm{NaCl}]$ e $25^{\circ} \mathrm{C} .179$

Figura 5.7 - Efeito da dosagem do polianfótero nos resultados de resistência das ligações interfibras medidos pelo teste de Scott Bond. Condições dos testes de adsorção: $168 \mathrm{mg} / \mathrm{L}, 1 \mathrm{mM}[\mathrm{NaCl}]$ e $25^{\circ} \mathrm{C}$.

Figura 5.8 - Comparação entre a quantidade dosada de polianfótero e a quantidade adsorvida na superfície da fibra. Condições dos testes de adsorção: $168 \mathrm{mg} / \mathrm{L}, 1 \mathrm{mM}[\mathrm{NaCl}], \mathrm{pH} 6,5$ e $25^{\circ} \mathrm{C}$.

Figura 5.9 - Efeito do pH no índice de tração do papel. Condições dos testes de adsorção: dosagem de 0,3\% base polpa seca, $168 \mathrm{mg} / \mathrm{L}, 10 \mathrm{mM}[\mathrm{NaCl}]$ e 25 ${ }^{\circ} \mathrm{C}$.

Figura 5.10 - Efeito da força iônica no índice de tração. Condições dos testes de adsorção: dosagem de 0,3\% base polpa seca ,168 mg/L, pH 4,3 e $25^{\circ} \mathrm{C}$.

Figura 5.11 - Efeito do pH na turbidez e no diâmetro hidrodinâmico de partículas de polianfóteros em solução. A fotografia abaixo ilustra a diferença de turbidez para a faixa de $\mathrm{pH}$ estudada. Condições dos testes de adsorção: 168 mg/L (turbidez) e 336 mg/L (diâmetro hidrodinâmico), 10 mM [NaCl] e 25 ${ }^{\circ} \mathrm{C}$.

Figura 5.12 - Efeito do $\mathrm{pH}$ na densidade de carga líquida do polianfótero. Condições dos testes: $168 \mathrm{mg} / \mathrm{L}, 10 \mathrm{mM}[\mathrm{NaCl}]$ e $25^{\circ} \mathrm{C}$. 
Figura 5.13 - (A) Efeito do $\mathrm{pH}$ nas mudanças de frequência de ressonância e nas (B) mudanças de dissipação de energia para diferentes níveis de $\mathrm{pH}$ e força iônica constante, medidos com a balanças microgravimétrica. Condições dos testes de adsorção: $10 \mathrm{mM}$ [NaCl], $168 \mathrm{mg} / \mathrm{L}$ [PAnf], 130 $\mu \mathrm{l} / \mathrm{min}$ de vazão e $25^{\circ} \mathrm{C}$.

Figura 5.14 - Imagens em microscopia de força atômica de camada de polianfótero, para três condições de $\mathrm{pH}, 2 \mathrm{D}$ à esquerda e 3D à direita. Detalhe cental: perfil de cada superfície, próximo a diagonal, com range variando de $-3,00 \mathrm{~nm}$ a 3,00 nm. Condições dos testes de adsorção: $10 \mathrm{mM}$ [NaCl], $168 \mathrm{mg} / \mathrm{L}$ [PAnf], $30 \mathrm{~min}$ de adsorção e $25^{\circ} \mathrm{C}$.

Figura 5.15 - Efeito da força iônica na tubidez da solução de polianfótero ao longo da curva de $\mathrm{pH}$. Figura em destaque: turbidez em função da concentração de sal. Condições do teste: [PAnf] $=168 \mathrm{mg} / \mathrm{L}, \mathrm{pH} 4,3 \mathrm{e}$ temperatura ambiente de $25^{\circ} \mathrm{C}$.

Figura 5.16 - (A) Efeito da força iônica no tamanho aparente de partícula e na (B) densidade de carga líquida do polianfótero em solução. Condições de testes: (A) $\left[\right.$ PAnf] $=336 \mathrm{mg} / \mathrm{L}, \mathrm{pH} 4,3$ e $25^{\circ} \mathrm{C}$ e (B) $[$ PAnf] $=168 \mathrm{mg} / \mathrm{L}, \mathrm{pH} \mathrm{4,3}$ e $25^{\circ} \mathrm{C}$.

Figura 5.17 - Mudanças de frequência em função do tempo para verificar a dinâmica de adsorção do polianfótero em (A) substrato de sílica e em (B) filme de celulose para diferentes concentrações de sal. Condições de testes: [PAnf] $=168 \mathrm{mg} / \mathrm{L} ; \mathrm{pH} 4,3$ e $25^{\circ} \mathrm{C}$.

Figura 5.18 - (A) Frequências de ressonância e (B) dissipações de energia de equilíbrio para a adsorção do polianfótero sobre celulose e sílica em diferentes concentrações de sal. Resultados apresentados para antes e depois da lavagem no respectivo nível de força iônica da solução. Condições dos testes: $[$ PAnf $]=168 \mathrm{mg} / \mathrm{L}, \mathrm{pH} 4,3$ e temperatura $25^{\circ} \mathrm{C}$.

Figura 5.19 - D-f plots de camadas de polianfóteros adsorvidas sobre (A) substrato de sílica e sobre (B) filme de celulose em diferentes concentração de sal. Condições dos testes: $[\mathrm{PAnf}]=168 \mathrm{mg} / \mathrm{L}, \mathrm{pH} \mathrm{4,3}$ e temperatura $25^{\circ} \mathrm{C} .209$

Figura 5.20 - Mundanças de frequência de ressonância e de dissipação de energia em três frequências harmônicas para camada de polianfótero 
adsorvida em superfície de silica em pH4,3, $10 \mathrm{mM} \mathrm{[NaCl],} \mathrm{[PAnf]} \mathrm{=} 168 \mathrm{mg} / \mathrm{L}$ e $25^{\circ} \mathrm{C}$.

Figura 5.21 - Comparação entre os valores de adsorção de polianfótero, experimentais e estimados pelo modelo de Voigt, para as três frequências harmônicas estudadas, $3^{\mathrm{a}}$, $5^{\underline{a}}$ e $7^{\underline{a}}$, antes e após a etapa de lavagem. Condições: superfície de silica, $\mathrm{pH} 4,3,[\mathrm{NaCl}]=10 \mathrm{mM}$, [PAnf] $=168 \mathrm{mg} / \mathrm{L}$ e $25{ }^{\circ} \mathrm{C}$.

Figura 5.22 - Resultados de espessuras da camada de polianfótero, antes e depois da etapa de lavagem, estimados usando o modelo para camada rígida, equação de Sauerbrey, e o modelo viscoelástico, modelo de Voigt. Condições: superfície de silica, $\mathrm{pH} 4,3,[\mathrm{NaCl}]=10 \mathrm{mM},[\mathrm{PAnf}]=168 \mathrm{mg} / \mathrm{L}$ e $25{ }^{\circ} \mathrm{C}$.

Figura 5.23 - Resultados das massas específicas de polianfótero e de espessuras das camadas para cinco níveis de força iônica, utilizando a equação de Sauerbrey e o modelo de Voigt, para superfícies de adsorção de (A) sílica e de (B) filme de celulose. Condições dos testes: pH4,3; [PAnf] = $168 \mathrm{mg} / \mathrm{L}$ e $25^{\circ} \mathrm{C}$.

Figura 5.24 - Efeito da força iônica, do substrato e da concentração do polianfótero na habilidade de inchamento de camadas preadsorvidas do

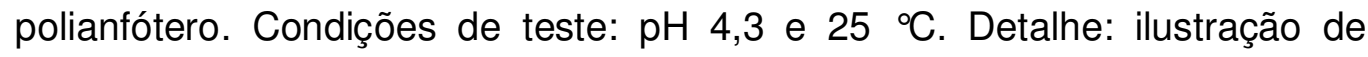
camada de polímero preadsorvida em diferentes estados de inchamento. ......219

Figura 5.25 - Efeito da concentração de sal do meio de dispersão, sem polímero, para diferentes superfícies modelos. Condições de teste: $\mathrm{pH} 4,3$ e $25^{\circ} \mathrm{C}$

Figura B 1 - Variações de frequência e de dissipação de energia em função do tempo devido à adsorção do polianfótero. Condições: superfície de sílica, 10 $\mathrm{mM} \mathrm{NaCl}, \mathrm{pH} 4,3$, temperatura $25^{\circ} \mathrm{C}$ e $168 \mathrm{mg} / \mathrm{L}$ [PAnf]. Legenda: T1 corresponde ao início da dosagem do polianfótero; T2 corresponde ao final da dosagem do polianfótero; T3 corresponde ao início da lavagem com meio de dispesão sem polianfótero; $\Delta f$ corresponde a variação de frequência e $\Delta D$ corresponde à variação de dissipação de energia 
Figura B 2 - Variações de frequência e de dissipação de energia em função do tempo devido à adsorção do polianfótero. Condições: superfície de celulose, $0,1 \mathrm{mM}[\mathrm{NaCl}], \mathrm{pH} 4,3$, temperatura $25^{\circ} \mathrm{C}$ e $168 \mathrm{mg} / \mathrm{L}$ [PAnf].

Figura B 3 - Variações de frequência e de dissipação de energia em função do tempo devido à adsorção do polianfótero. Condições: superfície de celulose, $1 \mathrm{mM}[\mathrm{NaCl}], \mathrm{pH} 4,3$, temperatura $25^{\circ} \mathrm{C}$ e $168 \mathrm{mg} / \mathrm{L}$ [PAnf].

Figura B 4 - Variações de frequência e de dissipação de energia em função do tempo devido à adsorção do polianfótero. Condições: superfície de celulose, $10 \mathrm{mM}$ [NaCl], $\mathrm{pH} 4,3$, temperatura $25^{\circ} \mathrm{C}$ e $168 \mathrm{mg} / \mathrm{L}$ [PAnf]. 256

Figura B 5 - Variações de frequência e de dissipação de energia em função do tempo devido à adsorção do polianfótero. Condições: superfície de celulose, $100 \mathrm{mM}[\mathrm{NaCl}], \mathrm{pH} 4,3$, temperatura $25^{\circ} \mathrm{C}$ e $168 \mathrm{mg} / \mathrm{L}$ [PAnf].

Figura B 6 - Variações de frequência e de dissipação de energia em função do tempo devido à adsorção do polianfótero. Condições: superfície de celulose, $1000 \mathrm{mM}[\mathrm{NaCl}], \mathrm{pH} 4,3$, temperatura $25^{\circ} \mathrm{C}$ e $168 \mathrm{mg} / \mathrm{L}$ [PAnf].

Figura B 7 - Variações de frequência e de dissipação de energia em função do tempo devido à adsorção do polianfótero. Condições: superfície de sílica, 0,1 $\mathrm{mM}[\mathrm{NaCl}], \mathrm{pH} 4,3$, temperatura $25^{\circ} \mathrm{C}$ e $168 \mathrm{mg} / \mathrm{L}$ [PAnf].

Figura B 8 - Variações de frequência e de dissipação de energia em função do tempo devido à adsorção do polianfótero. Condições: superfície de sílica, 1 $\mathrm{mM}[\mathrm{NaCl}], \mathrm{pH} 4,3$, temperatura $25^{\circ} \mathrm{C}$ e $168 \mathrm{mg} / \mathrm{L}$ [PAnf].

Figura B 9 - Variações de frequência e de dissipação de energia em função do tempo devido à adsorção do polianfótero. Condições: superfície de sílica, 10 $\mathrm{mM}\left[\mathrm{NaCl}\right.$, $\mathrm{pH} 4,3$, temperatura $25^{\circ} \mathrm{C}$ e $168 \mathrm{mg} / \mathrm{L}$ [PAnf].

Figura B 10 - Variações de frequência e de dissipação de energia em função do tempo devido à adsorção do polianfótero. Condições: superfície de sílica, 100 $\mathrm{mM}[\mathrm{NaCl}], \mathrm{pH} 4,3$, temperatura $25^{\circ} \mathrm{C}$ e $168 \mathrm{mg} / \mathrm{L}$ [PAnf].

Figura B 11 - Variações de frequência e de dissipação de energia em função do tempo devido à adsorção do polianfótero. Condições: superfície de sílica, $1000 \mathrm{mM}[\mathrm{NaCl}], \mathrm{pH} 4,3$, temperatura $25^{\circ} \mathrm{C}$ e $168 \mathrm{mg} / \mathrm{L}$ [PAnf].

Figura $\mathrm{B} 12$ - Resultados de $\Delta \mathrm{D}$ gerados pela balaça microgravimétrica devido à adsorção do polianfótero em superficies de sílica $(A)$ e em filme de celulose (B), para três frequências harmônicas. Condições dos testes: $1000 \mathrm{mM}$ [NaCl], pH4,3; $168 \mathrm{mg} / \mathrm{L}$ [PAnf] e $25^{\circ} \mathrm{C}$ 


\section{ÍNDICE DE TABELAS}

Tabela 1.1 - Experimentos e respectivas medições realizadas em laboratório .......... 5

Tabela 2.1 - Análise de fibras de polpas branqueadas no equipamento Kajaani ..... 18

Tabela 2.2 - Propriedades de algumas cargas utilizadas na fabricação de papel ....21

Tabela 2.3 - Classificação de polímeros de acordo com sua ionicidade e com o seu peso molecular.

Tabela 2.4 - Carga iônica de alguns componentes do sistema de suspensão de fibras em meio aquoso

Tabela 2.5 - Potenciais eletrocinéticos para fibras, finos e cargas, alguns, em diferentes condições de $\mathrm{pH}$

Tabela 2.6 - Correlações qualitativas entre as características dos flocos e os fenômenos que ocorrem na fabricação de papel.....

Tabela 2.7 - Mecanismos de floculação, características físicas dos flocos e efeito das condições de processo .

Tabela 3.1- Reagentes e seqüência de adição na etapa de formação de folha para fábricas de papel nacionais

Tabela 3.2 - Dosagens de reagentes adotados neste estudo e suas respectivas funções e observações 103

Tabela 3.3 - Ordem de adição de reagentes e tempos de retenção para os testes de retenção com nanopartículas......

Tabela 3.4 - Resultados das análises de polpa e das frações 1, 2 e 3................... 114

Tabela 5.1 - Resultados da análise da polpa................................................ 166

Tabela 5.2 - Condições de adsorção do polianfótero nas fibras ........................... 170

Tabela 5.3 - Condições dos teste com polianfótero em solução para as propriedades turbidez, densidade de carga e diâmetro hidrodinâmico.

Tabela 5.4 - Resultados de densidade e de viscosidade do meio de dispersão na presença de $168 \mathrm{mg} / \mathrm{L}$ de polianfótero para diferentes condições de força iônica

Tabela 5.5 - Resultados aproximados antes e após a etapa de lavagem para variação de frequência, dissipação de energia, diâmetro hidrodinâmico das partículas em solução e índice de tração do papel. 
Tabela 5.6 - Relação entre a rugosidade de superfície determinada através de AFM e o diâmetro hidrodinâmico, determinado através de DLS. 195

Tabela 5.7 - Resultados alcançados com os testes de adsorção em superfícies de sílica e de filme de celulose para diferentes valores de força iônica

Tabela 5.8 - Condições adotadas durante a adsorção das camadas do polianfótero

Tabela B 1 - Efeito da dosagem de polianfótero no comprimento de autorruptura 247

Tabela B 2 - Efeito da dosagem de polianfótero no Scott Bond (ligações interfibras)

Tabela B 3 - Efeito do pH no índice de tração do papel ....................................... 248

Tabela B 4 - Efeito da força iônica no índice de tração do papel.............................248

Tabela B 5 - Efeito do pH e da força iônica na turbidez da solução de polianfótero249

Tabela B 6 - Diâmetro hidrodinâmico, desvio padrão e índice de polidispersidade de partículas de polianfóteros para os ângulos de 30,2; 62,2 e 90 em valores de $\mathrm{pH} 4,3$ e 5,35 e $10 \mathrm{mM}$ de $[\mathrm{NaCl}]$

Tabela B 7 - Diâmetro hidrodinâmico, desvio padrão e índice de polidispersidade de partículas de polianfóteros para os ângulos de 30,2; 62,2 e 90 em valores de $\mathrm{pH} 6,53$ e 7,24 e $10 \mathrm{mM}$ de $[\mathrm{NaCl}]$

Tabela B 8 - Diâmetro hidrodinâmico, desvio padrão e índice de polidispersidade de partículas de polianfóteros para os ângulos de 30,2; 62,2 e 90 em valores de $\mathrm{pH} 8,48$ e 9,31 e $10 \mathrm{mM}$ de $[\mathrm{NaCl}]$

Tabela B 9 - Diâmetro hidrodinâmico, desvio padrão e índice de polidispersidade de partículas de polianfóteros para os ângulos de 30,2; 62,2 e 90 em valores de força iônica de 0,1 e $1 \mathrm{mM}$ de $[\mathrm{NaCl}]$ e pH fixo de 4,3.

Tabela B 10 - Diâmetro hidrodinâmico, desvio padrão e índice de polidispersidade de partículas de polianfóteros para os ângulos de 30,2; 62,2 e 90 em valores de força iônica de 100 e 1000 mM de $[\mathrm{NaCl}]$ e pH fixo de 4,3.

Tabela B 11 - Resultados de variação de frequência devido à adsorção do PAnf sobre substrato de sílica, antes e após a lavagem, em função da concentração de sal.

Tabela B 12 - Resultados de variação de dissipação de energia devido à adsorção do PAnf sobre substrato de sílica, antes e após a lavagem, em função da concentração de sal 
Tabela B 13 - Resultados de variação de frequência devido à adsorção do PAnf sobre filme de celulose, antes e após a lavagem, em função da concentração de sal......

Tabela B 14 - Resultados de variação de dissipação de energia devido à adsorção do PAnf sobre filme de celulose, antes e após a lavagem, em função da concentração de sal.................................................................... 262 


\section{SUMÁRIO}

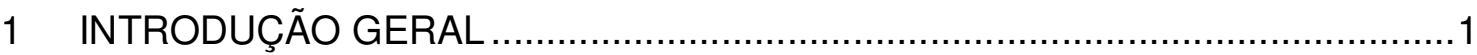

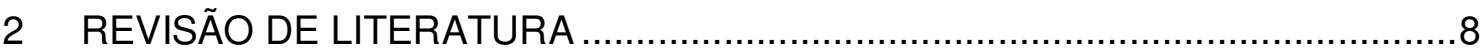

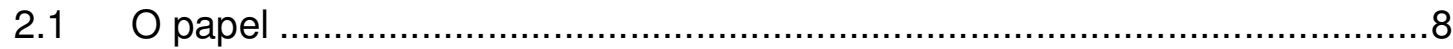

2.2 Constituintes da suspensão de fibras para fabricação de papel ..................14

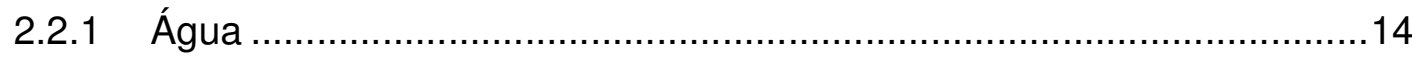

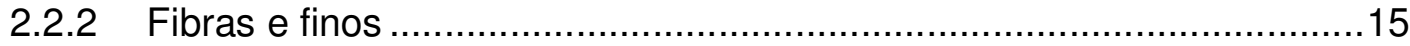

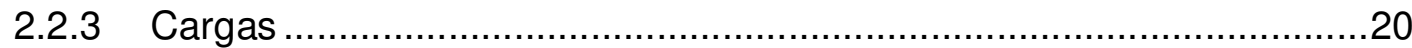

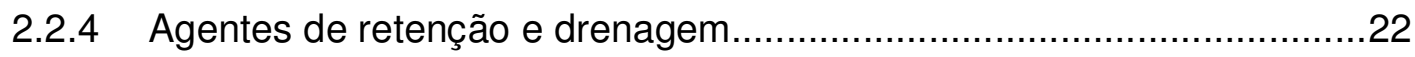

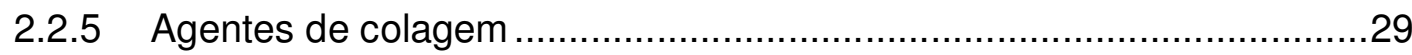

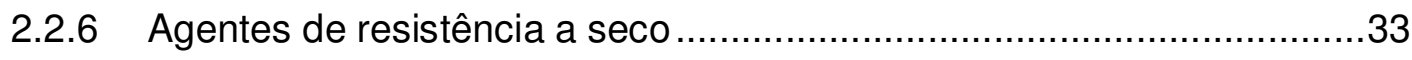

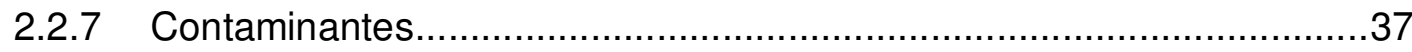

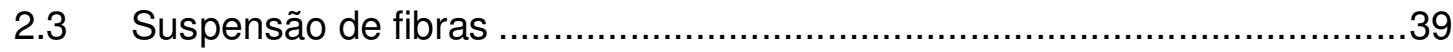

2.3.1 Constituição e densidade de carga.........................................................39

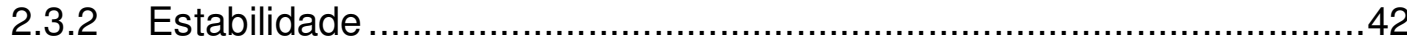

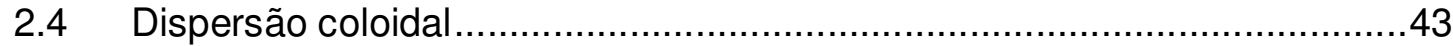

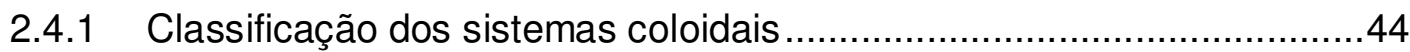

2.4.2 Formação da Dupla Camada Elétrica (DCE) ......................................45

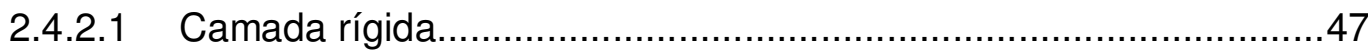

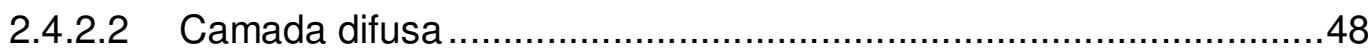

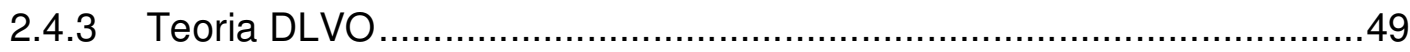

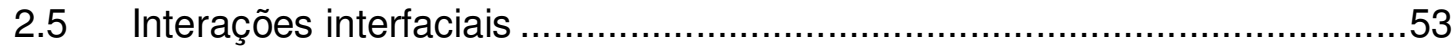

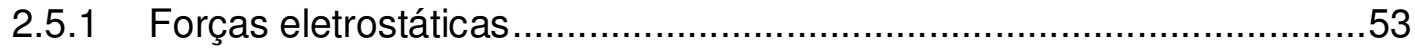

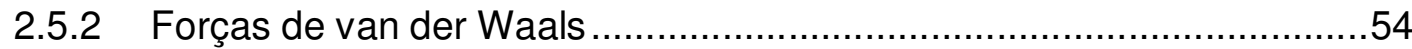

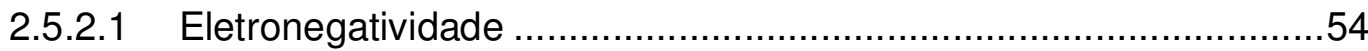

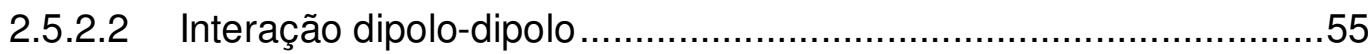

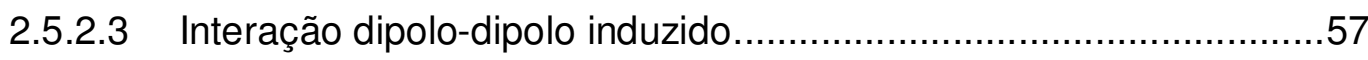

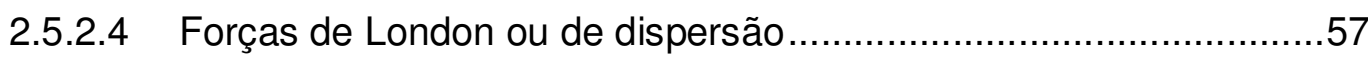

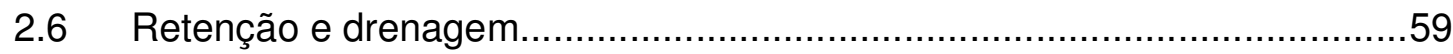

2.6.1 Mecanismos de agregação de partículas .............................................63

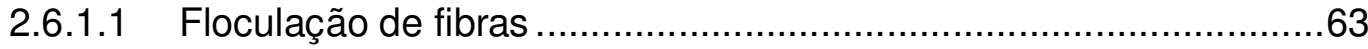

2.6.1.2 Sistemas de retenção de micropartículas .....................................64 
2.6.1.2.1 Compressão da Dupla Camada Elétrica.....................................65

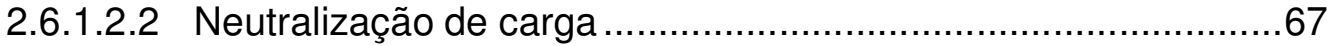

2.6.1.2.3 Atração eletrostática ou heterofloculação ..................................68

2.6.1.2.4 Modelos que utilizam polieletrólitos catiônicos............................69

2.6.1.2.4.1 Modelo tipo patch ou tipo mosaico .....................................69

2.6.1.2.4.2 Modelo de floculação tipo pontes ......................................71

2.6.1.2.4.3 Modelos de floculação complexos.....................................74

2.6.1.2.4.4 Floculação com dois polímeros de cargas opostas..............75

2.6.1.2.4.5 Floculação com nano ou micropartículas ............................76

2.6.1.2.4.6 Modelo de floculação por rede com polímero não iônico ....81

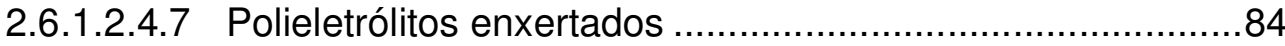

2.6.2 Características dos flocos formados e seu efeito nos processos de retenção e drenagem e na qualidade de formação da folha ...............................85

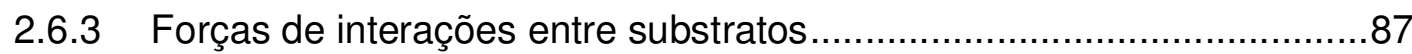

3 EFEITO DA DOSAGEM DE COAGULANTE E DA FORÇA DE CISALHAMENTO NO PROCESSO DE DRENAGEM E DE RETENÇÃO DE PARTÍCULAS................91

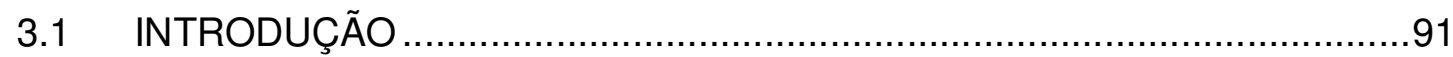

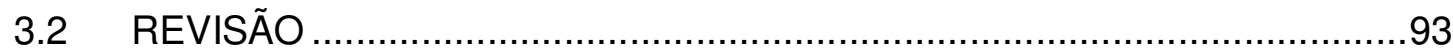

3.2.1 Programas de retenção de partículas .....................................................93

3.2.2 Efeito da dosagem de coagulante na retenção de partículas .................95

3.2.3 Efeito da força de cisalhamento na retenção de partículas ....................98

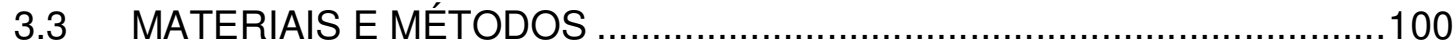

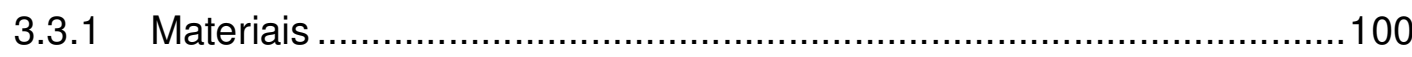

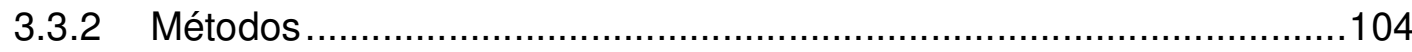

3.3.2.1 Caracterização da suspensão de fibras .....................................104

3.3.2.2 Preparo da suspensão de fibras ..............................................104

3.3.2.3 Comprimento médio de fibras e teor de finos na fração 1 ..............105

3.3.2.4 Determinação do potencial Zeta na fração 1 ................................105

3.3.2.5 Determinação do teor de finos orgânicos na fração 2 ....................105

3.3.2.6 Determinação do $\mathrm{pH}$ na fração 3 ..............................................107

3.3.2.7 Determinação da condutividade na fração 3 ...............................108

3.3.2.8 Determinação da demanda catiônica para substâncias orgânicas

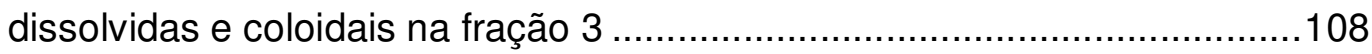

3.3.2.9 Determinação da turbidez ....................................................... 109 


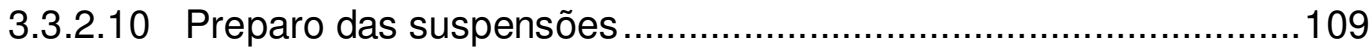

3.3.2.11 Testes de retenção e drenagem..................................................110

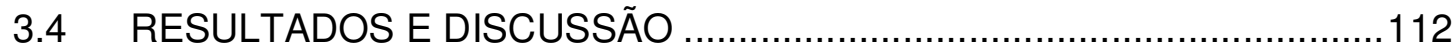

3.4.1 Caracterização da suspensão de fibra ………................................112

3.4.2 Efeito da dosagem do coagulante na retenção de partículas e na drenagem

3.4.3 Efeito de forças de cisalhamento na demanda catiônica e na turbidez da água branca 119

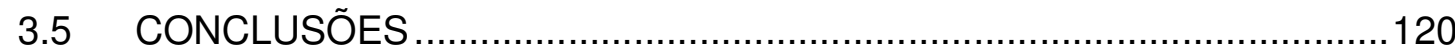

4 PRINCIPAIS MATERIAIS, PROCEDIMENTOS E TÉCNICAS UTILIZADAS NO

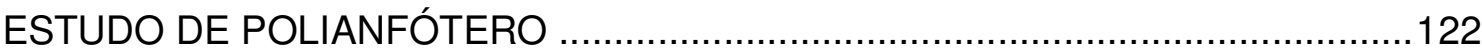

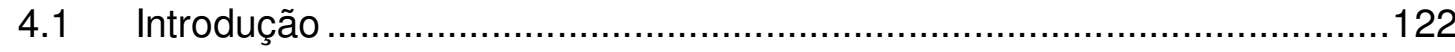

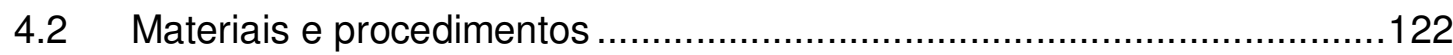

4.2.1 Superfícies modelos .................................................................122

4.2.2 Filmes finos de celulose.............................................................123

4.2.2.1 Limpeza dos cristais de quartzo revestidos com ouro...................123

4.2.2.2 Preparação da solução de celulose ...............................................125

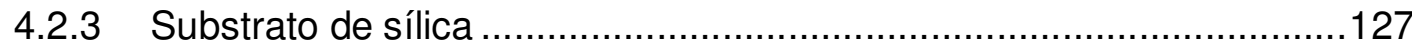

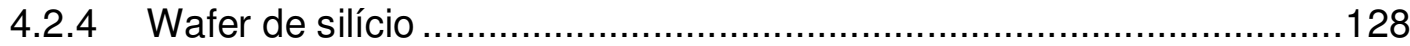

4.3 Técnicas Instrumentais ...............................................................129

4.3.1 Balança Microgravimétrica com Cristal de Quartzo e Dissipação de

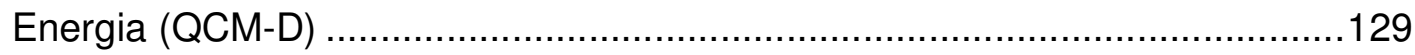

4.3.2 Microscopia de Força Atômica (AFM) .............................................133

4.3.3 Espalhamento Dinâmico de Luz .................................................136

4.3.4 Medidor de densidade de carga em partículas .................................138

5 POLIANFÓTEROS COMO AGENTE DE RESISTÊNCIA A SECO DO PAPEL 140

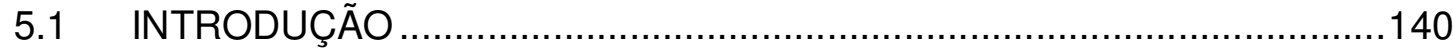

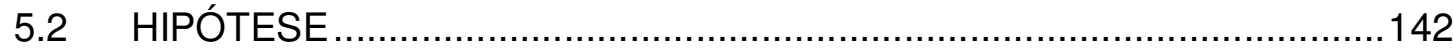

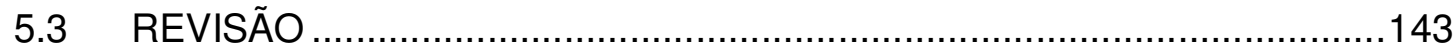

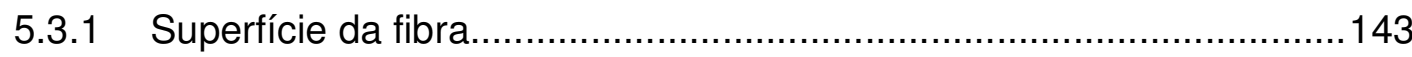

5.3.2 Resistência do papel ..................................................................... 144

5.3.3 Alternativas para aumentar a resistência a seco do papel ..................144

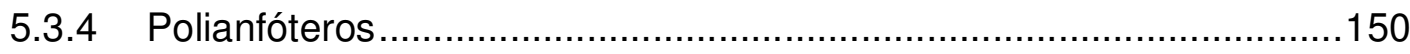


5.3.4.1 Polianfóteros em solução

153

5.3.4.2 Aspectos teóricos sobre a adsorção de polianfóteros.

156

5.3.4.2.1 Adsorção de cadeia simétrica simples de polianfóteros sobre superfícies carregadas.

156

5.3.4.2.2 Adsorção de polianfótero em multicamadas em superfície carregada 160

5.3.4.3 Estudos práticos sobre a adsorção de polianfóteros. 161

5.3.4.4 Propriedades viscoelásticas de camadas de polianfóteros adsorvidas em superfícies carregadas .....................................................163

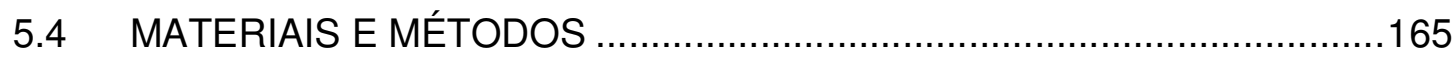

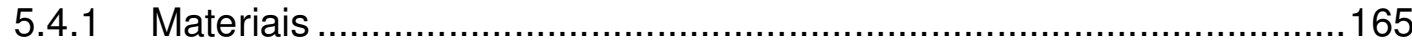

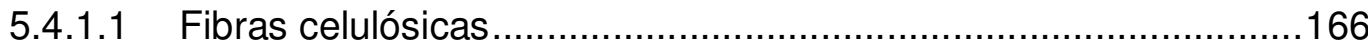

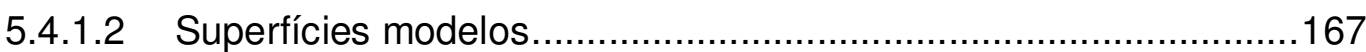

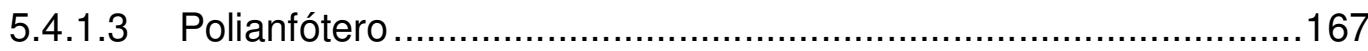

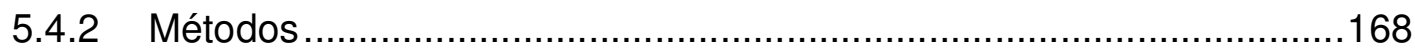

5.4.2.1 Adsorção do polianfótero em superfície de fibra, preparação de folhas manuais e teste de resistência mecânica ........................................168

5.4.2.2 Polianfótero em solução ..........................................................170

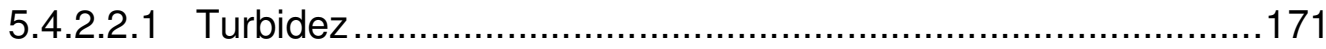

5.4.2.2.2 Densidade de carga ......................................................... 172

5.4.2.2.3 Diâmetro hidrodinâmico das partículas ...................................172

5.4.2.3 Adsorção em superfícies modelos ............................................174

5.4.2.3.1 Balança microgravimétrica com dissipação de energia ...........174

5.4.2.3.2 Microscopia de força atômica ...............................................177

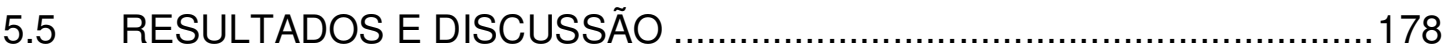

5.5.1 Efeito do polianfótero na resistência do papel ...................................178

5.5.1.1 Efeito da dosagem do polianfótero..............................................178

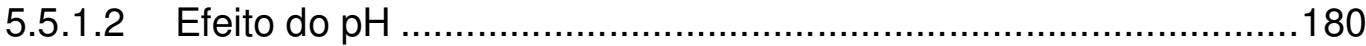

5.5.1.3 Efeito da força iônica..............................................................182

5.5.2 Estudo do polianfótero em nível molecular ........................................184

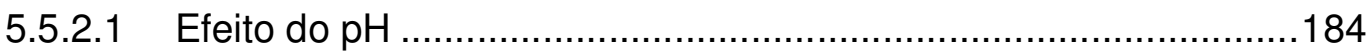

5.5.2.1.1 Polianfótero em solução......................................................184

5.5.2.1.2 Adsorção em superfícies modelos ……………………….....189

5.5.2.1.2.1 Substratos de sílica ........................................................189 
5.5.2.1.2.2 Wafer de silício 193

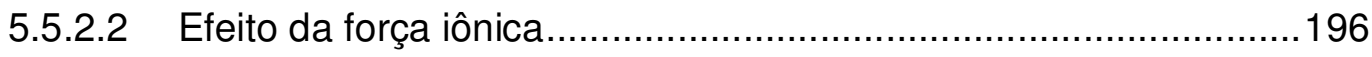

5.5.2.2.1 Polianfótero em solução.......................................................196

5.5.2.2.2 Dinâmica de adsorção do polianfótero em superfícies de sílica e de filme de celulose ....................................................................199

5.5.2.2.3 Avaliação do processo de adsorção de polianfótero em

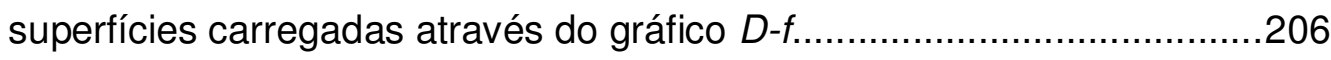

5.5.2.2.4 Espessura e massa específica das camadas adsorvidas de acordo com a equação de Sauerbrey e com o modelo de Voigt................210 5.5.2.2.5 Habilidade de inchamento de camadas de polianfóteros preadsorvidas em superfícies de carga oposta.....................................215

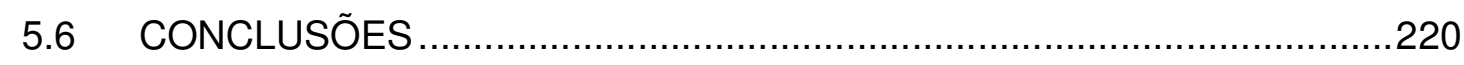

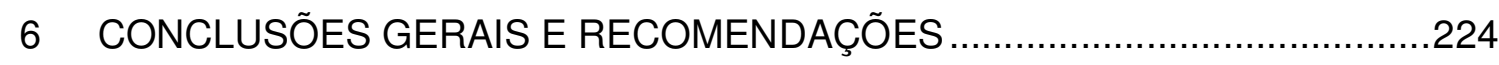

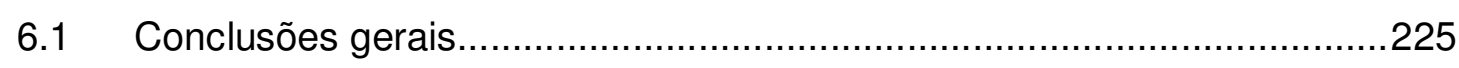

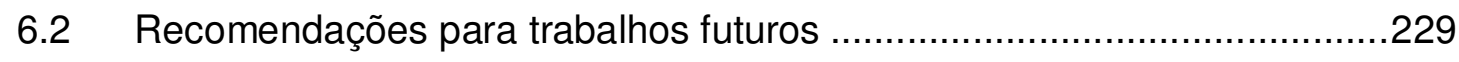

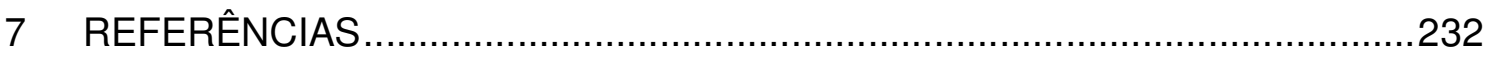

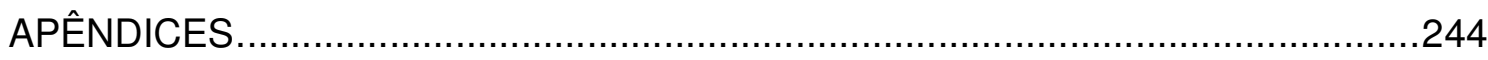




\section{LISTA DE ABREVIATURAS E SIGLAS}

\begin{tabular}{|c|c|}
\hline ACF & Autocorrelation Fuction \\
\hline AFM & Atomic Force Microscopy \\
\hline AKD & Alkyl Ketene Dimer \\
\hline A-PAM & Anionic- Polyacrylamide \\
\hline ASA & Alkyl Succinic Anhydrid \\
\hline ATC & Anionic Trash Catchers \\
\hline BJ & Britt Jar \\
\hline CD & Paper Machine Cross Direction \\
\hline CMC & Celulose microcristalina \\
\hline CMC-Na & Carboximetilcelulose de sódio \\
\hline C-PAM & Cationic-Polyacrylamide \\
\hline DC & Dissolved and Colloidal Substances \\
\hline DC & Demanda Catiônica \\
\hline DCE & Dupla Camada Elétrica \\
\hline DDJ & Dynamic Drainage Jar \\
\hline DLS & Dynamic Light Scattering \\
\hline DLVO & Derjaguin-Landau e Verwey-Overbeek \\
\hline DMAPAA & Dimethylaminopropyl acrylamide \\
\hline DMSO & Dimetilsulfóxido \\
\hline DQO & Demanda Química de Oxigênio \\
\hline ECF & Elemental Chlorine Free \\
\hline FBRM & Focused Beam Reflectance Measurement \\
\hline HPLC & High Performance/Pressure Liquid Chromatography \\
\hline ISO & International Organization for Standardization \\
\hline KPVS & Potassium Polyvinyl Sulfate \\
\hline MD & Paper Machine Direction \\
\hline Mesh & Número de vazios por polegada linear \\
\hline NMMO & N-methylmorpholine Oxide \\
\hline N-PAM & Neutral-Polyacrylamide \\
\hline NTU & Nephelometric Turbidity Units \\
\hline PAA & Polyacrilic Acid \\
\hline PAC & Polyaluminium Chloride \\
\hline PAE & Polyamide Polyamine Epichlorohydrin \\
\hline $\mathrm{PAH}$ & Polyallylamine Hydrochloride \\
\hline
\end{tabular}




\begin{tabular}{|c|c|}
\hline PAM & Polyacrylamide \\
\hline PAnf & Polianfótero \\
\hline PCC & Precipitated Calcium Carbonate \\
\hline PCD & Particle Charge Detector \\
\hline PCMA & poly[[2-(propionyloxy)ethyl] trimethylammonium chloride] \\
\hline Poli-DADMAC & Polydiallyldimethylammonium Chloride \\
\hline PEI & Polyethylene Imine \\
\hline PEO & Polyethylene Oxide \\
\hline PIE & Ponto isoelétrico \\
\hline PMAA- $b$-PDMAEMA & Poly(methacrylicacid)-block-Poly(dimethylamino)ethyl methacrylate \\
\hline PSS & Polystyrene Sulfonate \\
\hline PVA & Polyvinylamine \\
\hline PVAm & Polivinilamina \\
\hline QCM & Quartz Crystal Microbalance \\
\hline QCM-D & Quartz Crystal Microbalance with Energy Dissipation \\
\hline RMS & Root Mean Square \\
\hline rpm & Rotações por minuto \\
\hline SFA & Surface Forces Apparatus \\
\hline SFM & Scanning Force Microscopy \\
\hline SZP & System Zeta Potential \\
\hline TAPPI & Technical Association of Pulp and Paper Industries \\
\hline TCF & Totally Chlorine Free \\
\hline UV & Ultravioleta \\
\hline UVO & Ultravoleta - Ozônio \\
\hline $\mathrm{V}_{\mathrm{A}}$ & Forças de atração \\
\hline VCP & Votoratim Celulose e Papel \\
\hline $\mathrm{V}_{\text {máx. }}$ & Valor máximo de energia \\
\hline$V_{R}$ & Forças de repulsão \\
\hline WEC & Wet End Chemistry \\
\hline XPS & X-ray Photoelectron Spectroscopy \\
\hline ZD & Z-direction \\
\hline
\end{tabular}




\section{LISTA DE SÍMBOLOS E LETRAS GREGAS}

\section{SímBOLOS}

\begin{tabular}{|c|c|}
\hline$A$ & Área piezoelétrica ativa (Capítulo 4) \\
\hline$A$ & Valor médio da área da sessão transversal da fibra (Capítulo 5) \\
\hline "a" e "b" & Constantes de van der Waals \\
\hline$b$ & $\begin{array}{l}\text { Resistência ao cisalhamento por unidade de área ligada o que corresponde a } \\
\text { força das ligações (Capítulo 5) }\end{array}$ \\
\hline$C$ & $\begin{array}{l}\text { Constante sensitiva para cálculo da massa com a técnica da balança } \\
\text { microgravimétrica (Capítulo } 4 \text { ) }\end{array}$ \\
\hline$C$ & Concentração normal do polímero (Capítulo 4) \\
\hline$C_{i}$ & Constantes moleculares (Capítulo 2) \\
\hline$C S T$ & Consistência média da suspensão de fibra \\
\hline$D$ & Dissipação de energia (Equação 4.4) \\
\hline$D$ & Coeficiente de difusão (Equação 4.7) \\
\hline$d$ & Diâmetro esférico hidrodinâmico equivalente \\
\hline$\Delta D$ & Variação da dissipação de energia da oscilação do cristal \\
\hline$D I$ & Demanda iônica \\
\hline$E_{p}$ & Energia potencial resultante entre moléculas \\
\hline$F$ & Teor de finos \\
\hline fo & Frequência fundamental \\
\hline$\Delta f$ & Variação da frequência \\
\hline$g$ & Aceleração da gravidade \\
\hline$G\left(\tau_{a}\right)$ & Função de autocorrelação \\
\hline$I_{i}$ & Potenciais de ionização dos átomos ou moléculas \\
\hline$I\left(\tau_{a}\right)$ & Intensidade de flutuações detectada no tempo $\tau$ \\
\hline$I\left(\tau+\tau_{a}\right)$ & Intensidade de flutuações detectada no tempo $\tau+\tau_{a}$ \\
\hline$K_{B}$ & Constante de Boltzmann, $1,38.10^{-16}$ erg. ${ }^{\circ} \mathrm{K}^{-1}$ \\
\hline$L$ & Comprimento da fibra \\
\hline$\Delta m$ & Quantidade de massa adsorvida na superfície modelo \\
\hline
\end{tabular}


fundamental (Capítulo 4)

$n$

Número de moles (Capítulo 2)

$P \quad$ Pressão (Capítulo 2)

$P \quad$ Peso da amostra líquida (Capítulo 4)

$P \quad$ Perímetro da seção transversal da fibra (Capítulo 5)

$P R \quad$ Peso seco do resíduo do jarro

PS Peso seco da alíquota

$P U \quad$ Peso úmido da alíquota

$q_{i} \quad$ Carga dos átomos ou molécula

$r \quad$ Distância que separa os átomos ou moléculas ou distância que separa os centros dos dipolos

$R \quad$ Constantes dos gases

$R B A \quad$ Área relativa ligada da folha dando indicação do número total de ligações na folha

$\mathrm{R}_{\mathrm{z}} \quad$ Comprimento espiralado da cadeia polarizada do polímero

$S_{a} \quad$ Habilidade de inchamento ou mudança de conformação da camada adsorvida de polianfótero

$T \quad$ Temperatura absoluta (Capítulo 2 e 5)

$T$ Resistência à tração do papel (Capítulo 5)

$t_{l} \quad$ Espessura da camada adsorvida na superfície modelo

V Volume (Capítulo 2)

$V \quad$ Volume do polímero gasto (Capítulo 4)

$W_{a}$, Trabalho de adesão entre o sólido e o líquido

$x_{1}, x_{2}$ e $x_{2} \quad$ Fração molar dos componentes do polianfótero

Z Resistência à tração em zero-span

\section{LETRAS GREGAS}

$\begin{array}{ll}\alpha_{i} & \text { Polarizabilidade da molécula “i” } \\ \gamma_{\mathrm{LV}} & \text { Tensão superficial do líquido com o vapor } \\ \gamma_{\mathrm{S}} & \text { Energia de superfície do sólido } \\ \gamma_{\mathrm{SL}} & \text { Energia de interface sólido-líquido } \\ \delta & \text { Profundidade de penetração da camada viscosa }\end{array}$




\begin{tabular}{|c|c|}
\hline$\varepsilon$ & Constante dielétrica do meio \\
\hline$\zeta$ & Potencial eletrocinético, potencial zeta ou potencial de cisalhamento \\
\hline$\eta$ & $\begin{array}{l}\text { Viscosidade do diluente na determinação do diâmetro hidrodinâmico da } \\
\text { partícula }\end{array}$ \\
\hline$\eta_{f}$ & Viscosidade do meio líquido na interface com o cristal \\
\hline$\eta_{l}$ & Viscosidade da camada adsorvida na superfície modelo \\
\hline$\theta_{i}$ & Ângulo de contato ou ângulo de orientação entre os dipolos \\
\hline $1 / \kappa$ & Espessura da dupla camada elétrica ou comprimento de Debye \\
\hline$\lambda$ & Comprimento de Gouy-Chapman \\
\hline$\lambda_{1}$ e $\lambda_{2}$ & Comprimento das camadas adsorvidas em superfície carregada \\
\hline$\mu_{i}$ & Momento de dipolo da molécula "i” \\
\hline$\mu_{q}$ & Módulo de cisalhamento do quartzo, $2,947 \times 10^{-11} \mathrm{dynas} / \mathrm{cm}^{2}$ \\
\hline$\mu_{l}$ & Módulo de cisalhamento da camada adsorvida na superfície modelo \\
\hline$\rho_{q}$ & Densidade do quartzo, $2,648 \mathrm{~g} / \mathrm{cm}^{3}$ \\
\hline$\rho_{f}$ & Densidade do meio líquido na interface com o cristal \\
\hline$\rho_{l}$ & Densidade da camada adsorvida na superfície modelo \\
\hline$\rho$ & Densidade do material fibroso (Capítulo 5) \\
\hline$\rho_{\text {PAnf }}$ & Densidade da camada de polianfótero \\
\hline$\rho_{1}, \rho_{2}$ e $\rho_{3}$ & Densidade dos componentes do polianfótero \\
\hline$\sigma_{1}, \sigma_{2}$ e $\sigma_{3}$ & Superfícies carregadas \\
\hline$\tau$ & Constante do tempo de amortecimento da amplitude de oscilação \\
\hline$\tau_{a}$ & Tempo de decaimento \\
\hline$\Phi^{E I}$ & Energia potencial da interação \\
\hline$\Phi^{P}$ & Energia potencial de interação entre dois dipolos \\
\hline$\Phi^{\prime}$ & Energia potencial de interação entre dipolo e dipolo induzido \\
\hline$\chi$ & Taxa do módulo de armazenamento \\
\hline$\Psi_{\circ}$ & Potencial de superfície \\
\hline$\omega$ & Potencial de Stern \\
\hline
\end{tabular}




\section{INTRODUÇÃO GERAL}

A química da parte úmida da fabricação de papéis consiste em um sistema complexo que envolve diversas interações entre superfícies em um meio de dispersão. Mesmo considerando o desenvolvimento tecnológico ocorrido nas diversas etapas de fabricação do papel, ainda existem muitos fenômenos de interações interfaciais que necessitam ser mais bem entendidos. Esses fenômenos podem explicar os processos de agregação das partículas, os quais influenciam tanto a retenção das mesmas e a drenagem do meio de dispersão na parte úmida da máquina, quanto as propriedades voltadas à qualidade do produto acabado.

Apesar dos modernos recursos de automação para controle do processo produtivo em máquinas modernas e dos recursos para monitoramento da qualidade do produto final, ainda é possível se produzir grande quantidade de papel fora de especificação com causas desconhecidas. Este fato se deve, não somente ao grande número de variáveis existentes na etapa de formação da folha, mas também à variabilidade das características da polpa que alimenta a fabricação do papel e a não uniformidade das condições operacionais.

Atualmente, existem estudos sobre as interações interfaciais dos substratos da suspensão de fibras com resultados elucidativos em relação à retenção e drenagem, à formação de folha e as suas propriedades de resistência. Entretanto, a presença de grande número de variáveis não permite, às vezes, a aplicação desse conhecimento teórico para imediato diagnóstico da causa, o que leva ao profissional a fazer uso de métodos empíricos nas soluções dos problemas.

A maioria das fábricas de papel controla a formação da folha pelo monitoramento de parâmetros do produto acabado. Esse aspecto é bastante relevante porque os fenômenos que influenciam a qualidade do papel ocorrem, principalmente, no início do processo e, quando o problema é detectado, grande quantidade de papel já foi produzida.

O papel é formado a partir de uma mistura complexa de substratos dispersos em meio aquoso com características bastante heterogêneas considerando fatores como tamanho e forma das partículas sólidas; química de superfície e número e 
distribuição de sítios de adsorção, bem como a acessibilidade aos mesmos. Alguns dos principais componentes da suspensão são: as fibras, os fragmentos de fibras, os finos orgânicos e as cargas minerais. Todo esse material, seja em forma individual ou em forma de agregados, apresentam, em maior ou menor proporção, influência no processo de retenção e drenagem e na qualidade da folha.

Com o objetivo de melhorar as variáveis operacionais e a qualidade final do produto, vários reagentes químicos são, também, adicionados ao sistema e apresentam funções importantes no processo como um todo. Dentre outros, podem ser citados: agentes de retenção (p. ex. os polieletrólitos), agentes de drenagem (p. ex. sílica coloidal), os aditivos para controle da demanda iônica (p. ex. os polímeros de baixo peso molecular e elevada densidade de carga), os agentes de colagem responsáveis pelo aumento da resistência à penetração de líquidos no papel e os agentes de resistência a seco como o amido catiônico. Considerando ainda aditivos químicos, atualmente, estudos em nível de laboratório com polímeros anfóteros e com novas tecnologias para aplicação de polieletrólitos como a formação de complexos e a deposição de polieletrólitos em multicamadas, também têm mostrado resultados satisfatórios para a melhoria das propriedades de resistência do papel. Além dos reagentes citados, outros constituintes podem ser encontrados na suspensão de fibras como eletrólitos de baixo peso molecular que originam a força iônica e as substâncias orgânicas, dissolvidas e coloidais, muitas das quais formam o lixo aniônico. A composição e a proporção destas substâncias na suspensão de fibras influenciam sobremaneira nos fenômenos de interação interfaciais que ocorrem durante a formação da folha e, portanto, na retenção de partículas inorgânicas e orgânicas e na qualidade da folha.

Outro aspecto relevante é que, no processo de fabricação de papel, estão presentes forças decorrentes da hidrodinâmica e do cisalhamento da suspensão. Estas forças exercem efeito mecânico tanto no processo de floculação, promovendo o contato entre substratos e aditivos, quanto no processo de defloculação e refloculação dos contituintes da suspensão. Portanto, essas forças, sempre presentes nos deslocamentos da suspensão através de tubulações e bombeamentos, existentes em maior intensidade em máquinas de maior velocidade, influenciam em dada proporção na qualidade de formação do papel e no andamento da máquina. 
Em razão do desenvolvimento de técnicas avançadas capazes de caracterizar química e fisicamente as superfícies dos materiais em escala nanométrica e de medir pequenas quantidades de camadas de polieletrólitos depositadas em superfícies carregadas e suas propriedades viscoelásticas, bem como de medir fenômenos eletrocinéticos de suspensões aquosas, é esperado que o entendimento dos processos de interação entre componentes, retenção e drenagem, e dos processos de ligações interfibras e forças dessas ligações na fabricação do papel, seja mais efetivo. Podem-se citar algumas dessas técnicas, as quais foram utilizadas no presente estudo, a balança microgravimétrica com cristal de quartzo e dissipação de energia (QCM-D); a técnica de espalhamento dinâmico de luz (DLS); a de microscopia de força atômica (AFM); a de determinação de densidade de carga de polieletrólitos, dentre outras.

De maneira geral, o objetivo deste trabalho é a utilização de aditivos químicos para estudo da retenção de cargas e drenagem da água branca em processo de fabricação de papel bem como para o estudo da resistência a seco do papel.

Dessa forma, buscando entender os fenômenos interfaciais que ocorrem na etapa de formação da folha de papel, este trabalho descreve no Capítulo 2 os conceitos de química coloidal e de superfície, aplicadas à etapa química de formação da folha. Neste capítulo foram considerados da literatura pontos importantes relacionados à formação do papel incluindo os principais componentes da suspensão de fibras com suas características físicas, químicas e físico-químicas, os quais constituem a fase dispersa; bem como é discorrido sobre o meio de dispersão; sobre a teoria de ionização dos substratos em meio aquoso; sobre a formação da dupla camada elétrica em substâncias coloidais; sobre a teoria DLVO aplicada ao sistema de fabricação de papel; e sobre as forças de interações entre substratos. Os mecanismos de agregação de partículas da suspensão de fibras existentes na literatura também foram considerados neste capítulo.

Para se observar alguns desses fenômenos de interação, foi desenvolvido um trabalho de laboratório semelhante aos testes utilizados em fábricas de papel, utilizando o mecanismo de floculação complexo, o sistema Dual. Este mecanismo se baseia na associação de polímero iônico e micropartículas. Nesse estudo foi 
verificado o efeito da dosagem de coagulante $\mathrm{e}$ da presença de forças de cisalhamento no processo de retenção e drenagem de cargas inorgânicas discutidos no Capítulo 3.

No Capítulo 4, descreve-se um protocolo de limpeza de sensores de filmes de celulose desenvolvido neste trabalho, combinando os tratamentos enzimático e químico, o qual foi bastante útil nas pesquisas de adsorção de polianfóteros em filmes de celulose. Além, disso, a título de texto auto contido, descreve-se os conceitos e procedimentos de técnicas instrumentais avançadas as quais foram utilizadas no desenvolvimento deste trabalho.

No capítulo seguinte, Capítulo 5, foi estudada a aplicação de polianfótero como agente de resistência a seco. A avaliação da adsorção do polianfótero foi realizada tanto no material fibroso quanto em superfícies modelos, substratos de sílica e ultrafilmes de celulose. Com a utilização de técnicas em escala nanométrica, como QCM, AFM e DLS, puderam ser observadas e relacionadas as diferentes características do polímero na interface sólido-líquido e as propriedades viscoelásticas das camadas adsorvidas, para diferentes condições de $\mathrm{pH}$ e de força iônica.

Finalmente, no Capítulo 6 são apresentadas as conclusões gerais e propostos futuros trabalhos relacionados ao assunto.

A Tabela 1.1 mostra o resumo dos principais experimentos e as respectivas medições realizadas em laboratórios no desenvolvimento deste trabalho.

Houve extenso compartilhamento de infraestruturas dos laboratórios da VCP Piracicaba, da Escola Politécnica da Universidade de São Paulo, da Universidade do Estado da Carolina do Norte e do Instituto de Pesquisas Tecnológicas do Estado de São Paulo e intercâmbio com seus respectivos especialistas. 
Tabela 1.1 - Experimentos e respectivas medições realizadas em laboratório

\begin{tabular}{|c|c|}
\hline & Exp \\
\hline Capítulo 3 & $\begin{array}{l}\text { Título: EFEITO DA DOSAGEM DE COAGULANTE E DA FORÇA DE } \\
\text { CISALHAMENTO NO PROCESSO DE DRENAGEM E DE RETENÇÃO DE } \\
\text { PARTÍCULAS } \\
\text { (1) Caracterização da suspensão de fibras } \\
\text { - Caracterização da suspensão de fibras segundo norma da Tappi com o } \\
\text { equipamento Fiber Quality Analizer, pH, condutividade } \\
\text { - Determinação do teor de finos na polpa através da norma Tappi T 261-cm-00 } \\
\text { - Determinação do potencial zeta do material fibroso através do Mütek SZP-06 } \\
\text { - Determinação da demanda iônica de filtrados através do Mütek PCD-03 } \\
\text { Particle Charge Detector associado ao Mütek PCD-T3 Titrator } \\
\text { (2) Programa de retenção e drenagem e testes de cisalhamento } \\
\text { - Testes de retenção e drenagem através do aparelho de Britt Jar } \\
\text { - Determinação da turbidez do filtrado }\end{array}$ \\
\hline Capítulo 5 & $\begin{array}{l}\text { Título: POLIANFÓTEROS COMO AGENTE DE RESISTÉNCIA A SECO DO PAPEL } \\
\text { (1) Estudo do polianfótero em solução } \\
\text { - Determinação da turbidez, da densidade de carga do polímero e do tamanho } \\
\text { aparente de partícula através das técnicas de turbidímetro DRT-15CE, Mütek } \\
\text { PCD-03 Particle Charge Detector e BECKMAN COULTER N4 PLUS, } \\
\text { respectivamente } \\
\text { (2) Estudo de adsorção de polianfótero em fibras } \\
\text { - Preparação de folhas manuais de acordo com a norma TAPPI T205 sp-95 e } \\
\text { realização de testes físicos em papéis de acordo com as normas TAPPI T404 } \\
\text { cm-92 para índice de tração e TAPPI T833 pm-94 para a resistência de } \\
\text { ligação interfibras (Scott Bond) } \\
\text { (3) Estudo de adsorção de polianfóteros em superfícies modelos de sílica e de } \\
\text { filme de celulose } \\
\text { - Balança microgravimétrica de cristal de quartzo com dissipação de energia } \\
\text { - Microscopia de força atômica }\end{array}$ \\
\hline
\end{tabular}

Os polímeros na formulação do papel desempenham importantes funções como a melhoria dos parâmetros operacionais da máquina, retenção e drenagem de finos e de carga mineral, e como a melhoria da qualidade do papel como produto acabado. Neste trabalho foram ultizados polímeros para simular testes de retenção e drenagem bem como um polímero para aumentar a resistência a seco do papel, ambos em experimentos de laboratório. 
Os trabalhos publicados pelo autor, relacionados com a presente tese, estão listados abaixo:

SILVA, D. J.; YAMAGUCHI, T.; PARK, S.W.; HUBBE, M.; ROJAS, O. Swelling and water-holding ability of adsorbed polyampholytes. In: ACS NATIONAL MEETING AND EXPOSITION, 235., 2008, New Orleans, LA. Abstracts. New Orleans, 2008. Res. CELL49 [1169067]. (Poster presentation).

SILVA, D. J.; SONG, J.; YAMAGUCHI, T.; HUBBE, M. A.; PARK, S. W.; ROJAS, O. J. Swelling and water-holding ability of adsorbed polyampholytes. In: ACS COLLOID AND SURFACE SCIENCE SYMPOSIUM, 82., 2008, Raleigh, NC. Abstracts. Raleigh, 2008. Res. 258. (Poster presentation).

SILVA, D. J.; ROJAS, O. J.; HUBBE, M. A.; PARK, S. W. (2008). Dynamics of polyampholyte adsorption on cellulose nanofilms. In: ANNUAL MEETING OF THE BRAZILIAN MATERIALS RESEARCH SOCIETY (SBPMat), 7., 2008, Guarujá, SP, Brazil. Abstracts. Guarujá, 2008. (Poster presentation).

SILVA, D. J.; YAMAGUCHI, T.; SONG, J.; HUBBE, M. A.; PARK, S. W.; ROJAS, O. J. Adsorbed polyampholyte swelling ability and its effect on paper strength. In: PULP AND PAPER INTERNATIONAL CONGRESS \& EXHIBITION, 41., 2008, Sao Paulo. São Paulo, 2008. CD-ROM. (Poster presentation).

SILVA, D. J.; HUBBE, M. A.; PARK, S. W.; ROJAS, O. J. Adsorption and viscoelastic properties of polyampholytes monitored by QCM-D. In: CONGRESO IBEROAMERICANO DE INVESTIGACION EN CELULOSA Y PAPEL, 5., 2008, Guadalajara, Jalisco. Guadalajara, 2008. CD-ROM. (Oral presentation).

YAMAGUCHI, T., SILVA, D. J., HUBBE, M. A., ROJAS, O. J. The effect of cationic additives on the adsorption of polymapholyte on cellulose. In: ACS COLLOID AND SURFACE SCIENCE SYMPOSIUM,82., 2008, Raleigh, NC. Abstracts. Raleigh, 2008. Res. 252. (Poster presentation).

SILVA, D. J.; ROJAS, O. J.; HUBBE, M. A.; PARK, S. W. Stimuli-responsive polyampholyte and its adsorption behavior on model surfaces. In: ACS National Meeting \& Exposition, 237., 2009, Salt Lake City, UT. Res. 101. (Poster presentation).

SILVA, D. J.; ROJAS, O. J.; PARK, S. W.; HUBBE, M. A. Evaluation of adsorbed polyampholyte layers by using quartz crystal microbalance. In: International Symposium on Process Systems Engineering, PSE2009, 10., 2009, Salvador, BA. Anais... Salvador, BA, 2009. p.1929-1934. (Poster presentation).

SILVA, D. J.; ROJAS, O. J.; HUBBE, M. A.; PARK, S. W. Adsorption behavior of dry-strength polyampholytes as a function of solution $\mathrm{pH}$. In: PULP AND 
PAPER INTERNATIONAL CONGRESS \& EXPOSITION 42. São Paulo, SP, Brazil. Anais...São Paulo, SP, Brazil, 2009. Não paginado. (Oral presentation).

SILVA, D. J.; ROJAS, O. J.; HUBBE, M. A.; PARK, S. W. Enzymatic treatment as a pre-step for remove cellulose films in sensors. In: CONGRESSO BRASILEIRO DE POLÍMEROS 10. Anais... Foz do Iguaçu, PR, Brasil, 2009. Não paginado. (Apresentação em poster).

SILVA, D.J.; ROJAS, O.J.; HUBBE, M.A.; PARK, S.W.; YAMAGUCHI, T.; SONG, J. Polianfóteros: seu uso na fabricação de papel e seu comportamento em solução e em adsorção / Polyampholytes: their use in papermaking and their solution and adsorption behaviors, O Papel, v. 70, $n^{\circ}$ 9, p. 40-50, 2009.

SILVA, D.J.; ROJAS, O.J.; HUBBE, M.A.; PARK, S.W. Enzymatic treatment as a pre-step to remove cellulose films in sensors. Submetido ao Journal of Cellulose.

SONG, J.; YAMAGUSHI, T.; SILVA, D. J.; HUBBE, M. A.; ROJAS, O. J. Effect of charge asymmetry on adsorption and phase separation of polyampholytes on silica and cellulose surfaces. Journal Physical Chemistry B, v. 114, nº 2, p. 719-727, 2010. 


\section{REVISÃO DE LITERATURA}

Como o desenvolvimento dos trabalhos experimentais desta tese se insere na parte úmida da fabricação de papel, o conhecimento de tópicos que envolvem essa etapa se torna relevante. Portanto, na revisão geral de literatura, foram considerados os principais tópicos sobre "papel" e sua complexidade para produzí-lo.

\subsection{O papel}

De forma geral, o papel se apresenta como uma rede de fibras entrelaçadas, distribuídas estocasticamente nas três dimensões: direção da máquina ( $M D$ Machine Direction), direção transversal a da máquina ( $C D$ - Cross Direction) e direção ao longo da espessura do papel (ZD - Z-direction) (Figuras 2.1 A e B). Como a relação entre o comprimento da fibra e sua largura é muito elevada, da ordem de 30 a 40 vezes, as fibras se apresentam como "tubos" finos e o papel se aproxima de uma estrutura planar com duas dimensões, MD e CD (Figura 2.1 A). As características anatômicas, químicas e físicas dessas fibras conferem ao papel propriedades físico-mecânicas e ópticas particulares.

Além de fibras, o papel é constituído de fragmentos de fibras, de finos, de carga mineral e de aditivos químicos. No processo de formação de folha, o papel é o resultado de todos esses constituintes, distribuídos de forma aleatória na estrutura tridimensional da folha, tendo como veículo a água. 


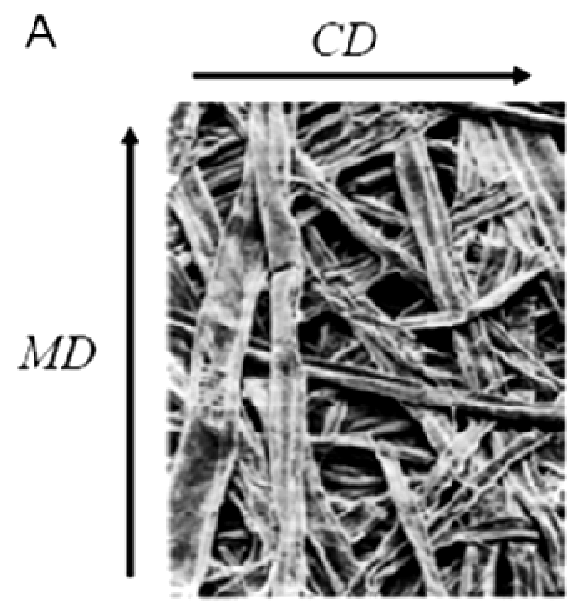

Extraido de Smook (1987)

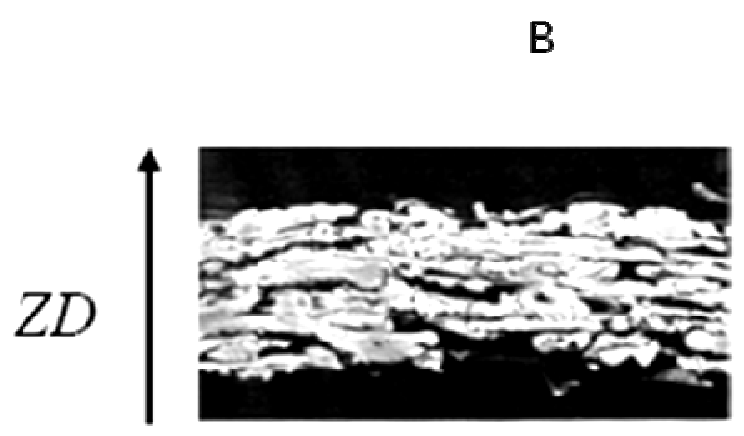

Extraido de Niskanen(1999)

Figura 2.1 - $(A)^{1}$ Fotomicrografia de uma folha de papel mostrando as direções do comprimento da máquina (MD) e da largura da máquina $(\mathrm{CD})$ e $(B)^{2}$ fotomicrografia de uma folha de papel na direção perpendicular (ZD) às direções MD e CD.

O papel, na sua forma mais simples, é um produto que apresenta funções importantes para a humanidade, especialmente, para o registro do desenvolvimento e do conhecimento dos diversos povos do mundo. O papel pode ser classificado em vários tipos a depender de seu uso. Impressão e escrita, para fins sanitários, embalagens, cartão e papéis especiais.

A uniformidade é um dos parâmetros responsáveis pela qualidade do papel e está diretamente relacionada ao tamanho e à distribuição dos flocos macroscópicos e microscópicos na folha de papel formada, influenciando tanto as propriedades físicomecânicas, quanto as propriedades ópticas e de superfície do papel. A uniformidade da folha consiste em um requisito de qualidade bastante exigido por parte dos usuários, normalmente, gráficas (MARTINS et al., 1995), ou quando o papel irá passar por etapas intermediárias antes do seu uso final, como as etapas de revestimento e de calandragem, ou ambas.

\footnotetext{
${ }^{1}$ Adaptada de SMOOK, G. A. Handbook for pulp \& paper technologists. Atlanta: Tappi Press, 1987. 419p. Página 182.

2 Adaptada de NISKANEN, K., KAJANTO, I.; PAKARINEN, P. Paper Structure. In: NISKANEN, K. Paper Physics. Helsinki, Finland: FAPET Oy, 1999. Book 16 of Papermaking Science and Technology Series Books, cap. 1. Página 21.
} 
As características físicas dos flocos e sua distribuição na folha são influenciadas tanto por aspectos químicos e mecânicos característicos de cada sistema, quanto por aspectos morfológicos da fibra e pelo seu histórico adquirido em etapas de processos anteriores (polpação, branqueamento e refino).

Definição mais precisa para formação consiste na variabilidade em massa do papel (NISKANEN, 1999). Essa variabilidade depende da aleatoriedade das fibras distribuídas individualmente, das interações entre elas, da floculação e das forças hidrodinâmicas inerentes à tecnologia de cada fábrica.

A título de ilustração, nas Figuras 2.2A e B podem ser observados diferentes formações de folha. As manchas mais escuras da Figura 2.2A correspondem às regiões de transparência da folha com flocos de dimensões maiores. Flocos de dimensões menores com maior uniformidade da folha podem ser observados na Figura 2.2B.

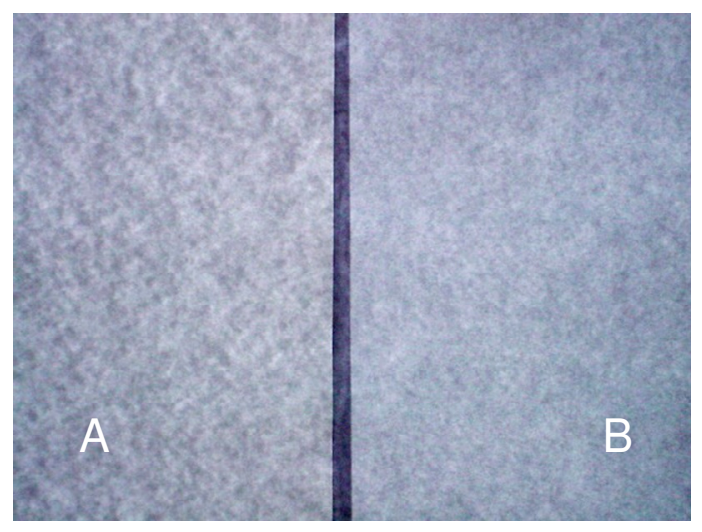

Figura 2.2 - Fotografia digital mostrando duas folhas de papel com tamanho de flocos diferentes: A- Folha formada com flocos maiores e B- Folha formada com flocos menores ${ }^{3}$.

$\mathrm{Na}$ formação da folha, na parte úmida da máquina, interações entre fibras, finos, partículas coloidais, minerais e polímeros, são importantes e influenciam tanto no

\footnotetext{
${ }^{3}$ SILVA, D.J. Floculação em sistema de fabricação de papel. Instituto de Química, USP. Monografia apresentada como parte das exigênicas da disciplina de Físico-química de interfases, $2^{\circ}$ semestre de 2005, 19p.
} 
desempenho do processo quanto na qualidade do papel como pode ser visto em Stén (1999).

As principais etapas da fabricação de papel são: preparo de massa; formação; prensagem, secagem da folha e acabamento.

A Figura 2.3, a título de ilustração, mostra as etapas de formação de folha de um processo genérico ${ }^{4}$.

A etapa de preparo de massa é considerada uma das mais importante, pois confere, em grande parte, as características de qualidade do papel. Esta etapa compreende basicamente o refino, adição de aditivos, ajustes de $\mathrm{pH}$ e de consistência e remoção de impurezas do sistema.

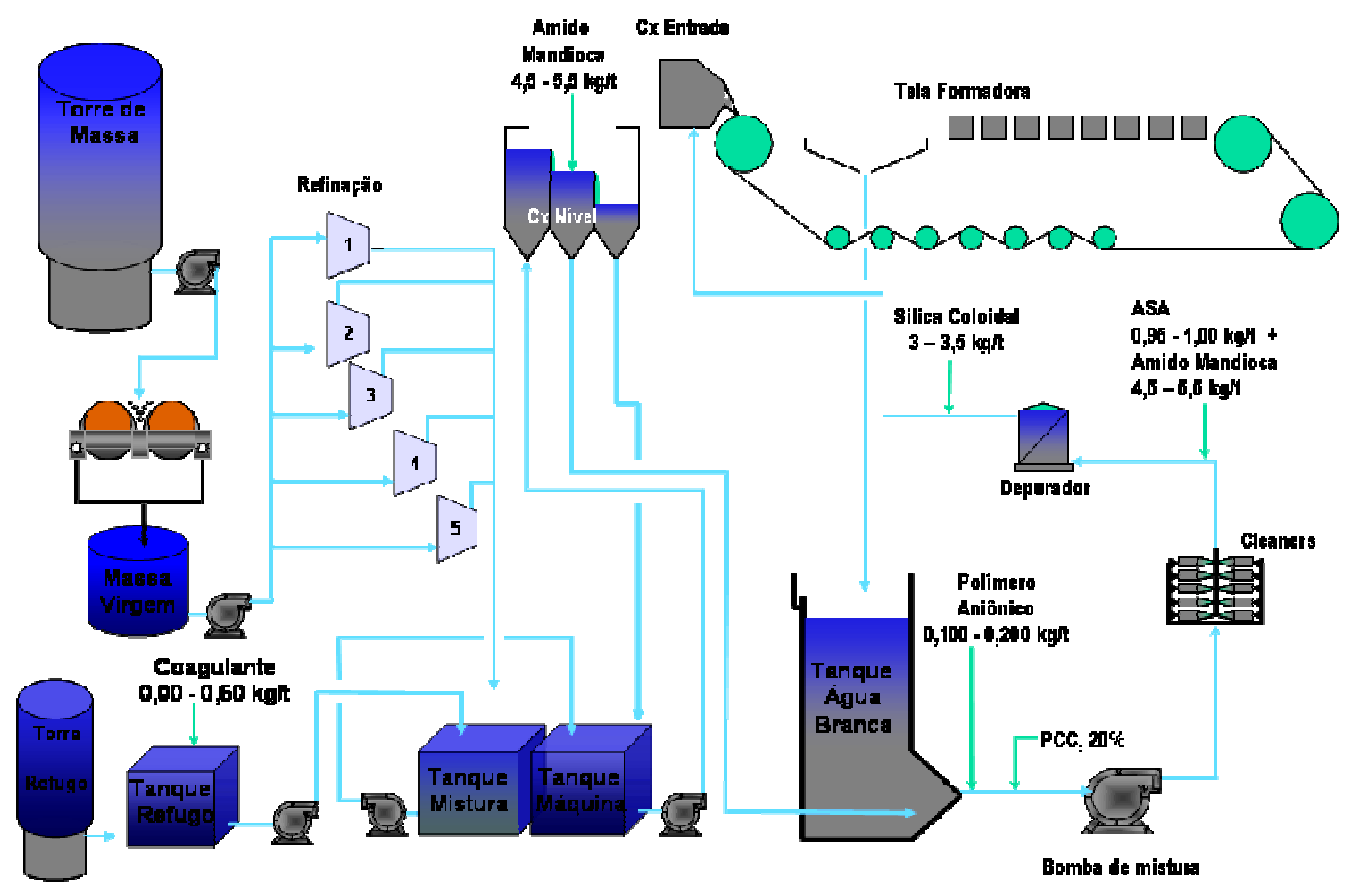

Figura 2.3 - Fluxograma das etapas de formação de folha de uma fábrica genérica.

Inicialmente, a suspensão de fibras do tanque de massa (torre) alimenta a etapa de refinação, após ter sua consistência e pH ajustados para, aproximadamente, 4,5\% e

\footnotetext{
${ }^{4}$ RODRIGUES, P. Apresentação cedida durante visita à empresa EKA Chemical. Sistema Compozil Select de Retenção e Drenagem. EKA Chemicals, Judiaí, Fevereiro de 2007.
} 
8,0, respectivamente (Figura 2.3). A polpa refinada alimenta o tanque de mistura onde, normalmente, é misturada com o refugo, o qual consiste de uma suspensão reaproveitada contendo refilos e material originado de quebras de folha (perda), ou ainda, pode conter fibra reciclada. Antes da mistura, normalmente é adicionado o primeiro reagente químico, o qual tem a função de coagular substâncias dissolvidas e coloidais através da reação de neutralização de cargas ou, também, como é conhecida, reação de coagulação. Após a mistura, a suspensão é conduzida para a caixa de nível onde é, geralmente, adicionado o amido modificado com carga positiva. Neste ponto, o amido tem a função principal de adsorver-se à superfície da fibra, conferindo-Ihe aumento das ligações interfibras e, portanto, da resistência a seco do papel e, ao mesmo tempo, preparando a superfície para a retenção de carga. Outra parte do amido é adicionada ao processo através da emulsificação de cola sintética. Após este ponto, a suspensão tem a sua consistência corrigida com água branca reciclada da máquina e com água de processo para, aproximadamente, $1 \%$, a depender da gramatura do papel a ser produzido. Através de uma bomba de mistura, a suspensão alimenta o sistema de limpeza (cleaners) que tem como função remover as impurezas. No caso do fluxograma da Figura 2.3, são dosados o polímero (neste caso, polieletrólito aniônico) e a carga (carbonato de cálcio precipitado que normalmente apresenta carga superficial positiva) na sucção da bomba de mistura aproveitando-se da turbulência natural da bomba para proporcionar o contato entre a carga e o polímero e a superfície da fibra numa mistura uniforme. Neste ponto, ocorre o fenômeno da floculação com retenção da carga a das substâncias anteriormente coaguladas. Após a remoção das impurezas, é adicionada a cola sintética emulsificada. A cola, com característica hidrofóbica, tem a função de aumentar a resistência à penetração de líquidos do papel evitando a penetração de líquidos em sua estrutura. A suspensão alimenta os depuradores que, devido à sua turbulência, provoca a defloculação dos agregados formados. Após o depurador, a refloculação ocorre na presença de micropartículas coloidais, o que proporciona a formação de flocos menores e mais densos. As micropartículas, que apresentam carga superficial negativa, ocupam os espaços interiores dos flocos onde seriam ocupados pelo meio de dispersão composto em sua maioria por água. Por isso, estas partículas contribuem para a remoção de água, ou seja, para o desaguamento. Quando comparados aos anteriores, os flocos formados após a depuração apresentam características de tamanho e de distribuição que conferem 
melhor qualidade de formação da folha se forem comparados aos flocos formados com programas de retenção convencional, sem micropartículas, apenas com polímeros.

A Figura 2.4 mostra, em linhas gerais, as principais etapas da fabricação do papel após o preparo de massa (SMOOK, 1987). As etapas seguintes à formação da folha são a prensagem, secagem e acabamento. A orientação das fibras no papel em relação à direção $M D$ da máquina ocorre, em grande parte, na saída da caixa de entrada. Por outro lado, a mesa plana contribui com os arranjos e distribuição dos flocos no papel. Na máquina de papel com mesa plana, a maior parte da água livre é drenada através da tela com o auxílio de cilindros, os foils, e de caixas de vácuo. Nas máquinas com tecnologia de dupla formação (Dual Former), a remoção da água branca ocorre através dos dois lados da folha, superior e inferior. A água drenada constitui a água branca que será reaproveitada, em parte, no próprio sistema, como citado anteriormente. A água contida nos poros da folha úmida e no lúmen das fibras que não foi removida na mesa plana será removida através do processo de prensagem. A água remanescente, a qual não foi possível remover através de processos mecânicos, será removida na etapa de secagem através da evaporação.

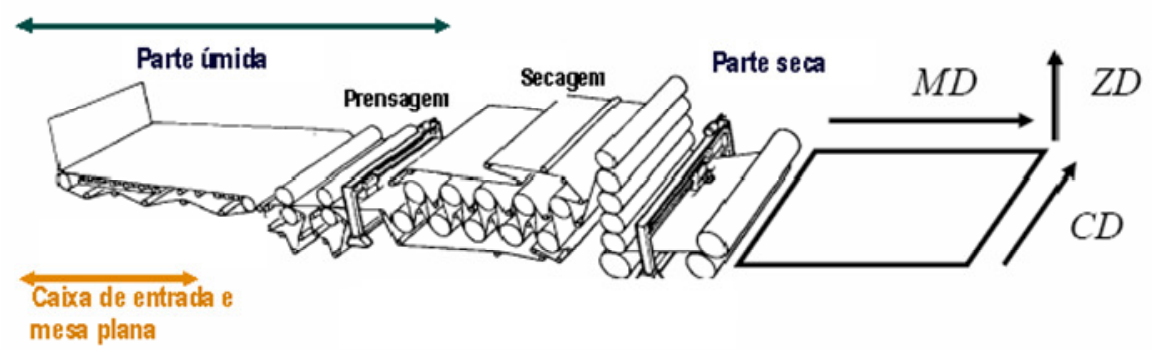

Figura 2.4 - Etapas da fabricação de papel - máquina com mesa plana ${ }^{5}$.

Para entender como ocorrem as interações entre superfícies, é importante conhecer os constituintes do papel, suas dimensões, formas e tipo de carga desenvolvida quando em meio aquoso.

\footnotetext{
${ }^{5}$ Adaptada de SMOOK, G. A. Handbook for pulp \& paper technologists. Atlanta: Tappi Press, 1987. 419p. p. 245.
} 


\subsection{Constituintes da suspensão de fibras para fabricação de papel}

\subsection{1 Água}

A água apresenta grande número de aplicações em ciência e tecnologia, sendo uma substância fundamental para o processo de fabricação de papel, pois consiste no veículo para os seus componentes, além de viabilizar as interações químicas e físicas entre os mesmos. Entre os constituintes da suspensão, a água está presente em maior proporção (HUBBE, 2005).

A água, no estado líquido, é um sistema complexo e apresenta propriedades peculiares (SWANSON, 2003). A explicação para essa complexidade está na combinação entre o tamanho pequeno da molécula e a distribuição de suas cargas conferindo-Ihe um caráter polar (Figura 2.5).

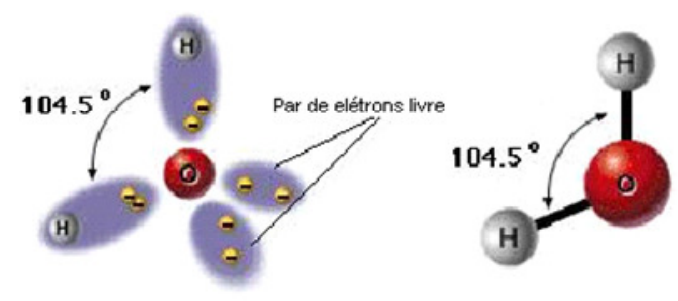

Figura 2.5 - llustração da molécula de água ${ }^{6}$.

Apesar de a molécula de água se apresentar como eletricamente neutra, suas cargas são separadas de forma a resultar em um dipolo elétrico (Figura 2.5). Devido a essa separação de cargas, duas moléculas podem se atrair por forças eletrostáticas entre a carga positiva do átomo de hidrogênio de uma molécula, com a carga negativa do átomo de oxigênio da outra.

6 Extraído de "Ponte de hidrogênio, força intermolecular intrigante!" Disponível em: $<$ http://www.ucs.br/ccet/defg/naeg/material didatico/textos interativos 33.htm>. Acesso em: 23 abr.2007. 
Como pode ser verificada na Figura 2.5, a geometria de uma molécula de água em relação à distribuição de suas cargas é, aproximadamente, tetraédrica com ângulo de $104,5^{\circ}$ entre os átomos de hidrogênio - oxigênio - hidrogênio $(\mathrm{H}-\mathrm{O}-\mathrm{H})$, um pouco menor do que um ângulo apresentado por um tetraedro ideal, 109,5‥ Isso é devido ao par de elétrons livres do átomo de oxigênio. Teoricamente, a distribuição tetraédrica de suas cargas permite que cada molécula de água forme ligações de hidrogênio com quatro moléculas vizinhas. Essa tendência confere à substância água algumas propriedades importantes. A forte atração entre as moléculas adjacentes de água confere à água líquida grande força de coesão interna e, conseqüentemente, propriedades como ponto de fusão, ponto de ebulição, calor de vaporização e tensão superficial, mais elevados do que a maioria dos líquidos comuns. Isto explica por que as substâncias apolares não são dissolvidas pela água, pois não podem interagir por meio de forças polares. A energia de ligação da ligação de hidrogênio entre moléculas de água é, aproximadamente, $20 \mathrm{~kJ} / \mathrm{mol}$ com comprimento da ligação entre os átomos hidrogênio-oxigênio $\left(\mathrm{H}^{\cdots \cdots} \mathrm{O}\right)$ de $0,16 \mathrm{~nm}$ e da ligação entre os átomos oxigênio-oxigênio $(\mathrm{O} \cdots \mathrm{O})$ de, aproximadamente, 0,26 $\mathrm{nm}$, ambos medidos a $40{ }^{\circ} \mathrm{C}$ (OJALA, 1999).

$\mathrm{Na}$ fabricação de papel, a qualidade da água usada no processo deve ser considerada, pois como a água é o meio de dispersão dos seus constituintes, poderá influenciar tanto na eficiência dos aditivos quanto nas interações químicas interfaciais entre os substratos da suspensão. A água é utilizada em grande quantidade em razão de a folha ser formada com suspensão de fibras com consistência muito baixa na caixa de entrada, cerca de 0,5 a 1,5\%, a depender do papel a ser produzido.

\subsubsection{Fibras e finos}

As características químicas e físicas das fibras, especialmente das suas superfícies, e o teor de finos que compõem determinada polpa são considerados parâmetros importantes tanto para a etapa de fabricação do papel quanto para a sua qualidade final. Estas características são definidas tanto durante as etapas de produção da 
polpa, polpação e branqueamento, quanto são oriundas da madeira, todas compõem em maior ou menor proporção o histórico da polpa.

O principal constituinte da polpa para fabricação do papel é a fibra, também conhecida como fibra celulósica. Apesar de também apresentar em sua composição outros constituintes como hemiceluloses, lignina e extrativos, é conhecida dessa forma em razão de apresentar proporção de celulose bem mais elevada em relação aos outros constituintes.

$\mathrm{Na}$ estrutura da madeira, a fibra apresenta um formato tubular com duas superfícies: uma interna em interface com o lúmen e outra externa, a qual situa-se em interface com a lamela média. A Figura 2.6 é uma representação muito conhecida dessa estrutura e citada, por exemplo, por Fengel e Wegener (1989) ${ }^{7}$.

As proporções dos principais constituintes da madeira são: 40 a 50\% de celulose; 20 a $30 \%$ de hemiceluloses; de 20 a $30 \%$ de lignina e de 1 a $10 \%$ de extrativos (PANSHIN; ZEEUW, 1980). Mesmo após a etapa química de individualização das fibras, a polpação, alguns compostos podem permanecer em sua estrutura porosa e, ou, sobre a sua superfície, como: lignina, hemiceluloses e extrativos.

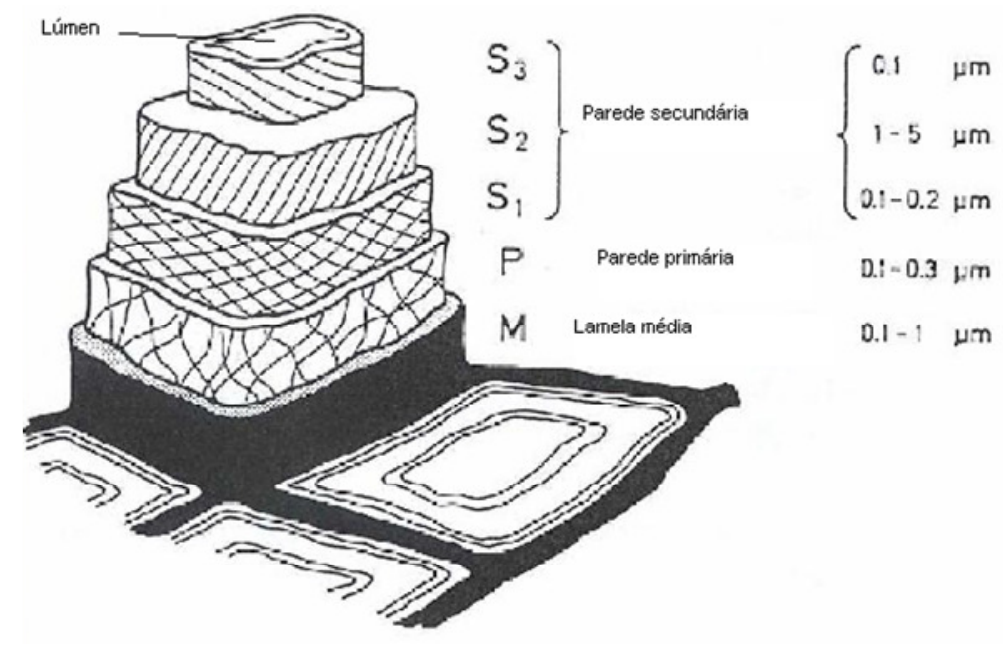

Figura 2.6 - Ilustração da estrutura da fibra de madeira.

7 FENGEL, D.; WEGENER, G. Wood: Chemistry, ultrasstructure, reactions. Berlin-New York: Walter de Gruyter, 1989. 613p. p.15. 
As hemiceluloses são polímeros ramificados que apresentam peso molecular mais baixo do que o polímero de celulose e são responsáveis pela grande parte dos grupos carboxílicos presentes na madeira, sendo as principais hemiceluloses presentes na madeira de eucalipto as 4-O-metilglucorono xilanas ou, simplesmente, xilanas (SJÖSTROM, 1993; RYDHOLM, 1965).

As hemiceluloses presentes na fibra podem apresentar diversas funções. Por apresentar grupos funcionais hidrofílicos em sua composição, participam da hidratação da fibra, aumentando a eficiência de refino e as propriedades físicomecânicas do papel. Também podem participar das interações na etapa de formação da folha. Polpas com maiores teores desses polímeros tendem a apresentar maior capacidade de retenção de água (OKSANEN; VIIKARI, 1997; REBUZZI; EVTUGUIN, 2007), fato que tem sido considerado importante para redução do fenômeno de hornificação da fibra durante a etapa de secagem. As xilanas, também, desempenham papel importante no desenvolvimento de carga de superfície.

A flexibilidade da fibra está relacionada com a espessura e porosidade da sua parede celular. Para uma mesma largura e porosidade, fibra mais espessa, geralmente se apresenta menos flexível. A flexibilidade pode contribuir com a formação de flocos macroscópicos. Também, pode influenciar as propriedades físicas que dependem do número de ligações interfibras tal como a resistência à tração.

Os parâmetros número de fibra por grama, coarseness (massa por comprimento de fibra) e teor de finos são considerados como variáveis de monitoramento da qualidade da polpa de celulose branqueada de eucalipto. Esses resultados podem sofrer elevadas variações dependendo das características químicas, físicas e anatômicas da madeira, mesmo quando se trata de madeira de mesma base genética como os clones a são (SILVA et al., 1997). Como a química da parte úmida é um fenômeno de superfície, as características acima influenciam no processo de 
retenção de cargas e de drenabilidade da folha e, portanto, no andamento da máquina e na qualidade do papel.

Resultados de estudos desenvolvidos por Silva et al. (1997), sobre análise das fibras de polpas branqueadas de dois diferentes clones de eucalipto, para nível de deslignificação baixo, número kappa 19, podem ser observados na Tabela 2.1. O estudo não contemplou a tendência de formação de flocos para as duas polpas.

Tabela 2.1 - Análise de fibras de polpas branqueadas no equipamento Kajaani

\begin{tabular}{lcc}
\hline \multicolumn{1}{c}{ Parâmetro } & Clone 1 & Clone 2 \\
\hline Comprimento médio de fibra, mm & 0,84 & 0,74 \\
\hline Número de fibras por grama, milhões & 14,6 & 21,7 \\
\hline Coarseness, mg/100m de fibra & 9,6 & 7,5 \\
\hline Finos, \% & 3,7 & 4,2 \\
\hline
\end{tabular}

A suspensão de fibras longas, com comprimento em torno 3 a $4 \mathrm{~mm}$, apresenta maior tendência à formação de flocos de maiores dimensões quando comparada à suspensão de polpa de celulose de fibra curta, as quais contêm fibras com comprimento em torno 0,6 a $0,8 \mathrm{~mm}$. A relação entre o comprimento e largura para fibra longa se encontra em torno de 50 a 100. Por outro lado, esta mesma relação para polpa de fibra curta situa-se em torno de 20 a 30. Apesar de possuir comprimento médio inferior ao da fibra longa, a suspensão de fibra curta apresenta forte tendência à formação de flocos macroscópicos (BLANCO; NEGRO; TIJIRO , 2001).

Depois das etapas químicas de polpação e de branqueamento, a etapa mecânica de refino exerce grande influência na estrutura física da fibra, na geração de finos e de substâncias coloidais e dissolvidas.

O tratamento mecânico de refino para a produção de papéis para impressão e escrita se faz necessário em razão do desenvolvimento das propriedades de 
resistência, apesar de existirem alguns aditivos químicos, como amido e poliacrilamidas que contribuem com a resistência a seco do papel. $\mathrm{Na}$ etapa de refino ocorrem tanto a fibrilação interna quanto a fibrilação externa das fibras. Sob o ponto de vista da química da parte úmida, esta etapa apresenta grande influência pelas seguintes razões: (a) aumenta a superfície específica da fibra, tanto através da fibrilação externa quanto através da fibrilação interna expondo mais sítios de adsorção; (b) proporciona a liberação de substância orgânicas de baixo peso molecular, isto contribui para o aumento do lixo aniônico do meio de dispersão em razão de sua solubilidade; (c) modifica sua estrutura interna alterando a micro e nanoporosidade e acessibilidade aos sítios de adsorção, o que possibilita o acesso de substância à parte mais interna das fibras, como os polieletrólitos; (d) contribui com o aumento do teor de finos da polpa, o que pode aumentar a demanda por polieletrólito considerando uma mesma eficiência de retenção.

São considerados finos, a fração de polpa que atravessa uma malha de 200 mesh. Isto equivale a um tamanho médio de partícula de $75 \mu \mathrm{m}$ (TAPPI T 261-cm-00) ${ }^{8}$. Esta definição é a mais largamente utilizada, porém, não impede de serem utilizados outros tamanhos de malha, desde que especificados no estudo.

Os finos podem ser gerados ao longo do processo. Porém, com o tratamento mecânico de refino, a polpa pode desenvolver mais finos em razão da quebra das fibras e da remoção de fragmentos de suas paredes, agravada quando se utiliza energia em excesso. Os fragmentos menores, juntamente com outras células de pequenas dimensões, as células de parênquima de raio, presentes em grande quantidade em madeira de fibra curta, constituem os finos. Os finos contribuem para o aumento da opacidade do papel, porém, em grandes proporções pode atua de forma negativa nas propriedades de resistência, especialmente, a propriedade índice de rasgo. Portanto, a depender da especificação do produto, o gerenciamento dos finos se constitui em aspecto indispensável.

Os finos podem ser classificados em (SCOTT, 1992): (a) Primários - são aqueles que estão naturalmente presentes na polpa da madeira. Podem ser células de parênquima e fragmentos de elementos de vasos para o caso das folhosas; (b)

\footnotetext{
${ }^{8}$ TAPPI test methods (2001).
} 
Secundários - são os finos gerados durante o tratamento de refinação da polpa. Consistem de fragmentos de microfibrilas e da parede celular das fibras; (c) Terciários - são gerados durante o fluxo e estão presentes na água branca por não terem sido retidos na mesa formadora. Podem ser gerados pela turbulência de bombeamento, de agitadores, dentre outros.

O encurtamento das fibras e a capacidade de inchamento das mesmas, ditada pelo grau de fibrilação interna, aumentam a resistência ao fluxo (BLANCO; NEGRO; TIJIRO, 2001). Outro fato importante a ser considerado é que, possivelmente, uma polpa mais refinada apresenta elevada resistência ao desaguamento, pois apresenta elevada superfície específica e elevado número de sítios para formação de ligações de hidrogênio entre o material fibroso e a água.

\subsubsection{Cargas}

Atualmente, as cargas são aditivos essenciais para melhoria da qualidade de alguns tipos de papéis. As cargas minerais influenciam na formação da folha de papel e nas propriedades ópticas, importantes parâmetros de qualidade de papéis destinados à impressão e escrita.

As cargas também conhecidas como pigmento, embora de cor branca, são utilizadas com o objetivo de preencher os espaços vazios entre a matriz de fibra conferindo melhoria na uniformidade das propriedades do papel: lisura e brilho superficial; imprimabilidade; opacidade; formação e estabilidade dimensional. As cargas são também utilizadas para reduzir os custos de fabricação do papel. Na composição do papel, a fração correspondente às cargas minerais pode variar de 20 a $35 \%$ a depender da classificação do mesmo (KROGERUS, 1999a). Por outro lado, as cargas reduzem, em parte, as propriedades de resistência do papel que estão relacionadas com o número de ligações interfibras (resistência à tração e ao alongamento). Outra desvantagem é o aumento da demanda do agente de retenção, pois podem contribuir de forma significativa na redução da eficiência de retenção. As cargas também reduzem a eficiência dos agentes de colagem interna do papel (SWANSON, 2003). Outro aspecto importante diz respeito à drenagem da manta. A 
drenagem na tela está diretamente relacionada com o teor de umidade no produto final, ou seja, um aumento de $5 \%$ no teor de carga, corresponde a um aumento de $1 \%$ no teor de umidade do produto final (BLANCO; NEGRO; TIJIRO , 2001). Em relação ao desaguamento na sessão de prensagem, esses autores reportaram que um aumento do teor de carga não afetou esse parâmetro significativamente.

Alguns tipos de cagas utilizados na fabricação de papel são: silicato de alumínio, talco ou silicato de magnésio, carbonato de cálcio natural (GCC) ou carbonato de cálcio precipitado (PCC), dióxido de zinco e dióxido de titânio (VELHO, 2003).

A Tabela 2.2, adaptada de Swanson (2003), mostra algumas propriedades importantes de algumas cargas utilizadas na fabricação do papel.

Tabela 2.2 - Propriedades de algumas cargas utilizadas na fabricação de papel

\begin{tabular}{lccccc}
\hline Propriedade & $\begin{array}{c}\text { Silicato de } \\
\text { alumínio }\end{array}$ & $\begin{array}{c}\text { Carbonato de } \\
\text { cálcio } \\
\text { precipitado }\end{array}$ & $\begin{array}{c}\text { Carbonato } \\
\text { de cálcio } \\
\text { natural }\end{array}$ & $\begin{array}{c}\text { Dióxido de } \\
\text { titânio } \\
\text { (anatase) }\end{array}$ & $\begin{array}{c}\text { Dióxido de } \\
\text { titânio (rutile) }\end{array}$ \\
\hline Alvura, \% & $75-85$ & 95 & - & 98 & 98 \\
\hline Índice de refração & 1,56 & 1,56 & - & 2,55 & 2,70 \\
\hline $\begin{array}{l}\text { Tamanho médio } \\
\text { de partícula, } \mu \mathrm{m}\end{array}$ & $0,5-1$ & $0,2-0,5$ & $1-5$ & 0,2 & 0,25 \\
\hline $\begin{array}{l}\text { Solubilidade em } \\
\text { água, g/100g }\end{array}$ & - & 0,0014 & - & - & - \\
\hline
\end{tabular}

Uma das principais razões de o PCC ser a carga mais utilizada entre os fabricantes de papel é que esta apresenta uma relação alvura/preço mais atrativa quando comparada à relação apresentada pelo dióxido de titânio, por exemplo.

Como enchimento da estrutura do papel, as seguintes propriedades das cargas são importantes: ópticas, superfície específica (tamanho e forma da partícula); química de superfície e solubilidade no meio aquoso. Outras propriedades podem ser 
citadas: pH, abrasividade e pureza. Além disso, durante o processo, as cargas devem alcançar desempenho satisfatório em termos de capacidade de dispersão no preparo da suspensão e capacidade de serem retidas (SWANSON, 2003).

As cargas, em relação às fibras, apresentam: maior fração de finos com diferentes formatos; densidade e dureza mais elevadas; melhores propriedades ópticas e não formam ligações de hidrogênio. Estas particularidades afetam as propriedades do papel em diferentes proporções (KROGERUS, 1999b).

As cargas podem ser retidas tanto mecanicamente, em que as partículas ficam presas na manta por filtração durante a formação da folha, quanto quimicamente, em que as partículas são retidas por meio de polieletrólitos através de mecanismos de floculação. A quantidade de carga retida mecanicamente é definida pelo tamanho da partícula da carga e pela porosidade da folha formada. Por outro lado, quando há floculação entre cargas, homofloculação de cargas, devido ao seu tamanho mais elevado, os flocos são mais facilmente retidos. Visto sob outro ângulo, como se trata de partículas com dimensões menores do que as dimensões da abertura da tela, a não retenção de carga, química ou mecanicamente, compromete tanto a eficiência de retenção quanto a qualidade da água branca.

Considerando que as cargas apresentam maior valor para a relação superfície específica/peso quando comparadas ao valor apresentado pelas fibras, é razoável supor que essas partículas apresentam maior capacidade de adsorver aditivos do que as fibras (BLANCO; NEGRO; TIJIRO, 2001).

\subsubsection{Agentes de retenção e drenagem}

Vários agentes químicos têm sido desenvolvidos com o objetivo de aumentar a eficiência operacional da máquina de papel e a qualidade do produto final com o menor custo possível, sendo este objetivo o maior desafio para os pesquisadores e, ou, fabricantes de papel.

A demanda por agentes de retenção mais eficientes tem crescido devido aos seguintes fatores: conversão do processo de colagem ácido para alcalino, 
incorporação de níveis de cargas mais elevados, aumento do grau do fechamento do circuito de água branca, aumento da velocidade operacional de máquinas e aumento da utilização de fibras recicladas (GALLAGHER, 2006).

Os agentes de retenção têm como principal objetivo fixar as partículas de pequenas dimensões por adsorção, as quais, mecanicamente, não seriam retidas na tela formadora, ou por serem menores do que a abertura da tela, ou por não terem sido filtradas pela manta.

Um dos primeiros agentes de floculação utilizados na fabricação de papel foi o sulfato de alumínio. Entretanto, com o aumento da velocidade da máquina de papel houve também um aumento das forças de cisalhamento e a necessidade de utilização de agentes de floculação que gerasse flocos mais resistentes, os polieletrólitos (BLANCO; NEGRO; TIJIRO, 2001).

Os polieletrólitos, também conhecidos como polímeros sintéticos, são caracterizados de acordo com a cadeia central, com o peso molecular, com o tipo e a densidade de carga. Quanto à ionicidade, na fabricação de papel podem ser utilizados polieletrólitos catiônicos, aniônicos ou neutros. O que, normalmente, determina o tipo de carga do polímero a ser utilizado são as cargas das superfícies da fibra e do material inorgânico a ser retido. É usual que a ionicidade do polímero seja diferente da ionicidade da carga inorgânica. Por outro lado, ensaios de laboratório e, ou, piloto, determinam a melhor composição da receita visando a otimização da retenção dessas cargas.

Em acordo com Scott (1996), os polímeros são rapidamente adsorvidos sobre as superfícies das fibras em sistema de fabricação de papel. Segundo esse autor, em menos de um segundo o polímero é adsorvido sobre a fibra.

A etapa de fabricação de papel apresenta-se como um sistema dinâmico, no qual a resistência da interação entre a cadeia do floculante e a superfície da partícula, em combinação com a turbulência do sistema, determinam se a floculação irá ocorrer a contento. Portanto, o ponto de adição do polímero é um aspecto importante no sentido de aumentar a sua efetividade. Outro aspecto importante é, se ocorrer a defloculação em razão dessas forças, quão rapidamente ocorrerá a refloculação das partículas (BLANCO; NEGRO; TIJIRO, 2001). Esses autores descrevem bem as 
diversas classificações dos agentes floculantes bem como as características dos flocos gerados a partir do uso desses agentes. A ionicidade e o peso molecular são dois aspectos importantes. Considerando sua ionicidade, os polímeros podem ser classificados de acordo com a sua percentagem de carga e de acordo com o peso molecular, em ambas os polímeros podem ser classificados em quatro categorias (Tabela 2.3).

Tabela 2.3 - Classificação de polímeros de acordo com sua ionicidade e com o seu peso molecular

\begin{tabular}{lcc}
\hline Classificação & lonicidade, $\%$ & Peso molecular, g/mol \\
\hline Baixa & $1-10$ & $1 \times 10^{3}-1 \times 10^{5}$ \\
\hline Média & $10-40$ & $1 \times 10^{5}-1 \times 10^{6}$ \\
\hline Alta & $40-80$ & $1 \times 10^{6}-5 \times 10^{6}$ \\
\hline Muito alta & $80-100$ & $>5 \times 10^{6}$ \\
\hline
\end{tabular}

De acordo com a composição química, os agentes floculantes podem ser classificados como: (a) substâncias inorgânicas ou eletrólitos; (b) produtos naturais e seus derivados; e (c) polímeros orgânicos sintéticos ou polieletrólitos.

Os coagulantes inorgânicos ou eletrólitos apresentam função de reduzir o potencial eletrocinético da suspensão, neutralizando-a, podendo inverter a carga resultante da suspensão. Sua atuação depende do $\mathrm{pH}$ do meio. Esses agentes coagulantes geram flocos com as seguintes características: pequenos, rígidos e compactos, com alta resistência à compressão. Esses fatores levam a baixa velocidade de sedimentação dos flocos. A principal vantagem desses agentes é o seu baixo custo em relação a alguns coagulantes orgânicos que apresentam efeito similar. Os eletrólitos mais comuns são os derivados de alumínio e sílica. Recentemente, o policloreto de alumínio (PAC) foi introduzido como eletrólito mais efetivo do que outros derivados do alumínio. O PAC também pode ser utilizado com os agentes floculantes sintéticos, em atuação conjunta, já que se trata de princípios de atuação 
diferentes. Outra aplicação do PAC é como potencializador da eficiência de polianfóteros (SONG et al., 2006).

A sílica nas formas de sílica ativa, preparada pela acidificação da solução de silicato de sódio, ou coloidal (Figura 2.7 A adaptada de Harris; Ford e Spada, 2004), também é utilizada como eletrólito inorgânico na fabricação de papel. A sílica se torna insolúvel em pH abaixo de 9, ocorrendo a polimerização. Neste caso, compostos metaestáveis de polissilicatos ou agregados coloidais, negativamente carregados (Figura 2.7 B adaptada de Gallagher, 2006), são gerados, os quais podem ser diluídos, se mantendo ativo por um certo período de tempo. Esse processo produz partículas com dimensões muito pequenas, 1 a $2 \mathrm{~nm}$. A sílica coloidal forma uma dispersão estável de partículas de sílica uniformes (gel), esféricas e amorfas (Figura 2.7 C adaptada de Gallagher, 2006). Atualmente, a sílica coloidal é utilizada em sistema de floculação complexo (dual system) em que utiliza micropartículas de sílica para melhoria da eficiência da drenagem, embora podendo atuar na retenção de partículas em razão de apresentar carga iônica (MOFFETT, 1994).
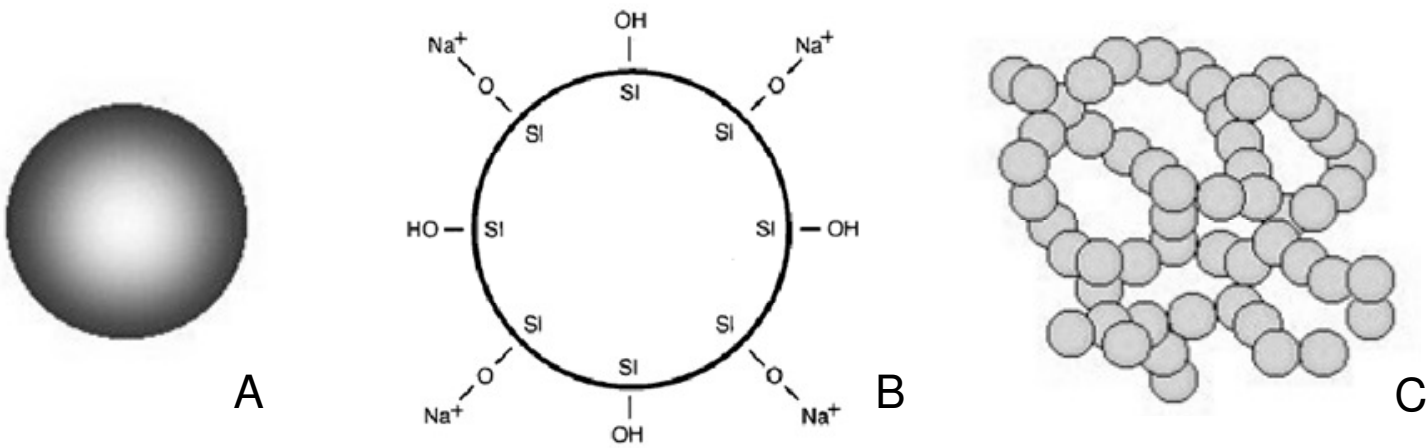

Figura 2.7 - (A) llustração de partícula de sílica coloidal com $5 \mathrm{~nm}$ e área superficial de 500 a $800 \mathrm{~m}^{2} / \mathrm{g}$; (B) Partícula de sílica coloidal com elevada carga aniônica, e (C) llustração de partícula de sílica na forma de gel com área superficial de 1200 - 1400 $\mathrm{m}^{2} / \mathrm{g}$.

Outro agregante inorgânico é a bentonita (Figura 2.8 A adaptada de Harris; Ford e Spada, 2004). Embora apresente tamanho de partícula relativamente grande (300 
$\mathrm{nm}$ ) em relação à sílica, a sua forma coloidal (montemorilonita) pode ser utilizada como agente coagulante em razão de apresentar elevada superfície específica e alta densidade de carga aniônica. Assim como a sílica coloidal, a bentonita é utilizada em sistema de floculação complexo, atuando em conjunto com os polieletrólitos. Uma das vantagens da bentonita é que se trata de uma substância anfótera, podendo atuar tanto em substâncias positivas quanto negativas.

Atualmente, outras micropartículas têm sido desenvolvidas. O micropolímero foi produzido para incorporar as vantagens das micropartículas inorgânicas: superfície carregada, tamanho pequeno e estrutura tridimensional; e dos polímeros floculantes e coagulantes: cadeias de polímero com carga controlada (Figura 2.8 B adaptada de Harris; Ford e Spada, 2004). Estas características conduzem a formação de uma microrede aniônica a qual contribui com a eficiência de retenção. Estas microredes quando secas, apresentam tamanho de 60 a $80 \mathrm{~nm}$ e, em emulsão, mede $130 \mathrm{~nm}$.
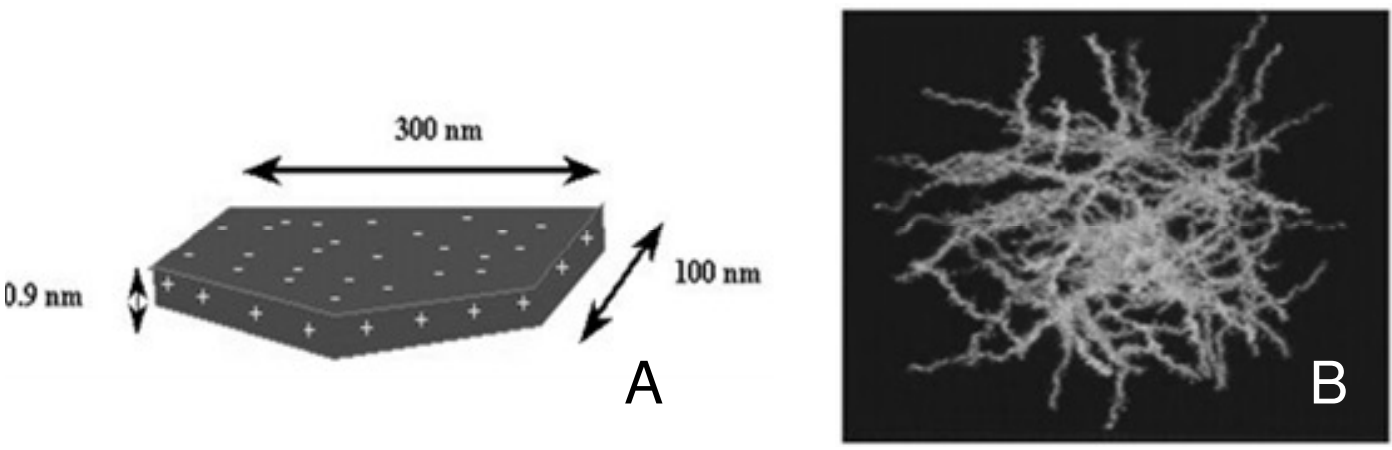

Figura 2.8 - (A) llustração de partícula de bentonita com área superficial acima de $800 \mathrm{~m}^{2} / \mathrm{g}$, e (B) llustração de um micropolímero.

Outros floculantes utilizados em sistemas de retenção de partículas são os polieletrólitos orgânicos. Estes floculantes naturais, contendo polissacarídeos, são mais bem representados pelo amido e seus derivados. Sua forma de atuação é baseada em interações por ligações de hidrogênio. 
Apesar de se apresentarem, naturalmente, como polímeros não iônicos, os amidos podem ser modificados produzindo polímeros catiônicos, aniônicos ou anfóteros. Em sua forma natural pode ser utilizado para aumentar a resistência a seco do papel. Porém, sua forma catiônica, além de contribuir para o aumento da resistência a seco, pode ser usada para melhorar a eficiência dos processos de retenção e drenagem da folha. Atualmente, o amido tem sido utilizado com o objetivo de regular o balanço de carga em sistemas que demandam alta carga catiônica. O amido catiônico pode ser facilmente consumido em sistemas com elevado teor de lixo aniônico por reações de neutralização de cargas.

Outros coagulantes orgânicos são as gomas. Estas substâncias são polissacarídeos solúveis em água, com alta variação da faixa de peso molecular e são efetivos em baixas concentrações (ROJAS; NEUMAN, 1999).

De acordo com o tipo, a densidade, a ordem de adição, a associação dos agentes de retenção com outros componentes e com a introdução de forças de cisalhamento no processo, a retenção ocorre segundo um determinado mecanismo. Os mecanismos mais comuns são a floculação tipo mosaico seguida de neutralização de carga (utiliza polieletrólito com baixo peso molecular e alta densidade de carga); e a floculação tipo ponte, sendo este último o mais comum (utiliza polieletrólito com alto peso molecular e média ou baixa densidade de carga). Nestes tipos de mecanismos são utilizados, normalmente, polieletrólitos catiônicos. Outros mecanismos, envolvendo micro e nanopartículas e polieletrólito neutro, são considerados complexos e são bastante utilizados comercialmente em razão de sua dupla vantagem: alta retenção de partículas, mantendo eficiência de drenagem.

No processo de adsorção de polieletrólitos sobre as fibras, os finos e as cargas, as principais variáveis são: densidade de carga do polieletrólito, distribuição da carga, comprimento de cadeia, conformação, flexibilidade da cadeia, disponibilidade dos grupos para formação de ligações de hidrogênio, concentração, tempo de contato e forças de cisalhamento.

A poliacrilamida (PAM), polieletrólito bastante utilizado como agente de floculação, está disponível nas formas catiônica, não iônica e aniônica. A denominação "poliacrilamida" é, normalmente, aplicada aos compostos cujas cadeias contêm 
acima de $50 \%$ de subunidades de acrilamida. As letras C, $\mathrm{N}$ e A na frente da sigla PAM, referem-se, respectivamente, poliacrilamida catiônica (C-PAM), a poliacrilamida não iônica (N-PAM) e poliacrilamida aniônica (A-PAM).

O floculante com nitrogênio tetravalente é bastante utilizado como polímero catiônico. O cloreto de poli dialildimetil amônio [Poli-DADMAC -poly (diallyldimethylammonium chloride)] se apresenta com faixa de peso molecular de baixo a médio (<10 $\mathrm{g} / \mathrm{mol})$. Como é um sal quaternário de amônio, não é afetado por variações de pH. É bastante utilizado em técnicas para determinação da demanda catiônica do sistema.

A polietilenoimina (PEI) é altamente ramificada. A cationicidade desse polímero reduz com o aumento do $\mathrm{pH}$. Apresentam cadeias mais curtas quando comparadas às cadeias da maioria das poliacrilamidas.

Outro polímero bastante utilizado em sistemas em que se utilizam papéis reciclados é o polieletrólito neutro óxido de polietileno (PEO).

Embora o PEO não seja muito utilizado em máquinas de papéis de imprimir e escrever, ele apresenta uma grande vantagem sobre os polieletrólitos eletricamente carregados, sua eficiência de atuação não é significativamente afetada pelo aumento da concentração de lixo aniônico no sistema. Porém, a elevação da concentração de fragmentos de lignina pode consumir parte desse polímero. Situação que pode ser verificada quando há aumento do grau de fechamento do circuito de água branca da máquina e, ou, quando a eficiência de lavagem da polpa que alimenta a fabricação de papel é baixa.

Lindström e Glad-Nordmark (1983) encontraram que o óxido de polietileno (PEO) era seletivamente adsorvido pelas polpas Kraft não branqueada, soda e sulfito não branqueada. Por outro lado, o PEO não era adsorvido pelas polpas kraft branqueada, mecânica, termomecânica e sulfito semiquímica neutra. Sendo que para as polpas que não adsorviam o PEO, não foi observado o fenômeno da floculação. Para explicar a afinidade de algumas polpas pelo PEO e outras não, os autores metilaram ou acetilaram a polpa Kraft não branqueada. Com isso, não foi observada a agregação de partículas com o PEO. Os autores concluíram que com a substituição dos grupos fenólicos residuais de lignina ainda presentes na polpa não 
branqueada por grupos metil ou acetil, não pode ocorrer interações por ligações de hidrogênio entre a carga positiva do grupo fenólico e a carga negativa do oxigênio éter do PEO (LINDSTROM; GLAD-NORDMARK, 1983).

\subsubsection{Agentes de colagem}

A colagem é um tratamento químico realizado no papel com o objetivo de reduzir a penetração de líquido em sua estrutura (ZHANG, KANNANGARA; HILDE, 2007). Esta interação, líquido e superfície do papel, pode ser avaliada através da medida do ângulo de contato, o qual é definido como o ângulo formado entre um plano tangente a uma gota de líquido e o plano da superfície onde o líquido se encontra depositado (RABOCKAI, 1979).

As Figuras 2.9 e 2.10 ilustram ângulos de contato entre uma gota de líquido e uma superfície de um plano horizontal. Nestas figuras, $\gamma_{S}$ significa a energia de superfície do sólido , $\gamma_{L V}$ significa a tensão superficial do líquido com o vapor; $\gamma_{S L}$ significa a energia de interface sólido-líquido e $\theta_{i}$ significa o ângulo de contato.

Os agentes de colagem de natureza hidrofóbica mais utilizados na fabricação de papel alcalino são o dímero de alquilceteno (AKD - Alkyl Ketene Dimer) e o anidrido alquenil succínico (ASA - alkyl succinic anhydrid). Estes agentes aumentam o ângulo de contato formado entre a gota de líquido e a superfície do papel (NEIMO; ANDERSSON, 1999). Fazendo uma analogia, a Figura 2.9 representaria um papel sem agente de colagem e a Figura 2.10, com agente de colagem, hidrofobização.

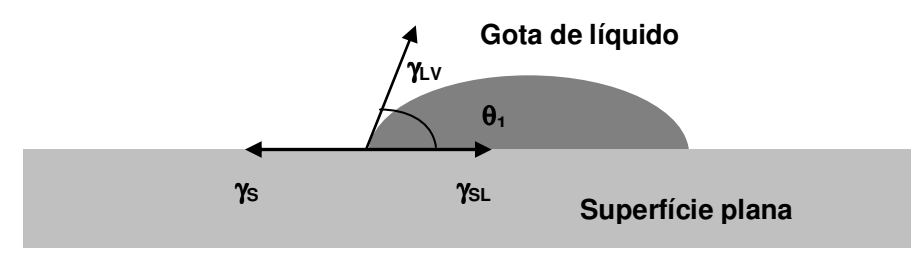

Figura 2.9 - Ângulo de contato entre uma gota de líquido e uma superfície plana horizontal. 


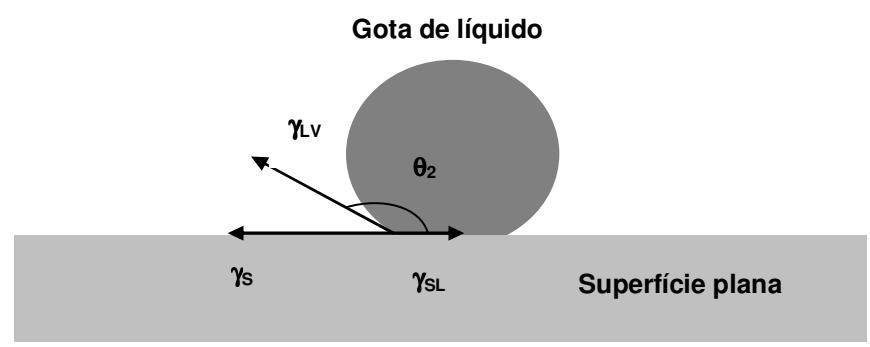

Figura 2.10 - Ângulo de contato entre uma gota de líquido e uma superfície plana horizontal.

A equação que representa o equilíbrio entre a gota e a superfície é conhecida como equação de Young (Equação 2.1) e está apresentada abaixo (SHAW, 1975).

$\gamma_{S}=\gamma_{S L}+\gamma_{L V} \cos \theta$

Equação 2.1

ou, escrita de outra forma,

$\gamma_{L V} \cos \theta=\gamma_{S}-\gamma_{S L}$

Equação 2.2

O trabalho de adesão, $W_{a}$, entre o sólido e o líquido pode ser expresso pela equação de Dupré (Equação 2.3).

$W_{a}=\gamma_{L V}+\gamma_{S}-\gamma_{S L}$

Equação 2.3

Associando as Equações 2.2 e 2.3 resulta na equação conhecida como YoungDupré (Equação 2.4).

$W_{a}=\gamma_{L V}(\cos \theta+1)$

Equação 2.4 
A Equação 2.4 relaciona duas variáveis relativamente fáceis de serem determinadas quais sejam: o ângulo de contato $(\theta)$ e a tensão superficial do líquido $\left(\gamma_{L V}\right)$.

Quando o ângulo de contato for zero grau, o co-seno será 1. Então o trabalho de adesão será máximo, duas vezes a tensão superficial do líquido. Isto significa que o líquido se espalha completamente na superfície. Por outro lado, se o ângulo for cento e oitenta graus, o co-seno será menos um. Então, o trabalho de adesão será zero. Isto significa que não há adesão entre as duas fases.

$\mathrm{Na}$ folha de papel, a hidrofobização é feita formando uma ligação covalente entre o agente de colagem e os grupos hidroxílicos da fibra celulósica. Os mecanismos de reação propostos para AKD e ASA estão mostrados nas Figuras 2.11 e 2.12 (ZHANG et al., 2007), respectivamente. Segundo Neimo e Andersson (1999), o efeito da colagem é atribuído às possíveis reações de esterificação dos agentes de colagem com os grupos hidroxílicos da celulose.

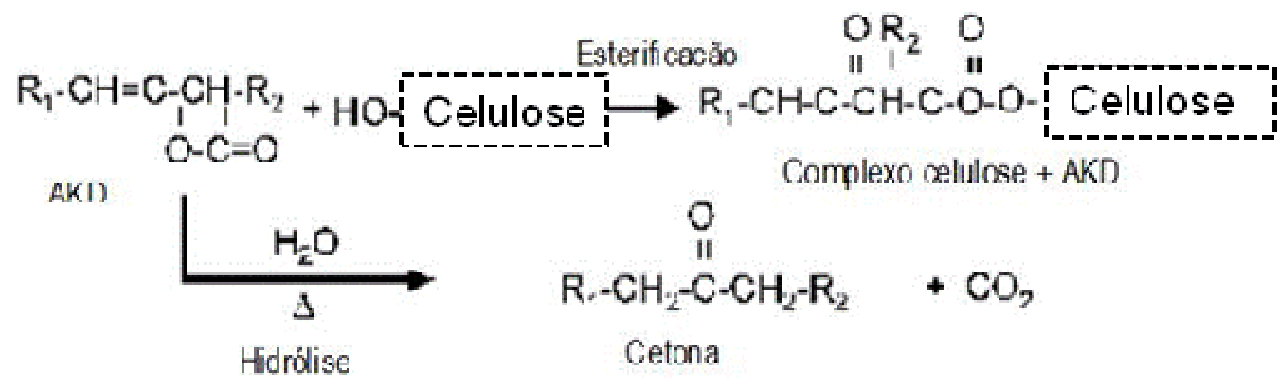

Figura 2.11- Mecanismo de reação da cola AKD com a celulose. 


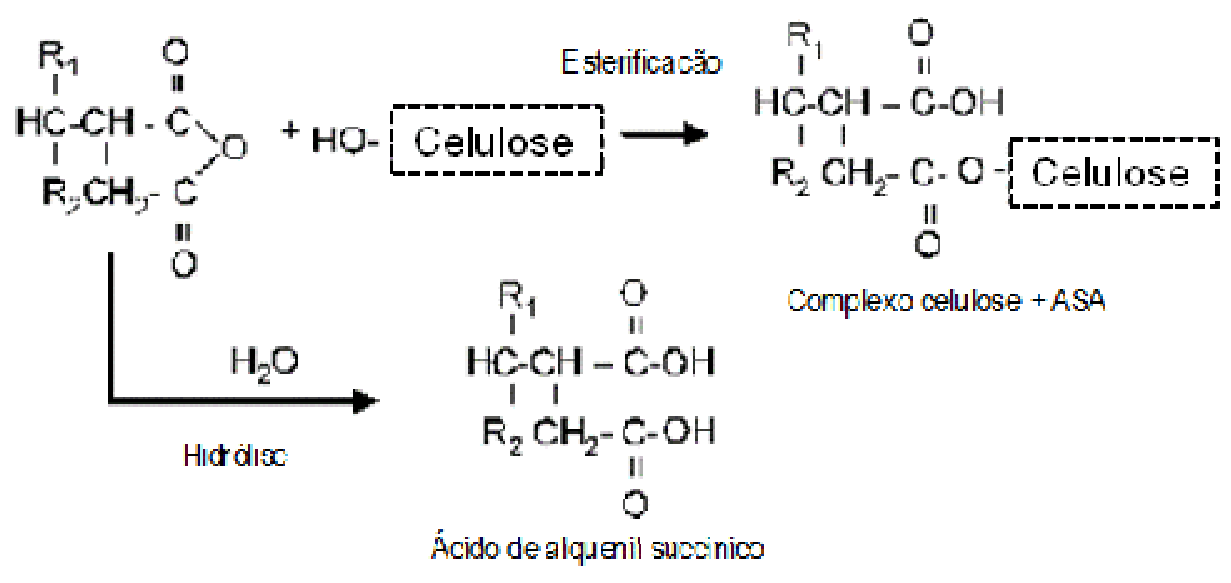

Figura 2.12 - Mecanismo de reação da cola ASA com a celulose.

Como pode ser visto nas Figuras 2.11 e 2.12, ilustrações conforme reportado por Zhang; Kannangara e Hilde (2007), uma parte da molécula dos agentes de colagem é um grupo hidrofóbico, o qual influência na capacidade de absorção superficial de água do papel. Para ocorrer as reações entre os agentes de colagem e as superfícies da fibra por adsorção, inicialmente, grande parte da água deve ser retirada por aquecimento. Estas reações ocorrem à temperatura de 100 a $120^{\circ} \mathrm{C}$ na seção de secagem.

A presença de resíduos dessas substâncias na água branca que recircula na máquina pode reduzir a eficiência de retenção, pois, embora em pequenas proporções, elas se associam, eventualmente, aos grupos funcionais da superfície da fibra que estavam disponíveis como sítios de adsorção para o polieletrólito. Portanto, os sítios negativos remanescentes das reações de adsorção de polieletrólito, são os potencialmente envolvidos nas reações com os agentes de colagem. 


\subsubsection{Agentes de resistência a seco}

A refinação e a adição de amido são duas alternativas amplamente usadas pelos fabricantes de papel para aumentar a sua resistência a seco. A utilização conjunta, refino e amido catiônico, consiste em uma das primeiras tecnologias adotada para melhorar a resistência a seco do papel, sendo ainda usada nos dias de hoje com esta finalidade.

Depois das fibras, das cargas minerais e da água, o agente de resistência a seco é a matéria prima mais usada na fabricação comercial de papéis e cartões (HUBBE, 2005). Considerando a química da parte úmida, o amido ionizado é adicionado para aumentar a resistência a seco do papel porque melhora as ligações interfibras. $O$ amido na forma catiônica também melhora a retenção de partículas e pode atuar nas reações de neutralização do lixo aniônico controlando a demanda catiônica, embora esta última não seja sua função principal quando adicionado após a etapa de refino da polpa. O amido também pode atuar como emulsificante dos agentes de colagem e, após a etapa de prensagem da folha, é aplicado na superfície do papel através da size press, com o objetivo de prevenir o arrancamento superficial no papel, numa etapa conhecida como colagem superficial.

Segundo Merta (2001), a adsorção de estruturas eletricamente carregadas, como o amido catiônico, sobre a superfície do material fibroso em interface sólido-líquido, é importante, pois pode controlar o processo de retenção de carga. O amido é um carboidrato polimérico que consiste de unidades de anidroglucose unidas através de ligações glucosídicas $\alpha-\mathrm{D}(1-4)$. A substância amido é um material heterogêneo constituído basicamente por dois tipos de polímeros: a amilose e a amilopectina. A amilose é um polímero essencialmente linear e pode conter, aproximadamente, 200 a 2000 unidades de anidroglucose com peso molecular variando de 10.000 a 50.000 $\mathrm{g} / \mathrm{mol}$ (Figura 2.13). Por outro lado, a amilopectina é um polímero ramificado que contem, além de unidades de anidroglucose ligadas através de ligações glucosídicas $\alpha-\mathrm{D}(1-4)$, ramificações periódicas no carbono C-6 (Figura 2.14). Cada ramificação contem 20 a 30 unidades de anidroglucose, aproximadamente, e peso molecular da ordem de milhões. Ilustrações do amido nas Figuras 2.13 e 2.14 de acordo com Rojas e Neuman (1999). 


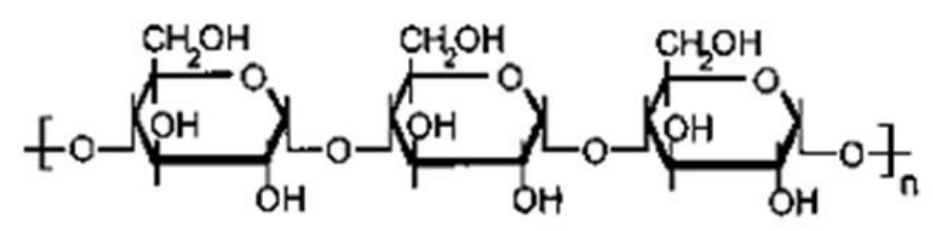

“n” varia de 200 a 2000 unidades de anidroglucose

Figura 2.13 - Diagrama esquemático da estrutura da amilose.

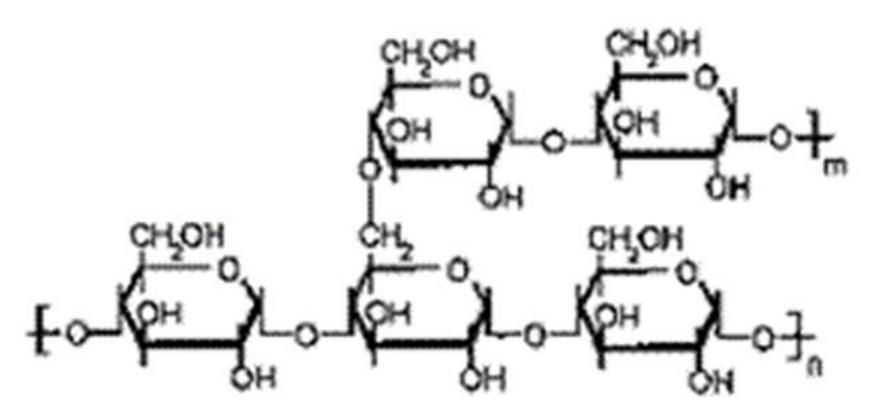

"n" varia de 200 a 2000 unidades de anidroglucose

" $m$ " varia de 20 a 30 unidades de anidroglucose

Figura 2.14 - Diagrama esquemático da estrutura da amilopectina.

A proporção de amilopectina e amilose pode variar. No amido de mandioca, por exemplo, esta razão é de $\sim 4,8$, sendo $83 \%$ de amilopectina e $17 \%$ de amilose. Por outro lado, no milho a razão é de $\sim 2,7$, sendo $73 \%$ de amilopectina e $27 \%$ de amilose (MERTA, 2001).

O amido de mandioca, após ionizado, tem sido bastante utilizado no Brasil como agente de resistência a seco. Isto, possivelmente, devido à presença de maior quantidade de amilopectina quando este é comparado com amidos provenientes de outras matérias primas. Na suspensão de fibras, como grande parte do amido catiônico é normalmente adicionado após a etapa de refino a $~ 4,5 \%$ de consistência, parte desse amido pode ser consumida por reações de adsorção e parte pode ser consumida em reações de neutralização do lixo aniônico. É comum em programas 
de retenção, antes da adição do amido, que estas substâncias aniônicas sejam neutralizadas com polímeros catiônicos específicos.

Rojas e Neuman (1999) estudaram a adsorção dos polissacarídeos goma "guar" e amido e suas interações com suspensões de fibras, de finos e de substâncias dissolvidas e coloidais, utilizando cromatografia líquida de alto desempenho (HPLC) e espectrofotometria. Estes autores verificaram que os comportamentos de adsorção e de agregação, os quais ocorrem em suspensão de fibras em meio aquoso, foram afetados tanto pelas características físico-química da superfície do substrato fibroso quanto pela natureza do polieletrólito, tipo de carga e grau de substituição. Foi observado também que reações de complexação, ou neutralização, entre as substâncias dissolvidas e coloidais e as moléculas de polissacarídeos ocorrem de forma evidente. A Figura 2.15, adaptada desses autores, mostra o mecanismo de complexação das substâncias orgânicas dissolvidas e coloidais sobre a superfície do material fibroso.

Os passos para as interações entre os polissacarídeos e os carboidratos coloidais e dissolvidos sugerido por Rojas e Neuman (1999) são: (a) mistura do polissacarídeo com os carboidratos coloidais e dissolvidos da suspensão de polpa; (b) complexação e associação das moléculas de polissacarídeos com os carboidratos dissolvidos e coloidais; (c) adsorção dos polissacarídeos, livres ou na forma de complexos, sobre os finos e fibras; e (d) associação dos finos e agregados sobre as fibras. 


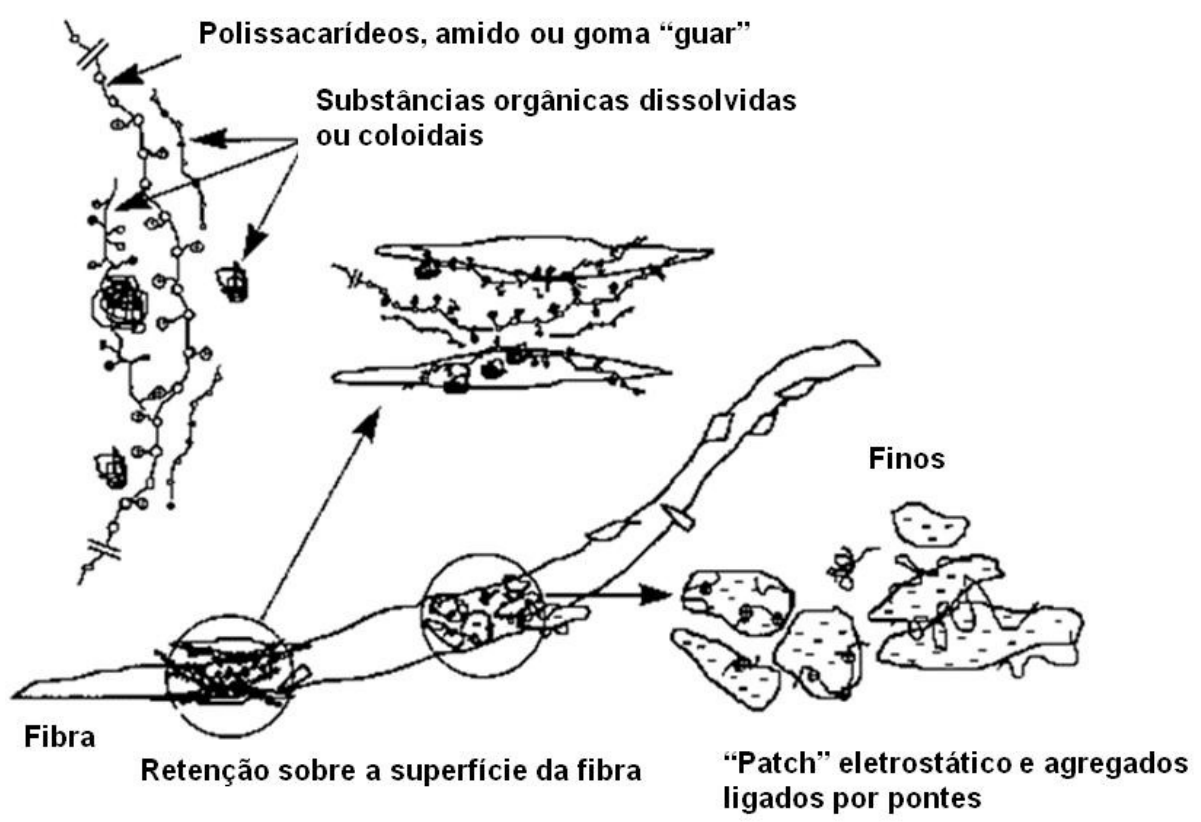

Figura 2.15 - Complexação das substâncias orgânicas dissolvidas e coloidais sobre a superfície do material fibroso.

Novas tecnologias têm sido propostas com o objetivo de aumentar a resistência a seco do papel, como por exemplo a utilização de polianfóteros (WANG, 2006a; WANG; HUBBE; SESAKI, 2006b; SEZAKI et al., 2006a; SEZAKI et al. 2006b; HUBBE, 2006; HUBBE et al., 2007a; HUBBE et al., 2007b) e a deposição de polímeros sintéticos em camadas sobre a superfície da fibra, alternando sua ionicidade. Esta última conhecida como polieletrótitos em multicamadas (ZHENG; MCDONALD; KHILLAN, 2006; WÅGBERG; FORSBERG; JOHANSSON, 2002; ERIKSSON; NOTLEY; WÅGBERG, 2005). A aplicação da tecnologia de montagem de polieletrólitos em camadas sobrepostas em escala comercial ainda se encontra sob estudo desde que são necessárias quantidades excessivas de polieletrólito na deposição de cada camada, intercaladas com lavagem. Portanto, as condições operacionais de fábrica atuais não permitiriam sua aplicação da forma que a mesma é descrita na literatura.

A utilização de polianfóteros como agente de resistência a seco pode ser verificada com maior detalhe no Capítulo 5 por ser o principal tema deste trabalho. 


\subsubsection{Contaminantes}

Nos últimos vinte anos, a exigência pela redução do consumo específico de água e de energia em unidades fabris tem sido cada ver mais crescente. Considerando a indústria de fabricação de papel, em que a água é usada em grandes proporções, o consumo específico desse insumo tem sido reduzido em atendimento às exigências ambientais atuais. Dessa forma, a concentração de substâncias indesejáveis na água de recirculação, conhecida como água branca, também foi aumentada.

A necessidade de se reduzir o consumo específico de água e, ao mesmo tempo, manter ou aumentar a eficiência do processo de retenção e drenagem apresentam comportamentos divergentes. Em outras palavras, quando a recirculação da água é elevada, a concentração de impurezas sólidas, dissolvidas e coloidais presentes no sistema também aumenta influenciando de forma negativa a eficiência de atuação dos polieletrólitos ionicamente carregados e, portanto, a eficiência da retenção. Os polieletrólitos positivamente carregados são os mais prejudicados.

Os principais contaminantes existentes na suspensão de fibras são as substâncias dissolvidas e coloidais presentes no meio de dispersão, também conhecidas como lixo aniônico. Essas substâncias podem ser orgânicas e inorgânicas e podem apresentar várias origens: (a) água de reposição, (b) polpa seca ou suspensão de fibra que alimenta o processo de fabricação de papel, (c) etapa de refino, (d) água branca recirculada ou (e) papéis reciclados, no caso de fábricas que utilizam esses tipos de papéis como fonte de matéria prima. Dessa forma, a quantidade e a qualidade efetiva dos contaminantes presentes no meio de dispersão durante as reações de neutralização e de adsorção na parte úmida da máquina é o resultado do balanço das quantidades que estão entrando no sistema e saindo com a folha formada, e das quantidades que estão sendo recirculada e gerada.

A qualidade da polpa utilizada pode contribuir para o aumento do teor de contaminantes de algumas maneiras. Polpa mal lavada, por exemplo, carrega consigo grande quantidade de substâncias dissolvidas e coloidais que contribui com o aumento do lixo aniônico. Outro exemplo é quando a polpa necessita de tratamento mecânico mais drástico para desenvolver propriedades de resistência. 
Neste caso, há tanto geração de partículas sólidas, os finos, quanto de substâncias orgânicas dissolvidas.

$\mathrm{Na}$ água branca, a qual é drenada na mesa plana, também é encontrado elevado teor de impurezas. Tais impurezas são principalmente os sólidos suspensos além das substâncias coloidais e dissolvidas. A quantidade e qualidade dessas impurezas dependem de vários aspectos sendo o principal a eficiência das reações de neutralização e de adsorção que ocorrem antes da formação da folha e a eficiência de retenção de partículas sólidas na mesa plana. Além do aspecto anterior, as forças de cisalhamento, naturalmente presentes no sistema, devem ser consideradas como variável que afetam a qualidade da água branca e, portanto, a eficiência de retenção.

As substâncias coloidais e dissolvidas são, principalmente, os constituintes orgânicos da madeira solúveis em água, como fragmentos de lignina, hemiceluloses e celulose de baixo peso molecular e, até mesmo, reagentes químicos arrastados das etapas de polpação e do branqueamento. Outras substâncias que também são classificadas como lixo aniônico, embora em menor proporção, são: ácidos graxos, amido aniônico e substâncias que compõem os aditivos de processo com carga negativa, como os polieletrólitos.

É importante conhecer a eficiência de retenção de sólidos suspensos e dissolvidos no papel, pois, o processo de retenção está também relacionado ao grau de fechamento de circuito da máquina. O aumento da concentração de impurezas, devido à recirculação de água ou a má retenção de micropartículas, torna o sistema mais sensível ao aparecimento de problemas como: depósitos, formação de espuma, aumento da atividade biológica, corrosão e má qualidade de formação da folha de papel, podendo comprometer suas propriedades físico-mecânicas e ópticas. Portanto, o monitoramento da qualidade e da vazão de recirculação da água branca torna-se um importante parâmetro de controle da eficiência de retenção de finos.

As substâncias inorgânicas, na fabricação de papel, conferem a força iônica do sistema e são compostas por íons presentes na suspensão. 
Na prática, os dois principais parâmetros que avaliam de maneira quantitativa o teor de substâncias coloidais e dissolvidas e a quantidade de eletrólitos dissolvidos no sistema são a demanda catiônica e a condutividade, respectivamente.

Os contaminantes também vêm com os papéis recicláveis. A depender do tipo de papel, o nível de contaminação é maior. Os papéis revestidos, por exemplo, possuem partículas de tinta, a qual apresenta componente hidrofóbico na sua composição, que contribuem com a formação do pitch branco, os stickies. Estas substâncias são prejudiciais ao andamento da máquina, pois, além de contribuir com a redução da produtividade do processo, reduz a qualidade final do papel.

\subsection{Suspensão de fibras}

\subsubsection{Constituição e densidade de carga}

As fibras estão em uma suspensão aquosa que é constituida de grande número de componentes que apresentam diferenças entre si sob diversos aspectos como tamanho, forma, superfície específica, rugosidade de superfície e carga elétrica, conforme ilustrado na Figura 2.16 com diversos constituintes que a compõem. A Figura 2.17 faz um comparativo entre os tamanhos desses constituintes na suspensão (ROJAS, 2003).

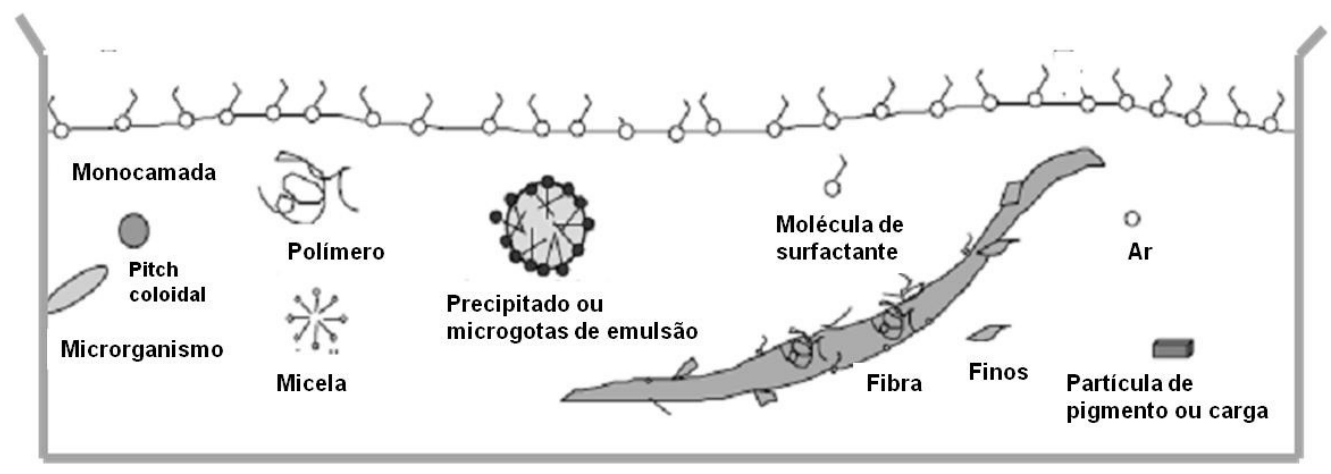

Figura 2.16 - Constituintes da suspensão de fibras. 
A suspensão contem fibras, finos, carga mineral e aditivos que têm como objetivo melhorar o processo de fabricação de papel e as suas propriedades. Outros constituintes do meio de dispersão são os contaminantes, os quais foram descritos no tópico 2.2.7.

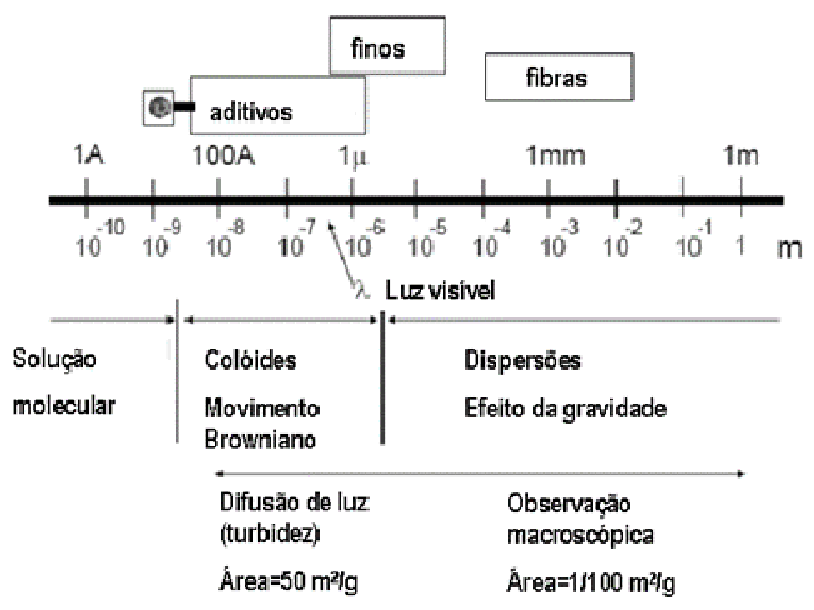

Figura 2.17 - Classificação, em tamanho, dos constituintes da suspensão de fibras.

O material fibroso quando disperso em meio aquoso desenvolve carga superficial em razão da presença de grupos funcionais ionizáveis como por exemplo as hidroxilas e as carbonilas. O grau de ionização dos grupos funcionais é determinado pelo $\mathrm{pH}$ do meio. Este $\mathrm{pH}$ também afeta o equilíbrio entre a carga iônica líquida da superfície e o teor de íons dissolvidos. Portanto, o valor do $\mathrm{pH}$ do sistema pode apresentar forte influência na eficiência dos processos de retenção e de drenagem e na qualidade do produto final.

As propriedades superficiais dos substratos em meio aquoso (superfície específica, carga iônica superficial e composição química), definem a capacidade de adsorção dos mesmos. As cargas superficiais de alguns constituintes da suspensão em meio aquoso podem ser verificadas na Tabela 2.4 adaptada de Blanco; Negro e Tijiro (2001).

O balanço de carga de uma suspensão de fibras, para a fabricação de papel, pode ser avaliado de duas maneiras: através da demanda iônica e da carga superficial. $O$ 
potencial eletrocinético $(\zeta)$, também conhecido como potencial zeta, mede, em $\mathrm{mV}$, a carga superficial líquida das superfícies dos substratos.

Tabela 2.4 - Carga iônica de alguns componentes do sistema de suspensão de fibras em meio aquoso

\begin{tabular}{ccc}
\hline & Carga iônica* & \\
\hline Positiva & Nula & Negativa \\
\hline Polieletrólito catiônico & $\begin{array}{c}\text { Aditivos não-iônicos, por exemplo os } \\
\text { surfactantes (PEO) }\end{array}$ & Polieletrólito aniönico \\
\hline Amido catiônico & Amido & Material celulósico \\
\hline $\begin{array}{c}\text { Carbonato de cálcio } \\
\text { precipitado (PCC) }\end{array}$ & Antiespumante & Hemiceluloses \\
\hline Eletrólitos & Polímeros anfóteros & Fragmentos de lignina \\
\hline Polímeros anfóteros & & Carbonato de cálcio natural \\
& & (GCC) \\
\hline & & Sílica coloidal \\
\hline
\end{tabular}

*A bentonita apresenta caráter anfótero. ${ }^{* *}$ Polianfóteros podem apresentar balanço de carga positivo, negativo ou nulo, a depender do $\mathrm{pH}$.

Por outro lado, a presença de sais dissolvidos na suspensão proporciona a troca de íons. Isto, tanto afeta as propriedades eletrocinéticas da suspensão quanto a adsorção dos diferentes substratos e a floculação das fibras e de finos (BLANCO; NEGRO; TIJIRO, 2001). A capacidade de as fibras trocarem íons reside na presença de grupos carboxílicos e hidroxílicos em sua superfície.

Grande parte dos mecanismos na química da parte úmida da fabricação de papel está relacionada às interações eletrostáticas envolvendo cargas iônicas geradas em meio aquoso. Os grupos carboxílicos dos carboidratos (celulose e hemiceluloses) são as principais fontes de carga aniônica resultante de uma suspensão aquosa de fibras branqueadas medido através do potencial eletrocinético. 
O conhecimento das propriedades do sistema em meio aquoso antes e após a adição dos aditivos de retenção, bem como o seu controle, consiste na base da química da parte úmida da fabricação do papel (BLANCO; NEGRO; TIJIRO, 2001). A Tabela 2.5, adaptada de Blanco; Negro e Tijiro (2001), mostra valores de potenciais eletrocinéticos, em condições específicas, para alguns constituintes da suspensão de fibras.

Tabela 2.5 - Potenciais eletrocinéticos para fibras, finos e cargas, alguns, em diferentes condições de $\mathrm{pH}$

\begin{tabular}{llcc}
\hline \multicolumn{1}{c}{ Substrato } & \multicolumn{1}{c}{ Condições de medição } & $\mathrm{pH}$ & $\begin{array}{c}\text { Zeta } \\
\text { potencial, mV }\end{array}$ \\
\hline Fibras & Agua desmineralizada + (solução de ácido & 4 & -15 \\
& sulfúrico ou solução de soda cáustica) & 6 & -25 \\
& & 8 & -30 \\
\hline Carbonato de cálcio & 1000 ppm em água desmineralizada + 10 ppm & - & +12 \\
precipitado & de Ca ${ }^{2+}$ & & \\
\hline Talco & Agua desmineralizada + ácido sulfúrico & 4 & -10 \\
& & 6 & -20 \\
\hline Dióxido de titânio & Agua desmineralizada + (ácido sulfúrico ou soda & 4 & -9 \\
Anatase & cáustica) & 6 & -28 \\
& & & \\
\hline Dióxido de titânio & Agua desmineralizada + (ácido sulfúrico ou soda & 4 & +25 \\
Rutilo & cáustica) & 6 & +4 \\
\hline
\end{tabular}

\subsubsection{Estabilidade}

O balanço das forças atrativas e repulsivas dos constituintes da suspensão de fibras determina a sua condição de estabilidade. Numa suspensão estável, as forças repulsivas se sobrepõem às atrativas, o que é conhecido como estabilização eletrostática. Por outro lado, se as forças atrativas foram dominantes, a condição da suspensão passa a ser instável podendo haver agregação das partículas. Outro aspecto importante a ser considerado em relação à estabilidade da suspensão de 
fibras é o movimento Browniano naturalmente presente em sistemas coloidais. As partículas coloidais se movimentam aleatoriamente a uma velocidade constante e dependente da temperatura do meio. Para uma suspensão estável, o choque entre as partículas devido a esse movimento deve ser de uma intensidade tal que as partículas se repelem entre si durante a colisão. Caso contrário, se as partículas permanecerem aderidas após a colisão, o sistema passa a ser instável (BLANCO; NEGRO; TIJIRO, 2001).

Polímeros de alto peso molecular, dosados em quantidade excessiva, são adsorvidos nas superfícies das partículas formandos loops e caudas em suas superfícies, os quais impedem sua aproximação, fenômeno também conhecido na química coloidal e de superfície como barreira estérica ou estabilização estérica. Dessa forma, a suspensão de fibras pode permanecer estável.

Os substratos da suspensão desenvolvem carga superficial e, dependendo de suas características físicas, se comportam como substâncias coloidais. Estas substâncias apresentam comportamento particular que é explicado pela ciência coloidal e de superfície. Como na suspensão de fibras existem substratos que se comportam e apresentam dimensões coloidais, a estabilidade da suspensão deve considerar os fenômenos interfaciais que explicam o comportamento desses substratos em sistemas aquosos. Portanto, antes de descrever sobre os sistemas de retenção e drenagem, no qual é realizada a desestabilização da suspensão de fibras, é importante conhecer sobre os tópicos de ciência coloidal e as interações químicas em interfaces.

\subsection{Dispersão coloidal}

A ciência coloidal se ocupa com sistemas nos quais um, ou mais, dos componentes apresenta pelo menos uma de suas dimensões dentro do intervalo de $1 \mathrm{~nm}$ a $1 \mu \mathrm{m}$ (SHAW, 1975).

Segundo Williams (1992) o termo dispersão coloidal pode ser usado para qualquer sistema de multifases no qual envolva forças superficiais entre partículas. Para este 
autor, numa dispersão coloidal podem ser identificadas duas fases: a dispersa, em que consiste de partículas que podem ser sólido, líquido ou gás; e o meio de dispersão, também conhecido como fase contínua, o qual, também, pode ser sólido, líquido ou gás. A fase dispersa e o meio de dispersão não precisa, necessariamente, estar no mesmo estado físico. Entretanto, as propriedades interfaciais entre ambas são diferentes.

As referências aos conceitos de interfase, interface e superfície em textos literários são, às vezes, empregadas sem distinção rigorosa. Segundo Rabockai (1979) interface é a superfície que separa duas fases, ou seja, apresenta duas dimensões em termos geométricos. Por outro lado, interfase é a região tridimensional onde ocorre uma transição contínua das propriedades de uma fase para as propriedades da outra.

Considerando que a suspensão de fibras apresenta material dispersos em que o tamanho dos sólidos pode variar de nanômetros até milímetros, conforme visto no tópico 2.3, então, de acordo com o conceito de Shaw (1975), a suspensão de fibras pode ser tratada como uma dispersão coloidal. Outro aspecto é que fibras, fragmentos de fibras e finos de dimensões superiores à escala coloidal atuam como superfícies macroscópicas que influenciam na mobilidade de partículas menores (WILLIAMS, 1992).

Antes de descrever sobre a aplicação dos conceitos e fundamentos da química coloidal e de superfície à fabricação do papel, é interessante conhecer a teoria e a terminologia envolvida neste assunto.

\subsubsection{Classificação dos sistemas coloidais}

Os materiais coloidais são classificados em duas grandes categorias, dependendo do grau de interação entre as partículas e o meio de dispersão, quais sejam (SWANSON, 2003):

a. Colóides liofílicos - são termodinamicamente estáveis e apresentam grande interação com o meio de dispersão. Neste caso não há interface 
perceptível entre a partícula coloidal e o meio, também, a superfície da partícula pode estar parcialmente dissolvida.

b. Colóides liofóbicos - apresentam estabilidade cinética que, muitas vezes, é conhecida como estabilidade coloidal. O sistema coloidal liofóbico apresenta uma discreta interface entre o material coloidal e o meio de dispersão.

\subsubsection{Formação da Dupla Camada Elétrica (DCE)}

A maioria das substâncias adquire carga superficial quando são expostas a um meio polar como o caso da água. Segundo a literatura (SHAW, 1975; WILLIAMS, 1992), tanto os colóides liofóbicos quanto os liofílicos desenvolvem o potencial repulsivo pela aquisição de carga elétrica na superfície da partícula em meio aquoso.

A aquisição de carga em superfícies sólidas em meio aquoso ocorre devido à presença de grupos funcionais. Na fabricação de papel utilizando polpa Kraft branqueada de eucalipto, os grupos carboxílicos são os principais responsáveis pelo desenvolvimento de carga nas superfícies das fibras e dos finos de fibras (ZHANG, 2006 ; FARDIM; HOLMBON, 2005). Estes grupos são introduzidos no material fibroso ao longo da linha de fibra. Na polpação, podem ser introduzidos durante a degradação alcalina, a qual produz grupos carboxílicos terminais na degradação de cadeias de carboidratos, celulose e hemiceluloses, reação conhecida como reação de despolimerização terminal. Podem ser, também, introduzidos pela reação que pára a reação de despolimerização terminal. Essa reação é conhecida como reação de bloqueio (RYDHOLM, 1965). No branqueamento, os grupos carboxílicos são introduzidos nas etapas oxidativas como os estágios de dioxidação e de peroxidação (DENCE; REEVER, 1996). Podem, também, estar naturalmente presentes nas hemiceluloses (SJÖSTROM, 1993).

No processo de fabricação de papel, a natureza da carga superficial do material celulósico desempenha papel fundamental nos fenômenos que envolvem interações interfaciais: dispersão de fibras, floculação e adsorção de polieletrólitos (HUBBE, 2006; ROJAS; HUBBE, 2004). Considerando o fenômeno da adsorção de 
polieletrólito, os grupos carboxílicos ionizados e sua acessibilidade é um aspecto importante nos processos de interação entre superfícies por que estes grupos constituem os sítios de adsorção para retenção de cargas inorgânicas.

O mecanismo que rege a aquisição de carga superficial em sistemas de suspensão de fibras é a ionização.

A Figura 2.18 ilusta a reação de ionização de grupos acídicos na superfície de um determinado substrato ${ }^{9}$ e a Figura 2.19 ilustra uma estrutura polimérica da cadeia de celulose contendo grupos carboxílicos ligados na cadeia.

Um aspecto importante em uma dispersão aquosa que influencia na aquisição de carga elétrica da superfície da fase dispersa é a concentração de prótons de hidrogênio na dispersão o que determina $0 \mathrm{pH}$ do meio, ou o potencial hidrogeniônico. É esperado que em valores mais baixos de $\mathrm{pH}$, os grupos carboxílicos, por exemplo, se encontrem mais na forma ácida, ou seja, pouco ionizados quando comparados ao grau de ionização desses mesmos grupos em valores de $\mathrm{pH}$ mais elevados. $\mathrm{O}$ valor de $\mathrm{pH}$ no qual a carga elétrica total é nula é chamado de ponto isoelétrico.

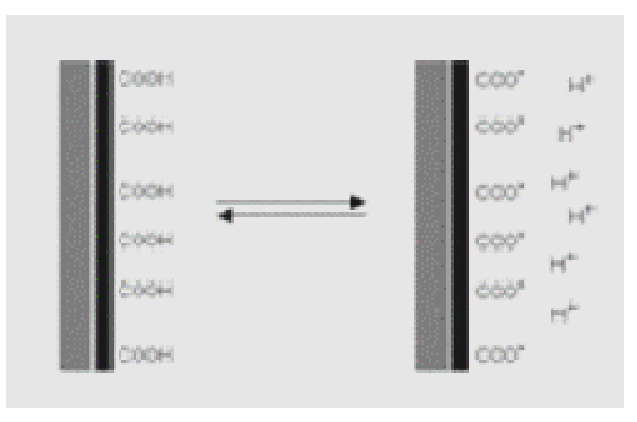

Figura 2.18 - lonização de grupos carboxílicos.

\footnotetext{
9 Adaptada de Zeta Potential - An Introduction in 30 Minutes. ZETASIZER NANO SERIES TECHNICAL. Technical Note MRK654-01,2007. Disponível em: <http://www.nbtc.cornell.edu/facilities/downloads/Zeta\%20potential\%20\%20An\%20introduction\%20in\%2030\%20minutes.pdf >. Acesso em: 01 Jun.2007.
} 


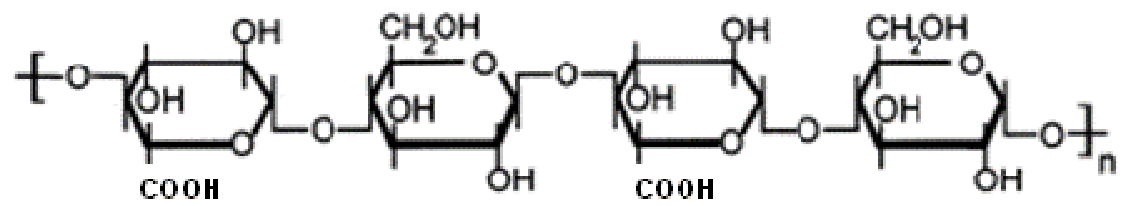

Figura 2.19 - llustração da estrutura polimérica da cadeia de celulose. Detalhe: presença de grupos carboxílicos e hidroxílicos.

A dupla camada elétrica (DCE) é formada devido ao fato de os sólidos suspensos, em meio líquido, se tornarem eletricamente carregados na interface sólido-líquido. As cargas desenvolvidas na superfície da partícula no meio de dispersão influenciam na distribuição de íons presentes nas proximidades, repelindo os íons de mesma carga (co-íons) e atraindo os íons de carga oposta (contra-íons) que se estende a uma distância finita na fase liquida a partir da superfície do sólido. A disposição desses íons em torno da superfície carregada no meio de dispersão, associada ao efeito da movimentação térmica, conduz a formação DCE.

Helmholtz em 1897; Gouy em 1910; Chapman em 1917; Debye e Huckel em 1923, e Stern em 1924 propuseram modelos para explicar a dupla camada elétrica (SHAW, 1975; WILLIAMS, 1992; HUNTER, 1993). O modelo atualmente aceito combina as diversas teorias apresentadas por esses pesquisadores com o objetivo de explicar os fenômenos que ocorrem na superfície de uma partícula eletricamente carregada quando imersa em um meio polar. O modelo divide a dupla camada elétrica em regiões.

\subsubsection{Camada rígida}

A camada rígida descrita por Helmholtz, conforme esquema da Figura 2.20 adaptada de Shaw (1975), apresenta íons de cargas opostas adsorvidos na superfície carregada. Nessa camada, os íons permanecem fortemente adsorvidos na superfície através de forças eletrostáticas e de van der Waals, mesmo com a existência de movimentação térmica. 


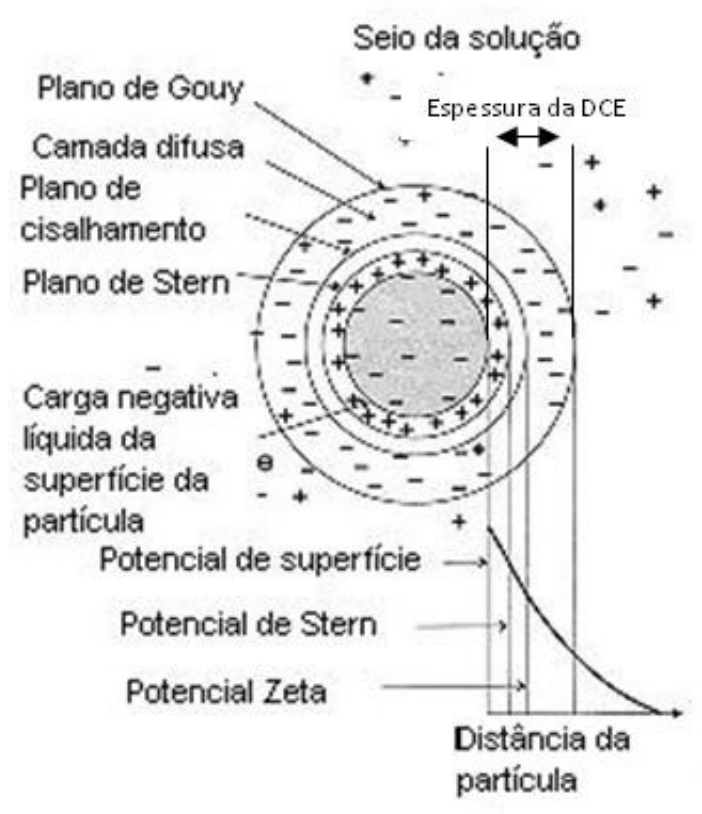

Figura 2.20 - Distribuição dos potenciais elétricos ao redor de uma partícula eletricamente carregada.

Vale destacar na Figura 2.20 algumas posições importantes na superfície da partícula carregada como os potenciais elétricos, potencial de superfície $\left(\Psi_{\circ}\right)$, potencial de Stern $(\omega)$ e o potencial zeta, este também conhecido como potencial de cisalhamento $(\zeta)$, e a espessura da dupla camada elétrica $(1 / \kappa)$, esta também conhecida como comprimento de Debye, a qual compreende entre a superfície da partícula e o plano de Gouy (Figura 2.20).

\subsubsection{Camada difusa}

A camada difusa, descrita por Gouy e Chapman, apresenta espessura variável e é influenciada por interações eletrostáticas e correntes térmicas (Figura 2.20). Nesta camada seus íons se encontram livres para se moverem no meio.

A Figura 2.21, conforme King (1975), ilustra a dupla camada elétrica desenvolvida na superfície do material fibroso no meio de dispersão aquoso. Na fase líquida, as 
cargas previnem que as partículas sólidas se aproximem uma das outras devido às forças repulsivas, conferido estabilidade à suspensão de fibras. Por outro lado, se as forças repulsivas forem baixas, a ponto de as partículas se situarem muito próximas, as forças atrativas de van der Waals irão predominar fazendo com que as partículas sejam agregadas. Portanto, o grau de separação entre as partículas é função da espessura da camada difusa (KING, 1975).

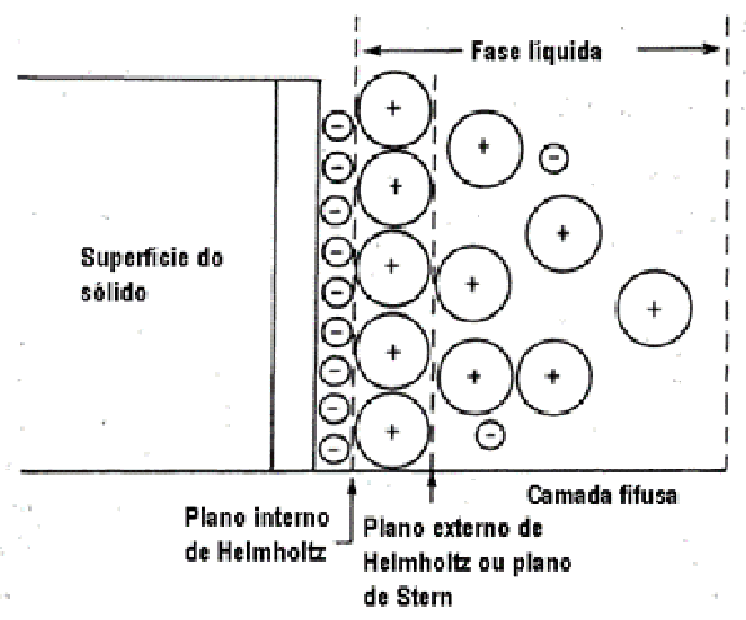

Figura 2.21- llustração da dupla camada elétrica da superfície do material fibroso.

\subsubsection{Teoria DLVO}

Conforme visto no tópico anterior, o fato de os substratos da suspensão de fibras desenvolverem carga elétrica negativa em meio aquoso, atraindo íons de carga oposta, leva a formação da dupla camada elétrica, constituída de uma superfície carregada e um meio polar onde se distribuem íons de carga oposta.

A teoria DLVO (Derjaguin-Landau e Verwey-Overbeek) é aplicada ao estudo da estabilidade de sóis liofóbicos, nos quais também pode ser considerada a suspensão de fibras em meio aquoso. Esta teoria assume que a superfície da fibra é plana e eletricamente carregada em meio aquoso (FARDIM, 2002a e 2002b). 
A Figura 2.22, adaptada de Swanson (2003), apresenta o comportamento da energia potencial entre duas partículas em relação à distância, o qual é explicado pela teoria DLVO.

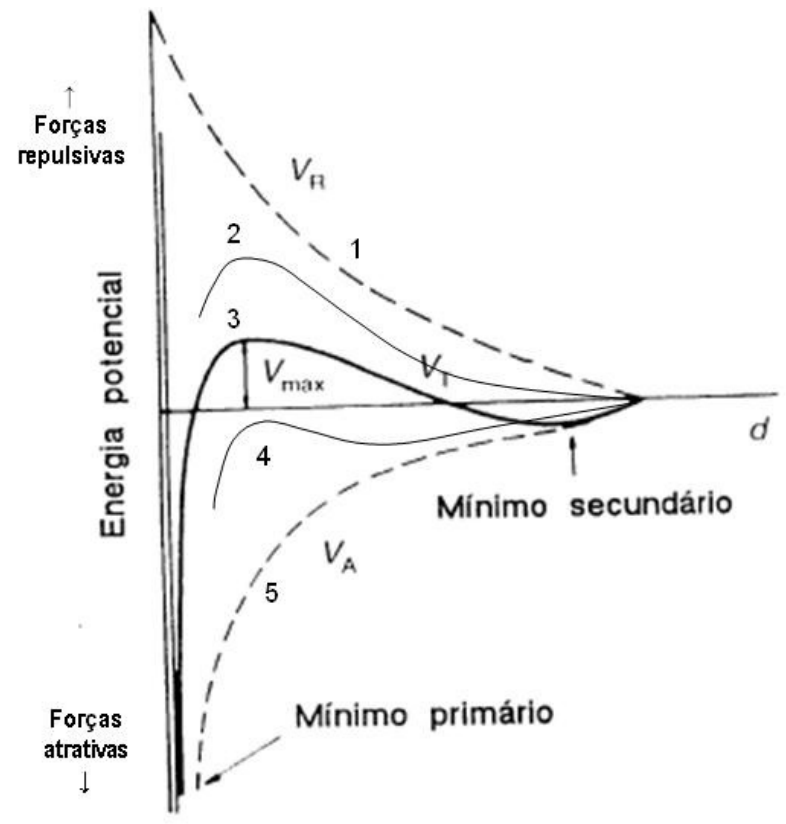

Figura 2.22 - Energia potencial entre duas partículas.

De acordo com a teoria DLVO, a energia potencial de interação total das partículas é obtida pelo somatório das forças de atração $\left(V_{A}\right)$ e das forças de repulsão $\left(V_{R}\right)$, originadas das DCE's ao redor das partículas, cuja intensidade depende do potencial de superfície e da distribuição dos contra-íons em que se encontra o meio de dispersão. Esse somatório dá origem à curva força, ou energia potencial, em relação à distância $(\mathrm{d})$ entre as superfícies de duas partículas. De acordo com a Figura 2.22, curva 3, podem ser identificadas duas regiões nas quais pode ocorrer agregação de partículas, uma mais próxima da superfície da partícula chamada de mínimo primário; e outra mais distante da superfície, conhecida como mínimo secundário. Em ambas as regiões, as forças atrativas estão presentes em maior intensidade quando comparadas às forças repulsivas. A curva de energia total mostra que, quando duas partículas se aproximam, a energia passa, inicialmente, pelo ponto de mínimo secundário. Neste ponto, as partículas estão unidas, porém separadas por uma película de líquido. As partículas se aproximam mais, até que seja alcançado 
valor máximo de energia $\left(\mathrm{V}_{\text {máx. }}\right)$, correspondendo à energia de repulsão máxima, ou energia de barreira. Para distâncias inferiores a este valor, as partículas se atraem e a coagulação ocorre no mínimo primário. Neste ponto, o sistema se encontra termodinamicamente estável.

A forma como se apresenta essa curva possibilita inferir sobre a tendência à agregação dessas partículas as quais compõem um determinado sistema, ou seja, sobre a estabilidade da suspensão coloidal ou sobre a estabilidade da suspensão de fibras.

Quando as partículas apresentam um tempo de estabilidade longo, estas partículas certamente possuem maior energia de repulsão entre as mesmas quando comparada à energia de atração. Isto pode ser representado pela curva 1 da Figura 2.22. A energia de repulsão é uma função exponencial da distância que separa as partículas, com alcance da ordem da espessura da dupla camada elétrica.

Por outro lado, quando as forças atrativas de van der Waals são mais significativas do que a energia repulsiva, curva 5 da Figura 2.22, o sistema tende a instabilidade, estado em que ocorre a agregação das partículas coloidais.

Pode-se observar ainda na Figura 2.22 que, quando a contribuição das forças repulsivas é elevada (curva 2), a curva apresenta um máximo de energia que representa a energia de barreira à agregação das partículas coloidais. Entretanto, quando essa contribuição for menos significativa, não existirá quase que nenhuma barreira à agregação das partículas o que na Figura 2.22 pode ser representada pela curva 4, por exemplo.

Outra característica importante desse balanço de forças é que a máxima energia de barreira à agregação entre partículas coloidais ocorre a distâncias muito pequenas e intermediárias às distâncias com tendência à instabilidade, ou seja, distâncias inferiores e superiores à faixa de distância que compreende a barreira de repulsão.

A energia de barreira à agregação das partículas coloidais pode ser reduzida pelo aumento de temperatura e, ou, pela presença de elevados níveis de forças hidrodinâmicas e de cisalhamento inerentes ao sistema. Para o caso do sistema de fabricação de papel, este fato é bastante relevante, pois a suspensão de fibras está 
constantemente sendo submetida a esses tipos de forças desde a etapa de preparo de massa até a formação da folha. Nessas operações, a energia cinética das partículas é aumentada podendo ultrapassar a barreira repulsiva levando à agregação. Certamente, no caso do sistema de fabricação de papel, a energia cinética das partículas coloidais adquirida a partir dessas fontes contribui em maior proporção quando comparada a agitação natural das partículas coloidais devido ao movimento Browniano, o qual também proporciona colisões entre partículas.

Embora o aumento da temperatura e a existência de forças hidrodinâmicas e de cisalhamento favoreçam a agregação das partículas coloidais, excesso dessas forças poderá causar a desagregação das partículas aglomeradas, ou seja, a defloculação. Às vezes, a defloculação é bem vista considerando a qualidade de formação da folha.

As curvas 2 e 3 da Figura 2.22 mostram um mínimo secundário a distâncias relativamente elevadas entre partículas. Estas distâncias estão na ordem de $200 \AA$ (SWANSON, 2003). Neste ponto ocorre instabilidade levando a floculação das partículas, porém, este tipo de floculação é facilmente reversível à estabilidade. Por outro lado, se ocorrer na região de mínimo primário, a instabilidade será irreversível.

A camada difusa da partícula pode ser afetada por parâmetros relacionados ao meio de dispersão como concentração de eletrólitos, bem como tamanho e valência dos mesmos, densidade de carga e pH do meio. Quanto maior a concentração de eletrólitos na fase líquida, maior a quantidade de íons disponíveis para neutralizar a carga da superfície da partícula reduzindo assim o efeito das forças repulsivas. Nesse caso, haverá predominância das forças atrativas. O tamanho e a densidade de carga dos eletrólitos, contra-íons, também são parâmetros que afetam a estabilidade da dispersão coloidal. Quanto maior a valência do contra-íon, menor será a quantidade necessária desse íon para neutralizar a carga da superfície.

Igualmente, variações de $\mathrm{pH}$, para a mesma concentração de eletrólitos do meio, podem afetar a espessura da DCE pela alteração do grau de ionização dos grupos funcionais presentes na superfície do material fibroso. 


\subsection{Interações interfaciais}

De forma geral, as ligações químicas entre átomos podem ser divididas em: covalente, dativa, iônica, metálica, por ligação de hidrogênio e forças de van der Waals. As quatro primeiras ocorrem entre átomos de uma mesma molécula (ligação intramolecular), enquanto que as duas últimas são comuns entre átomos de moléculas distintas (ligação intermolecular).

Em relação à química da parte úmida, é muito difícil ocorrer reações químicas diretas entre os substratos e os aditivos. Por outro lado, interações físico-químicas entre as superfícies desses substratos e o agente de retenção, são mais freqüentes (BLANCO; NEGRO; TIJIRO, 2001). Segundo estes autores, as forças de interação mais comuns presentes nessa etapa do processo são as eletrostáticas, as forças de van der Waals e as interações por ligação de hidrogênio. Essas interações são conseqüência direta das propriedades de superfície dos substratos e do sistema coloidal como um todo.

A estabilidade da suspensão de fibras é dependente das interações interfaciais que possam ocorrer entre os substratos que compõem essa suspensão. A seguir, descrição das forças de interação segundo Galemberk e Gandur (2006) ${ }^{10}$.

\subsubsection{Forças eletrostáticas}

Forças eletrostáticas, ou forças de Coulomb, são forças que surgem da interação entre átomos ou moléculas eletricamente carregados por cargas de sinais opostos. É uma das maiores forças de interação entre átomos e, ou, moléculas e são importantes para a fabricação de papel. A energia potencial da interação $\left(\Phi^{E I}\right)$ resultante da interação eletrostática é dada pela Equação 2.5,

$\Phi^{E I}=\frac{q_{1} q_{2}}{4 \pi \varepsilon r}$

Equação 2.5

${ }^{10}$ GALEMBERK, F.; GANDUR, M.C. Cientistas explicam o fenômeno da adesão. Disponível em: $<$ http://www.quimica.com.br/revista/qd393/adesivos tec1.htm>. Acesso em: 02.mai.2006. 
Em que, $q_{i}$ é a carga dos átomos ou molécula, $\varepsilon$ é a constante dielétrica do meio e $r$ é a distância que separa os átomos ou moléculas.

\subsubsection{Forças de van der Waals}

As forças de van der Waals também são essenciais para o processo de fabricação de papel desde que são forças atrativas responsáveis pela interação entre partículas.

A equação de van der Waals (Equação 2.6), consiste em uma das tentativas de descrever gases não ideais, a qual esta descrita abaixo:

$\left(P+\frac{a n^{2}}{V^{2}}\right)(V-b n)=n R T$

Equação 2.6

Em que, $P$ é a pressão, $V$ é o volume, $n$ é o número de moles, $R$ é a constante dos gases, $T$ é a temperatura absoluta e "a" e "b"constantes de van der Waals.

Essas interações que provocam desvio da lei dos gases ideais são conhecidas como forças de van der Waals. Para entendê-las melhor é importante conhecer sobre os tópicos: eletronegatividade, polaridade e momento de dipolo.

\subsubsection{Eletronegatividade}

A eletronegatividade está relacionada com as diferentes afinidades dos átomos pelos elétrons em uma ligação, dando origem à polaridade na molécula.

De forma simples, quando a distribuição das cargas, em moléculas com dois ou mais átomos, é desigual, há tendência de formação de um centro de carga positiva e 
outro centro de carga negativa. Neste caso, a molécula é dipolar ou apresenta momento de dipolo. A propriedade momento de dipolo possui consequências importantes no que diz respeito à interações entre átomos intra e intermoleculares.

Os momentos de dipolo são a medida da fração de caráter iônico em uma ligação. Em uma molécula, quando a ligação formada é puramente iônica, isso significa que o par de elétrons está em um dos átomos e a fração de caráter iônico da molécula resultante é um.

As interações que ocorrem entre dipolos determinam o tipo de força existente entre átomos e, ou, moléculas. As forças atrativas de van der Waals podem ser consideradas como o somatório das seguintes interações:

\subsubsection{Interação dipolo-dipolo}

A eletronegatividade diferenciada dos átomos que compõem uma molécula, conforme já visto anteriormente, pode fazer com que esta molécula apresente cargas virtuais em função de uma distribuição desuniforme dos elétrons.

A interação dipolo-dipolo, ou forças de Keesom, surge quando a extremidade positiva de uma molécula polar está direcionada para a extremidade negativa de outra molécula também polar.

As forças de interação de dipolo-dipolo são tipicamente mais fracas do que as ligações covalentes ou as iônicas e decrescem rapidamente com o aumento da distância entre os dipolos.

A energia potencial de interação entre dois dipolos $\left(\Phi^{P}\right)$ neste caso é dada pela Equação 2.7,

$$
\Phi^{P}=\frac{\mu_{1} \mu_{2}}{r^{3}}\left(2 \cos \theta_{1} \cos \theta_{2}-\sin \theta_{1} \sin \theta_{2} \cos \left[\phi_{1}-\phi_{2}\right]\right)
$$


Em que, $\mu_{i}$ representa o momento de dipolo da molécula "i", $r$ é a distância que separa os centros dos dipolos, $\theta_{i}$ representa o ângulo de orientação entre os dipolos "i".

As interações por ligações de hidrogênio são consideradas um caso particular de interações dipolo-dipolo e contêm um átomo de hidrogênio ligado a um átomo mais eletronegativo, como o caso típico do oxigênio e do nitrogênio. A energia potencial de interação dessas ligações pode variar de 2 a $10 \mathrm{cal} / \mathrm{mol}$, sendo maior do que a energia potencial obtida através de forças de van der Waals.

O tamanho pequeno do átomo de hidrogênio em relação aos outros átomos mais eletronegativos se torna um aspecto que diferencia as interações por ligações de hidrogênio das interações dipolo-dipolo com outros átomos. As distâncias intermoleculares de interações por ligações de hidrogênio são de, aproximadamente, 2 a $3 \AA$, enquanto que para as interações dipolo-dipolo normais esta distância gira em torno de 3,5 a $4,5 \AA$.

A ligação de hidrogênio é um tipo de interação que pode ocorrer no processo de fabricação de papel visto que nas superfícies dos substratos celulósicos estão presentes grupos funcionais como hidroxílicos e, principalmente, carboxílicos, potenciais formadores desse tipo de ligação na forma não ionizada.

$\mathrm{Na}$ suspensão de fibras, durante a fabricação de papel, os sítios hidrofílicos acessíveis, existentes nas moléculas de celulose e hemiceluloses, rapidamente fazem ligações de hidrogênio com as moléculas de água em sua volta. No processo inverso, para remoção da água remanescente da fibra durante a etapa de secagem, é necessária grande quantidade de energia térmica, normalmente em forma de vapor. Nesse caso, as ligações por ligações de hidrogênio entre moléculas de água e entre moléculas de água e cadeias de carboidratos, celulose principalmente, dão lugar a moléculas de celulose ligada por ligações de hidrogênio através de uma camada de moléculas de água. Nesta fase, o teor de umidade do papel já se encontra muito baixo. 


\subsubsection{Interação dipolo-dipolo induzido}

O dipolo induzido ocorre quando moléculas com distribuição uniforme da nuvem de elétrons são polarizadas por dipolos de outras moléculas, resultando numa interação dipolo-dipolo induzido ou força de Debye.

A energia potencial de interação $\left(\Phi^{\prime}\right)$ entre dipolo e dipolo induzido é dada pela Equação 2.8,

$$
\Phi^{I}=-\frac{\mu_{1}^{2} \alpha_{2}+\mu_{2}^{2} \alpha_{1}}{r^{6}}
$$

Em que, $\alpha_{i}$ é a polarizabilidade da molécula "i", $\mu_{i}$ é o momento de dipolo da molécula “i”", $r$ é a distância que separa os centros dos dipolos.

\subsubsection{Forças de London ou de dispersão}

Dos três tipos de forças de interação, as forças de London ou de dispersão são consideradas as mais importantes para os processos de floculação, pois, embora se trate de forças atrativas fracas quando é considerada a atuação de um átomo ou uma molécula de forma individual, o efeito torna-se maior quando se consideram todos os átomos e moléculas do sistema (BLANCO; NEGRO; TIJIRO, 2001).

Neste tipo de interação, as moléculas exercem forças umas sobre as outras mesmo sem apresentar momento de dipolo. Trata-se da força de atração mais comum e é encontrada em, praticamente, todos os materiais. Estas forças surgem da formação de dipolos instantâneos, provocando a formação de dipolos induzidos, também, instantâneos. Isto porque, momentaneamente, a distribuição de elétrons nas camadas pode estar assimétrica, desenvolvendo, temporariamente, carga dipolar, afetando a distribuição da nuvem eletrônica do átomo vizinho. A atração interatômica resultante é relativamente fraca e de vida curta, porém, muito significativa em átomos de grandes dimensões. 
A energia potencial dessa interação $\left(\Phi^{p}\right)$, para átomos ou moléculas similares, é dada pela Equação 2.9.

$$
\Phi^{p}=-\frac{3}{4}\left(\frac{\alpha_{1}^{2} C_{1}}{r^{6}}\right) \approx-\frac{3}{4}\left(\frac{\alpha_{1}^{2} l_{1}}{r^{6}}\right)
$$

Equação 2.9

Para átomos ou moléculas não similares, a energia potencial $\left(\Phi_{12}^{p}\right)$ é dada pela Equação 2.10.

$$
\Phi_{12}^{p}=-\frac{3}{4} \frac{\alpha_{1} \alpha_{2}}{r_{12}^{6}}\left(\frac{2 C_{1} C_{2}}{C_{1}+C_{2}}\right) \approx-\frac{3}{4} \frac{\alpha_{1} \alpha_{2}}{r_{12}^{6}}\left(\frac{2 I_{1} I_{2}}{I_{1}+I_{2}}\right)
$$

Em que, $\alpha_{i}$ é a polarizabilidade da molécula “i”, $C_{i}$ são as constantes moleculares que podem ser aproximadas por $I_{i}$ que são os potenciais de ionização dos átomos ou moléculas.

As forças atrativas atuam até uma certa distância interatômica ou intermolecular. A medida em que a distância vai diminuindo, passa por um ponto de máximo de forças atrativas, e há uma redução dessas forças até o ponto em que passam a atuar as forças repulsivas. Esse ponto, a uma distância interatômica ou intermolecular muito pequena, há sobreposição das camadas de elétrons. Para longas distâncias, as forças de interação, ou energia, são nulas. Explicação mais bem detalhada sobre o diagrama força-distância, teoria de DLVO, pode ser vista no tópico 2.4.3.

A energia potencial repulsiva, originada da sobreposição da camada externa de elétrons, para muitas moléculas, é proporcional ao inverso da distância entre moléculas, ou átomos, elevada a décima segunda potência.

A energia potencial resultante entre moléculas $\left(E_{p}\right)$, descrita pela equação de Lennard-Jones, é dada pela soma dos potenciais repulsivos e atrativos (Equação 2.11):

$$
E_{p}=\frac{1}{r^{12}}-\frac{1}{r^{6}}
$$


Em que, $r$ é a distância entre átomos ou moléculas.

Embora as ligações covalentes e iônicas proporcionem energias de interação intermoleculares maiores quando comparadas às força de van der Waals, estas atuam a uma distância maior, por isso, sendo conhecidas como forças de longo alcance e de grande importância para o estudo da química da parte úmida da fabricação do papel.

\subsection{Retenção e drenagem}

O termo retenção refere-se, basicamente, à fixação de partículas de pequenas dimensões, presentes na suspensão, em elementos com dimensões maiores como as fibras e os seus fragmentos. As partículas não fixadas através da adição de agentes químicos e nem retidas mecanicamente passam através da manta aumentando a concentração de sólidos secos da água branca. A concentração destes sólidos e as concentrações das substâncias dissolvidas e coloidais influenciam no grau de recirculação de água do sistema e na eficiência e custo operacional do processo. Geralmente, menores concentrações dessas substâncias são desejáveis. A Figura 2.23 apresenta, em forma de ilustração adaptada de Rodrigues $(2007)^{11}$, a comparação entre os tamanhos dos constituintes da suspensão e a dimensão de uma abertura da tela formadora.

A água presente na suspensão pode se encontrar de três maneiras distintas: na forma livre, a qual pode ser removida de forma mecânica e está presente envolvendo os substratos e no interior dos elementos celulares; na forma adsorvida, a qual só é removida através do aquecimento da folha; e a água de constituição, a qual faz parte da composição química das fibras, principalmente, e não é removida com as etapas normais da fabricação de papel. $O$ termo drenagem refere-se à remoção de água livre da folha formada inicialmente através de gravidade seguida de vácuo. A drenagem, a qual está relacionada com a habilidade de a manta ser

\footnotetext{
${ }^{11}$ RODRIGUES, P. Apresentação cedida durante visita à empresa EKA Chemical. Sistema Compozil Select de Retenção e Drenagem. EKA Chemicals, Judiaí, Fevereiro de 2007.
} 
desaguada, é o principal aspecto que influencia a produtividade de uma fábrica de papel, pois a eficiência de remoção de água da manta durante a formação da folha determina a velocidade de operação da máquina de papel, sendo esta diretamente proporcional à taxa de produção.

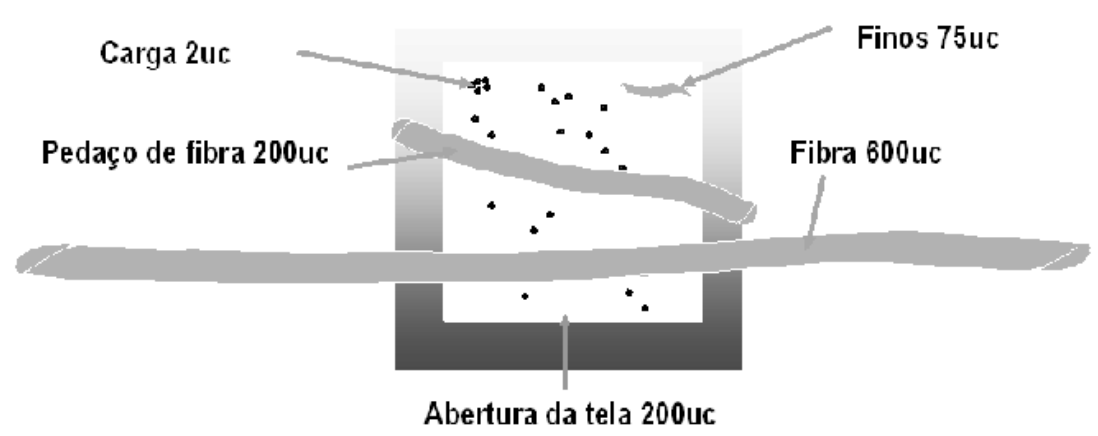

Figura 2.23 - Comparação entre os tamanhos dos substratos presentes na suspensão de fibras e as dimensões de uma abertura da tela formadora (uc corresponde à unidade de comprimento).

Na fabricação de papel, os processos de retenção de partículas e o de drenagem se comportam de forma inversa. Normalmente, a otimização dos dois processos é a alternativa perseguida pelos fabricantes. Programas que aumentam a eficiência dos dois processos, simultaneamente, têm sido desenvolvidos.

A retenção de finos pode ocorrer de duas maneiras: mecânica ou química. $\mathrm{Na}$ primeira, a manta formada pelos elementos de dimensões maiores funciona como um filtro para retenção dos elementos de dimensões menores. A retenção mecânica desses elementos pode não ser tão eficiente quando há a associação das duas: química seguida da retenção mecânica. Portanto, é comum proceder, antes da etapa de formação, a agregação e, ou, adsorção de partículas sólidas de dimensões reduzidas, a retenção. Desta forma, os agregados da coagulação e, ou, as partículas fixadas por adsorção serão mais facilmente retidos na mesa plana por apresentarem dimensões superiores do que quando de forma individualizada. Os agentes químicos responsáveis pela coagulação de substâncias coloidais e dissolvidas são os polímeros de baixo peso molecular e elevada densidade de carga, e os 
responsáveis pela adsorção química interfacial, são os polieletrólitos. Normalmente, a associação conjunta destes agentes, juntamente com o uso de micropartículas, é empregada na retenção das mesmas constituindo um programa de retenção e drenagem.

Conforme visto anteriormente, os agentes de retenção quando adicionados à suspensão de fibras têm como principal função a fixação de partículas de tamanhos micrométricos em superfícies de substratos com dimensões maiores, como é o caso das fibras. Com isso, essas partículas seguem com a folha de papel formada, melhorando a qualidade da água branca quanto ao teor de sólidos, podendo esta ser recirculada em maiores proporções.

Existem na literatura sobre 0 assunto diferentes terminologias relacionadas ao processo de retenção considerando partículas sólidas e substâncias coloidais e dissolvidas. Algumas delas são: retenção, floculação, coagulação, complexação e agregação. Para ficar mais bem esclarecido, neste trabalho e no setor industrial o termo floculação, historicamente, tanto pode estar relacionado ao processo de agregação de partículas sólidas com a utilização de polieletrólitos, floculação química, quanto pode está relacionado ao processo de floculação mecânica, quando as fibras formam naturalmente flocos macroscópicos sem a utilização de agentes químicos (SWANSON, 2003). Teoricamente, a floculação é um processo reversível. Por outro lado, a coagulação está relacionada ao processo de agregação de substâncias dissolvidas e, ou, coloidais, que ocorre com o auxílio de agentes coagulantes, os eletrólitos ou polímeros sintéticos de alta densidade de carga e baixo peso molecular. Tanto o processo de agregação de partículas sólidas quanto 0 processo de agregação de substâncias dissolvidas e coloidais influenciam na eficiência do processo de retenção na mesa plana. O processo de agregação de substâncias dissolvidas ou coloidais ocorre através de reações de neutralização ou, como também são conhecidas, reações de complexação, em que há uma agregação dessas substâncias formando estruturas maiores. Tanto o processo de adsorção de cargas inorgânicas quanto 0 de agregação de substâncias dissolvidas e coloidais contribuem com a eficiência retenção do sistema.

Também em relação à nomenclatura, existe na literatura, distinção entre a retenção de material na mesa plana e a retenção total do sistema. A primeira, também 
conhecida como retenção de primeiro passo, consiste na razão percentual entre os sólidos retidos sobre a mesa plana e os sólidos na caixa de entrada. Por outro lado, a retenção total é definida como a razão percentual entre o peso do papel deixando a máquina e o peso de toda matéria prima empregada, expresso em percentagem (SWANSON, 2003).

Considerando partículas sólidas, a retenção de cargas minerais e de finos depende de vários aspectos relacionados a estas micropartículas, como: densidade de carga superficial, hidrofobicidade, tamanho e forma das partículas e também (ROJAS; NEUMAN, 1999) de aspectos relacionados às características do agente de retenção como densidade de carga e peso molecular. Dentre outros aspectos, a eficiência de retenção de carga mineral é muito importante, pois, a presença de substâncias coloidais e dissolvidas no sistema pode modificar as características superficiais dessas cargas. Portanto, é de se esperar que os sítios carregados superficiais disponíveis das partículas de finos e de cargas minerais originadas da água branca se apresentem diferentes quando comparadas àquelas que estão entrando no processo pela primeira vez.

Anteriormente, quando ainda se produzia papel com máquinas de baixa velocidade, a retenção de partículas era realizada com eletrólitos à base de alumínio, os quais atuavam neutralizando as cargas superficiais das partículas em suspensão com consequente agregação das mesmas. Posteriormente, com o avanço tecnológico das máquinas de papel em que houve aumento de sua velocidade, a demanda por agentes de retenção mais eficientes também se elevou. Dessa forma, surgiram os polieletrólitos sintéticos que atuam individualmente ou de forma combinada nos chamados programas de retenção e drenagem. Os principais mecanismos descritos na literatura para suspensão de fibras utilizando polímeros catiônicos são o tipo "patch" (mosaico) ou através de formação de pontes de fixação entre substratos. Os polieletrólitos podem atuar ainda de forma combinada em que se utilizam polieletrólitos catiônico e aniônico, aplicados em seqüência, variando dosagem, peso molecular e densidade de carga, para agregação de partículas e, conseqüentemente, retenção das mesmas.

Em programas de retenção e drenagem mais recentes se utilizam polieletrólitos associados com micro e nano partículas, os quais contribuem com a modificação 
das características físicas dos flocos em relação aos programas anteriores, alcançando melhores resultados tanto para a retenção quanto para a drenagem. Outros programas que vêm sendo bastante estudados são os baseados na utilização de polieletrólito neutro associado à resinas fenólicas. Esse sistema retém partículas de pequenas dimensões formando redes através de ligações de hidrogênio. O polieletrólito mais utilizado com esta finalidade é o óxido de polietileno (PEO). Este sistema é mais utilizado em plantas em que a água branca apresenta alto teor de lixo aniônico como é o caso da fabricação de papel reciclado.

\subsubsection{Mecanismos de agregação de partículas}

A seguir são descritos os principais mecanismos de agregação de partículas que podem ser utilizados nos sistemas de retenção em fabricação de papel.

\subsubsection{Floculação de fibras}

Antes de descrever sobre a agregação de partículas utilizando agentes de retenção, alguns comentários sobre a agregação mecânica de fibras serão feitos.

Existem dois tipos de floculação numa suspensão de fibras: a mecânica em que as fibras naturalmente se enovelam formando agregados macroscópicos; e a floculação química, quando o agregado é formado a partir da adição de um polieletrólito (SWANSON, 2003). De maneira geral, as fibras apresentam uma tendência natural em se agregarem mecanicamente quando em suspensão aquosa, formando flocos estáveis visíveis a olho nu, mesmo com a baixa consistência que é utilizada no preparo da suspensão de fibras e com a carga superficial negativa que adquirem. Para Blanco; Negro e Tijiro (2001), o comprimento das fibras e a flexibilidade das mesmas são vistos como os principais responsáveis pela ocorrência desse tipo de floculação. Por outro lado, Swanson, 2003, além de considerar os dois fatores anteriores, enumera o tipo de polpa; a temperatura e a viscosidade do meio de dispersão; o tipo e a intensidade da refinação; a consistência da suspensão; as 
condições de turbulência da formação da folha; a presença de íons, especialmente, os polivalentes; a presença de material floculante, como alumínio e pigmentos, etc; e a presença de cola e de polieletrólito, como fatores que afetam o grau de floculação das fibras. Swanson (2003) acredita que os aspectos coloidais não tenham efeito significativo sobre a tendência de as fibras formarem flocos. Para este autor, os flocos, aparentemente, se formam durante o movimento das fibras, uma em relação às outras, como conseqüência da turbulência. Esta turbulência promove: (a) o contato entre as fibras; (b) o entrelaçamento entre elas, podendo ocorrer adesão entre suas superfícies; e (c) a defloculação, a depender da intensidade da turbulência. Um elevado grau de floculação das fibras, quando da formação da folha na mesa plana, conduz a formação de papel com baixa qualidade e, portanto, baixa uniformidade no papel acabado.

Sob o ponto de vista do número de tipos de substratos presentes no floco, a floculação pode ser homogênea, a qual apresenta um tipo de substrato, p.ex., apenas fibras; ou heterogênea, a qual apresenta mais de um tipo de substrato, p.ex., fibras, finos e cargas. Considerando a melhoria na eficiência de retenção, a floculação heterogênea é mais favorável.

Os flocos macroscópicos apresentam influência significativa nas características de formação da folha de papel. Já os flocos microscópicos, resultado da atuação do polieletrólito, influenciam nas propriedades ópticas e na porosidade da folha.

\subsubsection{Sistemas de retenção de micropartículas}

Conforme visto anteriormente, os substratos fibras, fragmentos de fibras e de finos e as cargas apresentam carga negativa em suas superfícies quando em suspensão aquosa. Estas cargas por sua vez, atraem íons positivos do meio de dispersão. Isto gera um valor de potencial zeta líquido que determina a magnitude das forças repulsivas existentes. Por outro lado, também existirão momentos de dipolo flutuantes que geram as forças atrativas de van der Waals, uma das principais responsáveis pela agregação de partículas (tópico 2.5.2.4). Dessa forma, a desestabilização de uma suspensão pode ser realizada de duas maneiras: 
reduzindo as forças repulsivas e aumentando as forças atrativas (BLANCO; NEGRO; TIJIRO, 2001). Entretanto, além das ligações por forças eletrostáticas e de van der Waals, Norell; Johansson e Persson (1999) consideram as interações por ligações de hidrogênio, as hidrofóbicas e as ligações covalentes, como interações que podem causar agregação entre os substratos em uma suspensão de fibras, embora estes autores consideram os sistemas em que ocorrem as interações eletrostáticas e por ligações de hidrogênio os mais comuns.

Em linhas gerais, o mecanismo de agregação de partículas será dependente da natureza química e física dessas partículas, do tipo de aditivo utilizado e das forças de cisalhamento presentes no sistema. Portanto, alterações na dupla camada elétrica (DCE), as quais causam instabilidade pela redução das forças repulsivas, e a utilização de aditivos, que mantêm as partículas agregadas, promovem a instabilidade da suspensão, desde que a intensidade das forças de cisalhamento não ultrapasse as forças de ligações entre partículas em cada agregado.

Os principais mecanismos de agregação de partículas apresentados na literatura podem ser, basicamente, divididos em simples e complexos (DOIRON, 1998). Estão incluídos no mecanismo de agregação simples, a compressão da dupla camada elétrica, a neutralização de cargas, a atração eletrostática ou heterofloculação e os modelos que utilizam um tipo de polímero como o patch, ou mosaico, e o por ponte. Por outro lado, os mecanismos de agregação complexos envolvem a combinação entre diferentes agentes de agregação, normalmente dois ou três, como polímeros ou polímeros associados com outras substâncias ou com partículas coloidais.

\subsection{Compressão da Dupla Camada Elétrica}

A agregação de partículas coloidais pode ocorrer quando há elevação da força iônica do meio devido, principalmente, à presença de sais inorgânicos monovalentes e divalentes, como cloreto de sódio e de cálcio, respectivamente. Com o aumento da força iônica, a concentração de cátions na solução também se torna mais elevada, conseqüentemente, a espessura da dupla camada elétrica (DCE) é reduzida. Neste caso, as partículas se movimentam umas mais próximas das outras ao ponto em 
que passam a atuarem as forças atrativas de van der Waals, levando à desestabilização da dispersão coloidal e a agregação de partículas. Nesse caso, a influência da força iônica do meio é maior na redução da espessura da DCE do que na redução do valor do potencial eletrocinético do sistema.

$\mathrm{Na}$ Figura 2.24, adaptada de Jafelicci Jr. ${ }^{12}$, está ilustrado um exemplo da compressão da DCE de uma partícula coloidal, em que há redução da espessura da DCE de $E_{1}$ para $E_{2}$ e do potencial eletrocinético de $\zeta_{1}$ para $\zeta_{2}$ em razão do aumento da concentração de eletrólitos de $\mathrm{C}_{1}$ para $\mathrm{C}_{2}$. Os íons divalentes comprimem mais a DCE do que os íons monovalentes.

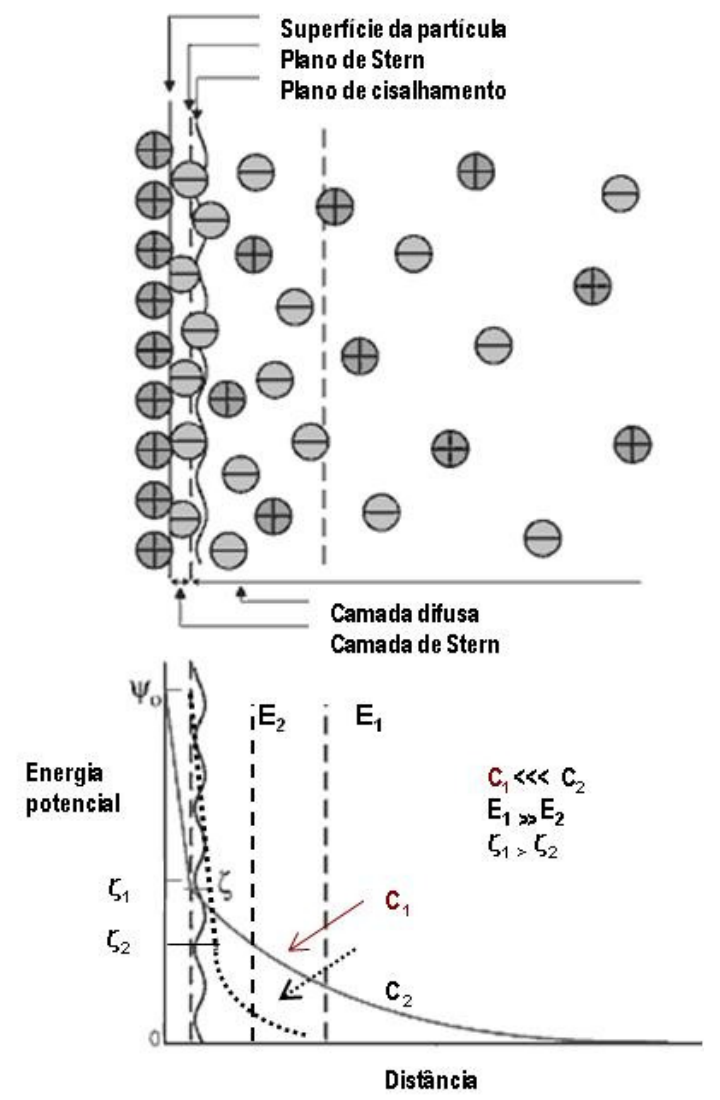

Figura 2.24 - Compressão da dupla camada elétrica. 12 Adaptada de Jafelicci Jr, M. Introdução à Química de Colóides e Superfícies. Disponível em:
$<$ http://www.iq.unesp.br/flotacao/MODULO1/aula3/aula3.htm>. Acesso em: 01.nov.2005. 


\subsection{Neutralização de carga}

As forças eletrostáticas da dupla camada elétrica das partículas coloidais apresentam longo alcance, especialmente quando a força iônica é baixa. Por outro lado, a estabilidade destas partículas é sensível à adição de pequenas quantidades de eletrólitos de carga oposta, os contra-íons, que levam à agregação das mesmas. Os eletrólitos comprimem a DCE reduzindo a barreira repulsiva o suficiente a ponto de as forças atrativas de van der Waals passarem a ser predominantes.

A neutralização de carga ocorre quando há adsorção de íons de carga oposta na superfície das partículas. Neste caso, as partículas se movimentam com menor velocidade e a redução do zeta potencial acontecerá de forma considerável devido à redução do potencial de barreira, permitindo que haja atuação das forças de van der Waals com desestabilização do sistema coloidal e agregação das partículas.

Este tipo de mecanismo apresenta um máximo de agregação à medida que 0 aditivo é adicionado. Aumentando a adição do agente além do ponto isoelétrico, os componentes da suspensão tendem a se redispersarem. Nesse ponto é criada uma nova energia de barreira repulsiva, agora com ionicidade oposta à anterior. Os agentes de agregação que atuam dessa forma, geralmente apresentam baixo peso molecular e elevada carga iônica. Embora, para uma mesma força iônica, a eficiência de agregação aumenta com a redução do potencial de cisalhamento, não é comum em sistemas atuais de retenção e drenagem de fabricação de papel, mantê-lo próximo ao ponto isoelétrico.

O tamanho e a valência do contra-íon em solução são dois fatores importantes que afetam a intensidade das forças repulsivas da dupla camada elétrica das partículas do sistema. Quanto maior a valência maior a redução do potencial de cisalhamento do sistema para uma dada força iônica.

A Figura 2.25, adaptada de Swanson (2003), mostra o efeito da carga do contra-íon no potencial eletrocinético da partícula sólida em meio líquido. De acordo com esta figura, quanto maior a valência do contra-íon menor a concentração necessária para neutralizar a carga da superfície do sólido e causar a neutralização do sistema. Este fato está de acordo com a regra de Schulze-Hardy, a qual prediz que a concentração 
requerida para desestabilizar uma suspensão coloidal diminui com o inverso da valência à sexta potência (SHAW, 1975).

O valor do $\mathrm{pH}$ do meio de dispersão também influencia no grau de ionização dos eletrólitos e, portanto, no grau de adsorção nas superfícies das partículas.

Exemplos de aditivos utilizados para agregação de partículas coloidais são: cátions polivalentes (policloreto de alumínio - PAC); polietileno imina (PEI); cloreto de polidialildimetil amônio (poli-DADMAC). Na fabricação de papel, o policloreto de alumínio é bastante utilizado para agregação das partículas coloidais quando comparado aos polímeros sintéticos em razão do seu baixo custo.

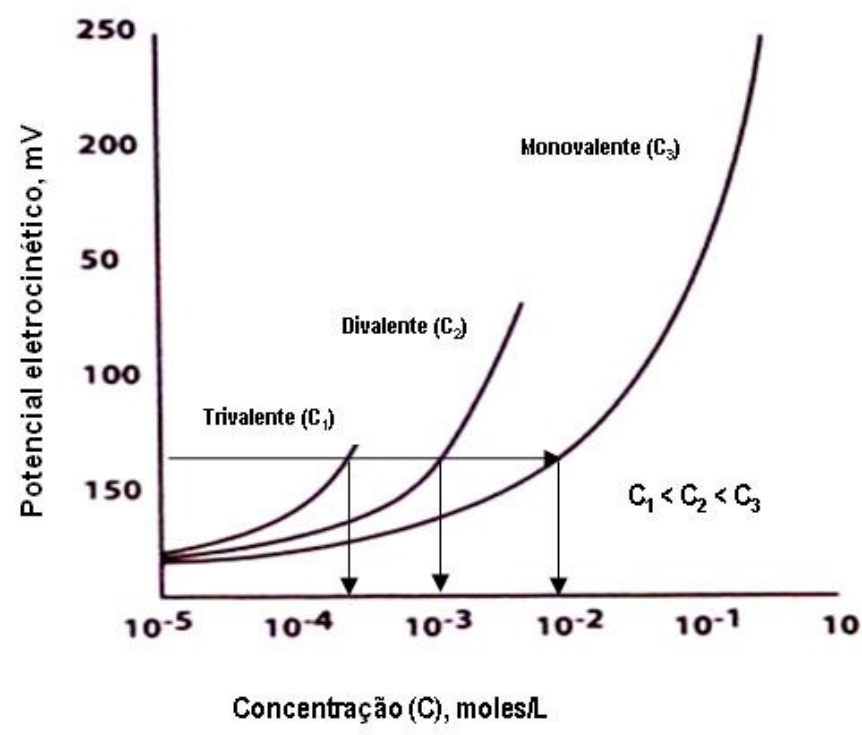

Figura 2.25 - Efeito da carga do contra-íon no potencial de superfície da partícula.

\subsection{Atração eletrostática ou heterofloculação}

A interação por atração eletrostática ou heterofloculação ocorre naturalmente entre superfícies de partículas que apresentam cargas opostas (BLANCO; NEGRO; TIJIRO, 2001). Podem ser citados como exemplo, a interação entre a superfície 
negativa da fibra e partículas de cargas positivas como o carbonato de cálcio precipitado.

\subsection{Modelos que utilizam polieletrólitos catiônicos}

Os modelos de agregação de partículas que utilizam polieletrólitos catiônicos apresentam mecanismos diferentes a depender da associação entre as características peso molecular e densidade de carga dos polímeros.

\subsection{Modelo tipo patch ou tipo mosaico}

Segundo Rojas e Hubbe (2004), patchs ou mosaicos são regiões de carga oposta a da superfície da partícula, criadas através da adsorção de polímeros (Figura 2.26) ${ }^{13}$. Para Blanco; Negro e Tijiro (2001) e Rojas e Hubbe (2004), este tipo de interação ocorre quando são utilizados polieletrólitos com baixos ou médios pesos moleculares $\left(<10^{5} \mathrm{Da}-\mathrm{g} / \mathrm{mol}\right)$ e altas densidades de carga $(>4 \mathrm{meq} / \mathrm{g})$. A densidade de carga do polímero é oposta à densidade de carga da suspensão em que se deseja utilizar o polímero.

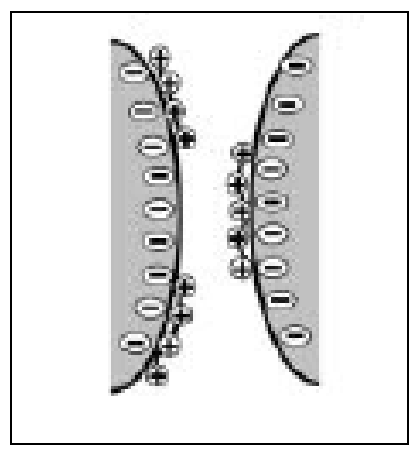

Figura 2.26 - Esquema ilustrando o modelo de floculação tipo patch.

13 Adaptada de ROJAS, O. J., HUBBE, M. A. The Dispersion Science of Papermaking. Journal of Dispersion Science and Technology, v.25, n 6, p. 713-732, 2004. 
Alguns autores denominam o termo patch e mosaico para o mesmo tipo de mecanismo de agregação de partículas (ROJAS e HUBBE, 2004; NORELL; JOHANSSON; PERSSON, 1999). Entretanto, Blanco; Negro e Tijiro (2001), consideram o mecanismo tipo mosaico como um caso particular do mecanismo tipo patch. Estes autores os diferenciam pelo tamanho da região de carga oposta que cobre a superfície da partícula, a qual é dependente do tamanho de cadeia do polímero. Polímeros com alta densidade de carga e cadeias curtas irão atuar no mecanismo tipo mosaico. Por outro lado, polímeros com alta densidade de carga e com cadeia mais longa atuarão segundo o mecanismo tipo patch. Neste estudo, não será feita distinção entre as denominações patch e mosaico. Será adotada a terminologia patch. Neste mecanismo, o polímero é completamente adsorvido na superfície da partícula, formando regiões com carga oposta à sua superfície, através da neutralização de cargas (ROJAS e HUBBE, 2004). O restante da superfície permanece com densidade de carga inalterada.

No caso da celulose, o polieletrólito é adsorvido na sua superfície em regiões planas, preferencialmente. Neste caso, poucas pontes são formadas e a existência de regiões com cargas positivas e negativas na superfície da fibra, ou dos seus fragmentos, promove forças atrativas entre os substratos, fibras e carga mineral, fazendo com que as mesmas sejam adsorvidas ao se colidirem. Caso o polímero seja adicionado em excesso, os flocos podem ser redispersos.

O grau de interação entre partículas, substratos, depende da densidade de carga das mesmas, do percentual da superfície da partícula coberta por cada região e do número de regiões. Para ocorrer este tipo de agregação, não é necessário que o sistema esteja no ponto isoelétrico, pois a interação entre partículas é dependente da presença de regiões positivas e negativas existentes nas superfícies das partículas (BLANCO, 1994). Segundo Blanco; Negro e Tijero, (2001) e Eklund e Lindström (1991) ${ }^{14}$ apud NORELL; JOHANSSON e PERSSON (1999), ótimo grau de cobertura para que ocorra a máxima agregação de partículas é de $50 \%$.

\footnotetext{
${ }^{14}$ Eklund, D.; Lindström, T. (1991). Paper Chemistry: An Introduction, DT Paper Science Publications, Grankulla, Finland apud NORELL, M.; JOHANSSON, K.; PERSSON, M. Retention and Drainage. In: GULLICHSEN, J.; PAULAPURO, H. Papermaking Chemistry. Helsinki, Finland: FAPET Oy, 1999. Book 4 of Papermaking Science and Technology Series Books, cap.3, p. 42-81..
} 
Para que ocorra o mecanismo tipo patch, as diferentes regiões carregadas na mesma superfície devem ser mais espessas do que a espessura da DCE (BLANCO; NEGRO; TIJERO, 2001). Estes autores explicam que se a força iônica do meio é baixa e a espessura da DCE é maior do que a espessura da região coberta com polímero, ocorrerá interação entre partículas pelo mecanismo de neutralização ao invés do mecanismo de atração eletrostática. Ainda, a espessura da DCE pode ser reduzida com a adição de eletrólitos. Por outro lado, se a força iônica for muito elevada, pode ocorrer desorção do polímero da superfície da partícula, não havendo interação através desse modelo. Dessa forma, a diferença entre os mecanismos de interação por neutralização e por patch é que no primeiro a interação entre partículas aumenta com o aumento da concentração do eletrólito e, no segundo, com a adição de eletrólito, a interação entre partículas alcançará um ótimo e decrescerá logo após o ponto de máxima interação. À medida que o peso molecular do polímero diminui, para as outras variáveis constantes, o mecanismo de agregação de partícula através da neutralização de cargas será preferencial ao invés do mecanismo tipo patch. A floculação do tipo patch é sensível às forças de cisalhamento, mas a refloculação das partículas é facilmente alcançada.

Exemplos de aditivos de retenção usados nestes mecanismos são: polietileno imina; poliacrilamida de baixo peso molecular; poliamina.

\subsection{Modelo de floculação tipo pontes}

A agregação de partículas envolvendo a formação de pontes entre as mesmas ocorre com a utilização de polieletrólitos não iônicos ou iônicos de média ou baixa densidade de carga e alto peso molecular, $>10^{6} \mathrm{Da}$, (ROJAS; HUBBE, 2004; BLANCO; NEGRO; TIJIRO, 2001; NORELL et al., 1999). Este tipo de mecanismo é importante, pois ele ultrapassa a barreira repulsiva criada entre as partículas coloidais as quais manteriam a suspensão estável, e alcança umas às outras através dos loops e caudas formados nas superfícies das mesmas.

A Figura 2.27, extraída de Blanco (1994), ilustra o mecanismo de agregação de duas partículas através do modelo de floculação por pontes. 


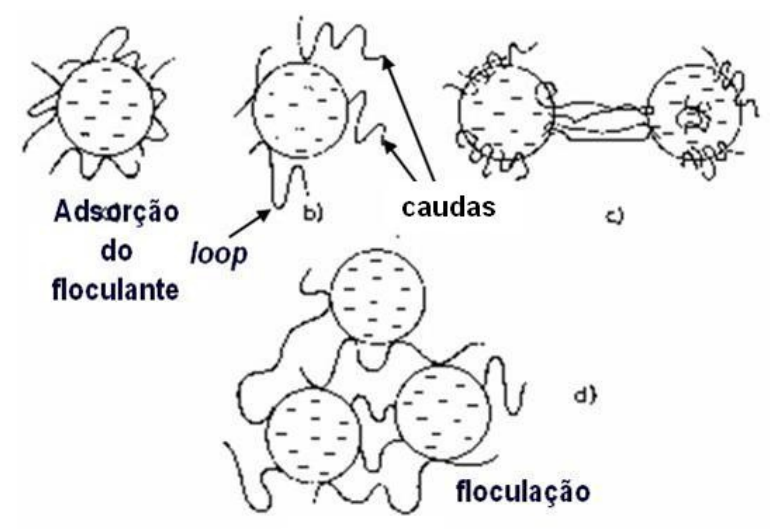

Figura 2.27 - Etapas do modelo de floculação por pontes: (a) adsorção; (b) formação de loops e caudas; (c) agregação entre duas partículas; e (d) crescimento do floco.

Conforme a literatura (ROJAS; HUBBE, 2004; BLANCO; NEGRO; TIJIRO, 2001; NORELL; JOHANSSON; PERSSON, 1999; BLANCO, 1994), neste mecanismo há, inicialmente, adsorção da cadeia do polímero pela superfície da partícula (Figura 2.27 a) com formação de loops e caudas que se estendem em direção ao meio de dispersão a uma distância superior a da espessura da DCE da partícula (Figura 2.27 b). Segundo Norell; Johansson e Persson (1999), em média, dez moléculas de polímero com alto peso molecular cobre uma partícula. Os loops e as caudas das cadeias dos polímeros interagem com as superfícies carregadas e formam pontes entre as partículas. Ou seja, duas partículas são agregadas, quando se aproximam o suficiente da região de atuação dos loops e das caudas estendidas na direção do meio de dispersão (Figura 2.27 c). O floco continuará crescendo através desse mecanismo até ocorrer o equilíbrio dinâmico entre a formação e a quebra do mesmo devido às forças de cisalhamento naturalmente presentes no sistema (Figura 2.27 d). Na ausência dessas forças, o movimento Browniano será o responsável pela colisão entre partículas. Os flocos formados são relativamente fortes e seu crescimento é dependente da freqüência de colisões entre partículas (NORELL; JOHANSSON; PERSSON, 1999). La Mer e Healy (1963 e 1962) ${ }^{15}$, apud NORELL;

15 La Mer, V.K.; Healy, T.W. (1963). Rev. Pure Appl. Chem. 13(9):112 e Healy, T.W.; La Mer, V.K. (1962). J. Phys. Chem. 66(10):1835 apud apud NORELL, M.; JOHANSSON, K.; PERSSON, M. Retention and Drainage. In: GULLICHSEN, J.; PAULAPURO, H. Papermaking Chemistry. Helsinki, Finland: FAPET Oy, 1999. Book 4 of Papermaking Science and Technology Series Books, cap.3, p. 
JOHANSSON; PERSSON (1999) e BLANCO; NEGRO; TIJIRO (2001), reportaram que a taxa máxima de formação de flocos era quando $50 \%$ da superfície da partícula estavam cobertos pelo polímero. Entretanto, segundo esses autores, a adição excessiva de polímero pode causar a estabilização estérica ou eletrostática (La Mer e Healy, 1963 e 1962, apud BLANCO; NEGRO; TIJIRO, 2001).

Neste mecanismo de floculação, há formação de flocos grandes e compactos difíceis de serem quebrados por forças de cisalhamento. Entretanto, quando estas forças são muito elevadas, os flocos se quebram ao mesmo tempo em que o polímero será degradado (Figura 2.28, adaptada de ROJAS e HUBBE, 2004). Ao contrário da floculação tipo patch, na floculação por pontes, a refloculação dos flocos quebrados é fortemente reduzida (ROJAS e HUBBE, 2004).

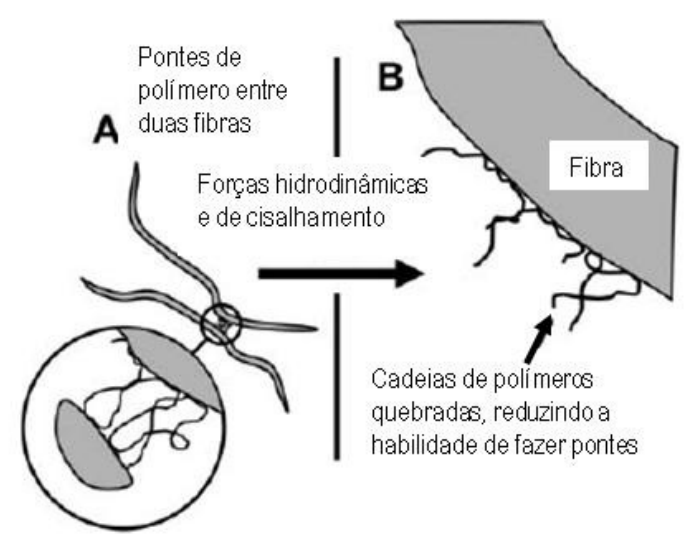

Figura 2.28 - Esquema ilustrando a redução da eficiência de um polímero floculante submetido à forças hidrodinâmicas e de cisalhamento.

Segundo Blanco; Negro e Tijiro (2001), a redução do potencial zeta pela adsorção de íons de carga oposta devido ao polímero afeta a espessura da DCE. Entretanto, este fato não compromete a floculação por pontes sendo que a floculação máxima pode ser atingida em valores de potencial zeta do sistema diferentes de zero. Por outro lado, se o polieletrólito é não iônico, o qual atua com formação de ligações de

42-81 e BLANCO, A., NEGRO, C., TIJERO, J. (2001). Develoments in flocculation: A literature review. UK, Pira International: 152. 
hidrogênio, neste caso, para haver a agregação da partícula será necessária a redução do potencial de superfície ou a compressão da DCE, ou seja, redução do potencial de barreira.

As forças de interação entre o polieletrólito e a superfície do sólido são determinadas pela natureza das partículas e das condições do meio de dispersão. Para Blanco; Negro e Tijiro (2001) e Blanco (1994), as forças de interação entre o polímero e a superfície aumentam à medida que a densidade de carga da superfície da partícula aumenta. Ainda, as interações seriam crescentes também com o aumento da densidade de carga do polímero. Em ambos os casos, considerando as condições do meio de dispersão constantes.

Atualmente, o desenvolvimento de polieletrólitos para serem utilizados na fabricação de papel deve considerar a presença de condições de elevadas concentrações de força iônica e de lixo aniônico devido ao aumento do grau de fechamento de circuito e, também, deve considerar sistemas com elevada intensidade de forças de cisalhamento devido ao desenvolvimento de máquinas modernas de altas velocidades.

\subsection{Modelos de floculação complexos}

Os modelos de floculação complexos utilizam a combinação de diferentes tipos de agentes floculantes para alcançar o efeito sinérgico. Nestes modelos as interações podem ocorrer entre os aditivos adicionados sem envolvimento das partículas e, ou, entre os aditivos e as superfícies das partículas ambos no meio de dispersão.

Blanco; Negro e Tijiro (2001) classificaram a floculação complexa de acordo com o tipo de interação entre floculantes, eletrostática ou não iônica; e com o local da interação, no meio de dispersão envolvendo floculantes ou na superfície da partícula, floculante e partícula. Por outro lado, Norell; Johansson; Persson (1999) classificaram a floculação complexa de acordo com os tipos de aditivos adicionados: dois polímeros de cargas opostas; nano e micropartículas; polímero não iônico (por rede) e polieletrólitos enxertados. Esta última classificação será seguida neste trabalho. 


\subsection{Floculação com dois polímeros de cargas opostas}

Este modelo envolve interações eletrostáticas entre polímeros com pesos moleculares e ionicidade diferentes e combina os modelos patch e por pontes. A rede formada com a adição dos dois polímeros também contribui com a retenção de partículas. A Figura 2.29, adaptada de Norell; Johansson; Persson (1999), ilustra o mecanismo de floculação que ocorre neste tipo de modelo.

O modelo de floculação com dois polímeros é baseado na adição de um polímero catiônico de elevada densidade de carga e baixo pelo molecular, por exemplo polietilenoimina (PEI), e um outro aniônico com elevado peso molecular e baixa densidade de carga, por exemplo poliacrilamida (PAM). O efeito na floculação é dependente da ordem de adição. Usualmente, o polímero catiônico é adicionado primeiro, até o ponto em que as forças repulsivas dêem lugar às forças atrativas, ocorrendo a floculação das partículas aniônicas, geralmente, fibras e cargas minerais. Após uma etapa de cisalhamento, os flocos são redispersos pela quebra das interações entre partículas. Em seguida, o polímero aniônico é adicionado formando novos flocos através de pontes entre fragmentos de flocos catiônicos (Figura 2.29). O intervalo de tempo entre as duas adições dependerá das características do polímero adicionado inicialmente, de forma a alcançar ótima adsorção e formação de locais onde a superfície apresente densidade de carga catiônica, mecanismo patch (NORELL; JOHANSSON; PERSSON, 1999). 


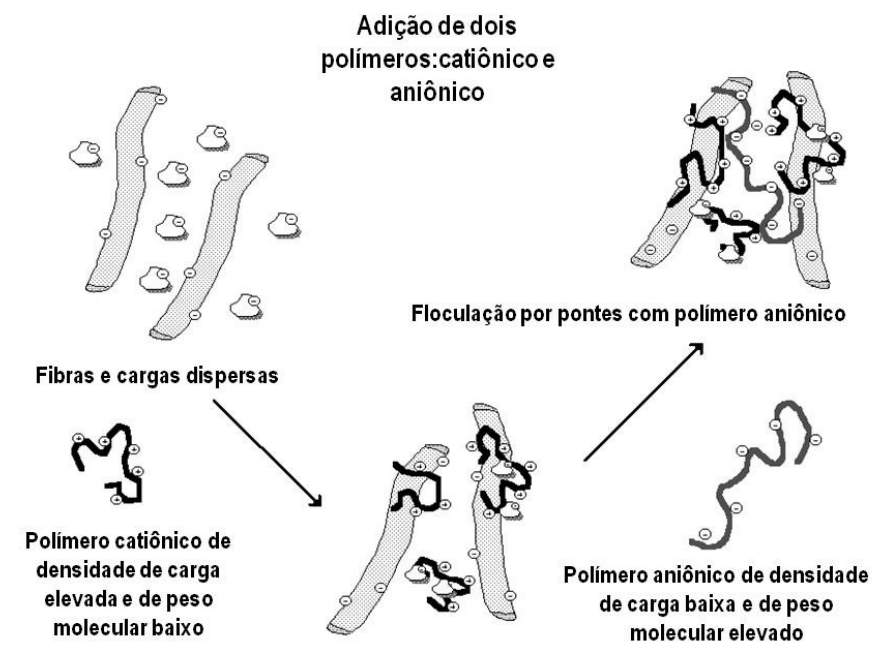

Figura 2.29 - llustração de sistema de floculação com a adição de dois polímeros de cargas opostas.

\subsection{Floculação com nano ou micropartículas}

O modelo com nano ou micropartículas se baseia na combinação entre um polímero catiônico de elevado peso molecular e nano ou micropartículas aniônicas. O polímero catiônico utilizado é, normalmente, um amido ou uma poliacrilamida. Por outro lado, a nano ou micropartícula aniônica pode ser a sílica coloidal, com dimensões que variam em torno de 2-3 nm, ou a montmorilonita, ou a bentonita, com dimensões aproximadas de 300nm (PRUSZYNSKI; CARDOSO; KAMLIN, 2002).

A Figura 2.30, adaptada de Norell; Johansson e Persson (1999), ilustra o mecanismo de floculação que ocorre neste tipo de modelo.

Primeiramente, o polímero catiônico é adicionado atuando como o modelo de floculação por pontes entre fibras, finos e carga mineral. Após, os flocos grandes e rígidos são fragmentados por forças de cisalhamento controladas em flocos menores, mais densos e mais resistentes (ROJAS; HUBBE, 2004; BLANCO; NEGRO; TIJIRO, 2001; NORELL; JOHANSSON; PERSSON,1999). Estas forças estão presentes em equipamentos como cleaners e depuradores. Em seguida, é adicionada a nano ou micropartículas com o objetivo de reflocular formando flocos 
com características descritas anteriormente (Figura 2.30). As micropartículas negativamente carregadas aderem às regiões positivas dos fragmentos por interações eletrostáticas.

Com relação ao mecanismo de floculação, Wågberg et al. (1996), estudando a floculação com micropartícula utilizando montmorilonita aniônica na presença de fibras revestida com polímero catiônico, concluíram que o modelo por ponte é o responsável pela adsorção destas partículas sobre as fibras e que a floculação aumentava com o aumento da dosagem de polímero catiônico. É possível que o modelo por ponte tenha sido favorecido pelo tamanho da partícula de montmorilonita $(300 \mathrm{~nm})$, maior em relação à espessura da DCE, da ordem de alguns nanometros.

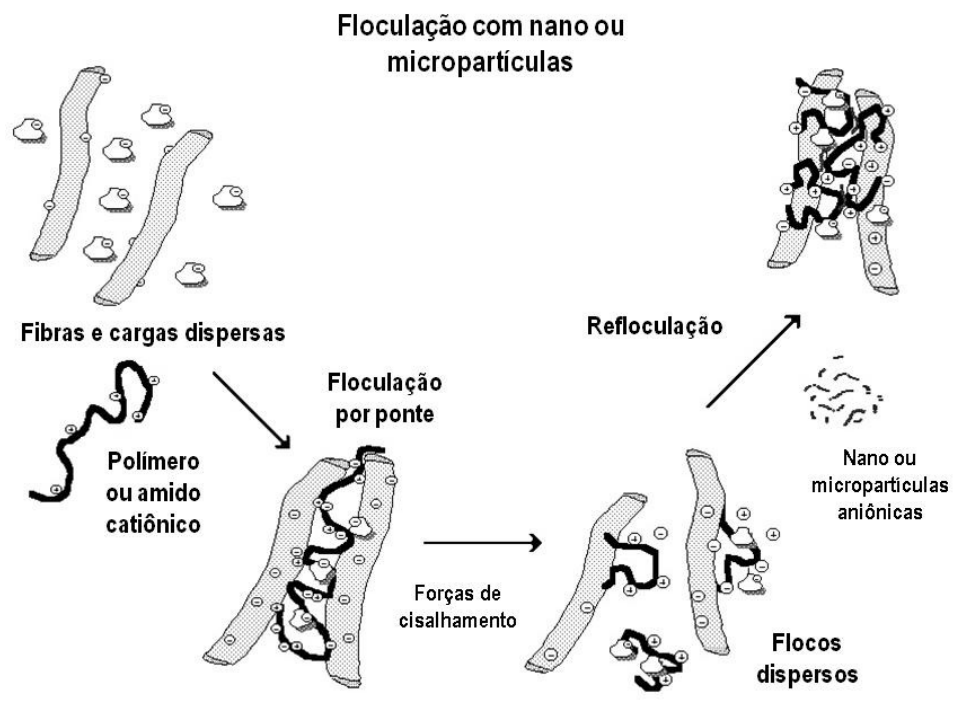

Figura 2.30 - Ilustração do modelo de floculação com nano ou micropartículas.

Portanto, neste tipo de modelo, as variáveis: peso molecular e densidade de carga do polímero, ponto de adição e tempo de reação, bem como o nível de cisalhamento, são importantes para atingir ótima eficiência na retenção de partículas de finos e de cargas. Segundo Blanco; Negro e Tijiro (2001), máquinas de papéis mais velozes com dois formadores (dual former) podem exigir polímeros catiônicos 
com maior peso molecular e com ramificações, do que o exigido em máquinas com velocidades inferiores e com formadores simples (mesa plana), para tipo de papel semelhante.

A presença de flocos com dimensões inferiores, devido ao cisalhamento, contribui para melhorar a qualidade de formação do papel e a drenagem do meio de dispersão, além de aumentar a porosidade da folha seca formada (Lindström, 1989, apud BLANCO; NEGRO; TIJIRO, $2001^{16}$ ). Entretanto, elevados níveis destas forças podem arrancar as partículas previamente retidas e comprometer os resultados de retenção e de qualidade da água branca.

Alince; Bednar e van de Ven (2001) investigaram o mecanismo de floculação com micropartícula utilizando poliacrilamida catiônica (C-PAM) e bentonita para avaliação da deposição do carbonato de cálcio precipitado (PCC) sobre as fibras em suspensões aquosas. Os resultados obtidos utilizando diversas quantidades de polímero e de bentonita indicaram que o C-PAM era adsorvido por ambos fibras e PCC criando pontos de ancoragem para as partículas de bentonita atuarem como ponte entre ambos. Foi observado também que a força de ligação entre o PCC e a fibra era mais forte com a bentonita do que a força de ligação quando utilizado o CPAM somente. Os autores mostraram que ótimo desempenho na deposição do PCC sobre as fibras depende da concentração de polímero e da bentonita e que, para uma dada concentração de bentonita, a deposição do PCC é reduzida com o aumento da dosagem do polímero. Os autores explicaram que o excesso de polímero pode reduzir a habilidade da bentonita em formar pontes.

Recentemente, micropartículas a base de polímeros orgânicos como poliacrilamida (PAM), celulose e lignosulfonados, têm sido introduzido. Harris; Ford e Spada (2004) citam o modelo de micropolímeros como um dos mais recentes, também conhecidos como micropartículas orgânicas, uma delas produzida pela tecnologia "Polyflex". Os autores descrevem que este modelo combina as vantagens das nano e micropartículas aniônicas com as vantagens dos polímeros coagulantes e floculantes. Sua eficiência é maior em razão da formação de uma microrede a qual também atua na retenção de carga.

${ }^{16}$ Lindström, T. Some fundamental chemical aspects on paper formation. In: FUNDAMENTAL RESEARCH SYMPOSIUM, 9., 1989, UK. apud BLANCO, A., NEGRO, C., TIJERO, J. Develoments in flocculation: A literature review. UK: Pira International, 2001. 152p. 
Segundo Kahl (1997) apud Norell; Johansson e Persson (1999) ${ }^{17}$, em alguns casos, as partículas aniônicas podem ser adicionadas juntamente com o polímero aniônico, o que caracteriza a combinação dos mecanismos de floculação com nano ou micropartículas e com o modelo de dois polímeros.

Segundo Andersson e Larsson apud Main e Simonson (1999) e Albinsson; Swerin e Ödberg (1995) ${ }^{18}$; e Breese e Nilsson apud Mirza; Conyngham e Covarrubias $(2002)^{19}$, os primeiros sistemas de floculação comerciais utilizando nano ou micropartículas foram com a sílica coloidal combinada com amido catiônico e com a bentonita combinada com poliacrilamida catiônica. As vantagens atribuídas a esses sistemas incluem: aumento da retenção, da drenagem, da uniformidade de formação da folha e da resistência a seco do papel. Rojas e Hubbe (2004) explicam que quando há a quebra das cadeias de polímeros adsorvidas na superfície devido ao cisalhamento, partículas de sílicas carregadas e de tamanhos reduzidos são capazes de se difundirem nas cadeias destes polímeros. Como estas partículas são extremamente negativas, elas se interagem eletrostaticamente com as cadeias positivas formando um volume menor das cadeias do polímero do que o volume sem estas partículas. Esta interação proporciona a perda de água do interior material polimérico o que contribue para o desaguamento.

Os polímeros utilizados nos sistemas com nano ou micropartículas são normalmente lineares e sem cadeias laterais. Em outro sistema, os modelos de micropartículas utilizando poliacrilamida catiônica (C-PAM) com e sem cadeias laterais, ambos associados com a bentonita foram propostos (BROUILLETTE et al., 2005). Estes autores mostraram que o sistema com a C-PAM ramificada apresentou melhores

17 KAHL, T. Das Positek- Verfahren als Mittel zur Optimierung der. Füllstoffretention. Wochenbl. Papierfabr. v. 125, $\mathrm{n}^{\circ}$ 1, p. 8, 1997 apud NORELL, M.; JOHANSSON, K.; PERSSON, M. Retention and Drainage. In: GULLICHSEN, J.; PAULAPURO, H. Papermaking Chemistry. Helsinki, Finland: FAPET Oy, 1999. Book 4 of Papermaking Science and Technology Series Books, cap.3, p. 42-81.

18 ANDERSSON, K.; LARSSON, H., Nordisk Cellulosa, v. 1, p. 55, 1985 apud MAIN, S.; SIMONSON, P. Retention aids for high-speed paper machines. Tappi Journal, v. 82, $n^{\circ}$ 4, p. 78-84, 1999 e ALBINSSON, C.-J.; SWERIN, A.; ÖDBERG, L. Formation and retention during twin-wire blade forming of a fine paper stock. Tappi Journal, v. 78, n 4, p.121-128, 1995.

19 BREESE, J; NILSSON, L. Papermaker, p.43-45, 1995, apud MIRZA, S.; CONYNGHAM, M.; COVARRUBIAS, R. M. New advances in microparticle retention technologies. In: AFRICAN PULP AND PAPER WEEK, 2002, African. Disponível em: < http://www.tappsa.co.za/archive/APPW2002/Title/New_advances_in_microparticle_/new_advances_in _microparticle_html>. Acesso em 06 jan. 2010. 
resultados para a retenção de primeiro passo e para a drenagem. Foi mostrado também que o sistema com polímero com cadeia lateral foi mais resistente às forças de cisalhamento. Os autores utilizaram PCC em seus estudos.

Um outro sistema de retenção baseado em nanopartículas de sílica catiônica e polímero aniônico foi proposto nesta mesma ocasião (CEZAR; XIAO, 2005). O novo sistema foi avaliado com a floculação de carga mineral na presença e na ausência de polpa com sílica modificada e polímero aniônico com baixo peso molecular e baixa densidade de carga. A presença de fibra contribuiu favoravelmente com os resultados de retenção da carga mineral. O mecanismo proposto pelos autores para explicação do novo modelo pode ser visto na Figura 2.31 extraida de Cezar e Xiao (2005). Quando a carga mineral é adicionada à suspensão de fibras, parte das partículas de carga mineral permanece na suspensão e poucas partículas são adsorvidas sobre as fibras por interação eletrostática entre as bordas positivas da carga mineral e a superfície negativamente carregada da superfície da fibra (I). A adição das nanopartículas de sílica positivas ao sistema modificou as propriedades de superfícies da fibra e das partículas de carga mineral quando as nanopartículas colidiram com as superfícies da fibra e da carga mineral (II). A adição do polímero aniônico conduziu a formação de pontes a qual aumentou a floculação. As cadeias de polímero aniônico, interagidas principalmente com a sílica catiônica, foram preadsorvidos sobre as superfícies da carga mineral e das fibras (III). A formação de mais flocos, resultado da formação de pontes interpartículas, foi induzida pela interação eletrostática com as nanopartículas de sílica catiônica (IV) as quais interagiram com as superfícies de carga mineral e de fibras. A redução da carga aniônica da superfície da fibra devido à adsorção das nanopartículas de sílica catiônica permitiu que mais polímero fosse adsorvido sobre as fibras. A interação eletrostática induzida pela sílica catiônica aderida às superfícies das fibras e das partículas de carga mineral conduziu a colisão mais efetiva das cadeias de polímero com fibras e com carga mineral. Isso conduz a formação de flocos de várias maneiras: entre partículas de carga mineral (IVa); entre fibras (IVb); e entre fibras e carga mineral (IVc). 


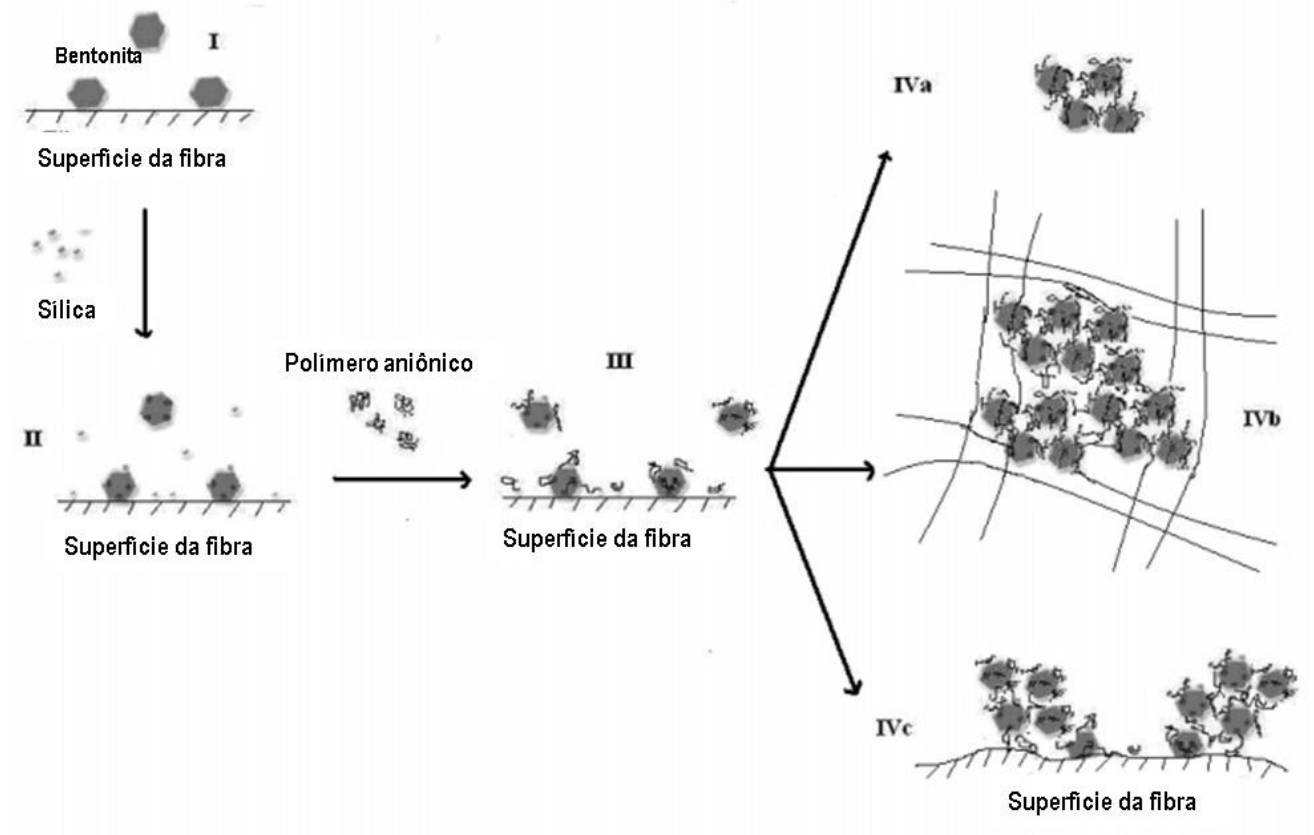

Figura 2.31 - Mecanismo de floculação com nanopartículas de sílica catiônica e polímero aniônico na presença de polpa.

Segundo Pruszynski (2002), apesar do desenvolvimento de novos programas de floculação, os modelos que utilizam partículas de sílica coloidal, bentonita e borosilicato, são os mais usados comercialmente.

\subsection{Modelo de floculação por rede com polímero não iônico}

O modelo de floculação por rede se baseia em interações não iônicas. Segundo Blanco; Negro e Tijiro (2001) e Norell; Johansson e Persson (1999), as ligações por ligações de hidrogênio têm um papel importante nas interações entre substratos. $O$ modelo se baseia na utilização de polímeros não iônicos solúveis em água, como o óxido de polietileno (PEO) de elevado peso molecular, como agente de retenção. Para que esses polímeros sejam efetivos, eles dependem de um cofator, o qual pode ser uma resina fenólica. A resina e o polieletrólito se interagem entre si formando complexos (GAUDREAULT; WHITEHEAD; van de VEN, 2005). 
Além da teoria acima, existem na literatura outras teorias que explicam como os complexos de resina e PEO se interagem com as fibras, finos e cargas minerais resultando na floculação e retenção dos mesmos, e a importância da presença do cofator neste processo de floculação.

Inicialmente, em 1983, Lindström e Glad-Normark sugeriram que este modelo de floculação ocorreria via mecanismo de captura de partículas quando redes instáveis de polímeros eram formadas e se moviam na suspensão. A floculação de partículas com o polímero utilizado nos estudos só ocorreu sob duas condições: na presença de fibras não branqueadas e quando o sistema era agitado. Entretanto, esta teoria não estava completamente correta. Para outras combinações de PEO e cofator estudadas, utilizando fibras branqueadas, por exemplo, não foi verificada a formação de redes e, portanto, não foi verificada a floculação.

De acordo com estudos de van de Ven (2005), cofatores contendo grupos fenólicos, como a lignina presente em fibra não branqueada, se mostraram efetivos na floculação utilizando este modelo. Estes autores mostraram também que o polímero PEO pode promover a floculação entre fibras e cargas através do processo conhecido como ligação por pontes de polímeros assimétricos. Este mecanismo se baseia no fato de que o PEO adquire habilidade de adsorver-se sobre as fibras, após ter sido adsorvido sobre as cargas, com isso, resultando na floculação, mesmo sem a presença de cofator.

Estudos realizados por Ma e Zhu (1999) apud Blanco; Negro e Tijiro (2001) ${ }^{20}$, para a floculação de finos de pasta termomecânica (TMP), mostraram que, na ausência de cofatores, o polímero era adsorvido sobre alguns finos, em outros não, através de ligações por ponte de polímeros assimétricos, enquanto que com a formação de complexos PEO+cofator, ocorria adsorção sobre todos os finos, sendo que, aparentemente, a presença do cofator contribuía positivamente para o aumento da resistência das pontes entre finos através de polímeros. A seqüência de adição do PEO e do cofator também se mostrou importante na observação do fenômeno. $A$ floculação se iniciava com a adição do PEO mesmo sem o cofator.

${ }^{20}$ MA, M., ZHU, S. Grafting polyelectrolytes onto polyacrylamide for flocculation. Part 1. Polymer synthesis and characterization. Coll. Polym. Sci. v. 277, n 2-3, p.15-122, 1999 apud BLANCO, A., NEGRO, C., TIJERO, J. Develoments in flocculation: A literature review. UK: Pira International, 2001. 152p. 
O mecanismo proposto para a floculação com polímeros não iônicos pode ser verificado na Figura 2.32 de acordo com Xiao; Pelton e Hamielec (1996). Segundo estes autores, as principais etapas são: adição do cofator, este podendo ser encontrado na forma livre ou adsorvido ao material coloidal; adição do polímero não iônico (Passo 1 na Figura 2.32), o qual forma complexo com o cofator, sendo este na forma livre ou combinada com partículas coloidais; pequenos agregados vão formando redes (Passo 2 na Figura 2.32) que se agregam formando complexos maiores, os quais se aderem à superfície da fibra (Passo 3 na Figura 2.32).

A vantagem da utilização desse tipo de polímero como agente de retenção é que, como não possui carga, ele se torna imune aos problemas relacionados aos altos níveis de substâncias coloidais presentes, por exemplo, em fabricação de papel jornal, os quais podem prejudicar a efetividade de polímeros eletricamente carregados.

De acordo com os estudos citados acima, o peso molecular do polímero e a presença de força de cisalhamento são variáveis importantes e que influenciam na eficiência de floculação de fibras. Por outro lado, a floculação de fibras para este modelo pode ocorrer, independente da presença de cofator, sendo que a presença deste proporciona efeitos positivos. 


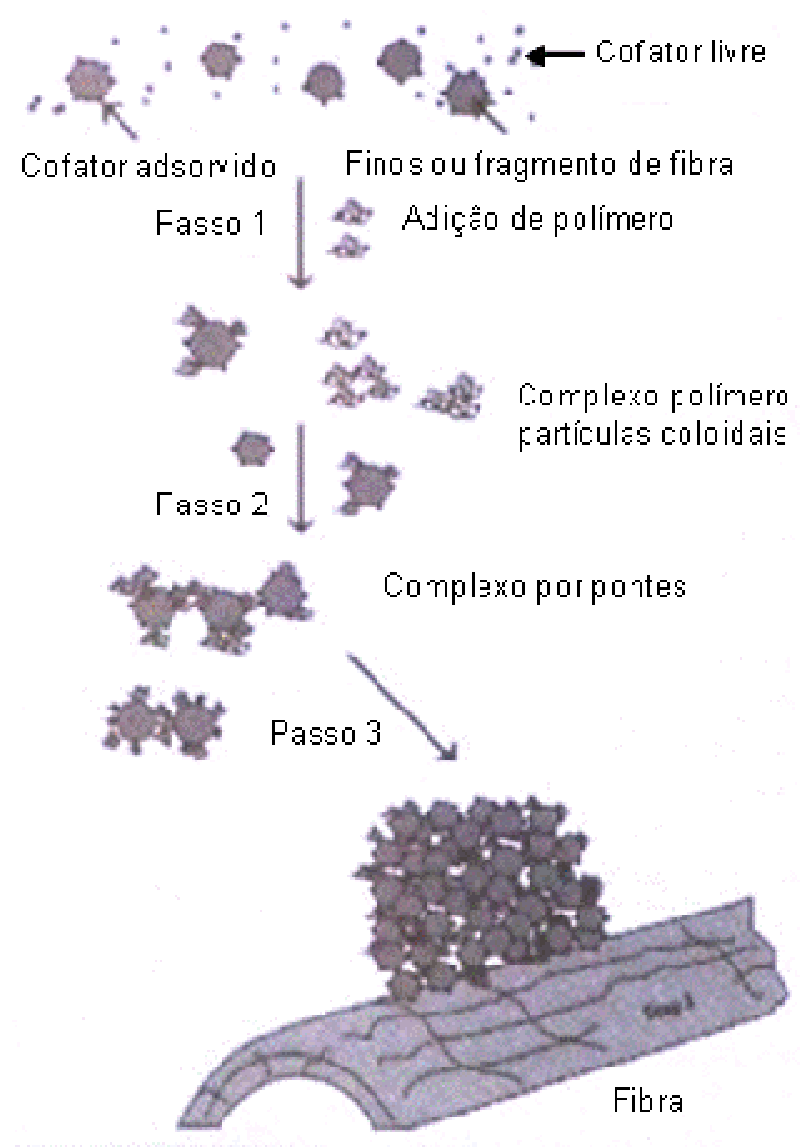

Figura 2.32 - Ilustração de floculação por rede.

\subsection{Polieletrólitos enxertados}

O enxerto de polímeros de alta densidade de carga e baixo peso molecular em polímeros não iônicos tem sido realizado pela técnica de radiação gama via polimerização com radicais livres (BLANCO; NEGRO; TIJERO, 2001). Este tipo de mecanismo tem se mostrado mais eficiente no processo de formação de pontes entre substratos quando comparado com processos em que são utilizados polímeros catiônicos convencionais.

Inicialmente, polímeros com essa característica, baixo peso molecular e alta densidade de carga, eram utilizados para captura de lixo aniônico ou outras impurezas do sistema. Entretanto, com o desenvolvimento deste modelo de 
floculação e verificação dos efeitos benéficos, os mesmos passaram a ser uma opção para serem utilizados no processo de retenção e drenagem da fabricação de papel através do uso de polieletrólito enxertados em polímero. Segundo Norell; Johansson e Persson (1999), uma grande vantagem deste modelo de floculação é que o mesmo pode ser utilizado em ambos os sistemas: com dois polímeros e com nano e micropartículas.

Segundo Blanco; Negro e Tijiro (2001), o mecanismo predominante neste modelo de floculação é a formação de pontes. Quando se compara a eficiência de um polímero catiônico que possui cargas distribuídas aleatoriamente com a eficiência do polímero com blocos de cargas positivos ao longo da sua cadeia, verificou-se que o segundo apresentou melhores resultados, especialmente, com relação à resistência das interações entre substratos.

\subsubsection{Características dos flocos formados e seu efeito nos processos de retenção e drenagem e na qualidade de formação da folha}

As características dos flocos variam com diversos fatores, dentre eles podem ser citados, o sistema de retenção e drenagem escolhido, o qual está relacionado com o tipo e a densidade de carga, à intensidade de turbulência do sistema, dentre outros.

Os autores Blanco; Negro e Tijiro (2001) mostraram, de forma resumida, as correlações qualitativas entre as características dos flocos e os fenômenos que ocorrem na fabricação de papel (Tabela 2.6) e a comparação dos mecanismos de floculação com relação às características dos flocos (Tabela 2.7).

Para alcançar, em sua totalidade, os benefícios do material não fibroso como as cargas minerais e os aditivos químicos, ambos adicionados na formulação do papel, esse material necessita ser distribuído de maneira uniforme sobre as fibras para minimizar a agregação espontânea das mesmas. 
Tabela 2.6 - Correlações qualitativas entre as características dos flocos e os fenômenos que ocorrem na fabricação de papel

\begin{tabular}{lll}
\hline Fenômeno & Favorável & Influência \\
\hline Processo & Flocos grandes & \\
Drenagem nos foils & Flocos pequenos \\
Drenagem a vácuo & Flocos macios & Flocos pequenos \\
Remoção de água na prensa & Flocos de fibra e carga & Flocos rígidos \\
Retenção & & Flocos homogêneos \\
\hline Produto & Flocos pequenos & \\
Formação & Flocos pequenos & Flocos grandes \\
Porosidade & Flocos pequenos & Flocos grandes \\
Resistência & Flocos grandes \\
\hline
\end{tabular}

Tabela 2.7 - Mecanismos de floculação, características físicas dos flocos e efeito das condições de processo

\begin{tabular}{|c|c|c|c|c|c|c|}
\hline \multirow{4}{*}{ Mecanismo } & \multicolumn{2}{|c|}{ Floco } & \multirow{4}{*}{ Refloculação } & \multirow[b]{2}{*}{ Floculação } & \multirow{4}{*}{$\begin{array}{l}\text { Influência do } \\
\text { lixo aniônico }\end{array}$} & \multirow{4}{*}{$\begin{array}{l}\text { Influência } \\
\text { da força } \\
\text { iônica }\end{array}$} \\
\hline & \multirow{3}{*}{ Características } & \multirow{3}{*}{$\begin{array}{l}\text { Resistência } \\
\text { ao } \\
\text { cisalhamento }\end{array}$} & & & & \\
\hline & & & & no ponto & & \\
\hline & & & & isoelétrico & & \\
\hline \multirow[t]{2}{*}{ Neutralização } & \multirow[t]{2}{*}{ Afrouxado } & \multirow[t]{2}{*}{ Muito baixa } & \multirow[t]{2}{*}{ Sim } & \multirow[t]{2}{*}{ Sim } & Muito & \multirow[t]{2}{*}{ Positiva } \\
\hline & & & & & negativa & \\
\hline \multirow{2}{*}{$\begin{array}{l}\text { Atração } \\
\text { eletrostática }\end{array}$} & \multirow[t]{2}{*}{ Afrouxado } & \multirow[t]{2}{*}{ Baixa } & \multirow[t]{2}{*}{ Sim } & \multirow[t]{2}{*}{ Sim } & Muito & \multirow[t]{2}{*}{ Negativa } \\
\hline & & & & & negativa & \\
\hline \multirow[t]{3}{*}{ Tipo patch } & \multirow{3}{*}{$\begin{array}{l}\text { Pequeno, } \\
\text { leve, rígido }\end{array}$} & \multirow[t]{3}{*}{ Baixa } & \multirow[t]{3}{*}{ Sim } & \multirow{3}{*}{$\begin{array}{c}\text { Não } \\
\text { necessaria- } \\
\text { mente }\end{array}$} & Negativa & \multirow[t]{3}{*}{ Positiva } \\
\hline & & & & & & \\
\hline & & & & & & \\
\hline \multirow[t]{5}{*}{ Tipo ponte } & \multirow{5}{*}{$\begin{array}{c}\text { Grande, duro, } \\
\text { flexível }\end{array}$} & \multirow[t]{5}{*}{ Alta } & Nenhuma ou & \multirow[t]{5}{*}{ Não } & Negativa para & \multirow[t]{5}{*}{ Positiva } \\
\hline & & & forma flocos & & concentração & \\
\hline & & & menores & & de carga alta & \\
\hline & & & & & para o tipo & \\
\hline & & & & & mosaico & \\
\hline \multirow[t]{4}{*}{ Complexa $^{1}$} & \multirow[t]{4}{*}{ Macroflocos } & Alta & Nenhuma ou & Não & & Negativa \\
\hline & & & forma flocos & & & \\
\hline & & & menores e & & - & \\
\hline & & & mais densos & & & \\
\hline Por rede ${ }^{2}$ & Macroflocos & Alta & Nenhuma ou & Não & & \\
\hline & & & forma flocos & & & \\
\hline & & & menores e & & - & - \\
\hline & & & mais densos & & & \\
\hline
\end{tabular}

1 - Floculação com dois polímeros e com nano e micro partícula; 2 - Floculação com polímero neutro e cofator. 


\subsubsection{Forças de interações entre substratos}

O conhecimento das forças de interações entre partículas coloidais e superfícies é uma condição prévia para o entendimento da estabilidade de sistemas de dispersão e de fenômenos de adesão (KAPPL; BUTT, 2002).

Os fenômenos de adsorção e as interações entre os substratos da suspensão de fibras estão diretamente relacionados com o desenvolvimento de propriedades do produto acabado (ROJAS; NEUMAN, 1999). Estes autores concluíram que os processos de agregação e de adsorção em meio aquoso são afetados tanto pelas características superficiais dos substratos de celulose quanto pela natureza do polímero, como tipo de carga superficial e grau de substituição.

Segundo Butt; Cappela e Kappe (2005), nos últimos anos a técnica de microscopia de força atômica com sonda coloidal (AFM colloidal probe) tem sido bastante utilizada em estudos com o objetivo de medir forças de interações entre substratos. No estudo de medições de forças de interação, o conhecimento das características do material é importante e a geometria do material deve ser bem definida, se plana ou esférica.

A interação entre camadas de celulose e partículas de sílica coloidal, avaliada por medição direta com AFM, foi estudada por Radtchenko; Papastavrou e Borkovec (2005). Foram encontradas forças repulsivas entre as superfícies negativas de sílica e de celulose em $\mathrm{pH}$ 9,5. As forças foram interpretadas quantitativamente em termos de interação eletrostática devido à sobreposição das camadas difusas originadas dos grupos carboxílicos da superfície de celulose contra a superfície negativa da sílica. Estes autores encontraram também que, para força iônica baixa, as forças entre a superfície de celulose e sílica eram repulsivas, dominadas por interações eletrostáticas, resultado da sobreposição da dupla camada elétrica. Por outro lado, para força iônica mais elevada, a força se mantinha repulsiva, porém, sua intensidade era reduzida devido à menor espessura da dupla camada elétrica conseqüência do aumento da condutividade.

Segundo os próprios autores, as primeiras medições diretas de forças atrativas de van der Waals entre superfícies de celulose regenerada em meio aquoso, em baixo 
valor de $\mathrm{pH}$ e elevado valor de força iônica, foram feitas por Notley; Pettersson e Wågberg (2004a). Embora a interação de van der Waals entre as superfícies de celulose seja relativamente fraca em comparação com outras superfícies, a queda crescente da força de interação em função da distância de separação pode ser verificada.

Estudo com ênfase em forças de superfícies e fenômeno de adesão, também foram realizados por Österberg (2000a). Nesse estudo, a autora utilizou as técnicas de AFM com sonda coloidal e SFA para medir forças de interações; e a técnica de espectroscopia eletrônica para análise química (XPS) para realizar estudos da composição química das superfícies envolvidas. A autora encontrou que a força de interação entre duas superfícies planas de celulose eram predominatemente estéricas repulsivas. Para distâncias longas, as forças de interação reduziram com o aumento da distância e com a redução de $\mathrm{pH}$. Os valores de $\mathrm{pH}$ estudados foram 6,0, 7,3 e 9,5. Quando as medições foram realizadas aproximando-se as duas superfícies, não ficou claro o comportamento da força de interação quanto à variação de $\mathrm{pH}$.

Resultados semelhantes para forças de interação foram encontrados para superfícies planas de mica revestidas com xilanas, medida em solução de $1 \mathrm{mM}$ de $\mathrm{KBr}$ em pH 10,1 (ÖSTERBERG, 2000a). As forças de interação entre as superfícies se comportaram inversamente proporcional a distância e eram mais elevadas para as xilanas de maior densidade de carga. Foram estudadas xilanas com densidades de carga de $0,5 \%$ e 0,9\%. A densidade de carga refere-se ao teor de grupos carboxílicos presentes medido com a técnica de XPS.

Para as forças de interação entre duas superfícies esféricas de celulose, em presença de 10mg/L de solução de xilana e pH 10, Öterberg (2000a) encontrou que, para distâncias curtas, a força normalizada pelo raio era reduzida com o aumento da concentração de $\mathrm{NaCl}$. Foram estudadas três concentrações do sal: 1, 10 e 100 mM.

O efeito do polímero catiônico - PCMA (poly[[2-(propionyloxy)ethyl] trimethylammonium chloride]) - sobre as forças de interações entre duas superfícies de celulose e entre uma superfície de celulose e de mica, em meio aquoso, também foi realizado em outro trabalho por Öterberg (2000b), utilizando a técnica de SFA 
(Surface Force Apparatus) com interferometria. Segundo a autora, a introdução do polieletrólito catiônico na solução muda drasticamente as interações entre as camadas de celulose devido à adsorção desse polímero sobre as superfícies de celulose. Depois de longo período de adsorção do polieletrólito sobre a superfície de celulose, a adsorção foi paralisada e foi observada repulsão eletrostática entre as superfícies de celulose revestidas com o polímero. Repulsão eletrostática também foi observada entre as superfícies de celulose e de mica (ÖSTERBERG, 2000b). A autora encontrou também que a força de interação entre duas superfícies planas de celulose diminui com a distância e predominava as forças repulsivas. As forças de interação repulsivas eram decrescentes com o aumento da distância e com a redução do $\mathrm{pH}$.

Em revisão publicada por Claesson et al. (2005), sobre interações entre superfícies carregadas e polieletrólitos, os autores levantaram vários resultados interessantes os quais serão descritos a seguir de forma resumida.

Para a adsorção de polieletrólito em superfície de carga oposta, a força dominante é a atração eletrostática entre as cargas da superfície e as cargas contrárias distribuídas ao longo da cadeia do polímero. A adsorção diminui com o aumento da força iônica. Fato este de acordo com os achados de Österberg (2000b). A interação entre superfícies carregadas é fortemente influenciada pela concentração do polieletrólito de carga oposta. Estudando o efeito da concentração do polieletrólito catiônico nas forças de interação entre duas superfícies de vidro, os autores encontraram que a força normalizada pelo raio diminui com a distância e com a redução da concentração do polímero (poli vinil amina - PVAm). Por outro lado, na ausência do polieletrólito, a força de interação foi maior, para uma determinada distância.

O aumento da força iônica da solução afetou as interações eletrostáticas de sistemas contendo polímero resultando em: (a) aumento da conformação espiralada da cadeia do polímero em solução; e (b) na redução da disponibilidade dos sítios de adsorção para interação com a superfície resultando em maior número de fração de loops e caudas com conseqüente redução da eficiência do polímero (CLAESSON; POPTOSHEVA; BLOMBERGA, 2005). 
Estudo sobre interações entre superfícies de celulose e sílica coloidal, utilizando as técnicas de AFM com sonda coloidal e a técnica de SFA, foi realizado por Holmberg et al. (1997). Os autores verificaram interações entre duas superfícies de celulose não carregadas eletricamente $(\mathrm{pH} 5,5-6)$, e uma superfície de celulose e outra de sílica coloidal, ambas carregadas negativamente. As interações foram estudadas na presença de um polieletrólito catiônico de alta densidade de carga - PCMA (poly[[2(propionyloxy)ethyl] trimethylammonium chloride]). Os autores encontraram que a presença do polieletrólito reduz a energia de barreira entre as superfícies. Não foram encontradas forças de interação entre as duas superfícies de celulose, imersas em $0,1 \mathrm{mM}$ de $\mathrm{KBr}$, para distâncias acima de $35 \mathrm{~nm}$. As interações entre uma superfície plana de celulose e uma superfície esférica de sílica coloidal (Raio 13 $\mu \mathrm{m}$ ) foram realizadas em meio aquoso, na ausência e presença do polieletrólito (20 mg/L). As forças medidas antes da adição do polieletrólito foram repulsivas. Na presença do polieletrólito, numa distância de separação de $11 \mathrm{~nm}$, foi observada forte força atrativa. As forças diminuem com a separação das superfícies. Os autores encontraram, também, que as forças de interação entre as superfícies de celulose e de sílica coloidal, na presença de $20 \mathrm{mg} / \mathrm{L}$ de PCMA, foram reduzidas com 0 aumento da concentração de $\mathrm{NaCl}$. 


\section{EFEITO DA DOSAGEM DE COAGULANTE E DA FORÇA DE CISALHAMENTO NO PROCESSO DE DRENAGEM E DE RETENÇÃO DE PARTÍCULAS}

\subsection{INTRODUÇÃO}

As cargas inorgânicas presentes na composição da maioria dos papéis finos e cartão exercem importância fundamental tanto nas características de qualidade do papel quanto no seu custo de produção. Como se tratam de partículas de dimensões reduzidas, embora com superfícies carregadas em meio aquoso, são difíceis de serem retidas mecanicamente durante a etapa de formação, necessitando, portanto, de agentes químicos que promovam essa retenção, de forma econômica e sem comprometer os parâmetros operacionais e os requisitos de qualidade do papel.

Nos dias de hoje, algumas das principais variáveis de formação em máquinas de papéis, que exercem efeito na retenção de cargas, na drenagem da água branca e na qualidade da folha formada são: (a) a concentração de sólidos orgânicos dissolvidos e coloidais, os quais compõem o lixo aniônico e conferem a demanda catiônica do sistema; (b) a concentração de eletrólitos, os quais compõem a força iônica e conferem a condutividade ao sistema, e (c) a presença de forças de cisalhamento. Outras variáveis que também apresentam efeito nos resultados das variáveis operacionais e de qualidade do papel são as condições de $\mathrm{pH}$ e de temperatura do sistema, bem como as características físicas e de densidade de carga das superfícies do material disperso e o tamanho a densidade de carga dos aditivos de processo.

Segundo Brouillette et al. (2005), um ponto importante a ser considerado é a tendência crescente do aumento da recirculação de fibras recicladas, sejam originadas de perdas operacionais ou de aparas. O aumento do teor desse material, bem como, os elevados níveis de reaproveitamento da água branca em sistemas de fabricação de papéis alcalinos, resultam na elevação da concentração de sólidos orgânicos dissolvidos e coloidais e da condutividade da água de recirculação do 
sistema; afetando significativamente a eficiência dos processos de retenção e de drenagem.

Outro aspecto relevante são as forças de cisalhamento presentes em modernas máquinas de fabricação de papel. Portanto, os principais objetivos dos estudos atuais, envolvendo retenção e drenagem, consideram máquinas com altas velocidades, papéis de alta qualidade e folhas com menor diferença entre as características dos lados feltro e tela da máquina (ALBINSSON; SWERIN; ÖDBERG, 1995).

O aumento das velocidades das máquinas também levou ao desenvolvimento de novos aditivos processuais, os quais conferem aos flocos não somente resistência às forças de cisalhamento dos sistemas atuais como também elevada capacidade de refloculação após a quebra dos mesmos, com um mínimo de perda de retenção possível (ALBINSSON; SWERIN; ÖDBERG, 1995). Neste sentido, novos aditivos como micropolímeros orgânicos (HARRIS; FORD; SPADA, 2004) e polímeros ramificados (BROUILLETTE et al., 2005) com elevada densidade de carga têm sido desenvolvidos.

Para atender às necessidades atuais, os sistemas de retenção e drenagem comerciais mais utilizados em máquinas de altas velocidades são os sistemas complexos a base de nano e micropartículas. Estes sistemas utilizam, normalmente, a sílica coloidal aniônica ou a bentonita, associada a um polieletrólito sintético de alto desempenho. Outros aditivos importantes nesses sistemas são o coagulante e o amido catiônico, ambos com funções essenciais, de neutralizar o lixo aniônico e de aumentar a resistência a seco do papel, dentre outros, respectivamente.

Este capítulo tem como objetivo estudar o efeito da dosagem do coagulante e da intensidade de forças de cisalhamento na drenagem da água branca e na retenção de partículas. Para tanto, foram adotadas as condições de dosagens e a sequência de dosagem de um sistema real. 


\subsection{REVISÃo}

\subsubsection{Programas de retenção de partículas}

Antes de considerar os efeitos das variáveis teor de substâncias orgânicas dissolvidas, força de cisalhamento e tamanho de partículas de sílica coloidal no processo de retenção, as informações sobre os sistemas de retenção mais adotados, após a realização de visitas à clientes e fornecedores, se fazem importantes $^{21}$. Essas informações também influenciaram na escolha do sistema que será utilizado neste capítulo para o estudo de algumas variáveis de processo na retenção e drenagem.

Segundo informações de fornecedores de especialidades químicas, a maioria dos programas de retenção do hemisfério norte adota polímero catiônico como retentor. Entretanto, considerando a realidade do Brasil, existem dois programas que são os mais utilizados: (a) amido catiônico, poliacrilamida catiônica e bentonita e (b) amido catiônico, poliacrilamida aniônica e sílica coloidal aniônica, sendo este último o mais utilizado. Como outras particularidades observadas, no Brasil normalmente se utiliza amido de mandioca como aditivo funcional para aumento da resistência a seco do papel e a cola sintética, normalmente, é ASA (Anidrido Alquenil Succínico) ${ }^{21}$.

Na Tabela 3.1 estão dispostas as seqüências de adição de reagentes na química da parte úmida (WEC - Wet End Chemistry) para três fábricas nacionais ${ }^{21}$.

Conforme pode ser verificado na Tabela 3.1, os sistemas adotados no Brasil se caracterizam pela presença de muitos reagentes com diferentes cargas iônicas. Isto torna o sistema muito complexo e, portanto, mais difícil de ser controlado considerando a presença de um grande número de variáveis: $\mathrm{pH}$, condutividade, teor de lixo aniônico, forças de cisalhamento, grande número de combinações de pontos de dosagem e ordem de aplicação dos reagentes.

\footnotetext{
${ }^{21}$ SILVA, D.J. Notas de reunião com fornecedores de reagentes para Wet End Chemistry (WEC). Janeiro de 2007.
} 
Tabela 3.1- Reagentes e seqüência de adição na etapa de formação de folha para fábricas de papel nacionais

\begin{tabular}{cccc}
\hline Ordem de adição & Fábrica 1 & Fábrica 2 & Fábrica 3 \\
\hline 1 & Neutralizante & Neutralizante & - \\
\hline 2 & Amido catiônico & Amido catiônico & Amido catiônico \\
\hline 3 & Polímero aniônico & Cola+Amido catiônico & Carga mineral \\
\hline 4 & Carga mineral & Carga mineral & Cola+Amido catiônico \\
\hline 5 & Cola+Amido catiônico & Polímero aniônico & Polímero aniônico \\
\hline 6 & Sílica aniônica & Sílica aniônica & Sílica aniônica \\
\hline
\end{tabular}

Pode-se observar na Tabela 3.1 que a diferença básica entre os programas é a ordem de aplicação de polímero, carga e cola. A Fábrica 3 não utiliza agente neutralizante.

Resultados de retenção de primeiro passo encontrados nessas fábricas situam-se em torno de $56 \%$, portanto, próximos a resultados encontrados em literatura, 53,8\% (BROUWER, 1991).

A Figura 3.1 ilustra o mecanismo de floculação utilizando os reagentes amido catiônico, polímero aniônico e micropartículas.

O mecanismo de floculação para este sistema é o mesmo descrito na Figura 2.30 do tópico 2.6.1.2.4.5. Basicamente, nesse sistema, o polímero aniônico faz a ligação entre as partículas de carga inorgânica e a superfície da fibra, formando um floco pouco denso e com maior quantidade de água retida na sua estrutura. Posteriormente, estes flocos são submetidos à forças de cisalhamento, ocorrendo a quebra dos mesmos (desfloculação). A refloculação ocorre na presença de nanopartículas de sílica coloidal, permitindo a formação de flocos menores, mais resistentes e mais densos com menor quantidade de água em seu interior, o que melhora a drenagem. 


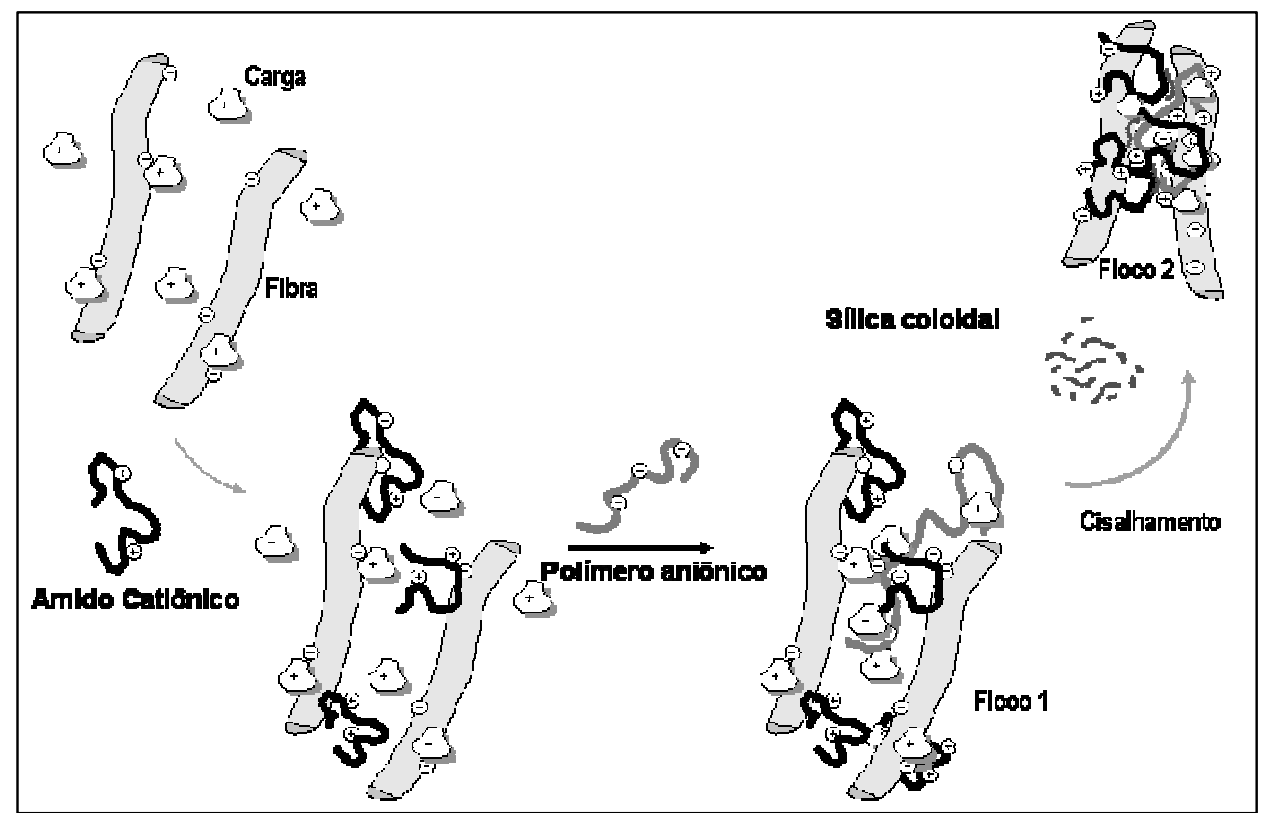

Figura 3.1 - Ilustração do mecanismo de floculação com nano ou micropartículas utilizando amido como polímero catiônico, polímero aniônico e sílica coloidal ${ }^{22}$.

\subsubsection{Efeito da dosagem de coagulante na retenção de partículas}

A composição da suspensão de fibras destinada à fabricação de papel é considerada bastante complexa (NORELL; JOHANSSON; PERSSON, 1999; BLANCO; NEGRO; TIJERO, 2001; ROJAS; HUBBE, 2004). Dentre as substâncias que compõem essa suspensão, podem ser citadas: as fibras, fragmentos de fibras, os finos orgânicos, os finos inorgânicos (carga), íons dissolvidos, substâncias orgânicas dissolvidas e partículas coloidais (WEBB, 2001; PRUSZYNSKI; CARDOSO; KAMLIN, 2002). No sistema real, em razão da recirculação da água branca, ainda podem ser encontradas substâncias químicas tais como agentes de retenção e de colagem, dentre outras.

Embora se trate de um sistema bastante complexo, o conhecimento da quantidade e da qualidade das substâncias presentes no sistema torna-se uma etapa importante para o entendimento dos fenômenos de interação entre as superfícies dos

\footnotetext{
${ }^{22}$ RODRIGUES, P. Apresentação cedida durante visita à empresa EKA Chemical. Sistema Compozil Select de Retenção e Drenagem. EKA Chemicals, Judiaí, Fevereiro de 2007.
} 
substratos e posterior controle das variáveis operacionais e de qualidade do produto (WILLIAMS, 1992). A qualidade do meio de dispersão, no caso água, também é importante, considerando que além de a mesma se apresentar em grande proporção no sistema de fabricação de papel (HUBBE, 2005), o teor de substâncias dissolvidas é elevado e apresenta efeito negativo na eficiência dos agentes químicos e, portanto, nas variáveis operacionais da máquina e na qualidade final do produto (KROGERUS, 1999a). Porém, são as substâncias orgânicas dissolvidas e coloidais presentes no processo de fabricação de papel, também conhecidas como lixo aniônico, grandes responsáveis pela redução da eficiência de retenção de carga.

Alguns estudos têm sido realizados com o objetivo de entender o comportamento das substâncias orgânicas dissolvidas e coloidais no processo de fabricação de papel (WÅGBERG; ÅSELL, 1995; ROJAS; NEUMAN, 1999; DUNHAM; SHERMAN; ALFANO, 2002). Segundo Ahrabi; Ström e Ödberg (1986) apud WÅGBERG e ASELL $(1995)^{23}$, desde que as mesmas se apresentam negativamente carregadas, todos os aditivos de processo que apresentam carga oposta são interferidos por elas com alteração de sua eficiência pela formação de complexos entre polieletrólitos e lixo aniônico.

Os autores Rojas e Neuman (1999), realizaram um estudo para verificar a interação entre as substâncias orgânicas dissolvidas e coloidais, carregadas negativamente, com os polissacarídeos orgânicos amido catiônico e goma guar, catiônica e aniônica, com vários graus de substituição. A avaliação da retenção de finos da suspensão de fibras foi realizada usando o parâmetro potencial zeta. Estes autores verificaram a ocorrência de reações de complexação entre as substâncias negativas e os polímeros orgânicos positivamente carregados. A maior retenção de finos se deu para dosagens entre 5 - $10 \mathrm{mg}$ do polissacarídeo por g de polpa seca, para valores de $-20 \mathrm{mV}$ e $-25 \mathrm{mV}$ para a goma guar e amido, ambos catiônicos, respectivamente. Nestas dosagens foram observados valores mínimos residuais de substâncias orgânicas dissolvidas e coloidais. Resultados inversos foram observados com o uso de goma guar aniônica.

${ }^{23}$ AHRABI, D.; STRÖM, G.; ODBERG, L. In. EUCEPA, 21., Anais..., 1986, v. 2, p. 22-47, paper $n^{\circ} 31$ apud WÅGBERG, L.; ÅSELL, I. The action of cationic polymers in the fixation of dissolved and colloidal substances - Part 2. Colloids and Surfaces A: Physicochemical and Engineering Aspects, v. 104, p. 169-184, 1995. 
Os pesquisadores Dunham; Sherman e Alfano (2002) estudaram o efeito da concentração de substâncias orgânicas dissolvidas e coloidais nos resultados de drenagem e de floculação de uma suspensão de polpa mecânica, com a adição do polieletrólito catiônico com baixo peso molecular e alta densidade de carga, [Polidialil-dimetil-amônio - Poli-(DADMAC)], como coagulante. Para ambos os parâmetros, drenagem e floculação, a presença dessas substâncias afetou de forma negativa. Considerando a drenagem, inicialmente houve um aumento e em seguida uma queda brusca dos valores desse parâmetro com a adição do coagulante. Entretanto, os resultados de floculação foram sempre favoráveis com a elevação da dosagem do coagulante. A redução da drenagem com a adição do coagulante, a partir de uma certa dosagem, foi atribuída pelos autores à formação de complexos do polímero com as substâncias orgânicas dissolvidas, formando agregados de dimensões reduzidas. Por outro lado, os resultados de floculação foram sempre favoráveis mesmo com a variação das dimensões dos agregados com a adição do coagulante. Os autores concluíram que a utilização de coagulante para neutralizar as substâncias orgânicas para melhorar a floculação, a partir de uma certa dosagem, específica de cada sistema, resulta na formação de complexos que retardam a drenagem.

Confirmação do estudo de Dunham; Sherman e Alfano (2002) foi realizada por Bhardwaj; Kumar e Bajpai (2005). Estes autores estudaram o efeito do potencial zeta nos resultados da retenção de primeiro passo e da drenagem de fibras secundárias. Os autores encontraram que a dosagem de poliacrilamida catiônica (CPAM) era diretamente proporcional à retenção e inversamente proporcional ao tempo de drenagem, enquanto que o potencial zeta tendeu ao ponto isoelétrico. Valores ótimos para a retenção e drenagem foram encontrados para a dosagem de C-PAM de $0,05 \%$ base polpa seca e potencial zeta de $-18 \mathrm{mV}$. O estudo demonstrou que o potencial zeta apresentou papel importante no comportamento da coagulação e desaguamento da suspensão de fibras recicladas.

Com o objetivo de reduzir a quantidade de substâncias orgânicas dissolvidas e coloidais (DC) da suspensão de fibras, Wågberg e Asell (1995) testaram em laboratório vários polieletrólitos catiônicos como agentes coagulantes (poliDADMAC, PEI e PVA). Os resultados mostraram que a eficiência dos polieletrólitos 
era largamente influenciada pela consistência da suspensão e pela concentração dessas substâncias. Consistência de fibras mais elevada (0, 5 e 30\% foram estudadas) e maior teor dessas substâncias (faixa estudada de 2800 a 3900 mg/L DQO) foram mais favoráveis à remoção.

\subsubsection{Efeito da força de cisalhamento na retenção de partículas}

Para Albinsson; Swerin e Ödberg (1995), em máquinas de papel modernas, a presença de altos índices de forças hidrodinâmicas e de cisalhamentos é inevitável, em razão da presença de elevadas velocidades de escoamento em tubulações e bombeamentos da suspensão de fibras. Essas forças, embora por um lado possam contribuir com a colisão entre os substratos e aditivos de processos provendo a interação. Por outro lado, a depender de sua intensidade, ocorre a quebra de flocos já formados. Portanto, os agentes de retenção atuais consideram a desfloculação e refloculação do material quando em situações de baixas turbulências como aspectos importantes na etapa da formação de folha.

A retenção de partículas durante a etapa de formação de folha pode ocorrer pela adsorção dessas partículas através de polímeros e pela homofloculação entre partículas de finos, seguida da retenção mecânica desses materiais pela folha formada. Em laboratório, os estudos de retenção de finos podem ser realizados em equipamentos como o jarro de drenagem dinâmica (DDJ - Dynamic Drainage Jar) ou, como também é conhecido, jarro de Britt (BJ - Britt Jar), o qual pode simular forças hidrodinâmicas e de cisalhamento, embora estas forças sejam diferentes quando comparadas com as existentes em máquinas de fabricação de papel comerciais.

Um estudo completo sobre o efeito de forças de cisalhamento e a adição de sílica coloidal aniônica e da montimorilonita de sódio, ao longo do tempo, nas dimensões dos flocos foi realizado por Alfano et al. (2000). Neste estudo, os autores utilizaram uma suspensão de celulose microcristalina, com floculação induzida por poliacrilamida catiônica (C-PAM). A avaliação das dimensões dos flocos foi realizada através do comprimento de corda medido com um microscópio de varredura à laser 
(FBRM - Focused Beam Reflectance Measurement), nas rotações de 400 e de 900 rpm. Estes autores observaram, ao longo do teste, que o tamanho do comprimento de corda mais elevado foi encontrado quando a floculação das partículas foi induzida por polímero catiônico associado com a sílica aniônica, seguido da montimorilonita de sódio com polímero e seguida do polímero somente, para as duas intensidades de forças de cisalhamento estudadas. Os autores também realizaram ciclos de forças de cisalhamento, intercalando as intensidades de rotação 400 e 900 rpm, no total de cinco ciclos de 13,5 min no total. Foi observada elevada queda do tamanho dos flocos quando a intensidade das forças passava de 400 para 900 rpm; e que, mesmo havendo a refloculação com a redução da intensidade das forças, a capacidade de os fragmentos se reagregarem foi reduzindo com os ciclos para os três experimentos avaliados, (1) com polímero, (2) com polímero e montmorilonita e (3) com polímero e sílica coloidal. A capacidade de floculação, desfloculação e refloculação permaneceu na mesma ordem até o fim do teste, porém mais elevada para os agregados induzidos por polímero catiônico associado com sílica aniônica, seguida pelo polímero associado com a montmorilonita e polímero somente.

O FBRM também foi utilizado por Yoon e Deng (2004) para avaliar, em tempo real, a capacidade de floculação e refloculação de uma suspensão de argila, sob duas intensidades de forças de cisalhamento (300 e 900 rpm). Os autores puderam avaliar a capacidade de floculação e de refloculação de diferentes mecanismos de floculação: (1) simples (C-PAM), (2) dois polímeros, (3) micropartícula e (4) óxido de polietileno com co-fator (PEO); de diferentes peso molecular do polímero e de diferentes densidades de carga. Assim como os autores Alfano et al. (2000), os testes de floculação e refloculação foram realizados adotando ciclos de intensidades de forças de cisalhamento, com 120 segundos cada ciclo, no total de cinco ciclos. Os autores concluíram que, no início da floculação, os sistemas PEO e simples polímeros apresentaram flocos maiores do que os demais sistemas. Entretanto, a refloculação de sistemas não iônico ou de baixa densidade de carga era insignificante após cessarem as forças de cisalhamento. Por outro lado, polímeros com alta densidade de carga, embora não forme flocos grandes, sua capacidade de refloculação era elevada. Os autores concluíram que elevados índices de floculação puderam ser alcançados pelo mecanismo de pontes, polímeros com alto peso molecular e baixa densidade de carga como o caso das poliacrilamidas. Entretanto, 
elevada refloculação somente ocorre com polímeros de baixo peso molecular e elevada densidade de carga, mecanismo tipo mosaico (patch), em que estão presentes elevadas forças eletrostáticas atrativas entre as partículas. Estes autores também encontraram que o sistema PEO era o mais resistente às forças de cisalhamento, seguido dos sistemas micropartícula, dois polímeros e simples polímero.

\subsection{MATERIAIS E MÉTODOS}

\subsubsection{Materiais}

A seguir são listados todos os materiais utilizados neste capítulo.

a. Polpa kraft de eucalipto com consistência aproximada de 4,5\%, branqueada utilizando a tecnologia ECF (Elemental Chlorine Free), com alvura comercial (90\% ISO), coletada em fábrica de papel após a etapa de refinação. A polpa foi fornecida pela Votorantim Celulose e Papel, unidade Piracicaba.

b. Solução de carboximetilcelulose de sódio (CMC-Na) 1 g/L. CMC-Na grau farmacêutico apresenta viscosidade baixa, $42 \mathrm{cP}$, grau de substituição de 0,75\% e 0,30\% de $\mathrm{NaCl}$, segundo informação do fornecedor. Este produto foi cedido pela empresa BLANVER Farmoquímica Ltda e foi utilizado neste trabalho como substância orgânica dissolvida, lixo aniônico, para ajustar a demanda catiônica do meio de dispersão.

c. Polieletrólito catiônico (Poliamina) - Foi utilizado poliamina catiônica de baixo peso molecular e alta densidade de carga, $10^{3}-10^{5} \mathrm{~g} / \mathrm{mol}$ e $40-$ $80 \%$, respectivamente, segundo classificação de Blanco; Negro e Tijiro (2001) e informações do fornecedor. Este produto é comercializado segundo o nome de EKA ATC 4150 e apresenta a função de coagulante 
de substâncias dissolvidas e coloidais (lixo aniônico) através de reações de neutralização de cargas. É também conhecido como capturador de lixo aniônico (ATC -Anionic Trash Catchers). A solução foi preparada com $0,2 \%$.

A variação da demanda catiônica final foi realizada controlando a dosagem do coagulante (Poliamina). Este tipo de procedimento é realizado nas fábricas, quando este reagente é, normalmente, dosado na recirculação da água branca.

d. Amido catiônico - Foi utilizado amido catiônico de milho, com grau de substituição mínimo e máximo de 0,035 e 0,042, respectivamente, teor de cinzas máximo de $2,00 \%$ e teor de umidade de $14 \%$. Este produto foi fornecido pela Corn Products Brasil e é comercializado sob o nome de FOXHEAD 5835 e apresenta, segundo o fornecedor, 27\% de amilose e $73 \%$ de amilopectina. A solução foi preparada a $1 \%$.

e. Cola sintética - Foi utilizada a cola AKD (Dímero de Alquil Ceteno) para colagem interna. Este produto foi fornecido pela empresa EKA Chemicals. A solução foi preparada a $0,5 \%$.

f. Carga - Carbonato de cálcio precipitado (PCC), em pó, com teor de umidade $0,98 \%$, dimensão média de partícula de 2,06 $\mu \mathrm{m}$ e alvura a seco de $96,7 \%$ ISO. Foram dosados $20 \%$ de carga mineral (carbonato de cálcio precipitado), base papel seco. Esta dosagem está de acordo com a literatura (ALBINSSON et al., 1995) e com os teores adotados em fábricas de papel de imprimir e escrever do Brasil. O PCC foi fornecido pela empresa Specialty Minerals e é comercializado com a denominação Albacar 5970 . A solução foi preparada a $20 \%$.

g. Polímero aniônico, poliacrilamida - A-PAM, com médio peso molecular e média densidade de carga, aproximadamente, $10^{5}-10^{6} \mathrm{~g} / \mathrm{mol}$ e $20 \%$, respectivamente, segundo classificação de Blanco; Negro e Tijiro (2001). O polímero aniônico foi fornecido pela empresa EKA Chemicals e é comercializado sob o nome EKA 7420. A solução foi preparada a $0,1 \%$ de 
concentração do polímero tal qual. A função do polímero foi de fixar as partículas de finos, orgânicos e inorgânicos, na superfície da fibra.

h. Sílica coloidal aniônica - Sílica coloidal aniônica, com 15\% de sólido, diâmetro de partícula entre $2-3 \mathrm{~nm}$ e superfície específica de $750 \mathrm{~m}^{2} / \mathrm{g}$, para máquinas de papéis que operam com sistemas alcalinos e neutros fornecida pela EKA Chemicals. Não foi informada a densidade de carga da amostra. A sílica é comercializada no mercado sob o nome de NP 442. Solução preparada a $1 \%$.

Os reagentes utilizados neste estudo foram de grau analítico. Também foi utilizada água destilada no preparo de soluções e na suspensão de polpa. Soluções:

a. Solução de $\mathrm{NaOH} 10 \mathrm{~g} / \mathrm{L}$, foi preparada e utilizada para ajuste de $\mathrm{pH}$. O $\mathrm{pH}$ de processo adotado nas empresas é levemente alcalino, aproximadamente 7,5. O Valor adotado neste estudo foi de $\mathrm{pH} 7,5 \pm 0,5$.

b. Solução de $\mathrm{H}_{2} \mathrm{SO}_{4} 0,1 \mathrm{~N}$ preparada e utilizada para ajuste de $\mathrm{pH}$.

c. Solução de cloreto de sódio, $10 \mathrm{~g} / \mathrm{l}$, foi utilizada para ajuste da condutividade. Os testes foram realizados a uma condutividade de 100 $\mu \mathrm{S} / \mathrm{cm}$. Valores de condutividade na massa e na caixa de entrada, variam de 150 a $300 \mu \mathrm{S} / \mathrm{cm}$ e de $\sim 250 \mu \mathrm{S} / \mathrm{cm}$, respectivamente.

Valores de condutividade encontrados na indústria variam de 100 a 600 $\mu \mathrm{S} / \mathrm{cm}$. A condutividade depende da eficiência de lavagem da polpa anterior e da condutividade e, ou, quantidade de água branca recirculada no sistema de água branca. Apesar de o valor adotado no estudo ter sido inferior ao valor médio praticado na indústria, este valor permaneceu fixo de forma que outras variáveis fossem evidenciadas. Originalmente, a suspensão de fibras $0,5 \%$ de consistência apresentou condutividade de $52 \mu \mathrm{S} / \mathrm{cm}$. 
A Tabela 3.2 mostra as dosagens dos reagentes adotadas neste estudo. As dosagens foram baseadas em valores reais praticados em fábrica de papel para impressão e escrita.

Tabela 3.2 - Dosagens de reagentes adotados neste estudo e suas respectivas funções e observações

\begin{tabular}{|c|c|c|c|}
\hline Reagente & Dosagem & $\begin{array}{l}\text { Função principal neste } \\
\text { trabalho }\end{array}$ & Observações ${ }^{24}$ \\
\hline $\begin{array}{l}\text { Poliamina, } \mathrm{kg} / \mathrm{t} \\
\text { de papel seco }\end{array}$ & $\begin{array}{c}\text { Variável de } \\
\text { acordo com a } \\
D C^{*}-0,5 \text { a } 1,75\end{array}$ & $\begin{array}{l}\text { Neutralizador ou } \\
\text { coagulante de lixo } \\
\text { aniônico }\end{array}$ & $\begin{array}{l}\text { Valor adotado em fábrica } \sim 0,75 \mathrm{~kg} / \mathrm{t} \text {. } \\
\text { Pode ser utilizado o policloreto de } \\
\text { alumínio (PAC) para esta função. }\end{array}$ \\
\hline $\begin{array}{l}\text { Amido } \\
\text { catiônico, } \mathrm{kg} / \mathrm{t} \\
\text { de papel seco }\end{array}$ & 9,0 & Resistência a seco** & $\begin{array}{l}\text { Utilizam entre } 9 \text { e } 10 \mathrm{~kg} / \mathrm{t} \text { de fécula } \\
\text { catiônico de mandioca. Parte dessa } \\
\text { dosagem é utilizada na emulsão da cola } \\
\text { ASA (Anidrido Alquenil Succínico) como } \\
\text { colóide protetor. }\end{array}$ \\
\hline $\begin{array}{l}\text { Cola } A K D, k g / t \\
\text { de papel seco }\end{array}$ & 0,95 & Colagem interna & Uso mais freqüente de ASA na indústria. \\
\hline Carga PCC & $\begin{array}{c}20 \% \text { da } \\
\text { composição do } \\
\text { papel seco }\end{array}$ & $\begin{array}{l}\text { Melhorar a qualidade } \\
\text { de formação e } \\
\text { propriedades ópticas }\end{array}$ & $\begin{array}{l}\text { Pode ser utilizado entre } 20 \text { a } 30 \% \text { a } \\
\text { depender do tipo de papel a ser } \\
\text { fabricado. }\end{array}$ \\
\hline $\begin{array}{l}\text { Polímero } \\
\text { aniônico, } \mathrm{kg} / \mathrm{t} \\
\text { de papel seco }\end{array}$ & 0,1 & Retentor de cargas & $\begin{array}{l}\text { O mais utilizado na indústria é o de alto } \\
\text { peso molecular e baixa densidade de } \\
\text { carga. }\end{array}$ \\
\hline $\begin{array}{l}\text { Sílica aniônica, } \\
\text { kg/t papel seco }\end{array}$ & 3 & Auxiliar de drenagem & $\begin{array}{l}\text { Pode ser usada tanto a sílica aniônica } \\
\text { quanto a bentonita anfótera. }\end{array}$ \\
\hline
\end{tabular}

*DC - demanda catiônica; * $\mathrm{Na}$ consistência em que o amido foi adicionado, além de contribuir com a resistência a seco do papel, contribui com o equilíbrio de cargas do meio de dispersão.

\footnotetext{
${ }^{24}$ SILVA, J.S. Notas de reuniões quando em visita à fábricas nacionais de papéis de imprimir e
} escrever. Janeiro - Fevereiro de 2007. 


\subsubsection{Métodos}

\subsubsection{Caracterização da suspensão de fibras}

A caracterização da suspensão de fibras seguirá a ilustração descrita na Figura 3.2.

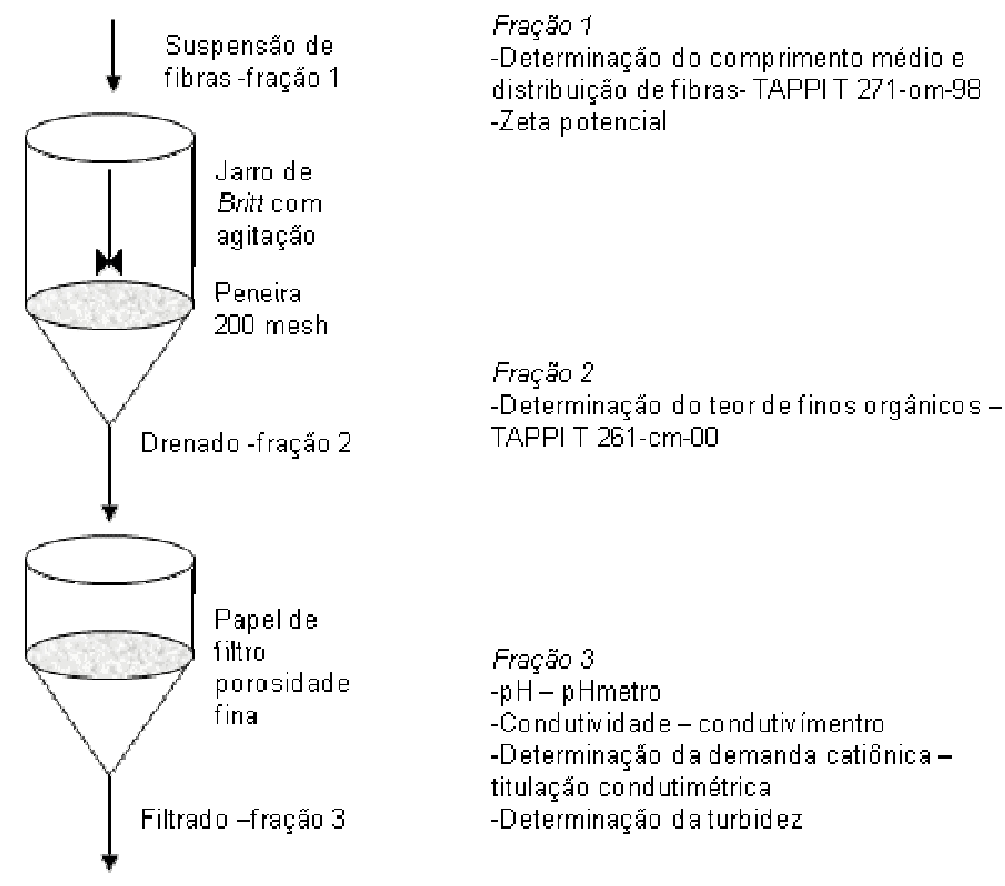

Figura 3.2 - Caracterização da suspensão de fibras.

\subsubsection{Preparo da suspensão de fibras}

A polpa, já refinada, coletada na indústria após a etapa de refino, foi exaustivamente lavada para remoção do excesso de finos e de materiais orgânicos dissolvidos e de partículas coloidais. Após, foi centrifugada por 10 minutos, desagregada manualmente e acondicionada em sacos de polietileno e mantida sob temperatura ambiente. A determinação do teor de umidade foi realizada seguindo a norma TAPPI T 550 - om-98. A quantidade de polpa preparada foi de, aproximadamente, $4 \mathrm{~kg}$ a.s. 


\subsubsection{Comprimento médio de fibras e teor de finos na fração 1}

A polpa refinada, depois de preparada conforme descrito no tópico 3.3.2.2 e sem ajuste de $\mathrm{pH}$, condutividade e demanda iônica, foi avaliada no analisador de fibras Fiber Quality Analyser LDA02 com o objetivo de determinar as características físicas das mesmas: comprimento médio de fibra, "coarseness" e teor de finos, dentre outros parâmetros. Foi seguida a metodologia TAPPI T 271-om-98. A análise foi realizada sem ajuste de pH, condutividade e de demanda catiônica.

\subsubsection{Determinação do potencial Zeta na fração 1}

A determinação do potencial zeta foi realizada após ajuste de $\mathrm{pH}$, condutividade e demanda iônica, na consistência de $0,5 \%$. A determinação foi realizada com o equipamento Mütek SZP-06 fabricado pela BTG. A Figura 3.3 mostra a foto do equipamento utilizado.

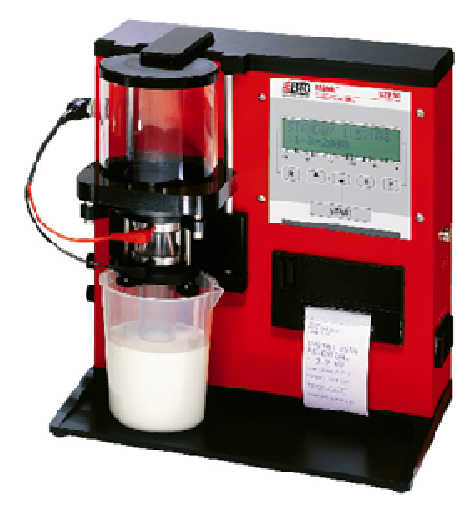

Figura 3.3 - Medidor do potencial zeta Mütek SZP-06.

\subsubsection{Determinação do teor de finos orgânicos na fração 2}

O teor de finos da polpa também foi determinado utilizando o jarro de Britt seguindo o método adaptado da Tappi T 261-cm-00. A Figura 3.4 mostra o equipamento Jarro de Britt utilizado nos testes. 


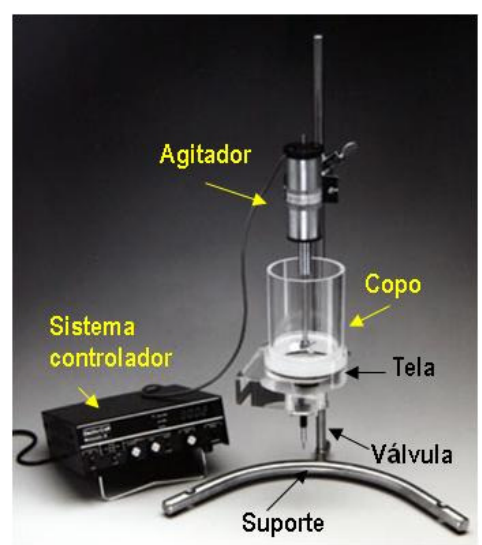

Figura 3.4 - Jarro de Britt para determinação da retenção e do teor de finos da polpa.

O Jarro de Britt é composto de um agitador, um copo rosqueável com tela removível de 200 mesh, um suporte e um sistema controlador do número de rotações por minuto e do sentido de rotação. Abaixo do copo, existe uma válvula que é aberta no momento da operação de drenagem. A altura do agitador em relação à tela localizada no fundo do copo é regulável. No copo onde foram feitas as análises, existiam três defletores com o objetivo de aumentar a turbulência simulando as forças de cisalhamento presentes em máquinas de papéis comerciais.

O procedimento deu-se conforme descrito a seguir. Inicialmente, $30 \mathrm{~g}$ de polpa a.s. foram desagregadas à consistência de $2 \%$ em 30.000 rpm. Após, adicionou-se água destilada até completar 10 litros ajustando a consistência para, aproximadamente, $0,5 \%$.

A consistência foi determinada para 3 amostras de $100 \mathrm{~g}$, aproximadamente, da suspensão que foram filtradas em papéis de filtro previamente tarado.

Para determinação dos finos, foram adicionados $0,5 \mathrm{~mL}$ de Orotan com o objetivo de manter os substratos dispersos. A adição de Orotan ocorreu também na água de lavagem da polpa agitada em jarro de Britt. 
O conteúdo de $500 \mathrm{~mL}$ de amostra foi colocado sob agitação no Jarro de Britt numa rotação de 750 rpm. Após, as fibras remanescentes, sem finos, foram coletadas em papel de filtro, secas em estufa $105 \pm 3{ }^{\circ} \mathrm{C}$ até peso constante e pesadas para realização dos cálculos. Foram feitas 6 lavagens com água destilada na presença de Orotan ou até a água drenada não apresentar finos visíveis, ou seja, turbidez próximo a da água.

O teor percentual de finos foi dado pelas Equações 3.1 e 3.2. Foi calculada a média de três determinações.

Determinação do peso seco da amostra:

$$
P S=(P U * C S T)
$$

Equação 3.1

Em que: $P S$ - Peso seco da alíquota, g; $P U$ - Peso úmido da alíquota, g; eCST Consistência média da suspensão de fibra, \%.

Determinação do teor de finos:

$$
F=\left[\frac{(P S-P R)}{P S} * 100\right]
$$

Em que: $F$ - teor de finos, \%; $P S$ - peso seco da alíquota, g; e $P R$ - peso seco do resíduo do jarro, g.

\subsubsection{Determinação do pH na fração 3}

A determinação do $\mathrm{pH}$ foi realizada com o auxílio de o pH-metro MP120pH Meter da Mettler Toledo seguindo metodologia do fornecedor do equipamento. Como o pH foi mantido em $7,5 \pm 0,5$, o ajuste foi realizado com soluções de ácido sulfúrico ou hidróxido de sódio, conforme o caso. 


\subsubsection{Determinação da condutividade na fração 3}

Foi realizada com o auxílio de um condutivímetro Sension 156 da $\mathrm{HACH}$ seguindo metodologia do fornecedor do equipamento.

\subsubsection{Determinação da demanda catiônica para substâncias orgânicas dissolvidas e coloidais na fração 3}

Neste trabalho, para determinação da demanda iônica foi utilizado o equipamento Mütek PCD-03 Particle Charge Detector da BTG (Figura 3.5A). Para determinação da demanda, o equipamento deve ser associado a um titulador automático, o Mütek PCD-T3 Titrator Three, também da BTG (Figura 3.5B). Como a carga líquida da suspensão de fibras em meio aquoso se apresenta negativa, a demanda será catiônica e o polímero utilizado foi o cloreto de polidialildimetil amônio (PoliDADMAC) com concentração de 0,001N.

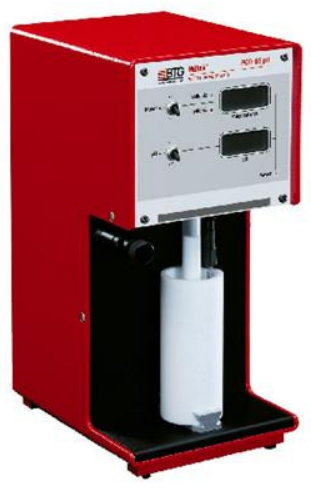

(A)

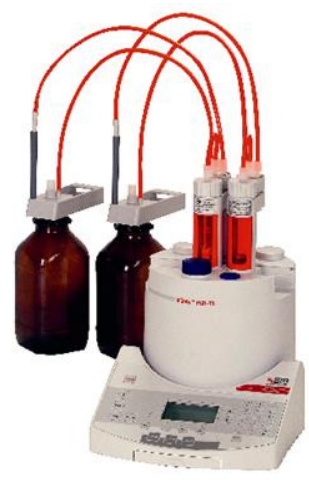

(B)

Figura 3.5 - (A) Medidor da demanda catiônica Mütek PCD-03 Particle Charge Detector da BTG e (B) Acessório para o medidor da demanda catiônica Mütek PCDT3 Titrator Three da BTG. 


\subsubsection{Determinação da turbidez}

A turbidez, em NTU, é uma técnica bastante utilizada para avaliação de sistemas de retenção na química da parte úmida da máquina de papel por permitir uma resposta rápida do comportamento do sistema. A turbidez apresenta uma forte correlação com a retenção de finos e carga na formação da folha. A relação é inversa, ou seja, quanto menor a turbidez, maior a retenção (BEGALA, 1992) ${ }^{25}$. Dessa forma, ao invés da retenção de primeiro passo, a turbidez foi adotada para avaliação dos testes neste trabalho e foi determinada com um turbidímetro $2100 \mathrm{P}$ da Hexis, seguindo procedimento sugerido pelo fabricante. Com isso, pode-se alcançar resultados rápidos para os testes realizados.

\subsubsection{Preparo das suspensões}

Antes de cada bateria de testes, foram preparados 10 litros de suspensão de fibras com consistência de $0,5 \%, \mathrm{pH}$ de $7,5 \pm 0,5$ e teor de finos médio de $15 \%$ conforme determinação no Jarro de Britt (Tópico 3.3.2.5). A suspensão preparada era deixada em repouso por, aproximadamente, 30 min para alcançar o equilíbrio. $O$ teor de finos considerado foi o original da polpa após exaustiva lavagem seguida de centrifugação.

O ajuste da demanda catiônica foi realizado através da dosagem de solução de carboximetilcelulose de sódio (CMC-Na) com concentração de $1 \mathrm{~g} / \mathrm{l}$. Para o ajuste foi desenvolvida uma curva de dosagem de demanda catiônica versus mg de CMC-Na por volume de água branca drenada. Para tanto, foram coletadas cinco amostras de $100 \mathrm{~mL}$ da suspensão de fibras, com pH e condutividade previamente ajustados. As dosagens consideradas foram 0,0; 1,0; 5,0; 7,5 e 10,0 mg CMC-Na por $100 \mathrm{~mL}$ de água branca.

Depois de encontrada a curva, foi dosado no sistema o volume de solução de CMCNa necessário para alcançar o valor de demanda catiônica desejado.

25 BEGALA, A. J. Papermaking process with improved retention and drainage. US Patent \#5098520 United States. Nalco. $1992 . \quad$ Disponível em: $<$ http://www.freepatentsonline.com/5098520.html>. Acesso em: 06 jan. 2007. 


\subsubsection{Testes de retenção e drenagem}

O sistema adotado para a realização dos testes de retenção e drenagem foi o sistema complexo com nano e micropartículas. Os testes foram realizados no equipamento de Jarro de Britt.

Para cada teste, foram utilizados $800 \mathrm{~mL}$ de suspensão de fibras com $\mathrm{pH}$, condutividade, demanda catiônica e temperatura ajustados.

Todos os testes de retenção e drenagem com nanopartículas foram realizados seguindo a ordem de adição de reagentes e os tempos de retenção descritos na Tabela 3.3. Nos testes, o tempo entre a adição do amido catiônico e do retentor foi de 20 segundos.

Após a abertura da válvula, eram esperados 5 segundos e, então, coletado um volume de água branca correspondente a 9 a 10 segundos de escoamento da mesma. Esse procedimento foi adotado em todos os testes.

Tabela 3.3 - Ordem de adição de reagentes e tempos de retenção para os testes de retenção com nanopartículas

\begin{tabular}{cl}
\hline Tempo, s & \multicolumn{1}{c}{ Atividade } \\
\hline 0 & $\begin{array}{l}\text { Início da agitação da suspensão de fibras com todos parâmetros ajustados no rpm } \\
\text { desejado, seguida da adição do coagulante }\end{array}$ \\
\hline 5 & Adição do amido catiônico \\
\hline 10 & Adição da cola sintética \\
\hline 15 & Adição da carga inorgânica \\
\hline 25 & Adição do polímero aniônico \\
\hline 40 & Adição da sílica coloidal \\
\hline 45 & Parada da força de cisalhamento (rpm) e abertura da válvula de drenagem \\
\hline 55 & Fim da coleta da água branca \\
\hline
\end{tabular}


A retenção de partículas em cada teste foi determinada com a determinação da turbidez da água branca drenada.

A drenagem foi medida através do volume escoado para o tempo de escoamento de 10 segundos.

Os testes foram realizados próximos do ponto zero de demanda final, entre -15 e -10 $\mathrm{mEq} / \mathrm{L}$. Esta situação não é a praticada na indústria. Os valores praticados em escala industrial para demanda na caixa de entrada situam-se em torno de $50 \mathrm{mEq} / \mathrm{L}$ segundo informações de fábrica ${ }^{26}$.

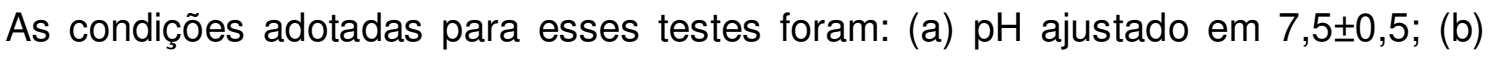
Condutividade ajustada em $100 \mu \mathrm{S} / \mathrm{cm}$; (c) Demanda catiônica ajustada para 50 $\mathrm{mEq} / \mathrm{L}$; (d) Potencial zeta da suspensão $-78,8 \mathrm{mV}$; e (e) Temperatura $23 \pm 1{ }^{\circ} \mathrm{C}$.

Os testes foram realizados em duplicata, ambos considerando as condições acima. Para cada teste foi preparada uma suspensão.

Testes:

1. Dosagens do coagulante de 0,$5 ; 0,75 ; 1,25 ; 1,5$ e 1,75 kg/ton de papel produzido;

2. Dosagens do coagulante de 0,$5 ; 1,25 ; 1,5 ; 2,0$ e 2,5 kg/ton de papel produzido;

3. Para o estudo do efeito de força de cisalhamento na retenção de partículas, as rotações de 450 e 900 rpm foram adotadas.

Todos os testes foram realizados com água destilada.

\footnotetext{
${ }^{26}$ SILVA, J.S. Notas de reuniões quando em visita à fábricas nacionais de papéis de imprimir e escrever. Janeiro - Fevereiro de 2007.
} 


\subsection{RESULTADOS E DISCUSSÃO}

\subsubsection{Caracterização da suspensão de fibra}

A caracterização da suspensão de fibras, especialmente no que diz respeito aos parâmetros teor de finos, demanda catiônica, potencial zeta, $\mathrm{pH}$, condutividade e turbidez, consiste em uma etapa importante antes da realização dos testes de retenção. Com esta caracterização, será possível simular uma suspensão modelo controlada para estudos posteriores de retenção de partícula.

Os parâmetros como pH e condutividade, foram facilmente ajustados com soluções de hidróxido de sódio ou ácido sulfúrico, e solução de cloreto de sódio, respectivamente. Por outro lado, considerando a concentração de substâncias orgânicas dissolvidas, a qual foi avaliada pela demanda catiônica do sistema, o carboximetil celulose de sódio (CMC-Na) mostrou ótima resposta ao ajuste deste parâmetro, apresentando elevada correlação, $R^{2}=0,9973$, (Figura 3.6). Na prática, o CMC-Na é utilizado na formulação do revestimento de papéis e é considerado um dos aditivos que mais contribuem com a elevação da demanda catiônica do sistema.

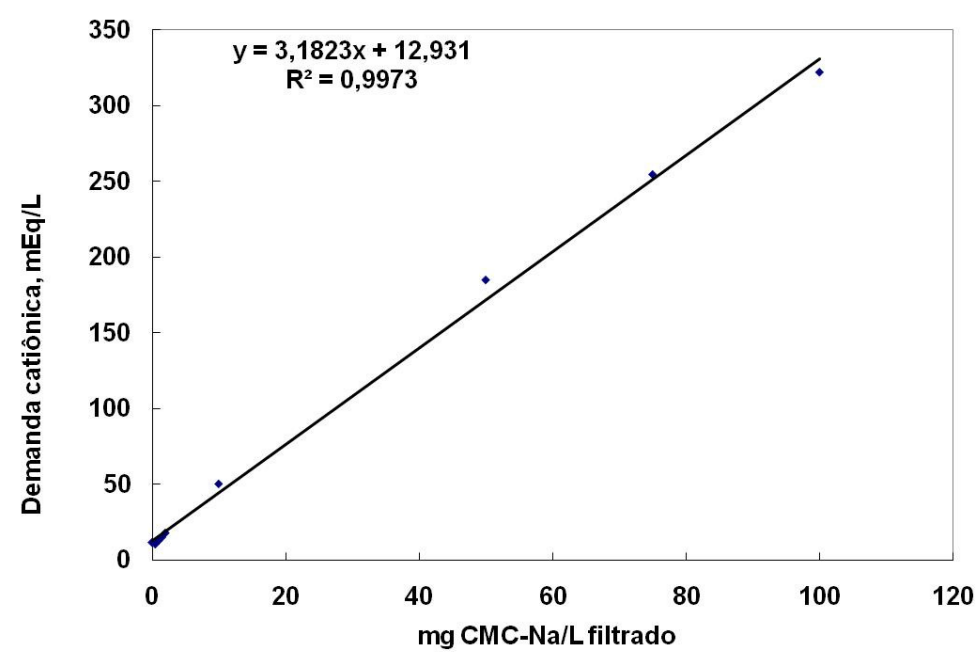

Figura 3.6 - Curva para ajuste da demanda catiônica (DC) inicial do sistema com solução de carboximetilcelulose de sódio (CMC-Na). 
A Tabela 3.4 mostra os resultados das análises das polpas após coleta na máquina e depois de lavada e centrifugada; e das frações 1, 2 e 3, com ajuste de demanda catiônica. A determinação do teor de finos foi realizada sem ajuste da demanda catiônica, fração 2 .

As repetições, bem como os desvios padrões e os coeficientes de variação para a análise de fibras em Kajaani e para o teor de finos em Jarro de Britt se encontram nas Tabelas A1 e A2 do APÊNDICE A, respectivamente.

Os resultados encontrados para a análise de fibras em Kajaani se encontram próximos aos valores encontrados na literatura para polpa branqueada de eucalipto (SILVA et al., 1997): comprimento médio de fibra entre 0,74 e 0,84 mm; número de fibras/g entre 14,64 e 21,7 milhões; Coarseness ${ }^{27}$ entre 7,45 e 9,55 mg/100m de fibra.

O valor médio de teor de finos orgânicos encontrado com o Jarro de Britt, embora maior do que a faixa de valor encontrado para polpa branqueada de eucalipto nacional, não refinada, 9 a $12 \%{ }^{28}$, se encontrou relativamente próximo, 15,50\%. A explicação para esse valor mais elevado pode ser devido à polpa já ter sido refinada, diferentemente das polpas avaliadas no estudo de Silva et al. (1997). O refino consiste em uma etapa mecânica que, dependendo da sua intensidade, pode haver geração de finos devido à remoção da parede celular e, ou, quebra das fibras.

Valor de potencial zeta da suspensão foi de, aproximadamente, $-25 \mathrm{mV}$ em razão do alto valor de condutividade apresentado por essa suspensão, $619 \mu \mathrm{S} / \mathrm{cm}$ (Tabela 3.4).

Pode-se verificar na Tabela 3.4 o fenômeno da compressão da dupla camada elétrica devido à elevada concentração de eletrólitos no meio de dispersão dada pelo valor da condutividade. Para a suspensão de fibras coletada na máquina, os valores de condutividade e de potencial zeta foram $619 \mu \mathrm{S} / \mathrm{cm}$ e de $-24,8 \mathrm{mV}$, respectivamente. Por outro lado, como a condutividade média da supensão modelo

\footnotetext{
${ }^{27}$ Peso por comprimento de fibra.

${ }^{28}$ SILVA, J.S. Notas de reuniões quando em visita à fábricas nacionais de papéis de imprimir e escrever. Janeiro - Fevereiro de 2007.
} 
foi de $99,7 \mu \mathrm{S} / \mathrm{cm}$, a suspensão apresentou mais eletronegativa, com potencial zeta de $-78 m V$.

Tabela 3.4 - Resultados das análises de polpa e das frações 1, 2 e 3

\begin{tabular}{|c|c|c|c|c|c|}
\hline & $\begin{array}{l}\text { Polpa após } \\
\text { coleta na } \\
\text { máquina* }\end{array}$ & $\begin{array}{l}\text { Polpa lavada e } \\
\text { centrifugada** }^{*}\end{array}$ & Fração $1^{* * *}$ & Fração 2 & Fração $3^{* * *}$ \\
\hline Comprimento médio, mm & - & 0,77 & - & - & - \\
\hline Largura, $\mu \mathrm{m}$ & - & 16,73 & - & & \\
\hline \# de fibras/g, $10^{6}$ & - & 24,63 & - & - & - \\
\hline Coarseness, mg/100m & - & 6,4 & - & - & - \\
\hline Potencial zeta, mV & $-24,8$ & - & -78 & $x$ & - \\
\hline Teor de finos, $\%$ & - & - & - & 15,50 & - \\
\hline $\mathrm{pH}$ & 7,65 & - & - & - & 8,41 \\
\hline Condutividade, $\mu \mathrm{S} / \mathrm{cm}$ & 619 & - & - & - & 99,7 \\
\hline Demanda catiônica, mEq/L & 35,5 & - & - & - & 8,75 \\
\hline Turbidez, NTU & - & - & - & - & 47,4 \\
\hline Temperatura, ${ }^{\circ} \mathrm{C}$ & 26,9 & - & - & - & 25,1 \\
\hline
\end{tabular}

${ }^{*}$ Resultados medidos após resfriamento; ${ }^{\star *}$ Polpa com teor a.s. 26,7\%; ${ }^{\star \star \star}$ Suspensão após ajuste de $\mathrm{pH}$ e condutividade.

Valores comuns de condutividade para máquina de papel se encontram entre 400 e $600 \mu \mathrm{S} / \mathrm{cm}^{28}$. Estes valores pode ser conseqüência do recebimento de polpa que foi submetida à baixa eficiência de lavagem em fábrica de papel integrada ou do maior grau de fechamento do circuito de água branca da máquina. Segundo Ojala (2006), valores elevados de condutividade podem afetar negativamente a eficiência da retenção de cargas em razão da redução do comprimento do polímero. Essa redução se deve a sua contração ou redução da densidade de carga da superfície das fibras devido à compressão da dupla camada elétrica (RADTCHENKO; PAPASTAVROU; BORKOVEC, 2005). Por outro lado, valores controlados, elevados 
ou não, garantem que o processo de retenção ocorra de maneira uniforme (OJALA, 2006).

\subsubsection{Efeito da dosagem do coagulante na retenção de partículas e na drenagem}

Não é comum na literatura estudar o processo de retenção adicionando grande variedade de aditivos da química da parte úmida no mesmo ensaio. A avaliação de um aditivo com a amostra de suspensão de fibras de fábrica, na qual já pode ter sido adicionado alguns aditivos, é comum quando se deseja encontrar um produto substituto ou otimizar algum dos aditivos. Neste trabalho, a opção escolhida foi a de adotar um sistema de floculação, adicionar sequencialmente os aditivos e estudar os efeitos já mencionados.

A Figura 3.7 mostra os resultados do efeito da dosagem de coagulante na retenção de partículas, medido pelos valores de turbidez da água branca, para as condições fixas de $\mathrm{pH} 7,5 \pm 0,5$, de condutividade de $100 \mu \mathrm{S} / \mathrm{cm}$ e de demanda catiônica inicial de $50 \mathrm{mEq} / \mathrm{L}$.

Como se pode observar na Figura 3.7, a redução da demanda catiônica pela dosagem do neutralizador poliamina, reduziu os valores da turbidez da água branca até um valor de demanda catiônica em torno de 3,0 mEq/L. A partir deste ponto, houve inversão das condições do sistema, refletindo num aumento da turbidez da água branca e, portanto, na redução da eficiência de retenção de partículas. 


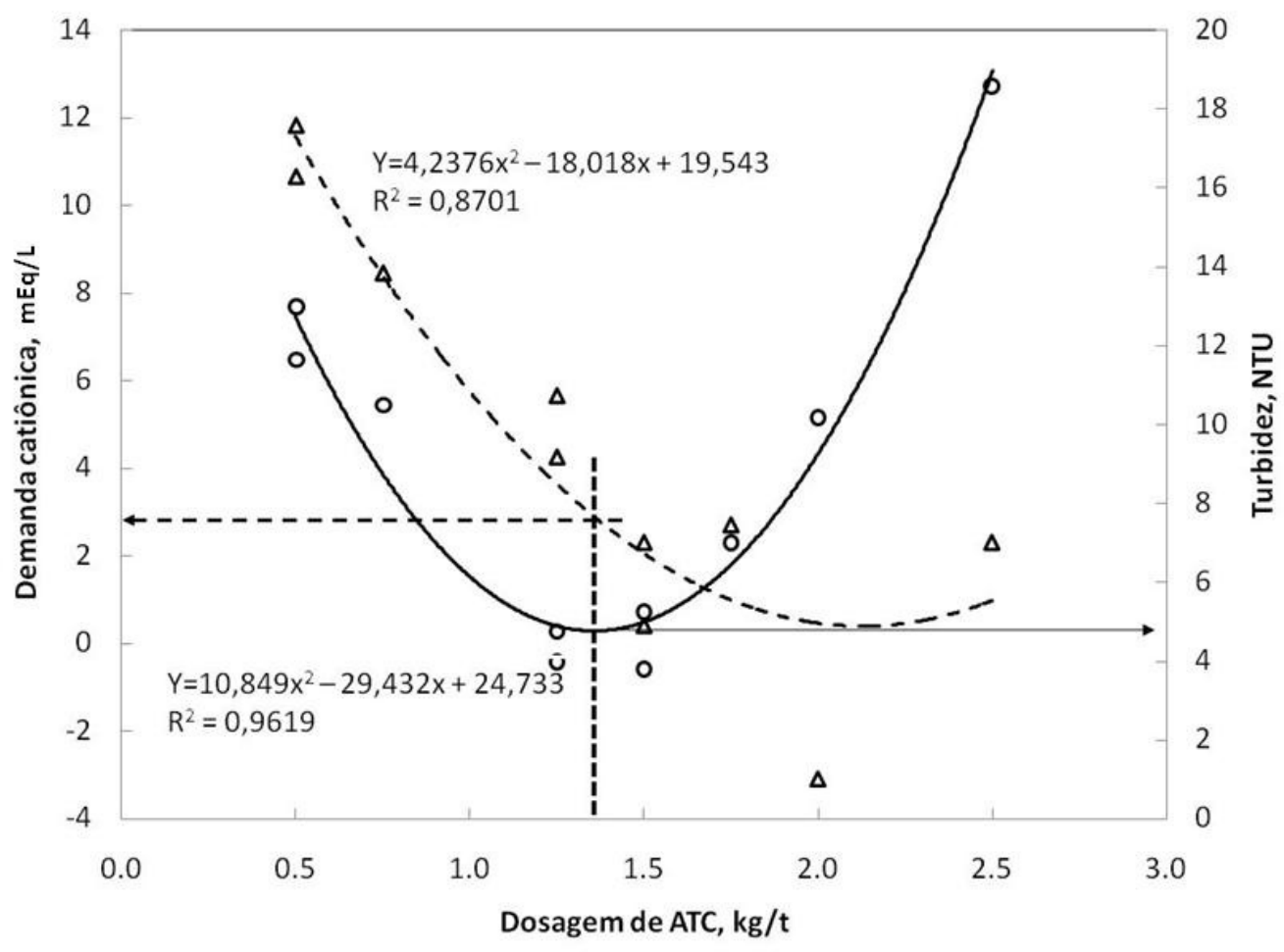

Figura 3.7 - Efeito da dosagem de coagulante na demanda catiônica e na turbidez da água branca. Dosagens base papel seco: amido, $9 \mathrm{~kg} / \mathrm{t}$; cola AKD, 0,95 kg/t; carga PCC, 20\% base papel seco; polímero aniônico, 0,1kg/t; sílica aniônica, 3 kg/t.

A redução dos valores de turbidez da água branca com a adição do polímero coagulante pode ser atribuída às reações de complexação do coagulante com as substâncias orgânicas dissolvidas, principalmente CMC-Na, neutralizando-as, favorecendo a atuação do polímero retentor através da floculação por pontes para valores de demanda mais elevados, em torno de $10 \mathrm{mEq} / \mathrm{L}$ (Figura 3.7). Por outro lado, a adição de excesso do coagulante promoveu a redispersão desses agregados, invertendo a carga do sistema e, portanto, voltando a se elevar os valores de turbidez. Resultados semelhentes foram encontrados por Dunham; Sherman e Alfano (2002), utilizando o polidialildimetil amônio (Poli-DADMAC) como polímero de baixo peso molecular e elevada densidade de carga. Nesta situação, a redispersão das substâncias orgânicas dissolvidas pode também ter contribuído para redução da eficiência de atuação do agente de retentor. 
Um aspecto importante a ser observado é a possibilidade de o amido catiônico ter atuado como agente coagulante das substâncias orgânicas dissolvidas, conforme sugerido por Rojas e Neuman (1999), especialmente, para baixas dosagens do polímero utilizado como coagulante (Poliamina). As possíveis reações que ocorreram, preferencialmente, entre as substâncias coloidais e dissolvidas e o amido ao invés das interações eletrostáticas com os sítios negativamente carregados das superfícies do material fibroso, foram ajudadas pela baixa consistência em que normalmente são realizados os testes de laboratório (0,5\%), quando comparada com a consistência que é freqüentemente empregada em escala comercial no ponto de adição do amido catiônico ( 4,5\%).

Pode ser verificado pelos resultados que as condições do presente sistema próximo à neutralidade do meio de dispersão é muito sensível à variações, passando de uma condição favorável de retenção para outra oposta. Em fábricas de papel pode ser verificado que a demanda catiônica praticada está entre 50 e $60 \mathrm{mEq} / \mathrm{L}$ na caixa de entrada, ponto antes da formação da folha na mesa plana e onde já foram adicionados todos os aditivos. Desta forma se garante que não ocorrerá a inversão do sistema e a atuação do agente de retenção será através de floculação por pontes.

Parte do amido catiônico, em concentrações mais elevadas do agente coagulante, pode também ter formado complexos com o polímero aniônico reduzindo assim a sua eficiência. Adicionalmente, o polímero catiônico utilizado como neutralizador do lixo aniônico, adicionado em excesso, pode, também, ter atuado sobre o retentor de carga. Para o sistema estudado, valores de demanda inferiores a $5 \mathrm{mEq} / \mathrm{L}$ não são favoráveis à retenção de cargas, o que pode ser mostrado com o aumento dos valores de turbidez.

A Figura 3.8 mostra o efeito da dosagem do coagulante na drenagem da suspensão de fibras avaliada pela velocidade de escoamento em $\mathrm{mL} / \mathrm{s}$. 


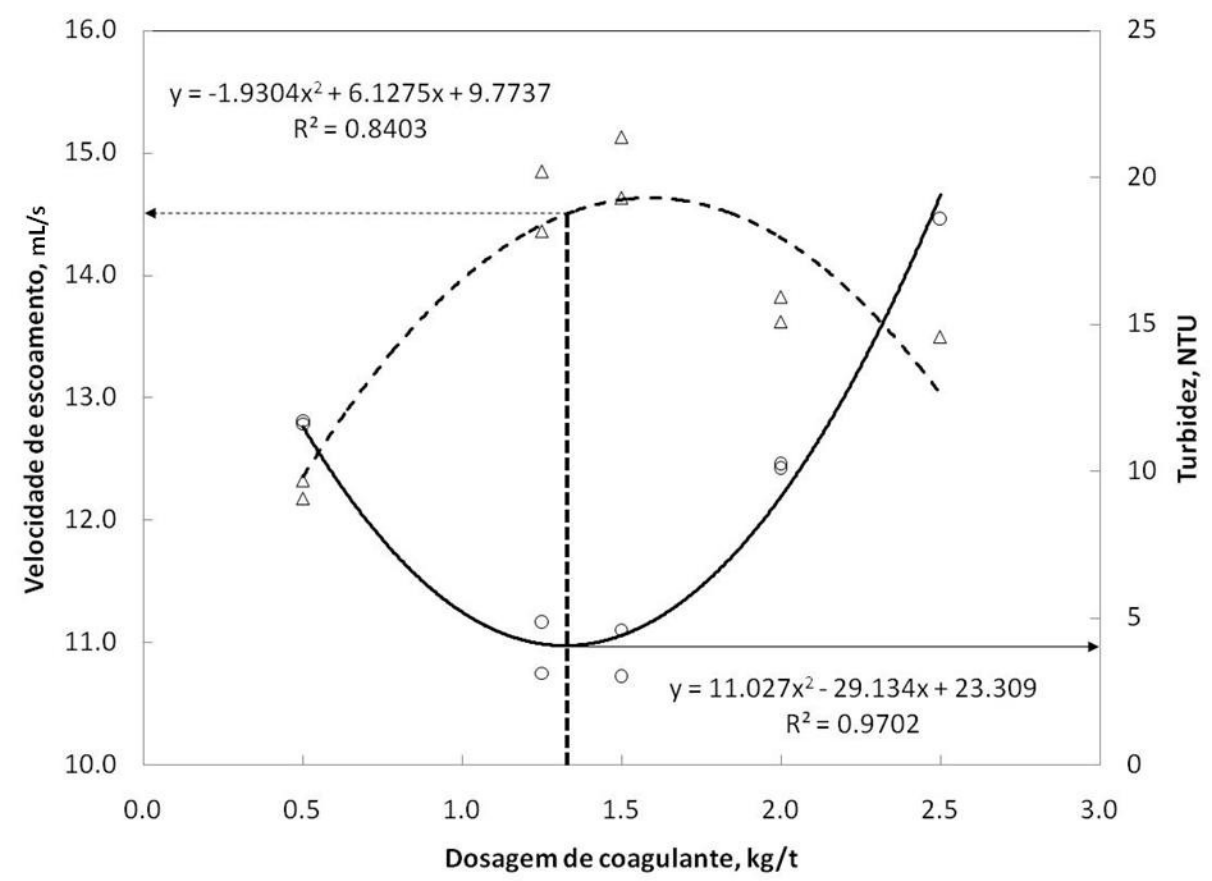

Figura 3.8 - Efeito da dosagem de coagulante na drenagem do sistema.

Como pode ser observado, existe um ponto ótimo de dosagem para os dois parâmetros avaliados que não são coincidentes. O valor mínimo de turbidez se dar à dosagem de 1,3 kg/t de coagulante. Enquanto que o máximo de escoamento ocorre com a dosagem de $1,6 \mathrm{~kg} / \mathrm{t}$ de coagulante. Ambos calculados a partir da derivada primeira da equação. Dessa forma, para que o sistema de retenção não seja comprometido, dosagens de coagulante inferior a 1,3 kg/t devem ser adotadas.

As Tabelas A 3 e A 4 do APÊNDICE A apresentam as repetições do estudo do efeito da dosagem de coagulante na retenção de partículas e drenagem da suspensão, respectivamente. 


\subsubsection{Efeito de forças de cisalhamento na demanda catiônica e na turbidez da água branca}

A Figura 3.9 mostra o efeito das forças de cisalhamento na demanda catiônica e na turbidez da água branca, para valores de cisalhamentos correspondentes a rotação no jarro de Britt de 450 e 900 rpm.

Pode-se observar que a ação mecânica pode ter causado rompimento dos flocos com liberação de partículas, aumentando a turbidez da água branca de 12,3 para 36,8 NTU para forças de cisalhamento correspondentes à 450 e 900 rpm, respectivamente. A liberação de finos orgânicos e inorgânicos pode ter ocorrido tanto pelo arrancamento dessas partículas, quanto pela quebra das cadeias dos polímeros devido ao choque entre flocos e destes contra as paredes e com os defletores do jarro de Britt. Como houve redução da demanda catiônica de 11,2 para $7,8 \mathrm{mEq} / \mathrm{L}$ com o aumento dessas forças, é possível que a quebra tenha ocorrido nas cadeias de polímeros catiônicos, poliamina e amido, este último em maior proporção. Em sistemas com alto grau de cisalhamento, são necessários polímeros retentores com alto poder de adsorção e elevada energia de ligação. Isto é possível com o alto grau de substituição existentes nos polímeros mais modernos (BROUILLETTE et al., 2005). A ramificação dos polímeros retentores também pode ser uma alternativa para aumentar a resistência desses ao cisalhamento.

A Tabela A 5 do APÊNDICE A apresenta as repetições do estudo do efeito do cisalhamento na retenção de partículas. 


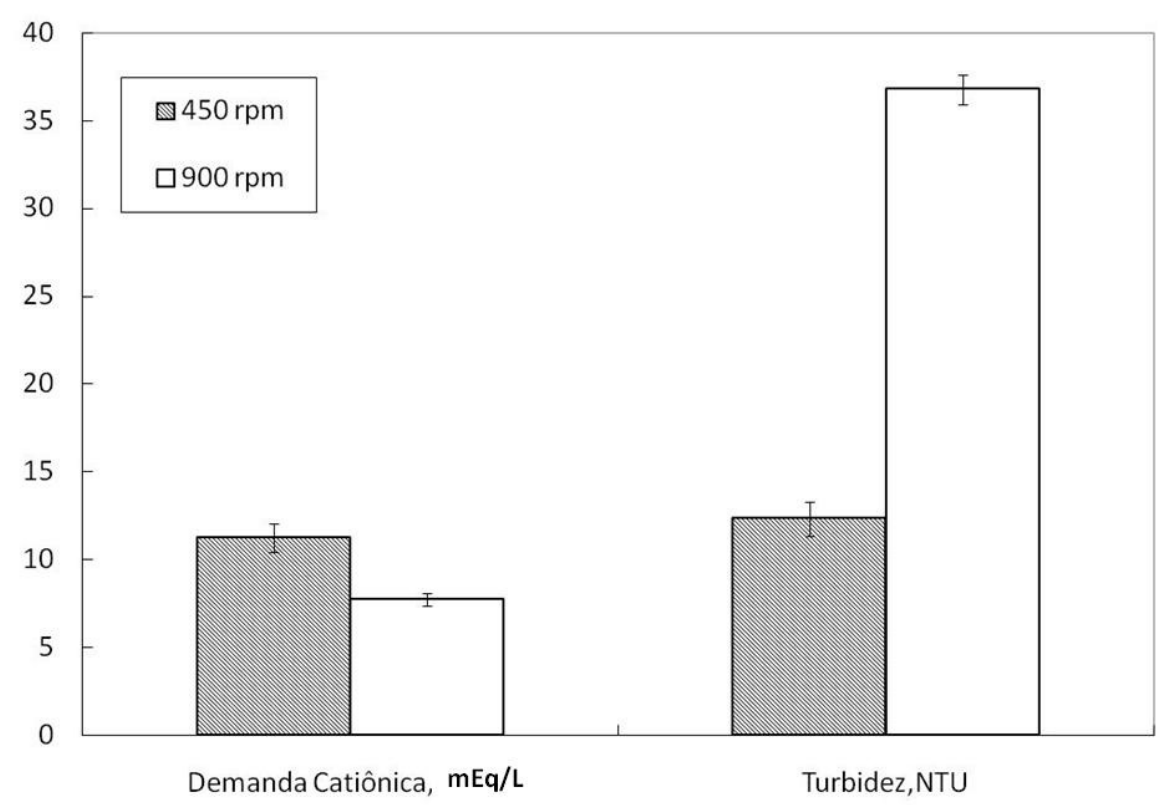

Figura 3.9 - Efeito de forças de cisalhamento na demanda catiônica e na turbidez da água branca. Dosagens base papel seco: ATC, 0,5 kg/t; amido, $9 \mathrm{~kg} / \mathrm{t}$; cola AKD, $0,95 \mathrm{~kg} / \mathrm{t}$; carga PCC, $20 \%$ base papel seco; polímero aniônico, 0,1kg/t; sílica aniônica, $3 \mathrm{~kg} / \mathrm{t}$.

A Tabela A 5 do APÊNDICE A apresenta as repetições do estudo do efeito do cisalhamento na retenção de partículas.

\subsection{CONCLUSÕES}

Amostra de polpa branqueada de eucalipto foi preparada e caracterizada para ser utilizada como suspensão modelo para estudos de retenção de partículas e de drenagem da água utilizando o aparelho de jarro de Britt. Os efeitos da dosagem de coagulante e da força de cisalhamento nessas variáveis foram estudados. 
A paritr dos resultados alcançados pode-se concluir que:

- O sal de carboximetilcelulose desenvolveu ótimo papel quando utilizado como substância orgânica dissolvida para ajuste da demanda catiônica de sistemas modelos para testes de retenção de partículas e drenagem da suspensão;

- A retenção de partículas alcançou melhor resultado quando a carga líquida do sistema se encontrava ainda negativa (demanda catiônica de aproximadamente $3 \mathrm{mEq} / \mathrm{L})$. Nesta condição, a drenagem da suspensão não foi a máxima para o sistema em questão. Demandas próximas a zero reduziram de forma significativa a eficiência de retenção de partículas;

- O estudo mostrou que, para se trabalhar com segurança, os valores de demanda catiônica devem ser maiores do que o valor de demanda correspondente ao máximo de retenção de partículas (turbidez mínima), sem comprometer a drenagem do sistema;

- Resultado mais favorável de retenção de partículas foi alcançado para o sistema em que foi aplicada menor intensidade de forças de cisalhamento, quando comparado ao resultado alcançado pelo sistema em que foram aplicadas forças de cisalhamento de maior intensidade. 


\section{PRINCIPAIS MATERIAIS, PROCEDIMENTOS E TÉCNICAS UTILIZADAS NO ESTUDO DE POLIANFÓTERO}

\subsection{Introdução}

Serão descritos aqui os principais procedimentos utilizados para a preparação de superfícies modelos de sílica e de filme de celulose. As superfícies modelos têm como objetivo simular os fenômenos cinéticos e de adsorção em nível molecular de forma a esclarecer tais fenômenos em interface sólido-líquido. Por exemplo, os filmes de celulose têm como objetivo simular a superfície de uma fibra nos experimentos de adsorção em balança microgravimétrica com cristal de quartzo. Fibras de polpa branqueada de eucalipto também foram preparadas para serem utilizadas em testes de adsorção de polímero e em testes de resistência do papel.

Várias técnicas foram utilizadas na realização deste trabalho. Entretanto, neste capítulo serão descritos os princípios fundamentais das principais técnicas: balança microgravimétrica (QCM-D), microscopia de força atômica (AFM), espalhamento dinâmico da luz (DLS) e medidor de densidade de carga (PCD).

\subsection{Materiais e procedimentos}

\subsubsection{Superfícies modelos}

Neste trabalho foram utilizados três tipos de superfícies modelos nos experimentos de adsorção em interface sólido-líquido: filmes finos de celulose e substrato de sílica para teste de adsorção em escala nanogravimétrica (QCM-D); e substrato de sílica para estudo da camada adsorvida com a técnica de microscopia (AFM). 


\subsubsection{Filmes finos de celulose}

Os filmes finos de celulose foram desenvolvidos a partir de Avicel, celulose microcristalina (CMC) adquirida da Fluka BioChemika. O procedimento utilizado para confecção desses filmes foi o sugerido por Gunnars; Wågberg e Cohen Stuart (2002).

A preparação dos filmes de celulose exigiu dois outros procedimentos prévios: (a) limpeza dos cristais de quartzo revestidos com ouro e (b) preparação da solução de celulose.

\subsubsection{Limpeza dos cristais de quartzo revestidos com ouro}

No caso de sensores revestidos com substrato de ouro sem uso, foi seguido o procedimento de limpeza recomendado pelo fabricante, Q-Sense, Suécia. Inicialmente, esses sensores foram submetidos à luz UV de ozônio por 15 min seguido por imersão em solução de limpeza na proporção em volume de 5:1:1 de água Milli-Q, solução de amônia $25 \%$ e solução de peróxido de hidrogênio $30 \%$, respectivamente. Essa mistura, juntamente com os sensores, foi aquecida a $75{ }^{\circ} \mathrm{C}$ por $10 \mathrm{~min}$. Após, os sensores foram lavados com água Milli-Q, secados com nitrogênio e tratados novamente com luz de ozônio-UV por mais 15 min imediatamente antes do seu uso. Neste caso, os sensores já estão prontos para iniciar o processo de revestimento com filme de celulose.

Entretanto, no caso de reaproveitamento de sensores usados (após os teste de adsorção), a limpeza dos mesmos recebeu um pretratamento com enzimas antes do procedimento descrito anteriormente. Como opção para limpeza dos sensores usados, além da sugerida pelo fabricante, a imersão em solução de "piranha" (7:3, ácido sulfúrico concentrado e peróxido de hidrogênio $30 \%$, v/v) era também utilizada no laboratório da Universidade do Estado da Carolina do Norte para essa finalidade. Entretanto, ambas as soluções de limpeza apresentavam desvantagens sob o meu ponto de vista, especialmente com relação ao tempo demandado e à dificuldade de remoção do filme de celulose, podendo danificar as superfícies dos sensores, os quais são de custo elevado. O tratamento enzimático antecedendo ao tratamento 
químico com a solução de limpeza do fabricante foi desenvolvido e proposto pela primeira vez nesta pesquisa e, posteriormente, foi apresentado no $10^{\circ}$ Congresso Brasileiro de Polímeros ${ }^{29}$, em cujo artigo pode-se obter maiores detalhes sobre 0 procedimento proposto. A Figura 4.1 ilustra o roteiro sugerido para os tratamentos enzimático e químico.

1. Tratamento enzimático (sensores com filme): $80 \mathrm{~min}, \mathrm{pH} 4,5,45^{\circ} \mathrm{C}, 10 \mathrm{mM}$

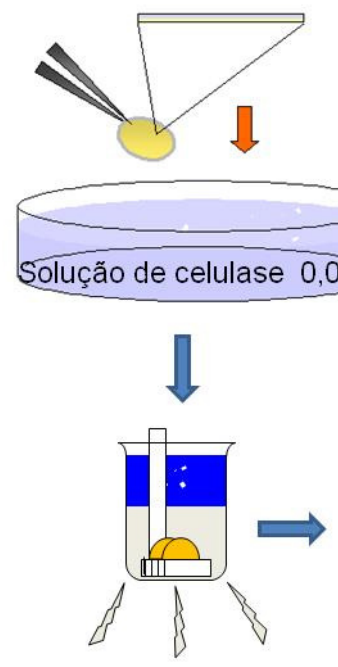

2. Banho de ultrassom: $20 \mathrm{~min}$

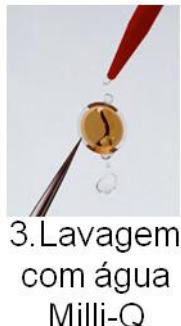

Milli-Q

\section{Tratamento com UVO por $15 \mathrm{~min}$}

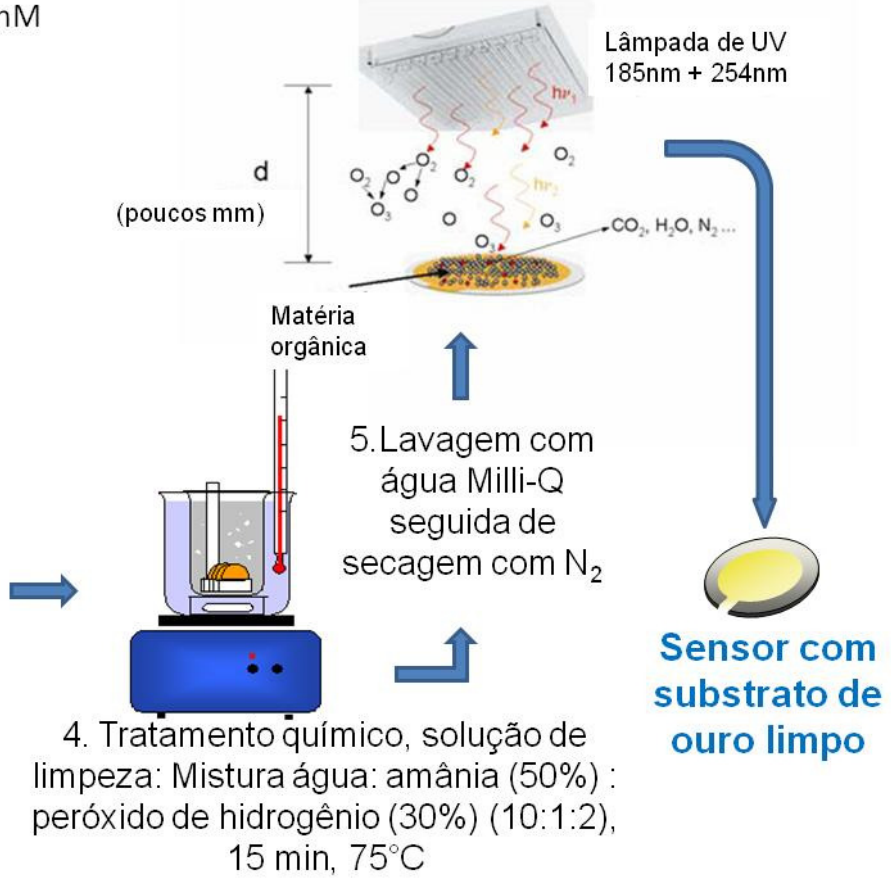

Figura 4.1- Tratamento enzimático utilizado para limpeza dos sensores usados nos testes de adsorção, antecedendo a limpeza química.

Em linhas gerais, a remoção do filme de celulose da superfície do substrato de ouro para posterior reuso do mesmo foi facilitada e abreviada pela imersão dos sensores em uma mistura de $40 \mathrm{~mL}$ de solução de $\mathrm{NaCl} 10 \mathrm{mM}$ com $1 \mathrm{~mL}$ de 0,4\% p/v da solução de mistura enzimática de celulase da espécie Aspergillus. A enzima foi adquirida da Sigma (Sigma C2605-50 mL, 095K0723). Os sensores ficaram imersos

${ }^{29}$ SILVA, D. J.; ROJAS, O. J.; HUBBE, M. A.; PARK, S. W. Enzymatic treatment as a pre-step for remove cellulose films in sensors. In: CONGRESSO BRASILEIRO DE POLÍMEROS 10., Anais... Foz do Iguaçu, PR, Brasil, 2009. 
por 80 min a $45^{\circ} \mathrm{C}$, seguido de banho de ultrassom por $20 \mathrm{~min}$, lavagem com água Milli-Q para remoção do filme de celulose solto, e posterior secagem com nitrogênio. Após, os sensores foram tratados com a solução química sugerida pelo fabricante, seguida de lavagem com água Milli-Q e secagem com nitrogênio. Antes de serem usados, os sensores já sem o filme eram submetidos ao banho de luz ozônio por 15 mim. A média do ângulo de contato das superfícies dos sensores de ouro limpas, utilizando o método da gota de água, situou-se entre $6,4^{\circ}$ e $7,1^{\circ}$.

Durante o desenvolvimento deste procedimento, foram testadas duas concentrações de sal, 0,1 e $10 \mathrm{mM} \mathrm{NaCl}$. Foi verificado que o tempo necessário para a remoção do filme de celulose, controlado a partir da determinação do ângulo de contato durante a atividade enzimática a cada $10 \mathrm{~min}$, era o mesmo, ou seja, $80 \mathrm{~min}$.

\subsubsection{Preparação da solução de celulose}

Para preparação da solução de celulose foi seguido o procedimento desenvolvido por Gunnars; Wågberg e Cohen (2002). A solução de celulose foi preparada misturando $0,05 \mathrm{~g}$ de celulose microcristalina (CMC) com 2,5 mL de N-metilmorfolina $50 \%$ (NMMO) adquirida da Aldrich. A mistura foi submetida à temperatura de $115^{\circ} \mathrm{C}$ por, aproximadamente, $10 \mathrm{~min}$, sob constante agitação até a completa dissolução da CMC (GUNNARS; WÅGBERG; COHEN, 2002). A Figura 4.2 mostra o procedimento geral de preparação de filmes de celulose sobre substrato de ouro. Após a dissolução da CMC, $5 \mathrm{~mL}$ de dimetil sulfóxido (DMSO), adquirida da Fisher Chemical, foram adicionados para ajuste da viscosidade. Em paralelo, os sensores de cristal de quartzo revestidos com ouro, foram preparados para receber a solução de celulose. Como a densidade de carga líquida da superfície desses sensores limpos e a solução de celulose são negativas, fez-se necessário o uso de uma solução de polímero com carga líquida positiva como ancorador. Com esta finalidade, foram utilizados $20 \mathrm{~mL}$ de solução de polivinilamina (PVAm) da BASF, na concentração de 100 mg/L. Em placas de Petri, os sensores foram imersos nessa solução por 20 min, seguido por lavagem com água ultrapura e secagem com nitrogênio. Finas camadas de solução de celulose, a $50^{\circ} \mathrm{C}$, revestiram as superfícies dos substratos de ouro utilizando a técnica de spin-coating. Duas gotas da solução 
filtrada foram necessárias para o revestimento completo de cada superfície. Antes de iniciar o processo de spin-coating para remoção do excesso da solução, 5 segundos eram esperados para adsorção do polímero celulose dissolvido na camada de polímero PVAm. O processo de spin-coating era realizado em 40 segundos, sendo 10 segundos para alcançar a velocidade de rotação, 5000 rpm, e 30 segundos nesta velocidade. Outros 10 segundos eram necessários para o equipamento paralisar.

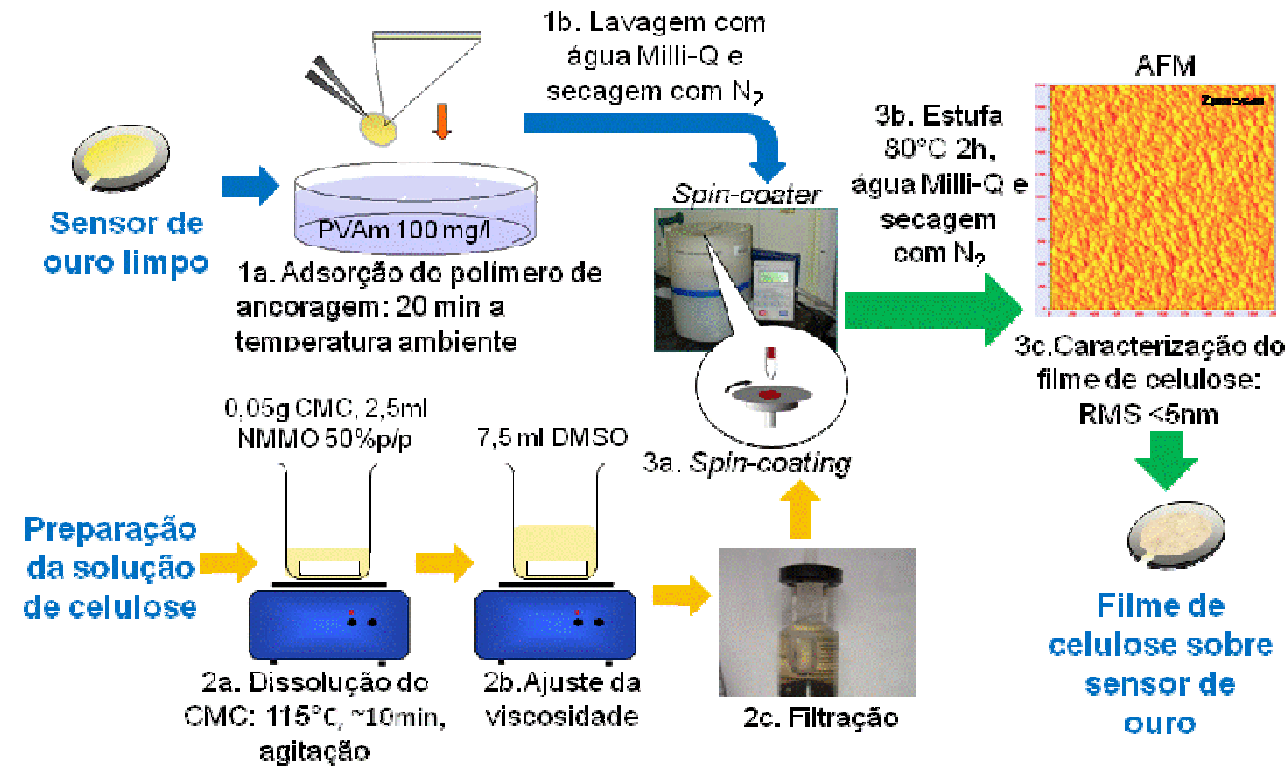

Figura 4.2 - Procedimento de preparação de filmes finos de celulose.

As superfícies dos filmes depositadas eram planas e uniformes e os filmes eram ultrafinos. A espessura média dos filmes, medida por elipsometria, era de $15 \mathrm{~nm}$ (SONG, 2008). As rugosidades dos filmes modelos secos foram menores do que 5 $\mathrm{nm}$ de acordo com os resultados de RMS (root-mean-square) medidas pela técnica de AFM (Figura 4.3). A média das medidas do ângulo de contato, $26^{\circ}$, estava de acordo com a literatura (GUNNARS; WÅGBERG; COHEN, 2002; SONG, 2008). A medida era realizada após a secagem dos filmes à vácuo, à temperatura de $43^{\circ} \mathrm{C}$, durante à noite. 


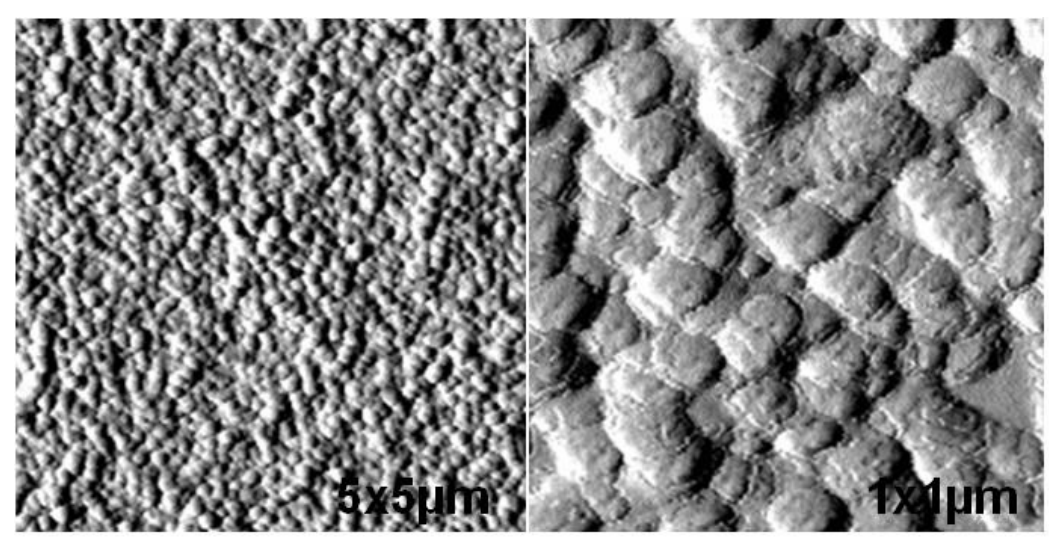

Figura 4.3 - Fotomicrografia dos filmes de celulose gerada pela técnica de $\mathrm{AFM}^{30}$.

\subsubsection{Substrato de sílica}

Substratos de silica que, segundo a literatura, apresentam balanço de carga negativo maior do que o balanço negativo dos filmes de celulose (RADTCHENKO, PAPASTAVROU; BORKOVEC, 2005), foram utilizados para comparação. O cristal de quartzo de dióxido de silício $\left(\mathrm{SiO}_{2}\right)$ era constituído, da superfície para o interior, de $50 \mathrm{~nm}$ de $\mathrm{SiO}_{2}$ (superfície ativa), $10 \mathrm{~nm}$ de titânio, 100nm de ouro, $5 \mathrm{~nm}$ de crômio e quartzo.

Antes de serem utilizados, os sensores eram limpos de acordo com o procedimento sugerido pelo fornecedor do equipamento, Q-Sense, Suécia, o qual será descrito sumariamente a seguir, conforme o esquema da Figura 4.4. Os sensores de sílica foram imersos numa solução de limpeza Hellmanex $2 \%$ p/p adquirida da HELLMA Worldwide e submetidos a banho de ultrassom por 20 min. Após, os sensores foram exaustivamente lavados com água Milli-Q. Com o objetivo de ativar os grupos silanol da superfície dos sensores ( DUVAL et al., 2002), esses foram imersos por 3 min em solução de $\mathrm{NaOH} 10 \%$ p/p seguido de lavagem com água Milli-Q, secagem com nitrogênio e acondicionamento em dessecador contendo sílica gel. Antes de serem utilizados, os sensores foram soprados com nitrogênio e expostos a luz de ozônio-

\footnotetext{
${ }^{30}$ Imagens em AFM de filmes de celulose confeccionados por Deusanilde Silva e Xiaomeng Liu, NCSU, maio de 2008.
} 
UV por 15 min. A média do ângulo de contato das superfícies dos sensores de sílica limpas, usando o método de gota de água, foi de $6^{\circ}$.

1. Banho de ultrassom: $20 \mathrm{~min}$, Hellmanex $2 \%$

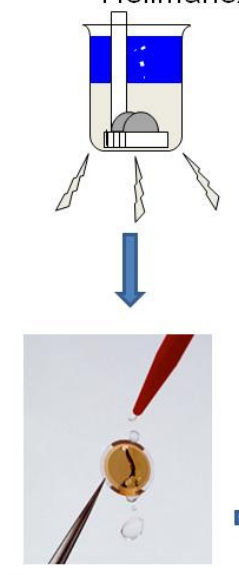

2. Lavagem com água Milli-Q

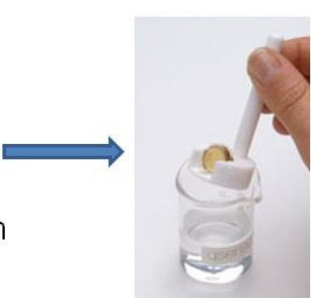

3. Tratamento químico: 3 min em solução de $\mathrm{NaOH}$ $10 \%$
6. Tratamento com UVO: $15 \mathrm{~min}$
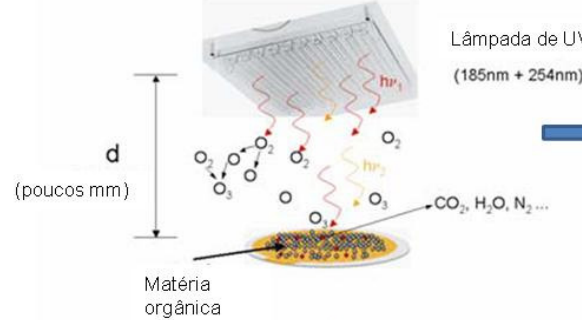

$$
\begin{aligned}
& \text { 4. Lavagem } \\
& \text { com água } \\
& \text { Milli-Q }
\end{aligned}
$$

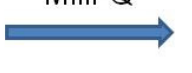

5. Secagem $\operatorname{com~} \mathrm{N}_{2}$

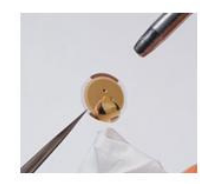

Lâmpada de UV

$(185 \mathrm{~nm}+254 \mathrm{~nm})$
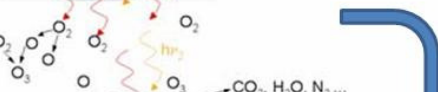

4 sintine
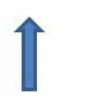

$\mathrm{CO}_{2}, \mathrm{H}_{2} \mathrm{O}, \mathrm{N}_{2}$
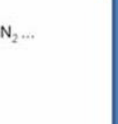

Sensor de sílica limpo

Figura 4.4 - Procedimento para limpeza de sensores de sílica para QCM.

\subsubsection{Wafer de silício}

Wafers de silício foram utilizados como substratos nos teste de adsorção do polianfótero para fazer as imagens em microscópio de força atômica (AFM). Antes,os wafers foram limpos com solução conhecida como 'piranha' com composição descrita anteriormente. Lavagem com água Milli-Q, secagem com nitrogênio e acondicionamento em dessecador, também eram procedidos. Sopragem com nitrogênio e tratamento com luz de ozônio por 15 min foram realizados antes de utilizá-los em teste de adsorção.

A adsorção do polímero anfótero foi realizada em um becker sob as mesmas condições utilizadas com a balança microgravimétrica para os parâmetros 
concentração, pH e força iônica. Informações mais detalhadas sobre o processo de adsorção serão vistas no capítulo 5 .

\subsection{Técnicas Instrumentais}

\subsubsection{Balança Microgravimétrica com Cristal de Quartzo e Dissipação de Energia (QCM-D)}

A balança microgravimétrica com cristal de quartzo e dissipação de energia (QCM-D

- Quartz Crystal Microbalance with Energy Dissipation), fabricada pela Q-Sense, Suécia, foi utilizada para estudar a adsorção do polímero anfótero em superfícies modelos: substrato de sílica e filme de celulose. $O$ instrumento possue quatro células acopladas a uma bomba injetora de amostra com quatro saídas individuais permitindo a realização de quatro experimentos simultaneamente. A adsorção foi realizada em superfícies de discos finos revestidos de óxido de silício ou de ouro, este revestido com filme de celulose, constituídos de um par de eletrôdos de cristal de quartzo que envolve os discos formando um 'sanduíche' (Figura 4.5A). Com a aplicação de uma corrente alternada aos eletrodos, há oscilação do cristal em razão de suas propriedades piezoelétricas (Figura 4.5B).

As mudanças na frequência de ressonância do cristal de quartzo devido à quantidade de massa adsorvida na superfície do sensor foram monitoradas em tempo real (Figura 4.5B). Estudos da dinâmica e da cinética do processo de adsorção também poderão ser realizados. 

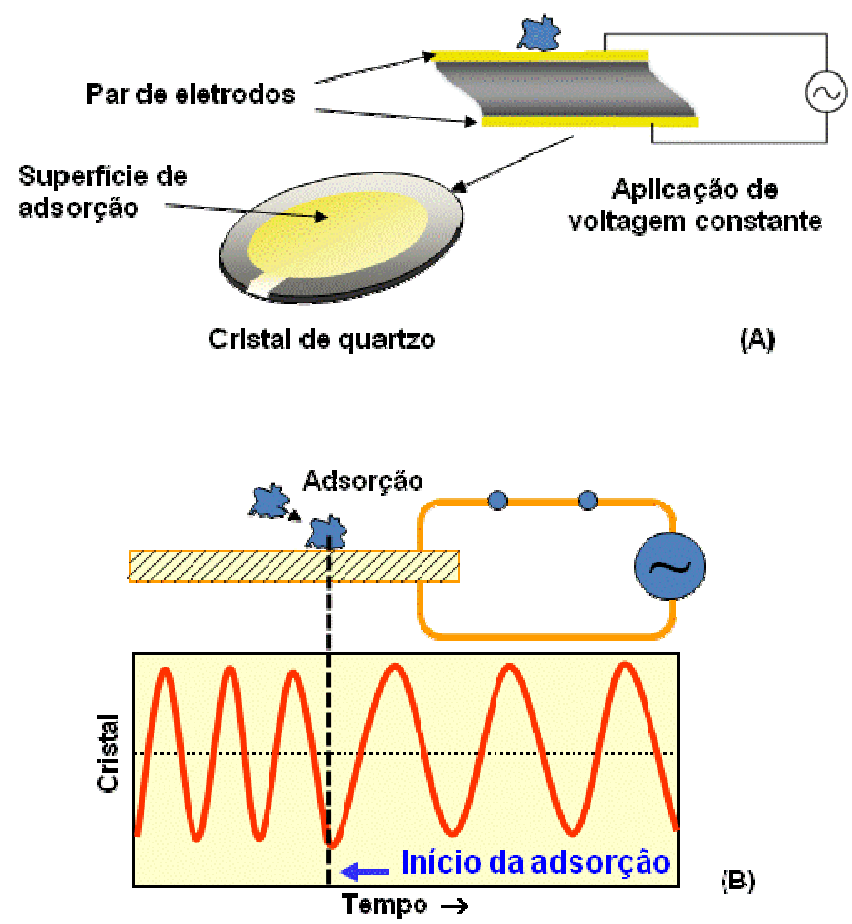

Figura 4.5 - Princípio de funcionamento da balança microgravimétrica com cristal de quartzo e dissipação de energia.

As mudanças em frequência de ressonância foram assumidas como sendo proporcionais à massa adsorvida para o caso de camadas rígidas (SAUERBREY, 1959). Por outro lado, o modelo de Voigt foi utilizado para camadas viscoelásticas (VOINOVA et al., 1999). A frequência fundamental, fo, correspondente à frequência de oscilação sem massa adsorvida, foi de $4,95 \mathrm{MHz}$. A constante sensitiva, $C$, no caso da equação de Sauerbrey, utilizada para camada rígida, foi de $17,7 \mathrm{ng} \cdot \mathrm{Hz}^{-1} \cdot \mathrm{cm}^{-2}$. A massa adsorvida, $\Delta m\left(\mathrm{ng} \cdot \mathrm{cm}^{-2}\right)$, foi calculada a partir da Equação 4.1, onde $n$ corresponde ao número de frequências harmônicas ímpares múltiplas da frequência fundamental $(n=1,3,5,7,9,11)$.

$$
\Delta m=-\frac{C \cdot \Delta f}{n}
$$




$$
\Delta f_{m}=-\frac{2 \times f_{0}^{2} \times \Delta m}{A \times \sqrt{\rho_{q} \mu_{q}}}
$$

A Equação 4.2 é um rearranjo da equação de Sauerbrey, onde $\Delta f_{m}$ é a mudança em frequência, $\quad \rho_{q}=2,648 \mathrm{~g} \cdot \mathrm{cm}^{-3}$ é a densidade do quartzo, $\mu_{q}=2,947 \times 10^{-11}$ dynas. $\mathrm{cm}^{-2}$ é o módulo de cisalhamento do quartzo e $A$ é a área piezoelétrica ativa. Esta equação não é válida para massas não rigidamente depositadas. A mudança na frequência de ressonância do cristal também depende da viscosidade $e$ da densidade do meio líquido na interface com o cristal ( $\eta_{f}, \rho_{f}$, respectivamente), Equação 4.3.

$$
\Delta f_{\text {aquoso }}=-\frac{n \times f_{0}^{3 / 2}}{\sqrt{\pi \rho_{q} \mu_{q}}}\left(\rho_{f} \eta_{f}\right)^{1 / 2}
$$

As propriedades viscoelásticas da camada adsorvida foram avaliadas medindo a dissipação de energia da oscilação do cristal, $D$. Tipicamente, uma camada macia é capaz de amortecer a oscilação do ressonador (Figura 4.6B). Por outro lado, uma camada rígida produziria um efeito de amortecimento mais devagar (Figura 4.6A).

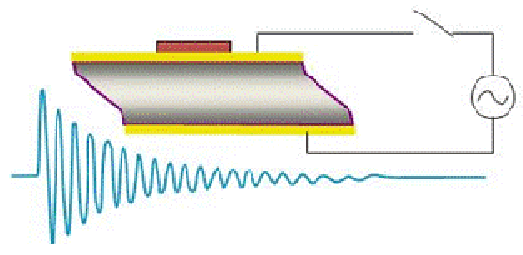

A energia dissipa vagarosamente Pequeno ou baixo, $\Delta \mathrm{D}$ - Filme rígido

(A)

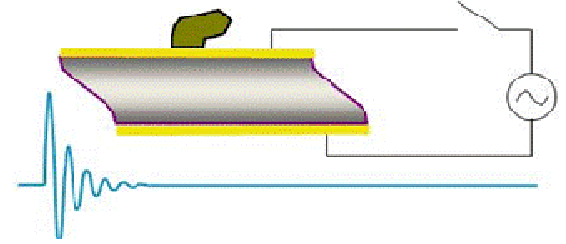

A energia dissipa rapidamente Grande ou elevada, $\Delta \mathrm{D}$ - Filme macio

(B)

$\Delta$ relacionado à massa adsorvida $e$ $\Delta \mathrm{D}$ relacionado à viscoelaticidade da camada adsorvida

Figura 4.6 - Dissipação de energia: (A) Filme rígido e (B) Filme macio. 
A dissipação de energia, ou amortecimento, foi definida pela Equação 4.4, onde $f$ é a frequência de ressonância fundamental e $\tau$ é a constante do tempo de amortecimento da amplitude de oscilação (RODAHL; KASEMO, 1996).

$$
D=(\pi f \tau)^{-1}
$$

Em caso de filmes macios (filmes mais viscoelásticos), o equipamento possue um programa denominado $Q$-Tools, fornecido pelo próprio fabricante do equipamento, Q-Sense, em que a massa específica adsorvida e a espessura da camada podem ser estimadas utilizando o modelo viscoelástico disponível. No caso deste trabalho, o modelo utilizado foi o de Voigt. A Figura 4.7A mostra a geometria da superfície modelo onde a camada de polímero adsorvida está sujeita a um stress de cisalhamento, $\sigma$, e se comporta como um elemento de Voigt com viscosidade de cisalhamento, $\eta_{\mathrm{I}}$, correspondendo a um amortecedor, e o módulo de cisalhamento, $\mu_{1}$, correspondendo a uma mola (Figura 4.7B) ( VOINOVA et al., 1999; TAMMELIN et al., 2004).
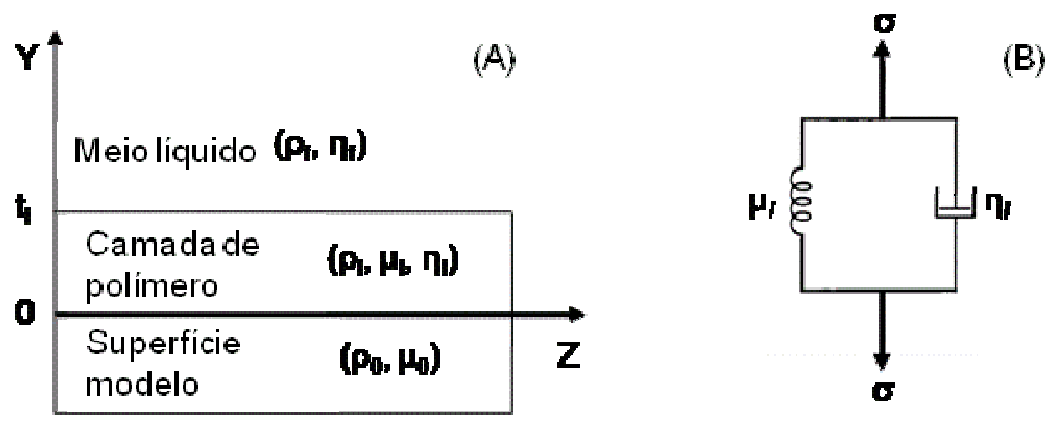

Figura 4.7 - Geometria da superfície modelo revestida com uma mono camada $(A)$ e o esquema do modelo viscoelástico de Voigt (B). Em que "p" é a camada e " $f$ " é fluido. 
A metodologia seguida para modelar as estimativas da massa adsorvida e da espessura da camada nas condições de adsorção apropriadas foi adaptada da literatura (MUNRO; FRANK, 2004).

A derivação do modelo de Voigt descrita pelos autores Vogt et al. (2004) foi:

$$
\begin{aligned}
& \Delta f \approx \frac{t_{l} \rho_{l} f}{2 \pi \rho_{0} t_{0}}\left(1+\frac{2 t_{l}^{2} \chi}{3 \delta^{2}\left(1+\chi^{2}\right)}\right) \\
& \Delta D \approx \frac{2 t_{l}^{3} \rho_{l} f}{3 \pi f_{0} \rho_{0} t_{0}} \frac{1}{\delta^{2}\left(1+\chi^{2}\right)}
\end{aligned}
$$

\section{Equação 4.6}

Em cujas equações, $\mu_{l}$ é o módulo de perda, $\chi=\frac{\mu_{l}}{\eta_{l} f}$ é a taxa do módulo de armazenamento e $\delta=\sqrt{\frac{2 \eta_{l}}{\rho_{l} f}}$ é a profundidade de penetração da camada viscosa.

\subsubsection{Microscopia de Força Atômica (AFM)}

Segundo Butt; Cappela e Kappe (2005), a microscopia de força atômica (AFM Atomic Force Microscopy) pertence a uma série de microscopias de varredura por sonda inventada na década de oitenta. Dentre outras aplicações, essa técnica é utilizada para se obter imagens de superfícies diversas, em escala submicrométrica, tanto no ar, quanto no líquido ou no vácuo, cujo funcionamento se baseia na mensuração de forças, tanto atrativas quanto repulsivas, existentes entre a superfície da amostra estudada e a superfície da ponta presente no equipamento (BUTT; CAPPELA; KAPPE, 2005). 
A Figura 4.8 A, adaptada de Butt; Cappela e Kappe (2005), mostra um esquema do funcionamento do microscópio de força atômica e a Figura $4.8 \mathrm{~B}^{31}$ mostra a relação de forças interatômicas entre superfícies, em função da distância. O microscópio de força atômica pode trabalhar em três modos diferentes: modo de contato (contact mode), modo de contato intermitente (tapping mode) ou o modo de não contato (non contact mode). Para cada um desses modos, a força de interação entre a superfície da amostra e a ponta difere entre si, conforme pode ser verificado na Figura 4.8B.

Na microscopia de força atômica, a varredura da amostra é feita por uma ponta (tip), a qual é montada na extremidade de uma alavanca (cantilever). A amostra fica sobre os varredores (scanners) que são constituídos por material piezoelétrico responsável pelo deslocamento em altura, direção $z$, e no plano $x, y$, Figura 4.8A. A força entre a ponta e a superfície da amostra é medida através do monitoramento da deflexão da alavanca durante a varredura. A imagem da topografia da superfície da amostra é obtida plotando a deflexão da alavanca em função da sua posição, $x$ e y, sobre a superfície. A imagem também pode ser obtida plotando a altura em função da posição x e y na superfície da amostra, mantendo a força constante, sendo esta forma a mais comum. A força atuante entre a ponta e a amostra é a de van der Waals. A depender da distância entre a ponta e a amostra, há atuação de um dos três modos, conforme mostra o gráfico da Figura 4.8B.

Os valores positivos de força correspondem às interações repulsivas e os valores negativos às interações atrativas. Para grandes distâncias entre a ponta e a superfície da amostra, a força tende a zero. Para pequenas distâncias, a força é repulsiva e aumenta rapidamente com a redução dessa distância. Para valores de distância intermediários, a força é atrativa, alcançando um valor máximo a uma dada distância particular de cada amostra, considerando as mesmas condições de avaliação (Figura 4.8B).

No modo de contato intermitente, utilizado neste trabalho, a ponta presa na extremidade do cantilever opera oscilando com toques intermitentes na superfície da amostra ao longo da varredura. Durante este processo, a ponta oscilante passa por

31 THERMO MICROSCOPES. A Practical Guide to Scanning Probe Microscopy. Disponível em: <http://web.mit.edu/cortiz/www/AFMGallery/PracticalGuide.pdf >. Acesso em: 05 jun 2006. 
diferentes alturas da superfície da amostra, gerando diferentes variações de amplitude. A amplitude de oscilação é definida pelo RMS (Root Mean Square), a qual é obtida pelo sinal gerado no fotodiodo através do feixe de laser transmitido (Figura 4.8A). Através de um feedback com o computador, o RMS da amplitude de oscilação é mantido constante durante a varredura, movendo o cantilever verticalmente a cada ponto. Desta forma, a posição vertical do cantilever e as posições $\mathrm{x}$ e y correspondentes, são armazenadas no computador gerando, ao final da varredura, a imagem da superfície da amostra (Figura 4.9) ${ }^{32}$. Este modo de operação é indicado para varredura de amostras que apresentam superfícies frágeis como é o caso de uma camada de polímero adsorvida.

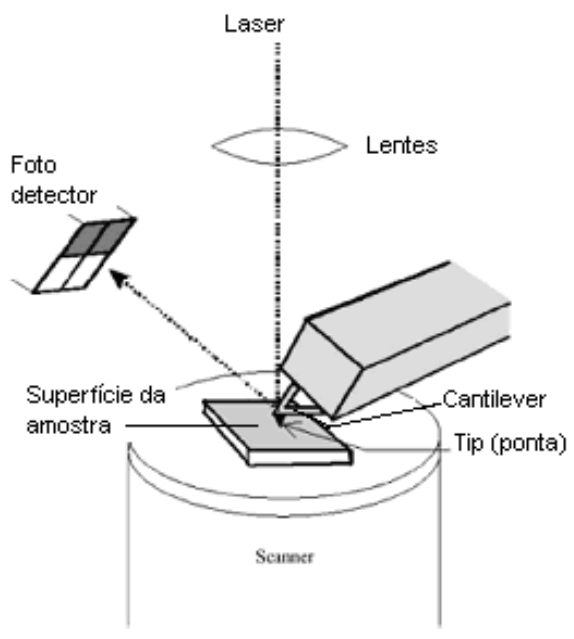

(A)

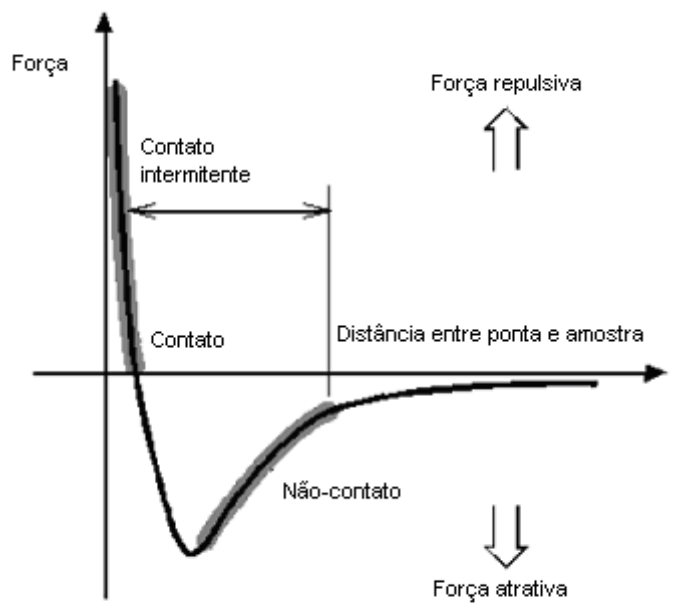

(B)

Figura 4.8 - (A) Esquema do funcionamento do microscópio de força atômica. (B) Forças interatômicas em função da distância para os três modos de operação do microscópio de força atômica: contato, contato intermitente e não contato.

\footnotetext{
32 THERMO MICROSCOPES. A Practical Guide to Scanning Probe Microscopy. Disponível em: < http://web.mit.edu/cortiz/www/AFMGallery/PracticalGuide.pdf >. Acesso em: 05 jun 2006.
} 


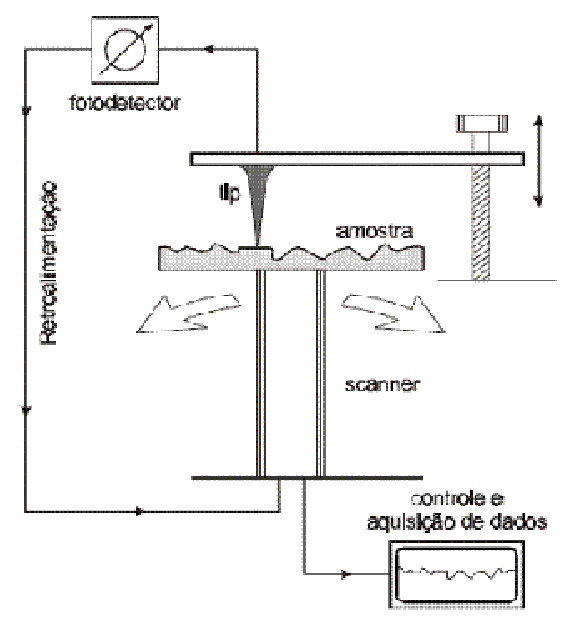

Figura 4.9 - Princípio de funcionamento do AFM.

\subsubsection{Espalhamento Dinâmico de Luz}

A tendência de formar agregados em resposta às variações das condições do meio de dispersão onde o polímero usado se encontrava, foi verificada como um fenômeno importante para a modificação do comportamento e da cinética de adsorção desse polímero em interações interfaciais. Nos tópicos pertinentes desta pesquisa, será verificada que o conhecimento da morfologia do polímero na fase dispersa, em termos de tamanho aparente de partículas, sob as formas individualizada e, ou, em agregados, juntamente com os resultados obtidos por outras técnicas, foi um fator que contribuiu para o entendimento de sua funcionalidade como aditivo de resistência a seco na fabricação de papel.

Neste trabalho foi estimado o diâmetro hidrodinâmico médio das partículas no meio de dispersão para as diferentes condições de força iônica e de pH utilizando a técnica de espalhamento dinâmico de luz. O equipamento utilizado foi o COULTER N4 PLUS fabricado pela BECKMAN, Califórnia, EUA. Esse sistema possue uma fonte de luz composta por um laser de hélio-neon de $10 \mathrm{~mW}$, correspondente ao comprimento de ondas, $\lambda$, de 632,8 nm. Diagrama de blocos, adaptado do manual do fornecedor, mostrando o funcionamento desse equipamento, pode ser visto na Figura 4.10. 
Nesse sistema, o diâmetro aparente da partícula é determinado através da medida da taxa de difusão das partículas no meio de dispersão. A taxa de difusão é medida quando um feixe de laser ilumina as partículas. A luz espalhada por essas partículas é recebida por cabos de fibra óptica situados em um determinado ângulo e transmitida para o tubo fotomultiplicador através de um motor descontínuo (stepper motor), em seguida para $O$ amplificador e descriminador de pulsos, onde é transformada em sinal elétrico. A qualquer instante, a luz recebida pelo detector, para um dado ângulo, é a soma da luz espalhada por todas as partículas no volume de espalhamento para o referido ângulo. $O$ volume de espalhamento refere-se à porção de amostra da cubeta definida pela interseção da luz incidente com o ângulo, ou o "campo de visão" visto pelo detector. Essa soma da luz espalhada é o resultado da interferência na posição do detector da luz originada de cada partícula com a luz originada de todas as outras partículas. Como as partículas estão sempre mudando de lugar umas em relação às outras devido ao movimento Browniano, a intensidade de luz que chega ao detector também é mudada. Essas flutuações na intensidade da luz incidente contêm informações sobre taxa de difusão das partículas.

A velocidade desse movimento é medida através do coeficiente de difusão. Dessa forma, conhecendo-se o coeficiente de difusão, a temperatura, a viscosidade e o índice de refração do fluido, o tamanho da partícula pode ser determinado pela equação de Stokes-Einstein, Equação 4.7,

$D=\frac{K_{B} T}{3 \pi \eta d}$

Equação 4.7

Em que $D$ é o coeficiente de difusão, $K_{B}$ é a constante de Boltzmann $\left(1,38.10^{-16}\right.$ erg. ${ }^{\circ} \mathrm{K}^{-1}$ ), $T$ é a temperatura absoluta, $\mathrm{K}$ (mantida constante); $\eta$ é a viscosidade do diluente, (constante) e $d$ é o diâmetro esférico hidrodinâmico equivalente, nm.

Para o cálculo do coeficiente de difusão e, dessa forma, do diâmetro da partícula, através da mudança da intensidade do sinal de luz, esse sinal é transformado matematicamente na função de autocorrelação, a qual é definida na Equação 4.8: 
$G\left(\tau_{a}\right)=\left\langle I\left(\tau_{a}\right) \times I\left(\tau+\tau_{a}\right)\right\rangle$

Equação 4.8

Em que $G\left(\tau_{a}\right)$ é a função de autocorrelação, $I\left(\tau_{a}\right)$ é a intensidade de flutuações detectada no tempo $\tau, I\left(\tau+\tau_{a}\right)$ é a intensidade detectada no tempo $\tau+\tau_{a}, \tau_{a}$ é o tempo de decaimento, e \langle\rangle é uma média de tempo.

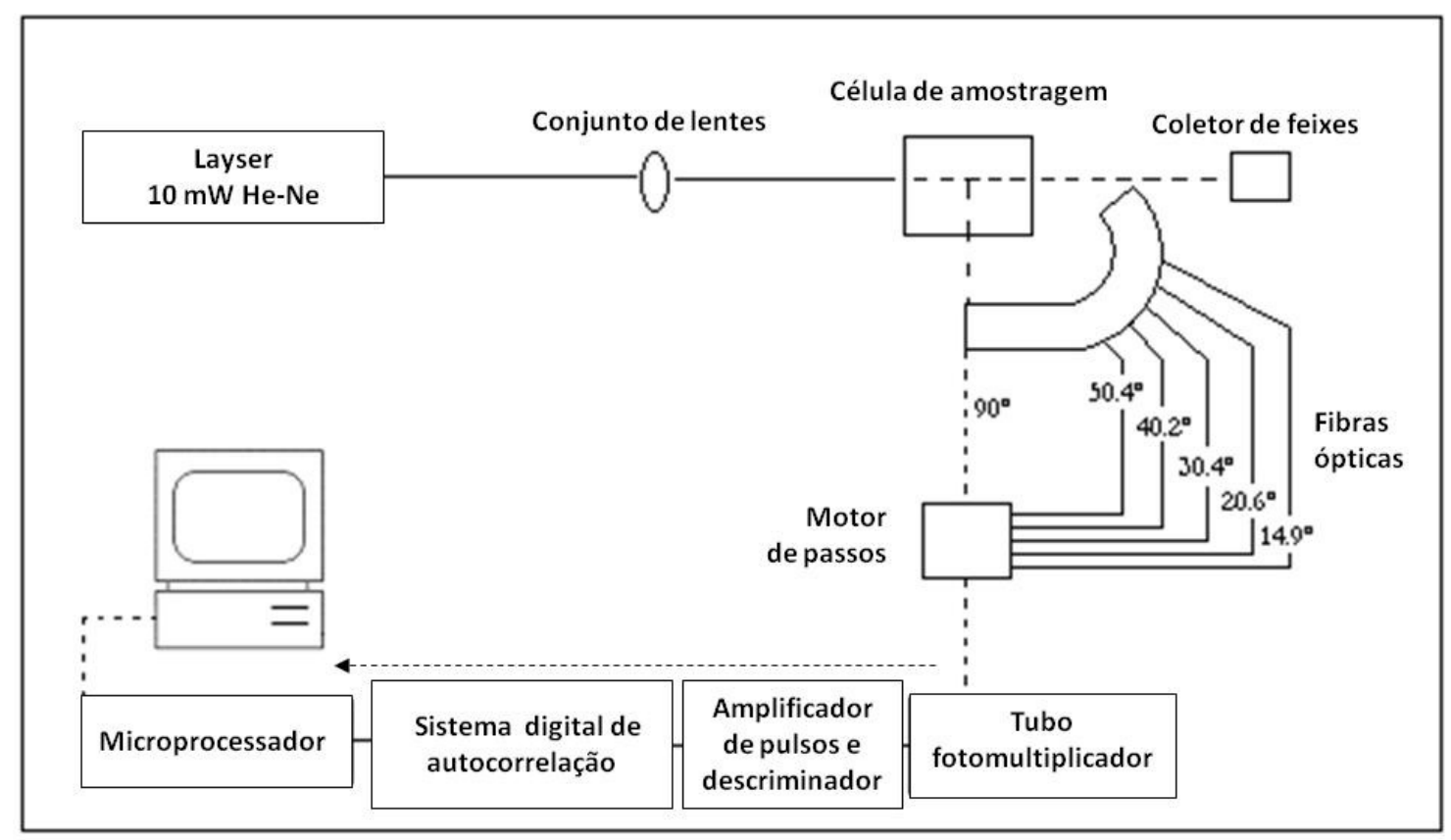

Figura 4.10 - Diagrama de bloco do funcionamento do COULTER N4 PLUS.

\subsubsection{Medidor de densidade de carga em partículas}

No presente trabalho, as determinações da demanda iônica e da densidade de carga líquida do polianfótero foram realizadas com o equipamento Mütek $P C D-03$, Particle Charge Detector, acoplado com o Mütek PCD-T3 Titrator Three, ambos da BTG, Alemanha (Figura 4.11). A carga líquida de uma suspensão coloidal ou de uma solução de polímero pode ser dada tanto em meq. $I^{-1}$ quanto em meq. $\cdot \mathrm{g}^{-1}$ através de 
titulações com soluções de polímeros aniônico e catiônico, a depender do caso, com concentrações normais conhecidas. Para carga líquida negativa, o polímero utilizado foi o cloreto de poli-dialil-dimetil-amônio (Poli-DADMAC) com concentração de 0,001 N. Em casos de carga líquida positiva, a titulação foi realizada com o polímero aniônico sulfato de poli-vinil potássio (KPVS). Ambos se caracterizam por apresentarem baixo peso molecular e elevada densidade de carga.

O princípio de medição se baseia no potencial de carga desenvolvido quando há a separação dos contra íons de superfícies eletricamente carregadas através do deslocamento do pistão (Figura 4.11 A e B), com movimentos de cima para baixo e vice-versa. A amostra contida na célula é titulada com polímero de carga oposta, até alcançar o potencial de carga neutra. A quantidade de polímero adicionada indica a demanda de carga da amostra a qual pode ser calculada segundo a Equação 4.9,

$D I=\frac{(V * C)}{P} * 1000$

Equação 4.9

Em que, DI é a demanda iônica, catiônica ou aniônica, em meq. ${ }^{-1}$; caso a amostra tenha sido medida em volume, o resultado será em meq..$^{-1}$; $V$ é o volume do polímero gasto, $\mathrm{mL}$; $C$ é a concentração normal do polímero, $\mathrm{N}$; $P$ é o peso da amostra líquida, mg ou, em volume, mL; e 1000 é o fator de cálculo para a correção da densidade de carga.
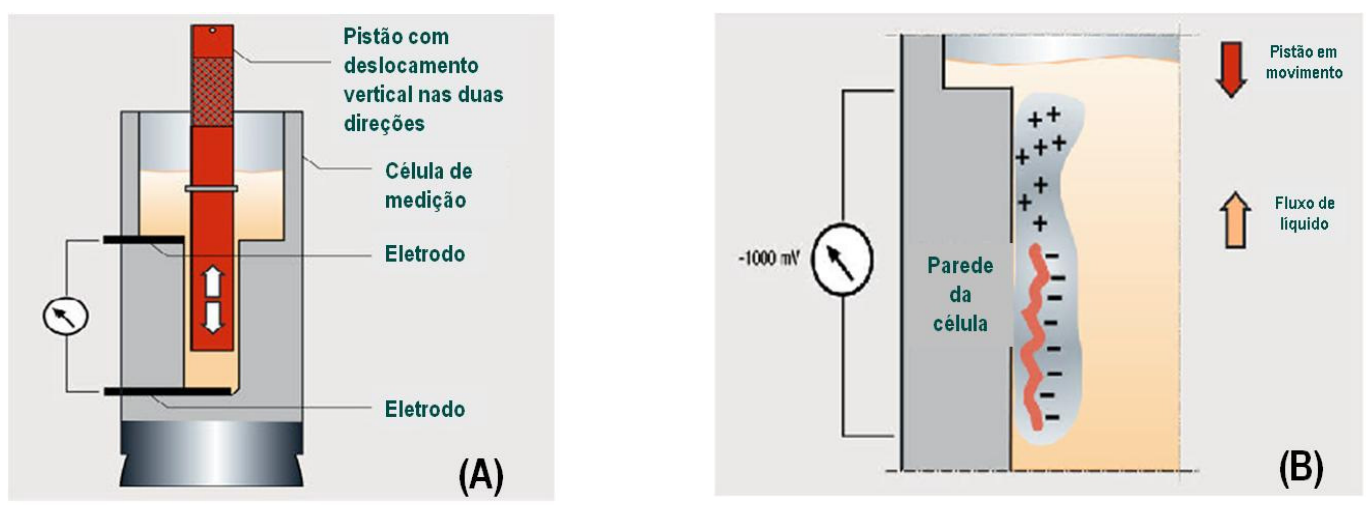

Figura 4.11 - Princípio de funcionamento do Mütek PCD-03. 


\section{POLIANFÓtEROS COMO AGENTE DE RESISTÊNCIA A SECO DO PAPEL}

\subsection{INTRODUÇÃO}

Dentre as propriedades funcionais típicas do papel, sua resistência a seco constitue uma característica importante considerando o papel como produto acabado. Os aditivos mais comumente utilizados para modificação da surperfície de fibra e aumentar a resistência a seco do papel incluem os amidos e as poliacrilamidas. Ainda, o amido, em dosagens inferiores às utilizadas na fabricação dos papéis de imprimir \& escrever e cartões, também é utilizado na formulação de suspensões de fibras para produção de papéis para fins sanitários. Considerando alternativas menos tradicionais, a utilização de diferentes tipos de estruturas poliméricas como os polianfóteros (SONG; WANG; HUBBE, 2006; SEZAKI et al., 2006b; HUBBE et al., 2007b; SILVA et al., 2008b), o carboximetil celulose (BLOMSTEDT; KONTTURI; VUORINEN, 2007), os complexos com polieletrólitos (GÄRDLUND; WÅGBERG; GERNANDT, 2003; GERNANDT et al., 2003; HUBBE, 2005; LOFTON et al., 2005; HEERMANN; WELTER; HUBBE, 2006) e os polieletrólitos em multicamadas (WÅGBERG et al., 2002; ERIKSSON; NOTLEY; WÅGBERG, 2005; LINDSTRÖM; WÅGBERG; LARSSON, 2006; ZHENG; MCDONALD; KHILLAN, 2006), podem ser citadas como tecnologias com a finalidade de aumentar a sua resistência a seco através de interações em interface sólido-líquido, com mudanças nas características de superfície.

No processo de adsorção de polieletrólito em superfícies sólidas é importante considerar os mecanismos que controlam o comportamento de adsorção. Segundo Fleer et al. (1993), as interações eletrostáticas são usualmente as mais importantes no processo de adsorção. Estudos sobre comportamento de adsorção de polímeros têm mostrado os detalhes sobre os efeitos do balanço de carga entre polímeros e superfícies carregadas, incluindo cinética, extensão do polímero, espessura da camada adsorvida e forças de interação de superfície (ROJAS; NEUMAN; CLAESSON, 2001; ROJAS, 2002a; ROJAS et al., 2002b; CLAESSON; DEDINAITE; ROJAS, 2003). Além das interações eletrotáticas, os estudos anteriores citam 
também as interações não eletrostáticas como importantes no comportamento de adsorção. Em trabalho mais recente publicado por Kudaibergenov e Ciferri (2007), interações hidrofóbicas, além das eletrostáticas e não eletrostáticas, também foram reportadas como responsáveis pelos fenômenos de adsorção entre polianfóteros e superfícies carregadas.

No processo de fabricação de papel, as variáveis pH e força iônica da suspensão de fibras são importantes para o controle dos parâmetros operacionais e da qualidade do papel desde que os fenômenos interfaciais que ocorrem entre os constituintes da suspensão, especialmente as interações eletrostáticas, dependem das condições de carga das superfícies dos componentes no meio de dispersão. Dessa forma, a carga líquida dos aditivos funcionais também pode ser afetada pelo sistema modificando, assim, sua eficiência.

Dentre as tecnologias citadas acima para aumento de resistência a seco do papel, neste trabalho foi utilizado um polímero classificado como anfótero, o qual será tratado daqui para adiante como polianfótero.

Segundo Bohidar (2002), polianfóteros são polímeros que apresentam cargas positivas e negativas na mesma cadeia molecular e apresentam propriedades diferenciadas quando comparados com os polieletrólitos monocarregados. Este autor observa que uma particularidade que essas moléculas apresentam é o seu comportamento antipolieletrólito. Quando em solução, a solubilidade aumenta e a molécula se expande com o aumento da força iônica no ponto isoelétrico. Outra particularidade, é que essas macromoléculas assumem diferentes estados de agregação quando submetidos a diferentes condições de $\mathrm{pH}$. No $\mathrm{pH}$ do ponto isoelétrico, quando a densidade de carga líquida é nula, a precipitação do polímero também ocorre e a solubilidade é baixa (PATRICKIOS et al., 1999).

Os polianfóteros têm recebido atenção para serem usados em escala comercial em diversos campos, sendo um deles na fabricação de papel. O comportamento desses polímeros em solução e em interface sólido-líquido, visando sua aplicação como agente de resistência a seco, constitue uma linha de pesquisa do grupo de professores da Universidade do Estado da Carolina do Norte, EUA. 
Um dos desafios dos estudos sobre esses polímeros é o de relacionar o seu comportamento em solução, para diferentes condições de $\mathrm{pH}$, força iônica e temperatura, com as interações interfaciais e as propriedades das camadas adsorvidas. Considerando sua aplicação para fabricação de papel, as explicações para os diferentes resultados de resistência podem ser encontradas nas propriedades viscoelásticas das camadas adsorvidas formadas sob diferentes condições de $\mathrm{pH}$ e de força iônica.

Este capítulo tem como objetivo entender o comportamento de um polianfótero de alta densidade de carga em solução, o comportamento de adsorção em interfaces sólido-líquido e os resultados de resistência mecânica do papel através da utilização das técnicas de balança microgravimétrica com cristal de quartzo e dissipação de energia, microscopia de força atômica, espalhamento dinâmico da luz, densidade de carga do polímero, dentre outras, para diferentes condições de pH e de força iônica.

\subsection{HIPÓTESE}

O principal desafio dos estudos com polianfóteros, não somente no campo de aplicação para fabricação de papel como agente de resistência a seco, é o de relacionar o comportamento deste tipo de polímero em solução com o comportamento de adsorção em superfícies carregadas (DOBRYNIN; RUBINSTEIN; JOANNY, 1997; DOBRYNIN; OBUKHOV; RUBINSTEIN, 1999; MAHLTIG et al., 1999; MAHLTIG et al., 2000; MAHLTIG; JÉRÔME; STAMM, 2001; WANG 2006; SEZAKI et al., 2006a; SEZAKI et al, 2006b; HUBBE et al., 2007a; HUBBE et al., 2007b; DOBRYNIN, 2008; SONG, 2008). No caso de sua atuação como agente de resistência a seco, ainda não se sabe ao certo por que esses polímeros, quando submetidos à algumas condições de $\mathrm{pH}$ e força iônica do sistema, modificam significativamente as propriedades de resistência mecânica do papel. Hipóteses como adsorção em agregados (HUBBE et al., 2007b) e polarização das cadeias e separação de fases na interface sólido líquido (SONG et al., 2010), foram propostas. 
Alguns estudos de literatura mostraram diferenças nos comportamentos adquiridos pelos polianfóteros em solução relacionadas à proporção de grupos positivos e negativos e as condições de pH e de força iônica do meio de dispersão (SEZAKlet al., 2006a; HUBBE et al., 2007a).

Neste estudo é proposto que as propriedades viscoelásticas das camadas adsorvidas sobre as superfícies das fibras celulósicas, relacionadas com o grau de hidratação das mesmas, estejam diretamente relacionadas com os resultados de resistência mecânica do papel e que essas propriedades possam ser influenciadas pelas dimensões das estruturas do polianfótero no meio de dispersão. O estudo dessas propriedades será realizado, basicamente, através da balança microgravimétrica com dissipação de energia em tempo real associada com as técnicas de microscopia de força atômica e espalhamento dinâmico de luz.

\subsection{REVISÃo}

\subsubsection{Superfície da fibra}

Um fator importante que contribui para o aumento da resistência a seco do papel é o número e a disponibilidade de grupos ionizáveis na superfície do material fibroso como os grupos hidroxílicos e carboxílicos. Na presença de água, esses grupos desenvolvem cargas negativas que se apresentam como sítios potenciais para as interações eletrostáticas com outros componentes ou entre os próprios materiais fibrosos. Durante o processo de secagem do papel, a medida em que a água é retirada, a presença desses grupos contribui para a formação de ligações de hidrogênio, as quais influenciam na resistência do papel (HUBBE, 2006). Portanto, qualquer tratamento com o objetivo de expôr e, ou, aumentar a concentração desses grupos na superfície da fibra, poderá favorecer positivamente a resistência do papel. Estudo tem mostrado que o aumento em 16,5\% no teor de grupos carboxílicos em 
polpa kraft de fibra longa, branqueada com a tecnologia ECF (Elementary Chlorine Free), aumentaria o índice de tração em, aproximadamente, 6\% (DANG, 2007).

\subsubsection{Resistência do papel}

Baseado em dados experimentais, Page (1969) desenvolveu uma equação teórica válida para papéis sem a adição de cargas (Equação 5.1), para explicar a resistência à tração,

$$
\frac{1}{T}=\frac{9}{8 Z}+\frac{12 A \rho g}{b P L(R B A)}
$$

Em que $T$ é a resistência à tração do papel; $Z$ é a resistência à tração em zerospan; $A$ é o valor médio da área da sessão transversal da fibra; $\rho$ é a densidade do material fibroso; $g$ é a aceleração da gravidade; $b$ é resistência ao cisalhamento por unidade de área ligada o que corresponde a força das ligações; $P$ é o perímetro da seção transversal da fibra; $L$ é o comprimento da fibra e $R B A$ é a área relativa ligada da folha dando indicação do número total de ligações na folha (PAGE, 1969).

De acordo com a Equação 5.1, a resistência à tração, $T$, está diretamente relacionada, dentre outros parâmetros, com a resistência ao cisalhamento por unidade de área ligada, $b$, e com a área relativa ligada da folha de papel, $R B A$. Portanto, qualquer alternativa que possa contribuir para o aumento dos mesmos, também irá aumentar a resistência a seco do papel.

\subsubsection{Alternativas para aumentar a resistência a seco do papel}

O tratamento mais comum para desenvolver a resistência do papel é a aplicação de energia mecânica que tem, como consequência, o aumento da flexibilidade da fibra e da sua superfície específica, permitindo o aumento do número das ligações interfibras. Em estudo desenvolvido por Silva et al. (1997) para polpa branqueada de eucalipto, aumento no índice de tração de $136 \%$ com refino em moinho PFI (500 
rpm) em relação à polpa sem refino, pode ser encontrado (19 N.m/g, sem refino, e $45 \mathrm{~N} . \mathrm{m} / \mathrm{g}$, com refino). Por outro lado, aditivos químicos específicos podem ser utilizados para o mesmo propósito. Dentre os aditivos, o amido modificado se constitue no mais comum. Em estudo de Dang (2007), os resultados mostraram que a adição de $2 \%$ de amido catiônico houve um aumento de $23,7 \%$ no índice de tração para a polpa ECF com teor de grupos carboxílicos de 4,49 mmol/100g de polpa seca, e de 13,7\% para a polpa ECF com teor de grupos carboxílicos de 3,98 $\mathrm{mmol} / 100 \mathrm{~g}$ de polpa seca. Para aumentar o teor de grupos carboxílicos, este autor tratou a polpa referência com $2 \%$ de hidróxido de sódio e $1 \%$ de peróxido de hidrogênio, a $10 \%$ de consistência, $60^{\circ} \mathrm{C}$ e o tempo de $2 \mathrm{~h}$. A dosagem de $0,25 \%$ de amido na polpa sem tratamento com peróxido resultou no aumento de $4,6 \%$ do índice de tração.

Outras alternativas menos convencionais são a utilização de carboximetil celulose (BLOMSTEDT; KONTTURI; VUORINEN, 2007), a utilização de complexos de polieletrólitos (PEC) (GÄRDLUND; WÅGBERG; GERNANDT, 2003; GERNANDT et al., 2003; LOFTON et al., 2005; HEERMANN; WELTER; HUBBE, 2006), a utilização de polieletrólitos em multicamadas sobre o material celulósico (layer-by-layer) (WÅGBERG et al., 2002; ERIKSSON; NOTLEY; WÅGBERG, 2005; LINDSTRÖM; WÅGBERG; LARSSON, 2006; ZHENG; MCDONALD; KHILLAN, 2006) e a utilização de polianfóteros (CARR et al., 1977; SONG et al., 2006; SEZAKI et al., 2006b; HUBBE et al., 2007b; YAMAGUCHI et al., 2008; SILVA et al., 2008b).

Em relação à polpa referência, a utilização de carboximetil celulose $(C M C)$ na dosagem de $1 \%$ base polpa seca de eucalipto resultou no aumento de $55 \%$ no índice de tração de folhas manuais de laboratório (BLOMSTEDT; KONTTURI; VUORINEN, 2007).

Considerando a formação de complexos, alguns estudos importantes envolvendo a preparação e caracterização de complexos ( GERNANDT et al., 2003) e a aplicação dos mesmos para o aumento da resistência do papel (GÄRDLUND; WÅGBERG; GERNANDT, 2003; LOFTON et al., 2005; HEERMANN; WELTER; HUBBE, 2006) podem ser citados. 
Complexos formados com o polímero catiônico poliamida-poliamina epicloridrina (PAE), e com o polímero aniônico carboximetilcelulose (CMC) foram inicialmente propostos (GÄRDLUND; WÅGBERG; GERNANDT, 2003; GERNANDT et al., 2003). Os autores encontraram que mudando a proporção dos polímeros durante a preparação dos complexos, a densidade de carga resultante e a quantidade adsorvida eram alteradas. Os reflexos dessas alterações foram observados nos resultados de resistência do papel. Os autores observaram aumento no índice de tração com o aumento da proporção do polímero catiônico em relação ao aniônico nos complexos. Valor mais elevado de resistência foi atingido quando o polímero aniônico tinha sido neutralizado em $60 \%\left(\mathrm{q}^{+} / \mathrm{q}^{-} 0,6\right)$ para as condições sem sal e com $0,01 \mathrm{M}$ de cloreto de sódio. No último caso, os autores encontraram valores mais elevados de resistência à tração, mostrado que a presença de sal favoreceu o aumento da resistência do papel. Quando a neutralização do polímero aniônico em $60 \%$ foi atingida, não mais foi verificado aumento na resistência do papel com a adição do polímero catiônico. Os valores de aumento na resistência do papel coincidiram com o aumento da quantidade adsorvida. Esses valores foram confirmados pela adsorção em superfície de fibras e em superfícies modelos de óxido de silício.

Lofton et al. (2005) utilizaram os polímeros cloreto de dialildimetil amônio (PoliDADMAC) e carboximetilcelulose (CMC), como polímeros positivo e negativo, respectivamente, para serem utilizados no desenvolvimento da resistência a seco do papel. Estes autores utilizaram fibras recicladas de papel de imprimir off set como fonte de matéria prima para confecção de papel em laboratório. Foi observada que a saturação inicial das fibras com polímero positivo era mais favorável ao aumento da resistência do papel e explicaram que as macromoléculas do polímero positivo, previamente adsorvidas na surperfície, atuaram como ponto de ancoragem para os complexos de polieletrólitos com a densidade de carga resultante negativa. Para a ordem inversa de adição, estes autores observaram redução na resistência do papel. O polímero cloreto de dialildimetil amônio (poli-DADMAC) é um polieletrólito fortemente catiônico e o carboximetilcelulose (CMC) é um polímero aniônico. Portanto, ocorre uma complexação de associação entre as partículas com cargas devido à interação eletrostática entre poli-íons com cargas opostas. 
Heermann; Welter e Hubbe (2006), utilizando os mesmo polímeros que o trabalho anterior, Poli-DADMAC e CMC, formaram complexos para aumento da resistência a seco de papéis de fibras curtas e longas. Igualmente aos resultados apresentados por Gärdlund; Wågberg e Gernandt (2003), eles observaram um aumento na resistência do papel com o aumento da proporção entre os polímeros positivo e negativo porém até um ponto ótimo de $40 \%$ de substituição. A partir deste ponto, foi observada redução na resistência.

Apesar de os estudos ainda se encontrarem em desenvolvimento laboratorial, outra alternativa que vem sendo proposta para o aumento da resistência do papel é a deposição de camadas de polímeros positivos e negativos, alternadamente, sobre o material celulósico ( WÅGBERG et al., 2002; ERIKSSON; NOTLEY; WÅGBERG, 2005; LINDSTRÖM; WÅGBERG; LARSSON, 2006; ZHENG; MCDONALD; KHILLAN, 2006). A técnica de deposição de polieletrólitos em camadas com cargas alternadas foi inicialmente proposta pelo Decher (1997) na busca de uma alternativa mais simples para a produção de filmes finos para serem utilizados como modelos em seus estudos. O processo de montagem das camadas se baseia na interação eletrostática existente entre íons de sinais opostos de policátions e poliânions. A deposição de cada camada de polímero é intercalada com uma etapa de lavagem para remoção do excesso do polímero não adsorvido em questão, sendo esta etapa a que dificulta a viabilidade operacional desta alternativa na fabricação do papel.

Considerando estudos de laboratório na área de fabricação de papéis, o primeiro trabalho usando esta técnica foi o de Wågberg et al. (2002). Estes autores utilizaram os polímeros positivo, cloridrato de polialilamina (PAH - polyallylamine hydrochloride), e negativo, ácido poliacrílico (PAA - polyacrilic acid), para montagem de camadas sobre a superfície de fibras com o objetivo de aumentar a resistência mecânica do papel. Os autores observaram que a resistência à tração de papéis secos feitos com fibras longas branqueadas aumentou de 20 para $40 \mathrm{kN} . \mathrm{m} / \mathrm{kg}$ com a formação de 4 pares de camadas mais uma camada, totalizando 9 camadas. A espessura de cada par de camadas, medida através de microscopia de força atômica, foi, em média, de $10 \mathrm{~nm}$ no pH 7,7 e 0,05 mol/L de $\mathrm{NaCl}$. Este aumento foi atribuído ao aumento da área de contato entre moléculas e ao aumento da interação específica entre fibras. 
Utilizando os mesmos polímeros que Wågberg et al. (2002), Eriksson; Notley e Wågberg (2005) estudaram a influência da montagem de multicamadas sobre a superfície de fibras de conífera totalmente livre de cloro (TCF) na resistência do papel. Em paralelo, os autores avaliaram a adsorção sobre superfícies modelo de óxido de silício, em nível molecular, para diferentes condições de $\mathrm{pH}$, usando a técnica de reflectometria de adsorção no ponto de estagnação. Utilizando superfícies modelo, os autores observaram que a quantidade adsorvida era dependente do $\mathrm{pH}$ do processo de adsorção e proporcional ao número de camadas de polímeros sobrepostas. A maior quantidade de massa adsorvida na surperfície foi encontrada para a condição de $\mathrm{pH}$ de adsorção de 7,5 , para o polímero positivo $\mathrm{PAH}$, e de 3,5 , para o polímero negativo PAA. Outras condições de $\mathrm{pH}$ estudadas foram PAH /PAA, 5,0/ 5,0 e 7.5/7,5. Sendo esta última a pior condição.

Eriksson; Notley e Wågberg (2005) verificaram que o índice de tração foi diretamente proporcional à quantidade de massa adsorvida e que o balanço de cargas em cada condição de $\mathrm{pH}$ foi o fator responsável para a adsorção de multicamadas com diferentes viscoelasticidades. Este fato foi confirmado com outro estudo dos mesmos autores, para as mesmas condições, utilizando a balança microgravimétrica de cristal de quartzo com dissipação de energia e o mesmo par de polieletrólitos (NOTLEY; ERIKSSON; WÅGBERG, 2005). Segundo estes autores, camadas mais rígidas e compactas foram formadas quando os polieletrólitos estavam muito carregados eletricamente. Por outro lado, estruturas mais viscoelásticas, ricas em água, foram formadas quando a densidade de carga do PAA foi reduzida.

Posteriormente, Eriksson; Torgnysdotter e Wågberg (2006) realizaram um aprofundamento do trabalho de Eriksson; Notley, e Wågberg (2005), avaliando as ligações interfibras e o seu efeito na resistência do papel. Estes autores encontraram que maior número de ligações interfibras resultava em papéis mais resistentes. As avaliações foram realizadas através das seguintes medições: (a) superfície específica realizada através de análises de adsorção de nitrogênio, (b) grau de contato de ligações interfibras através da técnica de espalhamento de luz e (c) criação de ligações covalentes na área de ligação devido à formação do grupo 
amida, pela reação de grupos carboxílicos com o grupo amina, através de análises de infravermelho.

Multicamadas de polieletrólitos positivo, cloreto de polidialildimetil amônio (PoliDADMAC), e negativo, sulfonato de poliestireno (PSS), formadas sobre superfícies de fibras longas branqueadas, mostraram influenciar as propriedades de superfícies das fibras em termos de molhabilidade e adesão (LINDSTRÖM; WÅGBERG; LARSSON, 2006). Superfícies mais hidrofóbicas foram encontratadas quando o polímero positivo se encontrou na camada mais externa da multicamada. O oposto foi encontrado quando o polímero negativo se encontrava na camada mais externa. Correlação positiva foi encontrada entre a quantidade adsorvida, o número de camadas e o índice de tração do papel. A adsorção também foi aumentada com o aumento da força iônica. Os autores testaram o intervalo de 0 a $100 \mathrm{mM}[\mathrm{NaCl}]$. Estudos utilizando superfícies modelos também mostraram correlação positiva entre quantidade adsorvida e número de camadas (ERIKSSON; NOTLEY; WÅGBERG, 2005).

Diferentemente dos estudos anteriores, porém usando o mesmo processo de deposição em multicamadas, Zheng; Mcdonald e Khillan (2006) estudaram o efeito de misturas de polpa TCF de conífera, revestidas com diversos policátions e poliânions, na resistência do papel. Eles encontraram que a melhor composição entre fibras revestidas com sinais opostos foi de 50:50\%, quando foi alcançado o dobro da resistência. O aumento da resistência do papel foi atribuído à interações eletrostáticas existentes entre fibras revestidas de duas maneiras: (1) com sequência de dois pares de camadas de polieletrólitos seguida de uma última camada positiva e (2) com sequência de dois pares de camadas seguida de uma última camada negativa (ZHENG; MCDONALD; KHILLAN, 2006).

Outra alternativa que vem sendo estudada para aumento da resistência a seco do papel é a utilização de polianfóteros. Estudos teóricos e práticos sobre o comportamento desses polímeros sob diferentes condições de pH e de força iônica, bem como sobre o comportamento de adsorção, serão descritos a seguir. 


\subsubsection{Polianfóteros}

Conforme citado anteriormente, polianfóteros são polímeros naturais ou sintéticos que apresentam ambas as cargas, positiva e negativa, na mesma cadeia, apresentando, portanto, comportamento antipolieletrólito (BOHIDAR, 2002). Considerando polímeros naturais, como é o caso das proteínas, estas são copolímeros que possuem grupos ácidos e básicos fracos aleatoriamente distribuídos na cadeia e a ionização de suas cargas depende do $\mathrm{pH}$ do meio (WEN; STEVENSON, 1993; CIFERRI; KUDAIBERGENOV, 2007). Com o desenvolvimento de técnicas de polimerização, foi possível sintetizar polianfóteros que apresentem diferentes propriedades. O peso molecular, a distribuição de carga e a distribuição dos monômeros na molécula podem ser citados como parâmetros que afetam a conformação do polímero em solução e o seu comportamento de adsorção em interfaces. Parâmetros relacionados à superfícies de interação, como densidade e distribuição de cargas, também são importantes. O grande número de parâmetros pode dificultar a completa compreensão do comportamento desses polímeros em solução e a sua adsorção em interfarces.

Os polianfóteros têm recebido atenção especial em testes de laboratório para serem aplicados como agentes de resistência a seco do papel, entre outros usos potenciais. Entretanto, em nível comercial, através de informação pessoal, esse tipo de polímero vem sendo utilizado em uma fábrica de papel no Japão, Nippon Paper, para aumentar a resistência do papel $^{33}$. Várias pesquisas considerando os comportamentos em solução e em interfaces têm sido reportadas nos últimos anos (SONG; WANG; HUBBE et al. 2006; WANG; HUBBE; SEZAKI et al., 2006a; SEZAKI et al., 2006b; WANG et al., 2007; HUBBE et al., 2007a; HUBBE et al., 2007b; SONG, 2008), e a habilidade desses polímeros para aumentar a resistência do papel, também tem sido considerada (SONG; WANG; HUBBE et al. 2006; HUBBE et al., 2007a; YAMAGUCHI et al., 2008; SILVA et al., 2008a; SILVA et al., 2008b).

Segundo a literatura, o primeiro trabalho sobre a aplicação de polianfóteros como aditivo de resistência do papel foi publicado em 1977 por Carr et al. (1977). Polianfóteros à base de amido foram preparados através da xantação de derivados

\footnotetext{
${ }^{33}$ Informações fornecidas pelo Eng. Takashi Yamaguchi, pesquisador visitante na NCSU, da Nippon Paper, Japão. NCSU, North Carolina, US, outubro de 2008.
} 
de amido catiônico de milho, que tinham grupos aminas terciárias, [$\mathrm{CH}_{2} \mathrm{CH}_{2} \mathrm{~N}\left(\mathrm{C}_{2} \mathrm{H}_{5}\right)_{2}$ ] ou quaternários de amônio, [- $\mathrm{CH}_{2} \mathrm{CHOHCH}_{2} \mathrm{~N}+\left(\mathrm{CH}_{3}\right)_{3}$ ] fixados através de ligações. Grupos de xantatos aniônicos foram introduzidos nas aminas de amido catiônico. Os autores mostraram que a adição de polianfóteros à base de amido na parte úmida foi eficiente para aumentar as resistências a úmido e a seco, e que foram superiores àquelas obtidas por polieletrólitos de amido somente, catiônico ou aniônico.

No estudo de Hubbe et al., (2007a), referente ao uso de polianfóteros como agente de resistência a seco do papel, os autores observaram aumento do comprimento de autorruptura quando o polímero era adicionado. Foram utilizadas quatro amostras de polianfóteros com densidades de carga crescentes e grupos carregados aleatoriamente distribuídos, porém, com a mesma proporção entre os grupos positivos (dimetil amino propilacrilamida) e negativos (ácido metileno butadióico também conhecido como ácido itacônico), 5:4, respectivamente. Os pesos moleculares médios dessas amostras eram semelhantes com, aproximadamente, 3 $\times 10^{6} \mathrm{~g} / \mathrm{mol}$. As proporções entre os grupos positivos e negativos para as quatro amostras em mol \%, foram: 2,5:1, 5:2, 10:4 e 20:8. Como se tratavam de terpolímeros, além dos dois anteriormente citados, as amostras apresentavam um monômero neutro, acrilamida, para completar 100\%. Os autores estudaram o desempenho das amostras como agentes de resistência a seca em três níveis de $\mathrm{pH}: 4,0 ; 5,0$ e 8,5. Esses autores encontraram valores mais elevados para resistência do papel para o $\mathrm{pH}$ mais próximo do ponto isoelétrico de cada amostra, em torno de 7,0, e com densidade de carga líquida assimétrica positiva, $\mathrm{pH}$ 5,0. Neste $\mathrm{pH}$, a densidade de carga líquida da fibra se apresenta negativa conforme resultados encontrados em literatura (RADTCHENKO; PAPASTAVROU; BORKOVEC, 2005). Estes autores mediram as densidades de cargas de superfícies de sílica e de celulose através da técnica de microscopia de força atômica. Os resultados encontrados foram: para sílica $-0,40$ e $-2,0 \mathrm{mC} / \mathrm{m}^{2}$, e para celulose $-0,21$ and $-0,80 \mathrm{mC} / \mathrm{m}^{2}$, para os valores de $\mathrm{pH} 4,0$ e 9,5 , respectivamente.

Hubbe et al. (2007a), encontraram resultados de resistência de autorruptura mais elevados para o políanfótero de média densidade de carga, 10:4 mol \%. Esses autores reportaram que o fenômeno de adsorção pode ser explicado pelo gradiente 
de carga entre o polímero e a superfície das fibras. A título de comparação, estes autores também testaram dois polímeros monocarregados, um catiônico com $5 \mathrm{~mol}$ \% e um aniônico com 2 mol \%, e um teste em branco, sem polímero. Os resultados com o polímero aniônico foram inferiores quando comparados com o teste em branco, enquanto que os resultados com o polímero positivo foram superiores. Entretanto, todos os resultados de resistência com as amostras de polianfóteros foram mais elevados do que os apresentados com o polímero catiônico somente. Os autores explicaram o fenômeno em termos de interação eletrostática entre a carga líquida positiva dos polianfóteros e a carga negativa da superfície das fibras. A diferença entre os resultados alcançados pelos polianfóteros em relação aos apresentados pelo polímero catiônico foi explicada em nível de comportamento coloidal no meio de dispersão e de testes de adsorção em superfícies de fibras. Maiores resultados de turbidez foram encontrados para valores de $\mathrm{pH}$ próximos ao ponto isoelétrico, com dois pontos de máximo, em comparação com valores de pH extremos e para o teste com menor força iônica do meio. Quantidades mais elevadas de polímero adsorvidas pelas fibras foram encontradas para a amostra de polianfótero 10:4 mol \% para os valores de $\mathrm{pH}$ 5,0 e 8,5 em relação ao $\mathrm{pH} \mathrm{4,0.}$ Esses autores notaram que, mesmo apresentando densidade de carga líquida negativa, portanto, igual ao da superfície das fibras em $\mathrm{pH}$ alcalino, a quantidade adsorvida também foi significativa para o caso dos polianfóteros. Fato que não foi observado com o polímero negativo monocarregado, em que a adsorção foi nula. No caso do polianfótero de maior densidade de carga, 20:8 mol \%, a maior adsorção foi apresentada para o $\mathrm{pH}$ de 8,5, não correlacionando com os resultados de resistência do papel. Os autores observaram que outras interações, além de eletrostáticas, poderiam ser responsáveis por esse comportamento.

Em estudos realizados por Silva et al. (2008b) e Yamaguchi et al. (2008), com dois desses polianfóteros, foram encontrados que a resistência de autorruptura aumenta com o aumento da dosagem do polianfótero. Estes autores utilizaram os polianfóteros 20:8 mol \% nas condições de pH 6,5 e $10 \mathrm{mM} \mathrm{NaCl}$, e 5:2 mol \% nas condições de $\mathrm{pH} 7,0$ e $1000 \mu \mathrm{S} / \mathrm{cm} \mathrm{Na}_{2} \mathrm{CO}_{3}$, respectivamente.

Aspectos teóricos e práticos reportados na literatura sobre polianfóteros serão considerados a seguir com o objetivo de entender melhor a habilidade desses 
polímeros como agentes de resistência a seco, considerando a importância dessa propriedade tanto na fabricação de papéis quanto na utilização desses como produto acabado.

\subsubsection{Polianfóteros em solução}

Antes de reportar os principais estudos sobre o assunto, é importante apresentar algumas terminologias que serão utilizadas nos textos a seguir. Tal como encontrado em Dobrynin; Rubinstein e Joanny (1997), denomina-se de carga balanceada, ou de carga líquida neutra ou carga simétrica, o polianfótero com iqual número de carga positiva e negativa. Por outro lado, denominou de carga líquida ou carga assimétrica o polianfótero que apresente valor absoluto de carga diferente de zero para a diferença entre o número de monômeros positivos e negativos.

Considerando um modelo teórico, o grupo de pesquisa de Dobrynin tem proposto algumas configuração para as cadeias de polianfóteros, dependendo da natureza da carga do polímero e de alguns aspectos da suspensão (DOBRYNIN; RUBINSTEIN; JOANNY, 1997; DOBRYNIN, 2008). Para polianfóteros com grupos carregados distribuídos aleatoriamente na cadeia e assimétrico, estes autores propuseram três regimes de configuração para as cadeias em suspensão (Figura 5.1 extraída de Dobrynin, 2008): (a) Conformação Gaussiana ou em glóbulos; (b) Conformação extendida na forma cilíndrica, e (c) Conformação colapsada em glóbulos alternados com parte da cadeia extendida, formando uma estrutura que os autores denominaram de colar. No caso da configuração Gaussiana (Figura 5.1a), a repulsão eletrostática é menor do que a energia térmica fazendo com que o polímero adquira uma configuração na forma enrolada. No caso da conformação extendida na forma de um cilindro (Figura 5.1b), a repulsão eletrostática entre o excesso de cargas para a cadeia de polianfótero assimétrica é maior do que a energia térmica. Isto promove o esticamento da cadeia, a qual apresenta comportamento semelhante a de um polieletrólito monocarregado. Para a última conformação, a presença de glóbulos colapsados formando um colar (Figura 5.1c), os autores propuseram a existência de forças induzidas flutuantes, atrativas e repulsivas, entre as cargas em excesso. 


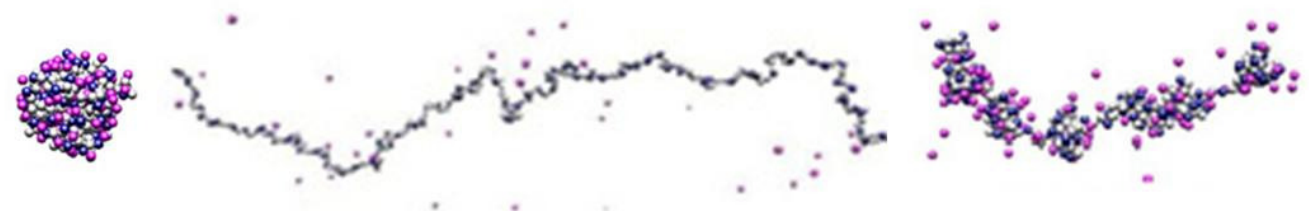
(a) Glóbulo
(b) Extendida
(c) Colar

Figura 5.1 - Diferentes conformações para as cadeias dos polianfóteros assimétricos. Em azul são os monômeros carregados negativamente; em rosa são os monômeros carregados positivamente e em cinza são os monômeros neutros.

Considerando estudos práticos, alguns pesquisadores observaram comportamentos diferentes para os polianfóteros em diferentes condições de $\mathrm{pH}$ e de concentração de sal (MAHLTIG et al., 1999; PATRICKIOS et al., 1999; MAHLTIG et al., 2000; IBRAEVA et al., 2004; SEZAKI et al., 2006a; MAHLTIG; JÉRÔME; STAMM, 2001).

O comportamento de um polianfótero composto por três blocos, ácido metacrílico (negativo), metacrilato de dimetilaminoetil (positivo) e metil metacrilato (neutro), foi avaliado sobre diferentes condições de pH, concentração do polímero, concentração de sal e presença de proteína, usando a técnica de turbidimetria (PATRICKIOS et al., 1999). Foi observado que a precipitação das cadeias de polianfóteros deu-se rapidamente próximo ao ponto isoelétrico. Estes autores observaram que o tamanho dos agregados era independente da concentração de polímero e aumentava suavemente com o aumento da concentração do sal. Por outro lado, embora a região de precipitação não tenha sido influenciada pela concentração do polímero, esta região decresceu com o aumento da concentração de sal na solução.

A precipitação de cadeias de polianfóteros foi explicada por Cheong e Panagiotopoulos (2005) apud Dobrynin (2008) $)^{34}$. Esses autores observaram que as interações eletrostáticas entre os monômeros de cargas opostas promovem a

${ }^{34}$ CHEONG, D.W.; PANAGIOTOPOULOS, A.Z. Phase behaviour of polyampholyte chains from grand canonical Monte Carlo simulations. Mol Phys, v. 103, p. 031-3044, 2005 apud DOBRYNIN, A. $\mathrm{V}$. Theory and simulations of charged polymers: From solution properties to polymeric nanomaterials. Current Opinion in Colloid \& Interface Science, v. 13, p. 376-388, 2008. 
separação de fases das cadeias de polianfóteros em solução. Essa separação de fases foi julgada por aqueles autores ser dependente de diversos fatores como o grau de polimerização da cadeia, a sequência de carga ao longo da cadeia do polímero, a resistência das interações eletrostáticas da cadeia e a temperatura da solução.

Os comportamentos coloidal e eletrocinético de três polianfóteros à base de acrilamida com elevado peso molecular e diferentes proporções entre os grupos positivos e negativos foram estudados por Sezaki et al. (2006a). Máximo valor de turbidez foi encontrado para o pH próximo ao ponto isoelétrico para solução livre de sal. Estes autores também observaram que os valores mais elevados de turbidez se relacionavam à coagulação das partículas devido a redução de solubilidade das cadeias de polianfóteros em solução.

A formação de complexos entre cadeias de polianfóteros compostos por cloreto de dimetil dialil amônio de sódio (DMDAAC) e ácido maléico (MA) foi mostrado por Ibraeva et al. (2004). Estes autores encontraram que alternando frações equimolar dos copolímeros DMDAAC e MA, o comportamento antipolieletrólito poderia ser verificado no ponto isoelétrico. Enquanto que o excesso de grupos quaternário de amônio conduzia ao comportamento de um polieletrólito convercional.

Avaliação do tamanho de micelas de polianfóteros constituído por dois blocos de ácido polimetacrílico com metacrilato de polidimetilaminoetil, PMAA- $b$-PDMAEMA, em solução, sob diferentes condições de pH, pode ser citada (MAHLTIG et al., 1999; MAHLTIG et al., 2000). No primeiro estudo, o PMAA-b-PDMAEMA apresentava peso molecular em torno de $68 \times 10^{3} \mathrm{~g} / \mathrm{mol}$ e proporção entre os blocos PMAA e PDMAEMA de 90:10. Estes autores encontraram a coexistência de estruturas pequenas e grandes em solução utilizando a técnica de espalhamento dinâmico de luz. Isto foi atribuído a coexistência de polímeros na forma de cadeias individuais e na forma de agregados. Foram encontrados diâmetros de micelas da ordem de $11 \mathrm{e}$ $95 \mathrm{~nm}$, para o $\mathrm{pH}$ de 4,8, e da ordem de 12,5 e $57 \mathrm{~nm}$, para $0 \mathrm{pH}$ de 2,8, para a concentração fixa de $\mathrm{NaCl}$ de $0,01 \mathrm{~mol} / \mathrm{L}$. A precipitação do polímero foi verificada pela redução da transmissão de luz. Esses autores encontraram ainda que a transmissão de luz era fortemente influenciada pelas condições de pH e não pelas concentrações de sal estudada, 0,01 e 0,04 mol/L de $\mathrm{NaCl}$. 
Avaliação de polianfótero semelhante, PMAA-b-PDMAEMA, porém com diferente proporção entre os grupos negativo e positivo, 19:81, ponto isoelétrico de 9,3, e peso molecular de $62 \times 10^{3} \mathrm{~g} / \mathrm{mol}$, foi realizada por Mahltig et al. (2000). Estes autores estudaram o comportamento do polímero em solução em diferentes valores de $\mathrm{pH}$ e compararam com a camada adsorvida em superfície modelo utilizando as técnicas de espalhamento dinâmico de luz (DLS) e de microscopia de força de varredura (SFM). Os autores encontraram que as estruturas adsorvidas na superfície do substrato de óxido de silício, avaliadas pelas imagens em SFM, se correlacionavam com as estruturas em solução avaliadas pela técnica de espalhamento de luz. Foi observado também que o tamanho médio de micelas reduziu com o aumento do $\mathrm{pH}$ de $208 \mathrm{~nm}$ em pH de 3,5 para de $84 \mathrm{~nm}$ em pH 9,4 com a técnica de DLS, e de 200 nm em pH 6,9 para 100 nm, aproximadamente, em pH 9,4 com a técnica de SFM.

\subsubsection{Aspectos teóricos sobre a adsorção de polianfóteros}

\subsection{Adsorção de cadeia simétrica simples de polianfóteros sobre superfícies carregadas}

Importantes aspectos teóricos sobre a adsorção de polianfóteros em superfícies carregadas têm sido desenvolvidos (DOBRYNIN; RUBINSTEIN; JOANNY, 1997; EVERAERS; JOHNER; JOANNY, 1997; DOBRYNIN; OBUKHOV; RUBINSTEIN, 1999).

Considerando uma cadeia de polianfótero individual e simétrica, Dobrynin; Rubinstein e Joanny (1997) reportaram que o mecanismo de adsorção se baseava na polarização da cadeia no campo elétrico como consequência da superfície carregada, na ausência de sal. Neste caso, três regimes de adsorção diferentes foram propostos (Figura 5.2 extraída de Dobrynin; Rubinstein e Joanny, 1997): (a) Regime de pólo; (b) Regime de cerca e (c) Regime de "panqueca". No regime de pólo, Figura 5.2a, o campo elétrico gerado pela superfície carregada, $\sigma_{1}$, induz a adsorção com o alongamento da cadeia na direção do campo. Neste caso a superfície apresenta densidade de carga suficiente, a ponto de o comprimento de Gouy-Chapman, $\lambda$, ser maior do que o comprimento espiralado da cadeia polarizada 
do polímero, $R_{z}$. $O$ gradiente do campo elétrico será maior próximo à superfície do substrato. Ainda, em superfícies com densidades de carga muito baixas, a adsorção não ocorrerá porque o ganho de energia não será suficiente para a polarização da cadeia. Nesta condição, a energia de atração entre a cadeia e a superfície é baixa e as cadeias podem se mover livremente na solução.

Por outro lado, no regime de cerca, Figura 5.2b, o comprimento de Gouy-Chapman, $\lambda$, torna-se próximo ao tamanho da cadeia do polianfótero, $R_{z}$. Neste caso, a adsorção ocorrerá e a densidade de carga da superfície, $\sigma_{2}$, será maior do que a do regime de pólo. O regime de "panqueca" ocorre quando a densidade de carga da superfície é bastante elevada, $\sigma_{3}$, Figura 5.2c. Neste caso, a parte da cadeia com carga oposta a da superfície ficará dentro do comprimento de Gouy-Chapman, $\lambda$, e a outra parte da cadeia, com mesma carga, ficará fora deste comprimento. Dessa forma, a cadeia formará loops na solução a uma distância, $R_{z}$, maior do que o comprimento de Gouy-Chapman.
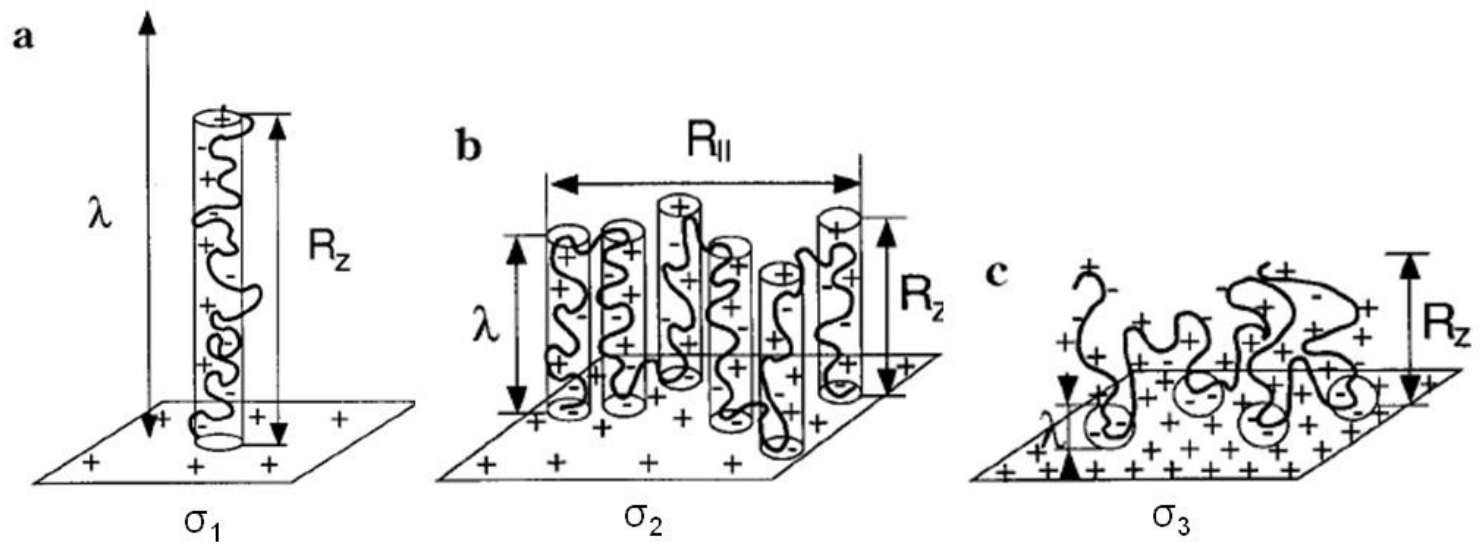

Figura 5.2 - Esquema das configurações da cadeia de polianfótero próximo à superfície carregada: (a) Regime de pólo; (b) Regime de cerca e (c) Regime de panqueca.

No caso de cadeias de polianfóteros que apresentem mesma carga do que a superfície, a adsorção ainda poderá acontecer se a carga da superfície for suficientemente carregada (DOBRYNIN; RUBINSTEIN; JOANNY, 1997). 
A discussão apresentada acima baseada nos estudos teóricos de Dobrynin; Rubinstein e Joanny (1997), considera a cadeia do polímero na ausência de eletrólitos de baixo peso molecular, situação tal qual não é a realidade encontrada em fábrica de papel. Segundo a literatura, a presença de eletrólitos de baixo peso molecular conduz à presença do fenômeno conhecido como blindagem de cargas (FLEER; COHEN STUART; SCHEUTJENS, 1993; DOBRYNIN; RUBINSTEIN; JOANNY, 1997; DOBRYNIN, 2008). Dessa forma, a configuração dos polianfóteros em solução pode ser modificada de acordo com a concentração de sal no meio de dispersão (DOBRYNIN; RUBINSTEIN; JOANNY, 1997; DOBRYNIN, 2008). Para baixa força iônica, as configurações estão próximas às configurações de sistemas sem a presença de sal. Por outro lado, em sistemas com elevados níveis de sal, as configurações mudam devido ao efeito da blindagem de cargas, em que os íons de cargas opostas do polianfótero ficam impedidos de se interagirem tanto intra quanto intermolecular e estes com a superfície carregada.

O efeito da blindagem de cargas para explicação do comportamento de adsorção de polieletrólito (ROJAS et al., 1998; SOLBERG; WÅGBERG, 2003; NOTLEY et al., 2004; ENARSSON; WÅGBERG, 2009) e de polianfóteros (DOBRYNIN; OBUKHOV; RUBINSTEIN ,1999; LE BERRE; MALMSTEN; BLOMBERG, 2001) na presença de eletrólito de baixo peso molecular tem sido aceito em várias pesquisas.

A densidade de carga do polieletrólito e da superfície de adsorção são consideradas como parâmetros que afetam o comportamento de adsorção de polieletrólitos em superfícies carregadas. Este comportamento também é dependente da concentração de eletrólitos no meio de dispersão. A adsorção de polieletrólito sobre superfície carregada de carga oposta como função da concentração de sal tem sido explicada pela teoria de Scheutjens-Fleer. Em linhas gerais, essa teoria explica que, para baixas concentrações de sal, a adsorção é atribuída ao mecanismo de troca iônica que ocorre na dupla camada elétrica. Esse mecanismo é favorecido pelo ganho líquido de entropia devido à liberação de contra íons para a fase líquida favorecendo as interações eletrostáticas. Para concentrações intermediárias de sal, além das interações eletrostáticas, as interações não iônicas também podem ocorrer. Neste caso, o aumento da concentração de sal reduz a repulsão entre as cadeias de polímero e a superfície aumentando a adsorção. Por outro lado, para 
elevadas concentrações de eletrólitos, a interação eletrostática entre o polieletrólito e a superfície carregada é reduzida pela blindagem de cargas (FLEER; COHEN STUART; SCHEUTJENS, 1993).

Com o objetivo de ilustrar o efeito da blindagem de cargas na adsorção e na desorção de polímeros, alguns estudos serão considerados.

Enarsson e Wågberg (2009) estudaram a adsorção de poliacrilamida catiônica em filme de celulose com a utilização da balança microgravimétrica com cristal de quartzo e dissipação de energia, na presença de vários níveis de concentração de sal, 0,1; 1; 10, 100 e 300 mM. Estes autores encontraram elevação da adsorção do polímero do nível mais baixo até a concentração de $10 \mathrm{mM}$. Para concentrações maiores do que este nível, as adsorções foram inferiores. Os autores explicaram este comportamento como efeito da blindagem de cargas (ENARSSON; WÅGBERG, 2009).

O efeito da concentração de sal na adsorção de poliacrilamida catiônica sobre superfície de fibra em pH 5,6, foi estudado por Solberg e Wågberg (2003). Três níveis de concentração de sal foram estudados: 1, 10 e 100 mM. Os autores encontraram máxima adsorção na concentração de $10 \mathrm{mM}[\mathrm{NaCl}]$. O aumento da quantidade adsorvida com a força iônica do meio de dispersão foi explicado pelo enconhimento do tamanho dos polímeros em solução podendo assim penetrar mais na superfície porosa da fibra. Para a concentração de $100 \mathrm{mM}$, os autores explicaram que a atração eletrostática foi reduzida pela presença dos eletrólitos de baixo peso molecular (SOLBERG; WÅGBERG, 2003).

A desorção de polianfóteros de superfície de mica com a adição de sal ( $\mathrm{NaCl})$ foi estudada por Le Berre; Malmsten e Blomberg (2001). Estes autores observaram que até a concentração de $10 \mathrm{mM}$ de sal, o efeito da presença de eletrólitos era mínimo. Entretanto, para concentrações maiores, a desorção do polímero da superfície carregada era significativa. Os autores atribuíram a desorção à blindagem de cargas entre o polímero e a superfície carregada. O polímero utilizado era constituído de três monômeros: acrilamida neutra, $87,1 \%$, acrilamida sulfonato de sódio como monômero negativo, 4,7\%, e cloreto de quaternário de amônio como monômero positivo, 8,2\%. A distribuíção dos monômeros era próxima à aleatória. 


\subsection{Adsorção de polianfótero em multicamadas em superfície carregada}

Depois de Dobrynin; Rubinstein e Joanny (1997) terem estudado sobre os regimes conformacional de polianfóteros simétrico para cadeia simples, outro estudo teórico envolvendo a deposição em camadas para sistema livre de sal também para cadeia simples, utilizando uma série de cálculos, tem sido recentemente reportado (DOBRYNIN; OBUKHOV; RUBINSTEIN, 1999). Na prática, a técnica de montagem em camada por camada é baseada na interação eletrostática entre macromoléculas de sinais opostos, intercaladas por lavagem para remoção do excesso do polímero em questão (DECHER, 1997). A aplicação teórica desta técnica não leva em consideração a possível reconformação das macromoléculas das camadas já adsorvidas na superfície carregada (DOBRYNIN, 2008).

A adsorção de multicamadas de polianfóteros em superfície carregada para polianfótero simétrico foi identificada para três regimes de adsorção diferentes (Figura 5.3 extraída de Dobrynin; Obukhov e Rubinstein (1999): (a) Multicamadas de polímeros com cadeias estendidas (Figura 5.3a). Neste regime, as cadeias são polarizadas e estendidas por um campo elétrico externo, a densidade de carga do polímero reduz a partir da superfície carregada e a adsorção pára quando a campo elétrico externo não for suficiente para polarizar a cadeia. Normalmente, esse regime ocorre para densidade de carga de superfície não muito elevada, $\sigma_{1}<\sigma>\sigma_{2}$, sendo o comprimento da primeira camada, $\lambda_{2}$, menor do que o comprimento de GouyChapman, $\lambda$. (b) Multicamadas de cadeias de polímero estendidas com subcamada (Figura 5.3b). Neste regime, a densidade de carga da superfície é mais elevada do que no regime anterior, $\sigma_{2}<\sigma>\sigma_{3}$. $O$ campo elétrico gerado pela superfície carregada é quase constante. A primeira camada, $\lambda_{2}$, apresenta comprimento maior do que 0 comprimento de Gouy-Chapman, $\lambda$, porém há também formação de uma subcamada próxima à superfície carregada com espessura semelhante ao comprimento de Gouy-Chapman. (c) Multicamadas de cadeias estendidas saturadas em subcamadas. Neste regime a densidade de carga da superfície é bastante elevada, $\sigma>\sigma_{3}$, e o comprimento de Gouy-Chapman é bastante reduzido. Entre as distâncias $\lambda_{2}$ e $\lambda_{1}$, aqueles autores reportaram há presença de multicamadas de cadeias estendidas. 


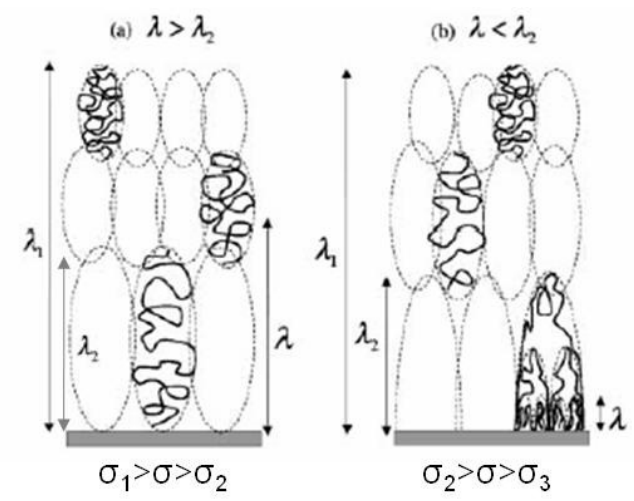

Figura 5.3 - Esquema da configurações das cadeias de polianfóteros adsorvidos em camadas. (a) Multicamadas de cadeias estendidas: lado esquerdo. (b) Multicamadas de cadeias estendidas com falso pincel: lado direito.

\subsubsection{Estudos práticos sobre a adsorção de polianfóteros}

Considerando os estudos práticos sobre a adsorção de polianfóteros em interfaces sólido-líquido, algumas pesquisas podem ser citadas ( MAHLTIG et al., 1999; MAHLTIG et al., 2000; MAHLTIG; JÉRÔME; STAMM, 2001; TRAN et al., 2006; SEZAKI et al., 2006b; SONG, 2008). Dentre estes estudos, exceto para Mahltig et al. (1999), existe um ponto em comum: foi observada máxima adsorção do polianfótero no $\mathrm{pH}$ próximo ao ponto isoelétrico, apesar da diferença encontrada entre os polianfóteros estudados nos diversos estudos.

Mahltig et al. (1999) esperavam que a máxima adsorção do polímero sobre superfície modelo de sílica, a qual coincidiu com a mais baixa transmissão de luz, fosse próximo ao ponto isoelétrico do polianfótero, $\mathrm{pH} 3,9$. Entretanto, não foi o que ocorreu. Através de medidas de potencial de corrente, os autores observaram também que o ponto isoelétrico do óxido de silício usado como substrato também era próximo de 3,9 , sendo esta a explicação para a baixa quantidade adsorvida neste $\mathrm{pH}$. Por outro lado, no estudo de adsorção de polianfótero semalhante, com proporção entre os grupos negativo e positivo, 19:81, ponto isoelétrico de 9,3 e peso molecular de $62 \times 10^{3} \mathrm{~g} / \mathrm{mol}$, foi observada máxima adsorção do polianfótero para $\mathrm{pH}$ próximo do ponto isoelétrico (MAHLTIG et al., 2000). De acordo com os resultados 
dos dois estudos anteriores, deve-se tomar cuidado com o ponto isoelétrico do substrato quando se fizer estudos de adsorção de polianfóteros.

Outro estudo sobre adsorção de polianfóteros diblocos copolímeros foi realizado pelo mesmo grupo de pesquisa em 2001 (MAHLTIG; JÉRÔME; STAMM, 2001). Estes autores utilizaram três polianfóteros com semelhantes pesos moleculares, porém, com diferentes proporções entre os grupos negativos e positivos, PMAA- $b-$ PDMAEMA, 84:16, 55:45, e 29:71. Neste caso, o pH do ponto isoelétrico aumentou com o tamanho do bloco positivo (PDMAEMA), correspondendo aos valores de $\mathrm{pH}$ 3,8; 5,9 e 8,9, respectivamente.

Considerando adsorção em superfícies de fibra, quantidade adsorvida significativa também foi encontrada quando os polianfóteros se encontravam com carga líquida neutra ou negativa (SEZAKI et al., 2006b). Semelhante ao comportamento encontrado por Mahltig et al. (2000), esses autores encontraram um platô depois de 60 min de incubação para a adsorção do polianfótero. Estes autores encontraram que a adsorção aumenta com a concentração de sal até o valor de $1000 \mu \mathrm{S} / \mathrm{cm}(\sim 10$ $\mathrm{mM})$.

Mesmo com a dificuldade de mostrar na prática como acontece a adsorção de polianfóteros, mono ou multicamadas, Song (2008) sugeriu que a adsorção desses polímeros, para condições fixas de pH, 7,0, e concentração de sal, $1000 \mu \mathrm{S} / \mathrm{cm}$, estudada através da técnica da balança microgravimétrica com sensores de cristal de quartzo e com dissipação de energia, ocorria em multicamadas. A formação de multicamadas sobre a superfície carregada foi proposta a partir de observações de valores elevados de mudanças na frequência e na dissipação de energia com o tempo, a qual ocorria especialmente para o polímero de maior densidade de carga. Em sua explicação, Song (2008) considerou a teoria proposta por Dobrynin; Obukhov e Rubinstein (1999), a qual descreveu a polarização da cadeia pelo campo elétrico externo criado por uma superfície carregada e a deposição das cadeias do polianfótero em multicamadas. Song (2008) utilizou em seu estudo as mesmas amostras de polímeros usadas no estudo de Hubbe et al. (2007a): quatro amostras de polianfóteros com densidades de carga crescentes e aleatoriamente distribuídas, porém, com a mesma proporção entre os grupos positivo (dimetil amino propilacrilamida) e negativo (ácido itacônico), 5:4, respectivamente. Os pesos 
moleculares médios dessas amostras eram semelhantes com, aproximadamente, 3 $\times 10^{6} \mathrm{~g} / \mathrm{mol}$. As proporções entre os grupos positivos e negativos para as quatro amostras em mol \%, foram: 2,5:1, 5:2, 10:4 e 20:8.

Em complemento ao trabalho de Song (2008), Song et al. (2010) reportam a separação de fases ou microprecipitação dos polianfóteros na interface, devido à polarização, seguida de interação entre a camada de polímero adsorvida e as cadeias da solução, como fenômeno responsável pela formação de camadas. Camadas mais viscoelásticas foram obtidas para a amostra de polianfótero densidade de carga mais elevada, devido as grandes variações na dissipação de energia observadas. No caso de superfície de filme de celulose, em que a adsorção foi mais limitada, os efeitos de polarização e interação eletrostática foram menos significaivos.

\subsubsection{Propriedades viscoelásticas de camadas de polianfóteros adsorvidas em superfícies carregadas}

Para determinação das propriedades viscoelásticas de camadas de polímeros adsorvidas em superfícies carregadas, a balança microgravimétrica com cristal de quartzo e dissipação de energia é a técnica mais utilizada ( HÖÖK et al., 1998a; TAMMELIN et al., 2004; NOTLEY; ERIKSSON; WÅGBERG, 2005; ONDARAL; WÅGBERG; ENARSSON, 2006; KONTTURI et al., 2008; SONG, 2008).

O efeito da força iônica nas propriedades viscoelásticas de camadas de amido catiônico adsorvidas em sensores de sílica, para pH 7,5, foi estudado por Tammelin et al. (2004) utilizando a técnica da balança microgravimétrica. Para força iônica quase nula, ou seja, sem sal, as camadas adsorvidas eram finas e rígidas, sendo a quantidade adsorvida na superfície calculada pela equação de Sauerbrey (SAUERBREY, 1959). Entretanto, para força iônica correspondente à $100 \mathrm{mM} \mathrm{NaCl}$,

a camada adsorvida foi mais bem estimada utilizando o modelo viscoelástico de Voigt (VOINOVA et al., 1999). Neste caso, a quantidade adsorvida foi maior. Para estes autores, a adição de eletrólitos de baixo peso molecular impede tanto a repulsão eletrostática intramolecular quanto a repulsão entre o polímero e a 
superfície. Para os dois casos, Tammelin et al. (2004) explicam que houve um aumento da quantidade adsorvida devido à redução do comprimento do polímero e a modificação da sua conformação na superfície, levando a formação de camada mais espessa e mais viscoelásticas.

As propriedades viscoelásticas de multicamadas adsorvidas em substrato de sílica, intercalando polímeros, positivo e negativo, em diferentes condições de $\mathrm{pH}$, foram estudadas por Notley; Eriksson e Wågberg (2005) através da técnica da balança microgravimétrica com dissipação de energia. Estes autores encontraram que a estrutura da multicamada era fortemente dependente da camada mais externa adsorvida a qual estava relacionada com a densidade de carga. Neste caso, estes autores verificaram que a viscoelasticidade aumentava quando a última camada adsorvida era positiva. Camadas mais viscoelásticas foram encontradas para a combinação polímero positivo no $\mathrm{pH}$ 7,5 e polímero negativo no $\mathrm{pH} 3,5$.

Considerando polianfóteros sintéticos, na prática, as pesquisas referentes às propriedades viscoelásticas de camadas adsorvidas em superfícies carregadas são recentes. Em estudos realizados por Song (2008) e por Song et al. (2010), as propriedades viscoelásticas de quatro amostras de polianfóteros, para condições fixas de $\mathrm{pH} 7$ e de força iônica $1000 \mu \mathrm{S} / \mathrm{cm} \mathrm{NaCl}$, foram realizadas in situ através da técnica de balança microgravimétrica com cristal de quartzo e dissipação de energia. Camadas mais viscoelásticas, o que correspodeu a maiores valores de mudança em dissipação de energia com o tempo, foram encontradas para o polianfótero com maior densidade de carga, 20:8 para os grupos positivo e negativo, respectivamente. Resultados mais reais foram determinados a partir do software do equipamento, Qtools, em que foram consideradas três frequências harmônicas para determinação dos valores estimados através do modelo viscoelástico de Voigt. Para o polianfótero $5: 2$, a espessura estimada foi o dobro da espessura estimada com o modelo rígido, $15 \mathrm{~nm}$ e $30 \mathrm{~nm}$, antes da lavagem, e $10 \mathrm{~nm}$ e $20 \mathrm{~nm}$, após a lavagem. Para o polianfótero com densidade de carga intermediária,10:4, o valor estimado para espessura até atingir o equilíbrio foi quatro vezes maior do que o valor estimado considerando camada rígida, $100 \mathrm{~nm}$ e $25 \mathrm{~nm}$, respectivamente. Entretanto, após a etapa de lavagem, estes autores observaram que esses valores se aproximavam, 13 
nm. Para os autores, a força de interação entre as estruturas e a superfície não eram fortes o suficiente para mantê-las adsorvidas.

As propriedades viscoelásticas das camadas de polímeros adsorvidas e a cinética de adsorção podem também ser avaliadas através de gráficos de dissipação de energia versus frequência em que o tempo é considerado como um parâmetro implícito, $D$-f plots. Nestes tipos de gráficos, diferenças no comportamento de adsorção de polímeros podem ser reveladas, as quais não são vistas diretamente nos gráficos de mudanças na frequência e na dissipação por tempo isoladamente.

Alguns estudos de literatura que utilizaram o gráfico tipo $D$-f plots para explicação das propriedades viscoelásticas e da cinética de adsorção de polímeros em interface sólido-líquido podem ser citados (ONDARAL; WÅGBERG; ENARSSON, 2006; KONTTURI et al., 2008).

Ondaral; Wågberg e Enarsson (2006) observaram que a adsorção de poliesteramida em superfície de óxido de silício para diferentes valores de $\mathrm{pH}(5,8$ e 10) e de concentração de sal ( 0 e $10 \mathrm{mM} \mathrm{NaCl}$ ) formavam camadas rígidas.

Kontturi et al. (2008) verificaram que camada mais rígida foi formada na adsorção em filme de celulose de amido catiônico com grau de substituição de 0,75. Por outro lado, camada mais dissipativa era formada com amido catiônico com grau de substituição menor, 0,20.

\subsection{MATERIAIS E MÉTODOS}

\subsubsection{Materiais}

Água destilada foi usada para formação de folhas manuais em laboratório no estudo do efeito da adição de polianfóteros como agente de resistência a seco do papel. Em todos os outros testes deste estudo foi utilizada água milli-Q. 
Soluções aquosas de hidróxido de sódio e ácido clorídrico $0,1 \mathrm{~N}$ foram preparadas para ajuste de $\mathrm{pH}$ do meio de dispersão.

Soluções de cloreto de sódio nos níveis de concentração de 0,1, 1, 10, 100 e 1000 $\mathrm{mM}$ foram preparadas para serem utilizadas no estudo do efeito da força iônica na adsorção do polianfótero em $\mathrm{pH}$ fixo de 4,3ะ0,05.

Todas as substâncias inorgânicas utilizadas neste estudo foram de grau analítico.

\subsubsection{Fibras celulósicas}

Nos testes de adsorção em fibras celulósicas seguidos da preparação de folhas e de teste físicos, foi utilizada polpa kraft branqueada de eucalipto pretratada. $O$ pretratamento consistiu na remoção da fração de finos através da lavagem exaustiva com água corrente, destilada, com o auxílio de uma peneira de 100 mesh. Depois desta etapa, o $\mathrm{pH}$ e o teor de sal eram ajustados para 6,5 e $1 \mathrm{mM} \mathrm{NaCl}$, respectivamente. Para caracterização da polpa, foi coletada uma amostra para análise com o analisador de fibras (Fiber Quality Analysis LDA02) de acordo com a metodologia TAPPI T 271-om-98. Os resultados da caracterização podem ser vistos na Tabela 5.1.

Tabela 5.1 - Resultados da análise da polpa

\begin{tabular}{ccccccc}
\hline Parâmetro & $\begin{array}{c}\text { Comprimento } \\
\text { médio, mm }\end{array}$ & $\begin{array}{c}\text { Largura } \\
\text { média, } \mu \mathrm{m}\end{array}$ & $\begin{array}{c}\text { Teor de } \\
\text { finos, } \%\end{array}$ & $\begin{array}{c}\text { Elemento de } \\
\text { vasos, \# }\end{array}$ & $\begin{array}{c}\text { Comprimento } \\
\text { de vasos, } \\
\mathrm{mm}\end{array}$ & $\begin{array}{c}\text { Largura de } \\
\text { vasos, } \mu \mathrm{m}\end{array}$ \\
\hline $\begin{array}{c}\text { Média } \\
\text { aritimética }\end{array}$ & 0,719 & 16,43 & 0,69 & 6,5 & 0,53 & 133,48 \\
\hline $\begin{array}{c}\text { Desvio } \\
\text { padrão }\end{array}$ & 0,006 & 0,096 & 0,069 & 2,082 & 0,032 & 9,194 \\
\hline
\end{tabular}

Nota: O número de fibras contadas foi de 3000. A fração de finos foi classificada como as partículas com dimensões entre 0,05 e $0,2 \mathrm{~mm}$. 
A suspensão de fibras foi desaguada por centrifugação, desagregada e acondicionada em sacos de polietilendo sob refrigeração. $O$ teor seco foi determinado em triplicata.

\subsubsection{Superfícies modelos}

As superfícies modelos usadas neste trabalho para o estudo de adsorção de polianfóteros foram: substrato de sílica e filmes ultrafinos de celulose para uso na balança microgravimétrica, e os wafers de óxido de silício para uso no microscópio de força atômica. Descrição detalhada de limpeza, preparação e ativação da superfície do óxido de silício pode ser vista no tópico 4.2.3 do capítulo 4 .

\subsubsection{Polianfótero}

O polianfótero usado neste trabalho foi sintetizado via polimerização por radical livre, com distribuição randômica dos três monômeros que fazem parte de sua composição (Figura 5.4, extraída de Wang et al., 2006). O monômero positivo foi o dimetil aminopropil acrilamida (DMAPAA), o negativo foi 0 ácido metileno butanodióico, também conhecido como ácido itacônico (IA). O monômero neutro, usado na quantidade suficiente para completar a composição final do polianfótero, $100 \%$, foi a acrilamida. O peso molecular do polímero sintetizado foi de $2,93 \times 10^{6}$ $\mathrm{g} / \mathrm{mol}$, com proporção dos grupos catiônico e aniônico de 5:4, de acordo com medições feitas em trabalho anterior, através da técnica de ressonância magnética nuclear (WANG et al., 2006). De acordo com esse trabalho, a viscosidade da solução aquosa do polianfótero com concentrção de $1 \mathrm{~g} / \mathrm{l}$ foi de $2400 \mathrm{mPa} . \mathrm{s}\left(25^{\circ} \mathrm{C}\right)$ e ponto isoelétrico de 7,5. Deste ponto em diante, a nomenclatura PAnf será adotada para substituir a palavra polianfótero. 


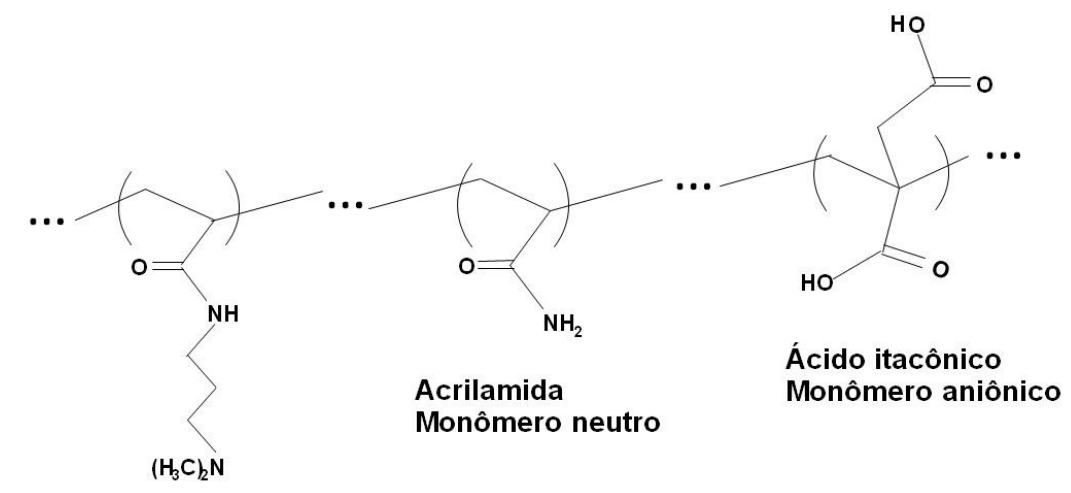

Dimetilaminopropil acrilamida

Monômero catiônico

Figura 5.4 - Composição molecular do polianfótero preparado randomicamente via polimerização por radical livre.

\subsubsection{Métodos}

\subsubsection{Adsorção do polianfótero em superfície de fibra, preparação de folhas manuais e teste de resistência mecânica}

Diferentemente de Sezaki et al. (2006b) e Mahltig et al. (2000) que encontram 60 min para o tempo de equilíbrio na adsorção de polianfóteros em fibras, os testes preliminares de adsorção realizados neste estudo mostraram que 30 min eram suficientes (Figura 5.5.A). O teste foi realizado da forma descrita a seguir. A uma suspensão de fibras, com consistência de 0,5\%, pH 6,5 e concentração de sal de 10 $\mathrm{mM} \mathrm{NaCl}$, foram dosados $1 \%$ de polianfótero, base fibra. Sob constante agitação, foram retiradas alíquotas da suspensão, ao longo do teste, e filtrada sob vácuo. $O$ filtrado foi titulado com solução de sal de sulfato de potássio polivinil (PVSK), 0,001N, em pH 3, de acordo com o procedimento descrito por Sezaki et al. (2006a). A quantidade não adsorvida ainda presente no filtrado foi estimada a partir da confecção da curva de calibração (Figura 5.5B). Esta curva foi construída nas mesmas condições de $\mathrm{pH}$ e de concentração de sal, a partir da titulação de seis concentrações conhecidas de polianfóteros. 

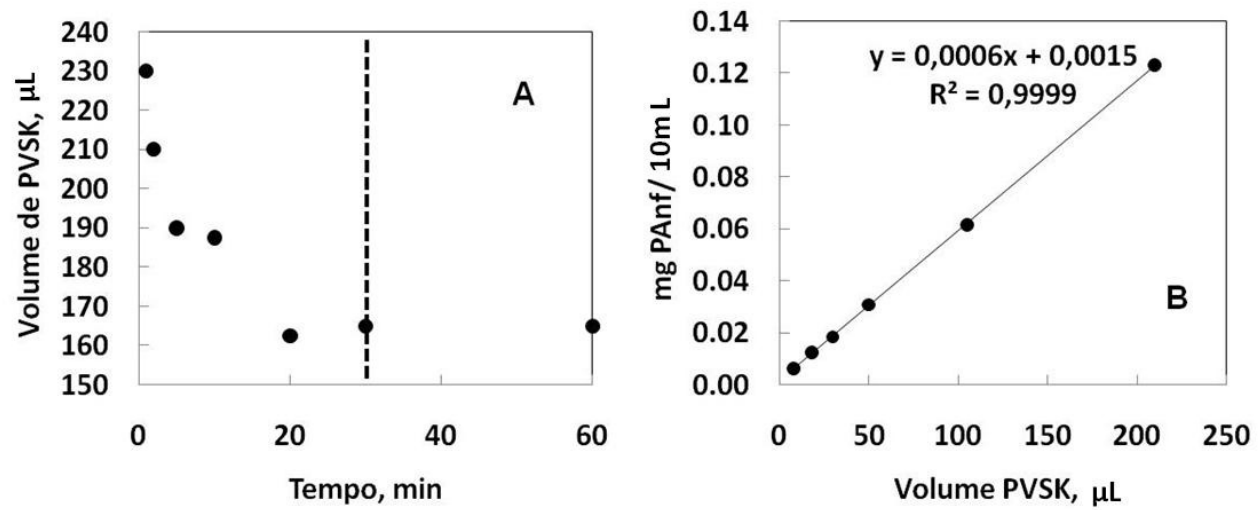

Figura 5.5 - (A) Volume de PVSK consumido em função do tempo de retenção na adsorção do polianfótero, e (B) curva de calibração massa do polianfótero em função do volume de PVSK gasto na titulação.

As folhas manuais de laboratório foram preparadas de acordo com o método TAPPI T205. As fibras foram ressuspensas para a consistência de 0,3\%. Antes de cada teste, solução do polianfótero era preparada sob as condições desejadas de $\mathrm{pH}$, força iônica e dosagem do polímero.

As condições de $\mathrm{pH}$, concentração de sal e dosagem do polímero para cada teste podem ser visualizadas na Tabela 5.2. A temperatura dos testes de adsorção foi ambiente, $25 \pm 2{ }^{\circ} \mathrm{C}$. Em todos os testes, a concentração de sal era ajustada e $\circ \mathrm{pH}$ era continuamente monitorado durante os $30 \mathrm{~min}$. Quantidade suficiente de água com pH e concentração de sal correspondentes ao teste era preparada para ser usada na formação das folhas, de forma a manter as mesmas condições de cada teste conforme Tabela 5.2 .

As folhas secas eram acondicionadas em sala climatizada à temperatura e umidade relativa de $23 \pm 1^{\circ} \mathrm{C}$ e de $50 \pm 3 \%$, respectivamente. Os testes físicos foram realizados de acordo com a norma TAPPI T404, índice de tração, e TAPPI T833 pm-94, resistência de ligação interfibras, conhecido como Scott Bond. Foram realizadas, no mínimo, cinco repetições. 
Tabela 5.2 - Condições de adsorção do polianfótero nas fibras

\begin{tabular}{|c|c|c|c|}
\hline $\begin{array}{l}\text { Condições } \\
\text { (Propriedade avaliada) }\end{array}$ & $\mathrm{pH}$ & $\begin{array}{l}\text { Concentração de sal, } \\
\qquad \mathrm{mM} \mathrm{NaCl}\end{array}$ & $\begin{array}{c}\text { Dosagem do polímero, } \\
\% \text { base fibra }\end{array}$ \\
\hline \multirow{3}{*}{$\begin{array}{l}\text { Efeito da dosagem } \\
\text { (Comprimento de } \\
\text { autorruptura, km, e } \\
\text { Teste de Scott Bond, } \\
\mathrm{J} / \mathrm{m}^{2} \text { ) }\end{array}$} & 6,5 & 1,0 & 0 \\
\hline & 6,5 & 1,0 & 0,29 \\
\hline & 6,5 & 1,0 & 0,58 \\
\hline \multirow{4}{*}{$\begin{array}{l}\text { Efeito do pH } \\
\text { (Índice de tração, } \\
\text { N.m/g) }\end{array}$} & 4,3 & 10,0 & 0,30 \\
\hline & 6,5 & 10,0 & 0,30 \\
\hline & 7,3 & 10,0 & 0,30 \\
\hline & 8,5 & 10,0 & 0,30 \\
\hline \multirow{3}{*}{$\begin{array}{l}\text { Efeito da força iônica } \\
\text { (Índice de tração, } \\
\text { N.m/g) }\end{array}$} & 4,3 & 5,0 & 0,30 \\
\hline & 4,3 & 10,0 & 0,30 \\
\hline & 4,3 & 100,0 & 0,30 \\
\hline
\end{tabular}

\subsubsection{Polianfótero em solução}

As propriedades de turbidez, de densidade de carga e de espalhamento dinâmico de luz das soluções de polianfóteros foram determinadas em (a) larga faixa de pH para concentração de sal fixa de $10 \mathrm{mM}[\mathrm{NaCl}]$ e em (b) pH fixo em cinco níveis de concentração de sal ambos à temperatura ambiente, $25^{\circ} \mathrm{C}$, conforme Tabela 5.3. 
Tabela 5.3 - Condições dos teste com polianfótero em solução para as propriedades turbidez, densidade de carga e diâmetro hidrodinâmico

\begin{tabular}{lcc}
\hline Condições & $\mathrm{pH}$ & Concentração de sal, \\
(Propriedade avaliada) & 3,3 a 10,2 & $\mathrm{mM} \mathrm{NaCl}$ \\
\hline Turbidez, NTU & 35 determinações & 10 \\
\cline { 2 - 3 } & 4,3 & $0,1,1,10,100$ e 1000 \\
\hline Densidade de carga, $\mathrm{mEq} / \mathrm{L}$ & 4,3 a 8,9 & 10 \\
\cline { 2 - 3 } & 16 determinações & $0,1,1,10$ e 100 \\
\hline Diâmetro hidrodinâmico, $\mathrm{nm}$ & 4,3 & 10 \\
\hline
\end{tabular}

\subsection{Turbidez}

As determinações de turbidez foram realizadas com o turbidímetro DRT-15CE fabricado pela HF Scientific, Inc. para concentração de polianfótero de $168 \mathrm{mg} / \mathrm{L}$. Foram realizadas várias determinações ao longo da curva de pH e em cinco níveis de força iônica (Tabela 5.3). Solução do polianfótero com concentração de $168 \mathrm{mg} / \mathrm{L}$ foi preparada e ajustada o $\mathrm{pH}$ para 3,3 com solução de $\mathrm{HCl} 0,01 \mathrm{~N}$. A partir deste ponto, gotas de solução de $\mathrm{NaOH} \quad 0,01 \mathrm{~N}$ eram adicionadas a solução de polianfótero. Após atingir o pH de equilíbrio, amostra da solução era coletada e medida a turbidez. Este procedimento foi realizado sob agitação ao longo da faixa de pH estudada para os cinco níveis de concentração de sal. 


\subsection{Densidade de carga}

A densidade de carga teórica do polianfótero usado neste estudo foi de $0,20 \mathrm{~mol} / \mathrm{mol}$ de grupos catiônicos e 0,16 mol/mol de grupos aniônicos (WANG et al., 2007). Como este tipo de polímero tem cargas positivas e negativas, espera-se que a densidade de carga líquida mude com a variação do $\mathrm{pH}$ da solução. O efeito da força iônica, em $\mathrm{mM}$, na densidade de carga líquida, em $\mathrm{mEq} / \mathrm{L}$, foi estudado em cinco níveis

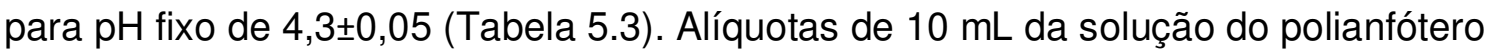
com $168 \mathrm{mg} / \mathrm{L}$ foram tituladas com solução de sal de sulfato de potássio polivinil (PVSK) $0,001 \mathrm{~N}$, até atingir o ponto neutro de corrente em $\mathrm{mV}$, medido pelo equipamento Mütek PCD-03pH fabricado pela BTG.

Para determinação da densidade de carga ao longo do pH, $200 \mathrm{~mL}$ da solução do polianfótero foram preparados e ajustados o $\mathrm{pH}$ para 4,3. A medida em que se adicionava a solução de hidróxido de sódio sob agitação, esperava-se atingir o equilíbrio e fazia-se a determinação da densidade de carga. Foram feitas 16 determinações ao longo da faixa de $\mathrm{pH}$.

Para determinação da densidade de carga de cada solução de polianfótero em diferentes concentrações de sal, foram preparados $100 \mathrm{~mL}$ para cada concentração e ajustas para $\mathrm{pH} 4,3 \pm 0,05$. Alíquota de $10 \mathrm{~mL}$ foi retirada para determinação da densidade de carga. Na concentração de 1000 mM não foi possível determinar pois a elevada concentração de eletrólitos interferiu na sensibilidade do equipamento.

A explicação do princípio de funcionamento desse equipamento pode ser encontrada no tópico 4.3.4 do capítulo 4.

\subsection{Diâmetro hidrodinâmico das partículas}

A determinação do diâmetro hidrodinâmico das partículas em solução, para diferentes níveis de $\mathrm{pH}$ e de concentração de sal conforme Tabela 5.3, foi realizada através da técnica de espalhamento dinâmico de luz (DLS) com o equipamento BECKMAN COULTER N4 PLUS, fabricado pela Beckman Coulter, Inc., Califórnia, 
EUA. Este sistema era composto de uma fonte de laser de Helio-Neon, $10 \mathrm{~mW}$, equivalente ao comprimento de onda de $632,8 \mathrm{~nm}$. As funções de autocorrelação (ACF) foram determinadas para cada $\mathrm{pH}$ da solução na concentração do polianfótero de $336 \mathrm{mg} / \mathrm{L}$. Esta concentração permitiu que o coeficiente de difusão das partículas por segundos se encontrasse dentro da faixa recomendada pelo fabricante, $5,0 \times 10^{4}$ até $1,0 \times 10^{6}$. Os resultados de autocorrelação foram relacionados com o coeficiente de difusão e, a partir deste, o tamanho da partícula foi calculado com a equação de Stokes-Einstein com espalhamento de luz detectado nos ângulos 30,$2 ; 62,6$ e $90^{\circ}$. Os testes foram realizados, pelo menos, em duplicata.

Para avaliação dos resultados, foi considerada a análise unimodal associada aos critérios sugeridos pelo manual do fabricante para avaliação de amostras com larga distribuição de tamanho de partículas. Os critérios considerados foram: (1) volume de espalhamento, o qual é proporcional a quantidade de luz espalhada. Nesse critério, a quantidade de luz espalhada em um determinado ângulo $\beta$ é maior do a mesma quantidade de luz espalhada no ângulo de $90^{\circ}$ em um fator de $1 / \operatorname{sen} \beta$. Neste caso, as dimensões de partículas menores são mais realistas medidas em ângulos maiores; (2) O tempo de coleta para o processo de difusão visto por um ângulo $\beta<90^{\circ}$ é $(1 / \mathrm{k})^{2}$ mais longo do que o tempo de coleta no ângulo de $90^{\circ}$, em que $1 / \mathrm{k}$ significa distância percorrida. Portanto, para partículas de pequenas dimensões, quanto menor o ângulo de detecção maior o tamanho aparente da partícula; (3) Partículas com índice de refração maior do que o índice de refração do meio mostraram menores valores de espalhamento de luz em ângulos maiores e, ao contrário, maiores espalhamentos de luz em ângulos menores; Por fim, (4) a dimensão da partícula é determinada baseando-se no movimento Browniano. Se a forma da partícula se distancia do formato esférico, além da difusão translacional ela também sofre difusão rotacional. Esses efeitos são minimizados quando a medição é realizada em ângulos menores. Dessa forma, os resultados alcançados com o ângulo de $62,6^{\circ}$ foram considerados na avaliação dos resultados desde que neste ângulo os critérios puderam ser atendidos em maior proporção e os erros minimizados. Os resultados alcançados para todos os ângulos podem ser encontrados no Apêndice B, Tabelas B6 a B10. 
Para determinação do diâmetro hidrodinâmico, $100 \mathrm{~mL}$ de solução foram preparados, ajustado o pH sob agitação, esperado atingir o equilíbrio e realizado a leitura no equipamento.

Para cada concentração de sal, foram preparadas $100 \mathrm{~mL}$ de solução de

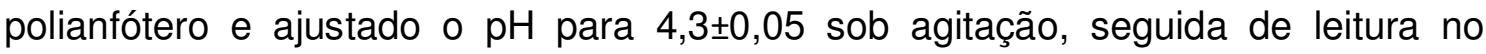
equipamento.

A explicação do princípio de funcionamento desse equipamento pode ser encontrada no tópico 4.3.3 do capítulo 4.

\subsubsection{Adsorção em superfícies modelos}

\subsection{Balança microgravimétrica com dissipação de energia}

Balança microgravimétrica com dissipação de energia composta por quatro câmaras (QCMD E4 fabricado pela empresa Q-Sense, Suécia) foi utilizada para avaliação da adsorção do polianfótero em superfícies modelos. O instrumento está acoplado a uma bomba com seringa com fluxo contínuo de entrada fixado em $130 \mu \mathrm{l} / \mathrm{min}$ para todos os experimentos. As mudanças na frequência de ressonância do cristal de quartzo devido à adsorção do polianfótero foram monitoradas em tempo real permitindo, assim, o estudo da dinâmica do processo de adsorção. A mudança na dissipação de energia, relacionada ao amortecimento da oscilação do sensor, foi utilizada para estudos das propriedades viscoelásticas das camadas adsorvidas. Esta informação foi relevante no entendimento da relação entre a estrutura da camada adsorvida e o grau de hidratação das macromoléculas na interface.

As mudanças na frequência de ressonância foram assumidas como sendo diretamente proporcional à massa de polianfótero adsorvida para camadas rígidas de acordo com o reportado na literatura (SAUERBREY, 1959). Para camadas viscoelásticas, o modelo de Voigt foi usado na determinação da massa específica e da espessura da camada adsorvida (MUNRO; FRANK, 2004; TAMMELIN et al., 2006; VOGT et al., 2004; VOINOVA et al., 1999). Os dados usados no modelo de 
Voigt, com o auxílio do software Q-Tools, incluindo a densidade e a viscosidade do meio de dispersão na presença de $168 \mathrm{mg} / \mathrm{L}$ de polianfótero, foram obtidos experimentalmente (Tabela 5.4). As densidades da solução de polianfótero em cada concentração de sal foram obtidas através da medição do peso para um volume fixo de $5000 \mu \mathrm{l}$ com 0,0001g de precisão usando a balança fabricada pela Adventurer SL de Ohaus. A viscosidade foi determinada segundo a norma TAPPI T230 om-89 usando o viscosímetro fabricado pela empresa Cannon Instrument. Os valores médios destes parâmetros foram determinados com quatro repetições a temperatura ambiente, $25^{\circ} \mathrm{C}$.

Tabela 5.4 - Resultados de densidade e de viscosidade do meio de dispersão na presença de $168 \mathrm{mg} / \mathrm{L}$ de polianfótero para diferentes condições de força iônica

\begin{tabular}{rccccc}
\hline & \multicolumn{5}{c}{ Concentração de sal, mM [NaCl] } \\
\cline { 2 - 6 } Parâmetro do fluido & 0,1 & 1 & 10 & 100 & 1000 \\
Densidade $\left(\rho_{\mathrm{f}}\right), \mathrm{kg} / \mathrm{m}^{3}$ & 1002,94 & 1000,23 & 1002,31 & 1005,74 & 1043,72 \\
\hline Viscosidade $\left(\eta_{\mathrm{f}}\right), \mathrm{kg} / \mathrm{m} . \mathrm{s}$ & 0,00107 & 0,00109 & 0,00100 & 0,000968 & 0,00187 \\
\hline
\end{tabular}

A densidade da camada do polianfótero usado neste estudo foi calculada como $\rho_{P A n f}$ $=1255 \mathrm{~kg} / \mathrm{m}^{3}$ pela Equação 5.2:

$\rho_{\text {PAnf }}=x_{1} \rho_{1}+x_{2} \rho_{2}+x_{3} \rho_{3}$

Equação 5.2

Em que, DMAPAA ${ }^{35}, x_{1}=0,2 \mathrm{~mol} / \mathrm{mol}$ e $\rho_{1}=952 \mathrm{~kg} / \mathrm{m}^{3} ; \mathrm{PAM}^{36}, x_{2}=0,72 \mathrm{~mol} / \mathrm{mol} \mathrm{e}$ $\rho_{2}=1302 \mathrm{~kg} / \mathrm{m}^{3}$; e IA ${ }^{37}, x_{3}=0,08 \mathrm{~mol} / \mathrm{mol}$ e $\rho_{3}=1573 \mathrm{~kg} / \mathrm{m}^{3}$ (Whitaker Oil Company, 2008).

35 ChemYQ. China. N,N-dimethyl aminopropyl acrylamide; DMAPAA. Disponível em: <http://www.chemyq.com/En/xz/xz13/127669cadgx.htm>. Acesso em: 21 dez. 2008.

${ }^{36}$ NIANWEI, Y.; KEQIANG, C. Ultrasonically initiated emulsifier-free emulsion copolymerization of $n-$ butyl acrylate and acrylamide. Part I: Polymerization mechanism Polymer. Polymer, v. 45, p. 35873594, 2004. 
Assim, considerando que a camada do polianfótero está $50 \%$ hidratada, $0,5 \mathrm{~mol} / \mathrm{mol}$, a densidade efetiva da camada usada no software $Q$-Tools foi de $1128 \mathrm{~kg} / \mathrm{m}^{3}$ $(1128 \times 0,5+1000 \times 0,5)$. Apesar de a densidade da camada ter sua quantidade de água arbitrada, análises de sensibilidade realizada com outros valores de densidade mostraram pequenas diferenças nos parâmetros de saída do software Q-Tools. Além disso, esse valor é usado apenas como dado de entrada para fins comparativos.

Os resultados de mudança em frequência e de dissipação de energia foram monitorados com o tempo, antes e depois da injeção do polímero, para os diferentes substratos e as diferentes condições de força iônica e de $\mathrm{pH}$. No final do processo de adsorção foram efetuadas lavagens com o respectivo meio de dispersão, sem polímero, com o objetivo de determinar a quantidade de polímero efetivamente adsorvida. Durante os experimentos, o conjunto célula-líquido foi estabilizado em 25 ${ }^{\circ} \mathrm{C}$ e cada solução foi injetada paralelamente à superfície de adsorção através de uma bomba a um fluxo contínuo de $130 \mu \mathrm{l} / \mathrm{min}$. Antes da injeção da solução com polímero, as superfícies modelos eram montadas nas células, injetada a solução sem polímero e o conjunto era deixado em repouso durante à noite para atingir o equilíbrio, visando boa linha de base. Todos os experimentos com a balança microgravimétrica foram repetidos pelo menos duas vezes. Das doze frequências harmônicas, em cada repetição, os resultados foram salvos para as primeiras cinco frequências, $3^{\circ}, 5^{\circ}, 7^{\circ}, 9^{\circ}$ e $11^{\circ}$. Destas cinco frequências harmônicas, os resultados da terceira são usados na avaliação dos resultados.

Para avaliação do efeito do $\mathrm{pH}$ na adsorção do polianfótero, foram adotados três níveis de $\mathrm{pH} 4,3 ; 6,5$ e 8,5. Substratos de óxido de silício previamente preparados de acordo com o descrito no tópico 4.2 .3 do capítulo 4, foram utilizados como superfícies modelos nos experimentos de efeito de $\mathrm{pH}$ na adsorção de polianfóteros.

Substratos de óxido de silício e superfícies de filme de celulose, estas preparadas de acordo com o descrito nos tópicos 4.2.3 e 4.2.2 do capítulo 4, respectivamente, foram utilizados para avaliação do efeito da força iônica na adosorção do polímero.

\footnotetext{
${ }^{37}$ Whitakeroil Oil Company. United States. Itaconic Acid - Material Safety Data Sheet. Disponível em: <http://www.whitakeroil.com/product-details/items/485.html>. Acesso em: 21 dez. 2008.
} 
As condições fixas de pH 4,3 em cinco níveis de força iônica, 0,1; 1,0;10;100 e 1000 mM, foram adotadas. A dinâmica de adsorção e o grau de hidratação das camadas adsorvidas foram avaliadas nas condições de $\mathrm{pH}$ fixo e força iônica variada. As espessuras das camadas e as quantidades de massa adsorvidas foram avaliadas para diferentes condições de concentração de sal.

A descrição detalhada do princípio de funcionamento da balança microgravimétrica pode ser encontrada do tópico 4.3.1 do quarto capítulo.

\subsection{Microscopia de força atômica}

Antes de proceder com as imagens no microscópio de força atômica (AFM), foram realizados os testes de adsorção do polímero em contato com superfícies dos wafers de silício, $(15 \times 15) \mathrm{mm}^{2}$ conforme a seguir. Soluções do polianfótero com $168 \mathrm{mg} / \mathrm{L}$, para cada nível de $\mathrm{pH}(4,3 ; 6,5$ e 8,5) a concentração fixa de sal de 10 $\mathrm{mM}$, foram preparadas. Os substratos de silício foram fixados em pinças metálicas, na posição vertical, e imersos em $40 \mathrm{~mL}$ de solução do polímero em becker. Durante o processo de adsorção, o sistema foi continuamente agitado. Todos os testes de adsorção nos wafers de sílicio foram feitos sob as mesmas condições com variação do $\mathrm{pH}$ de adsorção. Conforme mostrado na Figura 5.5A, o tempo de 30 min também foi utilizado como o tempo de incubação nos testes de adsorção nos wafers de sílicio. Depois deste tempo, o processo de adsorção foi interrompido e os substratos com o filme de polianfótero foram lavados com solução sem polímero sob as mesmas condições de $\mathrm{pH}$ e de concentração de sal. Os filmes foram secos com nitrogênio e armazenados em placas de Petri dentro do dessecador contendo sílica gel. As imagens foram realizadas em AFM Nanoscope III da Digital Instrument Co, EUA, no modo de contato intermitente. Duas áreas foram escaneadas para estudo, $(5 \times 5)$ e $(1 \times 1) \mu m^{2}$.

A descrição detalhada do princípio de funcionamento da microscópia de força atômica pode ser encontrada do tópico 4.3.2 do quarto capítulo. 


\subsection{RESULTADOS E DISCUSSÃO}

\subsubsection{Efeito do polianfótero na resistência do papel}

O efeito do polianfótero na resistência a seco do papel foi verificado para diferentes dosagens do polímero, em diferentes condições de $\mathrm{pH}$ e de força iônica. No estudo de cada efeito, as outras duas variáveis permaneceram constantes.

\subsubsection{Efeito da dosagem do polianfótero}

O efeito da dosagem do polianfótero na resistência do papel foi estudado em três níveis, através de medições do comprimento de autorruptura da folha, norma TAPPI T404, e do teste de determinação da resistência interfibras por área de amostra de papel, Teste de Scott Bond, norma TAPPI T833 pm-94. Pode ser observado que tanto o comprimento de autorruptura (Figura 5.6) quanto à resistência das ligações interfibras (Figura 5.7), aumentaram com a dosagem do polímero. Estes resultados estão de acordo com os resultados encontrados por de Yamaguchi et al. (2008). Estes autores estudaram o efeito da dosagem de polímero em fibras curtas de fábrica americana. Eles utilizaram amostra de polianfótero com densidade de carga inferior ao polianfótero utilizado neste trabalho, 5:2 mol \% para a proporção dos grupos positivo e negativo, nas condições de $\mathrm{pH}$ 7,0 e $1000 \mu \mathrm{S} / \mathrm{cm} \mathrm{Na}_{2} \mathrm{CO}_{3}$. 


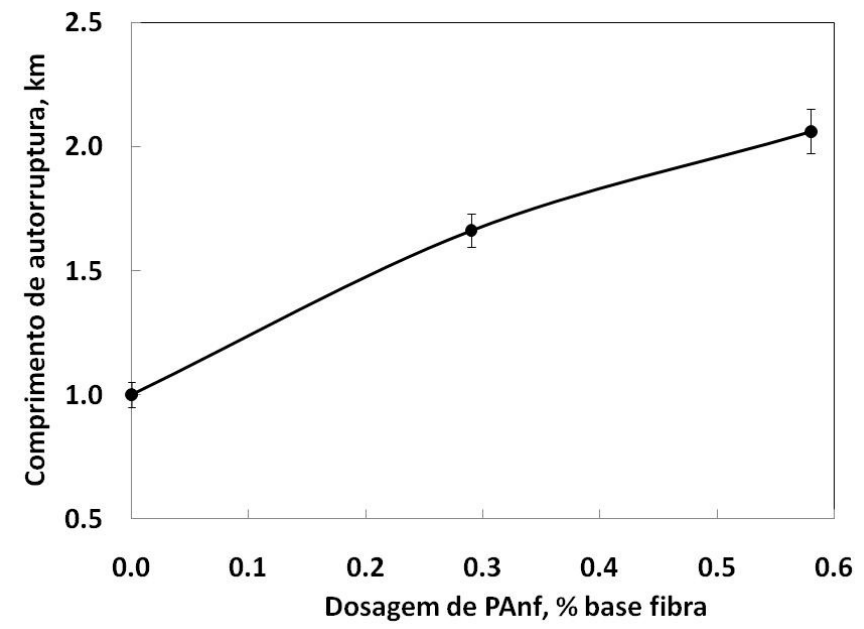

Figura 5.6 - Efeito da dosagem do polianfótero no comprimento de autorruptura do papel. Condições dos testes de adsorção: $168 \mathrm{mg} / \mathrm{L}, 1 \mathrm{mM}[\mathrm{NaCl}]$ e $25^{\circ} \mathrm{C}$.

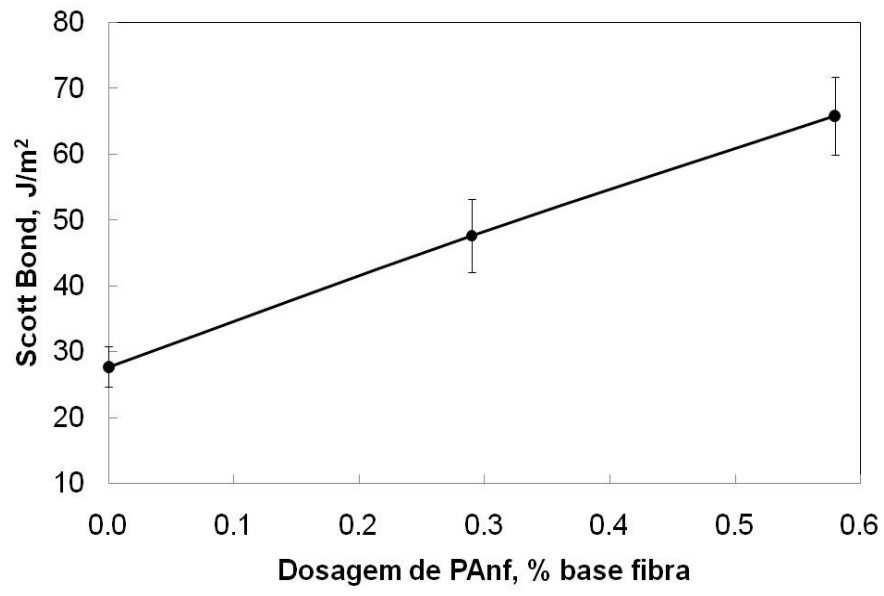

Figura 5.7 - Efeito da dosagem do polianfótero nos resultados de resistência das ligações interfibras medidos pelo teste de Scott Bond. Condições dos testes de adsorção: $168 \mathrm{mg} / \mathrm{L}, 1 \mathrm{mM}[\mathrm{NaCl}]$ e $25^{\circ} \mathrm{C}$.

De acordo com a Figura 5.8 também pode ser observado que a quantidade de polímero efetivamente adsorvida pela superfície das fibras também foi diretamente proporcional à dosagem para a faixa utilizada. Isso poderia contribuir com o aumento da força de ligação em nível molecular e com o aumento da área de ligação interfibras, conforme reportado por Page (1969). Comportamento semelhante foi 
encontrado por Sezaki et al. (2006b) quando estes autores estudaram o efeito da concentração de três polianfóteros tribloco na quantidade adsorvida sobre 0 substrato de fibra de celulose, com diferentes proporções para os grupos positivos e negativos.

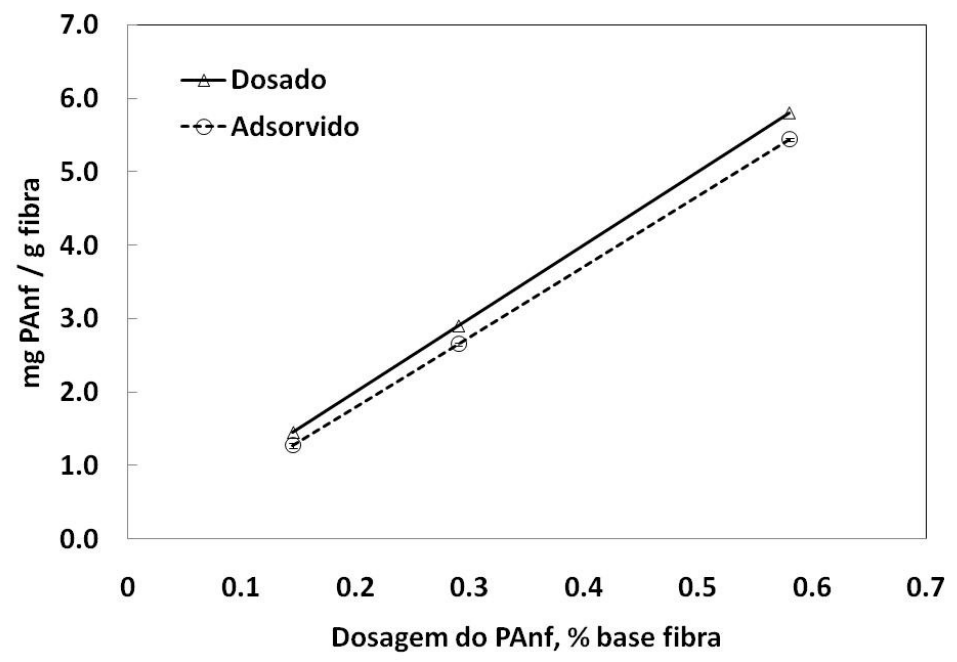

Figura 5.8 - Comparação entre a quantidade dosada de polianfótero e a quantidade adsorvida na superfície da fibra. Condições dos testes de adsorção: $168 \mathrm{mg} / \mathrm{L}, 1 \mathrm{mM}$ $[\mathrm{NaCl}], \mathrm{pH} 6,5$ e $25^{\circ} \mathrm{C}$.

\subsubsection{Efeito do $\mathrm{pH}$}

O estudo do efeito do $\mathrm{pH}$ na resistência do papel foi realizado em quatro valores de $\mathrm{pH}$, incluindo o ponto isoelétrico, usando dosagem fixa de $0,3 \%$ de polianfótero base polpa seca, através da avaliação da propriedade índice de tração. Como pode ser verificado na Figura 5.9, os resultados mais elevados para o índice de tração foram encontrados em valores de $\mathrm{pH}$ intermediários. Melhor resultado foi encontrado no $\mathrm{pH}$ do ponto isoelétrico, $\mathrm{pH}$ 7,3. Considerando valores de $\mathrm{pH}$ mais baixos, os resultados de índice de tração aumentam do $\mathrm{pH}$ ácido para $\circ \mathrm{pH}$ do ponto isoelétrico $(7,3)$. Após este ponto, a resistência cai drasticamente. Este comportamento está de acordo com o encontrado por Hubbe et al. (2007a) para polpa de fibra curta 
branqueada, onde foram considerados três níveis de pH: 4,0;5,0 e 8,5. Estes autores usaram amostras de polianfóteros com a mesma proporção dos grupos positivos e negativos que o polianfótero utilizado neste estudo. No caso deles, melhor resultado para comprimento de autorruptura foi encontrado para $\mathrm{o} p \mathrm{H}$ intermediário $(\mathrm{pH} 5,0)$.

De acordo com os resultados mostrados neste trabalho (Figura 5.6) e no trabalho de Yamaguchi et al. (2008) sobre o efeito da dosagem no comprimento de autorruptura, pode-se esperar que a quantidade adsorvida, a qual foi proporcional a dosagem de polímero, exerce efeito importante na propriedade de resistência do papel. Embora os autores Sezaki et al. (2006b), Mahltig et al. (1999); por Mahltig et al. (2000) e Tran et al. (2006) tenham verificado o efeito do pH na adsorção de polianfóteros em substratos modelos sem verificar o efeito na resistência do papel, estes autores mostraram que a maior quantidade adsorvida deste tipo de polímero se encontrava próximo ao ponto isoelétrico. Fato este que coincide com o resultado mais elevado de índice de tração alcançado neste trabalho (Figura 5.9).

Sezaki et al. (2006b) verificaram, também, que polianfóteros negativamente carregados ou simétricos (carga nula) eram significativamente adsorvidos sobre as fibras. Entretanto, a quantidade adsorvida era menor quando comparada com o polímero positivamente carregado. O mesmo também foi encontrado por Dobrynin; Rubinstein e Joanny (1997) considerando estudos teóricos. Considerando os resultados observados nos dois estudos anteriores, pode-se verificar que a possível adsorção que ocorreu em superfícies com os mesmos sinais, fibra e polímero, para $\mathrm{pH}$ acima do ponto isoelétrico, $\mathrm{pH} 8,5$, não teve efeito positivo nos resultados de resistência do papel (Figura 5.9). Por outro lado, partindo do $\mathrm{pH}$ com carga líquida positiva, $\mathrm{pH} 4,3$, até a carga neutra, $\mathrm{pH}$ 7,3, o índice de tração aumenta em torno de $21 \%$. No caso do ponto isoelétrico, o desenvolvimento da carga líquida negativa na superfície da fibra e a neutralização do polímero favoreceram as ligações interfibras. A polarização da cadeia através do campo elétrico externo (DOBRYNIN, A. V., OBUKHOV, S. P., RUBINSTEIN, 1999, e SONG, 2008) e a adsorção em camadas favorecida pela separação de fases na interface sólido-líquido (SONG et al., 2010) podem ter favorecido a adsorção de maiores quantidades de polímero em valores de $\mathrm{pH}$ próximos ao ponto isoelétrico. 


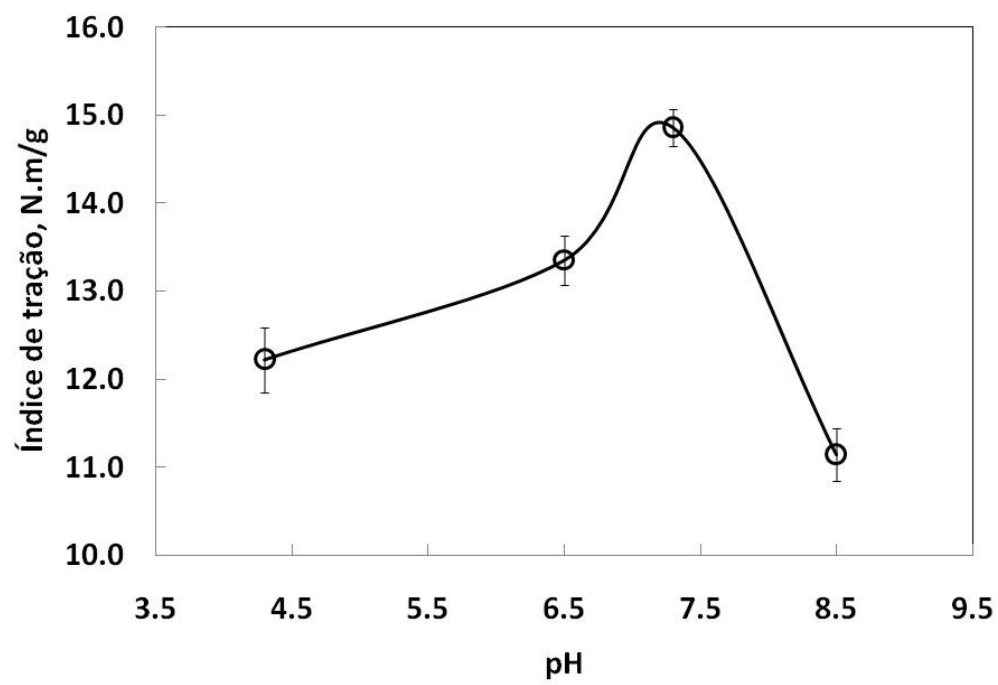

Figura 5.9 - Efeito do pH no índice de tração do papel. Condições dos testes de adsorção: dosagem de $0,3 \%$ base polpa seca, $168 \mathrm{mg} / \mathrm{L}, 10 \mathrm{mM}[\mathrm{NaCl}]$ e $25^{\circ} \mathrm{C}$.

\subsubsection{Efeito da força iônica}

Na Figura 5.10 são mostrados os resultados do estudo do efeito da força iônica na resistência do papel em três níveis de concentração de sal (5, 10 e 100 mM). De acordo com os resultados, não houve diferença significativa nesta propriedade para os níveis estudados.

Embora seja evidente na literatura o aumento da adsorção do polianfótero com o aumento da concentração de sal, tal como descrito em Mahltig et al. (1999) e em Sezaki et al. (2006b), isto não implicou em aumento do índice de tração. Confrontese Figura 5.9 em relação à variação de $\mathrm{pH}$ com a Figura 5.10 para extremo de $\mathrm{pH}$ 4,3 em relação à concentração de sal.

Mesmo considerando que haja uma tendência de aumento desta propriedade com o aumento da concentração do sal (Figura 5.10), a grande variabilidade dos resultados não permite dizer que estes parâmetros sejam diretamente proporcionais.

$\mathrm{Na}$ literatura explica-se que é esperado que haja mudança na conformação de polieletrólitos monocarregados e polianfóteros com a variação da concentração de 
sal na solução. De acordo com Bohidar (2002) polieletrólitos e polianfóteros respondem de forma diferente quando a concentração de sal do sistema varia a depender do pH. Considerando os polianfóteros, a elevação da concentração de sal faz com que estas moléculas tomem a forma estendida, especialmente no seu ponto isoelétrico, porque os eletrólitos impedem a interação eletrostática entre os sítios positivos e negativos da cadeia. Por outro lado, há encolhimento das cadeias de polieletrólitos monocarregados com o aumento da concentração de sal.

As repetições dos resultados dos testes físicos de encontram no Apêndice $B$ de acordo com o que segue: Tabela B1, efeito da dosagem no comprimento de autorruptura; Tabela B2, efeito da dosagem nas ligações interfibras; Tabela B3, efeito do $\mathrm{pH}$ no índice de tração para dosagem fixa de PAnf de 0,3\%, e Tabela B4, efeito da força iônica no índice de tração para dosagem fixa de PAnf de $0,3 \%$.

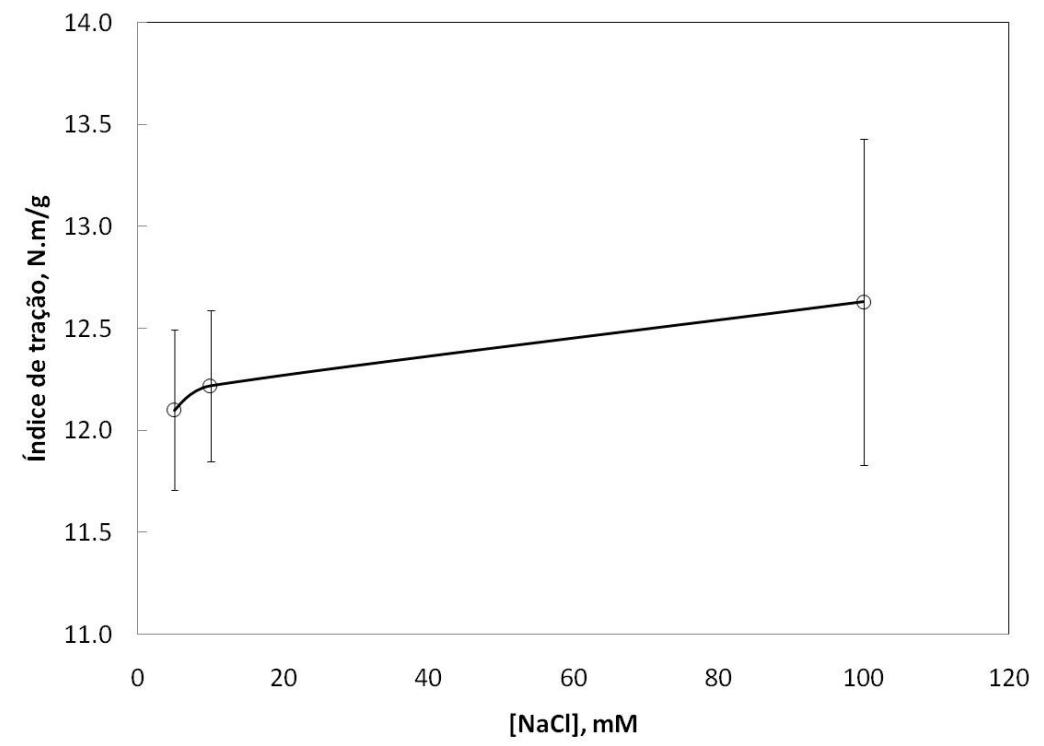

Figura 5.10 - Efeito da força iônica no índice de tração. Condições dos testes de adsorção: dosagem de 0,3\% base polpa seca ,168 mg/L, pH 4,3 e $25^{\circ} \mathrm{C}$. 


\subsubsection{Estudo do polianfótero em nível molecular}

Estudos em superfícies modelos em escala nanométrica, considerando as condições de $\mathrm{pH}$ e de força iônica, foram aqui desenvolvidos em nível molecular com o objetivo de correlacionar com os resultados de resistência do papel através da adsorção do polianfótero na superfície de fibras celulósicas.

\subsubsection{Efeito do pH}

O estudo do efeito do pH no comportamento de adsorção em substrato de sílica do polianfótero foi realizado em 3 níveis para concentração de sal fixa de $10 \mathrm{mM} \mathrm{NaCl}$ e temperatura de $25^{\circ} \mathrm{C}$. Todos estudos de adsorção foram realizados com o auxílio de técnicas nanométricas como balança microgravimétrica com dissipação de energia, espalhamento dinâmico de luz, microscopia de força atômica, dentre outras.

\subsection{Polianfótero em solução}

Para polianfóteros assimétricos, de elevada densidade de carga, como o usado neste estudo, o efeito do $\mathrm{pH}$ foi muito significativo. Neste estudo, o efeito do $\mathrm{pH}$ no comportamento do polianfótero em solução foi avaliado considerando três parâmetros: (a) a turbidez da solução e (b) o diâmetro hidrodinâmico das partículas (Figura 5.11), e (c) a densidade de carga líquida das cadeias do polímero em solução (Figura 5.12). Para todos os parâmetros, os resultados foram diferentes na faixa de $\mathrm{pH}$ estudada.

Para valores de $\mathrm{pH}$ extremos, o polímero se apresenta na condição estável e no estado solúvel na forma individual ou em pequenos agregados, os quais apresentam pouca tendência em espalhar a luz (Figura 5.11 - Detalhe: solução transparente, podendo ser vista a bancada do laboratório de cor branca). Neste caso, os resultados de turbidez foram baixos e são esperados tamanhos de partículas pequenos. Por outro lado, para valores intermadiários de $\mathrm{pH}$, as 
macromoléculas se tornam instáveis formando estruturas de tamanhos maiores as quais produzem elevada turbidez (Figura 5.11 - Detalhe: solução turva dificultando a visibilidade da bancada de cor branca). Observa-se também que, em valores de $\mathrm{pH}$ próximos ao ponto isoelétrico (veja Figura 5.12), a turbidez é reduzida o que leva à formação de dois pontos de máxima turbidez na faixa de $\mathrm{pH}$ estudada, antes e depois do ponto isoelétrico. Comportamento similar foi encontrado por Hubbe et al. (2007a) para polianfótero semelhante ao utilizado neste trabalho (20:8), porém com menor densidade de carga (5:2). A redução dos valores de turbidez próximo ao ponto isoelétrico está consistente com o tamanho dos agregados de moléculas neste ponto, $2211 \mathrm{~nm}$, o qual foi consideravelmente mais elevado do que o comprimento de onda da luz promovendo baixa eficiência no espalhamento de luz. Estes resultados estão consistentes com a formação de agregados de macromoléculas que pode resultar numa proporção mais elevada de espaços livres entre os volumes de agregados ocupados pelos cadeias de polianfóteros. Em estudos de literatura também foi observado que a formação de agregados aumenta a turbidez de soluções de polianfóteros (MAHLTIG et al., 1999; PATRICKIOS et al., 1999; MAHLTIG et al., 2000; SEZAKI et al., 2006a). Explicação para a formação de agregados foi dada por Cheong e Panagiotopoulos (2005) apud Dobrynin $(2008)^{38}$. Estes autores sugerem que as interações eletrostáticas entre os monômeros de cargas opostas promovem a separação de fases das cadeias de polianfóteros em solução, ocorrendo a precipitação das cadeias.

No presente estudo, os valores encontrados para o parâmetro diâmetro hidrodinâmico médio das partículas foram mais elevados do que os valores reportados nos trabalhos de Mahltig et al. (2000) e de Mahltig et al. (1999). Este fato pode ser explicado pelo peso molecular mais elevado e pela distribuição aleatória dos monômeros no caso do polímero usado neste trabalho, diferentemente dos polianfóteros diblocos usados nos dois trabalhos de Mahltig e coautores.

A explicação exata para os dois pontos de máximos não foi encontrada na literatura. No entanto, o balanço entre os grupos positivos e negativos como explicação é

38 CHEONG, D.W.; PANAGIOTOPOULOS, A.Z. Phase behaviour of polyampholyte chains from grand canonical Monte Carlo simulations. Mol Phys, v. 103, p. 031-3044, 2005 apud DOBRYNIN, A. $\mathrm{V}$. Theory and simulations of charged polymers: From solution properties to polymeric nanomaterials. Current Opinion in Colloid \& Interface Science, v. 13, p. 376-388, 2008. 
citado em alguns trabalhos (MAHLTIG et al., 1999; SEZAKI et al., 2006a; HUBBE et al., 2007a). Além disso, nem todos os polianfóteros apresentam este comportamento, considerando suas características e as condições do meio. Entretanto, uma explicação é sugerida neste trabalho. A partir do pH ácido, quando o polianfótero estudado apresenta características mais próximas de um polieletrólito monocarregado, o desenvolvimento de carga negativa com o aumento do $\mathrm{pH}$ parece promover preferencialmente as interações intramoleculares do que as interações intermoleculares (faixa de pH 3,5 até 6,5 da Figura 5.11). Neste caso, o aumento da turbidez e do tamanho das partículas apresentam comportamentos semelhantes. Por outro lado, a partir do $\mathrm{pH} 6,5$ até o ponto isoelétrico, as interações intermoleculares com a separação de fases e redução da solubilidade do polianfótero, parecem ser preferenciais, culminando no ponto isoelétrico, $\mathrm{pH} 7,3$. Dessa forma, os resultados de turbidez e tamanho de partícula apresentam comportamentos opostos. A partir do $\mathrm{pH}$ no ponto isoelétrico, o comportamento parece se inverter com o aumento do número de grupos negativos em relação aos positivos na macromolécula, até alcançar novamente macromoléculas com grande número de grupos negativos e com comportamento mais próximo de um polieletrólito comum.

A variação da turbidez ao longo do pH é reduzida com o aumento da força iônica do meio conforme pode ser verificado mais adiante na Figura 5.15. Neste caso, o efeito da blindagem de cargas se torna mais significativo (FLEER et al., 1993). É interessante observar que, no caso do polianfótero estudado, processo de separação de fases, ou seja, a solubilidade, é reversível e dependente do pH. 

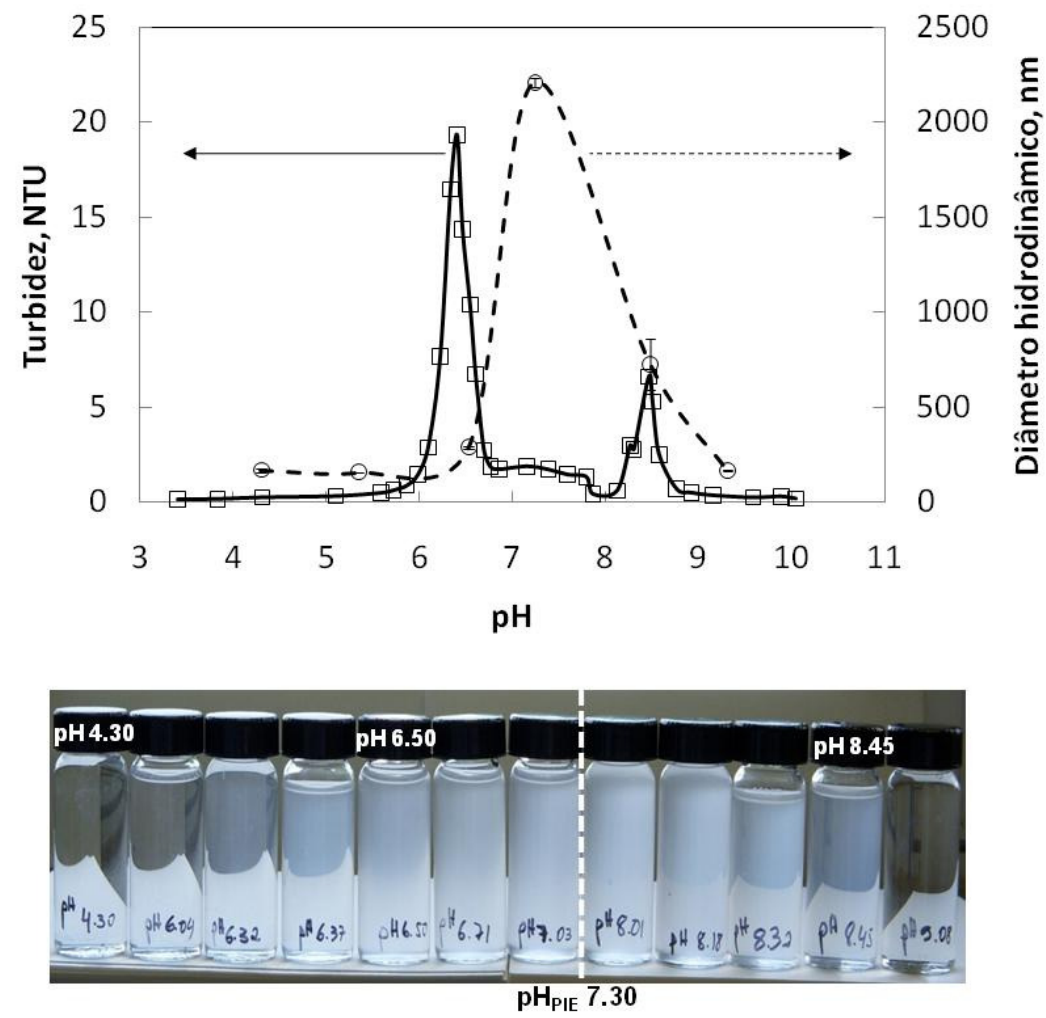

Figura 5.11 - Efeito do pH na turbidez e no diâmetro hidrodinâmico de partículas de polianfóteros em solução. A fotografia abaixo ilustra a diferença de turbidez para a faixa de $\mathrm{pH}$ estudada. Condições dos testes de adsorção: $168 \mathrm{mg} / \mathrm{L}$ (turbidez) e 336 $\mathrm{mg} / \mathrm{L}$ (diâmetro hidrodinâmico), $10 \mathrm{mM}[\mathrm{NaCl}]$ e $25^{\circ} \mathrm{C}$.

Em valores de $\mathrm{pH}$ extremos, o polianfótero parece assumir o comportamento de um polieletrólito monocarregado. Neste caso, para valores de $\mathrm{pH}$ ácidos, a densidade de carga líquida resultante foi positiva e o oposto pode ser observado em valores de $\mathrm{pH}$ alcalinos (Figura 5.12).

O valor de pH para o ponto isoelétrico do polianfótero estudado maior do que 7 está de acordo com o encontrado por Mahltig et al. (2001). Estes autores observaram que quanto maior a proporção entre os monômeros negativos para positivos, mais ácido se torna o ponto isoelétrico $(\mathrm{PI})$. Por outro lado, quanto menor esta proporção, mais alcalino se torna o ponto isoelétrico. Estes autores utilizaram três polianfóteros com pesos moleculares semelhantes, porém, com diferentes proporções entre os 
grupos negativos e positivos, PMAA-b-PDMAEMA: 84:16, $\mathrm{pH}_{\mathrm{PI}} 3,8 ; 55: 45, \mathrm{pH}_{\mathrm{PI}} 5,9$, e 29:71, $\mathrm{pH}_{\mathrm{PI}} 8,9$.

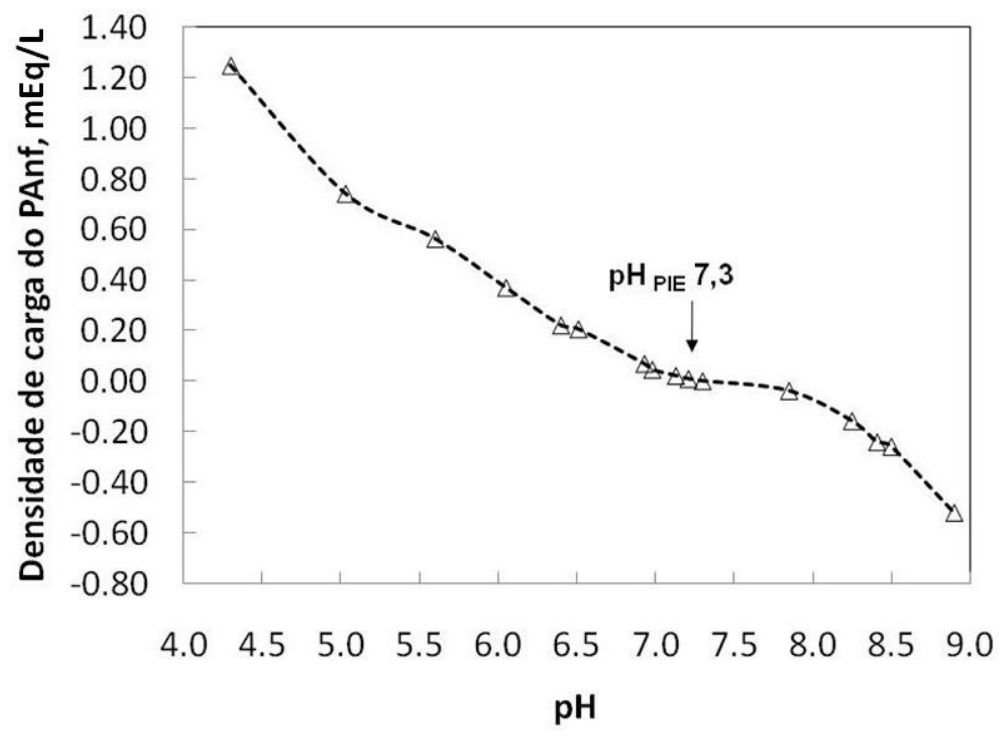

Figura 5.12 - Efeito do $\mathrm{pH}$ na densidade de carga líquida do polianfótero. Condições dos testes: $168 \mathrm{mg} / \mathrm{L}, 10 \mathrm{mM}[\mathrm{NaCl}]$ e $25^{\circ} \mathrm{C}$.

Os resultados de diâmetro hidrodinâmico, desvio padrão e índice de polidispersidade das cadeias do polianfótero em solução para os diferentes níveis de $\mathrm{pH}$ estudados e força iônica fixa de $10 \mathrm{mM} \mathrm{NaCl}$, se encontram nas Tabelas B5 a B8 do Apêndice B.

Os resultados de diâmetro hidrodinâmico, desvio padrão e índice de polidispersidade das cadeias do polianfótero em solução para os diferentes níveis de força iônica estudados e pH fixo de 4,3, se encontram nas Tabelas B9 e B10 do Apêndice B. A condição de $\mathrm{pH}$ 4,3 e força iônica $10 \mathrm{mM} \mathrm{NaCl}$ pode ser encontrada na Tabela B5 do mesmo apêndice. 


\subsection{Adsorção em superfícies modelos}

Os experimentos de adsorção do polianfótero em superfícies modelos para diferentes condições de $\mathrm{pH}$ foram realizados em substrato de sílica na balança microgravimétrica, e com wafers de silício e observação da camada adsorvida no microscópio de força atômica.

\subsection{Substratos de sílica}

Os testes de adsorção do polianfótero em substrato de sílica foram realizados com a balança microgravimétrica com dissipação de energia em três níveis de pH e com a concentração de sal e temperatura fixas. Estes testes têm como objetivo relacionar o comportamento de adsorção deste polímero em nível molecular com resultados práticos de testes de resistência do papel.

De acordo com as mudanças na frequência de ressonância com o tempo (Figura 5.13A), quantidade de polímero adsorvida mais elevada foi observada para o $\mathrm{pH} 8,5$ quando comparada com a quantidade adsorvida nas condições de $\mathrm{pH}$ 6,5 e 4,3, antes da lavagem com o meio de dispersão. Por outro lado, após a etapa de lavagem, a quantidade adsorvida foi mais elevada para o $\mathrm{pH}$ 6,5 quando comparada à quantidade adsorvida para o pH 8,5 (Figura 5.13A). Isto pode ser explicado pelas possíveis interações existentes entre a carga líquida positiva dos agregados de polímero em pH 6,5 (Figura 5.12) e a carga negativa da superfície de sílica. Conforme encontrado na literatura, a carga líquida da superfície de sílica é negativa na faixa de $\mathrm{pH}$ estudada: $\mathrm{pH} 4,0$ até 9,5 ; carga $-0,40$ até $-2,0 \mathrm{mC} / \mathrm{m}^{2}$ (RADTCHENKO; PAPASTAVROU; BORKOVEC, 2005). É esperado que as forças de interações eletrostáticas existentes entre cargas opostas tenham sido suficientementes fortes para manter os agregados adsorvidos na superfície para a condição de pH 6,5. Entretanto, a carga líquida negativa dos agregados de polianfóteros em pH 8,5, acima do ponto isoelétrico (Figura 5.12), não foi favorável para mantê-los adsorvidos. 
Considerando a dissipação de energia antes da lavagem, parâmetro que está relacionado com as propriedades viscoelásticas da camada adsorvida, valores mais elevados foram encontrados para a condição de $\mathrm{pH}$ próximo ao ponto isoelétrico,

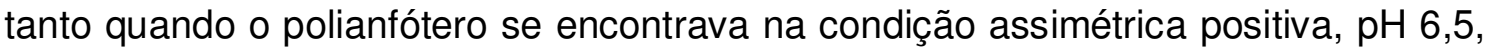
quanto para a condição de $\mathrm{pH}$ assimétrica negativa, $\mathrm{pH} 8,5$. Nestes valores de $\mathrm{pH}$, as camadas adsorvidas foram mais dissipativas do que a camada adsorvida na condição de pH 4,3 antes da etapa de lavagem. Forças de interação baixas entre os agregados de polianfótero e a superfície reduziram significativamente os valores de dissipação de energia para o valor de pH 8,5 depois da lavagem (Figuras 5.13 B). Neste caso, camada mais dissipativa foi encontrada para a condição de pH 6,5 após a lavagem.

A Tabela 5.5 mostra o resumo dos resultados dos testes para efeito de $\mathrm{pH}$. Os resultados dos testes para verificação do efeito de $\mathrm{pH}$ em superfície modelo com a balança microgravimétrica após a lavagem estão coerentes com os resultados dos testes do efeito do $\mathrm{pH}$ na resistência do papel, quando consideramos a variação de frequência relacionada com a quantidade de massa adsorvida e a dissipação de energia relacionada com a viscoelasticidade da camada. Dentre os três valores de $\mathrm{pH}$ avaliados com a balança microgravimétrica ( $\mathrm{pH} 4,3 ; 6,5$ e 8,5), o pH 6,5 apresentou índice de tração mais elevado em relação aos valores de pH extremos, 4,3 e 8,5. De certa forma, a comparação entre os resultados dos testes com a balança microgravimétrica na condição após a lavagem situa-se próximo da situação real para a etapa de formação de folhas. Nesta etapa, a consistência da suspensão de fibras durante a adsorção do polianfótero é de 0,5\%. Porém, para a formação de folha, quantidade de água destilada com as mesmas condições de $\mathrm{pH}$ e força iônica foi adicionada ao formador de forma que a consistência de formação situou-se em 0,04\%. Esta água pode ter removido parte do polianfótero que não estava fortemente aderida à superfícies das fibras. Entretanto, os resultados de variação na frequência e na dissipação de energia antes da lavagem foram proporcionais aos resultados de diâmetro hidrodinâmico de partícula, mostrando a relação entre a estrutura da camada adsorvida com as estruturas das macromoléculas na interface sólido-líquido durante o processo de adsorção (Tabela 5.5). 

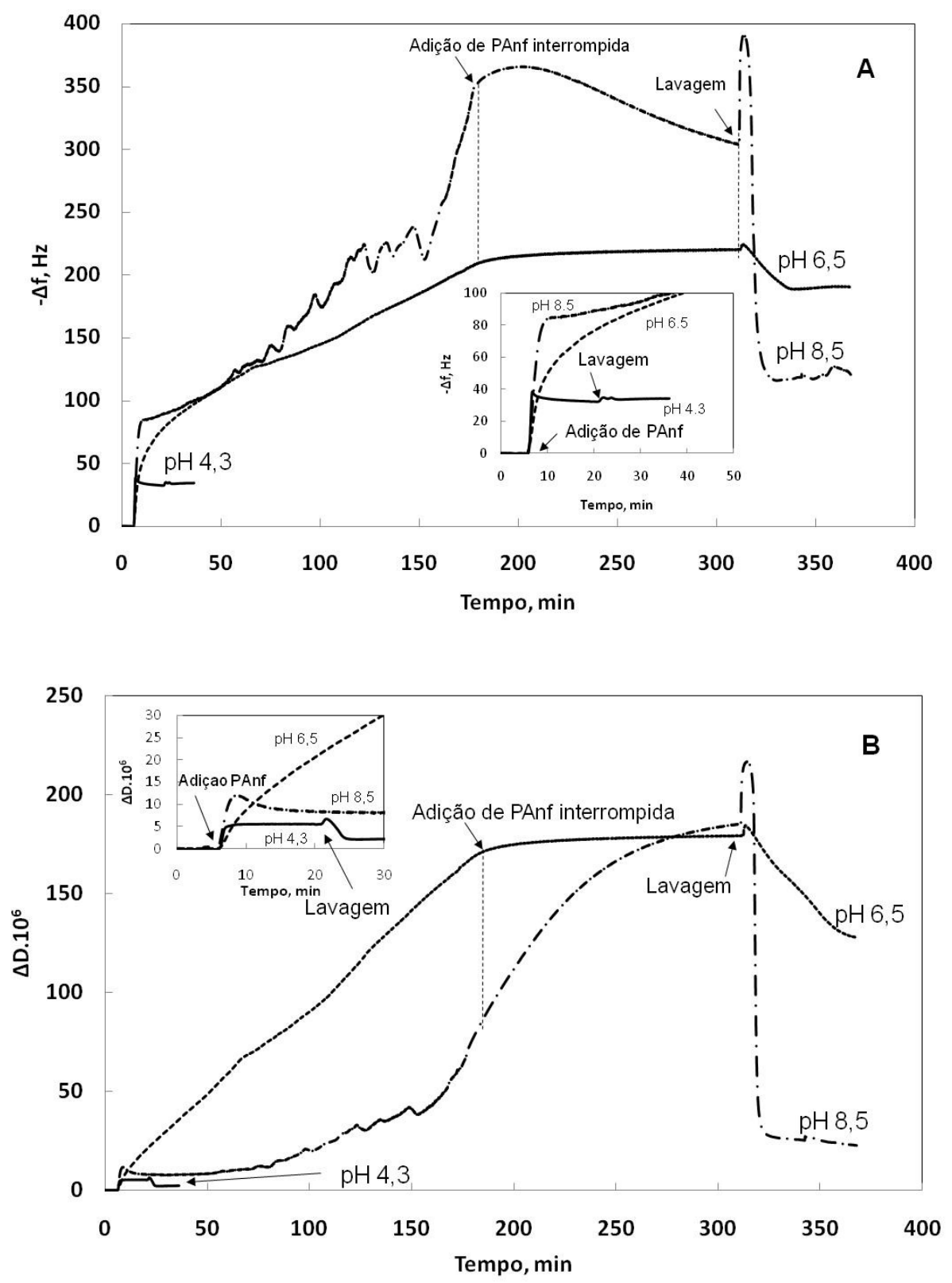

Figura 5.13 - (A) Efeito do pH nas mudanças de frequência de ressonância e nas (B) mudanças de dissipação de energia para diferentes níveis de $\mathrm{pH}$ e força iônica constante, medidos com a balanças microgravimétrica. Condições dos testes de adsorção: $10 \mathrm{mM}$ [NaCl], $168 \mathrm{mg} / \mathrm{L}$ [PAnf], $130 \mu \mathrm{l} / \mathrm{min}$ de vazão e $25^{\circ} \mathrm{C}$.

A dissipação de energia das camadas adsorvidas está diretamente relacionada com o seu grau de hidratação, ou seja, com a viscoelasticidade da camada. Portanto, é 
esperado que certa quantidade de água esteja armazenada dentro dos agregados formados em valores de $\mathrm{pH}$ próximos ao ponto isoelétrico. A habilidade de dissipação de energia dessas camadas provavelmente é responsável pelo aumento da resistência ao cisalhamento por unidade de área ligada relacionada a força da ligação, $b$, e, ou, pelo aumento da área relativa ligada da folha de papel relacionada ao número de ligações, $R B A$ da Equação 5.1 de Page (1969). Estes dois fatores levam ao aumento da resistência do papel. Por outro lado, é esperado encontrar quantidade mínima de água armazenada nas macromoléculas de forma individual ou na forma de pequenos agregados para o valor de $\mathrm{pH}$ 4,3 (Figuras 5.13 A e B).

Tabela 5.5 - Resultados aproximados antes e após a etapa de lavagem para variação de frequência, dissipação de energia, diâmetro hidrodinâmico das partículas em solução e índice de tração do papel

\begin{tabular}{ccccc}
\hline $\mathrm{pH}$ & $\begin{array}{c}\text { Variação da } \\
\text { frequência, } \mathrm{Hz}\end{array}$ & $\begin{array}{c}\text { Variação da } \\
\text { dissipação de } \\
\text { energia, } 10^{6}\end{array}$ & $\begin{array}{c}\text { Diâmetro } \\
\text { hidrodinâmico, } \\
\mathrm{nm}\end{array}$ & $\begin{array}{c}\text { Indice de } \\
\text { tração, N.m/g }\end{array}$ \\
\hline 4,3 & $36^{*} / 37^{* *}$ & $5 / 2,2$ & 171 & 12,2 \\
\hline 6,5 & $225 / 185$ & $175 / 125$ & 289 & 13,4 \\
\hline 7,3 & - & - & 2211 & 14,9 \\
\hline 8,5 & $305 / 120$ & $185 / 20$ & 728 & 11,1 \\
\hline 9,3 & - & - & 169 & - \\
\hline
\end{tabular}

${ }^{*}$ Antes $e^{* \star}$ após a etapa de lavagem.

Testes de adsorção do polímero em QCM na condição de $\mathrm{pH}$ 7,3, ponto isoelétrico, não foram realizados. Entretanto, resultados de nossos testes a serem publicados, realizados com o mesmo polianfótero, mostraram mudanças de frequência de -420 $\mathrm{Hz}$ e de dissipação de energia de $225.10^{6}$, após a etapa de lavagem para a condição de pH 7 (SONG et al., 2010, ver no Apêndice C).

A Figura B1 do Apêndice B mostra os resultados de variação de frequência e de variação de dissipação de energia para os testes realizados nos níveis de $\mathrm{pH}$ 6,5 e 
8,5 com a adsorção do polianfótero em substrato de sílica. As repetições para o nível de $\mathrm{pH}$ 4,3 podem ser vistas na Figura B9 do mesmo apêndice.

\subsection{Wafer de silício}

A realização das imagens em microscópio de força atômica dos experimentos de adsorção do polianfótero sobre superfície de óxido de silício, nas mesmas condições de $\mathrm{pH}$ utilizadas nos testes com a balança microgravimétrica, tem como objetivo principal verificar, comparativamente, as topografias das camadas adsorvidas e as características do polianfótero na interface sólido-líquido. As imagens foram coletadas ao ar à temperatura ambiente em camadas de polianfóteros adsorvidas e secas sobre vácuo à temperatura de $43^{\circ} \mathrm{C}$ (Figura 5.14).

A partir destas imagens, pode-se observar que a superfície modelo foi completamente preenchida com polianfótero para as três condições de $\mathrm{pH}$ estudadas (Figura 5.14). As rugosidades das camadas adsorvidas sobre as superfícies de óxido de silício à $10 \mathrm{mM}[\mathrm{NaCl}]$, calculadas no scan $(5 \times 5) \mathrm{nm}^{2}$, estão de acordo com os valores médios de tamanho de partícula medidos em solução com a técnica de espalhamento dinâmico de luz (Tabela 5.6), sendo a rugosidade mais elevada alcançada para o sistema que apresentou diâmetro hidrodinâmico médio maior. Estes resultados estão de acordo com os resultados encontrados por Mahltig et al. (2000). Diferentes formas de agregados podem ser observadas quando as três imagens são comparadas (Figura 5.14, 3D). Superfície mais plana pode ser verificada na condição de $\mathrm{pH} 4,3$, enquanto que superfícies mais irregulares podem ser observadas nas imagens para as condições de pH 6,5 e 8,5.

Considerando os três níveis de $\mathrm{pH}$ estudados e os estudos teóricos e práticos de literatura, algumas considerações sobre o processo de adsorção do polianfótero podem ser colocadas. O polianfótero de elevado peso molecular e elevada densidade de carga estudado neste trabalho, forma agregados visíveis entre os valores de $\mathrm{pH} 6,0$ e 8,7, os quais de acordo com a literatura, são resultados separação de fases do polianfótero em pH próximo ao ponto isoelétrico (Cheong e 
Panagiotopoulos, 2005, apud DOBRYNIN, 2008) ${ }^{39}$. Este comportamento reflete no resultado de tamanho de partícula conforme pode ser visto na Figura 5.11. A partir

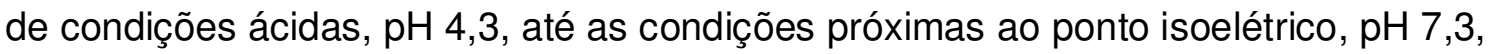
a adsorção destas estruturas aumenta com o aumento da densidade de carga da sílica devido ao aumento dos grupos silanol ( $\mathrm{SiO}^{-}$) dissociados na superfície do substrato (DUVAL et al., 2002) e devido à redução da solubilidade dos agregados em que ocorre a precipitação (Cheong e Panagiotopoulos, 2005, apud DOBRYNIN, 2008).
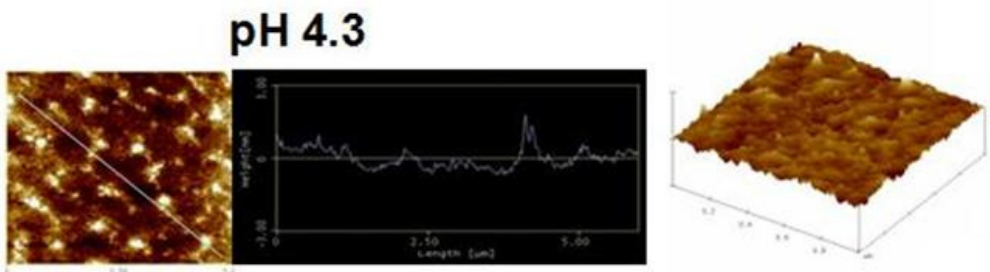

pH 6.5
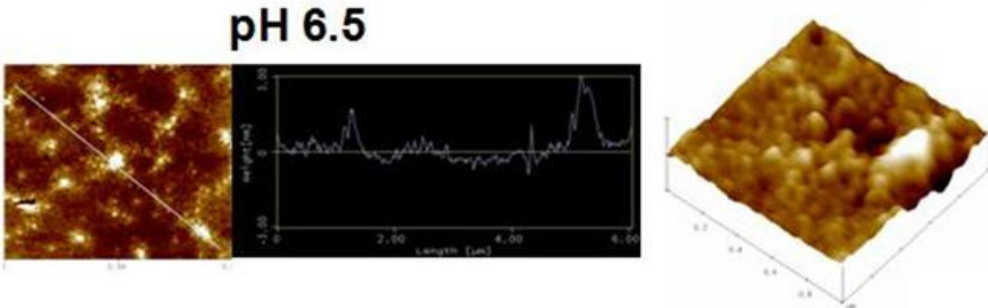

pH 8.5
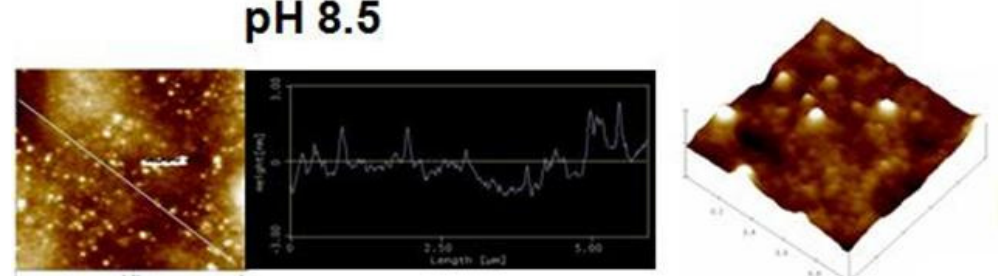

$(5 \times 5) \mu m^{2}$

(1x1) $\mu m^{2}$

Figura 5.14 - Imagens em microscopia de força atômica de camada de polianfótero, para três condições de $\mathrm{pH}, 2 \mathrm{D}$ à esquerda e 3D à direita. Detalhe cental: perfil de cada superfície, próximo a diagonal, com range variando de $-3,00 \mathrm{~nm}$ a 3,00 nm. Condições dos testes de adsorção: $10 \mathrm{mM}$ [NaCl], $168 \mathrm{mg} / \mathrm{L}$ [PAnf], $30 \mathrm{~min}$ de adsorção e $25^{\circ} \mathrm{C}$.

39 CHEONG, D.W.; PANAGIOTOPOULOS, A.Z. Phase behaviour of polyampholyte chains from grand canonical Monte Carlo simulations. Mol Phys, v. 103, p. 031-3044, 2005 apud DOBRYNIN, A. $\mathrm{V}$. Theory and simulations of charged polymers: From solution properties to polymeric nanomaterials. Current Opinion in Colloid \& Interface Science, v. 13, p. 376-388, 2008. 
Tabela 5.6 - Relação entre a rugosidade de superfície determinada através de AFM e o diâmetro hidrodinâmico, determinado através de DLS

\begin{tabular}{ccc}
\hline $\mathrm{pH}$ & Rugosidade, nm & Diâmetro hidrodinâmico, nm \\
\hline 4,3 & 0,32 & 171 \\
\hline 6,5 & 0,42 & 289 \\
\hline 8,5 & 0,60 & 728 \\
\hline
\end{tabular}

No caso de cargas opostas dos agregados de polímero e da superfície de adsorção, são esperadas que interações eletrostáticas sejam as principais responsáveis. Quanto mais próximo ao ponto isoelétrico, onde a superfície é negativa e os agregados se aproximam à densidade de carga nula, outros tipos de interações podem ser dominantes, como a polarização da cadeia devido ao campo elétrico gerado pela superfície (DOBRYNIN; RUBINSTEIN; JOANNY, 1997; SONG, 2008) e a precipitação das estruturas devido à baixa solubilidade (Cheong e Panagiotopoulos, 2005, apud DOBRYNIN, 2008). Interações entre a superfície negativa e agregados de polímeros com carga líquida negativa também podem ocorrer conforme reportado na literatura (DOBRYNIN; RUBINSTEIN; JOANNY 1997; SEZAKI et al., 2006b).

Pode-se levantar a hipótese de que a adsorção destes agregados de moléculas em superfícies carregadas pode ocorrer para valores de pH entre 6,0 e 8,7. Dessa forma, se os agregados pudessem ser polarizados através da indução de superfícies carregadas, a formação de mais de uma camada de agregado poderia ocorrer, como sugerido por Dobrynin; Obukhov e Rubinstein (1999). Entretanto, a separação de fases e precipitação dos agregados parece ser mais apropriada para este trabalho de acordo com os resultados alcançados. 


\subsubsection{Efeito da força iônica}

O estudo do efeito da força iônica no comportamento de adsorção do polianfótero em superfícies modelos e nas características das camadas de polímeros adsorvidas foi realizado em 5 níveis de concentração de sal, em pH e temperaturas fixas de $4,3 \pm 0,05$ e $25^{\circ} \mathrm{C}$, respectivamente. Todo estudo de adsorção foi realizado com auxílio de técnicas nanométricas como balança microgravimétrica com dissipação de energia, espalhamento dinâmico de luz, dentre outras. As superfícies modelos utilizadas foram as de substratos de sílica e de filmes de celulose.

\subsection{Polianfótero em solução}

Neste estudo, o efeito da força iônica no comportamento do polianfótero em solução foi avaliado considerando três parâmetros: (a) turbidez da solução, para cada concentração, ao longo da curva de pH (Figura 5.15); (b) diâmetro hidrodinâmico das partículas e (c) densidade de carga líquida do polímero em solução (Figura 5.16 A e $B$, respectivamente).

A Figura 5.15 apresenta, em escala semilogaritmica, os resultados de medição de turbidez para 35 pontos de $\mathrm{pH}$ para cada uma das concentrações de sal. Note-se nesta figura em destaque para $\mathrm{pH} 4,3$, os resultados de turbidez em função da concentração de sal, em escala semilogaritmica, o qual foi considerado para as discussões do efeito da força iônica na adsorção do polianfótero.

O efeito da força iônica na turbidez da solução de polianfótero para $\circ \mathrm{pH} 4,3$, embora tenha apresentado a tendência de aumento com a concentração de sal, os valores foram muito próximos conforme esperado (Figura em destaque da Figura 5.15). A diferença entre o maior e o menor valores foi de 0,25 NTU.

Conforme já discutido no tópico do efeito de $\mathrm{pH}$, as macromoléculas do polianfótero estudado neste trabalho têm a tendência de se aglomerar devido à redução de sua solubilidade, em condições de valores de $\mathrm{pH}$ intermediários apresentando dois picos de máximo na turbidez (Figura 5.11) conforme já encontrado literatura (HUBBE et 
al., 2007a). Entretanto, esta aglomeração pode ser reduzida com o aumento da concentração de eletrólitos de baixo peso molecular (PATRICKIOS et al., 1999). Na faixa de pH 6,0 a 8,5, para valores de força iônica (100 e 1000 mM), a turbidez é reduzida devido à blindagem de cargas (Figura 5.15). Para valores acima de 8,5, não foi observada correlação da turbidez com a concentração de sal. Por outro lado, para valores de $\mathrm{pH}$ abaixo de 6 , foi observado a tendência oposta àquela apresentada na faixa de $\mathrm{pH}$ entre 6 e 8,5. Para valores de $\mathrm{pH}$ extremos, era esperado que a solução de polianfótero apresentasse comportamento semelhante ao comportamento apresentado pelo polieletrólito monocarregado, aumento da turbidez com o aumento da concentração de sal devido ao encolhimento das cadeias.

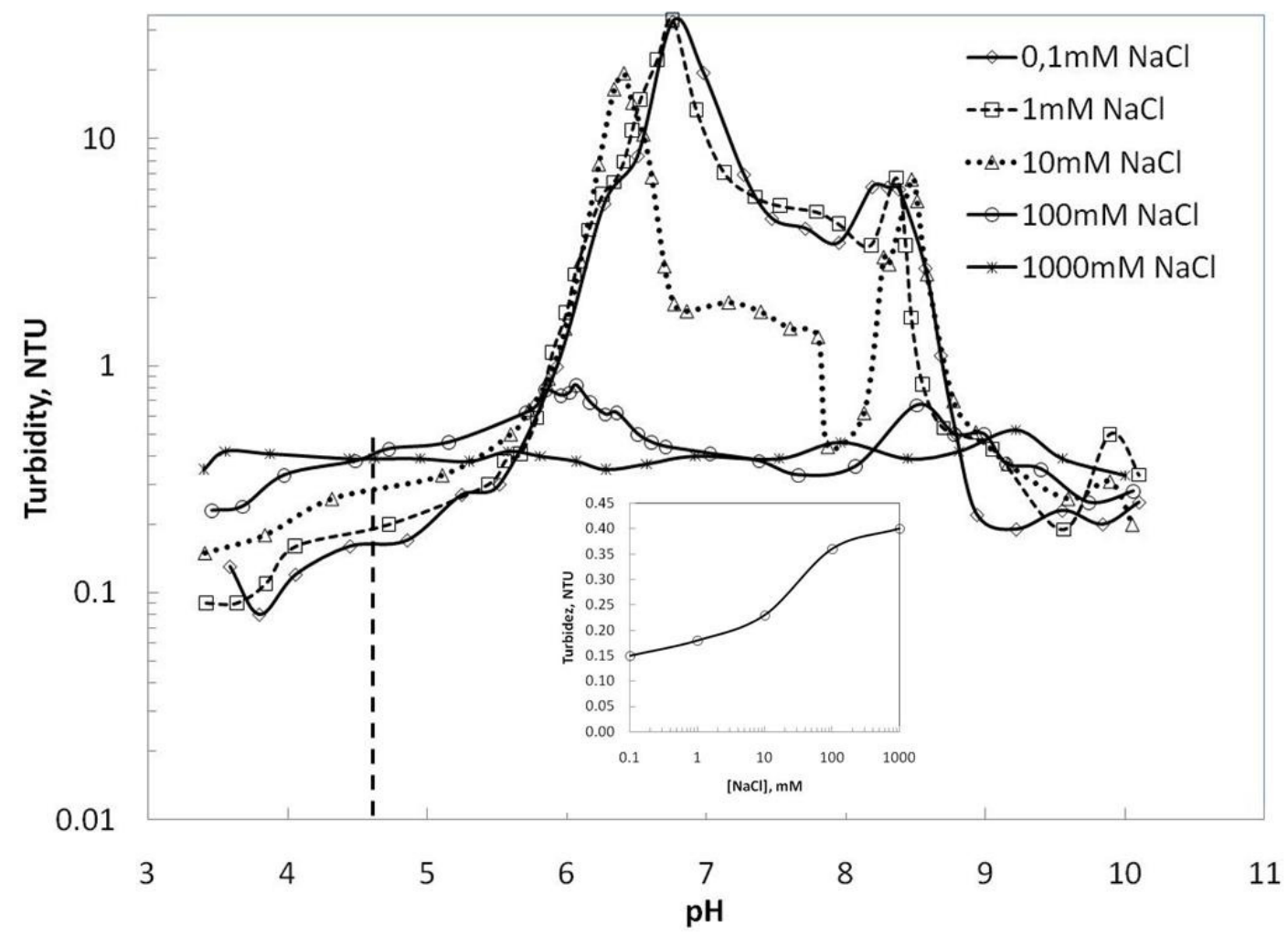

Figura 5.15 - Efeito da força iônica na tubidez da solução de polianfótero ao longo da curva de $\mathrm{pH}$. Figura em destaque: turbidez em função da concentração de sal. Condições do teste: [PAnf] = $168 \mathrm{mg} / \mathrm{L}, \mathrm{pH} 4,3$ e temperatura ambiente de $25^{\circ} \mathrm{C}$. 
A evolução do tamanho aparente das partículas do polianfótero e da densidade de carga líquida com a concentração de sal podem ser vistas na Figura 5.16 A e B, respectivamente. De acordo com Figura 5.16A pode-se observar que os tamanhos de partículas para cada concentração de sal foram próximos quando comparado com o efeito do $\mathrm{pH}$, embora tendência de aumento deste tamanho com a concentração de sal possa ser observado.
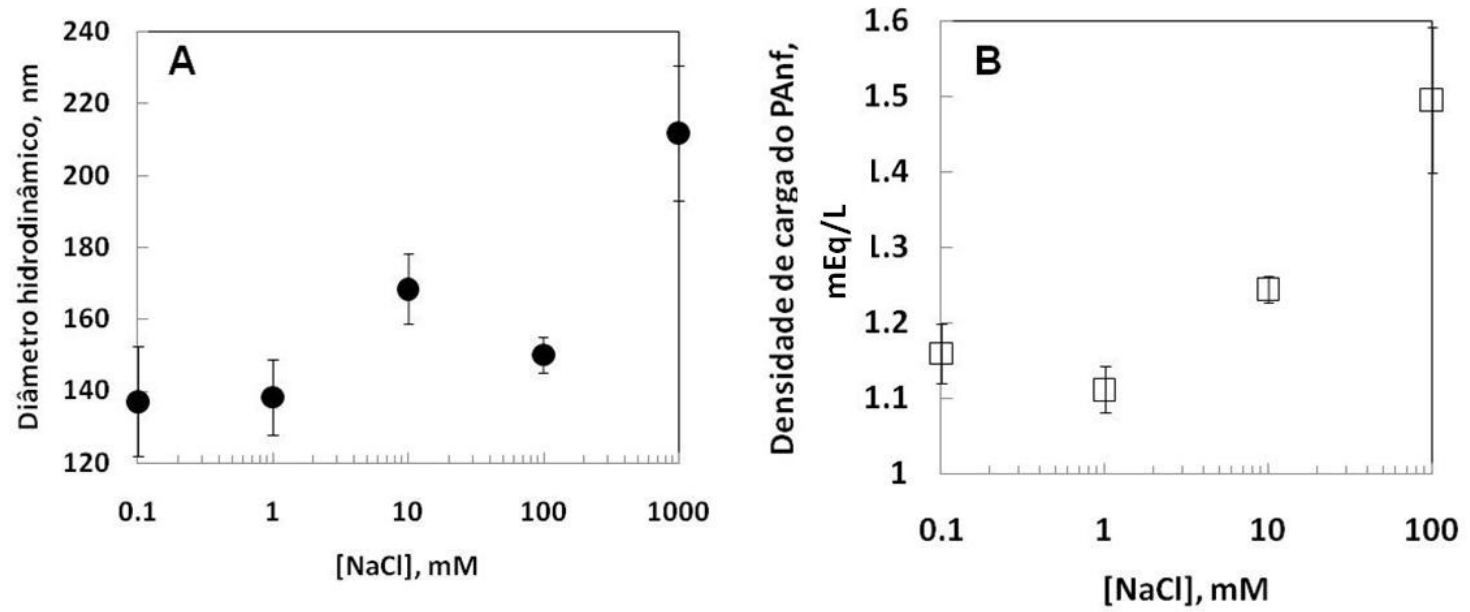

Figura 5.16 - (A) Efeito da força iônica no tamanho aparente de partícula e na (B) densidade de carga líquida do polianfótero em solução. Condições de testes: $(A)$ [PAnf] $=336 \mathrm{mg} / \mathrm{L}, \mathrm{pH} 4,3$ e $25^{\circ} \mathrm{C}$ e (B) [PAnf] = $168 \mathrm{mg} / \mathrm{L}, \mathrm{pH} 4,3$ e $25^{\circ} \mathrm{C}$.

Como discutido na literatura (NISATO; MUNCH; CANDAU, 1999; ZHAO et al., 2007; IBRAEVA et al., 2004), existe a tendência de esse tipo de polímero inchar no pH do ponto isoelétrico com o aumento da concentração de sal devido ao efeito antipolieletrólito. No presente estudo, o comportamento antipolieletrólito pode ser observado mesmo que os testes tenham sido realizados em $\mathrm{pH} 4,3$, distante do $\mathrm{pH}$ no ponto isoelétrico $(\mathrm{pH} 7,3)$. No presente caso, é esperado que a densidade de carga líquida do polianfótero seja predominantemente positiva (Figura 5.16B) ao longo da faixa de concentração de sal e que seu comportamento possa ser mais próximo ao de polieletrólito monocarregado, conforme descrito na literatura para polianfótero com alto valor de assimetria (NISATO; MUNCH; CANDAU, 1999; IBRAEVA et al., 2004). Entretanto, os resultados mostraram aumento do número de 
grupos positivos. Fato que está de acordo com os resultados de diâmetro de partícula, os quais mostraram pequeno inchamento das macromoléculas na forma individual ou em pequenos agregados (comportamento antipolieletrólito) ao longo da concentração de sal estudada, 0,1 a 100 mM. (Figura 5.16A).

Os resultados mostrados na Figura 5.16B estão de acordo com os resultados encontrados com Chen; Heitmann; Hubbe, (2003), lembrando que estes autores estudaram o efeito da concentração de sal no potencial de correntes de complexos formados por polieletrólitos monocarregados de cargas opostas (PVSK e PoliDADMAC). Segundo estes autores, o aumento na densidade de carga com o aumento da concentração de sal pode ser atribuído às mudanças da natureza não estequiométrica das cargas estabilizadas das macromoléculas na mistura, como por exemplo a blindagem de cargas. Com o aumento da força iônica, foi possível observar aumento proporcional dos grupos iônicos da região externa de cada estrutura.

\section{5.2.2.2 Dinâmica de adsorção do polianfótero em superfícies de sílica e de filme de celulose}

O efeito da força iônica na dinâmica de adsorção do polianfótero em superfícies de substrato de sílica e de filme de celulose foi monitorado em tempo real com o auxílio da balança microgravimétrica. As mudanças de frequências foram observadas após a injeção da solução de polímero até alcançar o equilíbrio do processo de adsorção.

É esperado, conforme literatura, que a velocidade de adsorção do polímero seja afetada tanto pela sua densidade de carga quanto pela densidade de carga da superfície do substrato e pelas condições do meio de dispersão (FLEER et al., 1993; ROJAS et al., 1998; ROJAS, 2002a; ROJAS et al., 2002b).

No caso deste trabalho, os testes foram realizados nas mesmas condições com duas superfícies diferentes; (1) substrato de sílica e (2) filme de celulose, de forma a se poder comparar os comportamentos de adsorção sobre as duas superfícies na presença de diferentes concentrações de sal $(0,1 ; 1 ; 10 ; 100$ e $1000 \mathrm{mM} \mathrm{NaCl})$. 
$\mathrm{O} \mathrm{pH}$ usado neste trabalho, $\mathrm{pH} 4,3 \pm 0,05$, consistiu no valor de $\mathrm{pH}$ abaixo da faixa de separação de fases do polianfótero. Neste ponto, o polianfótero em solução é pouco sensível à variações de $\mathrm{pH}$. Por exemplo, as variações de turbidez e de tamanho de partícula não foram tão significativas quanto aos resultados para estes parâmetros em valores de $\mathrm{pH}$ intermediários, $\mathrm{pH} 6$ a 9.

Com os resultados, puderam ser verificados os efeitos de substrato e da força iônica do meio na quantidade de polianfótero adsorvida. As análises dos resultados foram realizadas em dois pontos em cada concentração de sal: no ponto de equilibrio e a $63 \%$ da variação total da frequência antes do equilíbrio.

De acordo com a literatura, nas condições em que os testes foram realizados, tanto o substrato de sílica (MAHLTIG et al., 1999; DUVAL et al., 2002) quanto a superfície de celulose (RADTCHENKO; PAPASTAVROU; BORKOVEC, 2005) apresentaram densidade de carga líquida negativa no $\mathrm{pH}$ estudado. Por outro lado, o polianfótero apresentou densidade de carga líquida positiva conforme pode ser visto na Figura 5.16B, pH 4,3, 1,12 mEq/L. Segundo Radtchenko; Papastavrou e Borkovec (2005), a superfície de sílica apresenta densidade de carga de $-0,40 \mathrm{mC} / \mathrm{m}^{2}$ em $\mathrm{pH} 4$ e a superfície de celulose apresenta $-0,21 \mathrm{mC} / \mathrm{m}^{2}$, para o mesmo $\mathrm{pH}$. Portanto, era esperada que a adsorção ocorresse nessas condições, especialmente via interação eletrostática.

A Figura 5.17 mostra os resultados experimentais para as mudanças da frequência com a adsorção do polianfótero com o tempo sobre (A) substrato de sílica e sobre (B) filme de celulose. Nestas figuras destacam-se os pontos de injeção da solução de polianfótero, a partir dos quais pode-se observar o início das variações na frequência de ressonância em razão da adsorção do polímero nas superfícies.

A Tabela 5.7 mostra os resultados dos testes de adsorção do polianfótero no ponto de equilíbrio e a $63 \%$ do total adsorvido nas superfícies de sílica e de celulose para os níveis de concentração de sal estudados.

Em geral, as mudanças na frequência devido à adsorção do polianfótero no substrato de sílica, no ponto de equilíbrio, foram mais elevadas do que as mudanças observadas para adsorção em filme de celulose para todos os níveis de força iônica (Figuras 5.17 A e B e Tabela 5.7). Isto era esperado desde que, para esta condição 
de $\mathrm{pH}$, a carga da superfície de sílica apresenta quase o dobro da eletronegatividade da superfície de celulose (RADTCHENKO; PAPASTAVROU; BORKOVEC, 2005). Pode-se então observar que, neste caso, a densidade de carga da superfície foi um aspecto importante.
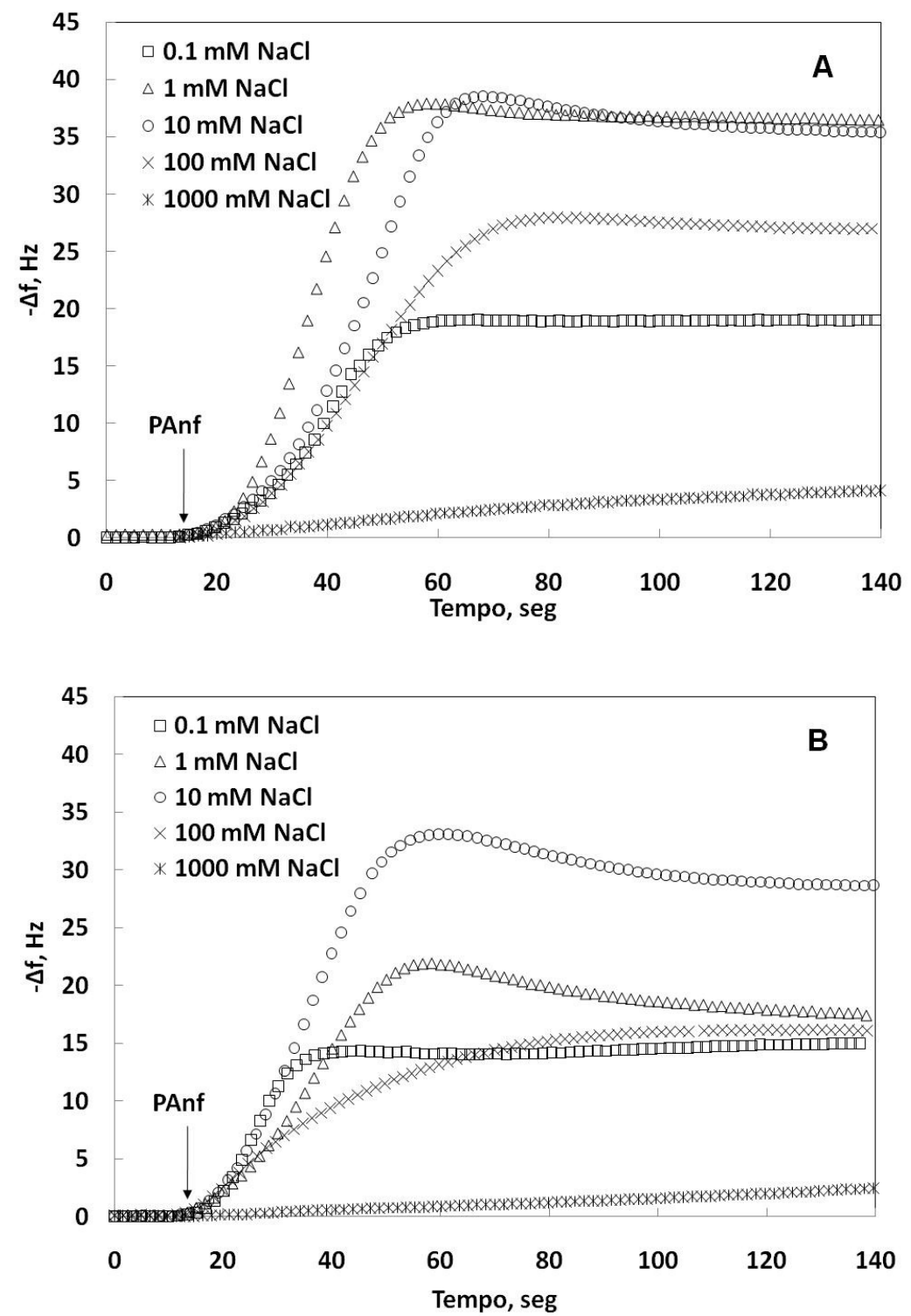

Figura 5.17 - Mudanças de frequência em função do tempo para verificar a dinâmica de adsorção do polianfótero em (A) substrato de sílica e em (B) filme de celulose para diferentes concentrações de sal. Condições de testes: [PAnf] $=168 \mathrm{mg} / \mathrm{L} ; \mathrm{pH}$ 4,3 e $25^{\circ} \mathrm{C}$. 
Tabela 5.7 - Resultados alcançados com os testes de adsorção em superfícies de sílica e de filme de celulose para diferentes valores de força iônica

\begin{tabular}{ccccc}
\hline [NaCl], mM & \multicolumn{2}{c}{ Sílica } & \multicolumn{2}{c}{ Celulose } \\
& $\begin{array}{c}-\Delta \mathrm{f}_{\mathrm{Eq}}{ }^{*} /-\Delta \mathrm{f}_{63 \%}{ }^{* *}, \\
\mathrm{~Hz} / \mathrm{Hz}\end{array}$ & $\mathrm{T}_{\mathrm{eq} .}{ }^{*} / \mathrm{T}_{63 \%}{ }^{* *}$, seg/seg & $\begin{array}{c}-\Delta \mathrm{f}_{\mathrm{Eq}}{ }^{*} /-\Delta \mathrm{f}_{63 \%}{ }^{* *}, \\
\mathrm{~Hz} / \mathrm{Hz}\end{array}$ & $\begin{array}{c}\mathrm{T}_{\mathrm{eq} .}{ }^{*} / \mathrm{T}_{63 \%}{ }^{* *}, \\
\text { seg } / \mathrm{seg}\end{array}$ \\
\hline 0,1 & $19,0 / 12,0$ & $558 / 41,6$ & $15,0 / 9,5$ & $744 / 27,9$ \\
\hline 1 & $36,5 / 23,0$ & $660 / 38,7$ & $17,6 / 11,1$ & $1032 / 35,5$ \\
\hline 10 & $35,4 / 22,3$ & $1506 / 47,8$ & $28,7 / 18,1$ & $1116 / 36,0$ \\
\hline 100 & $32,0 / 17,0$ & $4080 / 50,0$ & $16,1 / 10,1$ & $1584 / 43,0$ \\
\hline 1000 & $8,6^{* * *} / 5,4$ & Fixo: $2980^{* * *} / 242$ & $8,0^{* * *} / 5$ & Fixo: $2980^{* * *} /$ \\
& & & & 394 \\
\hline
\end{tabular}

*Resultados levantados quando o processo de adsorção atinge o ponto de equilíbrio;

${ }^{*}$ Resultados levantados quando o processo se encontra a $63 \%$ da quantidade máxima adsorvida, medida pela variação total da frequência;

${ }^{* * *}$ Resultados levantados quando o processo se encontrava a 2980 seg da injeção do polímero.

Para as superfícies avaliadas, foi observado que o tempo necessário para se atingir o equilíbrio aumenta com o aumento da concentração de sal. O aumento da quantidade de eletrólitos de baixo peso molecular no meio de dispersão pode ter dificultado a interação entre as cadeias de polianfótero e as superfícies. Fenômeno este conhecido como a blindagem de cargas (FLEER et al., 1993). Considerando o tempo para atingir $63 \%$ do total adsorvido, mesma tendência pode ser observada no caso do filme de celulose. Entretanto, para a superfície de sílica, a tendência de aumento ocorreu, exceto para a concentração de $1 \mathrm{mM}$ (Tabela 5.7).

Considerando o efeito da concentração do sal no processo de adsorção do polianfótero para cada superfície de adsorção, pode-se observar que a quantidade adsorvida de polímero aumenta até a condição de concentração de sal de $10 \mathrm{mM}$, mostrada com mais clareza para a superfície de filme de celulose. Esta observação pode ser vista tanto para a variação de frequência no equilíbrio quanto para a $63 \%$ do total adsorvido. Após esta concentração, a quantidade adsorvida, medida através da variação na frequência diminue com a concentração de sal (Tabela 5.7). Este 
comportamento também pode ser visto na Figura 5.18A, para os resultados médios de variação de frequência após terem atingido o equilíbrio, antes e após a lavagem das superfícies de sílica e de celulose. Enarsson e Wågberg (2009), também encontraram máxima adsorção em $10 \mathrm{mM}$ quando estudaram a adsorção de poliacrilamida catiônica em filme de celulose com QCM-D, para vários níveis de concentração de sal, 0,1; 1; 10, 100 e 300 mM. Mesma tendência foi encontrada por Solberg e Wågberg (2003) quando $10 \mathrm{mM}$ como a condição de concentração de sal de máxima adsorção de poliacrilamida catiônica sobre superfície de fibra em pH 5,6. Estes autores estudaram três níveis de concentração: 1, 10 e 100 mM. Os autores explicaram a adsorção mais baixa para a concentração de sal mais elevada em termos de blindagem de cargas.

A redução da quantidade de polianfótero adsorvida para concentrações elevadas de sal também pode ser devido a redução da carga da superfície com o aumento desta concentração segundo o que explicam os autores Radtchenko; Papastavrou e Borkovec (2005). Estes autores estudaram o efeito da concentração de sal sobre a densidade de carga de superfícies de sílica e de celulose e encontraram que a densidade de carga da superfície de celulose em pH 9,5 diminue com o aumento da concentração de sal na solução. Este comportamento foi explicado pelos autores como sendo devido à compressão da dupla camada elétrica. Mesmo comportamento foi encontrado para a superfície de sílica, -70 e $-11 \mathrm{mV}$ em pH 9,5 para 0,1 e $10 \mathrm{mM}$ de sal, respectivamente.

O efeito da concentração de sal nas variações da frequência e da dissipação de energia no equilíbrio para as superfícies de sílica e de filme de celulose, antes e após a lavagem, pode ser observado nas Figuras 5.18 A e B, respectivamente. 

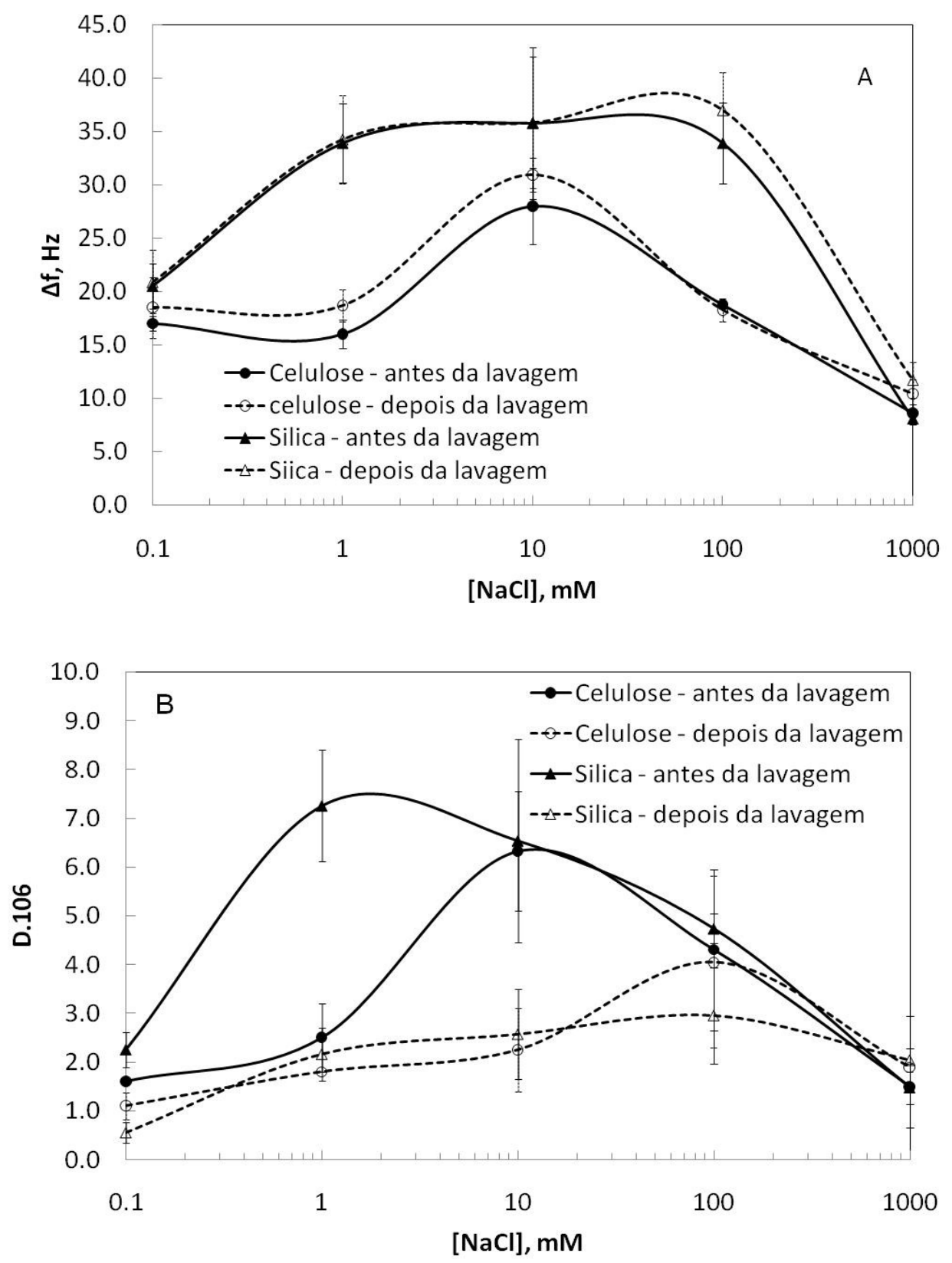

Figura 5.18 - (A) Frequências de ressonância e (B) dissipações de energia de equilíbrio para a adsorção do polianfótero sobre celulose e sílica em diferentes concentrações de sal. Resultados apresentados para antes e depois da lavagem no respectivo nível de força iônica da solução. Condições dos testes: [PAnf] $=168$ $\mathrm{mg} / \mathrm{L}, \mathrm{pH} 4,3$ e temperatura $25^{\circ} \mathrm{C}$.

Mudanças na frequência de ressonância para ambos os substratos, sílica e filme de celulose, no equilíbrio de adsorção para concentrações de sal extremas $(0,1$ e 1000 
$\mathrm{mM} \mathrm{NaCl}$ ) foram menores quando comparadas com níveis intermediários de força iônica (10 e 100 mM NaCl).

Para explicação do efeito da concentração de sal na adsorção do polianfótero sobre superfícies carregadas serão utilizadas as explicações descritas em FLEER et al. (1993) para polieletrólitos de elevada densidade de carga. Para baixas concentrações de sal, a adsorção ocorre devido a interações eletrostáticas entre as cadeias de polianfótero com densidade de carga positiva e a superfície modelo negativa. Valores baixos de adsorção do polímero em baixas concentrações de sal também pode ser explicados pelos tamanhos reduzidos das partículas (Figura 5.16A) e pela densidade de carga mais baixa nesta faixa de concentração (Figura 5.16B). À medida que a concentração de sal aumenta, estes autores sugerem que interações não eletrostáticas possam também ocorrer para a adsorção do polímero. Neste caso, com o aumento da concentração de eletrólitos, a repulsão entre as cadeias do polímero em solução e a superfície carregada diminue e, portanto, a adsorção do polímero aumenta. Valores mais elevados de tamanho de partícula e densidade de carga, também podem ter contribuido. Por outro lado, para concentração de sal elevada $(1000 \mathrm{mM})$, a adsorção do polianfótero é reduzida devido ao efeito da blindagem de cargas (FLEER et al., 1993) e redução da carga de superfície (RADTCHENKO; PAPASTAVROU; BORKOVEC, 2005), apesar da contribuição de interações eletrostáticas e não eletrostáticas, descrita anteriormente, e do tamanho de partícula (Figura 5.16A).

Para variação da dissipação de energia, Figura 5.18B, valores mais baixos foram encontrados em concentração de 0,1 e 1000 mM de $\mathrm{NaCl}$.

Não foram encontradas diferenças significativas nas mudanças de frequência relacionadas à quantidade de massa adsorvida do polianfótero antes e após a etapa de lavagem (Figura 5.18A). Por outro lado, as propriedades viscoelásticas das camadas adsorvidas foram reduzidas drasticamente (Figura 5.18B). Fenêmeno semelhante foi observado por Song et al. (2010), especialmente para as amostras de polianfóteros de densidades de carga mais elevadas, igual ao polímero estudado neste trabalho. Estes autores explicaram que a acentuada queda na dissipação de energia pode ser devido remoção de moléculas não suficientemente aderidas na camada adsorvida. Outra possibilidade sugerida aqui neste trabalho seria a 
possibilidade de reconformação das cadeias de polianfóteros com adensamento da camada após a lavagem que poderiam estar mantendo as cadeias da camada na forma estendidas através de interação eletrostática, além da remoção de cadeias não suficientemente aderidas.

As Figuras B2 até B11 do Apêndice B mostram as variações da frequência e da dissipação de energia para as superfícies modelos estudadas, filme de celulose e substrato de sílica, em função da força iônica para a condição de pH 4,3.

As Tabelas B11 até B14 do Apêndice B mostram os resultados das repetições do efeito da força iônica nas variações de frequência e de dissipação de energia antes e após a lavagem com meio de disperção sem polímero, na condição de equilíbrio.

\subsection{Avaliação do processo de adsorção de polianfótero em superfícies carregadas através do gráfico $D-f$}

A balança microgravimétrica com dissipação de energia (QCM-D) permite estudar a dinâmica de processos de adsorção de polímeros através da mudança na frequência de ressonância do eletrôdo de cristal de quartzo em tempo real. A dissipação de energia, relacionada com o amortecimento da oscilação do sensor, pode ser usada para estudar as propriedades viscoelásticas da camada adsorvida, isso é, sua rigidez ou sua maciez. Tipicamente, uma camada macia é capaz de amortecer mais efetivamente a oscilação do cristal.

Os gráficos considerando a variação na dissipação de energia e a variação na frequência em função do tempo este implícito, os quais são denominados de $D-F$ plots, têm sido utilizados para avaliar a mudança na estrutura da camada de polímero em superfícies carregadas durante o processo de adsorção (HÖÖK et al., 1998a; KONTTURI et al., 2008; SONG et al., 2010). Nesses gráficos também é possível ser estudado a viscoelasticidade da camada adsorvida.

A avaliação da viscoelasticidade das camadas de polianfótero, considerando que tem água acoplada nas estruturas, é importante para a aplicação deste polímero como agente de resistência a seco do papel. A água acoplada a estrutura de 
polianfótero adsorvido desempenha função positiva durante o processo de secagem da folha, pois confere maior número de ligações de hidrogênio na estrutura interna do papel e, consequentemente, maior resistência mecânica. Como os polianfóteros responde de maneiras diferentes quando expostos a diferentes condições do meio de disperção (DOBRYNIN; RUBINSTEIN; JOANNY, 1997; MAHLTIG et al., 1999; CIFERRI; KUDAIBERGENOV, 2007; KUDAIBERGENOV; CIFERRI, 2007; DOBRYNIN, 2008), é esperado a construção de camadas com características diferentes para as concentrações de sal estudadas.

O efeito da força iônica no processo de adsorção do polímero e nas propriedades viscoelásticas das camadas adsorvidas, ambos até o equilíbrio, podem ser vistos na Figura 5.19A para substrato de sílica e na Figura 5.19B para filme de celulose.

Para ambas as superfícies, substrato de sílica e filme de celulose, o processo de adsorção ocorre em duas etapas distintas, especialmente para as condições de força iônica de 0,$1 ; 1 ; 10$ e 100 mM. Para explicar melhor estas etapas, toma-se como exemplo a curva de adsorção na superfície de filme de celulose em força iônica $10 \mathrm{mM} \mathrm{NaCl}$. Na primeira etapa, representada pela reta $r_{1}$, o processo de adsorção ocorre de forma rápida, até a posição da curva onde os pontos se encontram mais espassados $(-\Delta f=22 \mathrm{~Hz})$, correspondentes a maiores variações de frequência. A partir deste ponto, onde ocorre o início da segunda etapa, representada pela reta $r_{2}$, a velocidade do processo de adsorção é reduzida até o ponto da curva onde a variação da frequência é bastante reduzida $(-\Delta f=33 \mathrm{~Hz})$. Na primeira etapa, a quantidade adsorvida é mais rígida, com menores valores para a razão $-\Delta \mathrm{D} / \Delta \mathrm{f}$. Por exemplo, para o ponto indicado pela letra (a), esta razão vale 0,05 $\mathrm{Hz}^{-1} \cdot 10^{6}(0,5 / 10)$. Na segunda etapa, a quantidade adsorvida é mais viscoelástica com valores de $-\Delta \mathrm{D} / \Delta \mathrm{f}$ maiores. Por exemplo, para o ponto indicado pela letra (c), esta razão é de $0,09 \mathrm{~Hz}^{-1} \cdot 10^{6}$ (2,8/30). Por outro lado, na concentração mais elevada de sal, 1000 mM, o processo de adsorção parece ocorrer em uma única etapa e de forma bastante lenta. Entretanto, camadas mais viscoelásticas puderam ser observadas nesta condição para ambas as superfícies de adsorção, observado pelo elevado valor de $-\Delta \mathrm{D} / \Delta \mathrm{f}$ em relação aos anteriores e representado na Figura 5.19B pela letra (b): $0,17 \mathrm{~Hz}^{-1} \cdot 10^{6}(1,3 / 7,5)$. Resultados semelhantes quanto ao processo de adsorção em duas etapas, foram encontrados por Höök et al. (1998a). Estes 
autores estudaram a cinética de adsorção de duas estruturas de proteínas em superfície de ouro através da mesma técnica, balança microgravimétrica. Foram identificadas duas etapas para o processo de adsorção das proteínas, sendo a primeira quantidade adsorvida, gerada na primeira etapa, mais rígida do que a segunda quantidade adsorvida a qual foi gerada na segunda etapa. Estes autores não mostraram o que ocorre após a segunda etapa de adsorção.

Para este estudo, outro fato interessante pode ser observado nos gráficos $D$ - $f$ é a mudança da conformação da camada adsorvida após a segunda etapa de adsorção onde continua a ocorrer variações na dissipação de energia para baixas variações de frequência (substrato de sílica), ou com variações positivas da frequência como se tivesse ocorrendo desorção de material. Isto foi mais evidente para a superfície de celulose para adsorção em baixos valores de concentração de sal. Resultados de remoção do material com a lavagem foram observados por Song et al. (2010).

Conforme pode-se observar na Figura 5.19, condições mais elevadas de concentração de sal são mais favoráveis a construção de camadas mais viscoelásticas. Entretanto, em condições reais, elevadas concentrações de sal não são comuns em fábrica de papel. Vale ressaltar que, na prática, não foi observada diferença entre os resultados para o índice de tração com a variação da força iônica do meio nos três níveis estudados (5; 10 e 100 mM). 

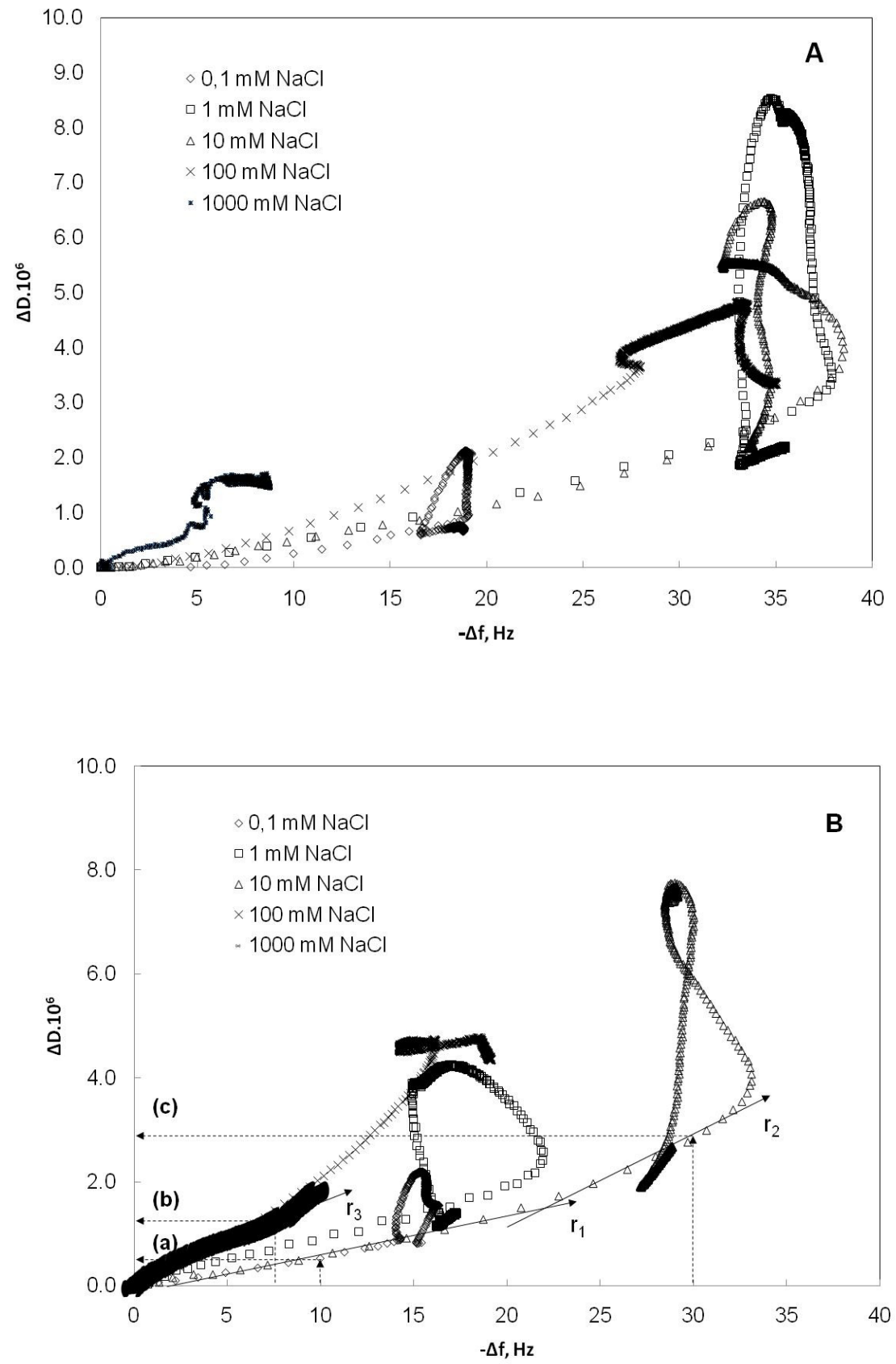

Figura 5.19 - D-f plots de camadas de polianfóteros adsorvidas sobre (A) substrato de sílica e sobre (B) filme de celulose em diferentes concentração de sal. Condições dos testes: $\left[\right.$ PAnf] $=168 \mathrm{mg} / \mathrm{L}, \mathrm{pH} 4,3$ e temperatura $25^{\circ} \mathrm{C}$. 


\subsection{Espessura e massa específica das camadas adsorvidas de acordo com a equação de Sauerbrey e com o modelo de Voigt}

Como as mudanças na frequência de ressonância são proporcionais à massa do polímero adsorvida e as mudanças na dissipação de energia estão relacionadas com as propriedades viscoelásticas da camada, é possível estimar a quantidade de massa de polímero adsorvida, incluindo a massa de água acoplada, e a espessura da camada adsorvida, através de modelos matemáticos. Estes parâmetros, então, podem ser estimados através da equação de Sauerbrey, a qual assume que a quantidade de massa adsorvida é proporcional às mudanças de frequência do QCM e é válida para camadas rígidas (SAUERBREY, 1959). Entretanto, esta equação não se aplica para estimar os mesmos parâmetros para camadas viscoelásticas, os quais seriam subestimados. Dessa forma, o software Qtools, próprio da balança, contendo modelos viscoelásticos, é utilizado para avaliar a camada de polímero adsorvida (VOINOVA et al., 1999). Descrições mais detalhadas sobre os modelos podem ser encontradas no tópico 4.3.1 do capítulo 4.

Neste trabalho, a espessura e a massa específica adsorvida do polianfótero foram estimadas com os dados de frequência e de dissipação de energia gravados pelo equipamento através de duas aproximações: a equação de Sauerbrey, para camadas rígidas, e o modelo de Voigt, para camadas viscoelásticas, de acordo com a literatura (RODAHL; KASEMO, 1996; VOINOVA et al., 1999; MUNRO; FRANK, 2004; VOGT et al., 2004). Procedimento mais bem detalhado pode ser encontrado no trabalho de Silva et al. (2009).

A partir da avaliação dos resultados de mudanças de frequência de ressonância e de dissipação de energia para as três frequências harmônicas consideradas, $3^{\underline{a}}$, $5^{\underline{a}} \mathrm{e}$ $7^{\text {a }}$ conforme frequências normalmente utilizadas em literatura (TAMMELIN et al., 2004; IRWIN et al., 2005; SONG, 2008), optou-se por testar um modelo viscoelástico, considerando que poderia não se tratar de camadas rígidas desde que para cada mudança de frequência $(\Delta f)$ a mudança da dissipação correspondente $(\Delta D)$ era maior do que zero tanto antes quanto depois da lavagem (Figura 5.20). 


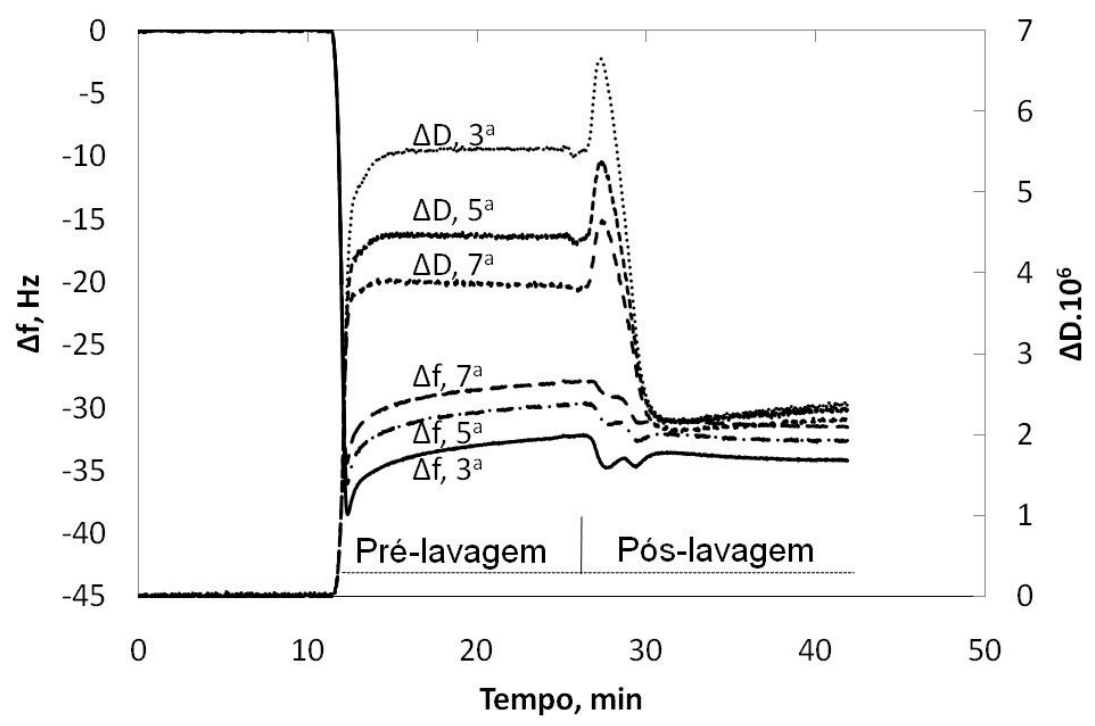

Figura 5.20 - Mundanças de frequência de ressonância e de dissipação de energia em três frequências harmônicas para camada de polianfótero adsorvida em superfície de silica em $\mathrm{pH} 4,3,10 \mathrm{mM}[\mathrm{NaCl}]$, [PAnf] $=168 \mathrm{mg} / \mathrm{L}$ e $25^{\circ} \mathrm{C}$.

Dessa forma, substanciais desvios da equação de Sauerbrey podem ser esperados e, por isso, o modelo de Voigt é recomendado (RODAHL; KASEMO, 1996; VOINOVA et al., 1999; MUNRO; FRANK, 2004; VOGT et al., 2004). Os resultados observados e estimados para as três frequências hamônicas estudadas estão mostrados na Figura 5.21, indicando que os dados de entrada e saída foram válidos. Portanto, o modelo viscoelástico para avaliar a espessura e a massa específica adsorvida foi mais adequado do que a equação de Sauerbrey indicada para filmes rígidos. A Figura 5.22 mostra que a espessura da camada adsorvida estimada pelo modelo de Voigt foi cinco vezes maior do que espessura estimada pela equação de Sauerbrey. O procedimento descrito no trabalho de Silva et al. (2009) foi realizado para todos os níveis de concentração de sal e para as duas superfícies de adsorção estudadas, substrato de sílica (Figura 5.23A) e de filme de celulose (Figura 5.23B). 


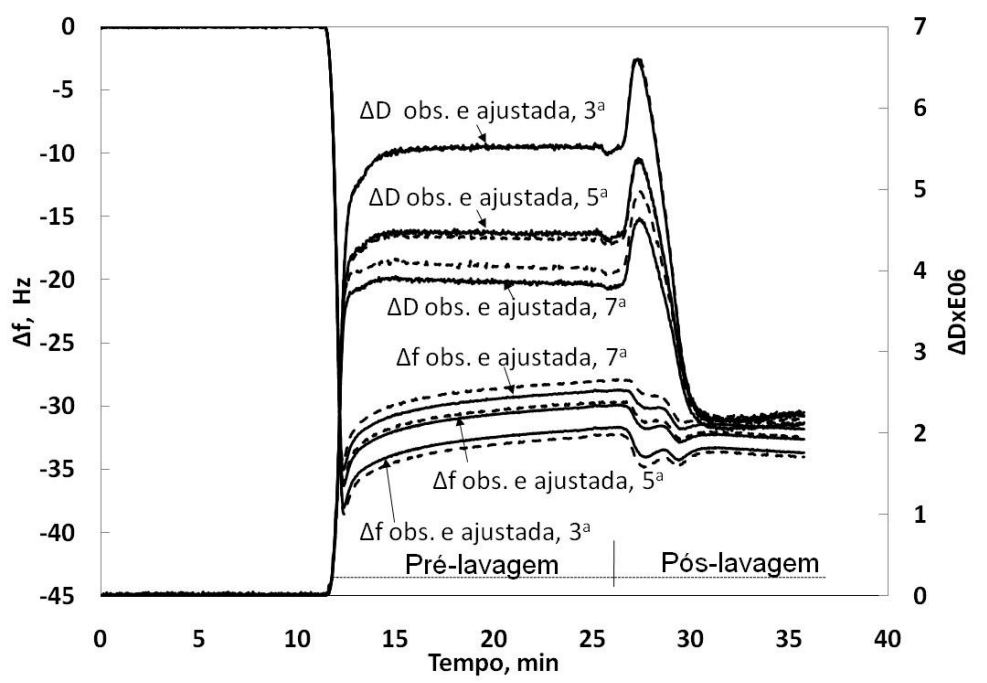

Figura 5.21 - Comparação entre os valores de adsorção de polianfótero, experimentais e estimados pelo modelo de Voigt, para as três frequências harmônicas estudadas, $3^{\underline{a}}, 5^{\underline{a}}$ e $7^{\underline{a}}$, antes e após a etapa de lavagem. Condições: superfície de silica, $\mathrm{pH} 4,3,[\mathrm{NaCl}]=10 \mathrm{mM}$, [PAnf] $=168 \mathrm{mg} / \mathrm{L}$ e $25^{\circ} \mathrm{C}$.

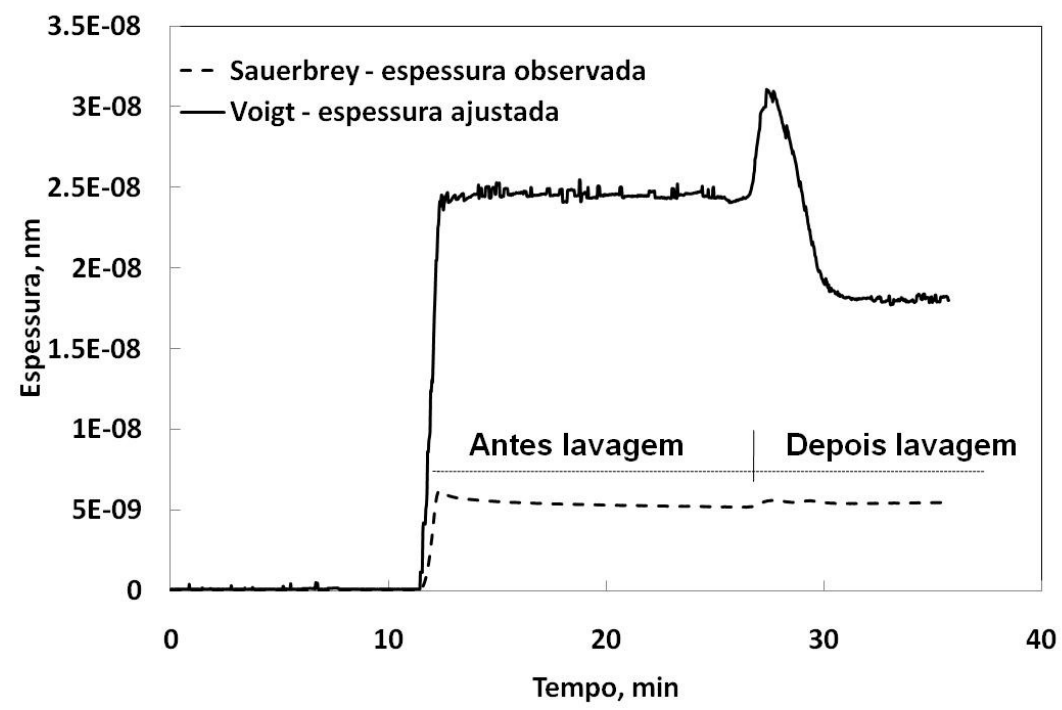

Figura 5.22 - Resultados de espessuras da camada de polianfótero, antes e depois da etapa de lavagem, estimados usando o modelo para camada rígida, equação de Sauerbrey, e o modelo viscoelástico, modelo de Voigt. Condições: superfície de silica, $\mathrm{pH} 4,3,[\mathrm{NaCl}]=10 \mathrm{mM}$, [PAnf $]=168 \mathrm{mg} / \mathrm{L}$ e $25^{\circ} \mathrm{C}$. 
Valores mais elevados de massas específicas e de espessuras foram encontrados para condições de concentração de sal intermediárias. Puderam ser observados elevados valores de dissipação de energia das camadas adsorvidas de polianfóteros, sugerindo camadas altamente dissipativas com elevada quantidade de água acoplada (Figura 5.18B e Figuras 5.19 A e B).

Em baixa concentração de sal $(0,1 \mathrm{mM})$, a baixa quantidade de massa de polianfótero adsorvida pode ser atribuída ao mecanismo de troca iônica na dupla camada elétrica (ROJAS; NEUMAN; CLAESSON, 2001; ROJAS, 2002a; ROJAS et al., 2002b), ou seja, há liberação dos íons de carga oposta à da superfície de adsorção permitindo a interação das cadeias de polianfóteros eletrostaticamente (FLEER et al., 1993; SONG et al., 2010). Outra possibilidade seriam os valores mais baixos de tamanho de partícula observados nesta condição (Figura 5.16A). Para concentrações de sal elevadas (100 e 1000 mM), há redução das interações eletrostáticas entre o polianfótero e a superfície devida à blindagem de cargas conforme Fleer et al. (1993).

Valores elevados de massa específica e de espessura da camada adsorvida, encontrados na condição de concentração de sal mais elevada (1000 mM) sobre a superfície de filme de celulose, não era esperado (Figura 5.23B). Estes resultados podem ser explicados pela presença de ruídos nos valores de mudanças na dissipação de energia observados e gravados durante o teste para todas as frequências harmônicas (APÊNDICE B, Figura B12 B), os quais foram computados na análises de estimativas. Este fato não foi observado para os resultados de sílica (APÊNDICE B, Figura B12 A). Valores ajustados mais elevados e semelhantes aos encontrados para a superfície de sílica, tanto para espessura quanto para massa específica adsorvida, foram encontrados para o filme de celulose. Entretanto, segundo a literatura, os filmes de celulose são orgânicos e conformáveis, estando sujeito à mudanças dinâmicas durante o processo de adsorção (ENARSSON; WÅGBERG, 2009). Estes autores estudaram a adsorção de poliacrilamidas catiônicas (CPAM) e de cloreto de dialildimetil amônio (Poli-DADMAC) sobre a superfície de filme de celulose com a técnica da balança microgravimétrica, em diferentes níveis de concentração de sal $(0,1 ; 1 ; 10 ; 100$ e 300 mM). Para o polieletrólito de baixa densidade de carga (CPAM), a máxima adsorção foi 
encontrada em $1 \mathrm{mM}$. Para o polieletrólito de elevada densidade de carga (PoliDADMAC), a adsorção máxima foi encontrada para $10 \mathrm{mM}[\mathrm{NaCl}]$.
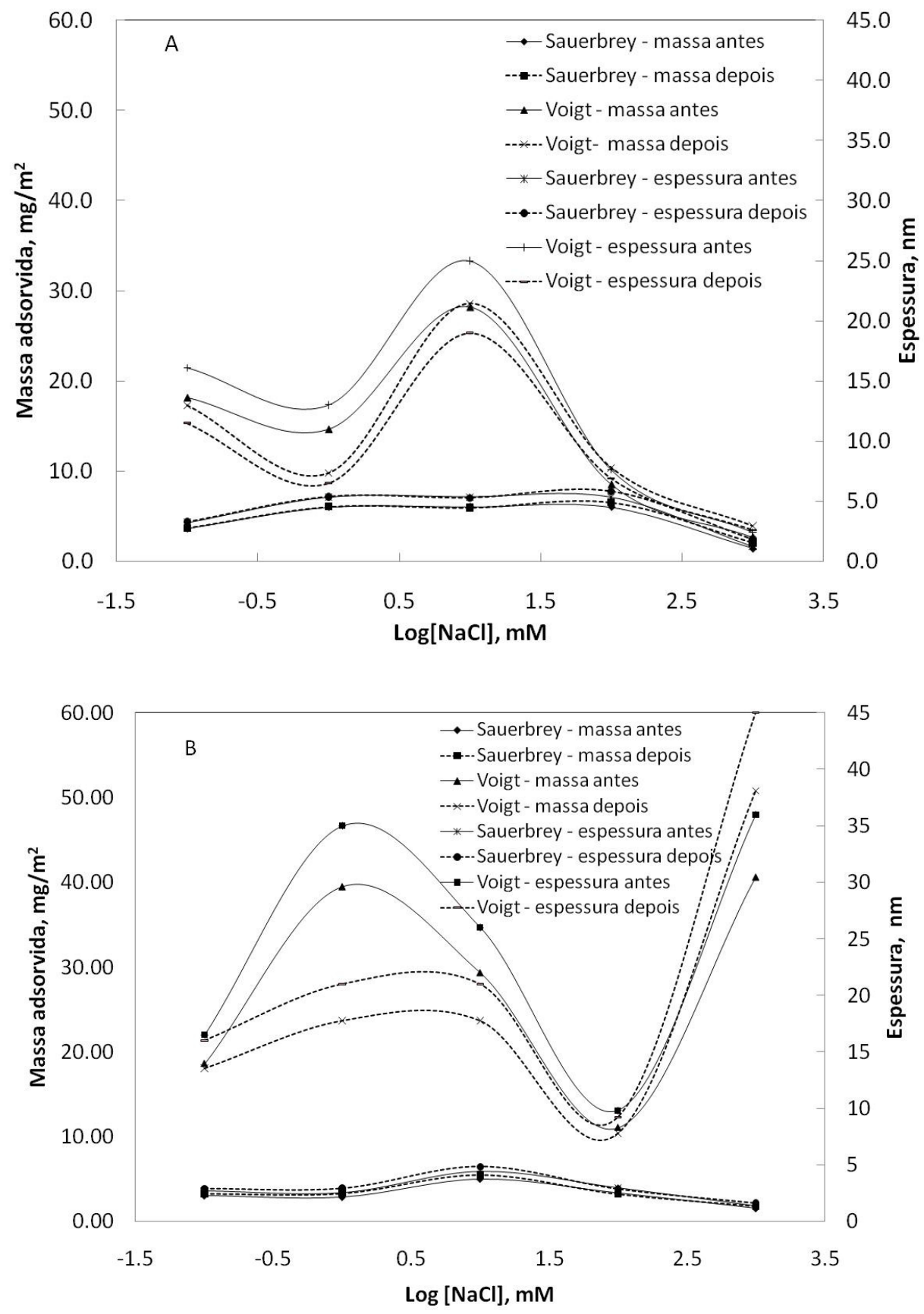

Figura 5.23 - Resultados das massas específicas de polianfótero e de espessuras das camadas para cinco níveis de força iônica, utilizando a equação de Sauerbrey e o modelo de Voigt, para superfícies de adsorção de (A) sílica e de (B) filme de celulose. Condições dos testes: $\mathrm{pH} 4,3 ;$ PAnf] $=168 \mathrm{mg} / \mathrm{L} \mathrm{e} 25^{\circ} \mathrm{C}$. 
Song (2008) comparou a espessura de camadas de polianfóteros com densidades de carga diferentes $(5: 4$ e $10: 8$ de grupos positivos para negativos, respectivamente), porém inferiores à densidade de carga do polianfótero usado neste trabalho (20:18 de grupos positivos para negativos). Este autor encontrou espessura de 15 e $30 \mathrm{~nm}$ para para o polianfóteros de baixa densidade de carga (5:4) e de 28 e $100 \mathrm{~nm}$ para o polianfótero de média densidade de carga (10:8), para os resultados de Sauerbrey e Voigt, respectivamente, adsorvidos em superfície de sílica. Mesmo não podendo fazer uma comparação direta pois, além da densidade de carga, as condições usadas por ele foram $\mathrm{pH} 7$ e $1 \mathrm{mM}$, os resultados alcançados neste trabalho também mostraram valores de espessuras mais elevadas para as camadas adsorvidas quando estimadas pelo modelo de Voigt em comparação com os valores estimados pela Equação de Sauerbrey em pH 4,3 e 10 $\mathrm{mM}$ para as superfícies de sílica e celulose (Figura 5.23 A e B).

\subsection{Habilidade de inchamento de camadas de polianfóteros preadsorvidas em superfícies de carga oposta}

Nas últimas décadas, hidrogels de polianfóteros, os quais apresentam respostas aos estímulos do meio, têm recebido atenção especial pelo seu potencial de aplicação nos campos da biosseparação, da medicina e farmaceútico (XU et al., 2006). As condições do meio incluem tanto a temperatura, o $\mathrm{pH}$, a pressão e o campo elétrico (XU et al., 2006) quanto a força iônica (MOFFAT et al., 2007; ZHAO et al., 2007).

No campo da fabricação de papel, em que existem diversos aditivos de processo, a sensibilidade da camada de polianfótero adsorvida aos estímulos das condições do meio pode ser uma alternativa favorável desde que as condições de $\mathrm{pH}$ e concentração de sal podem variar durante as etapas do processo e partículas de dimensões micro e nanométricas, como a sílica coloidal, necessitam ser retidas na estrutura do papel. Outro ponto importante é que dentro da estrutura do polímero adsorvido na superfície da fibra, possam ser fixadas nanopartículas com propriedades específicas como eletromagnéticas e ópticas, se tornando um diferencial para a estrutura do papel formado. 
Nesta pesquisa, camadas de polianfóteros preadsorvidas em superfícies modelos, foram utilizadas para realização dos seguintes testes de inchamento, ou mudança de conformação da camada, com solução de sal em quatro níveis de concentração (1, 10, 100 e 1000 mM): (1) efeito da superfície de adsorção (substrato de sílica e filme de celulose), (2) efeito da concentração de polianfótero usada na preadsorção da camada ([PAnf] = 168 e 1000 mg/L) e (3) efeito da força iônica do meio utilizada na preadsorção (1 e $10 \mathrm{mM}$ ). A Tabela 5.8 traz um resumo das condições de adsorção das camadas utilizadas nos testes de inchamento.

Tabela 5.8 - Condições adotadas durante a adsorção das camadas do polianfótero

\begin{tabular}{lcc}
\hline Substrato & $\begin{array}{c}\text { Concentração de NaCl, } \\
\mathrm{mM}\end{array}$ & $\begin{array}{c}\text { Concentração de polianfótero, } \\
\mathrm{mg} / \mathrm{L}\end{array}$ \\
\hline Filme de celulose & 1 & 168 \\
\hline Sílica & 1 & 168 \\
\hline Sílica & 10 & 168 \\
\hline Sílica & 1 & 1000 \\
\hline
\end{tabular}

Para esta avaliação, foi considerada a razão entre as mudanças na frequência $(\Delta f)$ e na dissipação de energia $(\Delta D)$ para cada teste e em cada concentração de sal, de acordo com a Equação 3,

$$
S_{a}=-\frac{\Delta f}{\Delta D}
$$

Em que $S_{a}$ é a habilidade de inchamento ou mudança de conformação da camada adsorvida de polianfótero, em $\mathrm{Hz} \cdot 10^{-6}$; $\Delta f$ é a mudança na frequência em $\mathrm{Hz}$, e $\Delta D$ é a mudança na dissipação de energia, em $10^{6}$. As mudanças de dissipação de 
energia estão relacionadas às propriedades viscoelásticas das camadas. Portanto, maiores valores de $S_{a}$ significam menores habilidades de inchamento da camada preadsorvida (menor quantidade de água acoplada) para diferentes condições do meio.

Os testes de preadsorção das camadas e os de inchamento foram realizados com a técnica de balança microgravimétrica. As condições de $\mathrm{pH}$ e de temperatura foram fixas em 4,3 e $25{ }^{\circ} \mathrm{C}$, respectivamente. Teste de inchamento para as superfícies modelos sem o polianfótero foram realizados como referência. É importante mencionar que as camadas de polianfóteros deste estudo foram construídas sob as condições descritas na Tabela 5.8 seguidas de lavagem. Após, as macromoléculas do polímero que se mantiveram eletrostaticamente adsorvidas na superfície, foram submetidas ao processo de inchamento. O processo de adsorção e o teste foram realizados seguidamente, sem remoção do cristal do aparelho de QCM.

Neste trabalho, as habilidades de inchamento das superfícies de celulose e de sílica sem polímero, com a variação da força iônica, apresentaram comportamentos semelhantes (retas inferiores da Figura 5.24 - as retas se sobrepõem). Maior concentração de sal implicou em menor capacidade de inchamento, menor $S_{a}=-\frac{\Delta f}{\Delta D}$. Isto é, há liberação de água existente na interface da camada com o meio com o aumento da concentração de sal. Neste caso, é esperada redução da dupla camada elétrica da superfície.

Para todos os resultados de inchamento, foram deduzidos os possíveis efeitos do meio de dispersão no substrato sem a camada de polímero. A Figura 5.25 mostra o efeito da concentração de sal no meio de dispersão, em cinco níveis, nos resultados de $\Delta f$ e $\Delta D$ para os substratos utilizados nos estudos referentes ao Capítulo 5 desta tese. Conforme pode ser observado, para todas as superfícies avaliadas, os resultados de $\Delta f$ e $\Delta D$ foram próximos e para os níveis elevados de concentração de sal, houve mudanças significativas na frequência e na dissipação de energia, especialmente para a concentração de 1000 mM (Figura 5.25).

Foi encontrado que a habilidade de inchamento da camada de polianfótero aumenta com a concentração de sal na solução, independente da superfície de adsorção, da concentração de polianfótero e da força iônica na construção prévia da camada 
(Figura 5.24). Esta habilidade foi maior para valores mais elevados de concentração de sal (100 e 1000 mM). Este comportamento está de acordo com os resultados encontrados na literatura (MOFFAT et al., 2007; ZHAO et al., 2007). Moffat et al. (2007) estudaram a resposta ao meio e a estabilidade de multicamadas de proteínas, pectina e lisina, para diferentes condições de $\mathrm{pH}$ e de força iônica. Eles atribuiram ao comportamento de inchamento ao efeito de blindagem do sal sobre as forças atrativas dentro da estrutura de multicamadas. Zhao et al. (2007), estudaram o efeito da força iônica no inchamento de polianfóteros. Estes autores observaram o efeito antipolieletrólito com a solução de $\mathrm{NaCl}$, ou seja, o inchamento foi proporcional à concentração de sal, seguido de equilíbrio em $0,5 \mathrm{~mol} / \mathrm{L}$. Entretanto, para eletrólitos multivalentes, como $\mathrm{CaCl}_{2}$, foi observado ponto de máximo de inchamento em 1,3 mol/L. Faixa de concentração de sal considerada: 0 a 5 mol/L.

A habilidade de inchamento da camada de polianfótero adsorvida sobre a superfície de filme de celulose foi mais elevada do que todos os casos em que a sílica foi utilizada como superfície de adsorção, mesmo quando foi usada concentração de polianfótero mais elevada (1000 mg/L). Isto pode ser explicado pelo fato de o filme de celulose ser uma camada orgânica com características dinâmicas, conforme já citado anteriormente.

Considerando as camadas de polianfóteros construídas sobre substrato de sílica, diferenças entre as habilidades de inchamento puderam ser facilmente verificadas para concentrações de sal mais baixas, 1 e $10 \mathrm{mM}$ (Figua 5.24). Para concentrações de sal mais elevadas (100 e 1000 mM), as diferença são pouco significativas. Não foi verificada diferença significativa entre as habilidades de inchamento para as diferentes concentrações de sal quando da construção da camada (veja sílica 168 $\mathrm{mg} / \mathrm{L}$ a $1 \mathrm{mM}$ e $10 \mathrm{mM} \mathrm{NaCl}$ ). 


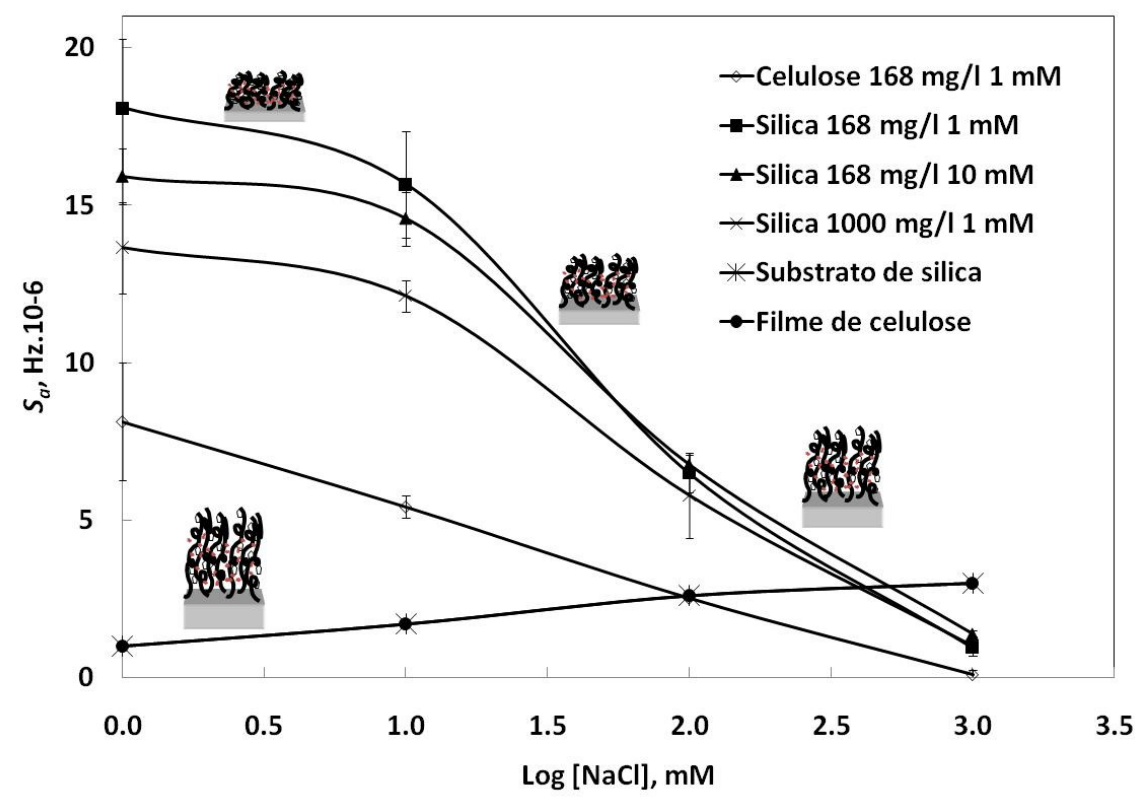

Figura 5.24 - Efeito da força iônica, do substrato e da concentração do polianfótero na habilidade de inchamento de camadas preadsorvidas do polianfótero. Condições de teste: $\mathrm{pH} 4,3$ e $25^{\circ} \mathrm{C}$. Detalhe: ilustração de camada de polímero preadsorvida em diferentes estados de inchamento.

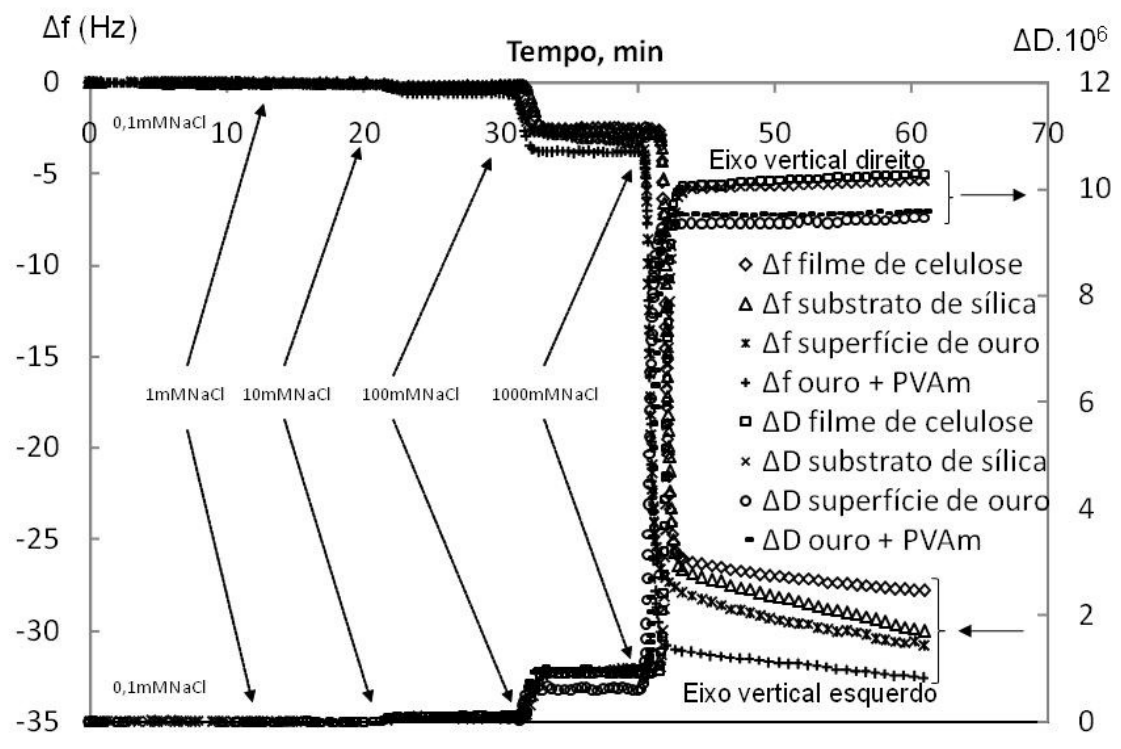

Figura 5.25 - Efeito da concentração de sal do meio de dispersão, sem polímero, para diferentes superfícies modelos. Condições de teste: pH 4,3 e $25^{\circ} \mathrm{C}$. 


\subsection{CONCLUSÕES}

A adsorção da amostra de um polianfótero, terpolímero de elevado peso molecular e densidade de carga, em superfícies modelos e em fibras celulósicas, visando sua aplicação como agente de resistência a seco, foi avaliada em diferentes condições de $\mathrm{pH}$ e de força iônica. De acordo com os resultados obtidos, as seguintes conclusões podem ser abaixo enumeradas:

- Considerando os resultados de espalhamento dinâmico de luz e de turbidez mostrados na seção sobre polianfótero em solução, este polímero assume diferentes tamanhos aparentes de partículas quando é submetido a diferentes condições de $\mathrm{pH}$ e de concentração de sal do meio de dispersão. Isto se deve a formação de agregados devido a separação de fases, resultado da baixa solubilidade do polímero em solução, conforme reportado por Cheong e Panagiotopoulos (2005) apud Dobrynin (2008) e por Song et al. (2010).

- Para os resultados mostrados na seção sobre efeito da força iônica nos parâmetros do polianfótero em solução ao longo da faixa de pH considerada, 3,3 a 10,2, o polianfótero estudado forma agregados com maiores valores de turbidez para valores de $\mathrm{pH}$ entre 6,0 e 8,7, considerando as concentrações de sal mais baixas, 0,1, 1 e $10 \mathrm{mM} \mathrm{NaCl}$. Por outro lado, para valores de concentração de sal mais elevados, 100 e 1000 mM NaCl, os valores de turbidez apresentaram-se baixos para a mesma faixa de $\mathrm{pH}$. Isto está diretamente relacionado ao efeito de blindagem de cargas positivas e negativas das cadeias do polianfótero em questão, o que impede a formação de agregados por forças eletrostáticas, conforme descrito por Fleer; Cohen Stuart e Scheutjens (1993); Dobrynin; Rubinstein e Joanny (1997) e Dobrynin (2008).

- Considerando o efeito da força iônica na turbidez, no tamanho aparente de partículas e na densidade de carga aparente das estruturas do polianfótero

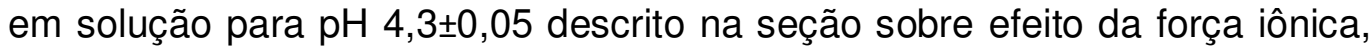
houve a tendência de aumento dos valores destes parâmetros com 0 aumento da concentração de sal. Embora para o valor de $\mathrm{pH}$ estudado, o 
comportamento deste polímero se aproxime a de um polieletrólito monocarregado, o comportamento antipolieletrólito pode ser verificado de acordo com polímeros que apresentem cargas positivas e negativas na mesma cadeia conforme descrito por Bohidar (2002).

- Através da balança microgravimétrica com dissipação de energia, pode ser observado que as características de tamanho do polianfótero no meio de dispersão, na forma individual ou na forma de pequenos ou grandes estruturas, afetaram sensivelmente as interações em interface sólido-líquido e as propriedades viscoelásticas das camadas adsorvidas. Considerando o efeito de $\mathrm{pH}$, camadas mais macias e dissipativas foram construídas em valor de $\mathrm{pH}$ intermediário, 6,5, próximo e abaixo do ponto isoelétrico, tanto durante a adição do polímero quanto após a etapa de lavagem. Estes resultados podem explicar os resultados mais elevados para resistência mecânica do papel para valores de $\mathrm{pH}$ em que a carga do polianfótero se encontra assimétrica positiva. Este fato pode contribuir com o aumento do número de ligações e aumento da área de ligações em nível molecular, explicando o aumento na resistência a seco do papel, conforme descrito pela equação de Page (1969).

- Conforme os resultados de efeito de pH mostrados tanto nos testes de aplicação do polianfótero como agente de resistência a seco quanto nos testes de adsorção deste polímero sobre superfícies modelos carregadas avaliados através de técnicas nanométricas, o controle do $\mathrm{pH}$ do sistema mostrou ser um procedimento importante na fabricação de papéis, pois este parâmetro afeta de forma significativa o equilíbrio dos grupos ácidos e básicos das cadeias do polímero em solução. Para condições extremas de $\mathrm{pH}$ tanto as características do polímero em solução quanto o comportamento de adsorção do polímero em superfícies carregadas foram modificadas de forma que nestas condições, a habilidade deste polímero como agente de resistência a seco do papel não foi utilizada em sua totalidade. O contrário foi observado para a faixa de $\mathrm{pH}$ de $6,5 \mathrm{a} 7,3$ (pH no ponto isoelétrico). Isto pode ser explicado pela formação de camadas mais viscoelásticas em razão das estruturas maiores formadas no meio de dispersão devido à redução da 
solubilidade do polímero no meio, conforme os resultados de turbidez, de espalhamento dinâmico de luz e da balança microgravimétrica.

- Considerando a concentração de sal, camadas mais viscoelásticas foram encontradas para valores intermediários (1 e $10 \mathrm{mM}$ ). Este comportamento está de acordo com os valores de massa específica e de espessura da camada estimados pelo modelo viscoelástico de Voigt. Este modelo se mostrou mais adequado quanto a estimativas dos resultados de massa específica e de espessura da camada com as variações da concentração de sal do que os resultados estimados com a equação de Sauerbrey para camadas rígidas. Considerando que o modelo viscoelástico de Voigt utiliza dados múltiplos de frequência e de dissipação de energia, foi encontrado que os valores estimados para a massa e a espessura da camada podem estar próximos aos reais e que as aproximações obtidas pela equação de Sauerbrey foram subestimadas, devido às camadas do polianfóteros adsorvidas serem dissipativas. $\mathrm{O}$ aumento da quantidade adsorvida com o aumento da concentração do sal até $10 \mathrm{mM} \mathrm{NaCl}$ pode ser devido aos resultados favoráveis de tamanho de partículas e de densidade de carga e à redução das forças de repulsão entre a superfície e as cadeias de polímero (FLEER et al., 1993). Baixos valores de adsorção para valores elevados de concentração de sal podem ser explicados tanto pela redução de carga de superfície (RADTCHENKO; PAPASTAVROU; BORKOVEC, 2005) quanto pelo efeito da blindagem de cargas (FLEER et al., 1993) que impede a interação entre os grupos carregados, superfície e polímero.

- Considerando os resultados de inchamento de camadas preadsorvidas de polianfóteros para diferentes concentrações de sal, avaliados através da técnica da balança microgravimétrica com dissipação de energia, o aumento da habilidade de inchamento dessas camadas com o aumento da concentração de sal do meio pode ser explicado pelo efeito da blindagem de cargas das cadeias promovendo a expansão da estrutura adsorvida conforme Moffat et al. (2007). Com a expansão, a estrutura se torna mais hidratada com o meio e portanto mais dissipativas. Camadas do polianfótero mais inchadas 
foram encontradas sobre filme de celulose quando comparadas com o substrato de sílica. 


\section{CONCLUSÕES GERAIS E RECOMENDAÇÕES}

A química da parte úmida do processo de fabricação de papel se constitue na etapa mais importante deste processo. Nesta etapa, interações em interfaces sólido-líquido entre os constituintes da suspensão, principalmente eletrostática, influenciam de forma definitiva nos resultados operacionais e nas caracterísitcas de qualidade do papel acabado.

A utilização de polieletrólito monocarregado visando o estudo de variáveis operacionais de retenção e drenagem, contemplado no Capítulo 3, e a utilização de um polianfótero visando o estudo da adsorção em superfícies carregadas para aplicação como agente de resistência a seco do papel acabado, contemplado no Capítulo 5, puderam ser avaliadas nesta tese.

Embora com objetivos diferentes, fica claro na presente Tese que tanto para retenção e drenagem quanto para resistência a seco, os aspectos fundamentais de físico quimica relativos à área de química coloidal e de superfície são os mesmos.

Portanto, preferiu-se mostrar os aspectos práticos de Engenharia no Capítulo 3 relativos ao uso de aditivos polieletrólitos e partículas de natureza nano e submicrons na química da parte úmida da fabricação de papel. Ainda assim, não deixaram de ser abordados aspectos práticos no Capítulo 5 quando foram realizados experimentos de resistência a seco em papéis formados manualmente com o uso do polianfótero.

Reconheceu-se que não bastava serem abordadas apenas os resultados finais da aplicação desses polímeros, ao largo, tais como capacidade de retenção, drenagem e resistência de folhas, mas sim que o conhecimento dos aspectos fundamentais de natureza química e nanotecnológica dos polímeros e da natureza de interação no meio coloidal. É dessa parte que se trata o Capitulo 5 onde se utilizam os instrumentos avançados tais como o microscópio de força atômica, a balança microgravimétrica com cristais de quartzo e dissipação de energia, espalhamento dinâmico de luz, etc, e interpretam-se seus resultados. 
A escolha do polianfótero para análises instrumentais em superfícies modelos se deu devido a este polímero, em relação aos polieletrólitos monocarregados, apresentar comportamento altamente dependente do $\mathrm{pH}$, podendo atuar como polieletrólitos monocarregados em valores de $\mathrm{pH}$ distantes do $\mathrm{pH}$ do seu ponto isoelétrico, se aproximando de polímero catiônico em valores de $\mathrm{pH}$ extremamente ácidos e se aproximando do comportamento aniônico em valores de $\mathrm{pH}$ extremamente básicos. Portanto, ao mesmo tempo que o estudo do polianfótero como agente químico da parte úmida da máquina de papel seja ainda hoje inovador, com a condição de baixo pH, embora não recomendado industrialmente quando se refere a sua utilização em processos de colagem alcalina, este polímero se tornou um candidato natural para estudos acadêmicos.

\subsection{Conclusões gerais}

Nos testes de retenção e drenagem, a utilização do sal de carboximetil celulose para simulação do teor de lixo aniônico e seu efeito na retenção foi um ponto importante. De forma geral, pode-se verificar que o aumento da dosagem do polímero neutralizador de lixo aniônico melhora a retenção de cargas inorgânicas, avaliada através da turbidez da água drenada, e a drenagem do sistema, avaliada através da velocidade de escoamento, até o ponto em que a carga do sistema é invertida pelo excesso de carga positiva, prejudicando os resultados destes parâmetros. Pode também ser confirmado que forças de cisalhamento em excesso prejudicam a retenção de carga mineral.

Os estudos, em nível molecular, sobre o comportamento do polímero anfótero em solução e o seu comportamento de adsorção sobre superfícies modelos carregadas, substrato de sílica e filme de celulose, para diferentes condições de $\mathrm{pH}$ e de força iônica, mostraram que são importantes para a explicação dos fenômenos de adsorção, envolvendo fibras celulósicas e polianfótero, e dos resultados de resistência mecânica do papel. 
As características tamanho das cadeias do polianfótero em solução, sob a forma individual e em forma de agregados, refletindo nas propriedades viscoelásticas das camadas adsorvidas do polianfótero e na quantidade de massa adsorvida, em função do $\mathrm{pH}$ do meio, tiveram papel importante na explicação dos resultados práticos do seu uso como agente de resistência a seco do papel. Maiores resultados de resistência mecânica, avaliada através da resistência à tração do papel, foram alcançados para valores de $\mathrm{pH}$ próximos ao $\mathrm{pH}$ do ponto isoelétrico onde foram encontradas maiores estruturas em solução do poliánfotero, maior quantidade de massa adsorvida e a formação de camadas mais viscoelásticas.

Embora na prática não seja comum utilizar dosagens elevadas de polímeros na fabricação de papel, os resultados dos testes do efeito da dosagem do polianfótero na resistência do papel mostraram a elevada capacidade de adsorção do material fibroso. Isto mostra que, nas condições em que os testes foram realizados, a densidade de carga líquida da superfície das fibras ainda se encontrava negativa e os grupos remanescentes, negativamente carregados, poderiam ter sido utilizados para adsorção com outras cadeias do polianfótero ou para interações com outros contituintes do meio de dispersão.

De maneira geral, nesta Tese foi mostrada a importância das condições do meio de dispersão com relação ao pH e à força iônica. Como a suspensão de fibras possue constituintes que podem desenvolver cargas em meio aquoso e que estas cargas podem variar com relação à ionicidade e à quantidade de grupos carregados, de acordo com o pH, e com relação principalmente à acessibilidade, de acordo com a força iônica, o controle das condições do meio e a escolha correta dos aditivos a serem usados no sistema se tornam aspectos importantes.

Com relação ao efeito do $\mathrm{pH}$, pode-se verificar que a adsorção do polianfótero em superfícies carregadas ocorre independente da ionicidade da superfície e do políanfótero. Entretanto, maiores quantidades adsorvidas foram observadas

próximas ao $\mathrm{pH}$ do ponto isoelétrico do polímero. Neste valor de $\mathrm{pH}$, embora a densidade de carga do polímero seja simétrica, ou seja, a diferença entre as cargas positivas e negativas seja nula, foram observadas na solução estruturas de cadeias do polianfótero maiores e camadas adsorvidas mais dissipativas, indicando que estas estruturas apresentam-se bastante hidratadas na interface sólido-líquido e, 
dessa forma, contribuiram para o aumento das ligações interfibras durante a etapa de secagem da folha de papel. Estas estruturas neutras, formadas devido à separação de fases, foram adsorvidas pela superfície da fibra através da precipitação devido a sua baixa solubilidade no meio.

A maior quantidade de polianfótero adsorvido, apresentada para valores de $\mathrm{pH}$ próximos ao ponto isoelétrico, sob dois aspectos principais, separação de fases devido à redução da solubilidade do polímero no meio de dispersão e a formação de multicamadas devido à polarização das cadeias pelo campo externo, podem ser consideradas as principais explicações para os maiores valores de resistência mecânica do papel nestas condições de $\mathrm{pH}$. Portanto, considerando o polianfótero utilizado neste estudo, condições de processo que favoreçam a sua adsorção, também irá contribuir para o aumento da resistência do papel. Dessa forma, quanto mais próximo o ponto isoelétrico do polímero for do $\mathrm{pH}$ de operação da máquina de papel, mais eficiente espera-se que o polímero seja.

Neste trabalho também foi observado que quando a superfície e o polímero apresentam cargas opostas ( $\mathrm{pH}$ abaixo do ponto isoelétrico), as forças de interações são mais fortes do que quando as cargas são iguais ( $\mathrm{pH}$ acima do ponto isoelétrico). Entretanto, a adsorção do polímero ocorreu mesmo considerando a última condição.

Neste estudo foi mostrado que a concentração de sal do sistema pode ser um aspecto favorável à adsorsão do polímero. Porém, quantidades elevadas de eletrólitos podem ser desfavoráveis às interações em interfaces sólido-líquido devido à blindagem de cargas.

Com relação à variação da turbidez em relação ao pH para baixos valores de concentração de eletrólitos, a explicação detalhada do fenômeno sobre a presença de dois pontos de máxima turbidez para alguns polianfóteros não foi encontrada na literatura. Entretanto, além do balanço dos grupos positivos e negativos sugerida por alguns autores, no presente trabalho ficou claro que a proporção entre as interações intramoleculares entre os grupos positivos e negativos, e as interações intermoleculares entre grupos opostos de cadeias diferentes, ao longo do $\mathrm{pH}$, podem ser também consideradas as responsáveis pelos aparecimento dos dois picos de máxima turbidez. 
Em condições de $\mathrm{pH}$ de 4,3, algumas conclusões gerais podem ser feitas a seguir considerando os testes do efeito da concentração de sal no comportamento de adsorção do polianfótero.

A presente Tese demonstrou que para o polianfótero de elevada densidade de carga utilizado neste estudo, o modelo viscoelástico de Voigt, em relação ao modelo de Sauerbrey para camadas rígidas, foi o que melhor estimou as quantidades e as espessuras das camadas adsorvidas nas superfícies carregadas ao longo da faixa de concentração de sal estudada.

Os resultados do estudo do polianfótero a nível molecular mostraram que ocorrem maiores quantidades adsorvidas do polímero em valores intermediários de concentração de sal e menores quantidades adsorvidas em valores extremos da faixa de concentração estudada. O comportamento de adsorção ao longo da curva se mostrou diferente. Interações eletróstaticas para baixos valores de força iônica, interações não iônicas, além de eletrostáticas para forças iônicas intermédiárias, e a blindagem de cargas para elevadas concentração de sal, foram os principais aspectos para explicação da quantidade adsorvida do polímero. Para elevados valores de concentrações de sal, além da blindagem de cargas, a redução da carga das superfícies modelos causando a redução da dupla camada elétrica e portanto do potencial de cisalhamento, também pode ser citada com causa da baixa adsorção.

A avaliação dos resultados de adsorção através dos gráficos de dissipação de energia versus variação da frequência, com o tempo implícito, foi considerado relevante pois pode ser observadas as etapas de adsorção do polímero para as condições estudadas.

A variação da conformação de camadas preadsorvidas com a variação da forças iônica, também foi um tópico importante mostrado nesta Tese. Com estes resultados, as condições de concentração de sal poderiam ser conduzidas de forma a beneficiar os resultados de inchamento da camada, os quais foram encontrados ser importantes com relação às propriedades de resistências do papel.

Para finalizar, neste estudo também foi mostrado a importância da utilização conjunta de técnicas instrumentais modernas para reforçar o entendimento do comportamento dos fenômenos. A balança microgravimétrica com dissipação de 
energia (QCM-D) foi fundamental para os estudos de adsorção do polímero em tempo real. Por outro lado, a determinação do tamanho aparente das cadeias do polianfótero em solução (DLS) e a visualização da camada adsorvida através da técnica de imagem (AFM) contribuiram para o entendimento dos resultados práticos.

\subsection{Recomendações para trabalhos futuros}

De acordo com a avaliação realizada ao longo da execução do presente trabalho, algumas recomendações para trabalhos futuros ou continuidade deste estudo serão descritas abaixo.

A avaliação do polianfótero como agente de retenção e drenagem, e sua resistência às forças de cisalhamento, também é uma sugestão interessante desde que se trata de uma macromolécula com dupla carga que, dependendo do $\mathrm{pH}$ de operação, comprovadamente, aumenta a resistência do papel. Por outro lado, estudos específicos sobre as interações entre os agentes químicos utilizados no Capítulo 3 poderão ser realizados com as técnicas em nanoescala utilizadas no Capítulo 5, visando melhor entendimento das interações em interface sólido-líquido e otimização dos sistemas de retenção e drenagem atuais.

Como o lixo aniônico é visto como componente desfavorável na água branca, conforme Capítulo 3, porém presente especialmente em situação de sistemas com elevado grau de fechamento do circuito de água, um estudo importante seria a formação de agregados dos mesmos com polieletrolitos de carga oposta e avaliação de sua adsorção em superfícies carregadas, tanto em nível molecular quanto em superfícies de fibras celulósicas, com o objetivo de mantê-los adsorvidos na superfície de fibras podendo, dessa forma, elevar o grau de fechamento do circuito de água branca em máquinas de papel.

Considerando que o estudo das características do polianfótero em solução e sua adsorção em superfícies carregadas foi importante para o entendimento das propriedades viscoelásticas das camadas adsorvidas e da conformação do polímero 
na interface, os resultados de massa específica e de espessura da camada, poderão ser confirmados com a determinação in sito da espessura da camada em construção através da técnica de elipsometria. Estes resultados poderão ser confrontados com os resultados estimados pelo modelo de Voigt.

Dentre as condições que afetam o processo de adsorção em interfaces sólidolíquido, a temperatura, o teor de lixo aniônico e a presença de eletrólitos multivalentes podem ter efeito nas características das camadas adsorvidas. Assim, uma sugestão seria incluir estas variáveis de condição industrial para avaliação da adsorção do polianfótero e respectivos efeitos na resistência do papel em pesquisas futuras.

A síntese de novos polianfóteros com características de peso molecular e proporção entre os grupos positivos e negativos diferentes, para estudos de comportamento de adsorção e de capacidade de inchamento, também é importante para estudos futuros visando não somente a função de aumento de resistência do papel mas também como agente de retenção de partículas tanto na suspensão quanto visando o pretratamento da água branca para redução do consumo específico de água de processo.

Estudo mais aprofundado sobre a morfologia do polímero e a sua polidispersidade no meio de dispersão, polianfótero inclusive, e sua correlação com as caracterísitcas da camada adsorvida é importante especialmente quando se trata de adsorção em superfície porosa como é o caso da fibra de celulose.

A caraterização da superfície da fibra e da superfície modelo de celulose em termos de densidade de carga, tamanho de poros e rugosidade, relacionando com a adsorção do polianfótero em superfície e, ou, na estrutura destas superfícies se torna um conhecimento importante considerando a correlação entre estas duas superfícies.

O estudo comparativo, em nível molecular, envolvendo o amido catiônico seguido do estudo de viabilidade econômica para comparação com o polianfótero se torna interessante numa etapa seguinte. $O$ amido é bastante utilizado para este fim e se caracteriza por ser um produto barato. 
A utilização prévia de polímeros carregados, atuando como sítios de adsorção de outros polímeros como o caso de polianfóteros, visando a preparação da superfície da fibra, também pode ser um estudo importante para aumentar a eficiência do polianfótero como agente de resistência a seco.

O estudo da atuação de polianfóteros na presença de partículas com elevadas superfícies específicas, semelhantes aos finos de natureza orgânica existentes em supensões de fibras, também é uma sugestão para pesquisa futura.

Não houve condições materiais e de tempo para o estudo exaustivo do efeito da força iônica em outros valores de $\mathrm{pH}$. Os quatro pontos de $\mathrm{pH}$ sugeridos a seguir são considerados os mais importantes, em razão de observações feitas neste estudo: 6,$5 ; 7,3 ; 8,5$ e 9,5, para continuidade dos estudos com este polianfótero.

Igualmente aos testes realizados neste estudo com o polímero duplamente carregado, estudos comparativos utilizando as mesmas técnicas nanométricas para polieletrólitos monocarregados são também recomendados para continuidade do presente estudo. 


\section{REFERÊNCIAS}

ALBINSSON, C.-J.; SWERIN, A.; ÖDBERG, L. Formation and retention during twinwire blade forming of a fine paper stock. Tappi Journal, v.78, n 4, p. 121-128, 1995.

ALFANO, J. C.; CARTER, P.W.; DUNHAM, A.J.; NOWAK, M.J.; TUBERGEN, K.R. Polyelectrolyte-induced aggregation of microcrystalline cellulose: reversibility and shear effects. Journal of Colloid and Interface Science, v. 223, p. 244-254, 2000.

ALINCE, B.; BEDNAR, F.; van de VEN, T.G.M. Deposition of calcium carbonate particles on fiber surfaces induced by cationic polyelectrolyte and bentonite. Colloids and Surfaces A: Physicochemical Engineening Aspects, v.190, p. 71-80, 2001.

BHARDWAJ, N. K.; KUMAR, S.; BAJPAI, P.K. Effects of zeta potential on retention and drainage of secondary fibres. Colloids and Susfaces A: Physicochem. Eng. Aspects, v. 260, p. 245-250, 2005.

BLANCO, A., NEGRO, C., TIJERO, J. Develoments in flocculation: A literature review. UK: Pira International, 2001. 152p.

BLANCO, A. Estudio de la floculación en la fabricación de papel. 1994. 441p. Tese (Doutorado) - University Complutense of Madrid, Madrid, Spain, 1994.

BLOMSTEDT, M.; KONTTURI, E.; VUORINEN, T. Surface modification of eucalyptus pulp by carboxymethylcellulose: effects on fiber properties and sheet strength. $\mathbf{O}$ Papel, v. 6, p. 51-63, 2007.

BOHIDAR, H. B. Characterization of polyelectrolytes by dynamic laser light scattering. In: TRIPATHY, S. K.; KUMAR, J.; NALWA, H. S. Handbook of Polyelectrolytes and their Applications. California: American Scientific Publishers, 2002. v. 2, p. 117-145.

BROUILLETTE, F.; MORNEAU, D.; CHABOT, B. E; DANEAULT, C. A new microparticulate system to improve retention/drainage in fine paper manufacturing. Appita Journal, v.58, $n^{\circ} 1$, p. 47-51, 2005.

BROUWER, P. H. The relationship between zeta potential and ionic demand and how it affects wet-end retention. Tappi Journal, v. 1, p. 170-179, 1991.

BUTT, H.-J.; CAPPELA, B.; KAPPE, M. Force measurements with the atomic force microscope: Technique, interpretation and applications. Surface Science Reports, v. 59 , p. 1-152, 2005.

CARR, M.E.; HOFREITER, B. T.; SCHULTE, M. I.; RUSSELL, C. R. Starch polyampholyte for paper. Tappi Journal, v.60, n 10, p. 66-69, 1977.

CAZAL, C. M.; BARBOSA, L. C. A.; MALTHA, C. R. A.; COLODETTE, J. L.; REIS, E. L.; MENDONÇA, V. R. Método prático para determinação quantitativa de grupos carboxílicos em polpa de celulose. In: INTERNATIONAL COLLOQUIUM ON 
EUCALYPTUS KRAFT PULP, 2007, Belo Horizonte. Anais... Belo Horizonte, 2007. Não paginado.

CEZAR, N.; XIAO, $H$. Novel retention system based on (2,3epoxypropyl)trimethylammonium chloride modified silica nanoparticles and anionic polymer. Ind. Eng. Chem. Res., v. 44, p. 539-545, 2005.

ChemYQ. China. N,N-dimethyl aminopropyl acrylamide; DMAPAA. Disponível em: <http://www.chemyq.com/En/xz/xz13/127669cadgx.htm>. Acesso em: 21 dez. 2008.

CHEN, J.; HEITMANN, J. A.; HUBBE, M. A. Dependency of polyelectrolyte complex stoichiometry on the order of addition. 1. Effect of salt concentration during streaming current titrations with strong poly-acid and poly-base. Colloids Surf. A, v. $223 n^{\circ} 1-3$, p. 215-230, 2003.

CIFERRI, A.; KUDAIBERGENOV, S. E. Natural and synthetic polyampholytes, 1 a. theory and basic structures. Macromolecular Rapid Communications, v. 28, p. 1953-1968, 2007.

CLAESSON, P. M.; DEDINAITE, A.; ROJAS, O. J. Polyelectrolytes as adhesion modifiers. Advances in Colloid and Interface Science, v. 104, p. 53-74, 2003.

CLAESSON, P. M.; POPTOSHEVA, E.; BLOMBERGA, E.; DEDINAITE, A. Polyelectrolyte-mediated surface interactions. Advances in Colloid and Interface Science, v. 114-115, p. 173-187, 2005.

DANG, Z. The Investigation of Carboxyl Groups of Pulp Fibers during Kraft Pulping, Alkaline Peroxide Bleaching, and TEMPO-mediated Oxidation. 2007. 234p. Tese (Doutorado) - School of Chemical and Biomolecular Engineering, Institute of Technology, Atlanta, Georgia, 2007.

DECHER, G. Fuzzy Nanoassemblies: Toward Layered Polymeric Multicomposites. Science, v. 277, p. 1232-1237, 1997.

DENCE, C. W.; REEVER, D. W. Pulp bleaching, principles and practice. Atlanta: Tappi Press, 1996. 868p.

DOBRYNIN, A. V.; RUBINSTEIN, M.; JOANNY, J.-F. Adsorption of a polyampholyte chain on a charged surface. Macromolecules, v. 30, p. 4332-4341, 1997.

DOBRYNIN, A. V., OBUKHOV, S. P., RUBINSTEIN, M. (1999). "Long-Range Multichain Adsorption of Polyampholytes on a Charged Surface." Macromolecules 32: 5689-5700.

DOBRYNIN, A. V. Theory and simulations of charged polymers: From solution properties to polymeric nanomaterials. Current Opinion in Colloid \& Interface Science, v. 13, p. 376-388, 2008.

DOIRON, B. E. Retention aid systems. In: GESS, J. M. Retention of fines and fillers during papermaking. Atlanta: Tappi Press, 1998. p. 157-176. 
DUNHAM, A. J.; SHERMAN, L. M.; ALFANO, J. C. Effect of dissolved and colloidal substances on drainage properties of mechanical pulp suspensions. Journal of Pulp and Paper Science, v. 28, nº 9, p. 298-304, 2002.

DUVAL, Y.; MIELCZARSKI, J. A.; POKROVSKY, O. S.; MIELCZARSKI, E.; EHRHARDT, J. J. Evidence of the existence of three types of species at the quartzaqueous solution interface at $\mathrm{pH}$ 0-10: XPS surface group quantification and surface complexation modeling. J. Phys. Chem. B, v. 106, p. 2937-2945, 2002.

ENARSSON, L.-E.; WÅGBERG, L. Polyelectrolyte adsorption on thin cellulose films studied with reflectometry and quartz crystal microgravimetry with dissipation. Biomacromolecules, v. 10, $n^{\circ} 1$, p. 134-141, 2009.

ERIKSSON, M.; NOTLEY, S. M.; WÅBERG, L. The influence on paper strength properties when building multilayers of weak polyelectrolytes onto wood fibres. $\mathbf{J}$. Colloid and Interface Sci., v. 292, p. 38-45, 2005.

ERIKSSON, M.; TORGNYSDOTTER, A.; WÅGBERG, L. Surface modification of wood fibers using the polyelectrolyte multilayer technique: Effects on fiber joint and paper strength properties. Ind. Eng. Chem. Res., v. 45, p. 5279-5286, 2006.

EVERAERS, R.; JOHNER, A.; JOANNY, J.-F. Polyampholytes: From single chains to solutions. Macromolecules, v. 30, p. 8478-8498, 1997.

FARDIM, P. Papel e química de superfície - Parte I - A superfície da fibra e a química da parte úmida. O Papel, v. 4, p. 97-107, $2002 a$.

FARDIM, P. Papel e Química de Superfície. Parte II - Revestimento e printabilidade." O Papel, v. 5, p. 75-83, 2002 b.

FARDIM, P.; HOLMBON, B. Origin and surface distribution of anionic groups in different papermaking fibres. Colloids and Surfaces A: Physicochem. Eng. Aspects, v. 252, p. 237-242, 2005.

FLEER, G. J.; COHEN STUART, M. A.; SCHEUTJENS, J. M. H. M.; COSGROVE, T.; VINCENT, B. Polymers at Interfaces. $1^{\text {a }}$ Ed. London: Chapman \& Hall, 1993. p.502.

GALLAGHER, T. M. Retention: the key to efficient papermaking. Nalco Chemical Company. Naperville, IL, USA. Disponível em: <http://wwwcsi.unian.it/educa/inglese/retentio.html>. Acesso em :22 jul. 2007.

GÄRDLUND, L.; WÅGBERG, L.; GERNANDT, R. Polyelectrolyte complexes for surface modification of wood fibres II. Influence of complexes on wet and dry strength of paper. Colloids and Surfaces A: Physicochemical and Engineering Aspects, v. $218, n^{\circ} 1$, p. $137-149,2003$.

GAUDREAULT, R.; WHITEHEAD, M.A.; van de VEN, T. G. Mechanisms of flocculation of microcrystalline cellulose by poly(ethylene oxide) and cofactor corilagin. In: FUNDAMENTAL RESEARCH SYMPOSIUM, 13., 2005, Cambridge. Anais... 2005. p. 1269-1292. 
GERNANDT, R.; WÅGBERG, L.; GÄRDLUND, L.; DAUTZENBERGD, H. Polyelectrolyte complexes for surface modification of wood fibres I. Preparation and characterisation of complexes for dry and wet strength improvement of paper. Colloids and Surfaces A: Physicochem. Eng. Aspects, v. 213, p. 15-25, 2003.

GUNNARS, S.; WÅGBERG, L.; COHEN STUART, M. A. Model films of cellulose: I. Method development and initial results. Cellulose, v. 9, p. 239-249, 2002.

HARRIS, N.; FORD, P.; SPADA, A. Decoupling: the latest developments in retention and drainage technology. In: AFRICAN PULP AND PAPER WEEK, 2004, African. Disponível em: <http://tappsa.co.za/archive2/APPW_2004/Title2004/Decoupling/decoupling.html>. Acesso em: 15 jun. 2007.

HEERMANN, M. L.; WELTER, S.R.; HUBBE, M.A. Effects of high treatment levels in a dry-strength additive program based on deposition of polyelectrolyte complexes: How much glue is too much? Tappi Journal, v. 5, nº, p. 9-14, 2006.

HOLMBERG, M.; WIGREN, R.; ERLANDSSON, R.; CLAESSON, P. M. Interactions between cellulose and colloidal sílica in the presence of polyelectrolytes. Colloids and Surfaces A: Physicochemical and Engineering Aspects, v. 129-130, p. 175183, 1997.

HÖÖK, F.; RODAHL, M.; KASEMO, B.; BRZEZINSKI, P. "Structural changes in hemoglobin during adsorption to solid surfaces: Effects of $\mathrm{pH}$, ionic strength, and ligand binding. Proc. Natl. Acad. Sci., v. 95, p. 12271-12276, 1998a.

HUBBE, M. A. Emerging technologies in wet end chemistry. UK: Pira International, 2005. 91p.

HUBBE, M. Bonding between cellulosic fibers in the absence and presence of drystrength agents - A review. BioResources, v.1, $n^{\circ}$ 2, p. 281-318, 2006.

HUBBE, M.; ROJAS, O.; ARGYROPOULOS, D.S.; WANG, Y.; SONG, J.; SULIC, N.; SEZAKI, T. Charge and the dry-strength performance of polyampholytes. Part 2. Colloidal effects. Colloids and Surfaces A Physicochem. Eng. Aspects, v.301, p. 23-32, 2007a.

HUBBE, M.; ROJAS, O.; SULIC, N.; SEZAKI, T. Unique behavior of polyelectrolytes as dry-strength additives. Appita Journal, v. 60, $n^{0}$ 2, p. 23-32, $2007 \mathrm{~b}$.

HUNTER, R. J. Introduction to modern colloid science. New York: Oxford University Press, 1993. 352p.

IBRAEVA, Z. E.; HAHN, M.; JAEGER, W.; BIMENDINA, L. A.; KUDAIBERGENOV, S.E. Solution properties and complexation of polyampholytes based on N,NDimethyldiallylammonium chloride and maleic acid or alkyl (Aryl) derivatives of maleamic acids. Macromol. Chem. Phys., v. 205, p. 2464-2472, 2004.

IRWIN, E. F.; HO, J. E.; KANE, S. R.; HEALY, K. E. Analysis of interpenetrating polymer networks via quartz crystal microbalance with dissipation monitoring. Langmuir, v. 21, $\mathrm{n}^{\circ} 12$, p. A-H, 2005. 
KAPPL, M.; BUTT, H.-J. The colloidal probe technique and its application to adhesion force measurements. Part. Part. Syst. Charact., v. 19, p. 129-143, 2002.

KING, C. A. Cellulose Fiber-to-Fiber and Fines-to-Fiber Interactions: Their Coagulation and Flocculation Tendencies as Affedted by Eletrolytes and Polymers in an Agittated Water Slurry.1975. 210p. Tese (Doutorado) - Institute of Paper Chemistry, Appleton, WI, 1975.

KONTTURI, K. S.; TAMMELIN, T.; JOHANSSON, L.-S.; STENIUS, P. Adsorption of cationic starch on cellulose studied by QCM-D. Langmuir, v. 24, p. 4743-4749, 2008.

KONTTURI, E.; TAMMELIN, T.; ÖSTERBERG, M. Cellulose-model films and the fundamental approach. Chem. Soc. Rev.,_v. 35, p. 1287-1304, 2006.

KROGERUS, B. Laboratory testing of retention and drainage. In: GULLICHSEN, J.; PAULAPURO, H. Papermaking Chemistry. Helsinki, Finland: FAPET Oy, 1999a. Book 4 of Papermaking Science and Technology Series Books, cap. 4, p. 82-93.

KROGERUS, B. Fillers and pigments. In: GULLICHSEN, J.; PAULAPURO, $H$. Papermaking Chemistry. Helsinki, Finland: FAPET Oy, 1999b. Book 4 of Papermaking Science and Technology Series Books, cap. 6, p.115-149.

KUDAIBERGENOV, S. E.; CIFERRI, A. Natural and synthetic polyampholytes, $2^{a}$ Functions and applications. Macromolecular Rapid Communications, v. 28, p. 1869-1986, 2007.

LE BERRE, F.; MALMSTEN, M.; BLOMBERG, E. Interfacial properties of a model polyampholyte studied by surface force measurements, ESCA, and ellipsometry. Langmuir, v. 17, p. 699-704, 2001.

LINDSTROM, T.; GLAD-NORDMARK, G. J. Selective adsorption, flocculation, and fractionation of wood pulps with polyethylene oxide. Journal of Colloid and Interface Science, v. 94, $n^{\circ}$ 2, p. 404-411, 1983.

LINDSTRÖM, R.; WÅGBERG, L.; LARSSON, P. T. Formation of polyelectrolyte multilayers on fibres: Influence on wettability and fibre/fibre interaction. J. Colloid and Interface Sci., v. 296, p. 396-408, 2006.

LOFTON, M. C.; MOORE, S.M.; HUBBE, M.A.; LEE, S.Y. Deposition of polyelectrolyte complexes as a mechanism for developing paper dry strength. Tappi Journal, v. 4, nº 9, p. 3-8, 2005.

MAHLTIG, B. W. H.; HARRATS, C.; MÜLLER-BUSCHBAUM, P.; JÉRÔME, R.; STAMM, M. Adsorption of polyampholyte copolymers at the solid/liquid interface: The influence of $\mathrm{pH}$ and salt on the adsorption behavior. Phys. Chem, Chem. Phys., v. 1, p. 3853-3856, 1999.

MAHLTIG, B.; GOHY, J.-F.; JÉRÔME, R.; BELLMANN, C.; STAMM, M. Adsorption of block polyampholyte micelles in monolayers at the silicon water interface. Colloid Polym Sci., v. 278, p. 502-508, 2000. 
MAHLTIG, B.; JÉRÔME, R.; STAMM, M. Diblock polyampholytes at the silicon/water interface: Adsorption at various modified silicon substrates. Phys. Chem. Chem. Phys., v. 3, p. 4371-4375, 2001.

MAIN, S.; SIMONSON, P. Retention aids for high-speed paper machines. Tappi Journal, v. 82, $n^{\circ}$ 4, p. 78-84, 1999.

MARTINS, M.; KILPP, S.; FREITAS, G.; ABDALLAH, M. Atendimento ao cliente e tendências de mercado para celulose de eucalipto. O Papel, v. $56, n^{\circ} 7$, p. 27-34, 1995.

MERTA, J. Interactions between cationic starch and anionic surfactants. 2001. 117p. Tese (Doutorado) - Department of Forest Products Technology, Helsinki University of Technology, Helsinki, FI, 2001.

MIRZA, S.; CONYNGHAM, M.; COVARRUBIAS, R. M. New advances in microparticle retention technologies. In: AFRICAN PULP AND PAPER WEEK, 2002, African. Disponível em: < http://www.tappsa.co.za/archive/APPW2002/Title/New_advances_in_microparticle_/ new_advances_in_microparticle_.html>. Acesso em 06 jan. 2010.

MODIN; C.; STRANNE, A.-L.; FOSS, M.; DUCH, M.; JUSTESEN, J.; CHEVALLIER, J.; ANDERSEN, L. K.; HEMMERSAM, A.G.; PEDERSEN, F.S.; BESENBACHER; F. QCM-D studies of attachment and differential spreading of pre-osteoblastic cells on Ta and $\mathrm{Cr}$ surfaces. Biomaterials, v. 27, p. 1346-1354, 2006.

MOFFAT, J.; NOEL, T. R.; PARKER, R.; WELLNER, N.; RING, S. G. The environmental response and stability of pectin and poly-L-lysine multilayers. Carbohydrate Polymers, v. 70, p. 422-429, 2007.

MOFFETT, R. H. On-site production of a silkambased microparticulate retention and drainage aid. Tappi Journal, v. 77, $\mathrm{n}^{\circ}$ 12, p. 133-138, 1994.

MUNRO, J. C.; FRANK, C. W. Polyacrylamide adsorption from aqueous solutions on gold and silver surfaces monitored by Quartz Crystal Microbalance. Macromolecules, v. 37, $n^{\circ}$ 3, p. 925-938, 2004.

NEIMO, L.; ANDERSSON, T. Internal sizing of paper. In: GULLICHSEN, J.; PAULAPURO, H. Papermaking Chemistry. Helsinki, Finland: FAPET Oy, 1999. Book 4 of Papermaking Science and Technology Series Books, cap. 7, p. 150- 203.

NIANWEI, Y. KEQIANG, C. Ultrasonically initiated emulsifier-free emulsion copolymerization of $\mathrm{n}$-butyl acrylate and acrylamide. Part I: Polymerization mechanism Polymer. Polymer, v. 45, p. 3587-3594, 2004.

NISATO, G.; MUNCH, J. P.; CANDAU, S. J. Swelling, structure, and elasticity of polyampholyte hydrogels. Langmuir, v. 15, p. 4236-4244, 1999.

NISKANEN, K., KAJANTO, I.; PAKARINEN, P. Paper Structure. In: NISKANEN, K. Paper Physics. Helsinki, Finland: FAPET Oy, 1999. Book 16 of Papermaking Science and Technology Series Books, cap. 1, p. 13-53. 
NORELL, M.; JOHANSSON, K.; PERSSON, M. Retention and Drainage. In: GULLICHSEN, J.; PAULAPURO, H. Papermaking Chemistry. Helsinki, Finland: FAPET Oy, 1999. Book 4 of Papermaking Science and Technology Series Books, cap.3, p. $42-81$.

NOTLEY, S. M.; BIGGS, S.; CRAIG, V. S. J.; WÅGBERG, L. Adsorbed layer structure of a weak polyelectrolyte studied by colloidal probe microscopy and QCM-D as a function of $\mathrm{pH}$ and ionic strength. Phys. Chem. Chem. Phys, v. 6, p. $2379-$ 2386, 2004.

NOTLEY, S. M.; ERIKSSON, M.; WÅGBERG, L. Viscoelastic and adhesive properties of adsorbed polyelectrolyte multilayers determined in situ with QCM-D and AFM measurements. Journal of Colloid and Interface Science, v. 292, p. 29-37, 2005.

NOTLEY, S. M.; PETTERSSON, B.; WÅGBERG, L. Direct measurement of attractive van der Waals' forces between regenerated cellulose surfaces in an aqueous environment. Journal of the American Chemical Society, v. 26, $n^{\circ} 43$, p. $13930-$ 13931, 2004a.

OJALA, T. Chemical bonds in papermaking. In: GULLICHSEN, J.; PAULAPURO, H. Papermaking Chemistry. Helsinki, Finland: FAPET Oy, 1999. Book 4 of Papermaking Science and Technology Series Books, cap. 2, p. 18-41.

OJALA, T. Ripasa's wet end controls. Automation. v. 1, p. 12-15, 2006.

OKSANEN, T. B.; J. VIIKARI, L. The role of hemicelluloses in the hornification of bleached kraft pulps. Holzforschung, v. 51, nº 4, p. 355-360, 1997.

ONDARAL, S.; WÅGBERG, L.; ENARSSON, L.-E. The adsorption of hyperbranched polymers on silicon oxide surfaces. Journal of Colloid and Interface Science, v. 301, p. 32-39, 2006.

ÖSTERBERG, M. On the interactions in cellulose systems: surface forces and adsorption. 2000a. 63p. Tese (Doutorado) - Department of Chemistry, Surface Chemistry, Royal Institute of Technology, Stockholm, Sweden. 2000a.

ÖSTERBERG, M. The effect of a cationic polyelectrolyte on the forces between two cellulose surfaces and between one cellulose and one mineral surface. Journal of Colloid and Interface Science, v. 229, p. 620-627, 2000b.

PAGE, D. A Theory for the Tensile Strength of Paper. Tappi Journal, v. 54, p. 674$681,1969$.

PANSHIN, A. J., ZEEUW, C. Textbook of wood technology. New York: McGrawHill, 1980. 772p.

PATRICKIOS, C. S.; SHARMA, L. R.; ARMES, S.P.; BILLIGHAMAND, N. C. Precipitation of a water-soluble ABC triblock methacrylic polyampholyte: Effects of time, $\mathrm{pH}$, polymer concentration, salt type and concentration, and presence of a protein." Langmuir, v. 15, p. 1613-1620, 1999. 
PRUSZYNSKI, P.; CARDOSO, X.; KAMLIN, B. Stabilization of performance of wetend of paper machine: A chemist's approach. In: Appita Conference, 2002, Rotorua, New Zeland. Anais... Rotorua, New Zeland, 2002. Não paginado.

RABOCKAI, T. Físico-Química de Superfícies. Washington: OEA, 1979. 128p.

RADTCHENKO, I. L.; PAPASTAVROU, G.; BORKOVEC, M. Direct force measurements between cellulose surfaces and colloidal silica particles. Biomacromolecules, v. 6, p. 3057-3066, 2005.

REBUZZI, F.; EVTUGUIN, D.V. About glucuronoxylan effect on the hornification of E. Globulus bleached pulps. In: INTERNATIONAL COLLOQUIUM ON EUCALYPTUS KRAFT PULP, 2007, Belo Horizonte. Anais... Belo Horizonte, 2007. Não paginado.

RODAHL, M.; KASEMO, B. Frequency and dissipation-factor responses to localized liquid deposits on a QCM electrode. Sensors and Actuators A-Physical, v. 54, $\mathrm{n}^{\circ}$ 1-3, p. 448-456, 1996.

ROJAS, O. J.; CLAESSON, P. M.; MULLER, D.; NEUMAN, R. D. The effect of salt concentration on adsorption of low-charge-density polyelectrolytes and interactions between polyelectrolyte-coated surfaces. Journal of Colloid and Interface Science, v. 205, p. 77-88, 1998.

ROJAS, O. J. Adsorption of polyelectrolytes on mica. In: HUBBARD, A. Encyclopedia of Surface and Colloid Science. New York: Marcel Dekker, 2002a. p.517-535.

ROJAS, O. J. Química del papel. Colômbia: Cargraphics, 2003. Série Competencias Laborales $n^{\circ} 3,266 p$.

ROJAS, O. J.; ERNSTSSON, M.; NEUMAN, R.D.; CLEASSON, P.M. Effect of polyelectrolyte charge density on the adsorption and desorption behavior on mica. Langmuir, v. 18, $n^{\circ} 5$, p. 1604-1612, 2002b.

ROJAS, O. J.; HUBBE, M. A. The Dispersion Science of Papermaking. Journal of Dispersion Science and Technology, v. 25, nº 6, p. 713-732, 2004.

ROJAS, O. J.; NEUMAN, R. D. Adsorption of polysaccharide wet-end additives in papermaking systems. Colloids and Surfaces A: Physicochemical and Engineering Aspects, v. 155, p. 419-432, 1999.

ROJAS, O. J.; NEUMAN, R. D.; CLAESSON, P. M. Desorption of low-charge-density polyelectrolyte adlayers in aqueous sodium n-dodecyl sulfate solution. Journal of Colloid and Interface Science, v. 237, p. 104-111, 2001.

RYDHOLM, A. S. Pulping Processes. New York: John Wiley \& Sons, 1965. 1269p.

SAUERBREY, G. Z. The use of quartz oscillators for weighing thin layers and for microweighing. Zeitschrift Fur Physik, v. 155, n² 2, p. 206-222, 1959.

SCOTT, W. E. Principles of Wet End Chemistry. Atlanta: Tappi Press, 1996. 184p. 
SEZAKI, T.; HUBBE, M.; HEITMANN, J. A.; ARGYROPOULOS, D. S.; WANG, X. Colloidal effects of acrylamide polyampholytes. Part 1. Electrokinetic behavior. Colloids and Surfaces A Physicochem. Eng. Aspects, v. 281, p. 74-81, 2006a.

SEZAKI, T.; HUBBE, M.; HEITMANN, J.A.; ARGYROPOULOS, D.S.; WANG, X.; WANG, X. Colloidal effects of acrylamide polyampholytes. Part 2: Adsorption onto cellulosic fibers. Colloids and Surfaces A Physicochem. Eng. Aspects, v. 289, p. 89-95, 2006b.

SHAW, D. J. Introdução à Química dos Colóides e de Superfícies. São Paulo: Edgard Blücher e EDUSP, 1975. 185p.

SILVA, D. J.; OLIVEIRA, R.C.; COLODETTE, J.L.; GOMIDE, J. L. Impacto da qualidade da madeira na deslignificação, no branqueamento e nas propriedades físico-mecânicas da polpa Kraft de eucalipto. O Papel, v. 58, n² 2, p. 33 - 43, 1997.

SILVA, D. J., HUBBE, M. A., PARK, S. W., ROJAS, O. J. Adsorption and viscoelastic properties of polyampholytes monitored by QCM-D. In: CONGRESO IBEROAMERICANO DE INVESTIGACION EN CELULOSA Y PAPEL, 5., 2008a, Guadalajara, Jalisco. Guadalajara, 2008a. CD-ROM

SILVA, D. J., YAMAGUCHI, T., SONG, J., HUBBE, M. A., PARK, S. W., ROJAS, O. J. Adsorbed polyampholyte swelling ability and its effect on paper strength. In: PULP AND PAPER INTERNATIONAL CONGRESS \& EXHIBITION, 41., 2008b, Sao Paulo. São Paulo, 2008b. CD-ROM.

SILVA, D. J., ROJAS, O. J., PARK, S. W., HUBBE, M. A. (2009b). Evaluation of adsorbed polyampholyte layers by using quartz crystal microbalance. In: International Symposium on Process Systems Engineering, PSE2009, 10., 2009, Salvador, BA. Anais... Salvador, BA, 2009. p.1929-1934.

SJÖSTROM, E. Wood Chemistry. Fundamentals and Applications. San Diego: Academic Press, 1993. 293p.

SMOOK, G. A. Handbook for pulp \& paper technologists. Atlanta: Tappi Press, 1987. 419p.

SOLBERG, D.; WÅGBERG, L. Adsorption and flocculation behavior of cationic polyacrylamide and colloidal silica. Colloids and Surfaces A: Physicochem. Eng. Aspects, v. 219, p. 161-172, 2003.

SONG, J.; WANG, Y., HUBBE, M.; ROJAS, O.; SULIC, N.R.; SEZAKI, T. Charge and the dry-strength performance of polyampholytes. Part 1. Handsheet properties and polymer solution viscosity. Journal of pulp and paper science, v. $32, n^{0} 3, p .156-$ 162, 2006.

SONG, J. Adsorption of Amphoteric and Nonionic Polymers on Organic Thin Films. 2008. 225p. Tese (Doutorado) - Wood and Paper Science, North Carolina State University, Raleigh, NC, 2008.

SONG, J.; YAMAGUSHI, T.; SILVA, D. J.; HUBBE, M. A.; ROJAS, O. J. Effect of charge asymmetry on adsorption and phase separation of polyampholytes on silica 
and cellulose surfaces. Journal Physical Chemistry B, v. 114, $\mathrm{n}^{\circ}$ 2, p. 719-727, 2010.

STÉN, M. Introduction to papermaking. In: GULLICHSEN, J.; PAULAPURO, H. Papermaking Chemistry. Helsinki, Finland: FAPET Oy, 1999. Book 4 of Papermaking Science and Technology Series Books, cap. 1, p. 12-17.

SWANSON, J. W. Colloid Chemistry of Papermaking Materials. Atlanta: Tappi Press, 2003. 278p.

TAMMELIN, T.; MERTA, J.; JOHANSSON, L.-S.; STENIUS, P. Viscoelastic properties of cationic starch adsorbed on quartz studied by QCM-D. Langmuir, v. 20, $n^{0} 25$, p. 10900-10909, 2004.

TAMMELIN, T.; SAARINEN, T.; ÖSTERBERG, M.; LAINE, J. Preparation of Langmuir/Blodgett-cellulose surfaces by using horizontal dipping procedure. Application for polyelectrolyte adsorption studies performed with QCM-D. Cellulose, v. 13, p. $519-535,2006$.

TRAN, Y.; PERRIN, P.; DEROO, S.; LAFUMA, F. Adsorption of randomly annealed polyampholytes at the silica-water interface. Langmuir, v. 22, p. 7543-7551, 2006.

UESAKA, T.; RETULAINEN, E.; PAAVILAINEN, L.; MARK, R. E.; KELLEY, S. Structural parameters: Fiber, bonds, and paper. In: MARK, R. E.; HABEGER JR., C. C.; BORCH, J.; LYNE, M.B. Handbook of physical test of paper. v.2, p. 873-900. 2007.

van de VEN, T. G. M. Association-induced polymer bridging by poly(ethylene oxide)cofactor flocculation systems. Advances in Colloid and Interface Science, v. 114115 , p. 147-157, 2005.

VELHO, J. L. Mineral fillers for paper why, what, how. Tomar: TECNICELPA, 2003. TECNICELPA Techinical books. 206p.

VOGT, B. D.; LIN, E. K.; WU, W.-L.; WHITE, C. C. Effect of film thickness on the validity of the Sauerbrey Equation for hydrated polyelectrolyte films. J. Phys. Chem. B, v. 108, p. 12685-12690, 2004.

VOINOVA, M. V.; RODAHL, M.; JONSON, M.; KASEMO, B. Viscoelastic acoustic response of layered polymer films at fluid-solid interfaces: Continuum mechanics approach. Physica Scripta, v. 59, n 5, p. 391-396, 1999.

WÅGBERG, L.; ÅSELL, I. The action of cationic polymers in the fixation of dissolved and colloidal substances. Part 2. Colloids and Surfaces A: Physicochemical and Engineering Aspects, v. 104, p. 169-184, 1995.

WÅGBERG, L.; BJORKLUND, M.; ÅSELL, I.; SWERIN, A. On the mechanism of flocculation by microparticle retention-aid systems. Tappi Journal, v. 79, $\mathrm{n}^{\circ}$ 6, p. 157-164, 1996.

WÅGBERG, L.; FORSBERG, S.; JOHANSSON, A.; JUNTTI, P. Engineering of fibre surface properties by application of the polyelectrolyte multilayer concept. Part I: 
Modification of Paper Strength. Journal of Pulp and Paper Science, v. 28, $n^{\circ} 7, p$. 222-228, 2002.

WANG, Y. Colloidal Behavior of Polyampholytes. 2006a. 107p. Dissertação (Mestrado) - Wood and Paper Science, North Carolina State University, Raleigh, NC, 2006a.

WANG, Y.; HUBBE, M.; SESAKI, T.; WANG, X.; ROJAS, O. J.; ARGYROPOULOS, D. S. The role of polyampholyte charge density on its interactions with cellulose. Nordic Pulp \& Paper Research Journal, v. 21, nº 5, p. 158-165, 2006b.

WANG, Y.; HUBBE, M.; ROJAS, O. J.; ARGYROPOULOS, D. S.; WANG, X.; SEZAKI, T. Charge and the dry-strength performance of polyampholytes. Part 3: Streaming potential analysis. Colloids and Surfaces A Physicochem. Eng. Aspects, v. 301, p. 33-40, 2007.

WEBB, L. J. Química da Parte úmida - Wet end chemistry for papermakers. In: CONGRESSO ANNUAL DE CELULOSE E PAPEL, 34., São Paulo, 2001. São Paulo, v.1, $n^{\circ}$ 5, p.3-54. (2001).

WEN, S.; STEVENSON, W. T. K. Synthetic pH sensitive polyampholyte hydrogels: A preliminary study. Colloid \& Polymer Science, v. 271, p. 38-49, 1993.

Whitakeroil Oil Company. United States. Itaconic Acid - Material Safety Data Sheet. Disponível em: <http://www.whitakeroil.com/product-details/items/485.html>. Acesso em: 21 dez. 2008.

WILLIAMS, R. A. Characterization of process dispersions. In: WILLIAMS, R. A. Colloid and Surface Engineering: Applications in the process industries. Oxford: Butterworth-Heinemann, 1992. p. 3-54.

XIAO, H.; PELTON, R.; HAMIELEC, A. Novel retention aids for mechanical pulps. Tappi Journal, v. 79, $n^{\circ} 4$, p. 129-135, 1996.

XU, S.; CAO, L.; WU, R.; WANG, J. Salt and pH responsive property of a starchbased amphoteric superabsorbent hydrogel with quaternary ammonium and carboxyl groups (II). Journal of Applied Polymer Science, v. 101, p. 1995-1999, 2006.

YAMAGUCHI, T., SILVA, D. J., HUBBE, M. A., ROJAS, O. J. The effect of cationic additives on the adsorption of polymapholyte on cellulose. In: ACS COLLOID AND SURFACE SCIENCE SYMPOSIUM,82., 2008, Raleigh, NC. Abstracts. Raleigh, 2008. Res. 252.

YOON, S.-Y.; DENG, Y. Flocculation and reflocculation of clay suspension by different polymer systems under turbulent conditions. Journal of Colloid and Interface Science, v. 278, p. 139-145, 2004.

ZHAO, Y.; CHEN, W.; YANG, Y.; YANG, X.; XU, H. Swelling behavior of ionically cross-linked polyampholytic hydrogels in varied salt solutions. Colloid Polym Sci, v. 285, p. 1395-1400, 2007. 
ZHANG, D. Characterization and enhancement of carboxyl groups in softwood kraft pulps during oxygen delignification. 2006. 250p. Tese (Doutorado) - School of Chemical \& Biomolecular Engineering, Georgia Institute of Technology, Atlanta, GA, 2006.

ZHANG, H.; KANNANGARA, D.; HILDE, M. The role of vapour deposition in the hydrophobization treatment of cellulose fibres using alkyl ketene dimers and alkenyl succinic acid anhydrides. Colloids and Surfaces A: Physicochem. Eng. Aspects, v. 297, p. 203-210, 2007.

ZHENG, Z.; MCDONALD, J.; KHILLAN, R. Layer-by-Layer nanocoating of lignocellulose fibers for enhanced paper properties. Journal of Nanoscience and Nanotechnology, v. 6, p. 624-632, 2006. 


\section{APÊNDICES}

\section{APÊNDICE A - RESULTADOS REFERENTES AO CAPÍTULO 3}

Tabela A 1 - Análise de fibras em Kajaani

\begin{tabular}{lcccccc}
\hline & $\begin{array}{c}\text { Comprimento, } \\
\mathrm{mm}\end{array}$ & $\begin{array}{c}\text { Largura, } \\
\mu \mathrm{m}\end{array}$ & $\begin{array}{c}\text { Diâmetro do } \\
\text { lúmen, } \mu \mathrm{m}\end{array}$ & $\begin{array}{c}\text { Espessura da } \\
\text { parede celular, } \\
\mu \mathrm{m}\end{array}$ & $\begin{array}{c}\text { \# de } \\
\text { fibras/g, } 10^{6}\end{array}$ & $\begin{array}{c}\text { Coarseness, } \\
\mathrm{mg} / 100 \mathrm{~m}\end{array}$ \\
\hline 1 & 0,77 & 16,67 & 11,81 & 2,26 & 24,3 & 6,2 \\
2 & 0,77 & 16,68 & 11,98 & 2,35 & 24,35 & 6,4 \\
3 & 0,78 & 16,76 & 12,07 & 2,36 & 24,83 & 6,5 \\
4 & - & 16,80 & 12,17 & 2,47 & 25,02 & 6,5 \\
\hline Média & $\mathbf{0 , 7 7}$ & $\mathbf{1 6 , 7 3}$ & $\mathbf{1 2 , 0 1}$ & $\mathbf{2 , 3 6}$ & $\mathbf{2 4 , 6 3}$ & $\mathbf{6 , 4}$ \\
\hline DP & 0,003 & 0,06 & 0,15 & 0,09 & 0,35 & 0,001 \\
\hline CV, \% & 0,33 & 1,42 & 1,26 & 3,72 & 1,42 & 1,961 \\
\hline
\end{tabular}

Tabela A 2 - Teor de finos determinado pelo Jarro de Britt

\begin{tabular}{cc}
\hline & Teor de finos, \% \\
\hline 1 & 15,11 \\
2 & 15,55 \\
3 & 15,85 \\
Média & $\mathbf{1 5 , 5}$ \\
\hline Desvio padrão & 0,30 \\
\hline CV,\% & 1,94
\end{tabular}


Tabela A 3 - Resultados de retenção

\begin{tabular}{ccc}
\hline Lixo aniônico, $\mathrm{kg} / \mathrm{t}$ & Demanda catiônica, $\mathrm{mEq} / \mathrm{L}$ & Turbidez, NTU \\
\hline 0.5 & 10.65 & 13 \\
0.5 & 11.82 & 11.65 \\
\hline 0.75 & 8.45 & 10.5 \\
\hline 1.25 & 5.65 & 3.975 \\
1.25 & 4.25 & 4.75 \\
\hline 1.5 & 2.3 & 3.79 \\
1.5 & 0.4 & 5.25 \\
\hline 1.75 & 2.7 & 7 \\
\hline 2 & -3.1 & 10.175 \\
\hline 2.5 & 2.3 & 18.6 \\
\hline
\end{tabular}

Tabela A 4 - Resultados de drenagem

\begin{tabular}{ccccc}
\hline Dos. coagulante, $\mathrm{kg} / \mathrm{t}$ & $\begin{array}{c}\text { Volume, } \\
\mathrm{mL}\end{array}$ & Tempo, $\mathrm{s}$ & $\begin{array}{c}\text { Velocidade de } \\
\text { escoamento, } \mathrm{mL} / \mathrm{s}\end{array}$ & Turbidez, NTU \\
\hline 0.5 & 124 & 10.06 & 12.33 & 11.6 \\
0.5 & 128 & 10.51 & 12.18 & 11.7 \\
\hline 1.25 & 136 & 9.47 & 14.36 & 3.1 \\
1.25 & 132 & 9.31 & 14.85 & 4.85 \\
\hline 1.5 & 138 & 9.43 & 14.63 & 3 \\
1.5 & 146 & 9.65 & 15.13 & 10.25 \\
\hline 2 & 133 & 9.62 & 13.83 & 10.1 \\
\hline 2 & 132 & 9.69 & 13.62 & 18.6 \\
\hline 2.5 & 127 & 9.4 & 13.5 & \\
\hline
\end{tabular}


Tabela A 5 - Efeito de forças de cisalhamento na retenção de partículas

\begin{tabular}{lcc}
\hline & Demanda catiônica, $\mathrm{mEq} / \mathrm{L}$ & Turbidez, NTU \\
\hline $450 \mathrm{rpm}$ & 10,65 & 13,0 \\
& 11,82 & 11,65 \\
\hline Média & $\mathbf{1 1 , 2 4}$ & $\mathbf{1 2 , 3 4}$ \\
DP & $\mathbf{0 . 8 2 7}$ & $\mathbf{0 . 9 5 5}$ \\
\hline 900 rpm & 7,5 & 37,4 \\
& 8,0 & 36,2 \\
\hline Média & $\mathbf{7 . 7 5}$ & $\mathbf{3 6 . 8}$ \\
DP & $\mathbf{0 . 3 5 4}$ & $\mathbf{0 . 8 4 9}$ \\
\hline
\end{tabular}


APENDICE B - RESULTADOS REFERENTES AO CAPÍTULO 5

Tabela B 1 - Efeito da dosagem de polianfótero no comprimento de autorruptura

\begin{tabular}{lccc}
\hline & \multicolumn{3}{c}{ Dosagem, \% } \\
\cline { 2 - 4 } & 0,0 & 0,29 & 0,59 \\
\cline { 2 - 4 } & 0.991 & 1.717 & 2.012 \\
1.069 & 1.762 & 1.923 \\
1.043 & 1.685 & 1.957 \\
0.959 & 1.520 & 2.055 \\
0.904 & 1.615 & 2.005 \\
& 0.994 & 1.634 & 2.017 \\
& 0.981 & 1.590 & 1.948 \\
& 0.965 & 1.599 & 2.077 \\
& 1.040 & 1.637 & 2.070 \\
& 0.929 & 1.723 & 2.140 \\
& 1.000 & 1.622 & 2.058 \\
& 1.069 & 1.748 & 2.234 \\
& 1.069 & 1.666 & 2.152 \\
Média & 1.010 & 1.703 & 2.158 \\
\hline Desvio padrão & 1.023 & 1.717 & 2.122 \\
\hline
\end{tabular}

Tabela B 2 - Efeito da dosagem de polianfótero no Scott Bond (ligações interfibras)

\begin{tabular}{lccc}
\hline & \multicolumn{3}{c}{ Dosagem, \% } \\
\cline { 2 - 4 } & 0,0 & 0,29 & 0,59 \\
\cline { 2 - 4 } & 25.2 & 44.1 & 56.7 \\
23.1 & 44.1 & 60.9 \\
& 29.4 & 42.0 & 67.2 \\
& 27.3 & 46.2 & 71.5 \\
& 31.5 & 54.6 & 67.2 \\
\hline Média & 29.4 & 54.6 & 71.5 \\
\hline Desvio padrão & $\mathbf{2 7 . 6 7 0 0 4}$ & $\mathbf{4 7 . 6 3 4 5}$ & $\mathbf{6 5 . 8 4 7 6 9}$ \\
\hline
\end{tabular}


Tabela B 3 - Efeito do pH no índice de tração do papel

\begin{tabular}{lcccc}
\hline & \multicolumn{4}{c}{$\mathrm{pH}$} \\
\cline { 2 - 5 } & 4,3 & 6,5 & 7,3 & 8,5 \\
\cline { 2 - 5 } & 12.23 & 13.59 & 14.59 & 11.51 \\
& 12.59 & 13.15 & 14.75 & 10.98 \\
& 12.51 & 13.23 & 15.00 & 10.86 \\
& 12.11 & 12.88 & 15.12 & 10.86 \\
& 11.66 & 13.34 & 14.82 & 11.11 \\
& & 13.53 & & 11.51 \\
\hline Média & 13.77 & $\mathbf{1 4 . 8 6}$ & $\mathbf{1 1 . 1 4}$ \\
\hline Desvio padrão & $\mathbf{1 2 . 2 2}$ & $\mathbf{1 3 . 3 5}$ & $\mathbf{0 . 3 0 3 1}$ \\
\hline
\end{tabular}

Tabela B 4 - Efeito da força iônica no índice de tração do papel

\begin{tabular}{lccc}
\hline & \multicolumn{3}{c}{ Força iônica, $\mu \mathrm{S} / \mathrm{cm}$} \\
\cline { 2 - 4 } & 700 & 1200 & 10000 \\
\cline { 2 - 4 } & 12.49 & 12.23 & 11.96 \\
11.67 & 12.59 & 12.91 \\
12.57 & 12.51 & 11.67 \\
& 12.44 & 12.11 & 13.40 \\
& 11.94 & 11.66 & 13.08 \\
& 11.67 & & 11.82 \\
Média & 11.92 & $\mathbf{1 2 . 2 2}$ & 13.60 \\
\hline Desvio padrão & $\mathbf{1 2 . 1 0}$ & $\mathbf{0 . 3 7 0 4}$ & $\mathbf{0 . 7 9 9 4}$ \\
\hline
\end{tabular}


Tabela B 5 - Efeito do pH e da força iônica na turbidez da solução de polianfótero

\begin{tabular}{|c|c|c|c|c|c|c|c|c|c|}
\hline \multicolumn{10}{|c|}{ Força iônica, $\mathrm{mM} \mathrm{NaCl}$} \\
\hline \multicolumn{2}{|c|}{0.1} & \multicolumn{2}{|c|}{1} & \multicolumn{2}{|c|}{10} & \multicolumn{2}{|c|}{100} & \multicolumn{2}{|c|}{1000} \\
\hline $\mathrm{pH}$ & $\begin{array}{c}\text { Turbidez, } \\
\text { NTU }\end{array}$ & $\mathrm{pH}$ & $\begin{array}{c}\text { Turbidez, } \\
\text { NTU }\end{array}$ & $\mathrm{pH}$ & $\begin{array}{c}\text { Turbidez, } \\
\text { NTU }\end{array}$ & $\mathrm{pH}$ & $\begin{array}{c}\text { Turbidez, } \\
\text { NTU }\end{array}$ & $\mathrm{pH}$ & $\begin{array}{c}\text { Turbidez, } \\
\text { NTU }\end{array}$ \\
\hline 3.59 & 0.13 & 3.42 & 0.09 & 3.41 & 0.15 & 3.46 & 0.23 & 3.4 & 0.35 \\
\hline 3.8 & 0.08 & 3.64 & 0.09 & 3.84 & 0.18 & 3.68 & 0.24 & 3.55 & 0.42 \\
\hline 4.06 & 0.12 & 3.85 & 0.11 & 4.32 & 0.26 & 3.98 & 0.33 & 3.87 & 0.41 \\
\hline 4.45 & 0.16 & 4.06 & 0.16 & 5.11 & 0.33 & 4.49 & 0.38 & 4.44 & 0.39 \\
\hline 4.86 & 0.17 & 4.73 & 0.2 & 5.6 & 0.5 & 4.73 & 0.43 & 4.62 & 0.39 \\
\hline 5.25 & 0.27 & 5.44 & 0.3 & 5.73 & 0.64 & 5.16 & 0.46 & 4.95 & 0.39 \\
\hline 5.52 & 0.3 & 5.56 & 0.38 & 5.87 & 0.88 & 5.71 & 0.62 & 5.3 & 0.38 \\
\hline 5.93 & 0.99 & 5.67 & 0.41 & 5.99 & 1.46 & 5.79 & 0.67 & 5.58 & 0.42 \\
\hline 6.27 & 5.18 & 5.79 & 0.59 & 6.1 & 2.89 & 5.85 & 0.78 & 5.81 & 0.4 \\
\hline 6.51 & 8.42 & 5.9 & 1.14 & 6.23 & 7.69 & 5.96 & 0.74 & 6.07 & 0.38 \\
\hline 6.76 & 32.9 & 6.0 & 1.71 & 6.34 & 16.49 & 6.02 & 0.76 & 6.28 & 0.35 \\
\hline 6.98 & 19.6 & 6.06 & 2.52 & 6.41 & 19.36 & 6.07 & 0.82 & 6.57 & 0.37 \\
\hline 7.27 & 6.97 & 6.16 & 3.96 & 6.47 & 14.37 & 6.17 & 0.69 & 6.92 & 0.4 \\
\hline 7.47 & 4.46 & 6.26 & 5.69 & 6.55 & 10.42 & 6.28 & 0.61 & 7.52 & 0.39 \\
\hline 7.71 & 4.03 & 6.34 & 6.43 & 6.61 & 6.76 & 6.36 & 0.62 & 7.96 & 0.46 \\
\hline 7.95 & 3.49 & 6.41 & 7.91 & 6.7 & 2.74 & 6.51 & 0.5 & 8.44 & 0.39 \\
\hline 8.19 & 6.15 & 6.47 & 10.85 & 6.77 & 1.87 & 6.61 & 0.46 & 8.81 & 0.42 \\
\hline 8.3 & 6.11 & 6.53 & 14.9 & 6.86 & 1.74 & 6.71 & 0.44 & 9.22 & 0.52 \\
\hline 8.38 & 6.0 & 6.65 & 22.2 & 7.16 & 1.9 & 7.03 & 0.41 & 9.55 & 0.39 \\
\hline 8.57 & 2.69 & 6.76 & 33.4 & 7.39 & 1.73 & 7.38 & 0.38 & 10.0 & 0.33 \\
\hline 8.68 & 1.11 & 6.93 & 13.4 & 7.6 & 1.46 & 7.66 & 0.33 & & \\
\hline 8.79 & 0.5 & 7.13 & 7.07 & 7.8 & 1.34 & 8.07 & 0.36 & & \\
\hline 8.94 & 0.22 & 7.35 & 5.54 & 7.87 & 0.44 & 8.51 & 0.67 & & \\
\hline 9.22 & 0.19 & 7.53 & 5.06 & 8.13 & 0.62 & 8.78 & 0.5 & & \\
\hline 9.55 & 0.23 & 7.79 & 4.76 & 8.27 & 3.01 & 8.99 & 0.5 & & \\
\hline 9.84 & 0.2 & 7.95 & 4.21 & 8.31 & 2.8 & 9.15 & 0.37 & & \\
\hline \multirow[t]{10}{*}{10.1} & 0.25 & 8.18 & 3.4 & 8.47 & 6.61 & 9.4 & 0.35 & & \\
\hline & & 8.36 & 6.73 & 8.51 & 5.3 & \multirow{9}{*}{$\begin{array}{c}9.74 \\
10.0 \\
6.0\end{array}$} & 0.25 & & \\
\hline & & 8.43 & 3.39 & 8.58 & 2.53 & & 0.28 & & \\
\hline & & 8.47 & 1.63 & 8.77 & 0.7 & & & & \\
\hline & & 8.55 & 0.83 & 8.93 & 0.51 & & & & \\
\hline & & 8.7 & 0.53 & 9.16 & 0.37 & & & & \\
\hline & & 9.05 & 0.43 & 9.59 & 0.26 & & & & \\
\hline & & 9.56 & 0.19 & 9.89 & 0.31 & & & & \\
\hline & & 9.89 & 0.5 & 10.05 & 0.2 & & & & \\
\hline & & 10.1 & 0.33 & & & & & & \\
\hline
\end{tabular}


Tabela B 6 - Diâmetro hidrodinâmico, desvio padrão e índice de polidispersidade de partículas de polianfóteros para os ângulos de 30,2; 62,2 e 90 em valores de pH 4,3 e 5,35 e $10 \mathrm{mM}$ de $[\mathrm{NaCl}]$

\begin{tabular}{|c|c|c|c|c|c|c|c|c|c|}
\hline $\mathrm{pH}$ & Ângulo, ${ }^{\circ}$ & ${ }^{1} d_{h}, n m$ & ${ }^{2} \mathrm{DP}_{1}, \mathrm{~nm}$ & ${ }^{4} \mathrm{PI}$ & $\mathrm{pH}$ & Ângulo, ○ & $\mathrm{d}_{\mathrm{h}}, \mathrm{nm}$ & $\mathrm{DP}_{1}, \mathrm{~nm}$ & $\mathrm{PI}$ \\
\hline \multirow[t]{20}{*}{4.3} & 30.2 & 555.4 & 243.1 & 0.819 & 5.35 & 30.2 & 621.3 & 271.8 & 0.816 \\
\hline & & 576.3 & 253.4 & 0.852 & & & 756.4 & 332.4 & 0.849 \\
\hline & & 618.1 & 271.8 & 0.853 & & & - & - & - \\
\hline & & 626.7 & 274.4 & 0.823 & & & - & - & - \\
\hline & & 533.5 & 230.2 & 0.73 & & & - & - & - \\
\hline & Média & 582.0 & - & - & & Média & 688.9 & - & - \\
\hline & ${ }^{3} D P_{2}$ & 40.0 & - & - & & $D P_{2}$ & 67.6 & - & - \\
\hline & 62.6 & 180.3 & 78 & 0.742 & & 62,6 & 159.6 & 68.1 & 0.67 \\
\hline & & 171 & 73.5 & 0.709 & & & 158 & 67.4 & 0.67 \\
\hline & & 154.1 & 66.3 & 0.712 & & & - & - & - \\
\hline & & 175.1 & 75.4 & 0.721 & & & - & - & - \\
\hline & & 173.3 & 75.3 & 0.769 & & & - & - & - \\
\hline & Média & 170.8 & - & - & & Média & 158.8 & - & - \\
\hline & $D P_{2}$ & 9.9 & - & - & & $D P_{2}$ & 0.8 & - & - \\
\hline & 90 & 81.2 & 38.7 & 2.53 & & 90 & 92.8 & 42.8 & 1.412 \\
\hline & & 85.6 & 40.3 & 1.956 & & & 91.8 & 42.8 & 1.666 \\
\hline & & 87.4 & 40.5 & 1.505 & & & - & - & - \\
\hline & & 82.8 & 39.4 & 2.48 & & & - & - & - \\
\hline & Média & 84.3 & - & - & & Média & 92.3 & - & - \\
\hline & $D P_{2}$ & 2.8 & - & - & & $D P_{2}$ & 0.5 & - & - \\
\hline
\end{tabular}

Diâmetro hidrodinâmico; ${ }^{2}$ Desvio padrão em relação à média na corrida; ${ }^{3}$ Desvio padrão da média do tamanho de partícula de todas as corridas; ${ }^{4}$ Índice de polidispersidade das partículas na corrida. 
Tabela B 7 - Diâmetro hidrodinâmico, desvio padrão e índice de polidispersidade de partículas de polianfóteros para os ângulos de 30,2; 62,2 e 90 em valores de pH 6,53 e 7,24 e $10 \mathrm{mM}$ de $[\mathrm{NaCl}]$

\begin{tabular}{|c|c|c|c|c|c|c|c|c|c|}
\hline $\mathrm{pH}$ & Ângulo, ${ }^{\circ}$ & ${ }^{1} d_{h}, n m$ & ${ }^{2} \mathrm{DP}_{1}, \mathrm{~nm}$ & ${ }^{4} \mathrm{PI}$ & $\mathrm{pH}$ & Ângulo, ${ }^{\circ}$ & $d_{h}, n m$ & $\mathrm{DP}_{1}, \mathrm{~nm}$ & $\mathrm{PI}$ \\
\hline \multirow[t]{12}{*}{6.53} & 30.2 & 605.5 & 248.7 & 0.519 & 7.24 & 30.2 & 1805.3 & 615.8 & 0.218 \\
\hline & & 579.4 & 240.8 & 0.559 & & & 1847.5 & 651.7 & 0.248 \\
\hline & Média & 592.45 & - & - & & Média & 1826.4 & - & - \\
\hline & ${ }^{3} D P_{2}$ & 13.05 & - & - & & $D P_{2}$ & 21.1 & - & - \\
\hline & 62,6 & 280.7 & 100.9 & 0.269 & & 62.6 & 2185.4 & 881.3 & 0.465 \\
\hline & & 297.3 & 102.9 & 0.23 & & & 2237.1 & 909.1 & 0.486 \\
\hline & Média & 289 & - & - & & Média & 2211.25 & - & - \\
\hline & $D P_{2}$ & 8.3 & - & - & & $D P_{2}$ & 25.85 & - & - \\
\hline & 90 & 232 & 86.4 & 0.311 & & 90 & 1981.8 & 727.1 & 0.293 \\
\hline & & 250.5 & 87.8 & 0.241 & & & 1795.2 & 766.7 & 0.674 \\
\hline & Média & 241.25 & - & - & & Média & 1888.5 & - & - \\
\hline & $D P_{2}$ & 9.25 & - & - & & $D P_{2}$ & 93.3 & - & - \\
\hline
\end{tabular}

'Diâmetro hidrodinâmico; ' ${ }^{2}$ esvio padrão em relação à média na corrida; ${ }^{3}$ Desvio padrão da média do tamanho de partícula de todas as corridas; ${ }^{4}$ Índice de polidispersidade das partículas na corrida.

Tabela B 8 - Diâmetro hidrodinâmico, desvio padrão e índice de polidispersidade de partículas de polianfóteros para os ângulos de 30,2; 62,2 e 90 em valores de pH 8,48 e 9,31 e $10 \mathrm{mM}$ de $[\mathrm{NaCl}]$

\begin{tabular}{|c|c|c|c|c|c|c|c|c|c|}
\hline $\mathrm{pH}$ & Ângulo, ${ }^{\circ}$ & ${ }^{1} d_{h}, n m$ & ${ }^{2} \mathrm{DP}_{1}, \mathrm{~nm}$ & ${ }^{4} \mathrm{PI}$ & $\mathrm{pH}$ & Ângulo, ${ }^{\circ}$ & $d_{h}, n m$ & $\mathrm{DP}_{1}, \mathrm{~nm}$ & $\mathrm{PI}$ \\
\hline \multirow[t]{12}{*}{8.48} & 30.2 & 620.4 & 230.9 & 0.211 & 9.31 & 30.2 & 716.3 & 314.2 & 0.837 \\
\hline & & 767.6 & 245 & 0.172 & & & 733.3 & 321.7 & 0.837 \\
\hline & Média & 694 & - & - & & Média & 724.8 & - & - \\
\hline & ${ }^{3} D P_{2}$ & 73.6 & - & - & & $D P_{2}$ & 8.5 & - & - \\
\hline & 62,6 & 590.9 & 199.3 & 0.209 & & 62.6 & 169.9 & 72.6 & 0.326 \\
\hline & & 864.8 & 283.6 & 0.189 & & & 167.6 & 72 & 0.98 \\
\hline & Média & 727.85 & - & - & & Média & 168.75 & - & - \\
\hline & $D P_{2}$ & 136.95 & - & - & & $D P_{2}$ & 1.15 & - & - \\
\hline & 90 & 626.1 & 146 & 0.07 & & 90 & 116.3 & 43.8 & 0.326 \\
\hline & & 902.2 & 182.2 & 0.049 & & & 101.1 & 45.1 & 0.98 \\
\hline & Média & 764.15 & - & - & & Média & 108.7 & - & - \\
\hline & $D P_{2}$ & 138.05 & - & - & & $D P_{2}$ & 7.6 & - & - \\
\hline
\end{tabular}

Diâmetro hidrodinâmico; ${ }^{2}$ Desvio padrão em relação à média na corrida; ${ }^{3}$ Desvio padrão da média do tamanho de partícula de todas as corridas; ${ }^{4}$ Índice de polidispersidade das partículas na corrida. 
Tabela B 9 - Diâmetro hidrodinâmico, desvio padrão e índice de polidispersidade de partículas de polianfóteros para os ângulos de 30,2; 62,2 e 90 em valores de força iônica de 0,1 e $1 \mathrm{mM}$ de $[\mathrm{NaCl}]$ e $\mathrm{pH}$ fixo de 4,3

\begin{tabular}{|c|c|c|c|c|c|c|c|c|c|}
\hline $\begin{array}{c}{[\mathrm{NaCl}],} \\
\mathrm{mM}\end{array}$ & Ângulo, ○ & ${ }^{1} d_{h}, n m$ & $\begin{array}{c}{ }^{2} \mathrm{DP}_{1}, \\
\mathrm{~nm}\end{array}$ & ${ }^{4} \mathrm{PI}$ & $\begin{array}{c}{[\mathrm{NaCl}],} \\
\mathrm{mM}\end{array}$ & Ângulo, ○ & $d_{h}, n m$ & $\mathrm{DP}_{1}, \mathrm{~nm}$ & $\mathrm{PI}$ \\
\hline \multirow[t]{14}{*}{0.10} & 30.2 & 718.90 & 319.90 & 0.95 & 1.00 & 30.2 & 687.60 & 305.70 & 0.94 \\
\hline & & 503.00 & 223.10 & 0.92 & & & 551.60 & 244.30 & 0.91 \\
\hline & & - & - & - & & & 609.10 & 270.10 & 0.92 \\
\hline & Média & 610.95 & - & - & & Média & 616.10 & - & - \\
\hline & ${ }^{3} D P_{2}$ & 152.66 & - & - & & $D P_{2}$ & 68.27 & - & - \\
\hline & 62.2 & 147.80 & 65.40 & 0.91 & & 62.6 & 136.60 & 60.00 & 0.84 \\
\hline & & 126.20 & 55.60 & 0.87 & & & 128.70 & 56.50 & 0.85 \\
\hline & & 159.10 & 70.60 & 0.93 & & & 149.60 & 66.10 & 0.89 \\
\hline & Média & 144.37 & - & - & & Média & 138.30 & - & - \\
\hline & $D P_{2}$ & 16.72 & - & - & & $D P_{2}$ & 10.55 & - & - \\
\hline & 90 & 18.30 & 9.00 & 7.49 & & 90 & - & - & - \\
\hline & & 17.30 & 8.50 & 5.17 & & & - & - & - \\
\hline & Média & 17.80 & - & - & & Média & - & - & - \\
\hline & $D P_{2}$ & 0.71 & - & - & & $D P_{2}$ & - & - & - \\
\hline
\end{tabular}

'Diâmetro hidrodinâmico; ${ }^{2}$ Desvio padrão em relação à média na corrida; ${ }^{3}$ Desvio padrão da média do tamanho de partícula de todas as corridas; ' ${ }^{4}$ ndice de polidispersidade das partículas na corrida. 
Tabela B 10 - Diâmetro hidrodinâmico, desvio padrão e índice de polidispersidade de partículas de polianfóteros para os ângulos de 30,2; 62,2 e 90 em valores de força iônica de 100 e $1000 \mathrm{mM}$ de $[\mathrm{NaCl}]$ e $\mathrm{pH}$ fixo de 4,3

\begin{tabular}{|c|c|c|c|c|c|c|c|c|c|}
\hline $\begin{array}{c}{[\mathrm{NaCl}],} \\
\mathrm{mM}\end{array}$ & Ângulo, ○ & ${ }^{1} d_{h}, n m$ & $\begin{array}{c}{ }^{2} \mathrm{DP}_{1}, \\
\mathrm{~nm}\end{array}$ & ${ }^{4} \mathrm{PI}$ & $\begin{array}{c}{[\mathrm{NaCl}],} \\
\mathrm{mM}\end{array}$ & Ângulo, ${ }^{\circ}$ & $d_{h}, n m$ & $\mathrm{DP}_{1}, \mathrm{~nm}$ & $\mathrm{Pl}$ \\
\hline \multirow[t]{18}{*}{100} & 30.2 & 578.00 & 253.60 & 0.84 & 1000 & 30.2 & 1063.50 & 467.30 & 0.85 \\
\hline & & 603.50 & 263.80 & 0.81 & & & 842.80 & 366.00 & 0.77 \\
\hline & & 604.50 & 265.30 & 0.84 & & & 839.80 & 367.60 & 0.82 \\
\hline & & - & - & - & & & 911.80 & 399.30 & 0.82 \\
\hline & Média & 595.33 & - & - & & Média & 914.48 & - & - \\
\hline & ${ }^{3} D P_{2}$ & 15.02 & - & - & & $D P_{2}$ & 104.77 & - & - \\
\hline & 62.60 & 155.20 & 66.50 & 0.85 & & 62.6 & 233.50 & 101.60 & 0.78 \\
\hline & & 149.60 & 63.90 & 0.77 & & & 199.40 & 86.20 & 0.74 \\
\hline & & 145.50 & 62.40 & 0.82 & & & 202.90 & 88.40 & 0.79 \\
\hline & & - & - & - & & & 259.50 & 113.70 & 0.83 \\
\hline & Média & 150.10 & - & - & & Média & 223.83 & - & - \\
\hline & $D P_{2}$ & 4.87 & - & - & & $D P_{2}$ & 28.29 & - & - \\
\hline & 90 & 96.00 & 44.80 & 1.70 & & 90 & 109.20 & 50.60 & 1.52 \\
\hline & & 89.40 & 39.30 & 0.84 & & & 125.70 & 57.80 & 1.36 \\
\hline & & 96.10 & 24.40 & 0.09 & & & 100.90 & 47.10 & 1.70 \\
\hline & & - & - & - & & & 111.00 & 50.20 & 1.07 \\
\hline & Média & 93.83 & - & - & & Média & 111.70 & - & - \\
\hline & $D P_{2}$ & 3.84 & - & - & & $D P_{2}$ & 10.32 & - & - \\
\hline
\end{tabular}

'Diâmetro hidrodinâmico; ${ }^{2}$ Desvio padrão em relação à média na corrida; ${ }^{3}$ Desvio padrão da média do tamanho de partícula de todas as corridas; ${ }^{4}$ Índice de polidispersidade das partículas na corrida. 


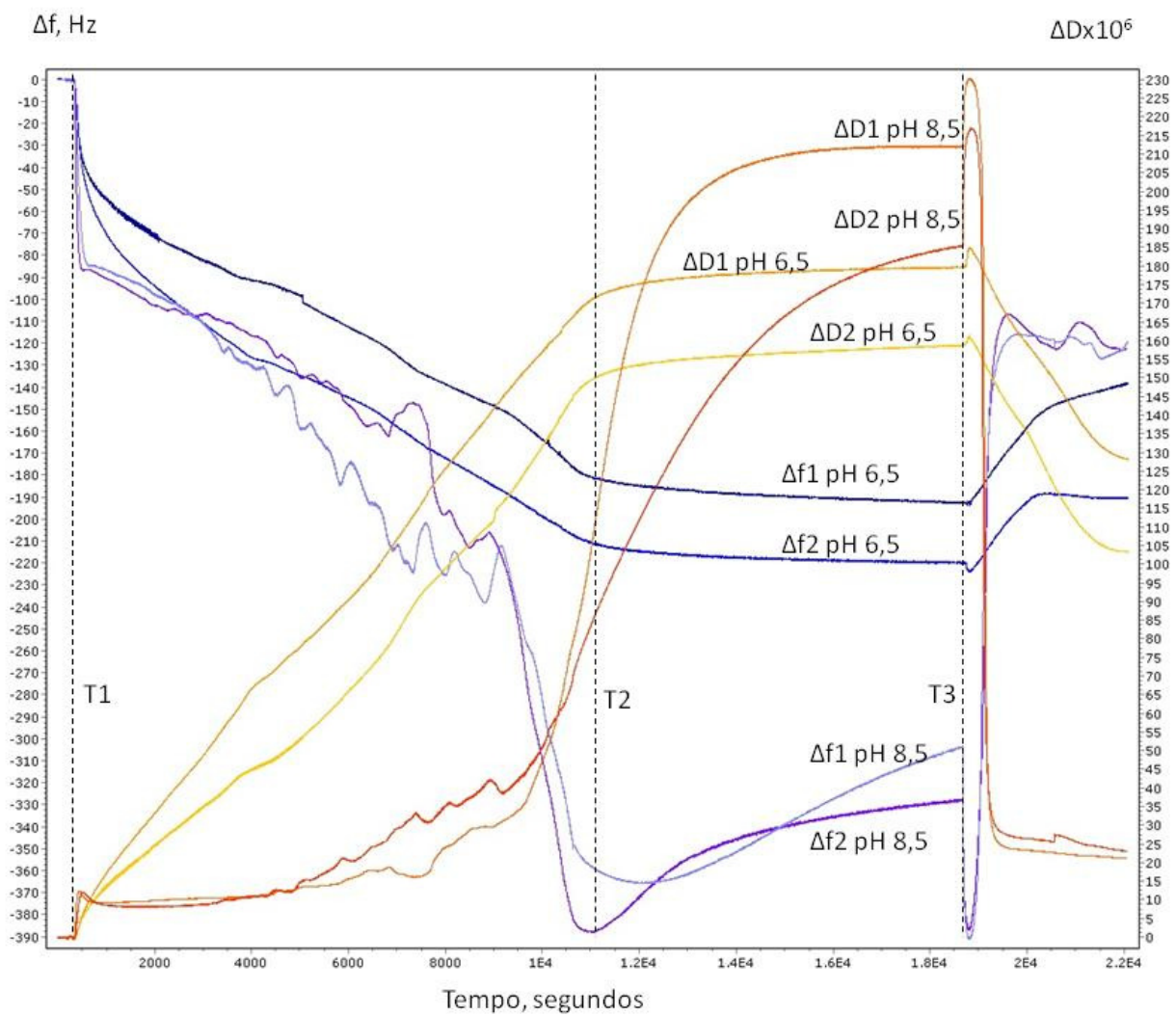

Figura B 1 - Variações de frequência e de dissipação de energia em função do tempo devido à adsorção do polianfótero. Condições: superfície de sílica, $10 \mathrm{mM}$ $\mathrm{NaCl}, \mathrm{pH} 4,3$, temperatura $25^{\circ} \mathrm{C}$ e $168 \mathrm{mg} / \mathrm{L}$ [PAnf]. Legenda: T1 corresponde ao início da dosagem do polianfótero; T2 corresponde ao final da dosagem do polianfótero; T3 corresponde ao início da lavagem com meio de dispesão sem polianfótero; $\Delta \mathrm{f}$ corresponde a variação de frequência e $\Delta \mathrm{D}$ corresponde à variação de dissipação de energia. 


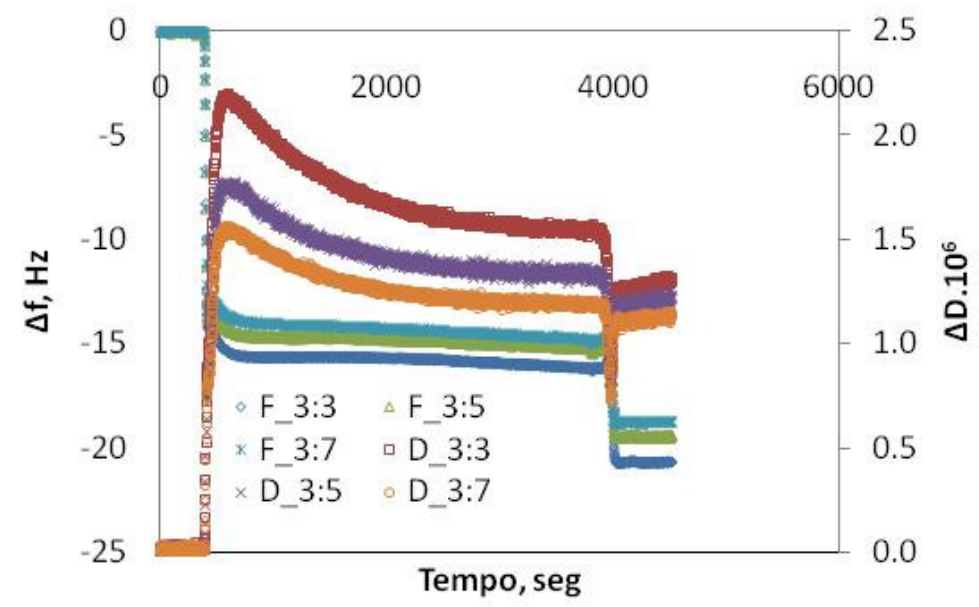

Figura B 2 - Variações de frequência e de dissipação de energia em função do tempo devido à adsorção do polianfótero. Condições: superfície de celulose, $0,1 \mathrm{mM}$ $[\mathrm{NaCl}], \mathrm{pH} 4,3$, temperatura $25^{\circ} \mathrm{C}$ e $168 \mathrm{mg} / \mathrm{L}$ [PAnf].

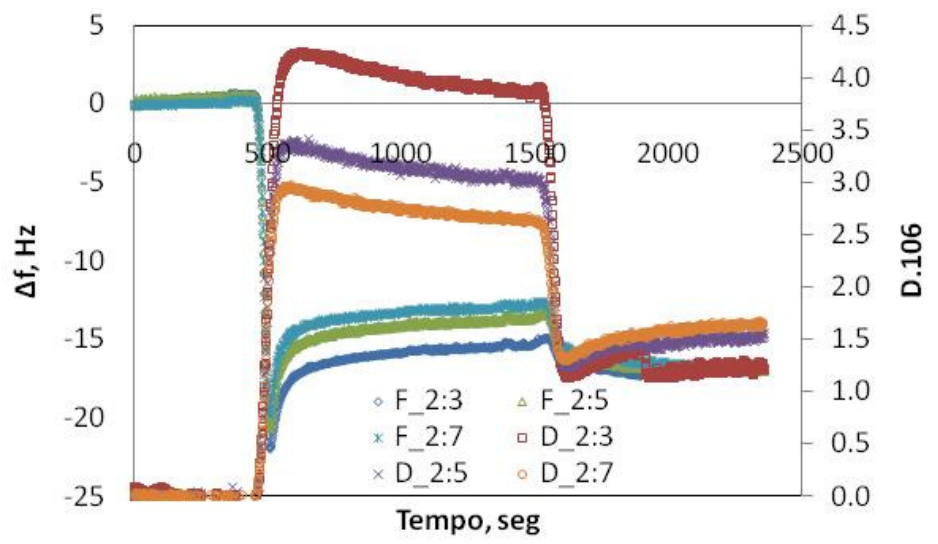

Figura B 3 - Variações de frequência e de dissipação de energia em função do tempo devido à adsorção do polianfótero. Condições: superfície de celulose, $1 \mathrm{mM}$ $[\mathrm{NaCl}], \mathrm{pH} 4,3$, temperatura $25^{\circ} \mathrm{C}$ e $168 \mathrm{mg} / \mathrm{L}$ [PAnf]. 


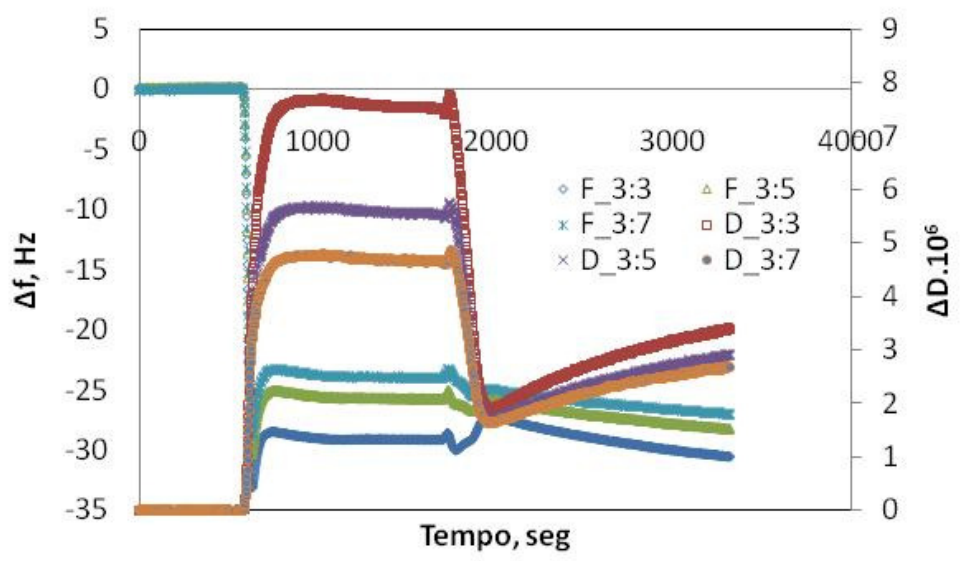

Figura B 4 - Variações de frequência e de dissipação de energia em função do tempo devido à adsorção do polianfótero. Condições: superfície de celulose, $10 \mathrm{mM}$ [NaCl], pH 4,3, temperatura $25^{\circ} \mathrm{C}$ e $168 \mathrm{mg} / \mathrm{L}$ [PAnf].

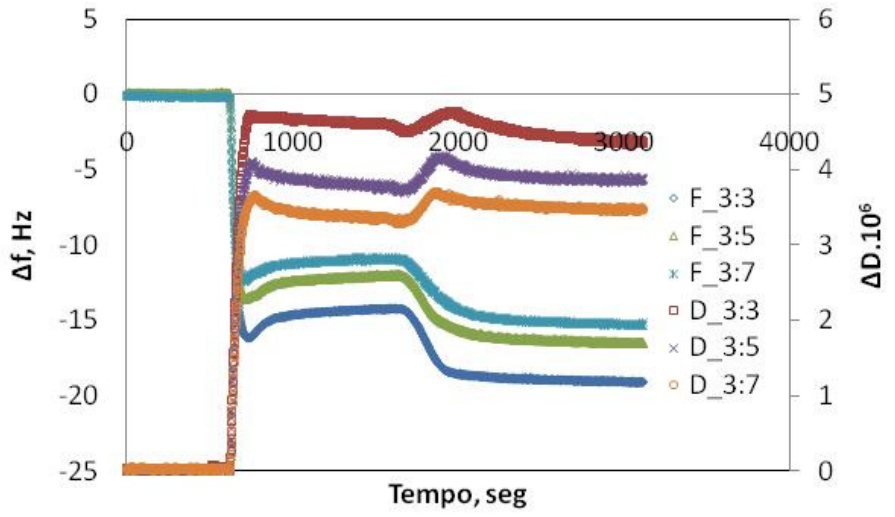

Figura B 5 - Variações de frequência e de dissipação de energia em função do tempo devido à adsorção do polianfótero. Condições: superfície de celulose, 100 $\mathrm{mM}[\mathrm{NaCl}], \mathrm{pH} 4,3$, temperatura $25^{\circ} \mathrm{C}$ e $168 \mathrm{mg} / \mathrm{L}$ [PAnf]. 


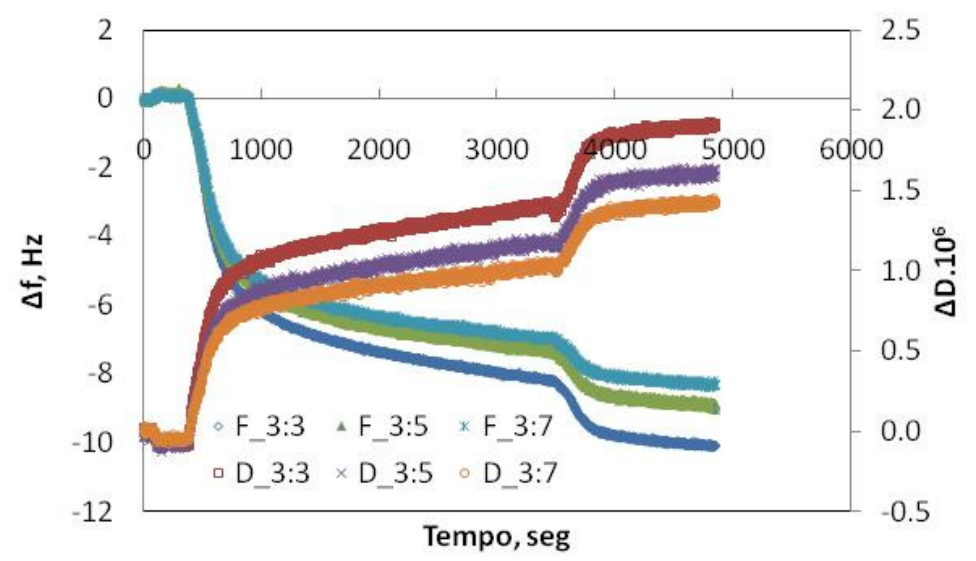

Figura B 6 - Variações de frequência e de dissipação de energia em função do tempo devido à adsorção do polianfótero. Condições: superfície de celulose, 1000 $\mathrm{mM}[\mathrm{NaCl}], \mathrm{pH} 4,3$, temperatura $25^{\circ} \mathrm{C}$ e $168 \mathrm{mg} / \mathrm{L}$ [PAnf].

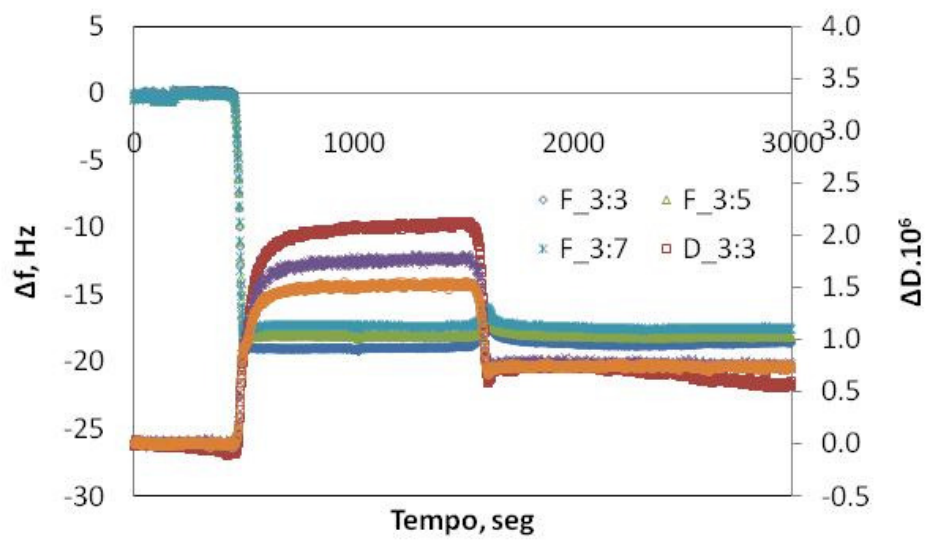

Figura B 7 - Variações de frequência e de dissipação de energia em função do tempo devido à adsorção do polianfótero. Condições: superfície de sílica, $0,1 \mathrm{mM}$ $[\mathrm{NaCl}], \mathrm{pH} 4,3$, temperatura $25^{\circ} \mathrm{C}$ e $168 \mathrm{mg} / \mathrm{L}$ [PAnf]. 


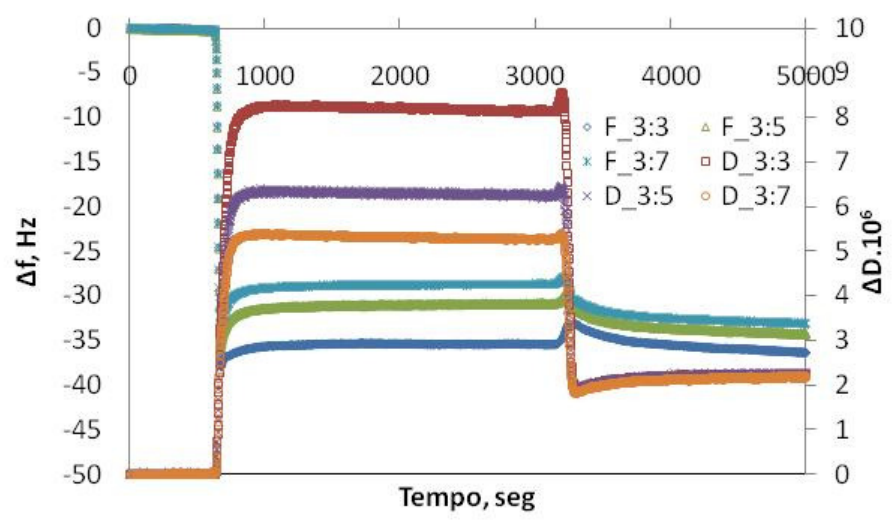

Figura B 8 - Variações de frequência e de dissipação de energia em função do tempo devido à adsorção do polianfótero. Condições: superfície de sílica, $1 \mathrm{mM}$ $[\mathrm{NaCl}], \mathrm{pH} 4,3$, temperatura $25^{\circ} \mathrm{C}$ e $168 \mathrm{mg} / \mathrm{L}$ [PAnf].

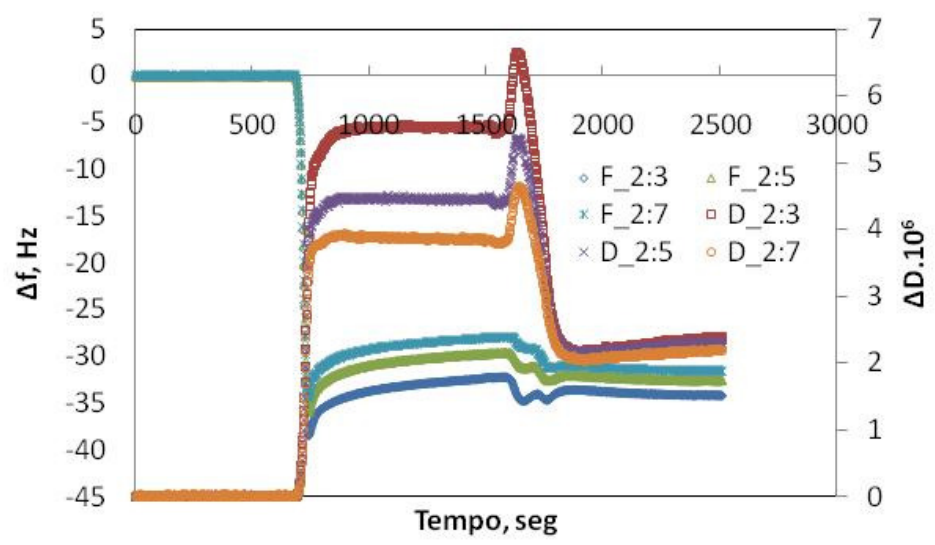

Figura B 9 - Variações de frequência e de dissipação de energia em função do tempo devido à adsorção do polianfótero. Condições: superfície de sílica, $10 \mathrm{mM}$ $[\mathrm{NaCl}], \mathrm{pH} 4,3$, temperatura $25^{\circ} \mathrm{C}$ e $168 \mathrm{mg} / \mathrm{L}$ [PAnf]. 


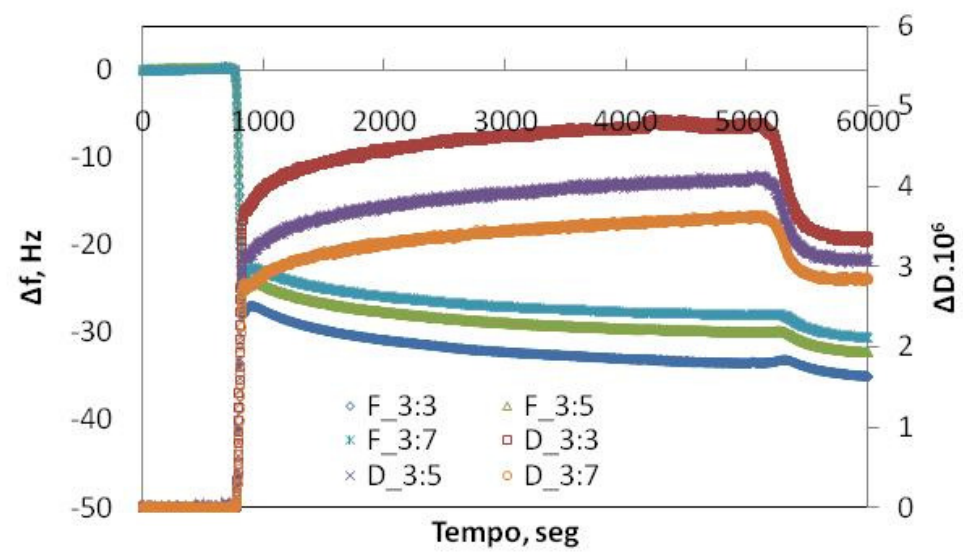

Figura B 10 - Variações de frequência e de dissipação de energia em função do tempo devido à adsorção do polianfótero. Condições: superfície de sílica, $100 \mathrm{mM}$ $[\mathrm{NaCl}], \mathrm{pH} 4,3$, temperatura $25^{\circ} \mathrm{C}$ e $168 \mathrm{mg} / \mathrm{L}$ [PAnf].

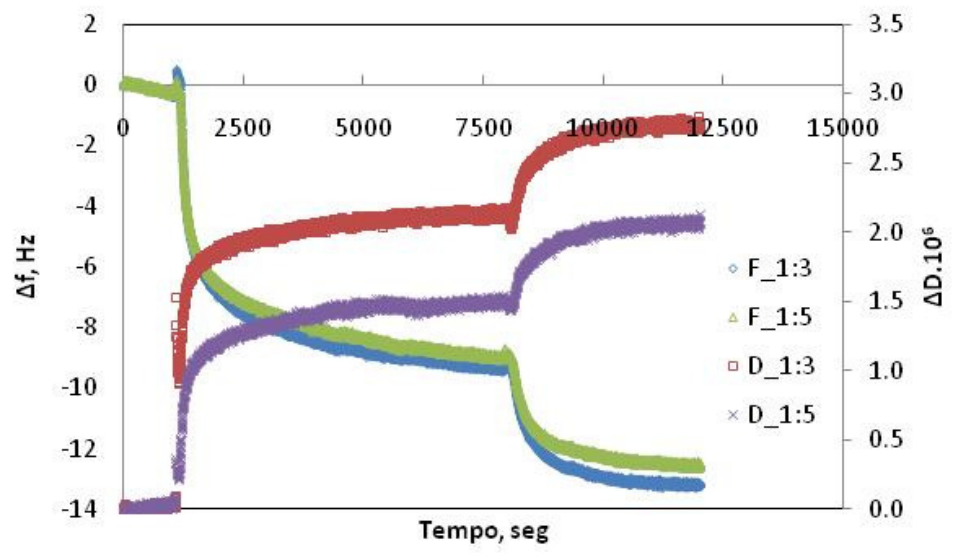

Figura B 11 - Variações de frequência e de dissipação de energia em função do tempo devido à adsorção do polianfótero. Condições: superfície de sílica, $1000 \mathrm{mM}$ [NaCl], pH 4,3, temperatura $25^{\circ} \mathrm{C}$ e $168 \mathrm{mg} / \mathrm{L}$ [PAnf]. 
Tabela B 11 - Resultados de variação de frequência devido à adsorção do PAnf sobre substrato de sílica, antes e após a lavagem, em função da concentração de sal

\begin{tabular}{lccccc}
\hline \multirow{2}{*}{ Antes da lavagem } & \multicolumn{5}{c}{ Concentração de sal, mM } \\
\cline { 2 - 6 } & 0.1 & 1 & 10 & 100 & 1000 \\
\hline & 19 & 30 & 29 & 30 & 7.5 \\
& 22 & 35.5 & 30.5 & 32.5 & 8.2 \\
& - & 30 & 40 & 34 & 8.5 \\
& - & 35.7 & 43.5 & 39 & - \\
\hline Média & - & 38.2 & - & - & - \\
Desvio Padrão & $\mathbf{2 0 . 5 0}$ & $\mathbf{3 3 . 8 8}$ & $\mathbf{3 5 . 7 5}$ & $\mathbf{3 3 . 8 8}$ & $\mathbf{8 . 0 7}$ \\
\hline Depois da lavagem & $\mathbf{2 . 1 2}$ & $\mathbf{3 . 7 0}$ & $\mathbf{7 . 1 0}$ & $\mathbf{3 . 7 9}$ & $\mathbf{0 . 5 1}$ \\
\hline & 0.1 & 1 & 10 & 100 & 1000 \\
& 18.8 & 33 & 36.5 & 34 & 9.8 \\
& 23 & 40 & 27.2 & 35 & 12.6 \\
& - & 28.6 & 37.8 & 37 & 12.8 \\
& - & 34.5 & 41.8 & 42 & - \\
\hline Média & - & 35.2 & - & - & - \\
Desvio Padrão & $\mathbf{2 0 . 9 0}$ & $\mathbf{3 4 . 2 6}$ & $\mathbf{3 5 . 8 3}$ & $\mathbf{3 7 . 0 0}$ & $\mathbf{1 1 . 7 3}$ \\
\hline Condições: pH 4,3; 168 & $\mathbf{2 . 9 7}$ & $\mathbf{4 . 1 1}$ & $\mathbf{6 . 1 8}$ & $\mathbf{3 . 5 6}$ & $\mathbf{1 . 6 8}$ \\
\hline
\end{tabular}

Condições: pH 4,3; 168 mg/L[PAnf] e $25^{\circ} \mathrm{C}$. 
Tabela B 12 - Resultados de variação de dissipação de energia devido à adsorção do PAnf sobre substrato de sílica, antes e após a lavagem, em função da concentração de sal

\begin{tabular}{lccccc}
\hline \multirow{2}{*}{ Antes da lavagem } & \multicolumn{5}{c}{ Concentração de sal, mM } \\
\cline { 2 - 6 } & 0.1 & 1 & 10 & 100 & 1000 \\
\hline & 2 & 6.5 & 5.1 & 4.4 & 0.6 \\
& 2.5 & 8 & 5.5 & 4.8 & 1.6 \\
& - & 5.7 & 4.7 & 5 & 2.2 \\
& - & 7.6 & 7.8 & - & - \\
\hline Média & - & 8.5 & 9.6 & - & - \\
Desvio Padrão & $\mathbf{2 . 2 5}$ & $\mathbf{7 . 2 6}$ & $\mathbf{6 . 5 4}$ & $\mathbf{4 . 7 3}$ & $\mathbf{1 . 4 7}$ \\
\hline Depois da lavagem & $\mathbf{0 . 3 5}$ & $\mathbf{1 . 1 4}$ & $\mathbf{2 . 0 9}$ & $\mathbf{0 . 3 1}$ & $\mathbf{0 . 8 1}$ \\
\hline & 0.1 & 1 & 10 & 100 & 1000 \\
& 0.4 & 2.3 & 1 & 1.8 & 1 \\
& 0.7 & 3 & 2.6 & 2.8 & 2.4 \\
& - & 1.5 & 0.8 & 3 & 2.7 \\
& - & 2 & 2.4 & 4.2 & - \\
\hline Média & - & 2 & 2.7 & - & - \\
Desvio Padrão & $\mathbf{0 . 5 5}$ & $\mathbf{2 . 1 6}$ & $\mathbf{1 . 9 0}$ & $\mathbf{2 . 9 5}$ & $\mathbf{2 . 0 3}$ \\
\hline
\end{tabular}

Condições: pH 4,3; $168 \mathrm{mg} / \mathrm{L}[\mathrm{PAnf}]$ e $25^{\circ} \mathrm{C}$.

Tabela B 13 - Resultados de variação de frequência devido à adsorção do PAnf sobre filme de celulose, antes e após a lavagem, em função da concentração de sal

\begin{tabular}{lccccc}
\hline Antes da lavagem & \multicolumn{5}{c}{ Concentração de sal, mM } \\
\hline & 0.1 & 1 & 10 & 100 & 1000 \\
& 16.5 & 15 & 24 & 19 & 7.8 \\
& 17.5 & 15.5 & 29 & 18.5 & 8.2 \\
& - & 17.5 & 31 & - & 8.5 \\
& - & - & - & - & 9.8 \\
\hline Média & $\mathbf{1 7 . 0 0}$ & $\mathbf{1 6 . 0 0}$ & $\mathbf{2 8 . 0 0}$ & $\mathbf{1 8 . 7 5}$ & $\mathbf{8 . 5 8}$ \\
Desvio Padrão & $\mathbf{0 . 7 1}$ & $\mathbf{1 . 3 2}$ & $\mathbf{3 . 6 1}$ & $\mathbf{0 . 3 5}$ & $\mathbf{0 . 8 7}$ \\
\hline Depois da lavagem & 0.1 & 1 & 10 & 100 & 1000 \\
& 20.5 & 17 & 31 & 19 & 9 \\
& 16.5 & 19 & 30.5 & 17.5 & 9.8 \\
& - & 20 & 29.2 & - & 10.4 \\
& - & - & 33 & - & 12.3 \\
\hline Média & $\mathbf{1 8 . 5 0}$ & $\mathbf{1 8 . 6 7}$ & $\mathbf{3 0 . 9 3}$ & $\mathbf{1 8 . 2 5}$ & $\mathbf{1 0 . 3 8}$ \\
Desvio Padrão & $\mathbf{2 . 8 3}$ & $\mathbf{1 . 5 3}$ & $\mathbf{1 . 5 8}$ & $\mathbf{1 . 0 6}$ & $\mathbf{1 . 4 1}$ \\
\hline Condic̃os: & & &
\end{tabular}

Condições: $\mathrm{pH} 4,3 ; 168 \mathrm{mg} / \mathrm{L}[\mathrm{PAnf}]$ e $25^{\circ} \mathrm{C}$. 
Tabela B 14 - Resultados de variação de dissipação de energia devido à adsorção do PAnf sobre filme de celulose, antes e após a lavagem, em função da concentração de sal

\begin{tabular}{lccccc}
\hline \multirow{2}{*}{ Antes da lavagem } & \multicolumn{5}{c}{ Concentração de sal, mM } \\
\cline { 2 - 6 } & 0.1 & 1 & 10 & 100 & 1000 \\
\hline & 1.6 & 2 & 4.5 & 4.6 & 1.4 \\
& 1.6 & 3 & 6.8 & 4 & 1.5 \\
& & 7 & & 1.5 \\
\hline Média & & & 7 & & 1.55 \\
Desvio Padrão & $\mathbf{1 . 6 0}$ & $\mathbf{2 . 5 0}$ & $\mathbf{6 . 3 3}$ & $\mathbf{4 . 3 0}$ & $\mathbf{1 . 4 9}$ \\
\hline Depois da lavagem & $\mathbf{0 . 0 0}$ & $\mathbf{0 . 7 1}$ & $\mathbf{1 . 2 2}$ & $\mathbf{0 . 4 2}$ & $\mathbf{0 . 0 6}$ \\
\hline & 0.1 & 1 & 10 & 100 & 1000 \\
& 0.9 & 1.8 & 1.5 & 4.4 & 1.8 \\
& 1.3 & 1.8 & 2 & 3.7 & 1.85 \\
& & & 2 & & 1.9 \\
\hline Média & & & 3.5 & & 2 \\
Desvio Padrão & $\mathbf{1 . 1 0}$ & $\mathbf{1 . 8 0}$ & $\mathbf{2 . 2 5}$ & $\mathbf{4 . 0 5}$ & $\mathbf{1 . 8 9}$ \\
\hline Condiçס̃ & $\mathbf{0 . 2 8}$ & $\mathbf{0 . 0 0}$ & $\mathbf{0 . 8 7}$ & $\mathbf{0 . 4 9}$ & $\mathbf{0 . 0 9}$ \\
\hline
\end{tabular}

Condições: pH 4,3; $168 \mathrm{mg} / \mathrm{L}[\mathrm{PAnf}]$ e $25^{\circ} \mathrm{C}$. 

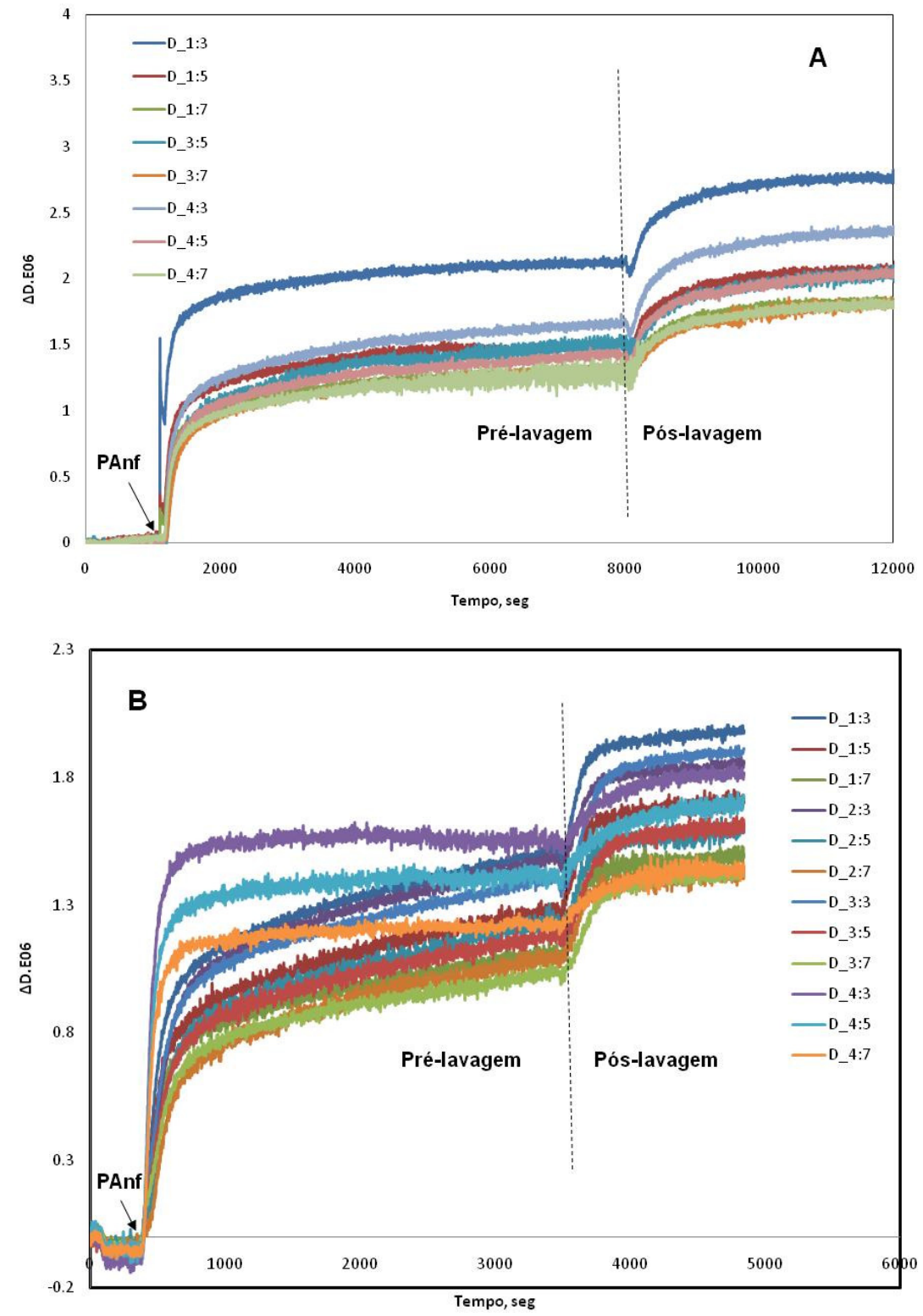

Figura $\mathrm{B} 12$ - Resultados de $\Delta \mathrm{D}$ gerados pela balaça microgravimétrica devido à adsorção do polianfótero em superficies de sílica (A) e em filme de celulose (B), para três frequências harmônicas. Condições dos testes: $1000 \mathrm{mM}[\mathrm{NaCl}], \mathrm{pH} 4,3 ; 168$ $\mathrm{mg} / \mathrm{L}$ [PAnf] e $25^{\circ} \mathrm{C}$. 
APENDICE C - TRABALHOS SELECIONADOS 


\title{
Polianfóteros: seu uso na fabricação de papel e seu comportamento em solução e em adsorção \\ Polyampholytes: their use in papermaking and their solution and adsorption behaviors
}

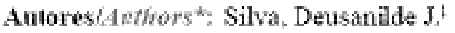 \\ Rojas, Orlando 3.? \\ Habbe, Martin A. \\ Patk, Song W: \\ Yamaguchi, Takashi $1^{3}$ \\ Song, Junlong
}

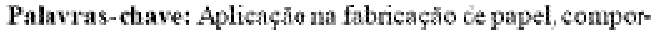
tamento de adsorço, comportamento no meio de dispersta, polingfoterss, resigriscin do popel

\section{BESIMO}

Este arligo considera a papel dos polianfóteros coms adiivo de resisténcia para papéis e tambén revisa estodos recentes que fornecem informaçses a respeito de coms funsonam. Resultados práticos que confrman a tubilidade

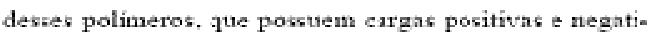

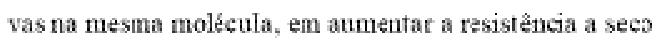
do papel serato citados, Será reportado um caso em que a capacidade superio: de os polianfóteros ammentarem a resistẻntia do papel esta relacicnada ac sen compontatmento en soluçho e quando dz sua adsorçno sobre superfeteis solidas.

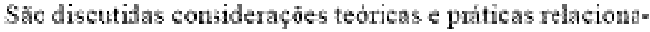
das a polianfoteros de acorto com traballos publicatos.

\section{CONSIDERACOES INICIAIS}

Alem dss propriedades funcionais tipicas, algmas das

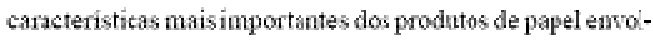
rent a sua ru sistencia a seco. A produtividade de umpressoras modernas depende fortemente de garmetros operacionas que afetam a resistincia do papel eo seu adamento.

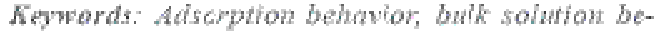
hawo, papermaking opphoaton, paper strengt poizampholyzes

\section{ARETRACT}

This athide censiders the rou of polympholytes as strengti addities for paper and abo rewews re-

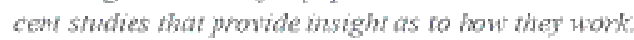
Practical resuls wht be cited that confon the abilin

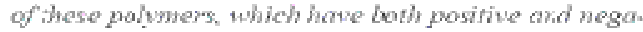

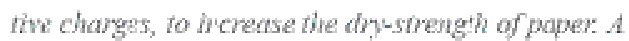
ate will be wade that the superior abitity of polyom pholytes to horese paper's stowgth is relaten to thet Behavors in soluton and when adsonbing onto solids

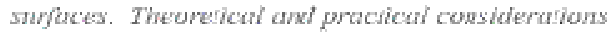
Hethed to volyomphobnes are discussed in ligh of phish hed work

\section{WITLL COHSIDERANONS}

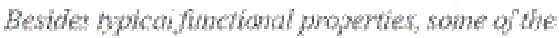

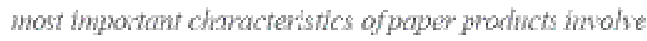

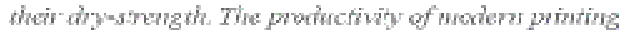

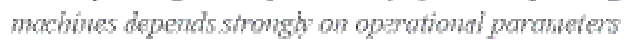

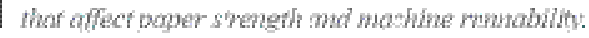

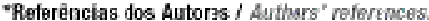

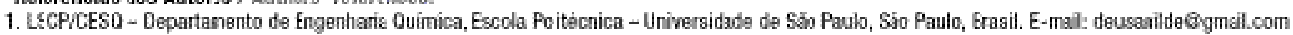

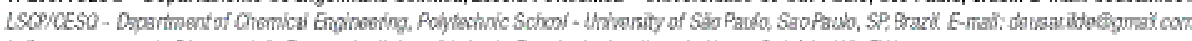

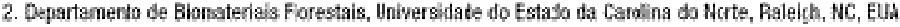

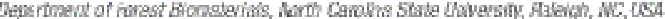

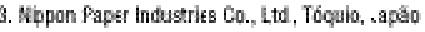

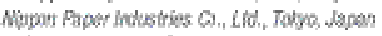

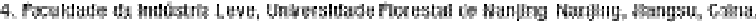

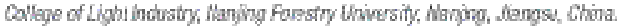


Considrando a resistencia i traçio, Page (1969) tesenvolveu uma equaçāo teórica (Eq. 1) para rapeis sem carga, baseada en obervises experinentais [1:

$$
\frac{1}{T}=\frac{9}{8 Z}+\frac{12 A \rho g}{b L(R B A)}
$$

En que $T$ a a resistencia a tracilo do papel: $Z$ a a re-

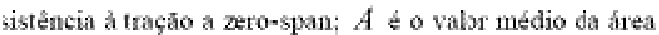
L sesso transversalda fbra $P$ e a denstade do naterial thboso; $g$ e a aceleraçào da gravidade; $h$ é resisténcia ao sisalhamento por unidade de arsa ligada; $P$ é o permetro

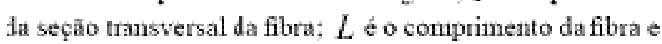
$R B A$ a a hea relativa lipada da folka [1].

De acodo con eta equaça, a restatancia a maço, $T$, mmenta com o aumento da resisteencia ao sisalhamento por uidade de area ligada, $b$, e con a àrea relativa lignda da tollus de papol, RBA. Portants, qualquer alternativs gua possa contribuír parao aumento desses parâmetros tambèm irá aumentar a resistancia a seco do payel [1].

O tratanento mas tradicional para desenwolver a resis.

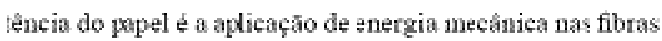
Je modo a afronxar a vua estrutura, on sejit, a refinaçĭb. Esse pocasso chnfere mabr flexibiliade as fibras, permitindo o anento de ligaços aterfibras durante o prosesso de secazemem. Por outro hado, os aditivos quimicos fodem ser nisados Fom a mesna finalidade. O aditwo mais comm nesta categoria to anido cationico, que ten sido uritizado rano para

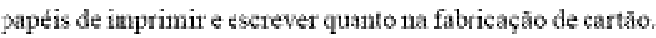

Outro fator impontante que afeta a restitencia a seco do papel is o trimaro a a diaponibilidade de prupos ioniziveis, tais como os grupos carboxilicos, sobre a superficie dxs anteriais celndósicos [2,3]. Em sistemas aquoses, esses qrupos

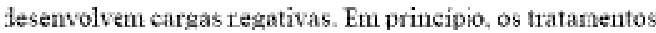

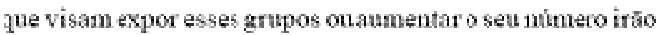
conttibuir para o inchamento das fbras ent suspensho, para resposta mais rápida so refino e, portanto, com mais eficácia no aumento da resistencia do papel.

Um proedimento que os fabricatites de papel tin adotado para slterar facilmente a zarga efetin da superficie Ias fibras e adicionando soluçoes de polimeros carregados. Tais polinetros poden contribuir com a retistencia do payel Mroves de sua adsorsto sobre a stperficis da fiba t, com isso, sumesto do minuese do pontes do hidrogenio nas areas te contato entre fibras [3, 4]. Agentes de resistência a seco irdicionais, inchundo $o$ amidos cationioos, tên sico amplamente utilizados for muitos anos.

Abordagens menos tradiciorais fazem use de diferentes tipos de estruiurs poliméricas, tais cono carboximet 1 celulose [5], complexos de polieletrolito [6-9], polielentolios en
Considerng tensio strength, Page (1969) dew oped a theretical entation (Eq. 1 for inflled poper posed on coperimental obsentions [1].

$$
\frac{1}{T} \uplus \frac{9}{8 Z}+\frac{12 A A g}{b P L(R B A)}
$$

when $T$ is tensile stwath of the paper $Z$ is the

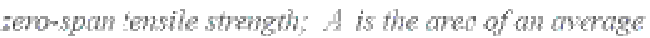
Aber cons section; $P$ is the density of the forons mate-

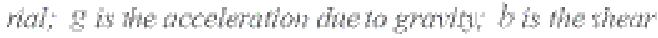
bond strength per wir bonded wed ${ }^{p}$ is the perheter of the fiber cross sections: $L$ is the fiber iength, and $R B A$ is the ralative bowd a d of the shed.

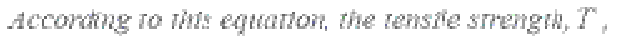
nowerses with inchesses in the shear bond strength per wit bonded and $b_{1} b$, ane the relative bonded and of

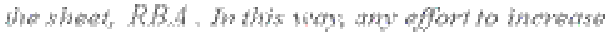

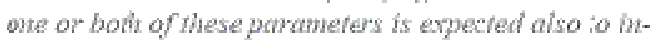
crease the strength of paper:

The wast traditomat treatwent to develop papr strugth is the aphi-ation of nechenical energy on

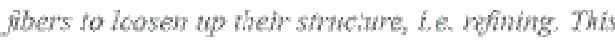
phoces confers more flewilhily to the fibers, altowh thew to whease the fiber-toy fber boudug dum the

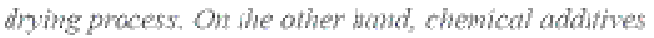
an be nsed ro fullit the same pupose. The wort com-

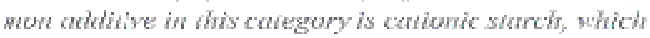
ing been ised in printing and writing gods as well as in papebourd manufactur.

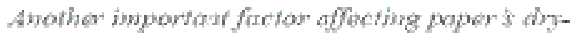
whength is the number and the araliablity of wontable

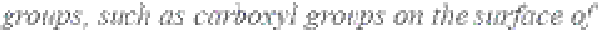

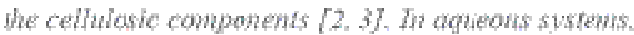
these groms develop negathe chages. $n$ princhle,

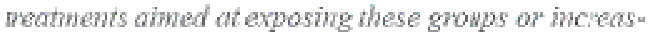

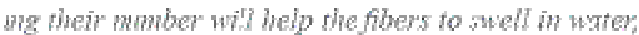

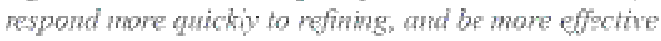
in increasigg paper strengh

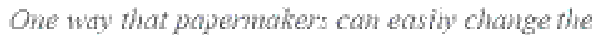

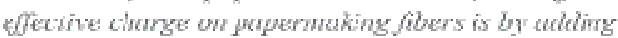
solwtions of charget polswer. such polymers con contribute to power s strength by adworbing on thz Wher surthes and increasing the dogroe of hydrogen ponding at the contuct areas betwen foren $[3,4$ ?

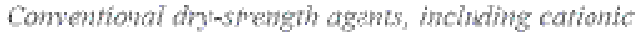

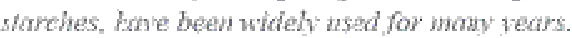

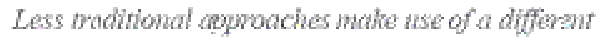

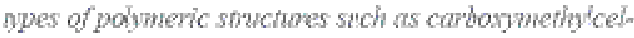
whose [s] as wall as polyelechlyte complexes [6-9] 
miltcanadis [10-13] e polianfoteros $[4,14-17]$, adicionadis ans materiais celulósicos.

Polianfóteros silo macromoléculas raturais orzanicas on sintetizas que possuem tanto grupos carregados positivos quanto negatiros em sul cstrutura [18] $\mathrm{c}$, portanto. apresentan algtimas propriedades particnlares. A principal caracteristica destasmolestlas 40 set comportanento anti polieletrolito, gue é nanisfestado com o amento da solubilidade quado a concentraçào de sal da soluço e anmentada. Esse comportamente é explicado pelo balanço das interaçểes eletrostatist entre of grupos poitivos enegatios da molecto

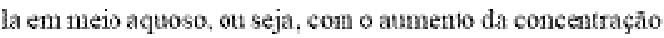
de eletrolnos lia dimintiço da atraça elerostatica antre os grupos de cargas opostas, resultando na mator expansa do folineto e portanto, anmentaxto a sua sodbilidude na soltgina, Ontre cameteristien importante d quea carga liquida dns macromoléculas depende do $\mathrm{pH}$, pois que possuem grupos positivos e negativos. Para una condiçăo fixa de forç ionnca

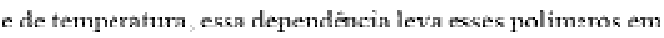

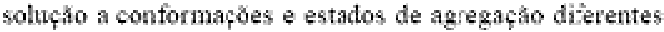
en soluçes de diferentes valores de $\mathrm{pH}$.

Considerando polianfoteros naturais, as proteinas contêm grupes àcidos e alcalinos fracos em que sua ionizaçåo depende do $\mathrm{pH}[19,20]$. Con s desenwolvimento de tenians de polinerizaça, foi possivel prepurar polianfoteros sintéticos con propriedades diferentes e peculiates. Eutre ouros parametros que afetam sua coufornaço en soluço e seu comortanento de interacho, poden ser citados o peso molecsiar, a densidede de carna, a distribuiça de carga e a distribuçĩo dos nonômeros na moléculia. Parametros rehcionados con as isteraçoes de stiperficie sỏo inportantes tambin. Esse grande mimero de paramstres fax som que seja difici compreerder plenanente o comportamemo desse tipo de polimeros en soluçăo consideraño configuraços a interaç hes am interfaces

Polianfơteros tểm recebidc atençâo especial en testes de hboratorio. Entre outros usos potenciais, eles sio utilizados para atumentar a resistentia à seco do papel. Segundo tosse conhecinente, op primeiro trabalhe bobre a aplicaço de polianfoteros como aditivo de resistencia do papel foi publicado em 1977 por Carr et al. (197t). Polianfóteros a base de anido foran preparados atravts da kantậa de derivado de anido stionico de milho, cue tinham grupos athinas terciatias, $\left[-\mathrm{CH}_{2} \mathrm{CH}, \mathrm{N}(\mathrm{C}, \mathrm{HS})\right]$ ou quaternărios de anonis $\left[-\mathrm{CH}_{2} \mathrm{CHOHCH}_{2} \mathrm{~N}^{+}\left(\mathrm{CH}_{3}\right\rangle_{3}\right]$ Sxados atraves de ligaçes Grupos de xantatos mionicos froram introluzidos thas aninas de ando cationico Os antores nostranam que a

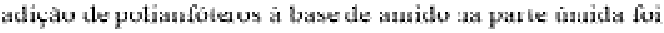
eficiente para potnover as resistencias a umido e a seco, e que form stperiors aquelas obtidas po polieletritios de ambido somente, satibnico on asionico [21].

Vartos trabulhos solve os con portamentos dos polianfoteros

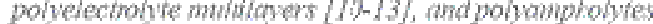

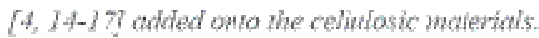

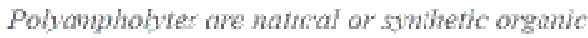

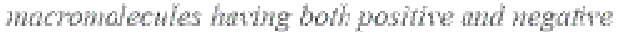

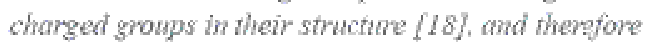
they hawe some distructive propentes, in man fer-

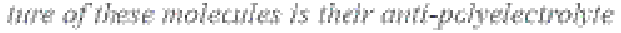
belowhor, which is manfested as morensed solubihy

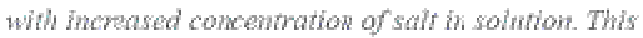
behaw is explabed by the balance of electrostatic interactions between powtipe and neguthe grongs of the moldule in the agreous medim with incrased

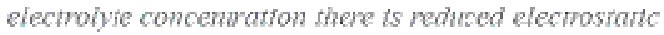
athaction betweet the oppoth charged groups wsulng th an horessed poimer expansion an

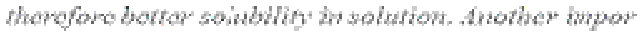
tant chancteristic is that the net chare of the nacmolecules depends on the $\mathrm{H}_{7}$ since they have both pastive and negrative grouprs for a fred cond thom of

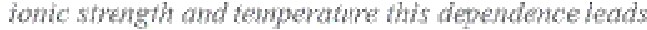
to diferen confomatons and she of ageregchon of

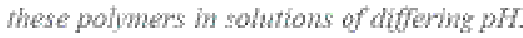

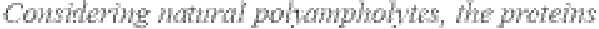
contain weak acido and basic gronps that display pH-dependent iomation 114,207 . Whin the dewlop-

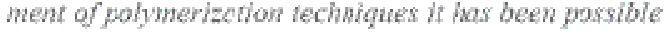
to prepare swhthetc polyompholves hatng thferent paricula propertics. Amorg other purameters that atfect thetr conformatron an solnon and whertwon behavior molecular wyght, charge density, charge distribution and mowner distribution h the molache adr be coted. Partanchers related to the surfoce inter-

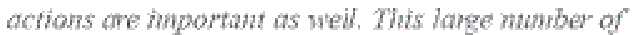
powneters mokes it wherewly dinchit to fully under-

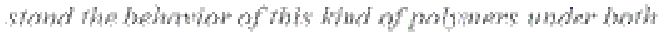
configurations in splufion and interface nteracions.

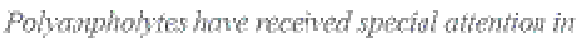

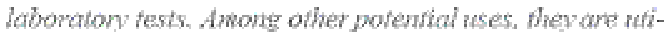

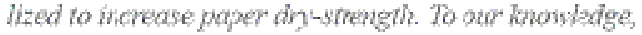

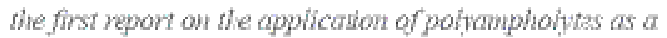

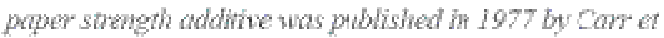

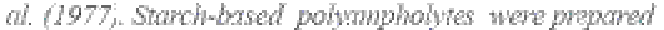

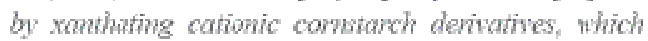

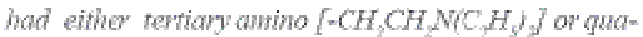
temary awnomun [-CH,HUHCH $A C H$ J $]$ gaps

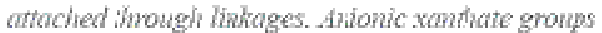

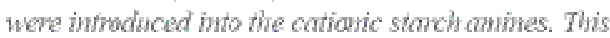

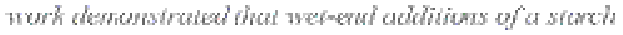
polyomplolyte was efectwe in powing both wet and dry strengthe exceding those given by either cotionic or

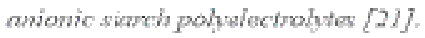

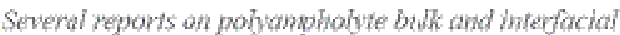




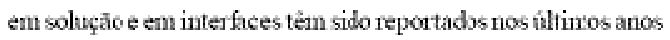
$[4,14,16,22-26]$. A capacidade desses polimeros en aumentan a resistencin do papel tén sido estudada tamberm $[15,17,22,27]$

Nos estudos de Song et al. (2006) e Hubbe ef of. 12007a) sobre a utilizaçio de polianfoteros cono arentes de resistencia a seco, os attore observaram aumento do comprimento

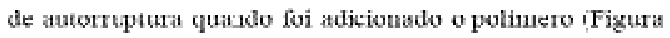
1A) [16, 22]. Eles util-zaram quatro amostras de poliantoteros con os grupos distribuidos to acaso na molecula, con peso

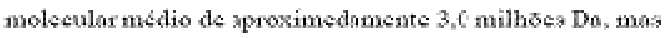
com densiliades de carga diferentes e com a mesma relaçäo entre os grupos positivos e napativos, 5:4. O monomers cationice zoi o $\mathrm{N}-\left[3-\mathrm{N}^{\top}, \mathrm{N}^{2}\right.$-dirretilaminopropil]acrilamida (DMAPAA), this amina terciaria, o nenoumero äiónico toi o weddo itaconico e o monomero neatro toi a acrilanda (Figuta IB). $\mathrm{O}$ efeitc do $\mathrm{pH}$ ta reststencia do papel tumbèn foi avalhado. Para os tres nived de $\mathrm{pH}$ atudados, $4,0,5,0$ e 8,5 , valores mais elevados de resistenca do papel formm enconirados pari valores de $\mathrm{pH}$ abaixo do ponto isolétrico (cerca de 7,0). No pH de assmetria de cargh, 4,0 e $5,0,0$ com-

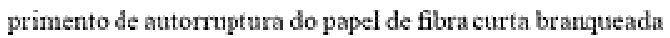
foi wais exevdo en pH 5, ou seja, mais proximo do ponto isoelétrice Neste $p F$ o polimeto apresentou carga positiva.

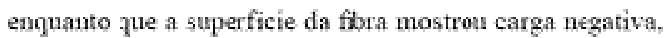
de acordo com as conclusbes do Radtcherko of al. [I8]. Volores mais elevalos de anprinento de antomptuso form encoutradss para its amostras de polianforos con calores intermeditios de densidade de carga. Hube fo al, 2007a) e Song ot of (2006) relataram que o fenômeno de adsorçâso pode ser explicado pela carga Iiquida coniraria entre o polimero a superficie da fiba. Eles tanben descobrinn que behowor howe been reportad in weent yours $64,14,16$ 22-26]. The ablity of these polwner to harase poper

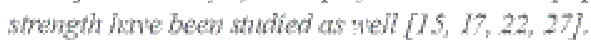

If the studtes of Song of al (2006) and Hubbe at al. 2007 al conceming the use of potwmpholves as a dy-stragh agent, the ahors obsened nowashg Lreaking tengh when the potymer wax added (Tigu we 2 ) 16,227 . Ther used fow samples of random polvowholytes whis awerage noleculor weight of ca.

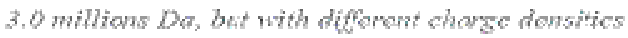

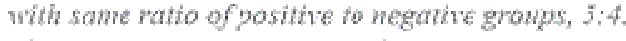

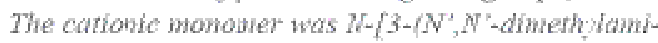

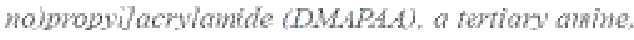
the anionic mononer was itaconic acd, and the newtral monower was acoulanide (FIgure LB). The effet of $p$ H on parer strengh was also naluats. For the three lenels of studict $\mathrm{pH}_{3} 4.0 .5 .0$ and 5.5 . they found higher wolues of paper stregg th for oppilcation wh wh walue below the loelectic point (around 7.0\%. At the pH for change asmmetry, 4.0 and 5.0 , the breaking lengh of bleached hardwood fiber Wandshers ware higher at pH 5 , ine, closer to

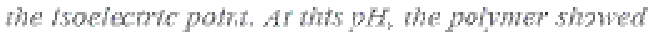
a wer posine chare, whie the nber sufoce showed

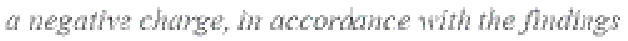

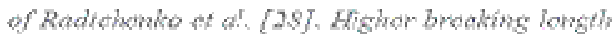
was fownd for the potyanpholyte sample wowh

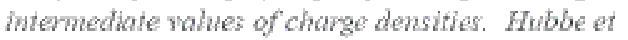

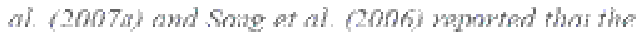
adsorptiom phenomenom con be explatined by the dif" fering ner chare behzen the potymer and the fiber
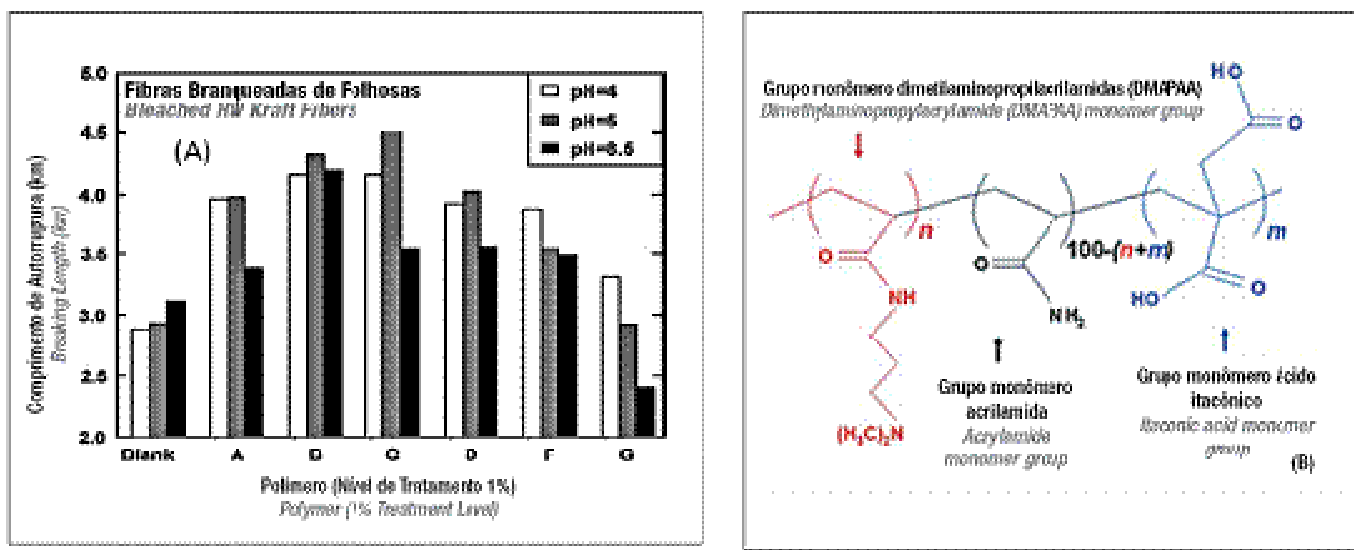

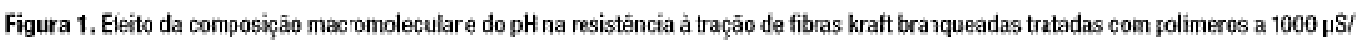

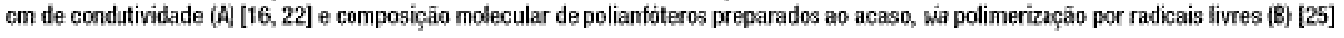

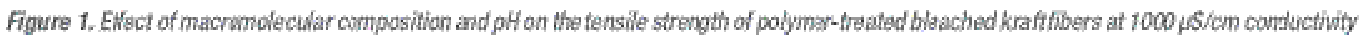

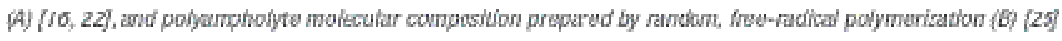


a quantidade adsorvida de massa diminuin para o polinero con a mior densidade de criga. Essen autores tanbén usaratun polieletrolitos convencionais, anibnice e cationico, e un test controle, sem adiço de polineros, para fins de comparaģo. A resisténcia a seco resultante da atlizaçåo do polimero anisico fol menor do gue twe caso do pslinero positiwo. No entante, todos os tratamentos que enwotweram polianfoteros resultaram em vilores de conprimento de antoruptum mais elevados do qu o tratamento con o polimero

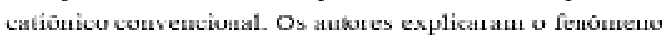
em termos de interaça eletrostatica ente a carga líquida positiva dos polimeros a corgat negative da superficie das

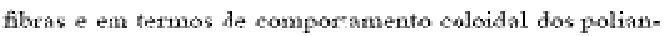
foreros en diferentes condiços de $\mathrm{pH}$. Valores de nubidez mais elevados forati encontrados em pH proximo ao ponto isoeletrios, o que significa que foram frmadns algumas estruturas de agregados com tzua no seu interior.

Nos trabalhos ds Silva ef al. (2008b e 2008c) e Yamaanchi ot al (2008), foi verifictio que a tesistencis do papel aumenton com o aunento da adiçio de polianfoter. Silva ef al. usaram amostra de poliznfótero com proporçà de $20: 8$ mol\% de grups positivos part negativos, empH 6.5 e $10 \mathrm{mM} \mathrm{NaCl}$ Lses autores encontran un amento relativo de $70 \%$ na resistencia do pape $(1,0$ e $1,7 \mathrm{~km}$ de comprimento de autorruptur, $0 \%$ e 1 th de dosagem de

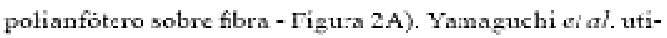
lizaram anostra de polimero son propoçĭo de $5: 2$ mol\% de grupos positivos para negativos, em $\mathrm{pH} 7,0$ e $1000 \mu \mathrm{S}$ cm $\mathrm{Na}_{2} \mathrm{CO}_{3}$. Fsses motos encontraxam atmenta felstiwo de $40 \%$ (hm 3,5 e 4,7 de comprimento de auturtupturs, $0 \%$ e $1 \%$ de dosagen de polianfotero sobre fibra - Figura 2 B). suffoce. They also fowd thot the adsobed onw of mass decreased for the polmer with the highest charge density. Tha also ased conemional paly electrolyes, anionic and cotronte, and a control tast

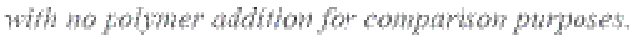
The dry stength resutting fon we of the anowh polymer was swaher than in the case of the poitre polymer However all the matwents inwohing polyanpholyes yelded higher shenth than tredment

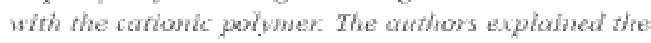

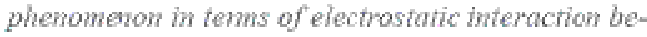
tween the net posine charge of polyners and nega

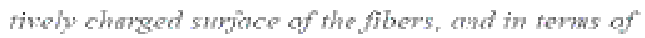
collold 7 behavion of the potyampholye at different

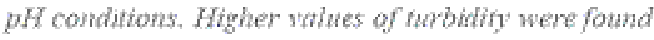
at pH vaites closer to soeteche powt, which neans that sane aggregate shoctares wh whter hiside whe fortued.

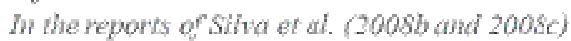
and Whognch et at. (2008) it was fowd that poper 3 strength wored with inchasing polfomplobe additron. Sha ef al ased the polvanphobte with a ratio of 20.6 not 5 of postive to negatre groups, at $\mathrm{pH}$

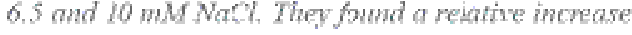

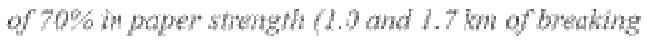

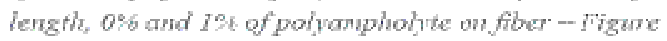
24. Yomguch et al. naed the sanple with a ratio of

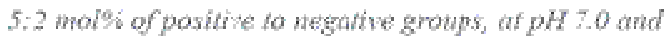

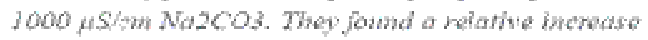
of the $40 \%$ (3.5 $\mathrm{mm}^{4} 4.9$ tan of breaking length, $0 \%$ and

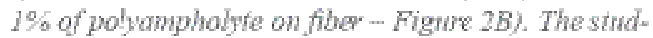
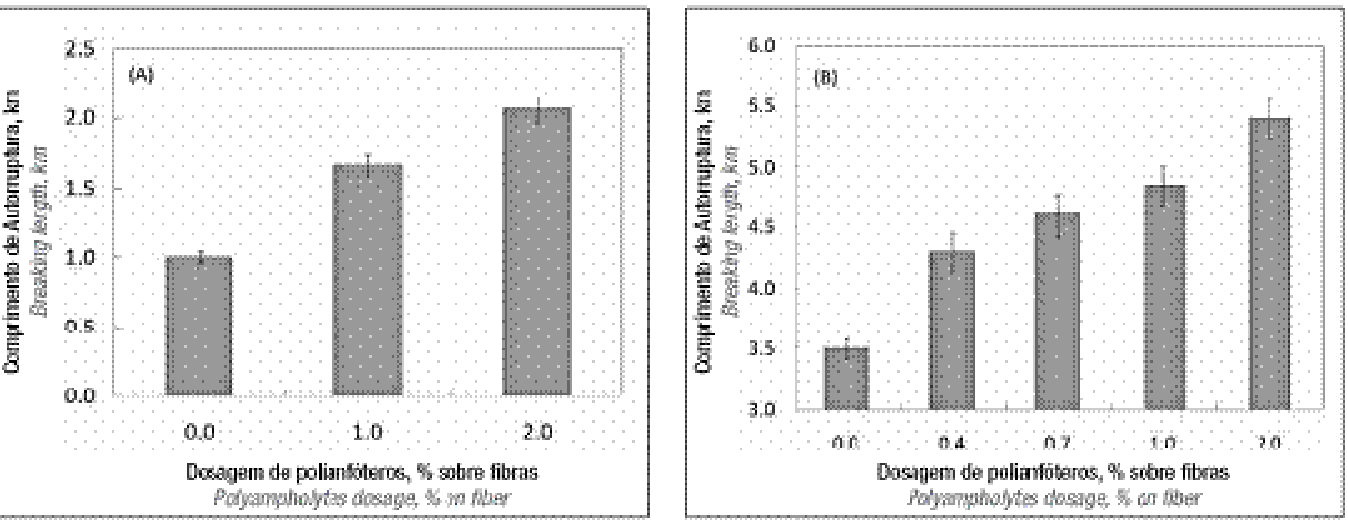

Fiqura 2. Edelo da dosagen de polianfótero na resisténcia do papel, comprimento de autorupura: (A) popa kratt branquada nío refinada

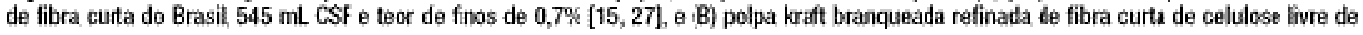

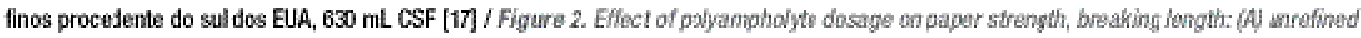

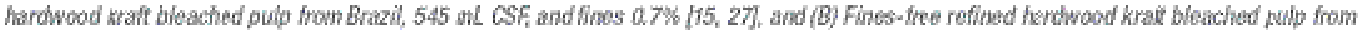

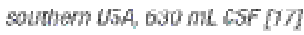


Os estudos utilizaram diferentes amostuas de fibras kraft de folloosis branqueadas.

Alguns aspectos teonicos e práticos dos poliantoteros em soluça e de sua adiorçio em interface sồido-liquudo sảo considertios abaixe, a fin de explienr o potencial deses polineros cono agentes de resstencia a seco do partel.

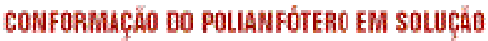

Dobrymin et at desenvolveram um molelo teorico e pro-

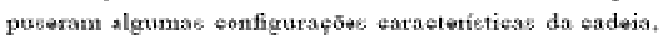
dependenb da natueza da caga do polintifotero, ben como alguns aspectos da saluçio $[29,30]$. Para polianfoteros assimétricos, con arupos curestados distribuibs alentoriamente. esses autores propmseram três regimes paras contiguraçă da codeh (Figura 3): (a) confornaçio Gaussian, (b) confonaçào estendida ja forma cilindrita, e (c) conformyça colapsada em gibutos altethdos con pate da cadeia estendia. No caso da cadeia de poliankitero estendida na frma cilindrica(b). A repula do Coulmb entre is corgas en excesso para a sidein de potinnotero assintuica e maix do que anergin térmica o que prome o alongamento ds cadeis en forma de um cilitidro, o que é analogo a comportamento de um

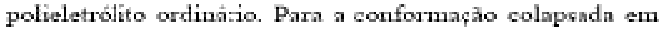
flobulos alemados com parte di exdera esteudida (c) cadeia de polianthero fortenente carregada tendea ter eswa cufignraçāo por causa da existència de forças induzidas fluhuntes, atrativas e repulsivas, entre as crigas en excesso.

De acordo con cheong et 7 . (1995), conforme citado por Dobrynin (2006), as interaços cletrost htican sutre monomeros de cargas opostas promovan separz̧̧o de fases de polianfóteros em soluçăo [20]. Alem disso, ver fricm-se que essa separaço erat dependente do gran de polimerizaçao da cadeia, da sequécia de carga ao longo da cadeia do polimero, da resistencis das inturaçöes eletrostáticas a da temperatua da solnhto.

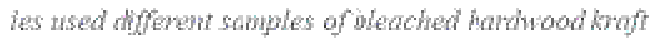
blenching fibers.

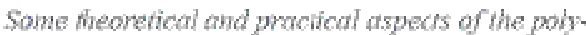

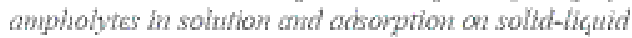

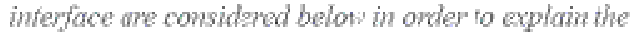
ability of these polywer to increase the paper shergth.

\section{POLVAMPHCYTE CONFAMATION IN SOLUTO}

Dobynim et al. have deneloped a theretical model

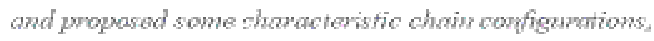
depending on the chased nature of the potyanphalyes,

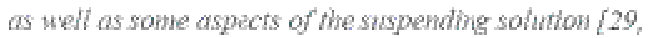

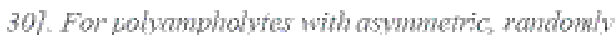

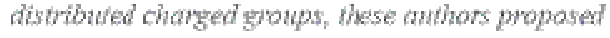
thee weghes of cham configtuation (Fine 3): (o) Gassian conformuson: (b) statched ino a cwimbrical shape and (c) colloped ino a necklace the globule $h$ case of a polywwhole stretched into crlindrical shope (b), we Contomb rentsion betueen the steds cherges

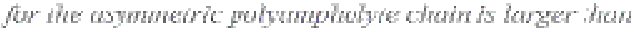

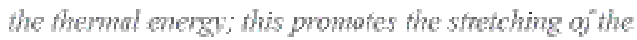

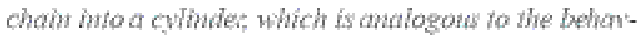

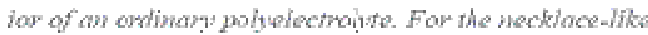
globule confouration (c), a stomgly chaged polum -

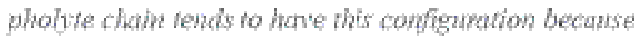
of the fuct?ation-indiced athotion and Coulomb repulsion behteris the extess chinges

In agreswent with cheorget al. (1995), as cired by Dobryin (2005), the alecturtatic weractions between oplasitely changed nonomers prowore phose

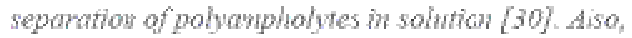
if was found that wh separtion was tependent on

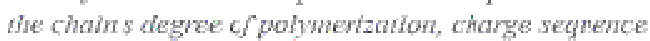
along the polymer twothone, shength of the elecrostatic interactions, wh solution tewpenture. (a)

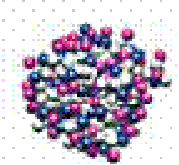

Ghindo Ghulu (b)

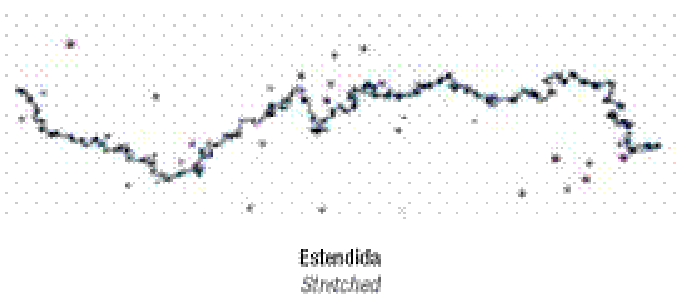

(c)

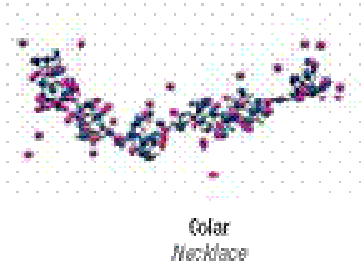

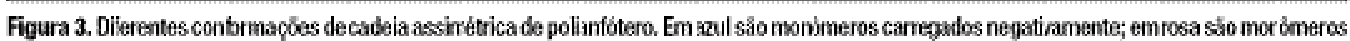

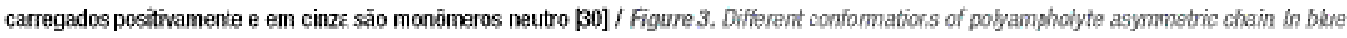

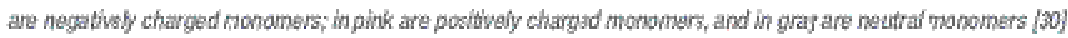


Os comportanientos coloidal eletrotinético de tréspolitin= foteros a bose de actilanida com at to peso wolectar e diferentes reloços entre as cargs positiva e negativas form estudodos por Sezakier al. [23]. Tubidez waxima foi twonttadaen pH pröximo ao ponto iscelétrico para soluçấ tivre de snd. Esses antores tamben observaram turidez mas elevida, a coal era consisenu con a redpento dit solubihdade dis macroncle culs do polineto devido a coaguhç̧o das pattic ths.

Propuitadades de solnçdes aquosas de polian fôteros a base

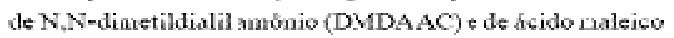
(MA) con a bew a pesença de sil, foram estudadis por Thaeva ef al. [31]. Esses antores encontraram qie os copolimeros apimolame glternato te DMDA AC e MA aprosentam conportanentos antipolieletrolito en seu ponto isoelétrico.

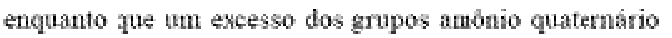
lewou a um comportamento tipso de poliesetrolito.

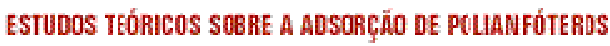

Estudes teóricos significatios tển sido desenvolvidos por Dobynin e sen grupo, o qual conshideron a adsorçio de endeias de polianfoteros sobre superficies carregadis [29. 32. 33]. Dobrynin al al definitam polianfotero con carga equilibrad ou com carga hquda neutra cu smetric cono tendo mimero igual ce grupos positivos e negatros, Al carga liquda on carga assinetrica de un polinftero i hual ao ralor abschuto da diferença sntre o muncro do grapes positives enegtivos.

Para una ưnica cadein de polinnfotero imétrico, Jobry

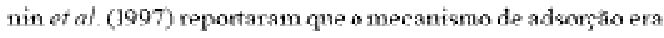

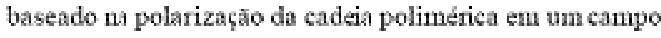
elétrico gerado pela superficie corregada [29]. Nesse caso. ttes regims de adsoşato diterentes, na ansincia de sal, puderam ser identificados (Finura 4): al regime do poolo, (b) regime de cerca, e (o) regime de panqueca. A expẻitaçâ detalhada sobre esses regines a fornecida pelos antores esumarizada aqui [29] No regime de polo, o eampo eletrico gerado pela stperficle cartegada induz o alchgamentoda cadeia ta direça do campo. O comprimento de Gouy-Chapman, $h$, pode ser muito maior do que o tamanho da bobira nab perturbada, $R-$, se a dustidade de carga da superficie for baixa Desta forma, a codeía do polianfótero se alonga em dirę̧io a su-

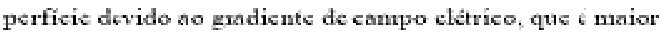
proxino da superficie. Para baxas densidudes de carcas da stperficie a adsorço nobo ocorre porque oguho de nergia

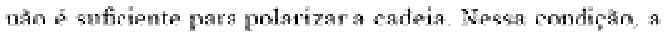
energia de atraçio entre a cade a $e$ a superficie e baixa e as endeias pedem se mover livenente en direçīo da shuço. No regine de cerea, 0 comprimento de Gony-Chapinas, $\lambda$, torna-5e proximo do tamanho da cadesa, $R z$. O regime de panquect acontece quando densidade de carga da ruperficie anment a ainda mais. Neste caso, a parte dacadeia cous carga oposta a da superficie fican deatro do comprimento Gouy-

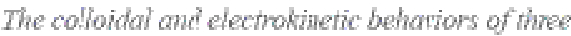

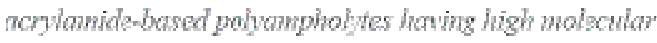
wasnes and differen whio of posith to ngatie chuges

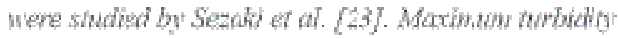

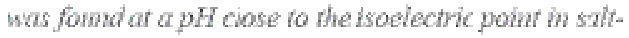
fre solution. Also they obsend a higher whidity that

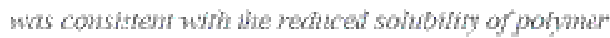

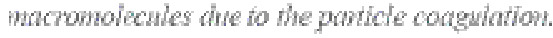

Agreous solution powaties of polvowpholytes

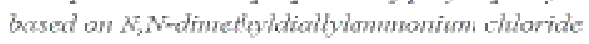

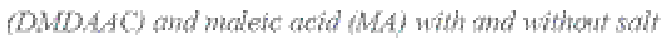

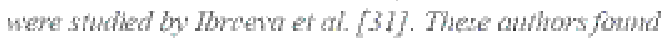

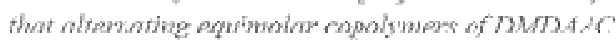
and MA showed antipalyetechobte behawor at its isodectric poin, while an awess of ammontan quaremay

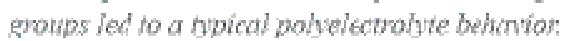

\section{THEOAETICH STUDIES ON THE POUAMPHOLYIE AOSOAPTION}

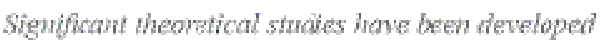

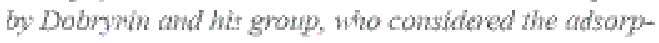
non of pobnmphobye chans onto a chrmed strface

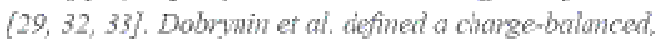

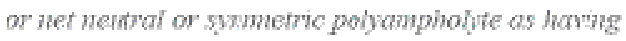
an expal namber of positive and hegatse gromps. The wet chare or charge aswmerry of a potwmphohte is

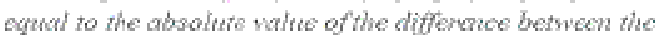

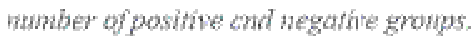

For angle and symetric polywhlotye chan,

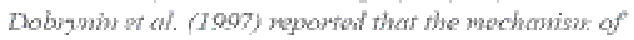

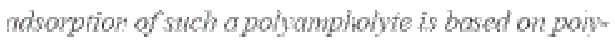
mor cham polarisatim in an eiechicalfold dhe to the

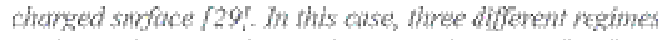

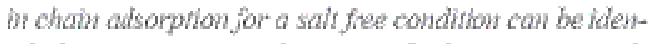
thied (Fing 4) (a) pole rsine, (b) fene reghe, and co pancalo negine The detaled explantion about

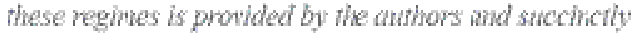
sthmoizd here $[29]$. Whe pho reghe the decticat fold of the charged surtace ind ance the rongation of the chom in the dipection of the fied Whe Gown-Chapman

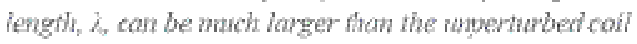

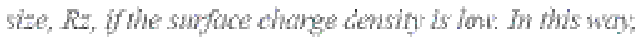

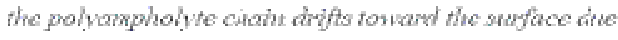
to the elewical fidd gratient what is higher mow the

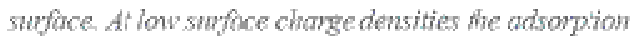

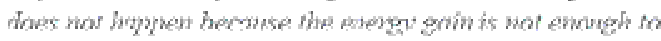
polorize the chath, th the conditon the atraction energy batween the choin ard the sufwe is low and the chans

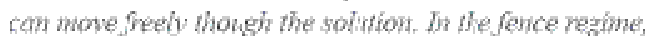

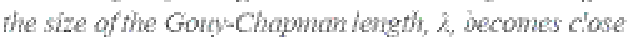
fo the size of the chain, R. The powcake negime hoppens when the surfuce change densiy, fivther werases, in the

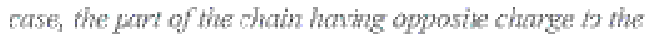




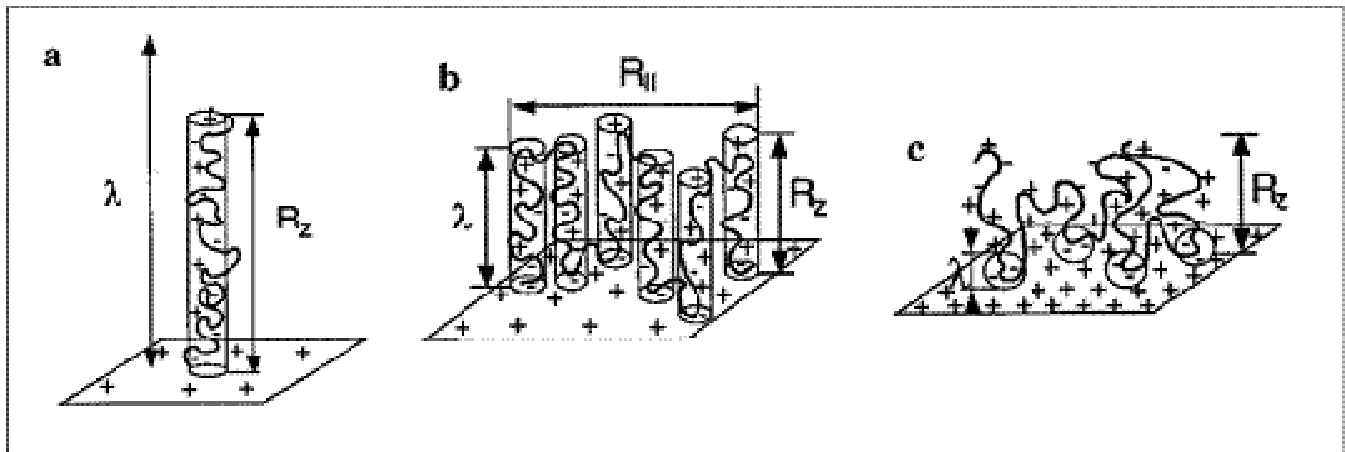

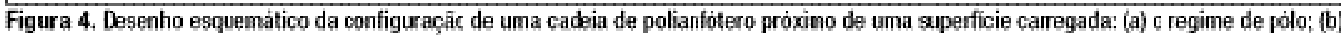

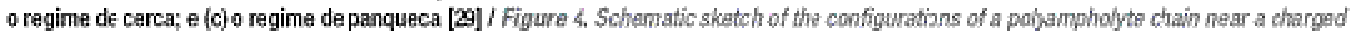

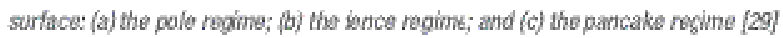

Chapman ¿, e a parte da cadeia com mesma carga fieara fora do comprimento Gruy-Clapman. A cadria formur toops us soluço a uma distincia. $R$. superion ao comprimento Gouy-Chapman, 2 .

No caso de as cadeias de polianfotems terem simal de

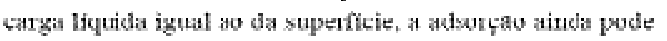
acontecerse a carga de superficie for grande osuficiente [29].

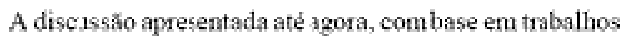
de Dobryain ot al. (1997 a 2008), dix respeito a cadoing de

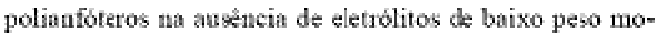
lecular [29,30], o que es situacho bastante diferente caquela enourada na fabrikaço de pupel. De fro. a presença de

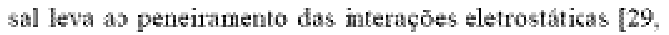
30, 34]. Pode-se esjerar que os tegines de configtraços do polinanfotero possam mudar com a presenca de sal em

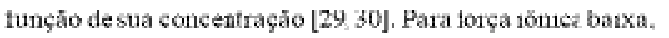
as configunços ctío próximas das previsós descritas para wh sistema sem sal Por outro lado, par niveis elevados de sal espera-se quas as configuraços mudem devido ao peneiramento eletrostatico. Dobrynin (20)s) explicn que as sargs anda interagen atraves do potencial de Coulonbonio afesado pelo peneiranento eletostätico a dintincias mito menores do que o comprimento de Debye, $\mathrm{rD}-(8 \mathrm{NhCs})^{\mathrm{L}}$. onde Cis a concentracto de sal [30].

O efeito do peneiramento eletrostáticotem sidoutilizado em diversus estudos para explizar o compontamento de ad= soreto e desorcho de polieletrólto [35-38] e de polianfoteros $[32,39]$ ne presença de eletrolitos com baixo peso moleculat:

\section{ESTUDOS MÁTICOS SCBRE A ADSTRÇÄO DE PHLANFÓYERLS}

Considerando os estudos praticos de adsoryio de polian-

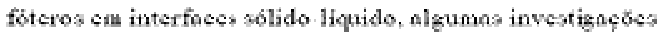
podem ser citadas [14, 16, 24, 40-43]. Dertre sases catudos, a adsorcho mixima do polimen foi encoifrada proxino as pouto sweletrico, apesar de se tratar de difenentes macromo-

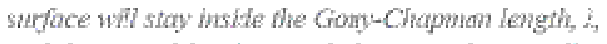
and the port of the chath with the same charge will atty autste of the Gowp-Chopman length. Whe ohan fom

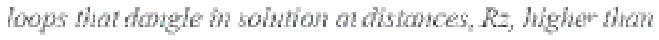
Goub Chandw lemgh, $\alpha$

In case of polyanipholye chatus hang die sane net sign of change w the suffoe the adronption still

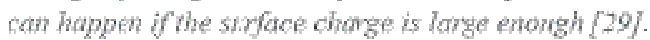

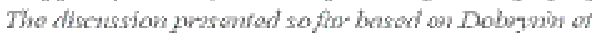
ar work (1097 and 2000 ) strich concans polvenplo-

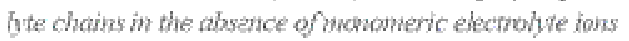
$[29,30)$, whoh is a shumbon alte difentit fon thon

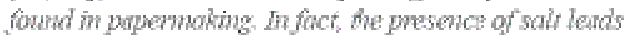

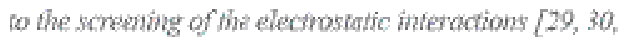

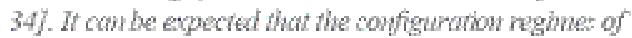

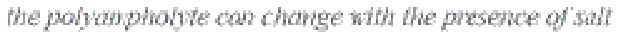
hpendhgon the conctumation 229,30 . For low ionic

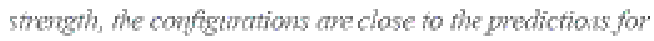

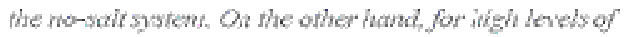

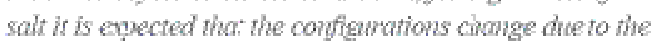

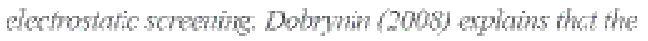
chager sth hienct twoweh the uncrend Coulowbic

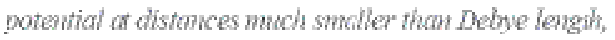

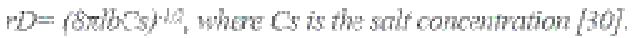

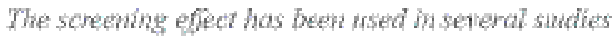

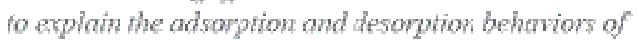

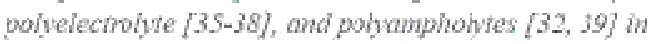
the presence of elecwolyes wh low nowector weight

\section{PRACTILAL STUDIES ON THE PUYYWPHOLYTE ADSOAPTION}

Considering prontical studes of adsorption of

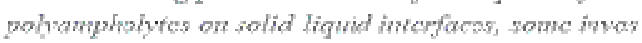
tigations tan be chd 174, 16, 24, 40-497. Among these

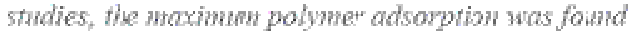
close to the isolectic point, regardles the defolts of 
leculas de poliantóteros, Sezaki of af tamben encoitraram significane adsorço sobre filras de carga negatipa para polianfóteros de carg̣a liquida neutra e camegndos nęativa= mente pari pH acmina de seu porto isoelétrico. Assun como Mahlige ef al [40], ssses autores encontrian um glato ai adsotçoto apos aproxinadathethe 60 min de inethaço [14].

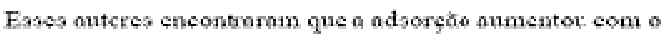
teor de sal até $1000 \mathrm{pl}$ Sicm.

En estudos de adsorçio de polianoteros diblocos. PMAA-biseo-PDMAFMA Gicido polimetilacritico-blocometacrilato de etil polidimetíl amino), 68,000 Da e razăo de blocos 9010, sobre superficies de oxido de silicio, Mahtig et al. (1999) encontraram dois máximos de adsorçà̀ perto do ponto isoeléticico ( $\mathrm{pH} 3,8$ ) [42] No ezutato, peica os nenluma Adsorço for encontrida no $\mathrm{pH}$ inoletrieo. Isto foi explicado jela falta de sirios de dosorça nesse $\mathrm{pH}$, tanto pana os grupos âcidos cututo para os basicos 142$]$ ipH isotétrico e $0,01 \mathrm{M}$ ce ambos os sais $\mathrm{NaSO}_{4}$ e $\mathrm{CaCl}_{2}$.

0 convortanento de adsorçio de un polianfótero tibloss semelhast ( 62.000 Da e proportho entre biocos de 19.81), fot avaliado pr Mabltig ef al. (2000) em diferentes condiz̧des de pH [40]. Os autores excontramamque a guanidade de polimeso

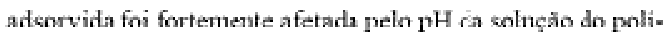
mero, o qual tamben desempentha tim papd no tantatho dos agregados de poliantuteros adsavidos nit stperticie do oxido de silcio. Adsorgro naxitna tatubein fo ercontrada pouxino ao ponto isodétrico, $\mathrm{pH}$ 9,4. Elipsonetria, microscopia deletròmica de varredura por sonda e técnicas de espalhmuento dinânico te hu foran usadas para stgertir tha adsoç̧o em monoctmada [40]. Eses autoresobervartn p̧ne a çuntidade adsorvida era funçio da concentraça do polimero seguindo uma isoterua de Langmuir. Elestamben cucontraran peque-

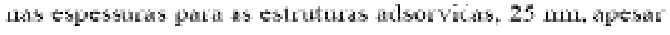
de valor mas elevado ter sido eneontrado ta foça hateral e no tamano aprente das micelss. As difeienças de trmanho

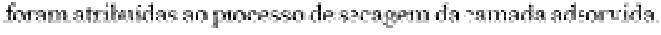

Outro estudo de adsorçio com copolimeros dblocos semelhanie foi realizado pelor mesmos autores em 2001 [4]. Eles considerarin trể amostras de polianföters con peso molscular semelhante e a razöes entre os blocos diferentes, FMAA-bloso-PDMAEMA 84:16, 55:45 e 29:71. O pouto isolétrico anuentou como tamanho do bloco positivo (PDMAEMA) correpondente aos valores de $\mathrm{pH} 3,8,5,9$ s 8,9, respetrivanente

\section{CONSIRERLEOEES FINAIS}

Os trabalhos publeados citados neste artigo mostran que os polianföteros apresentam vărios comportamentos distintos,

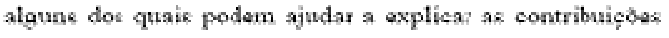
superionespara a restincia do pupel, sob condipos idequadas de $\mathrm{pH}$ e composiça. A conformaça do e tamarho dos agregados de polianfteros esuas cargas linudas en soluçōo

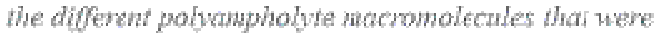

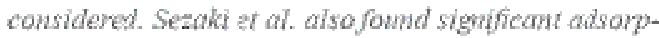
thol onto negatidy charged fibers for het-Hetithal and Heganwely chorged polyampholye at ph above is isoeloctric point Lithe Mahtig et al [ob], they found a platem th the adsoption wfer ca, 60 nin incubation 14]. The awhor fornd that the adsonption howsed with the sal content ap to 7000 if $5 / \mathrm{cm}$.

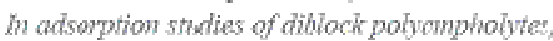

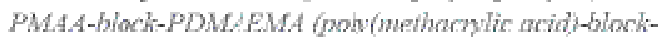

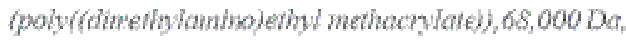

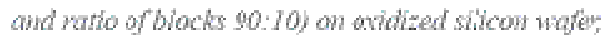

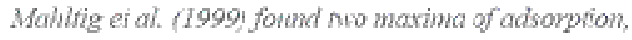

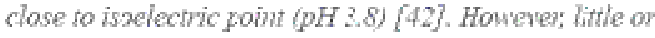
no adsonfion was fowd at the isodectric $p H$. Whis uas

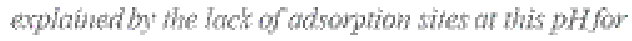
whe the acidic or whe basic wonower groups 142 , fro elecric pH and $0.01 \mathrm{M}$ of both shlt $\mathrm{NaSO}$, and $\mathrm{CrCl}$.

The adsorption behavia of a similar dibloch poly-

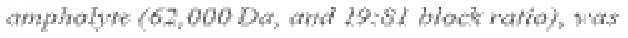
fiwhited by Mohlig et at (2000) at doren pH con-

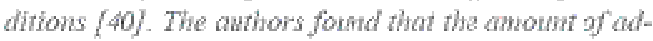

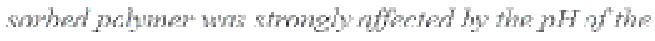
polywer solution, which also plays a wite in the atine of the polyowwholyte agsregates adsopbed on the siticon

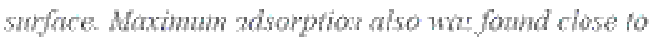
isolect ic point, pH 9. Ellipsomeny, scaning probe

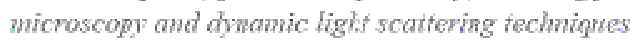

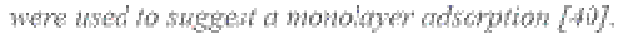

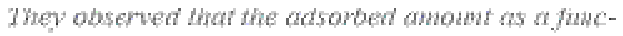

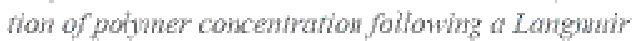
wotherm. They alsc fowd a wall thotness of the ad.

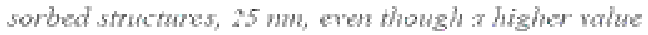

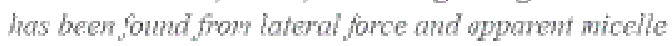
size. The dffepences in sise vere ascribed to the drying proces of the ahorbed tow

Anothe adsorpion study whith sima diblock copolymers was peformed by the sane authors in $200 \mathrm{~L}$ [4l. The considend three samples of polymphoWhes wh himblo nolechar was and diferw Wock moros, PMAA-block-PDMALMA, 84-16, 55:45, and 29:71. The isodectic point knowed with the size of the positive block (DDMAEMA) comesponding to $p H S$ of $3,8,5,9$ and 8,9 rewertheh.

\section{FINAL CONSIDERATIONS}

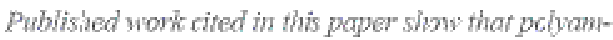

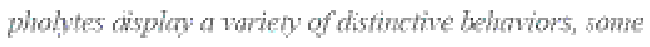

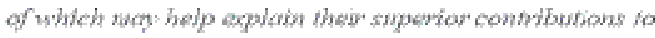
paper shereth whe sultable condihons of pH wa con-

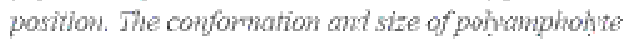
agregates and thei net chores in soluion apper to 
pareem ser aspector inportantes a considerar na explicaçäo da capacidade desse tipo de aditivo. Con base em artigos publicados, espen-sa gue as cnacteristicas do polinewo no meio de dispesto possm atetsr os fenonnenos intertaciais e as propriedades das camadas adsorvidas. Por consegunte,

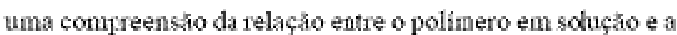
canada acsorvida pole ajudiar a esclarecere ot dade en armentar it resistencia is seco dessi classe deaditivos.

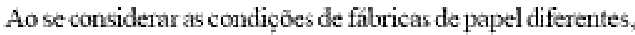

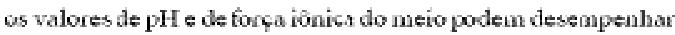

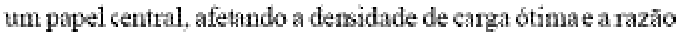
de cargas dos polinfótens. Para seleçio criteriosa do jolinero e de suas condigdes de usa, parese que existe um potemeial para atingir um aumento substancial na resistencia do papel.

\section{AGRADECHENTITS}

Os antores agradecem o apoio financeiro das CAPES, Coordenaço de Apefeiçoanento de Pessoal de Nivel Superior: be inportan aspents to be comsidered in the explamion

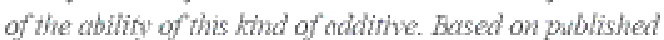

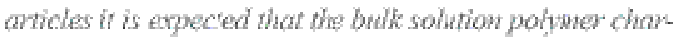
acteristic can abeat the interlactat phenonend and the

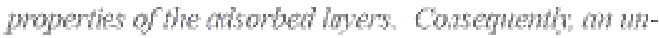
dextanding of the relation betwen tha polyner in bulk

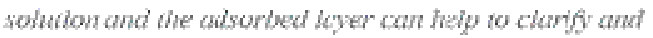
opthize he dr-srengh ablity of thi class of adtive.

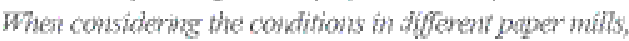

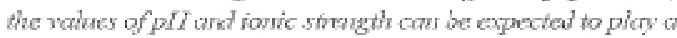

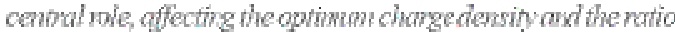
of chargar of the polwhphothe By a judcions selection of

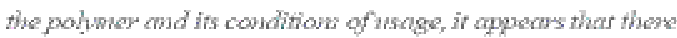

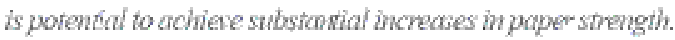

\section{AEKMOW EDEMENT}

The fwancial apport of CAPES, Brazhian Ministry

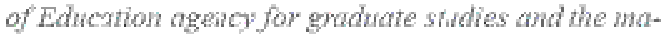
jor seholathos, in achowhedged.

\section{HEEEREIIELUS / REFEREULES}

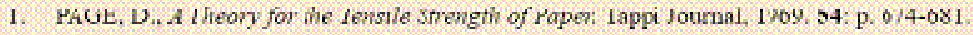

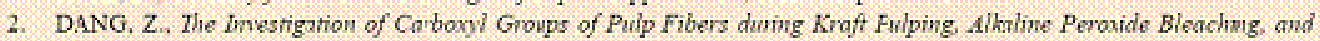

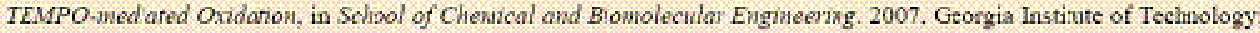
Alianta, GA.

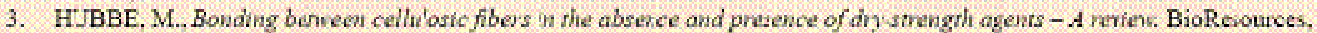
$2606,1(2): \mathrm{p} .281-318$

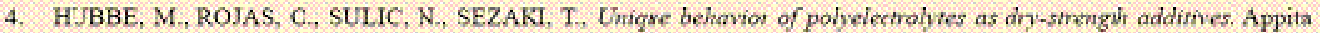
Jarmal, 2007 . $60(2)$ p. $23-32$

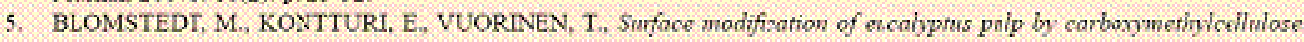
eftects an fibe properties and sheet strength. OPapel. 2007, 6: p. 51-63.

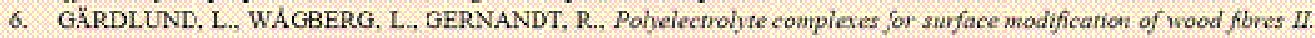

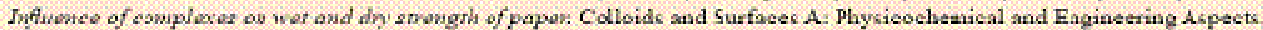
$2003,218(1)=p .137-149$

7. GERNANDT, R. WAGBERG.L., GARDLUND. L., DAUTZENEERGD, H. Polyeletolife tompletes for hathe

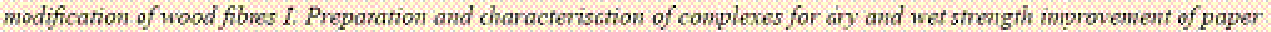
Colloids and surfaces A. Plysicochem. Eng. A peers, 2005,213 p. $15,25$.

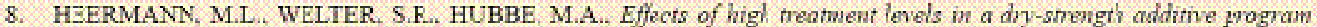

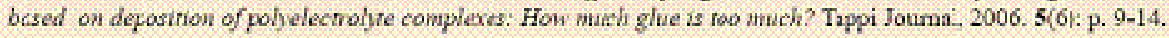

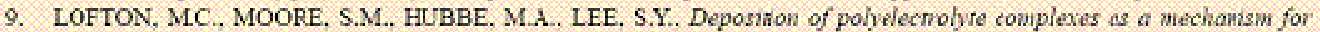

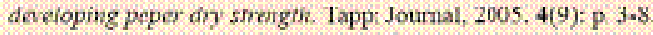

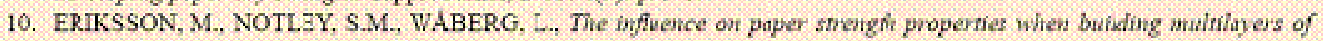
wak pohelectrobtes onio wood fibres, I. Collod and Interface $\$ c i$. 2005, 292; p 35-45.

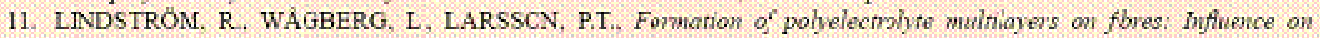
wettablity and fibrefibe interachion J. Colloid and Interfaze Sei, 2006.296 p. 306-408.

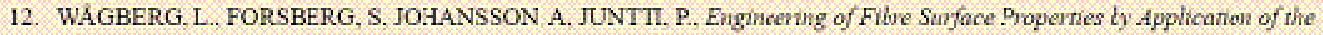

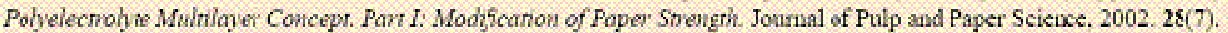

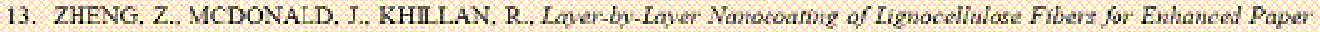
Poperties Vumal of Ninosicnce and Nanotechnology, 2006. 6 p. 624-632.

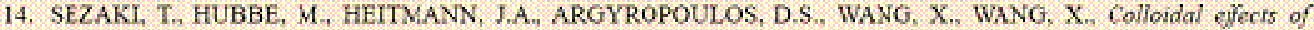
aoplanide poly nuphobres. Par 2t Adsomption onro cellubsie fibers. Colloids and Sutaes A Physicodiem. Eng. Aspects. $2006 b_{.} 289,5.895$

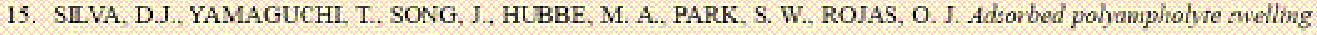

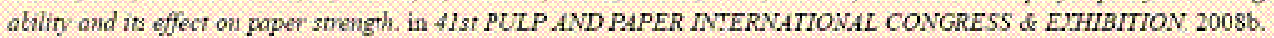
Sro Pailo. SP. Brazil, Orober 13 - 16.

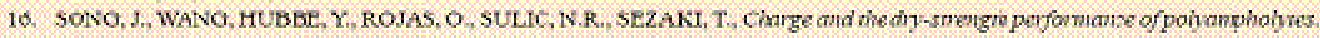

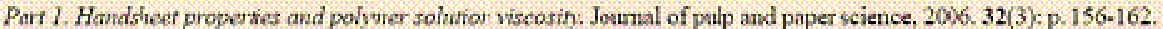


17. YAMAGUCHL, T, SILVA, D. J., HUBBE, M A. ROJAS, O. J. The offer of canonic dialnes on the adtorphon of

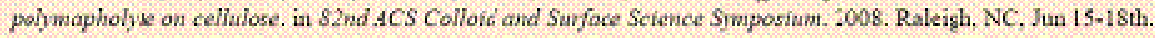

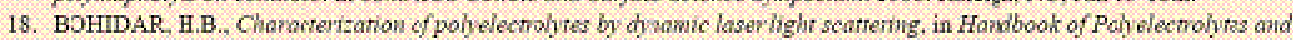

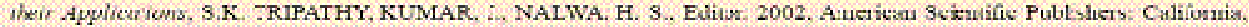
USA. p. $117-145$.

19. CIFERRI, A, KUDAIEERGENOV, S. E., Nataral and snutherte pohamphohtes, la, theon and basic strustures. Macromolecrlar Rapid Communicetions, 2007. 28. p, 1953-1968.

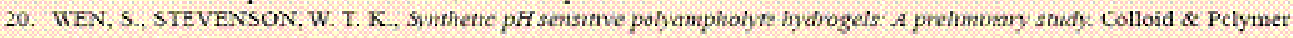
Science, 1993. 271:p. 38-49.

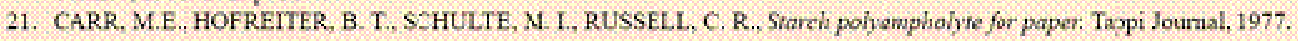
ar(10): p. $66-69$.

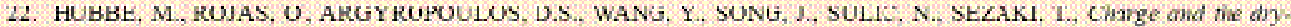

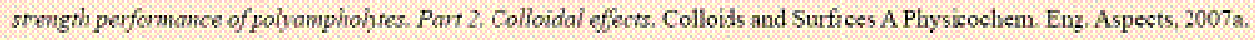
311: 23-32.

23. SEZAKI, T., HUBBE, M, HEITNANN, JA, ARGYROPOULOS, DS, WANG, X, Colloidal effeets of acyhimide

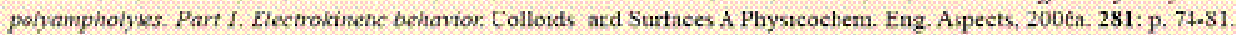

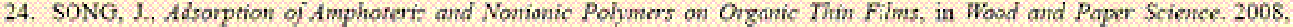
NCsU: Raleigh, NC. p. 225 .

25. WANG, Y. HUBBE, M. SESAKI. T. WANG, X. ROJAS, OJ ARGYROPOULOS. D.S., The role of polymphat le charge density on its inter achome with cell whose. Nordic Pulp \& Paper Researsh Journal, 20\%6, 21(5): p 158-165.

26. WANG, Y, HUBBE, M, ROIAS, D. ARGYropOULOS, DS, WANG, X, SEZAKI. I, Charge and the ditstength

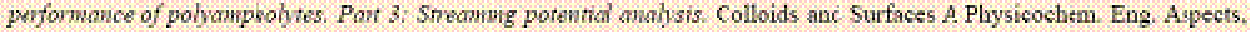
$2007,301: \mathrm{p}, 33.40$.

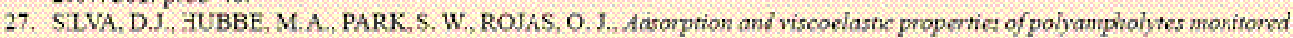

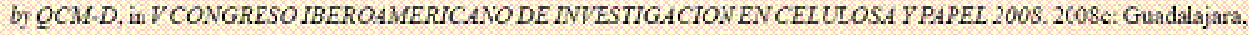
II. Mexico, October $20-23$.

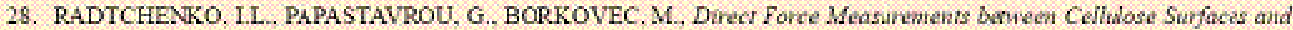
Collowdal Silta Pancles. Biomacronolesules, 2005. 61 p. 3757-3066.

29. DOBRYNIN, A V. RURINSTEIN, M, JOANNY, J,-F, Aasonption of a Pohumphalyte dain an a charged Surface. Nacromolectles, 1997,30 ; . $4332-441$.

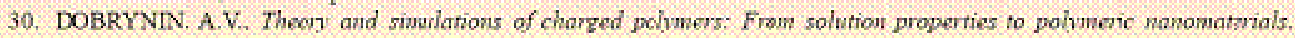
Current Opinon in Colloid $k$ Interfase Science, 2008. 13: p. 376-38s.

31. IRRAEVA. ZE, HAHN, M. JAFGER, W, MMENDNA, L. A. KUDAIBERGENOV, S.F, Solutiat Propertis and

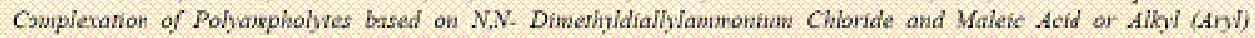
Denvarive of Maleamic Acids. Masponol. Chem. Phys. 2004. 205 a. 2464-2472.

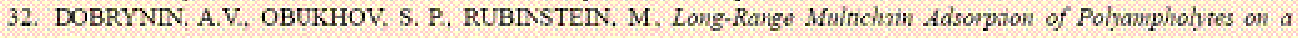
Changed Surfac Macromolecules, $1999,32: p, 5639-5700$.

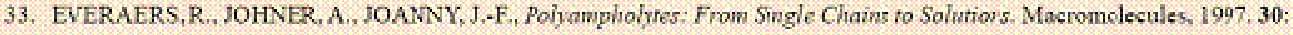
P 8478.8498

34. FLEER. GJ COHEN STUART, M. A. SCHRUTJENS, I. M. H. M. COSGRCVE. T. VINCENT, B. ed Poimmers at huofaces, ed C. Hall 1693: Londor.

35. EVARSSON L.E. WAGBERG. I. Pohdectohre Adsopnon on Thn Cellulos Fihs Swdied with Refecionem and

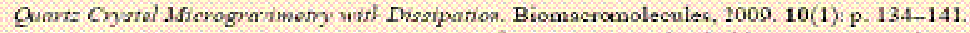

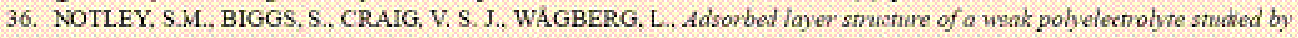

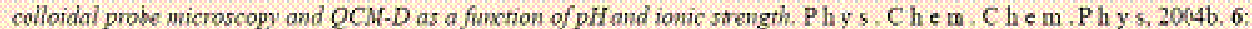
p. $2379-2356$

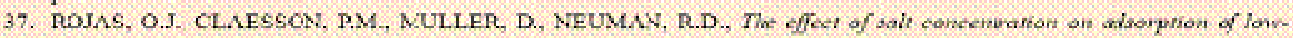

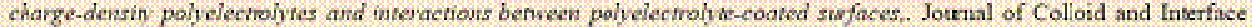
Sience, 1998. 205: p, 77.88.

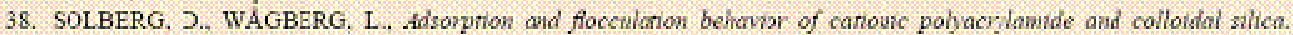
Colloils and Surfices A. Finysicoehem Ing. Aspeets, 2001.219 p. 161-172.

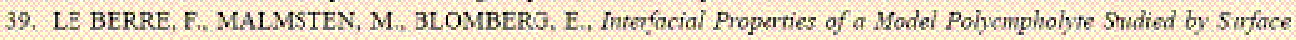

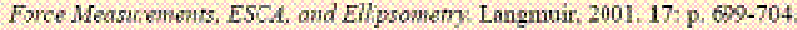

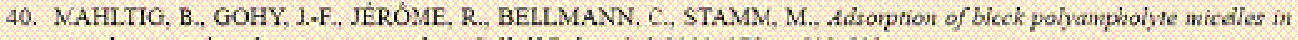

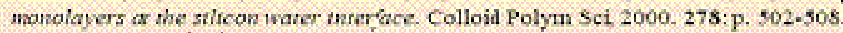

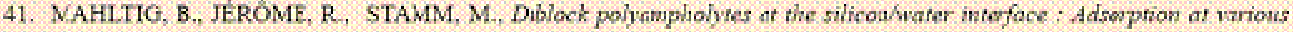
nodffed silown subsrans. Plys. Chrn. Chen. Phys... 2001 3. p. 4371.4375.

42. NAHLTIG. B.W. H. HARRATS, C. MULLER-BUSCHBAUM. P. JEROME. R. STAMM M. Adronphon of polympholve

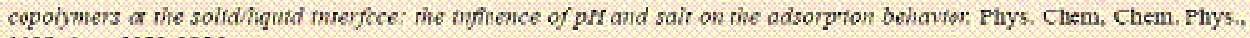
159, $1: p, 3853-3856$.

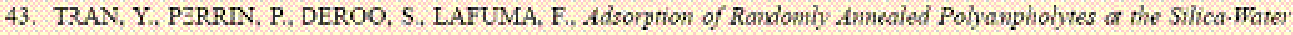
thitrfare. Langnuir, 2006. 22: p. $75-3=7551$. 


\title{
Enzymatic Application as a Pretreatment Step to Remove
}

\section{Cellulose Films from Sensors}

\author{
Deusanilde J. Silva ${ }^{\left(1^{*}\right)}$, Orlando J. Rojas ${ }^{(2,3)}$, Martin A. Hubbe ${ }^{(2)}$, Song W. Park ${ }^{(1)}$ \\ (1) Sao Paulo University, Campus Sao Paulo, Sao Paulo-SP-Brazil-deusanilde@gmail.com \\ ${ }^{(2)}$ North Carolina State University, Raleigh-NC-United States of America \\ (3) Helsinki University of Technology, Espoo, Finland
}

\begin{abstract}
In this work enzyme use is proposed as a pretreatment step to remove cellulose films from solid substrates or supports. Quartz crystal sensors and gold-coated wafers for work with quartz crystal microgravimetry and surface plasmon resonance, respectively, as well as other platforms common in reflectometry and other techniques, are usually coated with ultrathin films of cellulose for use in studies in the area of colloids and interfaces. In preparation for their reuse they usually need to be cleaned with one of the two treatments, either with hot acid or ammoniac solutions. Both treatments have shown some advantages and disadvantages for effective cellulose film removal. A mixture of cellulases from Aspergillus species is proposed as a pretreatment step to improve the release of the cellulose film from the surface of the respective substrate. Two concentrations of salt were considered in the enzymatic treatment, 1 and $10 \mathrm{mM} \mathrm{NaCl}$, at constant enzyme solution concentration, temperature and $\mathrm{pH}$. It was found that after $80 \mathrm{~min}$, the contact angle for both salt concentrations reached a plateau. Use of ammoniac solution after the enzymatic treatment was found to be a very practical and safe way to remove the films from the solid surfaces. The suggested protocol is very reliable and it doesn't require long and complicated procedures. The average water contact angle after the application of the proposed enzymatic and ammoniac treatments (between $6^{\circ}$ and $7^{\circ}$, respectively) was found to be satisfactory for the reuse of the sensors.
\end{abstract}


Keywords: Enzymatic treatment, Chemical treatment, Cleaning protocol, Cellulose model films, Quartz crystal sensors.

\section{INTRODUCTION}

Cellulose is the most abundant natural, renewable, and biodegradable polymer, and it is synthesized by an enzymatic process. This polymer has been considered as an important raw material for many applications, e.g., in the production of secondgeneration alcohol. Studies of bio-processing enzymatic treatments of cellulosic raw materials are becoming more frequent. In those studies it is usual to use model surfaces made by cellulose films to evaluate physical-chemical phenomena (Edgar and Gray 2003; Fält et al. 2003; Tammelin et al. 2006; Habibi et al. 2007; Kontturi et al. 2008; Enarsson and Wågberg 2009).

Typical model surfaces consist of a small amount of chemically defined compounds that are deposited on a flat substrate (Kontturi et al. 2006). Three notable examples of cellulose-based model films are nanocrystals (Edgar and Gray 2003; Lefebvre and Gray 2005; Habibi et al. 2007; Turon et al. 2008), nanofibrillar cellulose (Ahola, 2008a,b; Aulin, 2009) and regenerated cellulose, the latter of which has been considered relative to its development (Gunnars et al. 2002 and 2003; Fält et al. 2004) and use (Silva et al. 2008a and 2008b; Enarsson and Wågberg 2009; Silva et al. 2009b and 2009c).

On the other hand, enzymes have recently become popular in cleaning products, as they are more environmentally-friendly and effective compared with various other components of detergent formulations. In some applications, e.g., dishes and cotton clothes, it is usual to find several cleaning detergents with some amount of lipase and cellulase enzymes in their compositions.

Gold sensors coated with ultra-thin cellulose films have been used for quartz crystal microgravimetry with energy dissipation (QCM-D) (Fält et al. 2003; Jeong 2006; Tammelin et al. 2006; Ahola et al. 2008a; Kontturi et al. 2008; Enarsson and 
Wågberg 2009) in adsorption studies, as well as cellulose films coated on silicon oxide substrates for atomic force microscopy (AFM), in X-ray photoelectron spectroscopy (XPS) (Edgar and Gray 2003; Lefebvre and Gray 2005; Habibi et al. 2007; Yokota et al. 2007), and cellulose on gold sensors for surface plasmon resonance (SPR) (Song 2008; Song et al. 2009). These are good examples of model surfaces that have been largely used in recent research related to surfaces.

Any complete study using quartz crystal microgravimetry to study cellulose surfaces will require several cellulose film coatings. This is because each trial requires a flat and uniform film having highly reproducible characteristics. This can increase the cost of the project considerably if each sensor surface is discarded after its use. Alternatively, to reuse the sensors it is necessary to remove the old cellulose film from their surfaces. In the literature there are two chemical treatments that have been considered with this aim in mind: an acid solution composed of sulfuric acid and hydrogen peroxide has been adopted by some authors (Tran et al. 2006; Ayres et al. 2007), and an ammoniac solution composed of ammonium and hydrogen peroxide has been also suggested by QCM-D manufacturers. The acid treatment uses an extremely strong and corrosive solution, and as such has to be handled in a cautious way. The ammoniac solution is not as strong as the acidic one. Although it is a general procedure recommended by the manufacturer to clean gold sensors, its efficiency in the removal of cellulose film is low. Frequently the residual fragments of cellulose film over the sensors have to be removed mechanically, with a risk of scratching the quartz crystal surface. Also someone has to spend considerable time to prepare fresh cleaning solutions. Both protocols place substantial time demands to finish the process. In this way, the reuse of these sensors has been a challenge for researchers.

Cellulase activities have been studied by using cellulose model films (Ahola et al. 2008b; Turon et al. 2008). Hydrolysis dynamics of the film at solid-liquid interfaces were clearly verified in real time by quartz crystal microgravimetry. This process proceeds by binding of the protein onto the cellulose model film surface, resulting in a decrease in vibrational frequency, and by simultaneous hydrolysis of the cellulose polymer in a reversible process with the frequency increasing, until reaching a plateau value. 
In work concerning interfacial phenomena on polymeric organic thin films, Jeong studied the effect of hydrolysis conditions on cellulose film degradation (Jeong, 2006). The effects of $\mathrm{pH}\left(4.5,7\right.$, and 10), temperature $\left(28,33\right.$, and $\left.38{ }^{\circ} \mathrm{C}\right)$ and enzyme concentration (0.00056, 0.00167 , and $0.005 \%$ ) on the enzymatic activity, which was verified by using quartz crystal microgravimetry with energy dissipation. The best enzyme activity condition was found to be at $\mathrm{pH} 4.5$, with the highest temperature, and the highest enzyme solution concentration. For each variable studied the author fixed the best conditions for the other two.

Model films from native and amorphous celluloses were used by Ahola et al. (2008b) to investigate the dynamics and activities of mixture of cellulase enzymes in real time at different temperatures, starting with 20 up to $40{ }^{\circ} \mathrm{C}$, and several cellulase solution concentrations, starting with $0.01 \%$ up to $0.5 \%$ (v/v) (Ahola et al. 2008b). They found that the enzymatic degradation of the cellulose nanofibril films was very fast for the whole range of temperature. As the authors expected, faster rates of cellulose degradation were found at higher temperatures. The effect of enzyme solution concentration on the kinetics and degradation of cellulose nanofibril films was studied at $40^{\circ} \mathrm{C}, \mathrm{pH} 5.0$, and $0.1 \mathrm{mM}$ ionic strength. The authors found that higher enzyme concentration did not dramatically increase the already fast degradation rate (Ahola et al. 2008b).

Based on the reported efficiency of enzyme activity to consume cellulosic materials, we suggest here an enzymatic protocol as a pretreatment step to remove cellulose from solid substrates. Therefore the main objective of this work is to propose an associated cleaning protocol, enzymatic, followed by a chemical treatment, to reuse sensors in a safe, convenient, and reproducible manner.

\section{EXPERIMENTAL}

\section{Materials}

A milli-Q unit was used as source of ultra pure water in all experiments. Sodium chloride was used as a supporting salt to adjust the ionic strength of the buffer solutions, 1 and $10 \mathrm{mM}$. $0.1 \mathrm{~N} \mathrm{HCl}$ was used to adjust the required $\mathrm{pH}, 4.5$. All inorganic chemicals used in this work were analytical grade.

Reuse of quartz gold crystal sensors coated with cellulose film 
For these experiments quartz gold crystal sensors coated with cellulose nanofilms after the polymer adsorption studies (Silva et al., 2009b) were selected (four for each salt concentration). Average contact angles of $16^{\circ} \pm 1$ and $22^{\circ} \pm 1$ were observed for 1 and $10 \mathrm{mM} \mathrm{NaCl}$ enzyme solutions on these surfaces, respectively.

Enzyme solution

A cellulase enzyme mixture from Aspergillus species, supplied by Sigma (Sigma C2605-50 mL, 095K0723), was used in this work for the enzymatic hydrolysis.

\section{Method}

Cellulose thin film preparation

Cellulose nanofilms that were used as surface models for polymer adsorption work with quartz crystal microgravimetry were prepared as described by Gunnars et al. (2002). The surfaces obtained after spin coating deposition consisted of flat, uniform and ultrathin films. The root mean square roughness of the dry model films were less than $5 \mathrm{~nm}$ as measured by tapping mode Atomic Force Microscopy (Figure 1), and the average contact angle measured after overnight drying in $43{ }^{\circ} \mathrm{C}$ under vacuum, was around $26^{\circ}$.

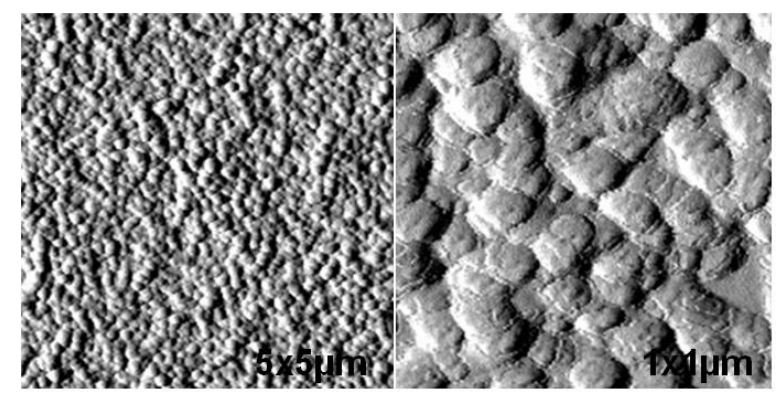

Figure 1 - Atomic force microscopy images of the cellulose film, $1 \times 1 \mu \mathrm{m}$ and $5 \times 5 \mu \mathrm{m}$ scan.

\section{Chemical treatment}

A hot ammoniac solution that is composed of $\mathrm{H}_{2} \mathrm{O}, 50 \% \mathrm{NH}_{4}$, and $25 \% \mathrm{H}_{2} \mathrm{O}_{2}$, with the ratio of 10:1:2, v/v/v, respectively that is recommended by the sensors supplier, $Q$ - 
Sense, Sweden, to clean gold quartz crystal sensors without cellulose film, was used. This solution demands a long time to remove the film from the sensors. Sometimes it was necessary to change the solution three times and to remove some persistent residual fragments mechanically and very carefully with a cotton swab to avoid damages on the sensor surface. It was usual to spend 2 hours for cleaning four sensors each time.

\section{Enzymatic followed by chemical treatment}

The new protocol involves the immersion of the used cellulose-coated sensors in an enzymatic solution $(0.01 \% \mathrm{v} / \mathrm{v})$ under controlled conditions of $\mathrm{pH}$, temperature and time of $4.5,45^{\circ} \mathrm{C}$ and $80 \mathrm{~min}$, respectively. Two salt concentration solutions were studied, 1 and $10 \mathrm{mM} \mathrm{NaCl}$. After this pretreatment, the sensors were submitted to an ultrasonic bath and washed, followed by an immersion an ammoniac solution during a short period of time (15 min), as suggested by the sensor vendor, Q-Sense. Based on the literature results (Jeong, 2006; Ahola et al. 2008b), the conditions of pH (4.5), temperature $\left(45^{\circ} \mathrm{C}\right)$ and enzyme solution concentration $(0.01 \%)$ were adopted in the present study. An oven set at $45{ }^{\circ} \mathrm{C}$ was used for the enzymatic treatment experiments. The ultrasonic bath step for $20 \mathrm{~min}$ was an important one since it helped to release the fragments of the film. After the ammoniac treatment, the sensors were washed with milli-Q water and dried with nitrogen gas. The sensors used to prepare new cellulose films were submitted to UV-ozone treatment for $15 \mathrm{~min}$ before use.

\section{Contact angle measurement}

A contact angle goniometer with a water drop probe was used to measure the contact angle of the sensor surfaces. The contact angle was the average of the measurements in both sides.

\section{RESULTS AND DISCUSSION}

Figure 2 shows the contact angle curves as a function of time for the proposed treatment in both conditions $1 \mathrm{mM}$ and $10 \mathrm{mM}[\mathrm{NaCl}]$. In this Figure $t_{1}$ indicates the 
time for the proposed treatment, that is, sensor immersed in enzymatic solution for $80 \mathrm{~min}$, and $t_{2}$ indicates $15 \mathrm{~min}$ for the sensor immersed in ammoniac solution. The symbol $(\square)$ in Figure 2 represents the application of $1 \mathrm{mM}$ of the salt, whereas $(x)$ represents the use of $10 \mathrm{mM}$ salt.

In order to control the cleaning procedure for quartz crystals, we have employed the criterion of contact angle of the cleaned quartz crystal gold sensors to be between $4^{\circ}$ and $6^{\circ}$, when applying ammoniac treatment only. Higher contact angle results were found in the present work for both conditions by using enzymatic treatment followed by ammoniac treatment, $6^{\circ}$ and $7^{\circ}$, for $1 \mathrm{mM}$ and $10 \mathrm{mM} \mathrm{NaCl}$, respectively. When the sensors were reused several times, the surfaces could become more hydrophobic, and some damage or scratching could be observed because of use.

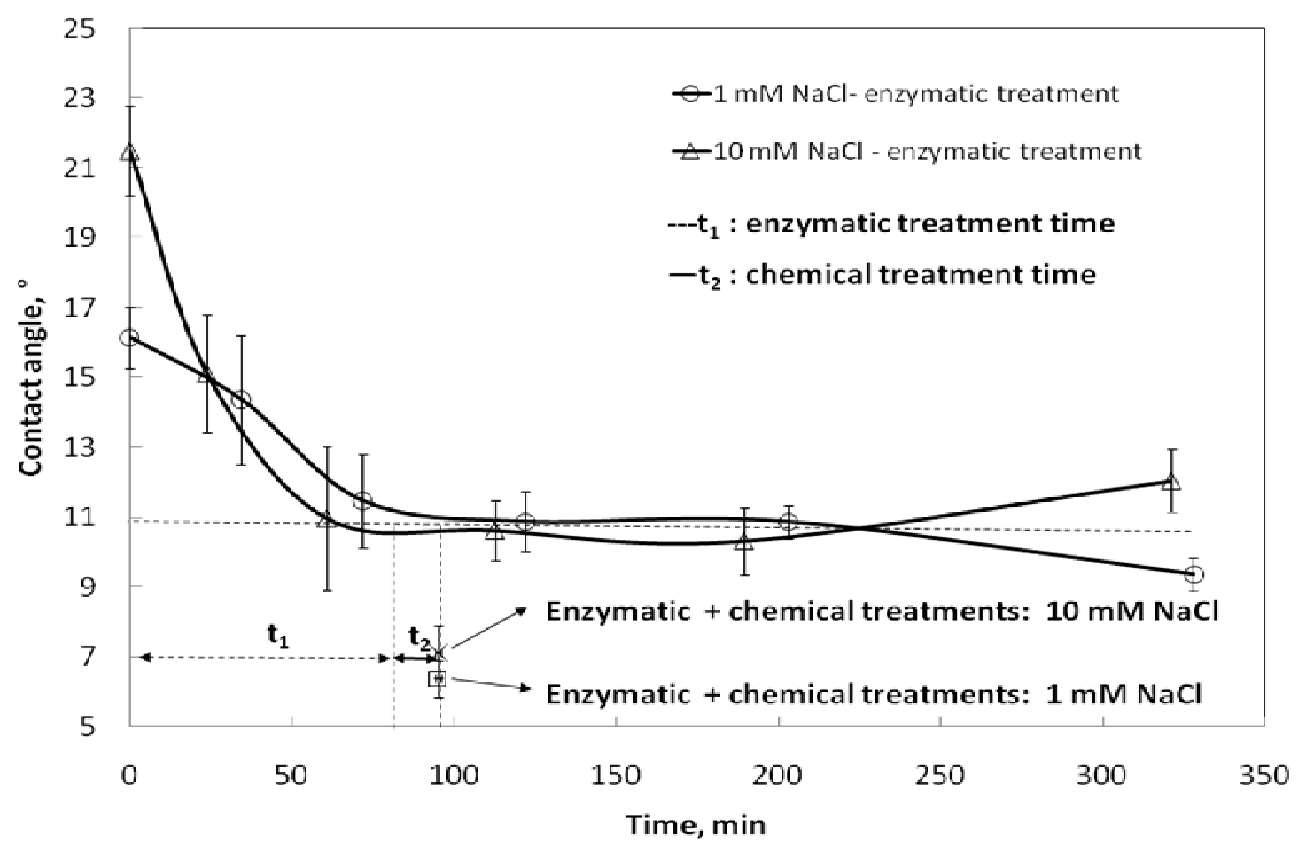

Figure 2 - Effect of enzymatic treatment on the contact angle of the cellulose coated-gold sensor surfaces with time incubation.

Figure 2 shows that with the enzymatic treatment it was possible to clean the sensors, as indicated by relatively low and stable contact angles. For the two $\mathrm{NaCl}$ concentrations and different starting contact angles at least 80 min were necessary to reach the lowest contact angles with the enzymatic treatment (around $11{ }^{\circ}$ ). This result was close to that found by Jeong in his studies of enzyme activity in 
regenerated cellulose film by using QCM-D at $\mathrm{pH} 4.5,38{ }^{\circ} \mathrm{C}$, and $0.005 \%$ enzyme solution concentration (Jeong 2006). On the other hand, the time found in this work was higher than that found by Ahola et al. (2008b) for nanofibril cellulose films, which was less than five minutes (Ahola et al. 2008b). These authors used a different cellulase solution mixture from that used in the present work, NS50013 cellulase complex from Novozymes (Celluclast ${ }^{\mathrm{TM}}$ ).

The proposed cleaning treatment resulted in sensor surfaces with a slightly higher water contact angle compared to that after ammoniac treatment only, $6^{\circ}-7^{\circ}$, vs. $4^{\circ}-6$ $\circ$, respectively. However, this enzymatic pretreatment followed by short time ammoniac treatment was found to be good enough for cleaning and reusing the sensors for the preparation of cellulose films suitable for the study of adsorption, degradation, and related effects.

\section{CONCLUSIONS}

In this study an enzymatic application has been proposed as a pretreatment step to a chemical treatment to remove cellulose thin films from surface sensors. According to the results obtained, the following conclusions can be drawn:

(1) The proposed enzymatic treatment was safer and placed less demand on researcher time when compared with the time required for use of ammonic solution alone;

(2) There was no significant difference between the final contact angle results for the two $\mathrm{NaCl}$ solutions employed after the enzymatic hydrolyses have reached plateau, $6^{\circ}(1 \mathrm{mM})$, and $7^{\circ}(10 \mathrm{mM})$;

(3) The combination of two treatments, enzymatic and chemical, was found to be a safe and useful protocol to clean cellulose film sensors for purpose of their reuse. Also, the combined protocol reduces the risk of damaging the sensor surfaces and increases the expected number of times that they can be reused. 


\section{ACKNOWLEDGEMENTS}

\section{The financial support of CAPES, Brazilian Ministry of Education agency for graduate studies and the major scholarships, is acknowledged. The authors also would like to express their thanks to Xiaomeng for her assistance in AFM imaging.}

\section{REFERENCES}

Ahola S, Österberg M, Laine J (2008a) Cellulose nanofibrils_adsorption with poly(amideamine) epichlorohydrin studied by QCM-D and application as a paper strength additive. Cellulose 15:303-314.

Ahola S, Turon X, Österberg M, Laine J, Rojas OJ (2008b) Enzymatic hydrolysis of native cellulose nanofibrils and other cellulose model films: Effect of surface structure. Langmuir 24:11592-11599.

Aulin C, Ahola S, Josefsson P, Nishino Y, Hirose Y, Österberg M, Wågberg L (2009) Nanoscale cellulose films with different crystallinities and mesostructures-Their surface properties and interaction with water. Langmuir 25: 7675-7685.

Ayres N, Cyrus CD, Brittain WJ (2007) Stimuli-responsive surfaces using polyampholyte polymer brushes prepared via atom transfer radical polymerization. Langmuir 23:3744-3749.

Edgar CD, Gray DG (2003) Smooth model cellulose I surfaces from nanocrystal suspensions. Cellulose 10:299-306.

Enarsson L-E, Wågberg L (2009) Polyelectrolyte adsorption on thin cellulose films studied with reflectometry and Quartz Crystal Microgravimetry with dissipation. Biomacromolecules 10:134-141.

Fält S, Wågberg L, Vesterlind E-L (2003) Swelling of model films of cellulose having different charge densities and comparison to the swelling behavior of corresponding fibers. Langmuir 19:7895-7903.

Fält S, Wågberg L, Vesterlind E-L, Larsson PT (2004) Model films of cellulose II - Improved preparation method and characterization of the cellulose film. Cellulose 11:151-162.

Gunnars S, Wågberg L, Cohen Stuart MA (2002) Model films of cellulose: I. Method development and initial results. Cellulose 9:239-249.

Gunnars S, Wågberg L, Cohen Stuart MA (2003) Model films of cellulose: I. Method development and initial results. Cellulose 10:185.

Habibi Y, Foulon L, Aguié-Béghin V, Molinari M, Douillard R (2007) Langmuir-Blodgett films of cellulose nanocrystals: Preparation and characterization. Journal of Colloid and Interface Science 316:388-397.

Jeong C (2006) Interfacial phenomena on polymeric thin films. Dissertation, North Carolina State University.

Kontturi E, Tammelin T, Österberg M (2006) Cellulose-model films and the fundamental approach. Chem. Soc. Rev. 35:1287-1304.

Kontturi KS, Tammelin T, Johansson L-S, Stenius P (2008) Adsorption of cationic starch on cellulose studied by QCM-D. Langmuir 24:4743-4749.

Lefebvre J, Gray DG (2005) AFM of adsorbed polyelectrolytes on cellulose I surfaces spin-coated on silicon wafers. Cellulose 12:127-134.

Silva DJ, Hubbe MA, Park SW, Rojas OJ (2008a) Adsorption and viscoelastic properties of polyampholytes monitored by QCM-D. In: $\underline{\text { }}$ Congreso Iberoamericano de Investigacion en Celulosa y Papel. Guadalajara, JL, Mexico, October 20 - 23.

Silva DJ, Rojas OJ, Hubbe MA, Park SW (2008b) Dynamics of polyampholyte adsorption on cellulose nanofilms. In: VII Annual Meeting of the Brazilian Materials Research Society (SBPMat). Guarujá, SP, Brazil, September 28 - October 2.

Silva DJ, Rojas OJ, Hubbe MA, Park SW (2009c) Adsorption behavior of dry-strength polyampholytes as a function of solution pH. In: 42nd Pulp and Paper International Congress \& Exposition. Sao Paulo, SP, Brazil, October 26 - 29. Accepted.

Silva DJ, Rojas OJ, Park SW, Hubbe MA (2009b) Evaluation of adsorbed polyampholyte layers by using Quartz Crystal Microbalance In: 10th International Symposium on Process Systems Engineering - PSE2009. Salvador, BA, August, 16-20.

Song J (2008) Adsorption of amphoteric and nonionic polymers on organic thin films, Dissertation, North Carolina State University.

Song J, Liang J, Krause WE, Hinestroza JP, Rojas OJ (2009) Development and characterization of thin polymer films relevant to fiber processing. Thin Solid Films 517:4348-4354.

Tammelin T, Saarinen T, Österberg M, Laine J (2006) Preparation of Langmuir/Blodgett-cellulose surfaces by using horizontal dipping procedure. Application for polyelectrolyte adsorption studies performed with QCM-D. Cellulose 13:519-535.

Tran Y, Perrin P, Deroo S, Lafuma F (2006) Adsorption of randomly annealed polyampholytes at the silica-water interface. Langmuir 22:7543-7551.

Turon X, Rojas OJ, Deinhammer RS (2008) Enzymatic kinetics of cellulose hydrolysis: A QCM-D study. Langmuir 24:3880-3887.

Yokota S, Kitaoka T, Wariishi H (2007) Surface morphology of cellulose films prepared by spin coating on silicon oxide substrates pretreated with cationic polyelectrolyte. Applied Surface Science 253:4208-4214. 


\title{
Effect of Charge Asymmetry on Adsorption and Phase Separation of Polyamplolytes on Silica and Cellulose Surfaces
}

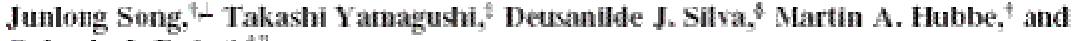 \\ Orlando J. Rojas

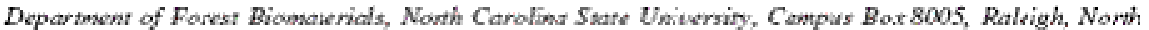

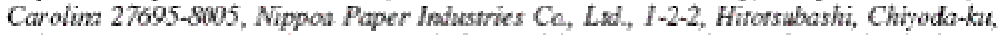

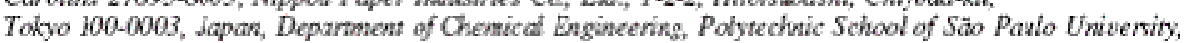

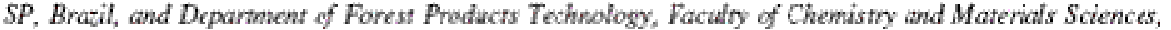

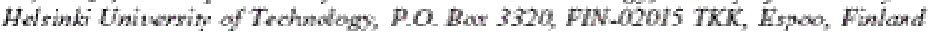

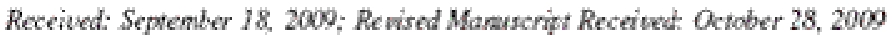

The relution bewwen the properties of polyampholytes in aqueous solution and heir adsomtion behariors on silce and cellulose surfaces was investigaled. Four polyanpholytes curying different charge densties but with the same nominal ratio of positwe to negative sesmens and twe structurally similar polyelectrolytes fa polycid and a polybase) were mvestigated by ung quat crysta microgravinetry using silica-costed and cellulos-coated cuartz rescolator. Time-resolved moss and rigidity (or viscoelasticity) of the adsorbad layer was dermined from the shifts in frepuency $(\Delta)$ and energy dissipation $(\Delta D)$ of the respective resonator. Therefore, elucidition of the dymamies and erant of adsorption, as well as the conformational changs of the adsobed macromblecules, were possible. The charge properties of the sodid surace played a crtcia role in the adsorption of the sudied polyampholytes, which was explained by the capability of the suffice to polarize the polympholyte at the interface. Under the sane experineniat conditions, the polyanpholytes had a higher nominal charge density phice-separaled near the interfse, profucing a sof, disipative, and loosely bound layer, in the case of cellulose substrates, whew sdoorption was timited, electrosiatic and polarization effects were concluded to be less sonificut.

\section{Introduction}

Polyamphobten are clarged macromolecules camying both

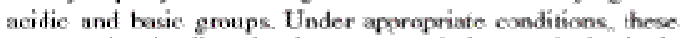
maromolouks dissociac in aqueous solution, poduciag inic groups on the polymer ctains and the regective cotnicricas in solution. If the jonke groups on the polymer chain are weul axids or busen then the net ehage of the polyompholyte can be thanged by vaying be $\mathrm{pH}$ of the aque ous medium. Close to the iscelectio pH, they crhibir a small net chyge and diplug

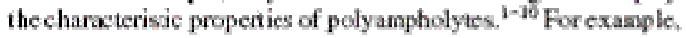
the deges of cxuension of polyamplolyes clowe to the chargebalanced state tends to increase with increasing salt concentrution. At the ise loctic $\mathrm{pF}_{\text {the }}$ thounts of positve and negutive chinges on the polyion are bulaned (chape symetry), giving a nat charge of zero. However, under sonditions of $\mathrm{pH}$ where thece is high charge isymmetry iwell above or below the isodectrie point), polyampholytes thehave similarly to simple polvelectrolytes.

Due to the mique properties of polyanphotytes, they have foud pomise in applications involving weting. Lubrestion, adtesion, and ather phenomena ${ }^{\mathrm{B}-\mathrm{B}}$ Polyampholytes are used to control the colloidal statility of dispersions in wadowator

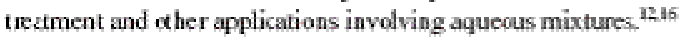

\footnotetext{
" Corresponding suthor. Te: +1-919-513-7404 For +1-919-5156902

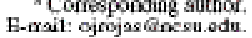
"North Carolna State Unversiby

"Nippos Paper industries Ca. L

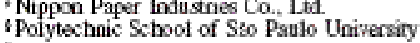

Halidi Bnimasity of Tehnotogy.

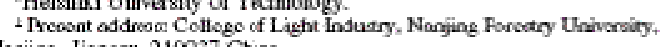
Narjing. Jiangsu, 210037 Chns
}

It has boendenenstracd that polyampholytes powide superior streng h improwenent for paper manufacture, compared to the dution of simple pelyclotwolyies, ${ }^{14,34,77-5}$ Finally, synthetic

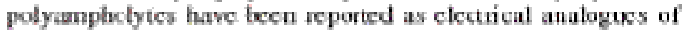
preaiss. 12 Therefor, understarding the behavior of polyampholytes with defind charge balance and stucture can be expected to abo shed ligh on bumacromoleculur adorption st interfaces:

There is a ned for chawedetizing polyampholyts adorption thas will bad io aew finctional materiale and perfermance Despite the existence of several theoretical and computational reports on their behavios at solid interfaces, $2,867902-25$ experimental dat to enticatly test the proposed theories and te directly allow the clucidation of the complex polyampholyte adorption ane sill lacking $16: 97$

Several methods are availatite to study polymer adoorption on phanas surfaces. These inelude radio lateling ${ }^{2 \pi}$ reflectance

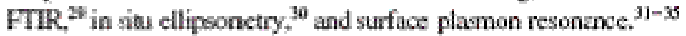

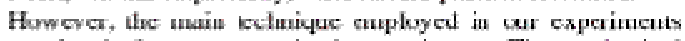
consistod if quatz orysal micograinetry. The meshanical oscillatoly nature of quatiz resonitors enabled the medsurement of unique propentics such as the viscoelaticity of atsoted polymer fayers, in addition to the mass uptake on the solid surfase ${ }^{3-1}$ -

A series of experiments wit3 synthetic, random polyampholyca huing increasing bol nominal ctarge densitics (at a constant ratio of cationic to anteric monomeric groups and molocular muss) wos conducted. Silica and cellulose anying neqative electrostatic charges (but with ifffent densitis) were used as substrates for adsorption. The effect of the $\mathrm{pH}$ of the adsothing polymer solution fand thus the polymer charge 


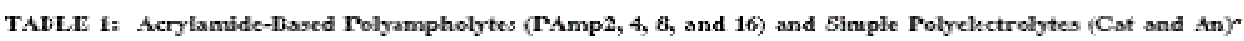

\begin{tabular}{|c|c|c|c|c|c|c|c|}
\hline sample & polyner type & $\begin{array}{c}\text { cationic } \\
\text { goups (mol } \% \text { ) }\end{array}$ & $\begin{array}{c}\text { caticnic } \\
\text { groups, WhR (not b) }\end{array}$ & $\begin{array}{l}\text { arionic groups } \\
\text { (mol \$) }\end{array}$ & $\begin{array}{l}\text { anionic grcups, } \\
\text { NMR foul t) }\end{array}$ & Vinouity (wPses) & $M_{*}^{2}\left(10^{6} \mathrm{Dn}\right)$ \\
\hline DAnp2 & Imphotionis & 25 & 2.6 & 2 & 2.4 & 5300 & 2.05 \\
\hline Phngt & amphoteric & 5 & 5 & 4 & 44 & 4900 & 285 \\
\hline PAnpl 6 & amphoteric & 20 & 18 & 16 & 168 & 2100 & 2.93 \\
\hline Cat & cotonis & 5 & 5 & 0 & $(1.2)$ & 3600 & 2.98 \\
\hline$A_{n}$ & anishic & 0.5 & 05 & 4 & 3.6 & 530 & 3.23 \\
\hline
\end{tabular}

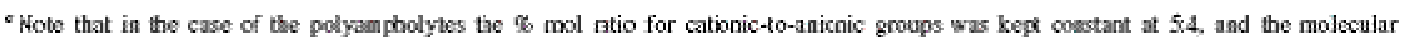

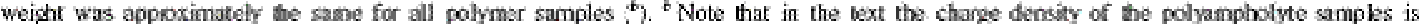

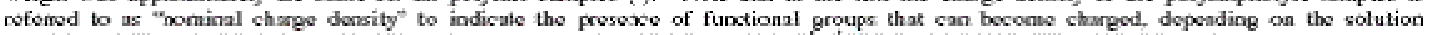

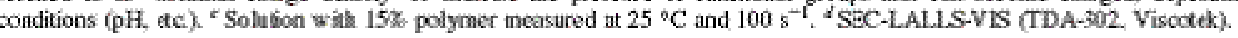

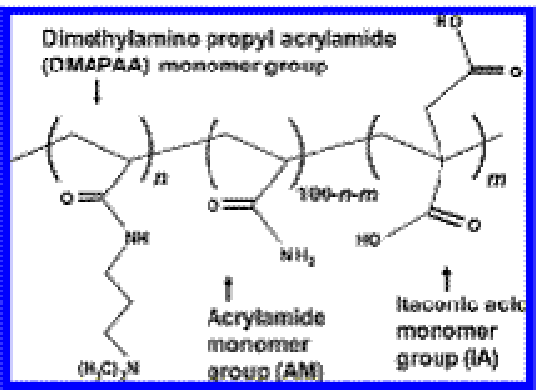

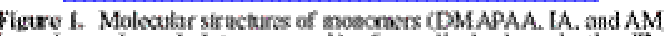

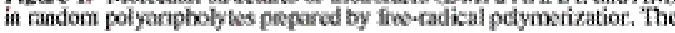

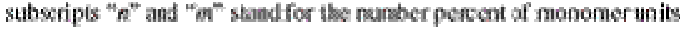
in fandon positions.

asymetry) on the dynmics and extent of adsorption was

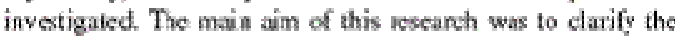
relationship berween the charged nature of the polymers and the adsorption and conformation of the respecive adscrbed fayers, An additional quexion to be clucidaled was whe the the rolationship between the bulk and the starfae behavior of polyampholytes is eomporible to these of mestwi polymes an well as simple polyelectrolyles.

\section{Exprimental Section}

Polyampholytes and Simple Polydectrdytes. Polyampholyte and polyclotrolyte sanples were pxpared by fresradicgl polymerization, giving a final contest of chaged monomers as findicased in Tahie I. A mepresentarive subucture of the random, amphoteric terpolymers used is thown in Figure 1. Txir pepartion and chasseterization was adressed in detail in ref 20 . The cationic monomer was $N-\left[3-\left(N, N^{2}\right.\right.$-dimelhylumimolfropyllacrylanide (DMAPAA) a tertiary amine. The anonic monomer was a dicarbox ylic acid, methylene batanedione nad abo known as itwonie sid (IA) in cach cros, the babne ancunt of neutral acrilanide (AM) monomer was added to comprise $100 \%$ on a molar beasis. The percentages of each monmer and molecular weight for the four polyampholytes and the cationic and aniosic sarples along with expenimstal values obtoned vin MMR are summarised in Table 1, which also lists other physical characterishics. All the polymers were expects to be andon with $\mathrm{g} g \mathrm{gnd}$ to the distribution of differen mowners in the mucromulecular stucture, but no attempl was made os contim this chameserisuc.

Irorganic ctenicals, inchuding tydrochlonic acid, sodum hydroxide, solium chloride, and sodrum rulfate were of reagent grade and acquired fron Aldrich All experiments were performed whth deionizod wake from an ion-exhange system (Purellow, his,) folluwed by a Milli-Q Gadital unt (esistivity $318 \mathrm{MO})$

The $\mathrm{pH}$ at the isoeketrid point (IEP) for PAmp 16 was found to be 7.3 at $10 \mathrm{mM}$ all conceatration. as determined by polyelectrolye titration with polyvinyl sulfofe (potissium salt) to a neutral straming current ond point using a Muick PCD04 charge indyzer trom BTG. The IEPs fer the other polyamphatyte simples (PAmp 2, 4, 8) were all cloce ti neitmi $\mathrm{pH}$. Solution visedsittes wew obteind with a Bookficld twodel BBL visometer (Tokimes, ins) at appoximudily is\% solids at 25 ${ }^{\circ} \mathrm{C}$. Molecular weigh was obened wia multiangle light seat-

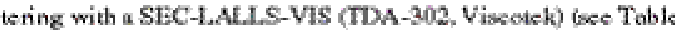
1).

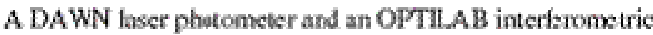
refractonder of $\mathrm{W}_{y}$ all Technology Corporation were employed ta mensure the radius of swnticn of PAmpt under three conditions of $\mathrm{pH}(4,7$, and 10 . These aside, neutrul, and basic condtions wew used bo podow Zimm poss from the static

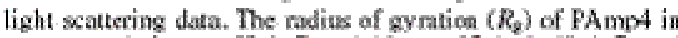
aqteots solution at pH 4,7 , and 10 was $55 \pm 6,69 \pm 7$, and $182 \pm 36$ am, respectively. The bydrodynamie diameicr and tubidity of the polyner wh the highs charge densily.

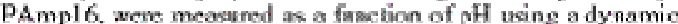
light wathring sysem (Beckman Couller N4 Plus) with a 10 mW Helium-Neon laser $(\lambda=632.8 \mathrm{~nm}$ ) a a light source. The measurements were performed an a PAmpl6 concentration of $336 \mathrm{mg} / \mathrm{L}$ in $10 \mathrm{mM} \mathrm{NaCl}$ solution. A rwaximum in the hydrodynamic rodius was cbseved at around the IEP, while the tubidity reached nelorive axima at values of pH slightly below or abowe the 1EP. This cculd be interpreted as being due to the asspeiation ketween marpmolecules that fomed aggregates with the pH zpprouching the IFP sine the electrostatic repulion is expected in be limicd at this point. Farfrom the IEP and because of the attraction by local positive ane negative groups, the polyanpholyte molosules coniracted and asembled into coils, Also, the viscosity of the polyner solutions decreased with incrensed polymer change density, as obsered from visosity data reported in Table 1 , which is consisten: with the charcenterie tendency of polympholytes w contract when they are less charged.

The relation between pH and the macronolecular size was consistent with the theoretical work of several authors, who indiented that polyampholytes contract inv colled conformations in the vicirity of their IEP but expand ty the effect of the charge asymmetry at extreme $\mathrm{pH}$ conditions 1,722

Siliea and Cellulose Substrates. The sthestrates used in this investigation consisted of $\mathrm{AT}$-cul quartz sensors couted with gold (fundmental frequescy of $5 \mathrm{MHz}$ ) for use in a quartz arystal microgravimetry These sensors were also coated with 


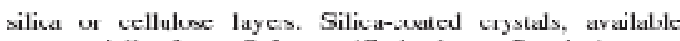
commercially from Q-Sense (Gohenturg, Sweden), were clened by imnersion in $2 \%$ sodiun dodecyl sulfate solution for at least $30 \mathrm{~min}$, follewed by double rinsizg with Mili-Q grade water and drying with nitroger. Jus before use, the silicacoxted crystals were treated with UV-ozone for $10 \mathrm{~min}$ to oxidize impunites and to zetivate silnol grours on the sufface. The type and magnitude of the charges on the silica sufaces depended on heir condtioning, the $\mathrm{pH}$ of the sumounding aqusus medium, and the backgrund electrolyte (type and conventration) For example, Radtchenko et al detemined a chace density of colloidal silica probes of -0.4 and $-2 \mathrm{mC}$ $\mathrm{m}^{2}$ at $\mathrm{pH} 4$ and 9.5 , respectively, by using AFM force mesurements against flat silica ${ }^{40}$

Cellulose thin films were prodused from microcrystalline cellowse (Avicel purhased from Fsher). The films were spin couted from NMMO solution on the silica-coeied sensors The prodocd followed in the nanufacture of the cellulose films, and their quality has been addressed in detsil elsewhere ${ }^{41-43}$ Conparatively, the ehares density of oellulsse is mueh bwer than that of silica. ${ }^{4 \$ 4,45}$ For example, surface darges of -0.21 and $-0.80 \mathrm{mC} / \mathrm{m}^{2}$ at $\mathrm{pH} 4$ and 9.5 , respectively, were obtined by fitting AFM force profiles to the DLVO equation in the case

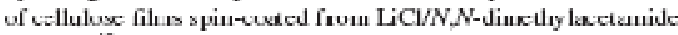
solution. 40

Quartz Crystal Microbala nce Measuremnts Adsopxion experiments with the polyamp holytes and the simple polyelectwotes were conducted o a quartz cryal micwbalane (OCM) witi dissipution monitoring, QCM-D Q300 nodel (Q-Sense, Gothenturg, Sweden), while experiments on the effect of $\mathrm{pH}$ on adsorption were conducted with a QCM-D E4 model (QSerse, Gothenburg, Sweden) run under eontinusus flow oon figuration. The principles of this tecinique can be found in refs 38,39 , and 46 . In the case of adsorbed rigid layers, the Sausbrey equation that relates the change in the mass of the senor $(\Delta m)$ and the recorded change in its oscillation frequency ( $\Delta f$ can be applied

$$
\Delta m=c \frac{\Delta f_{n}}{n}
$$

where $n$ is the overtone number $(n=1,3,5$, nd 7$)$ and $a$ is a contant representing the mass senitivity as $5 \mathrm{MHz}$. For the used crystals the mass sensitivity is $-0.177 \mathrm{mg} \mathrm{m}^{-1} \mathrm{~Hz}^{-1}$. The energy disipation $D$ in $Q C M$-D measuments is inversely propotional to the cosillating decay time constant $\tau$ of the cystal and can be cakulated aceording to ${ }^{3}$

$$
D=\frac{1}{\pi f \tau}
$$

where $\mathrm{x}$ is obtained by periodically disconnecting the oseilating cryal from the driver circuit via a computereontrolled relay during which the amplitude of the erystal oscillation decays exponentially in time. The crystals were mourted in a thermostatied liquid chamber, cesigned to provide a rapid, nonperturting excharge of the iquid in contact with the active side of the sensor.

In a typical experiment, the QCM adsorption module and mounted sensor were lat to sabilize with a backgound electrolyte solution $(0.1 \mathrm{mM} \mathrm{NaCl}$, unless stated otherwise), which was injected contnuously a a flow rate of $0.12 \mathrm{~mL}$ min. The constant $f$ and $D$ signals were offset to zero frequency and dissipation, which were then nonitored for an additional 10 min to obtain the experimental baseline. Thereafter, one milliliter of freshly prepared polymer solution $(0.1 \mu \mathrm{g} / \mathrm{L}$

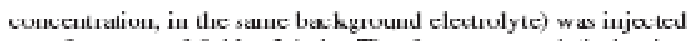
at a flow rate of $0.12 \mathrm{~mL} / \mathrm{min}$. The frequency and dissipation were montored until constant walues were reached. Following. a $3 \mathrm{~mL}$ buffer solution was used to rinse the adsorbed layer at the same flow rate. The system employed allowed for the measurement of up to four barmonics. In this study, the frequency and dissipation responses were recorded at ca. 15 , 25 , and $35 \mathrm{MHz}$, corresponding to the thid, fifth, and seventh overtones ( $n=3,5$, and 7 , wespectively). Dnly the normalized frequency and the disipation shifts ( $\Delta f / n$ and $\Delta D$, respectively), corresponting to the third overtone $\left(\Delta f / 3\right.$ and $\left.\Delta D_{2}\right)$, are presented in the discussion below.

It should be noted that the Sauerbey reation does not apply to viscoelastic or sof adlayers since they nay not fully couple with the motion of the sensor; i.e, the frequency change can he affertet hy the merhanisal properties of the film including the shear nodulus and viscosity. In such zases, the Sauerbrey equation tends to underestimate the cclculated nass, and therefore viscoelastie models anch as that of Voigt ${ }^{\text {-47 }}$ have been rewommended. Here the viweolastio fystem is anneptual ized as a spring ard dashpol corresponding to the clastic (storage) and inelastiv (damping) behaviou of the makrial. The energy losses (dissipution $D$ ) and the shift in frequency for the different svertures wese therefue sulleted and fited is the film viscosity, shear modulus, thickness, and density of the adsorted layer using QTools scftware (Q-Sense). More details on this approach can be found elsewhere. ${ }^{7,43}$

\section{Results and Discusion}

Polyampholyte Adsorption on Silica Surfaces. Dynamics

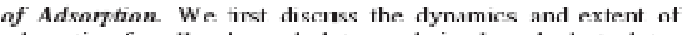
adsorption for all polyampholytes and simple polyelectrolytes at a $\mathrm{pH}$ of 7 (which is close to the IEF for the amphoteric polymers) with focus on the effect of the nominal change density of the macromolecules. In later sections, wa introduce the effect of $\mathrm{pH}$ of the adsorbing polyelectrolyte sclution on the extent of adsorption and adsurbed layer viscoelasticity. Figure 2 shows the QCM profiles corresponding to the acsorption of polyampholytes PAmp2, PAmp4, PArp8, and PAmpl6 as well as the simple polyclectrolykes "Car" and "An" on silica at a solution $\mathrm{pH}$ of 7 . The genera features of the $\Delta f$ curve as a function of

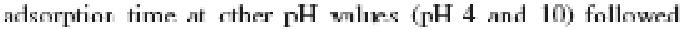
similar trends and are not presented here for brevity.

At first, when the polymers vere injected into the sdsorption unit, the molecules adsobed rapidly on the silica surface, presumably driven by net entropy grun in the gyatem when the counterions in the polymer and the surface were relessed, upon adsorption. In this initial stage, all the polyners exhibited similar adsorption rates (similar slopes in the $\Delta f-t$ curves during the first sceonds). Following the initial, fast adsorption, a slower adsorption dynamics was observed for the polyampiolytes of higher nominal charge density (PAmp8 and PAmp15).

It was observed that the polpmers carrying higher nominal charge density were adsuted in larger amounts. In other words, they adsobed in the form of layers that effectively reduced the resonance frequency of the sensor. This is in contrat with the behavior of simple polyelectrolytes that adsorbed on oppositely charged surfaces to a kesser extent wih increased charge density ${ }^{50-52}$ In fact, distinctive differences in the extent and dynamics of adsorption of polympholytes and single polyelectrolytes were observed, as shown in Figuz 2.

Interestingly, the smple eationic polyelectrolyte Cut reached a (relatively small) fequency plateau much faster than any of the other adsorbing polymers. Futhemore, there was in obvicus 
722 J. Phys. Chem B, Wol 114, N. 2, 2010

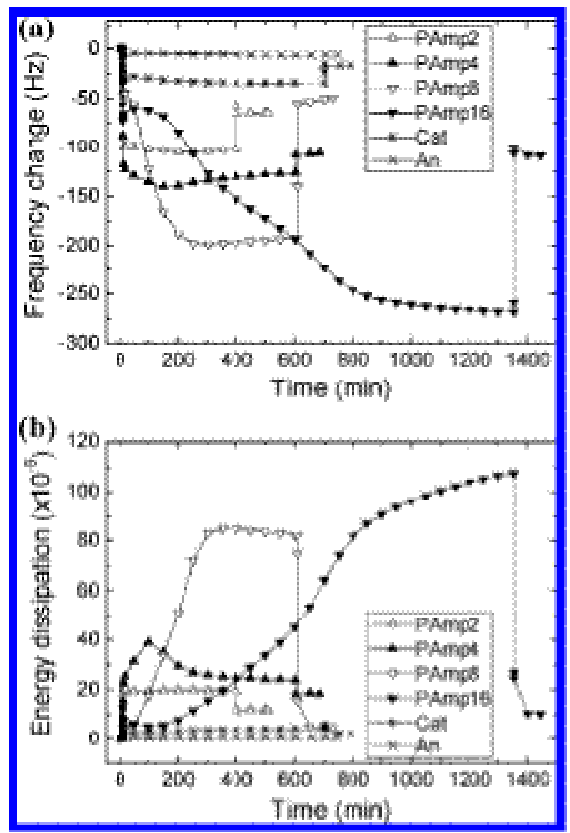

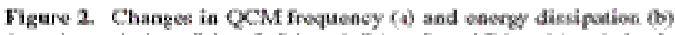

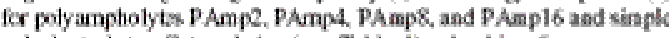

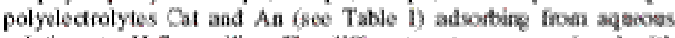

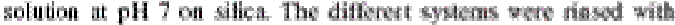

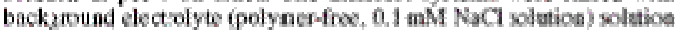

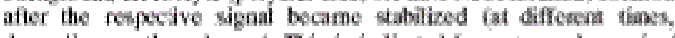

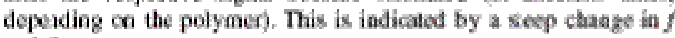
and $D$.

difference between the nominal low and high tharge dewity polympholycs: in the tint cuse PAnp2 and PAmpli, a maxmun adsuption was reached relatively faster with woly small frequeney shifis after reaching a plate au value, However, for tae bighly charged polymplotytes (PAmp 8 and PArapl6) consant frequency was reached only after a logg time in the case of PAmpi 6 , extrm:ly long times, of oner $20 \mathrm{~b}$, were requined for the frequency to haoms constant. It is nooposed that this phenomenon in causcd by slow acounulution and conimmational changes of the polyanpholyte a the interface. This hypothesis is also supported by observing the changes in

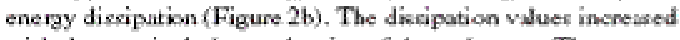
with the nominal charge density of the polymes. The energy discipat ion for adsobing polyanpholyts PAmp3 and PAmpl6 was much lager than for polyamptodytes PAmp2 and PAnp4. Thez won atse laser than for the smple polyclockolytex. If one akes a larger dissipation value as an indieation of a thicker, softer hyer, the dissipution asults wen therofore conidient with the fomation of a highly dissipative layer.

The experiments presend in Figuc 2 include a risaing step with excess bakground eketrolyte solutions that were effective in removing excess (loosely adsuted) polymers from the intef foce. As a nesult, a seond "platen" fropueny was reached after rinsing, ard it was taken as indicative of the effective for incursible) anount of polymer adsorbed.

The dissipation vidues for all the polyamphohtes wene very high. For rigid, ultrathin, and evenly istributed alsouted lavers, the Banertrey squation describes a proportional relationship between the adsorbed mass $(\Delta m)$ and the shifit of the $\mathrm{QCM}$ crysals" resonence fropuncy ( $\Delta f)$. On the other hand. if the
Song et al.

usoubed material exhbits a viscelastir behavior, such as for hyers of proteins or DNA, substantial deriations from the Suerbrey equation are expected to ocur. $3,34,30,50,54$ Our results fall is the laner caregory. Dissipation values ater polyampholyte

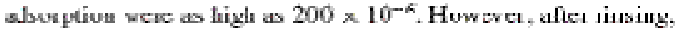
a shap drop in dissipation was always observed, indicative of extensive rmoval of loosely bound molecules, especally in the cise of PAmps and PAmpl6.

Bocause the Sauerbrey approximation could not be ipplied Gr accurate cakulation of the adsched mass, we used th: Voigt model to calculate the thickness and mass of the adsorbed layers (for both polympholyes und polyelectrolytes). The proedure for fitting the esperimental data to this mocel is described in inf 47. 15 Figure 3 , the thitknesses of low (PAmp2) and tight (PAmp8) tharge density polyampholytes are piesented to

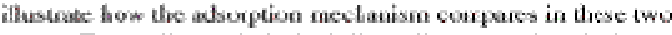
coses. The solid and dashed lines illustrate the thekness colulated by the Saurtrey and the Voigt madel, respertively. Even with a ks drsipdive adsoted layer such as that podwed by PAinp2, the Sauctery value way only half of the Voigt thickness. For swollen adsabed polymer layers, such as that

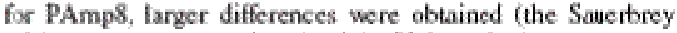
thickness whe ene fouth of the Voigt value).

Al pH 7 ias well as at the other values of solution $\mathrm{pH} \mathrm{H}_{4}$ the sarfoce was incgatively charged sine the IEP for silica is close to $\mathrm{pH}$ 2. Thus it is apected that the catimic groups were

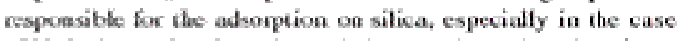
of high chase detesity polyamphelyes and smple polycations. It can be hoothesized that negtive groups of the plyampholyes cas be enirthed on the side fasing the bulk solution. In tum, these negative grotps could interact with available catopic grougs in neightoning polymers, giviug nise to in further storption phase separation or microprecipiation close to the sarface. It is worth noing that tubidity meastrements did not Heal deicedible changes in light transmissice when any of the polymer solutions were tested (at the sane coneentration and

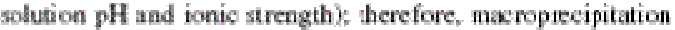
can be niled out in all ases. Interestingly, frem Figue J (right) tho different events centring in the case of PAmp3 adsorption cas beobneved: a rolaively fast adsonxion time kess than 100 min) that is followed by a very tow mass buifup (rewhing ca. $100 \mathrm{~nm}$ Voigt thictncsses). However, the extra amount of polymer that ascunulated in the second phase was ringed off rather quickly asd effotively, and the residua muse after rinsing was similas to that observed ai the end of the first adsarption plase fwith a ea. $10 \mathrm{~nm}$ Voigt thickness ${ }^{\mathrm{r}}$. Therefore, it is bypotherized that the initial adsorbed layer was dense, and because of excess electrostatio ehages the inithal adsotted layer was able to interact with ofter polyamphotyte molecules in solubion, thereby producing a phase separatian or mieroprecipitation with bosely bound moleveses. These observations are in stribing contrast with the behavior of simple polyelectrolytes and also with polyanpholytes with lower charge denaty, for example, PAmp2 (Figure 3, kft) and PAmpt that showed an adsorption hinetics that was quite fast, with ne phase sepuration, as described ahowe

Is passing, we note that changes of the solution bulk tensity na viscosity before and after rinsing are expected to contribute to a shift in frequency, however, this change was calculated to be small for the bo polymer concentrations used in our expenimeats. Therefore the observed changes are taker as the result of differences in mass in the interfacal region, next to the siffor surface. 


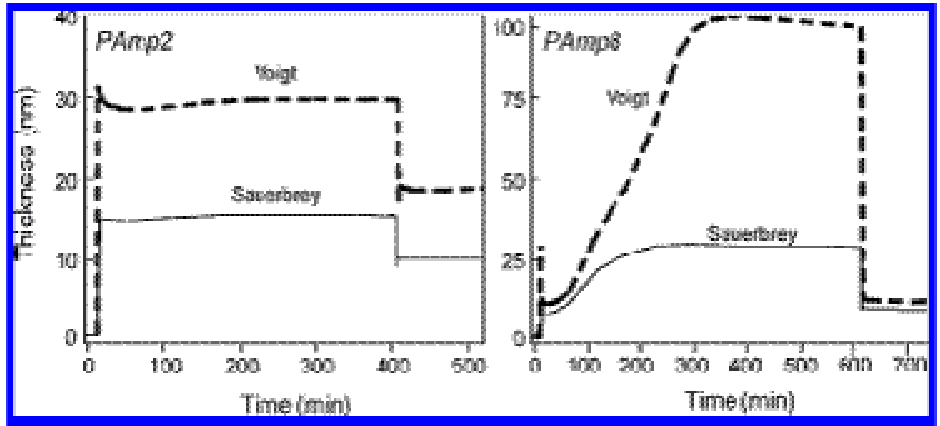

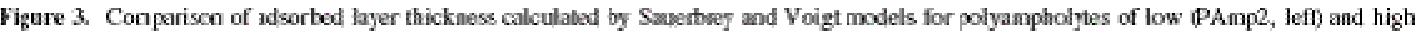
(PAmps, right, nominal charge density on silica. in the left figure, PAnspe was introduced soon after 0 mis time, and rissing with beckground

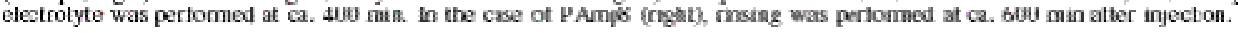

Conditions of charge symmetry at meutral pH (close to the IEP) favor the eontrotion of the polyampholybe molowgles to fom globules that could accumulate af the interface. However, the same waponses as described before were pbserved under solution cond tions kading to charge asymanetry of the polyanpholytes at pll 4 and 10, which fovers shain sxpsensing. Therefore, the slow changes in frequency observed upon polymer adscrption occurred regarliess of the $\mathrm{pH}$ conditions. The existene of a phase separation or a michopxcipitation wane before rinsing is therefore proposed to explain the otherved chunges in OCM measurement, for polyampholytes of high ricminal charge density. The effect of rinsing suggests that the attruction forres between the initid, strongly adsouted layer (fermed during the first, fast phase) and neightioning nescrmolecules in solution (cccumulated slowly during the second phre) were too weak to withatsud the cnsuing thear and difution effects upon insing.

No simple velationship was fomd betwern the adsobed mount after rinsing and the nominal change density of the polyampholykes. In general, it is expected that a calionic polyclectrolyk is able to neutralize the surfwe chare moch move efficienty than a typical polyanpholyte In the sese of adsobing potyampholyter, this nestralization pooses is likely to tepend on the avilable charged groups of the macromolecule.

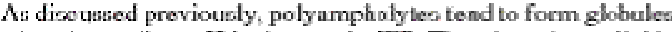
when the medium $\mathrm{pH}$ is dose to the IEP. Therelore, the avalable charged grouse that an able to nuthalize the surface dharge axe highly dependent on the confomation of such structures.

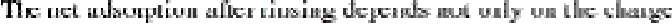
properties of surface and those of the polyanpholytes but also on the confermation of the adsabed layers. Since polyanapholytes en be expectsd to become worganized under the charge-induced electrosatic fields, the net adsaption affer nireing my also depend on the dynanics of adsorptivn. The retutionship hetween the initial structure of the ad soubed hyer. the balance of forces, ard their changes upon rinsing is a very complicated issue that ceserves futher investigation

Conformation of Adsorbed Layer and Phase Separation. $\Delta D-\Delta f$ plots have ben found uscful in interpeting the adsomtion mechanism when following the adsorption pro-

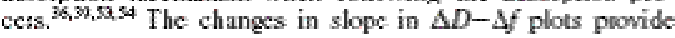
information thout changes in conformational regimes of the adsortaing species. Figure 4 show the relation between dis-

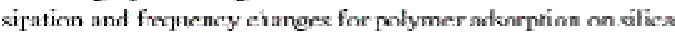
from solution at $\mathrm{pH} 7$. It is noted that for adsorption at pH 4 or 10 the $\Delta D-\Delta f$ plots cxtibited sinilur trends: At the begining of the adsorption process, all polymers investigated, polyan-

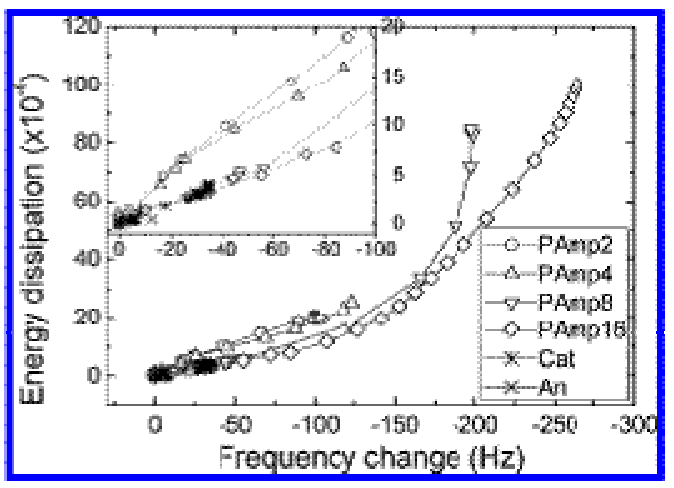

Figure 4. $\Delta D-A f$ prefile doring adsarption an silica from aqueous whition of polywnhtyes and plyolectolyts at pH 7. Data were recouded until adporption patezu and bofore applying a rinsing stop.

pholytes and polyelectrolytes, produced a near $\Delta D-\Delta f$ profile (see inset of Figure 4). The ragnitude of the ADAf slope followed the rame coder as the nominal dwarge dendty of the polyampholytes. PAmp? shows the stexpsi $\Delta D-\Delta f$ slope, indicating the buildup of a soff adsorted layer, while the opposite was true in the case of PAmp 16. This indicser that at least initially the higger charge density polyampholyes adsoit fash, as a compact layer. The cationic polyelectrolyte hud a sinilar slope to that of PAmpla On the other hand, the anionic

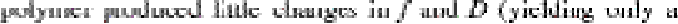
"point" in the $D-f$ frotiley due to the faet that adsorption was negligible.

As the adroted mass increased, the chnges in the $\triangle D V A f$ slopes differed for polymantholytes with kw and high nominal charge densitics. For polyampholytes with low charge density. for example, PAmp2 and PAmp4, as well as the cationio nolyelactrolyte, the linear $\Delta D-\Delta f$ profile was still abserved. On the other hand, folyamptolyles with igh charge densily, for exampk, PAnp8 and PArnpl6, showed a distinctive increase in slope with increased $A f$. Before rinsing, the wiscolssticity of the adsoubed film increased extensively and $a$ large amount of coupled water contribuled to the observed high-energy dissipation. These ohservations agree with our earlier ciscussion that a phose separation in the case of poly ampholytes of high charge demeity tronk place as she interface.

Adsorption of Polyampholytes on CAlulose Thin Filns. Adsorption of the studied polyampholytes in cellubose surfaces was also investigated. Figure Sillustrates the changes in QCM 


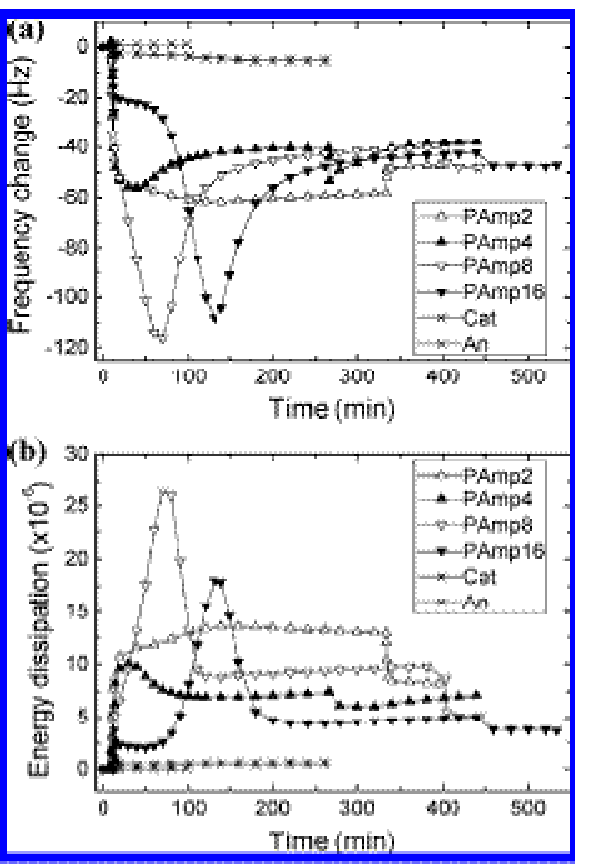

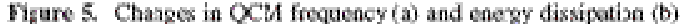
for polyanpholits PAnip2. PAmpt, PAmps and Panpls and simple polyeletrolyes Cat and An (sed Tabl D) adsothing fom aguous

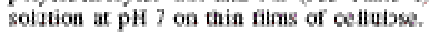

frequency ind dissipatior with idsoption time after the diferent polymer solutions at pH 7 were contacted with cellulose.

The observed adorpton behavior was quite different from that presented for siliea surfaces. These experiments were perfomed at least two times each, and the same trends were observed, albail small differences in the numerical values of frepuency and dissipaticn could be rocorded. First, the cxtent of adsorption was muct lower on ecllulose compared bo the case of siliea surfaces Secend, bor adserption plateas the dissipation vilues were mueh higher. Additiondly, freguency and dissipation eurves revealed a tistinctive ehange at some point during the adsorption proess in the case of poyampholytes PAm4. 8 and 16: A dip ir OCM renance freouency (correponding to a maximum in cncrgy disipation) (sce Figure 5). These changes durirg adsorption can also be seen in the $A D$-Af profies (not shown).

Why did byer reorgamization seeur distinedy in the eare of cellulose substrates, as compared to siliea surfaces? Several hy potheses could be suggested. A possible explanation is that after the initill, fast adssption of the PAmp macromatecular

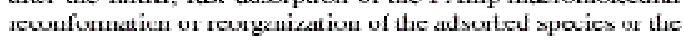
sulkstrate cocurred. Besiles the difference in charge dersities for silica and cellulose, it is worth noting that while the silica suface is impenetrable ollubse can be complant and undergo additiond swelling in response to svents becurring around it. Berase of the intrinsic nature of the cellulses, it could be argued that it may bocome detached from the subtrate. However, extensive evidence from AFM imaging from nary other experiments, conducted under severe conditions of $\mathrm{pH}$ and ionic strength, confirmed the wobutness of the thin films of xellulose. Therefore, a likely explanation is conform aional shanges of the aronther rolymer layer. Athernatively, it is
TABLE 2 Changes in Frequency and Dessipstivn upu Adsorption on Silica of PAmpd from Aquous Solution at pH Ranging from 4 to 10 (Date Recorded before Rinsing)

$\Delta 7^{2}$ anc $\quad \mathrm{pH}$ solution during adsoption of PAmp4

\begin{tabular}{|c|c|c|c|c|c|c|c|}
\hline \multirow[b]{2}{*}{$\begin{array}{c}A D_{3} \text { as plazasu } \\
\text { adsortion }\end{array}$} & \\
\hline & 4 & 5 & 5 & 7 & 8 & 9 & 10 \\
\hline$f_{3}$ & -31 & -71 & $\begin{array}{r}-74 \\
-35\end{array}$ & -95 & -104 & -92 & $-\frac{44}{78}$ \\
\hline
\end{tabular}

possible that water was released from the cellulase substrate when its charges were neuralized by the adsoiting polymer, as resently shown by other unthos. 3,3 and as discussod in light of the wotk by Kubnov et al. ${ }^{\text {h }}$ for systems inwolving linear polyions and opporitey charged swollen pobcloctrolyte xeworks.

Finally, it has necently teen established that the potarization of polyompholyte thine das responsible for their adsorption

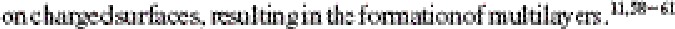
Dobynin, Rubinstein, and Joanny proposed that such a mechanism involyed indied polarization of the chains in the electrostutic fictd excoding from charged surfaces ${ }^{5 i}$ in such situations the charge density of the suracs plays an mportant role. Argubly, sine cellulose surfices have a lower charge density compared to that of silica surfaces, 40,6253 it is to be expected nat the conomation of adsotted polyanpludyes will be differat in these cases. With incresed surface chuge density. different adsorpion regines (such as the poic. fence. and pancabe) are expected, as proposed dicwhere. 'The net resule is the formation of a loose adsorbed layer on cellulose with litte restriction to worganization of the charged groups. Howerer. further experiments are needed to reach definits conclusions and especilly is elucidate the nature of the froquency and dissipation discotinuites sown in F gure 5 .

Effect of Solution pll on Polyampholvte Adsorpion. The $\Delta f-\triangle D$ profiles obtuined during the adsiption of different polyanphotydes in the ph range from 4 io to are reponted below. In these experiment and sompared to those reponted carlier. different aqueous background electrobyte type and conocntration were used ( $5 \mathrm{mM} \mathrm{N} \mathrm{N}_{3} \mathrm{SO}_{4}$ ). We first present the effot of $\mathrm{pH}$ on the adsorpion behrovior of PAmp4 on siliea, as ean be observed in Table 2.

The das in Table 2 do not reval the time roquind for PAnpt to reach the plaieau adsorption: however, we point ont that in neutral $\mathrm{pH}$ such a condition was reached after significantly longer times, as compared to adorption from solution at either lower or higher $\mathrm{pH}$ whlues. The IEP for PAmpl6 was 7.3 at an tonic strergth of $10 \mathrm{mM}$ salt concentratio. Similar values of IEP apply to the othe polymes (PAmp2,4, and 8). I is around this neutral $\mathrm{pH}$ value where the maximum change boh in frequency and in dissipation was observed. As the $\mathrm{pH}$ of the odsorting solution depsited from the IFP values $(\mathrm{pH}$ incressed toward $\mathrm{pF} 10$ or reduced to $\mathrm{pH} 4)$, a reduction in the platean fropuency and dissipation was apparen.

Figure 6 summarizes the adsarption behaviors, as a function of sulutiu $\mathrm{pH}(4,7$, and 10), her these rppexcniati ves of the polymers studied. The simple cationic polyelectrotyte (Cat), a low charge density potyampholyte (PAmp4), and the polyampholyte with the higbest change density (Pump16). If one takes a lager froquency as an indication of a largar adsorbed amount, it is clear that in all cases the extent of adsorption for polyampholytes was consistently larger than for thase of simple polyelectrodytes. For the negatively charged polyelectrolyte, An, negligible adsorption encurred in the case of the polyampholytes, it is evident that changes in the $\mathrm{pH}$ of the polymer solution flayed a diatinctive role in tems of the extent of prolyampholyte atcaption. Dethynin and Puhinstein se temon- 
Polyamptolytes on Silica and Cellulose Surfaces

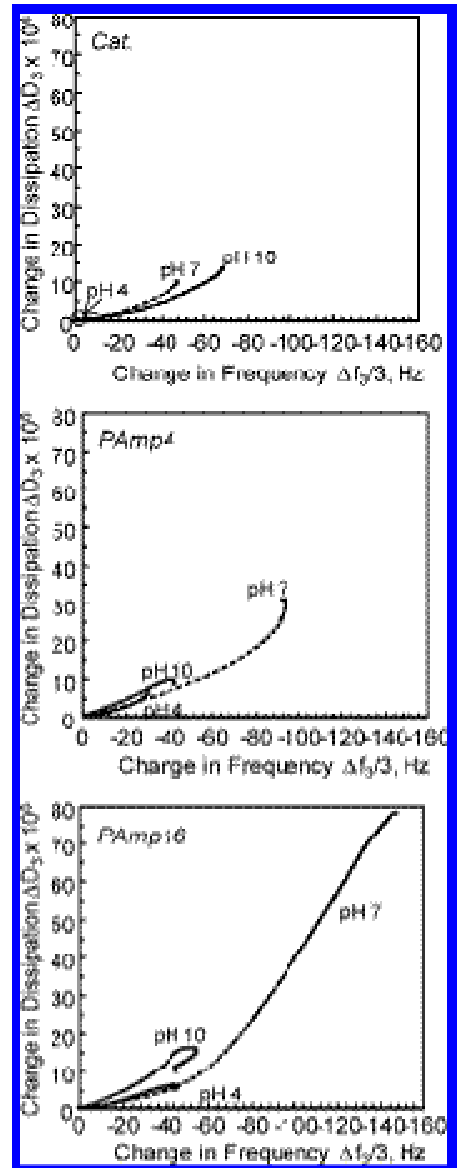

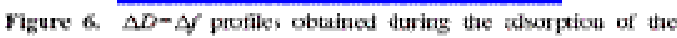
cotionic polyolotiolyte and polyamphotytes PAmpd and PAmp 6 on silic from aqueds solutior at pH 4,7 , and 10.

straed that because of the anionis and cationic groups in polyampholytes they are able to adsob on beth eationic and monic surfaces. In our cas, we used silica, which is ncgatvely charged at all $\mathrm{pH}$ values ased in these experiments. We cxpect that depending on the $\mathrm{pH}$ of the adsobing solution the adscbed polymers could change conformation to allow their opposite charge groups to interat more effectively with the chaged surfose. Also nonionic intenction tetween acrylamide sezments of the polymers and silica are expected to contribute to adsrption. Howewer, decoupling the eletrostaic and nonslectrostatic contributions to explain the sbserved behavior is nther shallenging. Some hight ow te shed by performing experiments at fifferent ionic strengths, and this is the subject of a fortheoming report.

I the case of the adsocption of Cat, we observed that at $\mathrm{pH}$ 4 a mitigible moun was atsorbed on sitica, whereas the exen of strorpion ixreased with increass of the solution's $\mathrm{pH}$. This is easily explained by the fact thai at higher $\mathrm{pH}$ the charge dersity of the silica surface increases. For example, Durval et al. studied the surface composition of a quartz surface reacted with aqueous solutions with $\mathrm{pH}$ ranging from 0 to 10 . By using $X$-rny photolotron spectrossopy, they detemined the presene of three surface specie, $\mathrm{SiOH}_{2}^{+}$, $\mathrm{SiOH}^{\circ}$, and $\mathrm{SiO}^{-}$, the
J. Phys. Chem. B, Vol. 114 No. 2, 2010725

Eomposition of which varied depunding on the pII. Furthemone, the density of the silenol group ( $\left.\mathrm{SiO}^{-}\right)$incened sigrificanty with $\mathrm{pH}$, while a higher proportion of pocitive charged $\mathrm{SiOH}^{2 \div}$ groups were found at extremely acidic condtions. At $\mathrm{HH}$, the dominant qpecies was $\mathrm{SiOH}^{\mathrm{j}}$.

These chservations, however, do not explain the extent of adsorption of the polympholytes at the paricus $\mathrm{pH}$ values tested: Polyampholyte adsomption did not reach a maximun at the highest $\mathrm{pH}$ but at an intemediste $\mathrm{pH}$ of $7, \mathrm{is}$, under cenditions of polyamphotytes' charge symmetry. This fact indicites that it is not the charge density of the substrate but rather some other resten for the obeervition of a raximum atsorption at neutral pH (for both PAmp4 and PAmp 6). Polyanpholytes with high tharge asymmetry (a: pH 4 and $\mathrm{pH} \mathrm{10}$, with ane conditions far from the IEP of the polyampholytes) tend to be cktended. white at pH 7 , whis is very chese w thei IFP. they tem to contract ins globule; if can te realled that the rudius of gyraticn of PAmp4 in aqueous solution at pH 7 was ca $69 \mathrm{~mm}$. while at $\mathrm{pH} 4$ and $\mathrm{pH} 10$ it was 95 and $182 \mathrm{~nm}$, respectively. The cunfomaticn of the same polyampholytes in solution (exicnsion or contracion sconding to the $\mathrm{H}$ conditions) and the resulturg solution \%iscosity wre correlated in catier reports by the autors ${ }^{20}$ All in all, at pH 7 the polyampholvtes are in the glotolar form, with a (close to) minimun radius of gyration. in suh creumstimcess the intial monohyer of adsorbing macromoloules con fit optimally on the surface. It is also in this sodition of shuze symatry that the industive inflwase of xeighoing group promotes the buildupot a linge adsoted amount. A maximum adsorption 3 anound the IEP has alwo ben reported fer natural polyampholytes, ${ }^{65}$ The dissipation in this nas is hagest, which mews that the adscutod layew aw highly hydrated and encrgy hisipative, in the ease of other polyampholycs, for example. PAmpl6, similar conctusions can be dnwn. However, as rotiod culicr in the dsctistion bout the sffect of polympholyes nominal change desity, phase separatón or mictoprecipitation gave tise to even larger ehinges in froqueney and dissiption.

Figure 7 illustrates qualiatively the balance of electrostatic whace bewosn silica and the studicd polymers. The silica surfice is aggatively chaged within the pH range from 4 to 10. while the simple rationic and anionic polyelectroytes are sfwayr positively und negatively chargod, ropoctively. Condibons for polympholytes charge asymmetry oceur between $\mathrm{pH}$ 4 and the respective IEP (not positive charges), while a net negaive chage is dominant beween the respective IEP and pil 10.

The polyampholytes eany net negative charges at $\mathrm{fH}$ 10. If one wer $s$ conside: only the wet charge, then it might be sxpected that no or linte polyampholyte adsorption would occur at high $\mathrm{pH}$, whore silica is also negatively charged. This is in zontrast with our experimental abservations since thece was a sizable adorption at this $\mathrm{pH}$. This effot can be cxplaned by the effect of polarization of the polyamphslyte chairs in the extemal clactrostic ficl crented by the chaged silica subetric. The formation of hydrogen bonding between the potymers and the sufface in these cases could also be a rontributing factor.

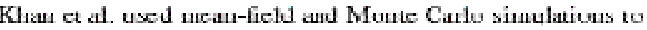
sonclude that for large cough surface charge densitic adsorption of polyampholytes occurred under conditions of polymer sharge balunce or when carrying the same net charg as the surtaces. Likewise, Mahlig el al $^{\text {b/ }}$ reponed expeniments on the adsorption of diblock potyanpholytes which oceurred even when the sibstate and the polympholytes exhibited the same sign of net tharge. They also fourd maximun adsorbed amounts 


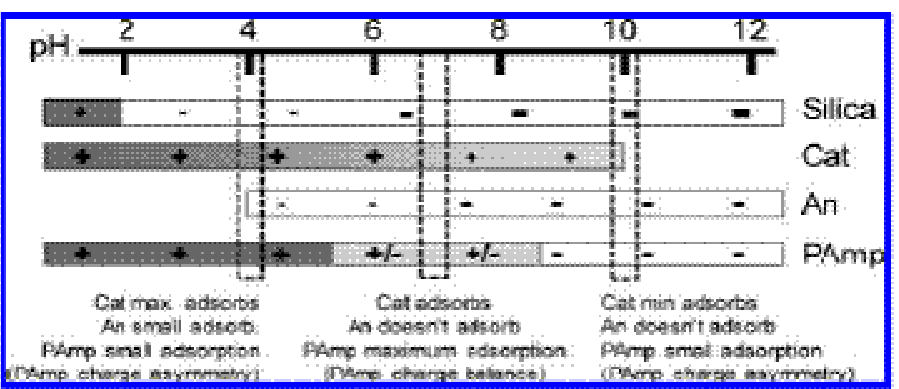

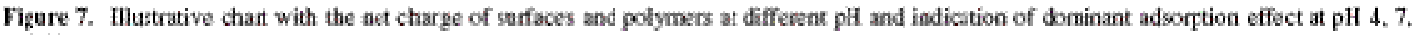
and 10.

ckes to the IEP of the jolymer as a function of $\mathrm{pH}_{+}$however, diedly it the IHP of the polyampholyte, no discotion wats measurable. This behavior was explanod by the fact that a

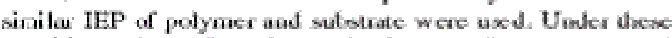
eonditions, the surface tharge denaiy was dose to nem, and thichefore eletrostatic interactions were limited. This example unlerseres the impertaned of the tharge bulance footyan. phitytes shage asymmetry and surace chrge densityle ats pointed out in Figare 7 .

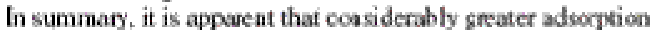

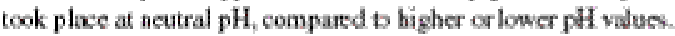
Thes rewils are consigent with the following antipatcd dfect of $\mathrm{pH}$ on the charged natures of both the polyanpholyt and the stica subitute. A few pH of 4 is expected to increas the

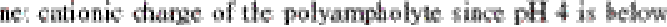

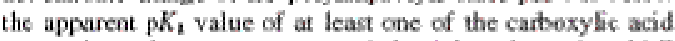

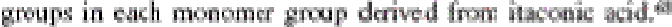
At the same tine, the mgative charge of the detrate is cxjected in the substantally less at $\mathrm{NH} 4$ comparod to nears $\mathrm{H}$ Or the basis of the chage usymmety of the polyampholye ind the charge density of the subirite, therfore, the adropton at the lower $\mathrm{pH}$ in expested to he less A sconcwhat different

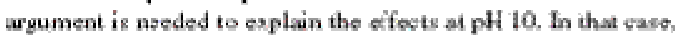

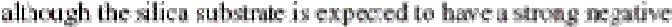
chinge, the $\mathrm{pH}$ in high celtgh so that a substantid proportion of the amine groups on the potympholyce will he in their depotonated, noutral form, thus reduing the number of poritive groups, at ang moment of úme that are avaluble to engage in

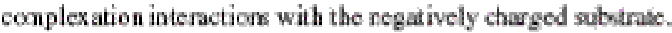

Is an atcmpt to comborte the ponte jea madc, PAmpt and PAmplo were compured on the basis the they tave the same ratio of positive to negative groups but with four times higher molar content of each type of charged monomer in the cabe of PAmp 16. From the respetive reshis, the relative positions of the curves were similar for both cases, and the net whomtion of the polympholyte baving higher densify of chargeable groups appeared to be consideratly higher under nestral $\mathrm{pH}$ conditions. The dissiperion data indieste that such aporent grester adsoption may have been due to a higher content of water held within the adsorbed layer in this case.

Numerical simulitions by other groups have shed light on the adsorption behavior of polyompolytes on charged surfaces. This in pur has boen done with the aim to beter underiand protein adscoption. Our experimental resals highlight the importance od the balance of charges. Finally, since the charge sequenee along the polymer backitone plays an important role in the solution and adsorbing procerics an importan disiection has to be mide regarding the apolication of or results to biomacromolecules. Contrary to the case of synthetic polyan- pholytes with random tharge distribution, froteins areexpected to contain amino acid sequences leading to unique threedimeniond strotures or conformations. The effect of sult

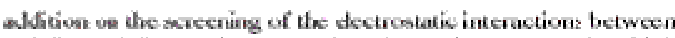
uhadinos changes is expested is play an important role which will be lighlighted is a future communication

\section{Conchusems}

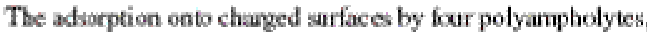
It having a fixcd charge nuto of 5.4 cathonic to anbio and

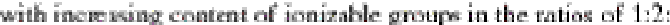
4.8, as well as two sinple potyclatrolytes (anionic and sationic). were meaned by wing the ONMD techique it wa found that the chuge popeties of bot substrates and polynes were

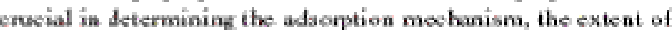

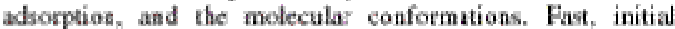
shorption in the case of high charge density saties and polyampholytes with high nomind charge densiy was diven

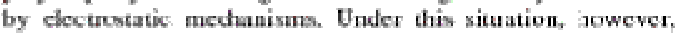
macromolacule accmulation, gosibly microprecipitation of plose sepuraton nea the interfuce, was dectable with quariy crystal minomminctry. For sufuces of bw dhare density adroting polyamplolyes of bow nominal charge density, electrobtat and potaikation eflects were minimized. Under this sitwation, simple, more compuet lween wers observed. Overall. the resulis presented in this repert allow a better undestanding of polympholyte adsorption and reveal that the extension of dromtion and eonformation of the dsorbd specics is a resull of a suble bulane of factors, including chage propertics of surfaces tharge density of potyanpholytes, and the polymer chage aymmetry, which is affecd by the pH of the aqueous mediun.

Adknowledpment The authors would like to acknowledge funding support from the USDA Cooperaive State Researh. Education and Extercion Service, grant nmber 2004-3550414655. Dr. T. Sezh (Hanm Chemied Corp. Japan) is gratetully aclowowledged for synthesizing and providing the polyamphiyte and polycicctrolyte samples.

Note Added alter ASAP Publication. This puper was publabud ASAP on Norcmber 19, 2009. Duc to poduction eme, dah in Table 1 was displaced. The revised puper was reposted en November 23,2009 .

\section{Relkreaces and Noto}

(1) Dotryoin, A. V. Colby, R H Rubinstein, M. I Pohm Sol Dart R 2004, 42,3513.

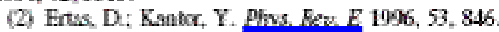


Polyamphotytes on Silica and Cellubse Surfaces

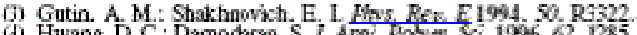

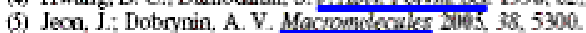

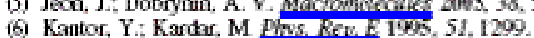

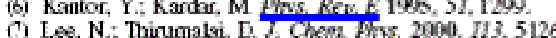

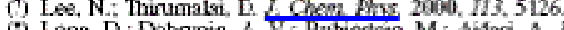

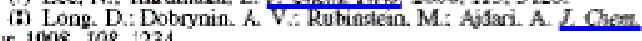
wes $1008,108,234$

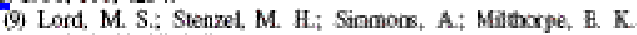
Biomiteriols 2016, 27,567

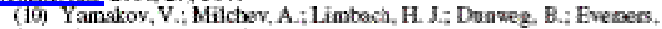

R. Pos Rou LA 2000. 55.405

(1) Dotrymin A. V. Phus Rew E 2001, 6305

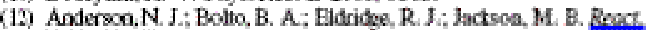
Dokn 190319,7 .

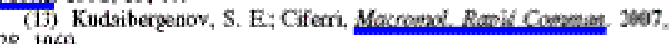
88,190

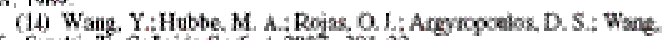

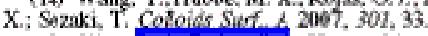

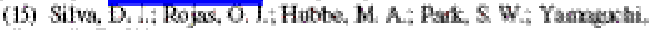
T: Solta O. D. $20 \%$, in pors.

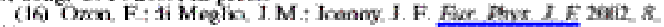
321.

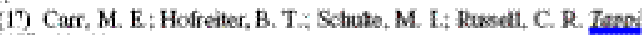
I. $197,00.66$

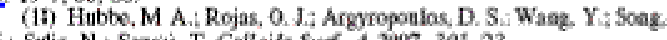

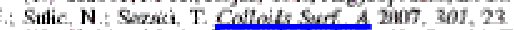

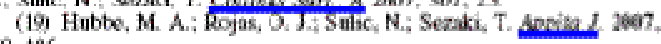
6. 106.

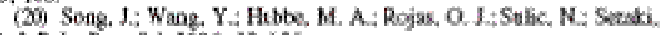

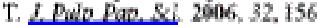

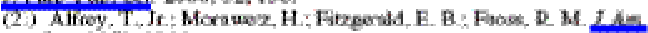

chete. boc 195,1864

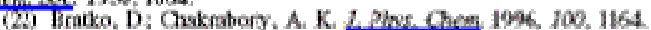

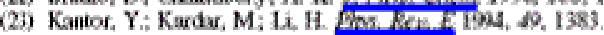

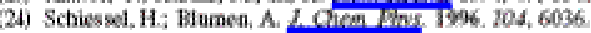

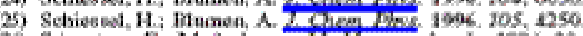

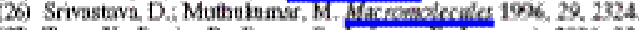
75,3

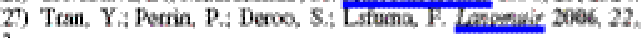
28,235 19.

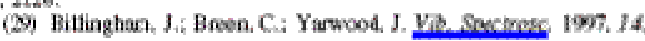

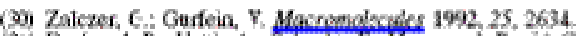

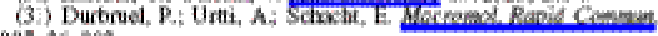

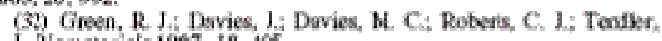
8. J. Shamaterids $195 \%, 18,48$

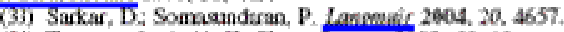

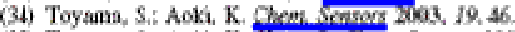

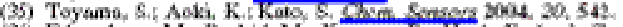

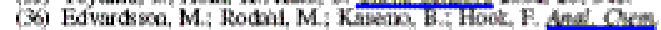
$2005,77,4918$

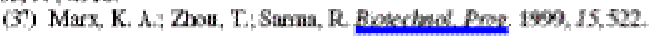

J. Phys. Chem. E, Vol. 114, No. 2, 2010727

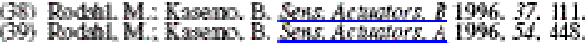

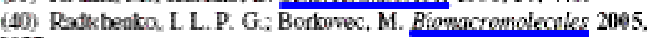
5. 3057.

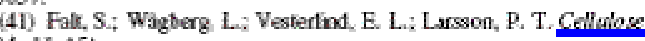
nou $11,15 \mathrm{~L}$.

(42) Gunar, S. Whgher. L.: Sunt. M. A. C. Collowa 2012,9.239.

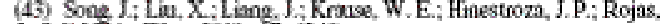

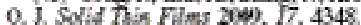

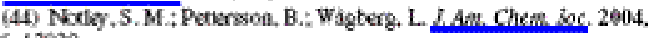
26. somen

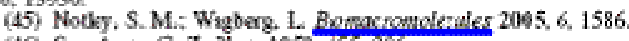

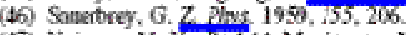

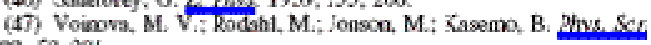
1609, 59, 391.

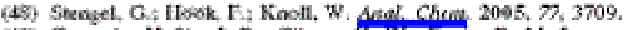

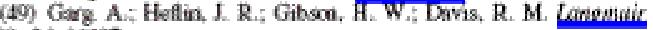
Whe 24.10487.

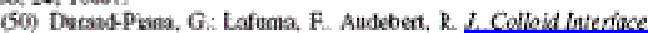

(4) 1587. $M D, 474$

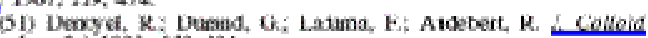

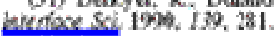

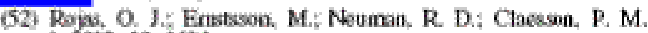
wethet th $202,18,64$

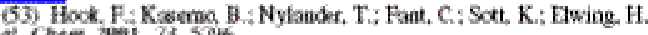

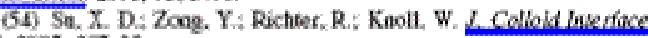
cat not 20,35

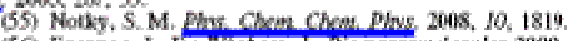

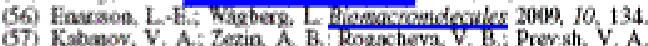

Gived Ged 1969, 30,2211 .

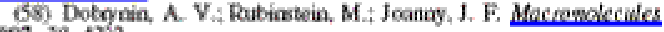
הin 34,43

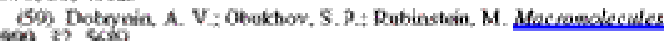

41

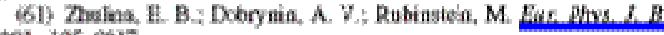

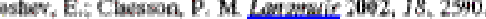

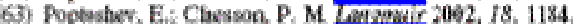

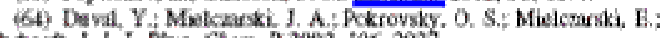

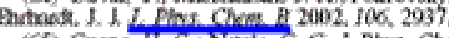

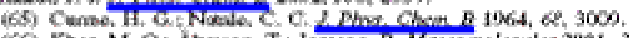
4.16.

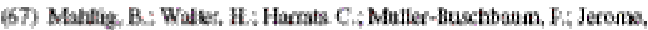

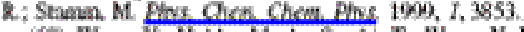

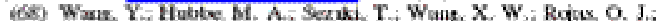

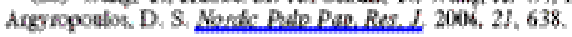

JPFonT 